UNIVERSIDADE DE SÃO PAULO

INSTITUTO DE GEOCIÊNCIAS

\title{
GEOLOGIA E EVOLUÇÃO PETROGENÉTICA DO MACIÇO ALCALINO DE ITATIAIA, MG-RJ
}

\section{PEDRO AUGUSTO DA SILVA ROSA}

Orientador: Prof. Dr. Excelso Ruberti

Tese de Doutorado

№ 571

COMISSÃO JULGADORA

Dr. Excelso Ruberti

Dr. Sérgio de Castro Valente (UFRRJ)

$\mathrm{Dr}^{\mathrm{a}}$. Leila Soares Marques (IAG/USP)

Drª . Elisa Soares Rocha Barbosa (UFG)

Dr. Valdecir de Assis Janasi (GMG/IGc/USP)

SÃO PAULO

2017 
Autorizo a reprodução e divulgação total ou parcial deste trabalho, por qualquer meio convencional ou eletrônico, para fins de estudo e pesquisa, desde que citada a fonte.

Ficha catalográfica preparada pelo Serviço de Biblioteca e Documentação do Instituto de Geociências da Universidade de São Paulo

Rosa, Pedro Augusto Da Silva

Geologia e Evolução Petrogenética do Maciço Alcalino de Itatiaia, MG-RJ. - São Paulo, 2017.

137 p. : il + anexos + mapas

Tese (Doutorado) : IGc/USP

Orient.: Ruberti, Excelso

1. Petrologia ígnea 2. Petrogênese 3. Geocronologia 4. Rochas alcalinas 5. Itatiaia I. Título 
Dedico este trabalho ao meu sobrinho Theo, na esperança de que encontre um mundo melhor, $e$ ao meu primo-irmão Leonardo, pela memória daqueles que se foram 



\section{AGRADECIMENTOS}

Antes de tudo agradeço aos meus pais, Maurício e Carmen Lúcia, por me oferecerem sempre todo o incentivo, oportunidade e confiança que me fizeram chegar até aqui. À minha irmã, Jaqueline, por sempre me apoiar e criticar nos momentos necessários (e bem-vindo Theo!), aos meus avôs Geraldo e Joaquim, por suas lições de vida e sabedoria que vão muito além de livros e aulas, e a todos meus familiares.

Ao professor Excelso pela confiança dedicada ao longo desses dez anos de ensinamentos e amizade. Aos professores Gaston Enrich, Rogério Azzone e Adriana Alves pelas inúmeras assistências, discussões e sugestões. Aos professores Valdecir Janasi, Sílvio Vlach, Renato Moraes, Mario Campos, Celso Gomes, Lucelene Martins, Marly Babinski, Patrício Muñoz, Fábio Ramos, Gergely Szobó, Horstpeter Ulbrich, Paulo Boggiani, Paulo Giannini, Oswaldo Siga Jr. e André Negrão que colaboram e me ensinam das mais diversas formas durante minha vida acadêmica.

Thanks Michael Marks for the confidence, reception, guidance and discussions during (and after) my internship in Tübingen. Thanks to Gregor Markl and Thomas Wenzel for their great help in my research; to Benjamin Walter, Maximilian Keim, Stefan Kreißl, Mathias Burisch and specially Rainer Babiel for the friendship, lunches and coffees during those cold months; and to Ralf Marquart and Rese Apfel for welcome me into their home (and save me from being frozen).

Aos amigos Tiago Rosa, lago Dias, Caroline Faria, Wesley Silva e Victor Prates que estiveram ao meu lado em momentos bons e ruins e me ajudaram a me tornar pessoa melhor. Aos amigos cambuienses, especialmente Leandro Bueno, Daniel Lima, Leonardo Rosa, os irmãos do RPG e o pessoal do Nós Travamos, que ao longo desses muitos anos fizeram parte da minha vida. Aos muitos amigos que a geologia e São Paulo me trouxeram, especialmente Vinicius Mendes, Mariane Vivan, Claudio Salazar, Alice Westin, Tabata Hoeger, Emanuel Amorer, Tatiana Guedes, Astrid Velandia, Paulo Fanucci, os brothers do Geodo, os companheiros de pós-graduação e graduação e a galera do Merça, que me ajudaram muito com conversas, conselhos, risadas, cafés e cervejas nessa vida acadêmica e/ou cotidiana.

À Bruna Miraya, Caio Santos (2x!), Claudio Mora, Emanuel Amorer, Geovane Moreira, Igor Barboza, Julio Cauhy, Lucaz Inglez, Ludmila Teixeira, Maria Paula Ramos, Matheus Caseri, Pedro Angelini, Rafael Capelle, Rafaela Gengo e Saulo Vieira pela inestimável ajuda nos trabalhos de campo.

Aos funcionários do Instituto de Geociências, especialmente Katherine Kutsumbos, Marcos Mansueto, Leandro Moraes, Vasco Loios, Vinícius Martins, Sandra Andrade, Arthur Onoe, Giselle Enrich, Kei Sato e Samuca que me auxiliaram muito o desenvolvimento deste trabalho.

Ao Parque Nacional de Itatiaia pelo apoio logístico, permissões e informações, especialmente Gustavo Tomzhinski, Léo Nascimento, Leonardo Cândido e os funcionários do Posto do Marcão. Parabéns ao Parque pelo seus 80 anos de criação.

À FAPESP (Processos 2012/19184-1, 2012/06082-6 e 2015/19974-0) pelo apoio financeiro que viabilizou este trabalho e minha sobrevivência durante esse período.

E a todas as pessoas que contribuíram direta ou indiretamente nessa caminhada. 
Mundo mundo vasto mundo, se eu me chamasse Raimundo seria uma rima, não seria uma solução (Poema de Sete Faces, Drummond)
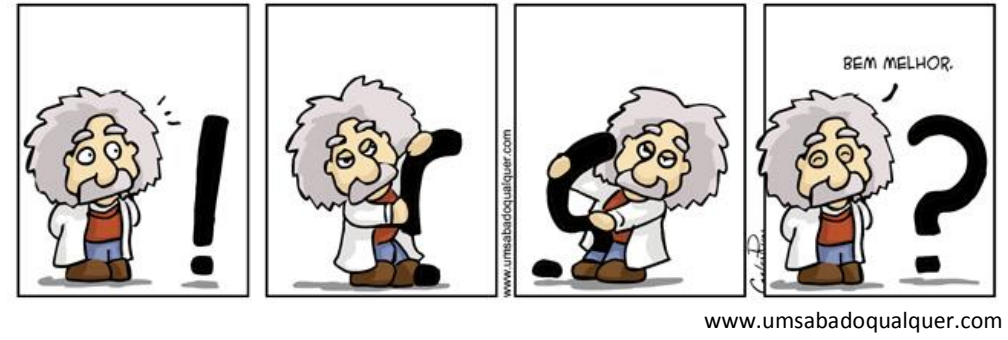



\section{RESUMO}

O Maciço Alcalino de Itatiaia (MAl) representa uma das maiores ocorrências alcalinas mesocenozóicas do Brasil, com aproximadamente $215 \mathrm{~km}^{2}$, situado entre os estados de Minas Gerais e Rio de Janeiro. Ocorre como um corpo alongado com $30 \mathrm{~km}$ de comprimento por 4,5 a 11,5 km de largura, orientado segundo SE-NW, e alojado ao longo de zonas de acomodação do Rifte Continental do Sudeste Brasileiro, em metapelitos, ortognaisses e granitos dos cinturões dobrados Ribeira e Brasília.

Novos dados de mapeamento geológico sugerem que o maciço evoluiu segundo um centro magmático, que migrou de sudeste para noroeste, gerando um complexo anelar com sucessivas intrusões em forma de meia lua, com idades variando de 71,3 a 67,5 Ma (U-PB em zircão). O MAI pode ser estruturalmente dividido em três setores: Sudeste (S-SE), Central (S-C) e Noroeste (S-NW). Esses setores possuem características litológicas e geomorfológicas distintas, sugerindo diferentes origens e/ou estágios de evolução.

O S-SE consiste de nefelina sienitos miaskíticos a agpaíticos onde ocorrem diques de fonolito afíricos, porfiríticos (alguns com pseudoleucita) ou brechóides, além de nefelinitos. A fácies mais insaturada encontra-se na borda em contato com as encaixantes regionais, sendo localmente peraluminosa, com a presença de coríndon modal e hercinita.

O S-C é representado por nefelina sienitos miaskíticos a agpaíticos, pulaskitos, nordmarkitos, quartzo álcali feldspato sienitos, um pequeno corpo granítico (alaskito) e traquitos porfiríticos a brechóides. Diques sin-plutônicos de traquitos sustentam o anel externo e diques de traquito e riolito ocorrem em diversos lugares pela área.

O S-NW apresenta nefelina sienitos e nordmarkitos, e localmente melagabro cumulático e biotita monzonito. Em sua parte central ocorre traquitos porfiríticos a brechóide e traquibasalto porfirítico.

As variedades litológicas nos três setores apresentam-se como possíveis intrusões distintas, cada uma com diferentes características petrográficas, assim podendo ser divididas em cinco grupos: 1) nefelina sienitos sem plagioclásio, caracterizados por uma forte insaturação em sílica e uma tendência de evolução tardi-magmática agpaítica (comumente com låvenita, hiortdahlita, rinkite, dentre outros minerais); 2) nefelina sienitos/pulaskitos com plagioclásio, que mostram-se menos insaturados em sílica e mais máficos, com diopsídio largamente substituído por magnésio-hastingsita e presença de plagioclásio (normalmente com textura anti-rapakivi); 3) série nordmarkito-granito, onde álcali feldspato quartzo sienitos e granito mostram uma variação progressiva nos teores de quartzo, índice de cor e granulação, enquanto os nordmarkitos não mostram uma clara ralação evolutiva; 4) associação anti-rapakivi, caracterizado pela textura porfirítica a glomeroporfirítica antirapakivi nas rochas e presença ocasional de enclaves microgranulares máficos arredondados; a 5) 
rochas básicas representadas pela ocorrência de um melagabro metassomatizado e um traquibasalto não mostrando relações geológicas claras com os sienitos.

Essas rochas foram originadas através da evolução de dois magmas parentais mantélicos distintos, por diferenciação fracionada e com alguma participação de processos de contaminação crustal: I) ankaratrito/basanito, que deram origem aos nefelinitos por fracionamento de diopsídio e aos nefelina sienitos do S-SE por fracionamento de diopsídio, apatita e tanfibólio; II) basanito/álcali basalto que geraram os traquibasaltos por fracionamento de diopsídio e os sienitos dos S-C e S-NW por fracionamento de plagioclásio, diopsídio e apatita, que por sua vez a) evoluíram para nefelina sienitos e b) para sienitos com quartzo, ultrapassando a barreira termal por processos assimilação crustal. 


\section{ABSTRACT}

The Itatiaia alkaline massif (IAM) comprises some of the largest Meso-Cenozoic alkaline igneous occurrences in Brazil, covering over $215 \mathrm{~km}^{2}$ between Minas Gerais and Rio de Janeiro states. It appears as an elongated, $30 \mathrm{~km}$ long and $4.5-11.5 \mathrm{~km}$ wide SE-NW-trending body emplaced along accommodation zones of the Continental Rift of Southern Brazil, intruding metapelites, orthogneiss and granites of the Brasilia and Ribeira fold belts. New data and geological mapping suggest that the massif evolved from a migratory magmatic center that manifested as ring structures and successive moon-shaped intrusions from SE to NW in three sectors: Southeastern (SE-S), Central (C-S) and Northwestern (NW-S). The distinct lithological and geomorphological characteristics of these sectors could be related to different origin and/or evolution stages.

SE-S consists of miaskitic to agpaitic nepheline syenites with dykes of aphiric, porphyritic (some with pseudoleucite) and breccioid phonolites and nephelinites. Its most silica-undersaturated units are in contact with the basement, being locality peraluminous with modal hercynite and corundum.

C-S is represented by miaskitic to agpaitic nepheline syenites, pulaskites, nordmarkites, quartz alkali feldspar syenites, a small alaskite body and porphyritic to breccioid trachytes. Sin-plutonic trachytes sustain the external ring and dykes of trachyte and rhyolite occur throughout this sector.

NW-S presents nepheline syenites and nordmarkites and locality cumulatic melagabro and biotite monzonite. In its central parts, porphyritic to breccioid trachytes and a trachybasalt body occur.

The lithological variants in the three sectors present themselves as discrete intrusive bodies, each one characterized by distinct petrographical features that correspond to five distinct petrographic sets: 1) plagioclase-free nepheline syenites, characterized by strong silica-undersaturation and late agpaitic tendency (commonly with låvenite, hiortdahlite and/or rinkite); 2) plagioclase-bearing nepheline syenite and pulaskite showing weak silica-undersaturation and increased mafic content, with widespread diopside replaced with magnesio-hastingsite and presence of plagioclase (usually with anti-rapakivi texture); 3) a nordmarkite-granite series in which alkali feldspar quartz syenite and granite show progressive variation in quartz content, color index and granulation, whereas nordmarkites do not show a clear common evolution; 4) a quartz syenite association characterized by anti-rapakivi porphyritic to glomeroporphyritic texture and occasional presence of rounded mafic enclaves; and 5) basic rocks represented by metasomatized melagabbro and trachybasalt, with an unclear geological relation to the syenites.

These rocks originated through the evolution of two distinct mantellic parental magma, which had some involvement of crustal contamination processes: I) ankaratrite/basanite, which generated the nephelinites of SE-S by fractional crystallization of diopside and the nepheline syenites by fractionation of diopside, apatite and tamphibole; II) basanite/alkali basalt, with generated the trachybasalt by fractionation of diopside and the syenites of C-S and NW-S by fractionation of 
plagioclase, diopside, and apatite, which evolved to a) nepheline-bearing syenites and b) quartzbearing syenites, crossing the thermal barrier though crustal assimilation processes. 


\section{SUMÁRIO}

1. INTRODUÇÃO

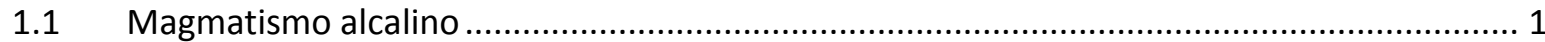

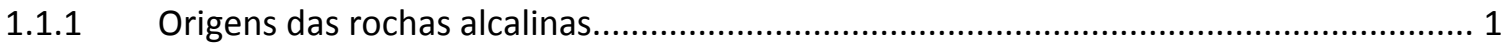

1.1.2 Associação de rochas insaturadas e supersaturadas em sílica ...................................... 3

1.1.3 A influência da fugacidade de $\mathrm{O}_{2}$ na paragênese mineral .......................................... 4

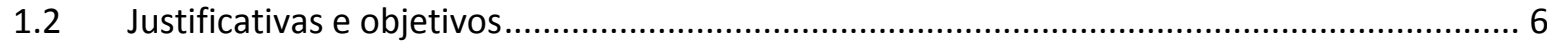

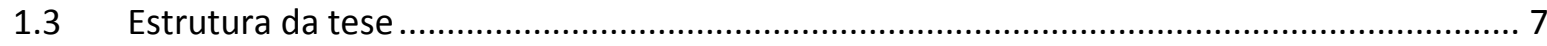

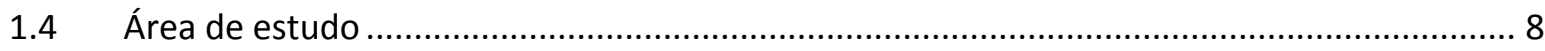

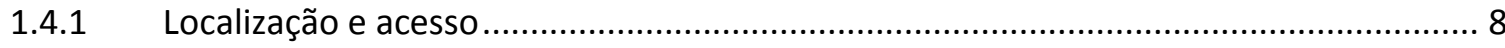

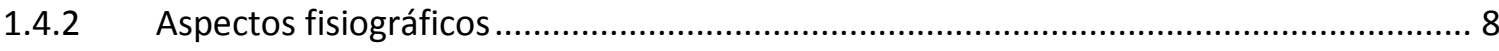

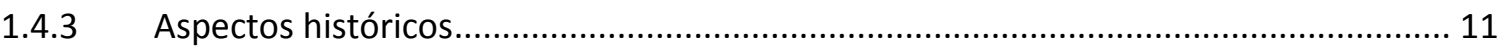

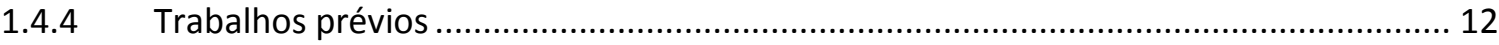

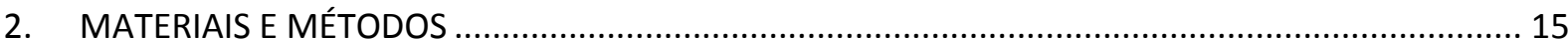

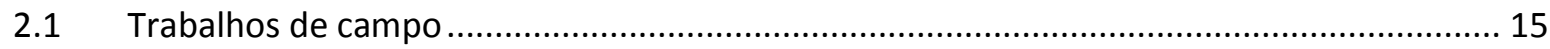

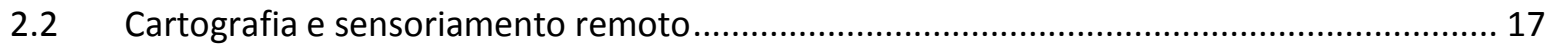

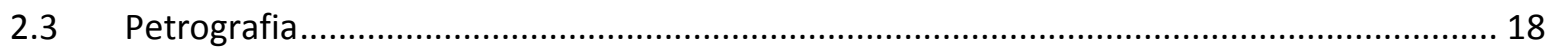

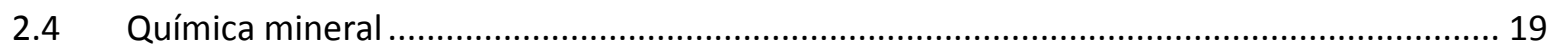

2.4.1 Determinação dos parâmetros intensivos .................................................................. 21

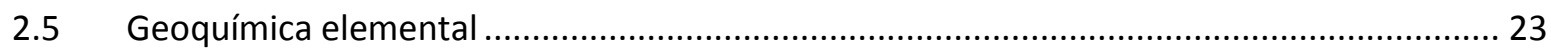

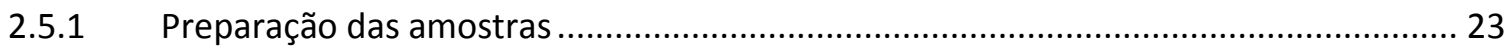

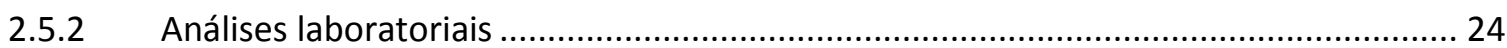

2.5.3 Tratamento dos dados e classificação........................................................................ 27

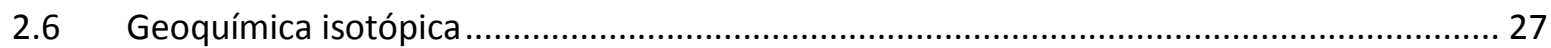

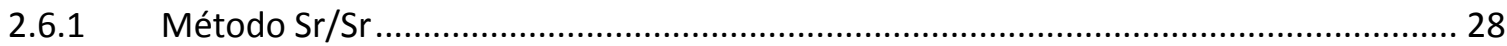

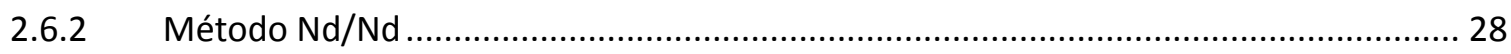

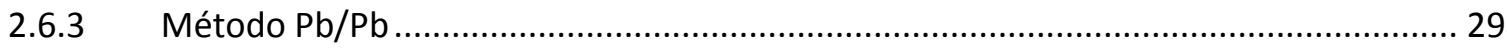

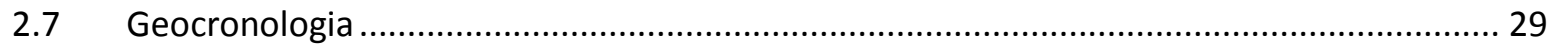

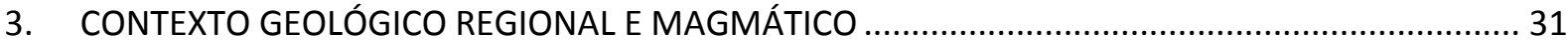

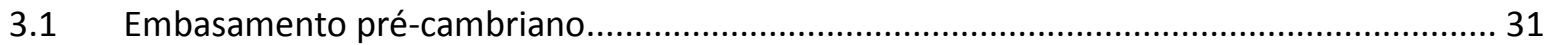

3.2 Tectônica meso-cenozóica e o Rifte Continental do Sudeste do Brasil ................................ 33

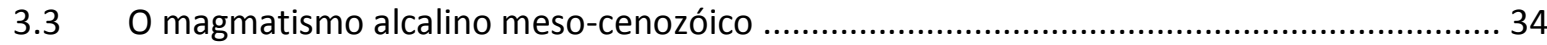

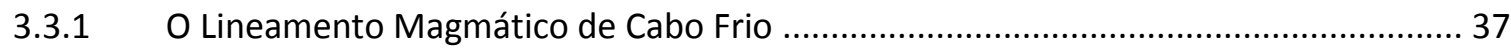

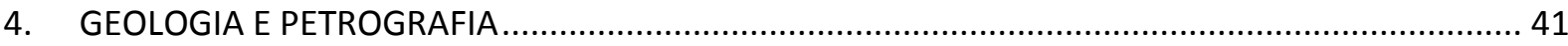

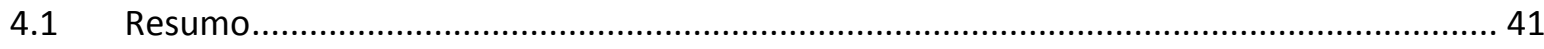

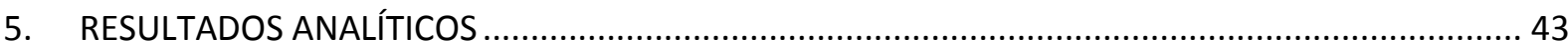




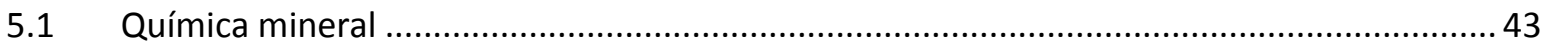

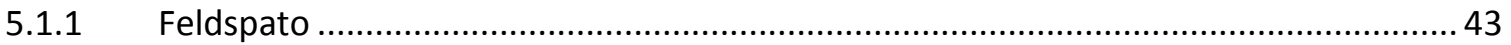

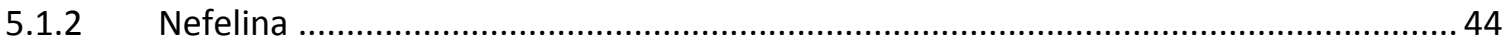

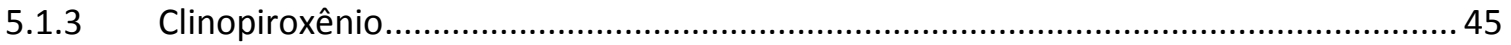

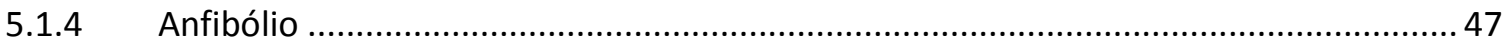

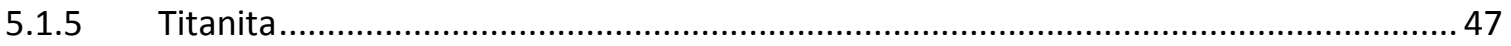

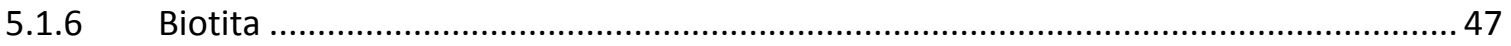

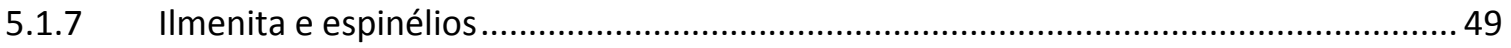

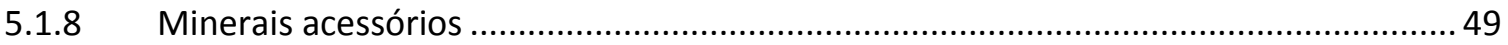

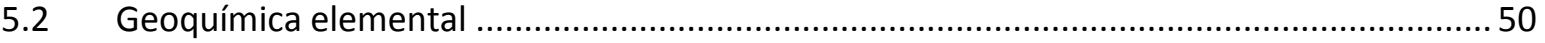

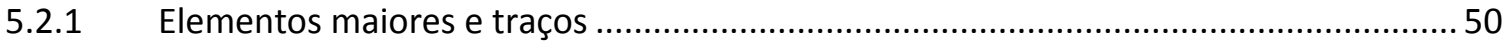

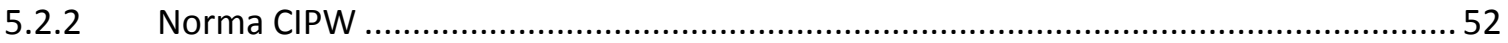

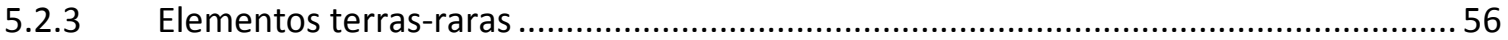

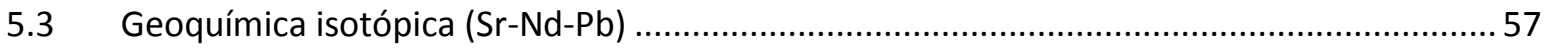

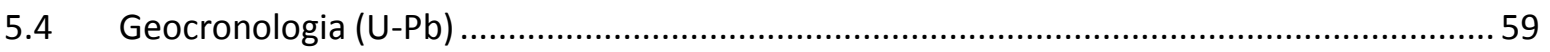

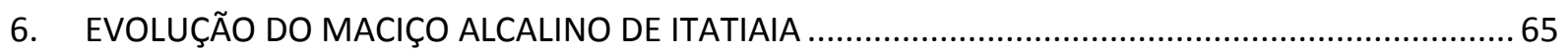

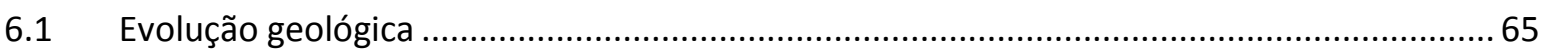

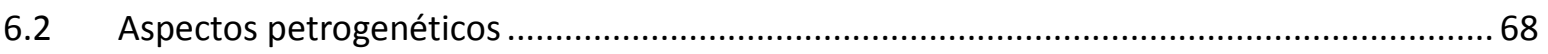

6.2.1 O manto litosférico na região sudeste do Brasil.............................................................. 68

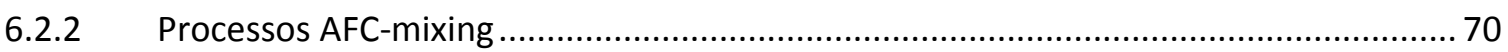

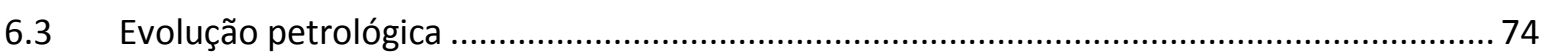

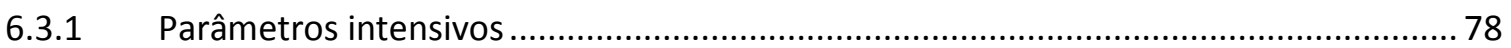

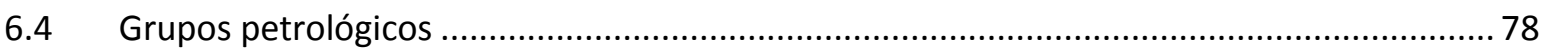

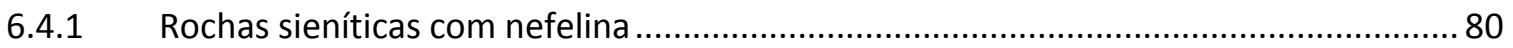

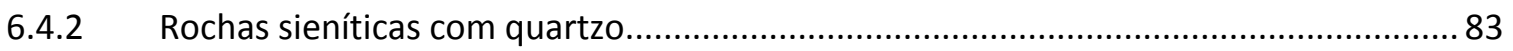

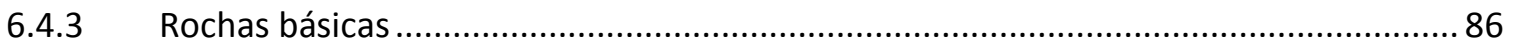

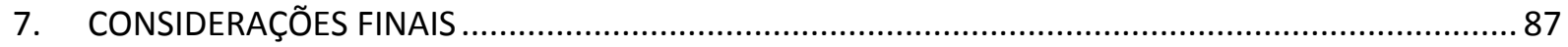

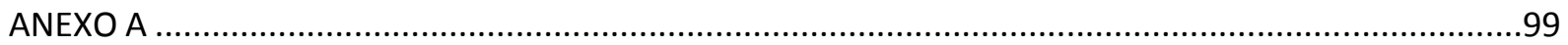

ANEXO B - Tabela de coordenadas e mapa dos afloramentos estudados

ANEXO C - Tabelas de análise modal de amostras representativas das principais unidades

ANEXO D - Mapa geológico do Maciço Alcalino de Itatiaia

ANEXO E - Tabelas com os resultados das análises de química mineral

ANEXO F - Tabelas com os resultados das análises de geoquímica elemental

ANEXO G - Tabelas com os resultados das análises de geoquímica isotópica ( $\mathrm{Nd}$-Sr-Pb)

ANEXO $\mathrm{H}$ - Tabelas com os resultados das análises de geocronologia U-P 


\section{LISTA DE FIGURAS}

Figura 1.1 - Localização e acessos à área de estudo. Limites: cinza, polígono de representação do mapa geológico; verde, área do MAl; rosa, área do PNI. Base: maps.google.com.br.

Erro! Indicador não definido.

Figura 1.2 - Em ambas figuras estão representados o contorno externo do MAI. A) Mapa topográfico da área do MAI elaborado com base em modelo digital de terreno ASTER GDEM (ASTER GDEM é um produto de METI e NASA). As cores representam as altitudes, em variação de $400 \mathrm{~m}$ com escala gradativa no intervalo, e em escala de cinza sobreposta é representada a declividade das encostas, branco $0^{\circ}$ a preto $\geq 45^{\circ}$. B) Imagem de satélite da área do MAI (Google Earth, 2015). É possível identificar as áreas urbanizadas e agriculturáveis nas regiões sudeste e noroeste, as florestas em verde escuro, e os campo de altitude na região central.

Figura 1.3 - Paisagens representativas do MAI. A) Florestas da região sudeste do maciço, onde ocorrem predominantemente nefelina sienitos. Vista a partir do Mirante do Último Adeus. No centro está o Rio Campo Belo. B) Campos de altitude da região do planalto central do maciço, onde domina sienitos com quartzo. Vista a partir da trilha Rebouças - Rancho Caído próximo à Pedra do Altar. (a) Morro do Couto; (b) Morro da Antena.

Figura 1.4 - Mapa geológico do Maciço Alcalino de Itatiaia segundo Ribeiro Filho \& Penalva (1965). Legenda: amarelo claro, depósito de talude (com textura de círculos) e sedimentos clásticos; abóbora, granito alcalino; amarelo escuro, quartzo sienito; roxo, brecha magmática; verde, nefelina sienito, foiaítos; rosa, gnaisse. Escala original 1:50.000.

Figura 2.1 - Diagramas confrontando resultados de análises de elementos traços obtidas em dois laboratórios: AcmeLabs (abscissa, X) vs. UNICAMP (ordenada, Y). Algumas escalas são logarítmicas. A linha tracejada representa a proporção 1:1 ideal. A linha vermelha nos elementos $\mathrm{Zr}$ e $\mathrm{Hf}$ representa o trend de discrepância nas rochas supersaturadas em sílica e ricas em zircão.

Figura 3.1 - Mapa geológico da porção sul do Orógeno Brasília (Campos Neto et al. 2010). A localização do MAl está marcada pelo retângulo preto.

Figura 3.2 - Mapa de distribuição dos quatro riftes do sistema RCSB: (A) Paraíba do Sul, (B) Litorâneo, (C) Ribeira, e (D) Marítimo; de suas falhas limitantes, preenchimentos sedimentares, intrusões/lavas alcalinas, charneira cretácea das bacias de Santos/Campos e o Rio Paraíba do Sul. (Zalán\& Oliveira, 2005)

Figura 3.3 - Províncias alcalinas da região centro-sul da Plataforma Sul-Americana e suas relações com as maiores feições estruturais: 1) Bacia do Paraná, Ordoviciano Inferior a Cretáceo Superior; 2) derrames da Formação Serra Geral, Cretáceo Superior; 3) Bacia de Bauru, Cretáceo Superior; 4) limites das bacias marginais; 5) províncias alcalinas; 6) idade das ocorrências alcalinas (losangos, Permo-Triássico; quadrados, Cretáceo Inferior; triângulos, Cretáceo Superior; círculos, Paleógeno); 7) arcos (AX, Alto Xingu; SV, São Vicente; BJ, Bom Jardim de Goiás; PG, Ponta Grossa; RG, Rio Grande; PP, Ponta Porã); 8) Sinclinal de Torres; 9) maiores zonas de fraturas (Rifts: MR, Mercedes; RM, Rio das Mortes; MG, Moirão; SR, Santa Rosa; AR Assunção. Lineamentos: TB, Transbrasiliano; AP, Alto Paranaíba; MJ, Moji-Guaçu; CF, Cabo Frio; RT, Rio Tietê; SL, São Carlos-Leme; PR, Paranapanema; PI, Piedade; GP, Guapiara; JC, São Jerônimo-Curiúva; RA, Rio Alonzo; PQ, Rio Pequiri; AM, Santa Lúcia-Aiguá-Merin). Modificado de Riccomini et al. (2005).

Figura 3.4 - Mapa com a distribuição das ocorrências da Província Alcalina da Serra do Mar (conforme Almeida, 1983, 1991; Schobbenhaus et al., 1984; modificado), o Rift Continental do Sudeste do Brasileiro (RCSB; Riccomini, 1990), as principais unidades tectônicas do embasamento e os granitos sin, tardi e pós colisionais. Ocorrências alcalinas: associadas ao sistema de riftes continental (RCSB) - 1) Poços de Caldas, 2) Bom Repouso, 3) Caxambú, 4) Passa Quatro, 5) Itatiaia, 6) Morro Redondo, 7) Serra dos Tomazes, 8) Tinguá, 9) Mendanha-Mapicuru, 10) Itaúna, 11) Tanguá, 12) Soarinho, 13) Rio Bonito, 14) Morro de São João, 15) Cabo Frio; ao longo da costa paralelas à falha de Santos - 16) Ponte Nova; 17) Monte de Trigo, 18) São Sebastião, 19) Serraria, 20) Mirante, 21) Búzios, 22) Vitória; ocorrência a sul da PASM - 23) Ipanema. Rifts: grábens do Paraíba do Sul: SP-São Paulo, Tb- Taubaté, Qz- Queluz, RVR- Resende-Volta Redonda, BPS- Baixo Paraíba do Sul; grábens do Litorâneo: SB- Sete Barras, RI- Ribeira de Iguape, St- Santos, Ub- Ubatuba, Gb- Guanabara, BSJ- Barra do São João. Domínios e terrenos Brasilianos: SGN- Nappe Socorro-Guaxupé, SBB- Cinturão Brasília Sul, SRD- Domínio São Roque, APDDomínio Apiaí, ET- Terreno Embú, OcT- Terreno Ocidental, OrT- Terreno Oriental, CFT- Terreno Cabo Frio. Compilado de: base cartográfica (Leite et al., 2004), tectônica cenozoica (Zalán \& Oliveira, 2005), províncias alcalinas (Almeida, 1983, 1991) e demais referências no texto do item 2.2

Figura 5.1 - Diagrama dos componentes moleculares Ab - An - Or, em proporção molecular, para feldspatos dos diferentes setores do MAI. As linhas pontilhadas representam os limites de solução sólida de feldspatos ternários para as temperaturas na pressão de 1 kbar, segundo modelo termodinâmico de Elkins \& Grove (1990).

Figura 5.2 - Diagrama dos componentes moleculares $\mathrm{Ne}-\mathrm{Qz}$ - Ks, em proporção molecular, para nefelinas dos diferentes setores do MAI. Temperaturas de equilíbrio segundo Hamilton (1961). Legenda idem Figura 5.1. . .45

Figura 5.3 - Diagramas $\mathrm{Mg}-\mathrm{Na}-\left(\mathrm{Fe}^{2+}+\mathrm{Mn}\right)$, em a.p.f.u., e $\mathrm{Al}_{\mathrm{T}}$ vs. Ti, em a.p.f.u., para clinopiroxênios dos diferentes setores do MAI. Legenda idem Figura 5.1 . 
Figura 5.4 - Diagrama Si vs. $\mathrm{Ca}_{\mathrm{B}}$, em a.p.f.u., para anfibólios dos diferentes setores do MAl. Os pontos cinza representam os membros finais hastingsita (Hst), ferro-edenita (Fed), katoforita (Ktp), ferro-richterita (Frct) e arfvedsonita (Arf). Legenda idem Figura 5.1.

Figura 5.5 - Diagramas Ca vs. REE $(\mathrm{La}+\mathrm{Ce}+\mathrm{Nd}+\mathrm{Y})$ e Ti vs. $\mathrm{Fe}^{3+}$, em a.p.f.u., para titanitas dos diferentes setores do MAl. A linha diagonal representa a proporção catiônica 1:1. Legenda idem Figura 5.1.

Figura 5.6 - Diagrama $\mathrm{Mg}-\mathrm{Al}-\mathrm{Fe}_{\mathrm{T}}$, em a.p.f.u., com membros finais eastonita, siderofilita, flogopita e annita (Deer et al., 1992) para biotitas dos diferentes setores do MAl. Legenda idem Figura 5.1 .............................................................49

Figura 5.7 - Diagrama $\mathrm{SiO}_{2}$ (\% em peso) vs. mg\# (mol \%), para os litotipos dos distintos setores do MAl. No destaque, a localização das amostras analisadas no mapa geológico simplificado. 50

Figura 5.8 - Diagrama TAS (total álcalis vs. $\mathrm{SiO}_{2}$, em \% de peso; Le Maitre, 2002) para as rochas dos diferentes setores do MAI. Os campos numerados são: 1- traquibasalto, 2-foidito, 3- traquiandesito, 4- fonolito, 5- traquito $(Q<20 \%)$ e 6 - riolito. Legenda idem Figura 5.7. 51

Figura 5.9 - Diagrama A/CNK vs. A/NK (Shand, 1943) para as rochas dos diferentes setores do MAl. Legenda idem Figura 5.7.

Figura 5.10 - Diagrama $\mathrm{Na}_{2} \mathrm{O}$ vs. $\mathrm{K}_{2} \mathrm{O}$ (Middlemost, 1975) para as rochas dos diferentes setores do MAl. Legenda idem Figura 5.7.

Figura 5.11 - Diagramas de Harker de elementos maiores (\% em peso), para rochas do MAI. Legenda idem Figura 5.7 ......53

Figura 5.12 - Diagramas de Harker de elementos traço (em ppm) para as rochas do MAl. Legenda idem Figura 5.7. Continua.

Figura 5.13 - Diagrama tipo spider para os elementos incompatíveis de rochas dos diferentes setores do MAl. Elementos normalizados pelo manto primitivo de McDonough \& Sun (1995). Legenda segue as mesmas cores da Figura 5.7; pontilhado destaca os diques e tracejado o traquibasalto (MAl226). . .56

Figura 5.14 - Diagrama tipo spider para os elementos terras raras de rochas dos diferentes setores do MAI. Elementos normalizados pelo condrito de McDonough \& Sun (1995). Legenda segue as mesmas cores da Figura 5.7; pontilhado destaca os diques e tracejado o traquibasalto (MAI226). 56

Figura 5.15 - Diagrama Idade (Ma) vs. $\varepsilon N d_{(i)}$, para rochas do MAI. Idade modelo $T_{D M}$ de acordo com Liew \& Hofmann (1988). Legendas idem Figura 5.7 e 5.13.

Figura 5.16 - Diagrama de barras com as idades ${ }^{206} \mathrm{~Pb} /{ }^{238} \mathrm{U}$ ( $\mathrm{Pb}$ comum corrigido por ${ }^{204} \mathrm{~Pb}$ medido) de zircão para cada análise $\mathrm{U}-\mathrm{Pb}$, determinada via SHRIMP, das amostras do Maciço Alcalino de Itatiaia. As barras de erro são de $1 \sigma$ para cada análise. As barras cinza escuro representam as idades médias dos cristais de zircão de cada amostra e as áreas cinza claro seus respectivos erros com $95 \%$ de confiança. . .59

Figura 5.17 - Imagens de catodoluminesência dos cristais de zircão analisados via SHRIMP, de rochas do MAI. Em cada cristal está marcado o spot analisado e sua respectiva idade. As idades em vermelho foram descartadas. Os erros variam de $\pm 0,8$ a $\pm 1,9$ por análise.

Figura 5.18 - Imagens de luz transmitida dos cristais de zircão analisados via SHRIMP, de rochas do MAI. Em cada cristal está marcado sua respectiva idade. As idades em vermelho foram descartadas. Os erros variam de $\pm 0,8$ a $\pm 1,9$ por análise.... 61

Figura 5.19 - Diagramas concórdia ${ }^{207} \mathrm{~Pb} /{ }^{235} \mathrm{U}$ vs. ${ }^{206} \mathrm{~Pb} /{ }^{238} \mathrm{U}$ de Wetherill (1956) para análises de zircão via SHRIMP, de rochas do MAI.

Figura 6.1 - Mapa geológico simplificado do MAI mostrando as localizações das amostras analisadas, associado ao diagrama das unidades (em ordem de colocação) vs. idade (U-Pb em Ma). Legenda idem Figura 5.7.

Figura 6.2 - Diagrama ${ }^{143} \mathrm{Nd} /{ }^{144} \mathrm{Nd}_{(i)} v$ s. ${ }^{87} \mathrm{Sr} /{ }^{86} \mathrm{Sr}_{(i)}$ para as rochas do MAl (símbolos idem Figura 5.7), com os campos de variação das Ilhas de Trindade e Martín Vaz (Marques et al., 1999; Siebel et al., 2000; Bongiolo et al., 2015), da Província Serra do Mar e LMCF (Brotzu et al., 1989, 2007; Garda et al., 1995; Thompson et al., 1998; Bennio et al., 2002, 2003; Ulbrich et al., 2002; Enrich et al., 2005; Azzone et al., 2016), porção nordeste da Província Magmática Paraná-Etendeka (RochaJúnior et al., 2013), Província Ígnea do Alto Paranaíba (Gibson et al., 1995; Araujo et al., 2001; Guarino et al., 2013) e dos diques toleíticos pré-Atlântico da região de Resende-Ilha Grande (Guedes et al., 2016). No diagrama suplementar soma-se os campos dos granitoides sin- e pós-orogênicos (Tupinambá et al., 2012; Carvalho et al., 2014; Janasi et al., 2015; Alves et al., 2016; Martins et al., 2016; Valeriano et al., 2016). Razões calculadas para idades iniciais de cada análise (intervalo de variação indicada na figura).

Figura 6.3 - Histograma com a distribuição de frequência das idades do magmatismo alcalino e das idades modelo $T_{D M}$ (em milhões de anos) da Província Serra do Mar, LMCF, porção nordeste da Província Magmática Paraná-Etendeka, Província Ígnea do Alto Paranaíba e dos diques toleíticos pré-Atlântico da região de Resende-Ilha Grande. Referências conforme a Figura 6.2. 70 
Figura 6.4 - Diagramas ${ }^{206} \mathrm{~Pb} /{ }^{204} \mathrm{~Pb}_{(\mathrm{i})} v s .{ }^{207} \mathrm{~Pb} /{ }^{204} \mathrm{~Pb}_{(\mathrm{i})}$ e ${ }^{206} \mathrm{~Pb} /{ }^{204} \mathrm{~Pb}_{(\mathrm{i})} v s .{ }^{208} \mathrm{~Pb} /{ }^{204} \mathrm{~Pb}_{(\mathrm{i})}$ para rochas do MAl e encaixantes regionais adjacentes. Triângulo, milonito (MAI027); círculo, leucogranito (MAl194C); e quadrado, biotita xisto (MAl168). Curvas de evolução isotópica do $\mathrm{Pb}$ (versão IV) para modelo de reservatórios juntos com campos contendo a composição moderna provável. Os incrementos nas curvas indicam intervalos de 100 Ma (Zartman \& Haines, 1988). Legenda idem Figura 5.7. 70

Figura 6.5 - Diagramas ${ }^{143} \mathrm{Nd} /{ }^{144} \mathrm{Nd}_{(i)} v s .{ }^{87} \mathrm{Sr}^{86} \mathrm{Sr}_{(\mathrm{i})}$ para as rochas do MAl e diques próximos. As curvas representam a tendência de mixing (com incrementos de 10\%) a partir de amostras iniciais primitivas com as encaixantes adjacentes, milonito (triângulo, MAI027), leucogranito (círculo, MAI194C); e biotita xisto (quadrado, MAI168). Os símbolos asterisco cinza são tephitos e basanitos de Thompson et al. (1998). Legenda idem Figura 5.7.

Figura 6.6 - Diagramas $\mathrm{SiO}_{2}$ (em \% de peso) vs. razões isotópicas iniciais e idades modelo $\mathrm{T}_{\mathrm{DM}}$. A Linha verde representa a tendência para o S-SE e a rosa para os S-C e S-NW. Legenda idem Figura 5.7.

Figura 6.7 - Diagramas mostrando as tendências de variações petrológicas em relação à ordem de intrusão de SE para NW (interpretada a partir de informações geológicas) das unidades do MAl. Legenda idem Figura 5.7. . .74

Figura 6.8 - Diagrama R1-R2 (De La Roche et al., 1980) representando as tendências evolutivas das unidades do MAl, as linhas cheias representam as séries das unidades e as tracejadas as possíveis trajetórias evolutivas dos gaps composicionais. As cores representam: verde, unidades do setor S-SE; vermelho, unidades dos setores S-C e S-NW; preto, possíveis injeções máficas nas unidades sieníticas; azul, possíveis processos de assimilação a partir da composição das encaixantes locais. Os asteriscos representam as possíveis composições dos líquidos parentais. Os círculos cinza representam as composições ideais dos minerais e as linhas pontilhadas a direção oposta ao fracionamento dos respectivos minerais. No diagrama (em mesma numérica) estão as distribuições das amostras do MAl (legenda idem Figura 5.7) e dos diques próximos (asteriscos cinza, Thompson et al., 1998)

Figura 6.9 - Relações petrogenéticas entre as unidades magmáticas do MAl. Os símbolos representam os principais processos petrológicos envolvidos.

Figura 6.10 - Diagrama de equilíbrio $\mathrm{NaAlSiO}_{4}-\mathrm{SiO}_{2}-\mathrm{KaISiO}_{4}$ (Hamilton \& MacKenzie, 1965) para as rochas dos diferentes setores do MAI. Legenda idem Figura 5.7.

Figura 6.11 - Diagramas de variação das razões $\mathrm{Nb} / \mathrm{Ta}$ e $\mathrm{Zr} / \mathrm{Hf}$ para as rochas do MAI. As linhas horizontais representam a razão condrítica de $\mathrm{McDonough} \mathrm{\&} \mathrm{Sun} \mathrm{(1995).} \mathrm{Elementos} \mathrm{em} \mathrm{ppm} \mathrm{e} \mathrm{SiO}_{2}$ em \% de peso. Legenda idem Figura 5.7 ..........77

Figura 6.12 - Diagramas de variação da anomalia ed $\mathrm{Eu}\left(\mathrm{Eu}^{\mathrm{E}} \mathrm{Eu}^{*}\right.$ ) vs. $\mathrm{SiO}_{2}$ (em \% de peso), índice A/NK, e $\mathrm{Sr}$ (em ppm) para as rochas do MAI. Legenda idem Figura 5.7.

Figura 6.13 - Diagramas de equilíbrio entre as fases minerais das rochas do Maciço Alcalino de Itatiaia calculados para $1 \mathrm{kbar}$ e $900^{\circ} \mathrm{C}$ para as atividades dos componentes minerais. A) Diagrama $a \mathrm{SiO}_{2} v s$. temperatura mostrando o equilíbrio nefelina - jadeíta (em clinopiroxênio) - albita (em feldspato alcalino). Os equilíbrios tracejados são considerados sub solidus (< $700^{\circ} \mathrm{C}$ ), sendo o de maior temperatura registrado na amostra MAI199, com $a \mathrm{SiO}_{2}$ de $\sim 0,55$. B) Diagrama $a \mathrm{SiO}_{2} v s$. $\log f \mathrm{fO}_{2}$ mostrando os equilíbrios magnetita - titanita - ilmenita - hedenbergita (em clinopiroxênio) e andradita - magnetita hedenbergite (em clinopiroxênio). Em cinza o campo de variação da $a \mathrm{SiO}_{2}$ e $f_{2} \mathrm{O}_{2}$ do $\mathrm{MAI}$. $\mathrm{HM}$, buffer hematita-magnetita; $\mathrm{FMQ}$, buffer fayalita-magnetita-quartzo. C) Diagrama $a \mathrm{SiO}_{2}$ vs. temperatura mostrando o equilíbrio Ca-tschermak (em clinopiroxênio) - anortita (em plagioclásio). Em cinza a área de estabilidade desse equilíbrio, mostrando-se abaixo da $a \mathrm{SiO}_{2}$ mínima do maciço.

Figura 6.14 - Mapa geológico simplificado com os grupos petrológicos do MAl e o diagrama mg\# vs. Q - foid (em \% normativa) com os campos de variação das rochas do MAI.

Figura 6.15 - Diagrama $\mathrm{Na} /(\mathrm{Na}+\mathrm{Ca})$ vs. $\mathrm{Fe}^{3+} /\left(\mathrm{Fe}^{3+}+\mathrm{Fe}^{2+}\right)$, em a.p.f.u, para clinopiroxênios e anfibólios das rochas insaturadas em sílica do MAI. Círculos, clinopiroxênio; triângulos, anfibólio. Em vermelho a sequência diopsídio $\rightarrow$ magnésio-hastingsita, onde o aumento do teor de $\mathrm{Fe}^{3+}$ é consequência do aumento progressivo de $\mathrm{fO}_{2}$ e menor dependência da disponibilidade de $\mathrm{Na}$. Em azul a sequência diopsídio $\rightarrow$ aegirina-augita $\rightarrow$ aegirina/arfvedsonita, onde a disponibilidade maior de $\mathrm{Na}$ induz à entrada de $\mathrm{Fe}^{3+}$ por substituição acoplada, e aumenta o consumo de $\mathrm{O}_{2}$, diminuindo progressivamente a $f \mathrm{O}_{2}$ do líquido.

Figura 6.16 - Diagramas de elementos maiores (em \% de óxido) vs. mg\# e razões (elementos maiores em \% de óxido e traços em ppm) para a série nordmarkito-granito (campo em rosa) e associação quartzo sienito anti-rapakivi (em cinza) com as linhas de mixing entre as amostras MAI182C e MAl110. Legenda idem Figura 5.7. 


\section{LISTA DE TABELAS}

Tabela 1.1 - Pontos culminantes do Maciço Alcalino de Itatiaia e suas posições em relação aos 35 pontos mais altos do Brasil (IBGE, 2012b). * Marcos geográficos não inclusos no anuário do IBGE, medidas não oficiais realizadas com aparelho GPS. 9

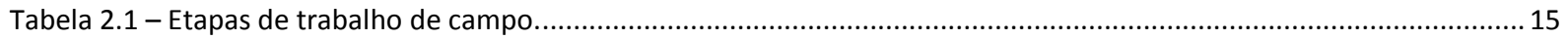

Tabela 2.2 - Configuração dos espectrômetros da microssonda eletrônica para análise química dos minerais. L, linha; $\mathrm{CH}$, canal; P, tempo de contagem no pico; $\mathrm{Bg}$, tempo de contagem para medida do backgound. * Fe medido como $\mathrm{Fe}_{2} \mathrm{O}_{3} \ldots . .20$

Tabela 2.3 - Configuração dos espectrômetros da microssonda eletrônica para análise química dos minerais com vistas à determinação dos parâmetros intensivos.

Tabela 2.4 - Limites de detecção (óxidos, em \% de peso; elementos traço, em ppm) para as análises de geoquímica elemental realizadas em diferentes laboratórios. A- AcmeLabs, óxidos via FRX, traço via ICP-AES/ICP-MS; B- UNICAMP, traço via ICPMS; C- Geoanalítica-USP, óxidos via FRX, traço via ICP-MS. $\left({ }^{*}\right)$ elementos analisados via FRX......

Tabela 2.5 - Fórmulas para cálculo dos índices petrológicos utilizados.

Tabela 6.1 - Classificação dos grupos petrológicos dos litotipos plagioclásio-free (Pl-free) e plagioclásio-bearing (PI-bearing) das unidades nefelina sieníticas e pulaskíticas do MAI. Não foram consideradas as rochas peraluminosas do NeS-I e do apêndice noroeste da unidade BtHblP. 


\section{INTRODUÇÃO}

O Maciço Alcalino de Itatiaia (MAl) é uma das maiores ocorrências alcalinas meso-cenozóica do Brasil, com aproximadamente $215 \mathrm{~km}^{2}$. Possui uma forma alongada NW-SE (30 por 4,5 a 11,5 km) com uma estrutura anelar na região central. $\mathrm{O}$ trabalho de mapeamento geológico realizado revelou uma complexidade geológica e litológica muito maior do que descrito até então nos poucos trabalhos anteriores. Foram identificadas 21 unidades petrográficas (além de variações faciológicas internas) de sienitos insaturados a supersaturados em sílica, traquitos, granito, monzonito, gabro, traquibasalto, além de diques de nefelinitos, fonolitos, traquitos e riolitos. Quase todas as unidades mostram um formato em meia-lua que migraram sucessivamente para NW, com idades mais jovens em diferentes pulsos magmáticos. As feições estruturais, as associações dos litotipos e as características geoquímicas sugerem a existência de três setores (SE, Central e NW) com diferentes características, que poderiam representar três diferentes origens e/ou processos evolutivos. Os processos geológicos, petrológicos e petrogenéticos envolvidos na geração da diversidade de rochas encontradas, bem como a associação pouco comum de rochas insaturadas e supersaturadas em sílica, são o alvo de estudo da presente tese.

\subsection{Magmatismo alcalino}

As atividades magmáticas alcalinas no planeta Terra ocorrem desde o pré-Cambriano até o presente e estão associadas a todos os ambientes tectônicos, principalmente intraplacas oceânicas (i.e. ilhas oceânicas) e continentais (predominantemente ao longo lineamentos tectônicos; i.e. zonas de rifts, arqueamentos tectônicos etc.), em zonas de subducção, tanto em margens continentais, quanto oceânicas, e mais raramente ao longo das dorsais oceânicas.

\subsubsection{Origens das rochas alcalinas}

As rochas ígneas alcalinas caracterizam-se pela presença de feldspatóides e/ou piroxênios e anfibólios alcalinos, incluindo assim rochas insaturadas a saturadas (Sørensen, 1974). Podem ser deficientes em sílica e/ou alumina e apresentar acmita ou feldspatóide na composição normativa. Quando afaníticas são caracterizadas com base nas variações da relação entre os teores (\% em peso) de sílica e dos totais de álcalis. Conjuntamente às rochas alcalinas podem ocorrer dunitos, peridotitos, carbonatitos, kimberlitos, lamprófiros, dentre outros. Também são caracterizadas pelos elevados 
teores de elementos incompatíveis e voláteis, como P, F, Cl, Zr, Ti, Nb, Ta e ETRs, o que pode gerar uma grande variedade mineralógica, tanto primária, quanto pós-magmática.

Elementos traço e características isotópicas de basaltos alcalinos de ilhas oceânicas e de continentes sugerem a presença de componentes enriquecidos em sua fonte no manto. Além disso, a ocorrência de flogopita e kaersutita em alguns xenólitos ultramáficos também mostram que esses componentes sofreram processos de hidratação. Os magmas gerados também possuem elevadas razões ${ }^{87} \mathrm{Sr} /{ }^{86} \mathrm{Sr}$ devido ao decaimento do ${ }^{87} \mathrm{Rb}$, e/ou assimilação de ${ }^{87} \mathrm{Sr}$ pelos fluídos que causaram o enriquecimento em álcalis. Esse enriquecimento em ${ }^{87} \mathrm{Sr}$ também poderia ser atribuído à assimilação de rochas graníticas da crosta continental por magmas que se originaram no manto litosférico ou em plumas. Entretanto, essas rochas tipicamente apresentam elevados teores de $\mathrm{Sr}$, o que deixaria suas razões isotópicas pouco susceptíveis às influências de $\mathrm{Sr}$ radiogênico incorporado das rochas encaixantes (Faure, 2001).

Vários autores (e.g. Hofmann, 1997; Faure, 2001 e referências) assumem que esses componentes foram enriquecidos por fluídos liberados de crostas oceânicas subductadas (com ou sem sedimentos) ou por plumas que ascenderam através do manto astenosférico. Em ambos casos, a melhor fonte de álcalis seria a água do mar que foi subductada, enquanto que a formação de magmas ricos em álcalis seria consequência da dinâmica de plumas mantélicas. A ocorrência de rochas alcalinas ao longo de rifts também estaria intimamente ligado à tectônica extensional associada com plumas.

Pilet et al. (2008) apresentam uma hipótese alternativa para o modelo de características geoquímicas controladas apenas por grandes processos tectônicos, e mostram que o componente enriquecido em basaltos alcalinos pode não ser necessariamente resultado de uma crosta oceânica reciclada. Eles sugerem que os componentes reciclados das fontes das ilhas caracterizadas por magmas toleíticos (e.g. Hawaii e Islândia) são diferentes daqueles das fontes das ilhas onde as composições com nefelina normativa são dominantes (e.g. Polinésia e ilhas do Atlântico). Também sugerem que magmas alcalinos são produzidos por uma alta taxa de fusão parcial de componentes mantélicos volumetricamente menores, ao invés de um baixo grau de fusão de um componente peridotítico dominante, como geralmente aceito. Se assim for, essas rochas alcalinas não trazem tanta informação sobre os componentes mantélicos predominantes. Também mostram que as mudanças nas razões isotópicas observadas em lavas alcalinas de uma mesma ilha oceânica, não necessariamente implicam em uma interação entre diferentes reservatórios. Em vez disso, elas poderiam refletir, em parte, o tempo integrado da história de uma suíte de veios com variáveis razões de elementos traço (e.g., $\mathrm{Nb} / \mathrm{Th}, \mathrm{Ba} / \mathrm{Nb}$ e $\mathrm{Ce} / \mathrm{Pb}$; incluindo razões que controlam a evolução de sistemas isotópicos críticos, como $\mathrm{U} / \mathrm{Pb}, \mathrm{Rb} / \mathrm{Sr}$ e $\mathrm{Sm} / \mathrm{Nd}$ ), resultados da cristalização fracionada dos agentes matassomáticos que percolaram a litosfera. 
Esses autores ainda discutem que apesar de líquidos básicos a ultrabásicos com nefelina normativa poderem ser produzidos por um baixo grau de fusão parcial de granada Iherzolitos, nenhum experimento de fusão em alta pressão com peridotito anidro obteve líquidos de composições possíveis para magmas parentais de basaltos alcalinos (OIBs). Entretanto, um baixo grau de fusão parcial ( 2 a $5 \%$ ) de um manto primitivo contendo 0,1 a $0,25 \%$ (em peso) de $\mathrm{CO}_{2}$ podem gerar magmas com nefelina normativa similares a basaltos alcalinos naturais. Eles ainda mostram que fusões parciais de quartzo e coesita eclogitos a altas pressões, ou seja, crosta oceânica reciclada, resultam em líquidos com hiperstênio normativo e não nefelina, logo não poderiam produzir líquidos alcalinos diretamente. Uma possível solução seria a crosta oceânica supersaturada perder sílica durante a subduç̧ão, resultando em um granada piroxenito insaturado, anidro ou com $\mathrm{CO}_{2}$, que por sua vez poderia gerar líquidos alcalinos com composições próximas de basaltos alcalinos.

\subsubsection{Associação de rochas insaturadas e supersaturadas em sílica}

As rochas ígneas alcalinas caracterizam-se pela presença de feldspatóides, piroxênios alcalinos e/ou anfibólios alcalinos, incluindo assim rochas insaturadas a supersaturadas em sílica. Com base no diagrama petrogenético residual (Hamilton \& MacKenzie, 1965), é possível um líquido evoluir para o mínimo dos sistemas nefelina sienítico ou granítico, gerando assim rochas insaturadas e supersaturadas respectivamente, entretanto, a existência de uma barreira termal entre os dois sistemas impede uma evolução para ambos (e.g. Sørensen, 1974; Foland et al., 1993; Nekvasil et al., 2004; Gupta et al., 2010).

Mesmo assim, a associação desses dois tipos é comum, e ocorre em maciços de várias províncias alcalinas e em diferentes contextos tectônicos. Tipicamente são complexos anelares e que pode ser distintos em três tipos: 1) onde a região central é constituída por rochas insaturadas com as zonas de borda formadas por rochas supersaturadas, isso pode se dar por um aumento gradativo nos teores de sílica, ou serem marcadas por contatos bruscos de unidades distintas, como llímaussaq e Kangerlussuaq, Groelândia (Marks \& Markl, 2001; Riishuus et al., 2006), Messum, Namíbia (Harris et al., 1999), e Abu Khruq, Egito (Landoll et al., 1994); 2) onde as rochas supersaturadas ocorrem apenas na porção central e são 'blindadas' do contato com as encaixantes (pelo menos em superfície) por rochas insaturadas, como Itatiaia, Brasil (Ribeiro Filho, 1967; Brotzu et al., 1997), Hekanzi, China (Yang et al., 2012) e Pilanesberg, África do Sul (Lurie, 2004; Elburg \& Cawthorn, 2016); ou ainda, 3) em maciços com rochas exclusivamente supersaturadas, ou com largo predomínio, entretanto associados a uma província com outros corpos com presença de rochas insaturadas, como Paresis, Província Cretácea de Damaraland, Namíbia (Mingram et al., 2000) e Sabongari, Lineamento de Camarões, Camarões (Njonfang et al., 2013). No entanto, a maioria das ocorrências possuem em comum assinaturas isotópicas que sugerem uma influência crustal para as rochas supersaturadas, com o 
aumento dos valores de ${ }^{87} \mathrm{Sr} /{ }^{86} \mathrm{Sr}$ e $\delta^{18} \mathrm{O}$ e diminuição de $\varepsilon \mathrm{Nd}$ e ${ }^{206} \mathrm{~Pb} /{ }^{204} \mathrm{~Pb}$ relacionados ao aumento dos teores de sílica em proximidade com a encaixante, enquanto que as rochas insaturadas e/ou mais primitivas apesentam componentes tipicamente mantélicos (e.g. Downes, 1984; Landoll et al., 1994; Harris et al., 1999; Upton et al., 2003; Riishuus et al., 2008; Curtis et al., 2013). Mesmo nos maciços do 20 ou 3o tipo citados acima (e suas referências) as assinaturas isotópicas também indicam componentes crustais para as rochas supersaturadas.

As possíveis explicações para a existência desse tipo de associação, à primeira vista paradoxal, envolvem basicamente duas vertentes, não excludentes entre si: 1) processos que ultrapassem ou mudem a barreira termal, como efeitos da presença de voláteis (Kogarko, 1974) ou outros componentes, mudanças nas pressões de água (Pankhurst et al., 1976), ou fracionamento complexo de minerais (Foland \& Henderson, 1976; Giret et al., 1980), ou 2) processos que abram o sistema, como interação com a crosta por hidrotermalismo, assimilação de encaixantes com cristalização fracionada (AFC) ou mistura com líquidos anatéticos crustais ricos em sílica (Foland et al., 1993). Em todas as ocorrências e referências do parágrafo anterior as interpretações correntes envolvem diferentes graus de assimilação de crosta, tanto das regiões basais, onde o magma teria um tempo de residência (e.g. Jung et al., 2004), quanto das porções mais superficiais, envolvendo processos de ascensão do magma (e.g. Marks \& Markl, 2001), sendo geralmente assumido modelos conjunto de cristalização fracionada (AFC). Entretanto, em ilhas oceânicas, livres de uma crosta rica em sílica, a associação de rochas insaturadas e supersaturadas também ocorre (e.g. Ascenção, Harris, 1983; Azores, Mungall \& Martin, 1995). A evolução de líquidos álcali basálticos para líquidos riolíticos sódicos por cristalização fracionada foi simulada experimentalmente, e pode ser viável através do fracionamento, sob determinadas condições de pressão de água e fugacidade de oxigênio, de clinopiroxênio nos estágios iniciais seguido de kaersutita (Nekvasil et al., 2004).

\subsubsection{A influência da fugacidade de $\mathrm{O}_{2}$ na paragênese mineral}

A maioria dos geotermobarômetros para rochas ígneas é baseada na saturação de elementos em alguns minerais ou equilíbrios químicos de paragêneses específicas e que são dependentes dos parâmetros intensivos (e.g. Buddington \& Lindsley, 1964; Wones, 1981; Watson \& Harrison, 1983; Harrison \& Watson, 1984). Temperatura, pressão, fugacidade de oxigênio $\left(f_{2}\right)$, atividades de sílica $\left(a \mathrm{SiO}_{2}\right)$ e $\mathrm{NaCl}(a \mathrm{NaCl})$ podem ser estimadas pela identificação e análises químicas dessas paragêneses.

Um dos mais comuns e poderosos geotermobarômetros é o equilíbrio QUILF (quartzo, ulvøespinélio, ilmenita e fayalita), que possui um papel importante nas relações entre óxidos de Fe-Ti e silicatos ferro-magnesianos em rochas ígneas ricas em Fe (Buddington \& Lindsley, 1964; Frost et al., 1988; Frost \& Lindsley, 1992). Em rochas onde os óxidos de Fe-Ti controlam $\mathrm{fO}_{2}$, o equilíbrio QUILF 
determina a temperatura e trajetória da $\mathrm{fO}_{2}$ durante a diferenciação e/ou o reequilíbrio óxido-silicato durante o resfriamento (Marks \& Markl, 2001; Schilling et al., 2011).

O geotermobarômetro QUILF pode ser expresso pelo equilíbrio:

$$
\underset{\text { quartzo }}{\mathrm{SiO}_{2}+2 \mathrm{Fe}_{2} \mathrm{TiO}_{4}}=2 \underset{\text { ulvøespinélio }}{\mathrm{FeTiO}_{3}}+\underset{\text { ilmenita }}{\mathrm{Fe}_{2} \mathrm{SiO}_{4}}
$$

que possui grande utilidade na estimativa dos parâmetros intensivos que governam os equilíbrios minerais nas rochas ígneas, pois combina dois equilíbrios dependentes de oxigênio:

$$
\begin{gathered}
6 \mathrm{Fe}_{2} \mathrm{O}_{3}=4 \mathrm{Fe}_{3} \mathrm{O}_{4}+\mathrm{O}_{2} \\
\text { em ilmenita magnetita } \\
2 \mathrm{Fe}_{3} \mathrm{O}_{4}+3 \mathrm{SiO}_{2}=3 \mathrm{Fe}_{2} \mathrm{SiO}_{4}+\mathrm{O}_{2} \\
\text { magnetita quartzo em olivina }
\end{gathered}
$$

pois a razão Fe-Mg em silicatos é menos propensa ao reequilíbrio do que em óxidos (Frost et al. 1988).

Rochas insaturadas em sílica não contém quartzo, porém podem conter magnetita, ilmenita e olivina em equilíbrio, sendo assim, possível aplicar o equilíbrio QUILF. Devido à dependência de sílica da reação (1), sienitos com quartzo podem conter magnetita, ilmenita ou ambas, entretanto, sienitos com nefelina tipicamente contém apenas magnetita (Frost et al., 1988; Markl et al., 2001, 2010; Mann et al., 2006; Schilling et al., 2011; Estrade et al., 2014). Como efeito disso, o equilíbrio:

$$
\underset{\text { em olivina }}{3 \mathrm{Fe}_{2} \mathrm{SiO}_{4}}+\mathrm{O}_{2}=\underset{\text { em espinélio }}{2 \mathrm{Fe}_{3} \mathrm{O}_{4}}+3 \mathrm{SiO}_{2}
$$

tipicamente controla a $\mathrm{fO}_{2}$ em nefelina sienitos e, devido à ausência de quartzo, a $a \mathrm{SiO}_{2}$ é $<1$ e determinada pelos equilíbrios:

$$
\begin{gathered}
\mathrm{CaAl}_{2} \mathrm{SiO}_{6}+\mathrm{SiO}_{2}=\mathrm{CaAl}_{2} \mathrm{Si}_{2} \mathrm{O}_{8} \\
\text { em clinopiroxênio em plagioclásio } \\
\mathrm{NaAlSi}_{3} \mathrm{O}_{8}=\mathrm{NaAlSi}_{2} \mathrm{O}_{6}+\mathrm{SiO}_{2} \\
\text { em feldspato em clinopiroxênio } \\
\mathrm{NaAlSi}_{3} \mathrm{O}_{8}=\mathrm{NaAlSiO}_{4}+2 \mathrm{SiO}_{2} \\
\text { em feldspato nefelina } \\
\mathrm{NaAlSi}_{2} \mathrm{O}_{6}=\mathrm{NaAlSiO}_{4}+\mathrm{SiO}_{2} \\
\text { em clinopiroxênio nefelina }
\end{gathered}
$$

As baixas atividades de $\mathrm{Fe}_{3} \mathrm{O}_{4}$ e $a \mathrm{SiO}_{2}$ normalmente levam o equilíbrio (4) a condições muito reduzidas (Markl et al., 2010).

Nefelina sienitos comumente evoluem para condições onde ilmenita e magnetita não são estáveis (no oxide field; Nicholls \& Carmichael, 1969), devido a reação:

$$
\mathrm{Fe}_{3} \mathrm{O}_{4}+\mathrm{Na}_{2} \mathrm{O}+4 \mathrm{SiO}_{2}=2 \mathrm{NaFe}^{3+} \mathrm{Si}_{2} \mathrm{O}_{6}+\mathrm{FeO}
$$

tornando óxidos de Fe-Ti instáveis na transição da saturação para a insaturação de sílica e na transição de alcalino para peralcalino do magma durante a cristalização. As condições de $\mathrm{fO}_{2}$ passam então a serem controladas pelo equilíbrio entre aegirina, arfvedsonita e aenigmatita devido a substituição acoplada:

$$
\left(\mathrm{Ca}, \mathrm{Mg}, \mathrm{Fe}^{2+}\right)+\mathrm{Fe}^{2+} \leftrightarrow \mathrm{Na}+\mathrm{Fe}^{3+}
$$


que conduz a evolução de sienitos alcalinos e tornam clinopiroxênio e anfibólio progressivamente mais sódicos pelas reações:

$$
\begin{gathered}
\begin{array}{c}
\mathrm{Na}_{2} \mathrm{O}+2 \mathrm{FeO}+4 \mathrm{SiO}_{2}+1 / 2 \mathrm{O}_{2}=2 \underset{\text { no líquido }}{2 \mathrm{NaFe}^{3+} \mathrm{Si}_{2} \mathrm{O}_{6}} \\
\text { aegirina }
\end{array} \\
\begin{array}{c}
3 \mathrm{Na}_{2} \mathrm{O}+10 \mathrm{FeO}+16 \mathrm{SiO}_{2}+\mathrm{O}_{2}+\mathrm{H}_{2} \mathrm{O}=2 \mathrm{Na}_{3} \mathrm{Fe}^{2+}{ }_{4} \mathrm{Fe}^{3+} \mathrm{Si}_{8} \mathrm{O}_{22}(\mathrm{OH}) \\
\text { arfvedsonita liquido }
\end{array}
\end{gathered}
$$

consumindo oxigênio das fases voláteis, $\mathrm{como}_{2} \mathrm{O}, \mathrm{CO}_{2}$ e $\mathrm{SO}_{2}$, e reduzindo mais ainda o sistema (Markl et al., 2010).

Em assembleias onde a $a \mathrm{SiO}_{2}$ é controlada pelo equilíbrio entre feldspatos e feldspatóides, dois equilíbrios tipo QUIF podem ser aplicados:

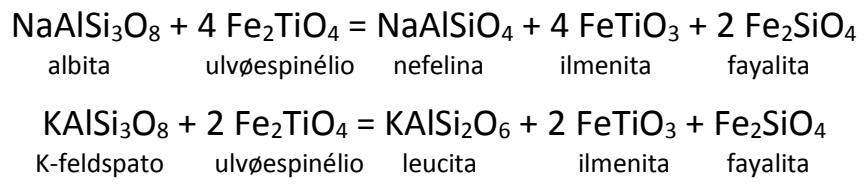

chamados AUNILF e KULILF, (13) e (14) respectivamente. Para sistemas sódicos, o campo natural de estabilidade da assembleia AUNILF é função das composições da albita, nefelina e olivina (13) e controlada pela razão da atividade sílica-fayalita. Quando essa razão é controlada pelo equilíbrio albitanefelina, determina a composição da olivina e a $\mathrm{fO}_{2}$ e consequentemente a estabilidade entre ilmenita e ulvøespinélio. Para sistemas potássicos, a assembleia KULILF envolve leucita e feldspato potássico e invariavelmente cristaliza olivina forsterítica na presença de ilmenita e magnetita, refletindo maior $\mathrm{fO}_{2}$ durante a cristalização do que em sistemas sódicos. Por causa do baixo teor de fayalita na olivina, a razão da atividade sílica-fayalita determina assembleias formadas por feldspato alcalino, magnetita, leucita, ilmenita e olivina (Schilling et al., 2011).

\subsection{Justificativas e objetivos}

O Maciço Alcalino de Itatiaia é uma das maiores ocorrências alcalinas do Brasil ( $\left.215 \mathrm{~km}^{2}\right)$ e encontra-se favoravelmente em uma região densamente habitada e industrializada, entre as cidades de Rio de Janeiro e São Paulo. Possui grande importância histórica, sendo a primeira ocorrência de rochas sieníticas registrada no Brasil (ainda no séc. XIX), área do primeiro parque nacional do país (criado em 1937) e um relevante marco geográfico, ambiental, científico e turístico.

À despeito de suas dimensões, o MAI apresenta variações mineralógicas, petrográficas e geoquímicas importantes, contendo rochas fortemente insaturadas a supersaturadas em sílica, melanocráticas a hololeucocráticas, sódicas a ultrapotássicas e peraluminosas, metaluminosas a peralcalinas, além de uma mineralogia acessória e traços bastante variada. Ressalta-se também, que é uma das poucas ocorrências alcalinas meso-cenozóico brasileiras, se não mundiais, com registro de um zonamento variando de rochas insaturadas em sílica nas bordas (nefelina sienitos) para rochas supersaturadas nas regiões centrais, destacando-se por apresentar certa progressão nos teores de 
sílica culminando com a ocorrência de um granito alcalino e diques riolíticos no centro do corpo. Sendo assim, um problema a ser compreendido são os processos petrológicos e mecanismos envolvidos na diferenciação desses magmas e geração da associação existente.

Apesar de sua importância e da grande complexidade geológica e petrológica, o MAI é carente de informações de detalhes. Dentro do contexto apresentado, considerou-se imprescindível o refinamento dos estudos geológicos e petrológicos reunindo informações petrográficas pormenorizadas dos litotipos representativos com um mapeamento de detalhe e estudos de química dos minerais essenciais e acessórios, geoquímica elemental e isotópica e determinações geocronológicas.

A integração dessas informações serviu de base para a elaboração de um modelo geológico de evolução petrológica e petrogenética do MAI, onde buscou-se contribuir para um melhor entendimento do contexto geodinâmico relacionado ao magmatismo da província na qual se insere, dos componentes litosféricos e/ou astenosféricos envolvidos nos processos de fusão associados ao magmatismo alcalino, bem como em suas relações ou não com plumas mantélicas.

\subsection{Estrutura da tese}

A presente tese está dividida em sete capítulos que abordam os seguintes temas:

- Capítulo 1, Introdução: uma breve introdução sobre o magmatismo alcalino e a ocorrência de rochas insaturadas e supersaturadas em sílica e apresentação da área de estudo.

- Capítulo 2, Materiais e métodos: descrição dos materiais, métodos e procedimentos analíticos utilizados para a obtenção dos dados e confecção dos elementos da presente tese.

- Capítulo 3, Contexto geológico regional e magmático: revisão bibliográfica sobre as rochas do embasamento e o contexto tectônico e magmático ao qual o objeto de estudo se insere.

- Capítulo 4, Geologia e petrografia: definição das unidades magmáticas e reavaliação do modelo de evolução geológica com base em sensoriamento remoto, mapeamento geológico de detalhe e petrografia. Este capítulo é apresentado em inglês no formato de artigo no ANEXO A. O artigo intitulado "Nepheline Syenites to Syenites and Granitic Rocks of the Itatiaia Alkaline Massif, Southeastern Brazil: new geological insights into a migratory ring Complex" foi submetido ao Brazilian Journal of Geology e aguarda resposta. Sua leitura é imprescindível para o entendimento desta tese.

- Capítulo 5, Resultados analíticos: descreve de maneira sistemática todos os resultados analíticos obtidos. 
- Capítulo 6, Evolução geológica do Maciço Alcalino de Itatiaia: integra e discute todos as informações apresentadas anteriormente, apresentando modelos geológicos, petrogenético e petrológico de evolução.

- Capítulo 7, Considerações finais: revisão e síntese das conclusões obtidas neste trabalho.

\section{4 Área de estudo}

O MAI compreende-se entre as latitudes $22^{\circ} 18^{\prime} 31^{\prime \prime}$ e $22^{\circ} 28^{\prime} 26^{\prime \prime} \mathrm{S}$ e as longitudes $44^{\circ} 34^{\prime} 15^{\prime \prime}$ e $44^{\circ} 50^{\prime} 18^{\prime \prime}$ W, tendo como centro e referência o Abrigo Rebouças, $22^{\circ} 23^{\prime} 07^{\prime \prime} S$ S $44^{\circ} 40^{\prime} 43^{\prime \prime}$ W. Divide-se entre os municípios de Itamonte, porção centro-norte, e Bocaina de Minas, porção nordeste, no estado de Minas Gerais, e Itatiaia, porção centro-sudeste, e Resende, nas porções oeste e leste, no estado do Rio de Janeiro. Cerca de três quartos da área de estudo está dentro do Parque Nacional de Itatiaia (PNI), contando com uma boa infraestrutura de apoio e acessos.

\subsubsection{Localização e acesso}

Devido à grande dimensão do corpo, o acesso é feito por várias vias. A principal referência é a Rodovia Pres. Dutra (BR-116) a partir da qual pode-se chegar às vias secundárias (Erro! Fonte de referência não encontrada.). $O$ acesso à Sede do Parque e à região meridional é feito a partir da cidade de Itatiaia seguindo-se pela BR-485, onde é possível seguir de carro até o Posto do Maromba, a partir daí o caminho segue por trilha até o Abrigo Rebouças através da Travessia Rui Braga. O limite ocidental do maciço é quase paralelo à BR-354, que liga a BR-116 (saída 330) até a cidade de Itamonte e de onde saem muitas estradas vicinais por boa parte da porção norte do corpo. $O$ acesso para a parte alta da área é feito por essa rodovia até a Garganta do Registo, divisa entre os estados do Rio de Janeiro e Minas Gerais, e seguindo-se pela BR-485 até o Abrigo Rebouças. O acesso à parte oriental é feito pela rodovia RJ-163 (saída 311) até Visconde de Mauá e depois seguindo até o vilarejo de Maromba pela RJ-151, de onde o caminho até o Abrigo Rebouças ou o Posto do Marcão é feito pela Travessia do Rancho Caído. Por essa rota também há várias estradas vicinais que adentram a área de estudo.

\subsubsection{Aspectos fisiográficos}

O maciço destaca-se topograficamente na região, juntamente com o vizinho maciço alcalino de Passa Quatro, possuindo uma altitude média de 1780 m, que varia de 530 m na região do Centro de Recuperação de Itatiaia (CRI), na porção sul, a 2792 m no Pico das Agulhas Negras (o 50 ponto mais alto do país), na região central (Figura 1.2A). Possui 40\% da área acima dos $2000 \mathrm{~m}$ e 13 dentre os 35 picos mais altos do país (Tabela 1.1), todos eles destacando-se na paisagem e sendo importantes 
Tabela 1.1 - Pontos culminantes do Maciço Alcalino de Itatiaia e suas posições em relação aos 35 pontos mais altos do Brasil (IBGE, 2012b). * Marcos geográficos não inclusos no anuário do IBGE, medidas não oficiais realizadas com aparelho GPS.

\begin{tabular}{ccccc}
\hline Posição & Topônimo & Altitude $(\mathbf{m})$ & Latitude (S) & Longitude (W) \\
\hline 5 & Pico das Agulhas Negras & 2792 & $22^{\circ} 22^{\prime} 47^{\prime \prime}$ & $44^{\circ} 39^{\prime} 40^{\prime \prime}$ \\
\hline 8 & Morro do Couto & 2680 & $22^{\circ} 23^{\prime} 04^{\prime \prime}$ & $44^{\circ} 41^{\prime} 49^{\prime \prime}$ \\
\hline 9 & Pedra do Sino & 2670 & $22^{\circ} 22^{\prime} 13^{\prime \prime}$ & $44^{\circ} 39^{\prime} 42^{\prime \prime}$ \\
\hline 11 & Pedra do Altar & 2665 & $22^{\circ} 22^{\prime} 24^{\prime \prime}$ & $44^{\circ} 40^{\prime} 22^{\prime \prime}$ \\
\hline 15 & Pico da Maromba & 2619 & $22^{\circ} 22^{\prime} 17^{\prime \prime}$ & $44^{\circ} 37^{\prime} 32^{\prime \prime}$ \\
\hline 16 & Morro do Massena & 2609 & $22^{\circ} 22^{\prime} 11^{\prime \prime}$ & $44^{\circ} 41^{\prime} 57^{\prime \prime}$ \\
20 & Pedra Furada & 2589 & $22^{\circ} 21^{\prime} 28^{\prime \prime}$ & $44^{\circ} 43^{\prime} 25^{\prime \prime}$ \\
$*$ & Morro da Antena & 2584 & $22^{\circ} 22^{\prime} 38^{\prime \prime}$ & $44^{\circ} 42^{\prime} 09^{\prime \prime}$ \\
\hline 22 & Pico Serra Negra & 2572 & $22^{\circ} 20^{\prime} 07^{\prime \prime}$ & $44^{\circ} 39^{\prime} 53^{\prime \prime}$ \\
\hline 23 & Pedra Cabeça de Leoa & 2483 & $22^{\circ} 23^{\prime} 12^{\prime \prime}$ & $44^{\circ} 36^{\prime} 58^{\prime \prime}$ \\
$*$ & Ovos da Galinha & 2466 & $22^{\circ} 21^{\prime} 51^{\prime \prime}$ & $44^{\circ} 39^{\prime} 40^{\prime \prime}$ \\
$*$ & Prateleiras & 2458 & $22^{\circ} 23^{\prime} 59^{\prime \prime}$ & $44^{\circ} 40^{\prime} 12^{\prime \prime}$ \\
\hline 24 & Pedra Assentada & 2453 & $22^{\circ} 23^{\prime} 57^{\prime \prime}$ & $44^{\circ} 39^{\prime} 39^{\prime \prime}$ \\
\hline 25 & Pedra Cabeça de Leão & 2420 & $22^{\circ} 23^{\prime} 15^{\prime \prime}$ & $4^{\circ} 37^{\prime} 39^{\prime \prime}$ \\
$*$ & Pedra do Camelo & 2318 & $22^{\circ} 22^{\prime} 12^{\prime \prime}$ & $44^{\circ} 42^{\prime} 38^{\prime \prime}$ \\
\hline 32 & Pico da Cara de Gorila & 2281 & $22^{\circ} 23^{\prime} 00^{\prime \prime}$ & $44^{\circ} 36^{\prime} 27^{\prime \prime}$ \\
34 & Morro do Urubu & 2270 & $22^{\circ} 24^{\prime} 40^{\prime \prime}$ & $44^{\circ} 39^{\prime} 56^{\prime \prime}$ \\
$*$ & Pedra do Picú & 1970 & $22^{\circ} 20^{\prime} 13^{\prime \prime}$ & $44^{\circ} 46^{\prime} 33^{\prime \prime}$ \\
\hline$*$ & Três Picos & $22^{\circ} 25^{\prime} 33^{\prime \prime}$ & $44^{\circ} 34^{\prime} 59^{\prime \prime}$ \\
\hline
\end{tabular}

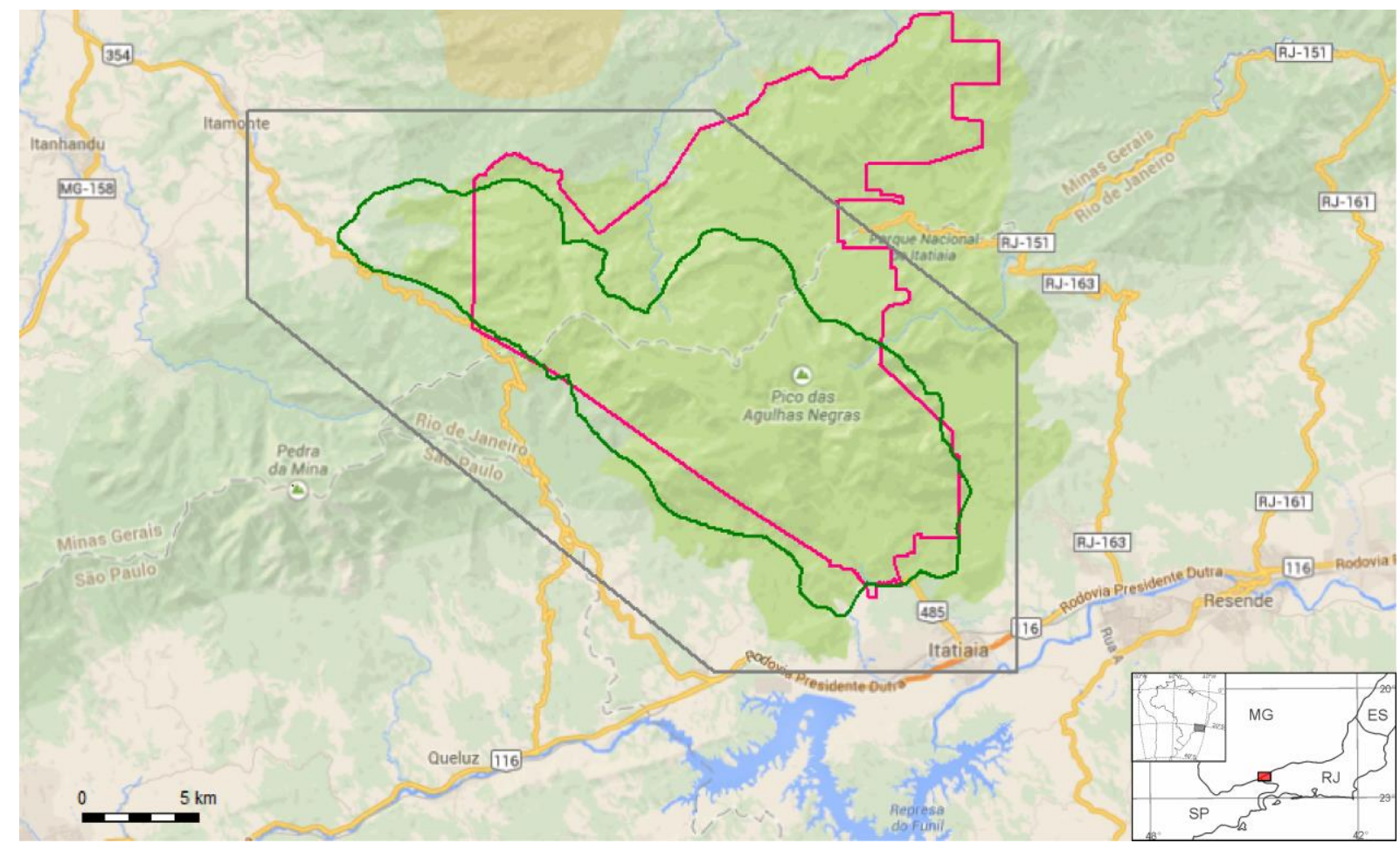

Figura 1.1 - Localização e acessos à área de estudo. Limites: cinza, polígono de representação do mapa geológico; verde, área do MAl; rosa, área do PNI. Base: maps.google.com.br. 


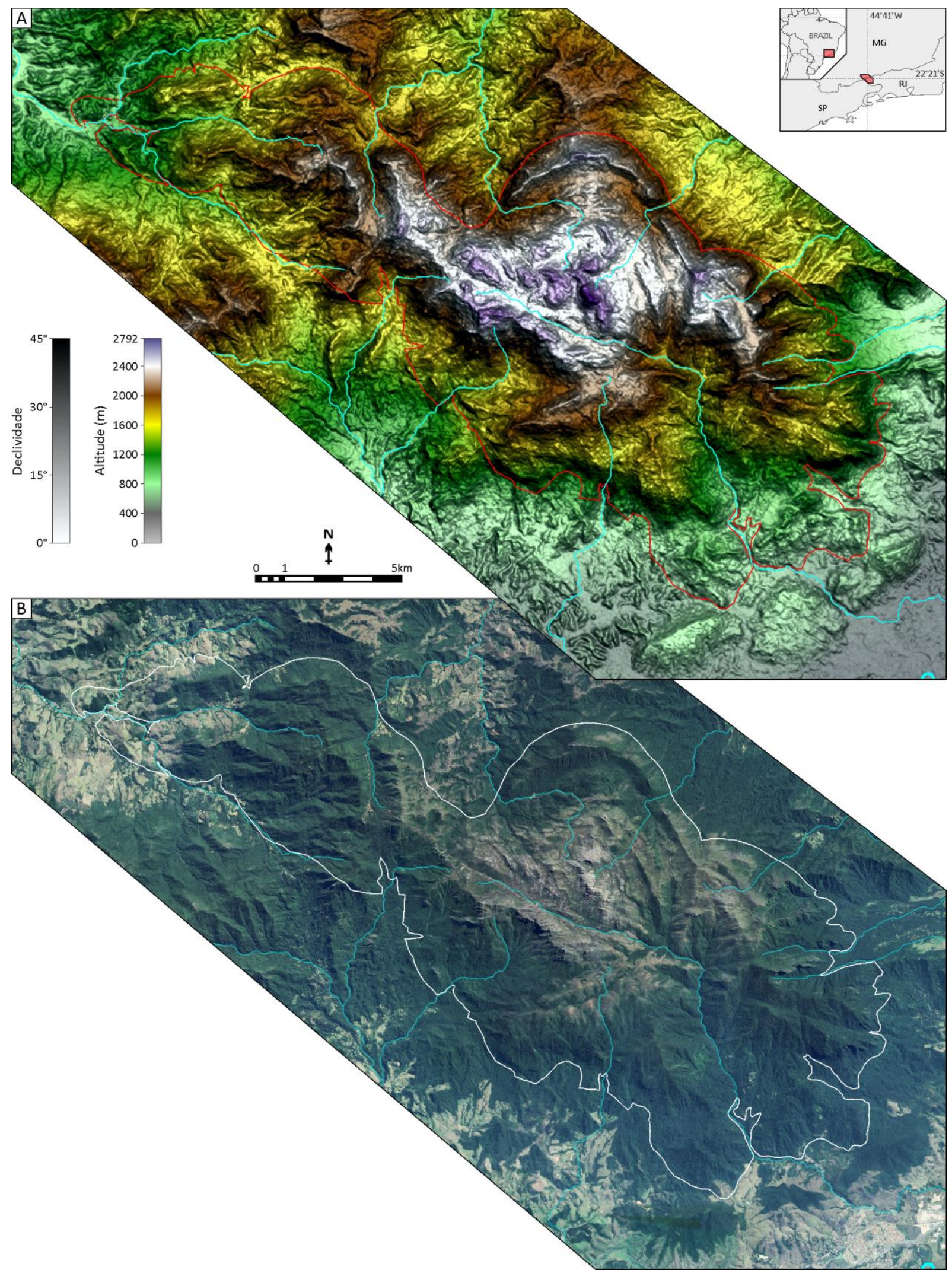

Figura 1.2 - Em ambas figuras estão representados o contorno externo do MAl. A) Mapa topográfico da área do MAI elaborado com base em modelo digital de terreno ASTER GDEM (ASTER GDEM é um produto de METI e NASA). As cores representam as altitudes, em variação de $400 \mathrm{~m}$ com escala gradativa no intervalo, e em escala de cinza sobreposta é representada a declividade das encostas, branco $0^{\circ}$ a preto $\geq 45^{\circ}$. B) Imagem de satélite da área do MAI (Google Earth, 2015). É possível identificar as áreas urbanizadas e agriculturáveis nas regiões sudeste e noroeste, as florestas em verde escuro, e os campo de altitude na região central. 
referenciais geográficos. Também representa um divisor das bacias do Rio Grande (tendo como principais rios na região o Aiuruoca e o Capivari) e do Paraíba do Sul (sendo o rio Campo Belo o principal tributário).

A vegetação na área do MAl é bastante exuberante e pertence ao Bioma Mata Atlântica, considerada uma das regiões mais importantes dentro de um dos 25 hotspot de biodiversidades do mundo (Myers et al., 2000). Constitui-se basicamente de florestas e campos de altitude, além de uma pequena área de pastagens e cultivo no extremo noroeste (Figura 1.2B). As áreas de floresta se dividem em Floresta Ombrófila Densa Montana até a altitude de 1.500m (Figura 1.3A) e Floresta Ombrófila Densa Alto Montana, acima de $1.500 \mathrm{~m}$ de altitude, com presença significativa de araucárias (Araucaria angustifolia). Essas florestas podem ser consideradas como uma das de maior riqueza florística dentre áreas de floresta atlântica no sudeste do Brasil (Pereira et al., 2006; IBGE, 2012a). Localmente ocorrem manchas onde domina o taquaruçú (Guadua tagoara), que torna praticamente inacessível muitos lugares devido à trama emaranhada e aos espinhos grandes e afiados.

É notável o rareamento e diminuição do porte das árvores com a elevação da altitude, onde os campos de altitude começam a tomar importância entre as cotas 1800 e 1900, tornando-se plenos a partir de 2100 m (Figura 1.3B), com exceção de algumas drenagens mais profundas. Nessas áreas são comuns manchas com touceiras de capim de até 2 metros de altura (Machaerina ensifolia e Cortadeira modesta) e de bambuzinho (Chusquea pinifolia e Chusquea microphylla) que podem bloquear a passagem. Nessa região também são comuns a formação de brejos e pequenas lagoas, como o Brejo da Lapa e da nascente do Rio Aiuruoca.

\subsubsection{Aspectos históricos}

Dentre as primeiras regiões de interesse científico do país está o maciço de Itatiaia, que tem merecido atenção de pesquisadores das mais diversas áreas há quase dois séculos. A região possui grande importância histórica, biológica, geomorfológica e geológica, tendo notoriedade em cada uma dessas áreas.

Um dos primeiros cientistas a visitar a região foi o famoso naturalista A. Saint-Hilaire no ano de 1822 em uma viagem de São João Del Rei, MG, para o estado de São Paulo, passando por Aiuruoca e pela escarpa norte da Serra de Itatiaia, de onde coletou várias espécies de plantas. O primeiro trabalho científico realizado no planalto de Itatiaia foi feito por A. F. M. Glaziou em 1872, tendo como membro da expedição a Princesa Izabel, onde foram coletadas numerosas espécies novas de plantas descritas por vários especialistas da época. A primeira referência sobre a fauna da região é dada por E. Ule, em 1894, em um trabalho de botânica dos campos do planalto (Pinto, 1950; Brade, 1956). As primeiras informações sobre a geologia e altimetria da região foram publicadas por Silva $(1876,1882)$, que também foi o primeiro à escalar o Pico das Agulhas Negras, em 1856, sendo considerado o pioneiro 
do alpinismo no Brasil. Lasaulx (1885) faz a primeira menção sobre rochas nefelina sieníticas no Brasil ao descrever amostras de Itatiaia enviadas por H. Bauer (Derby, 1887).

Esses trabalhos pioneiros despertaram o interesse científico para esta área de características peculiares e encravada na região mais populosa do país. Desde então inúmeros outros foram realizados, tanto nas áreas de floresta, quanto nos campos do planalto, especialmente nas áreas da botânica, entomologia, ornitologia e geomorfologia, enquanto a geologia não mereceu a devida atenção.

Com isto, em 1918 foi criada a Estação Biológica do Itatiaia, subordinada ao Jardim Botânico do Rio de Janeiro, a partir de terras adquiridas pelo Governo Federal uma década antes para instalação dos Núcleos Coloniais de Itatiaia e Visconde de Mauá. Em 14 de junho de 1937, através do Decreto no 1.713, a Estação Biológica foi transformada no Parque Nacional de Itatiaia pelo Presidente Getúlio Vargas, sendo assim, o primeiro do Brasil. Inicialmente abrangia área de 119,43 km², mas em 20 de setembro de 1982, através do Decreto no 87.586, foi ampliada para os limites atuais, $280 \mathrm{~km}^{2}$ (www.icmbio.gov.br/parnaitatiaia).

\subsubsection{Trabalhos prévios}

Apesar de suas dimensões e da diversidade litológica presente, o MAI conta com poucos estudos, sendo os últimos dados significativos produzidos há mais de 15 anos.

A primeira referência sobre a geologia do maciço é dada por Silva (1876), que num trabalho descritivo sobre a "montanha" Itatiaia (região do planalto e Agulhas Negras), sugere um "terreno de origem ígnea, granítico". Também sugere uma origem vulcânica, imaginando que os grandes lajedos enegrecidos, os depósitos coluvionares e as características erosões em caneluras e panelas, estas cheias de "cinzas", teriam se formado por processos de "convulsão vulcânica". Já Silva (1882) apresenta informações sobre as rochas, descrevendo uma "espécie de granito" composto de quartzo, feldspato e uma "substância negra formando cristais de bases quadradas", e citando um pórfiro nas vertentes e um "granito áspero de cristais de pontas negras pertencente ao gênero do traquito". Também cita um terreno sulfuroso no Picú (onde há uma fonte de água sulfurosa no bairro Engenho da Serra), com pirita, carbonato de ferro e peróxido de manganês. Esses trabalhos poderiam ter sido os pioneiros, e por um brasileiro, sobre as rochas alcalinas ou mesmo geologia do Brasil, entretanto as informações são vagas e insuficientes, mas possuem seu mérito.

Lasaulx (1885), registrando a primeira ocorrência de rochas nefelina sieníticas no Brasil, descreve duas variedades de rocha, um nefelina sienito de granulação fina e aspecto granítico com ortoclásio, plagioclásio, augita com bordas de hornblenda, nefelina idiomórfica, titanita abundante e alguma biotita, e um nefelina sienito pórfiro com ortoclásio e nefelina intercrescidos, nefelina idiomórfica, e augita, hornblenda e titanita. 
O primeiro estudo dedicado à geologia do maciço, e que perdurou por aproximadamente três décadas, foi feito por Lamego (1936). O autor descreve alguns litotipos, como sienito "nefelínico", sodalita sienito, sienito, foiaito, fonolito porfirítico, nordmarkito e quartzo sienito, com suas localizações aproximadas, algumas fotomicrografias e análises químicas. Associa o magmatismo à formação das bacias terciárias, especialmente de Resende, a partir de observações geomorfológicas e atribui idade do Cretáceo Superior, ou mesmo Eoceno. Também apresenta o primeiro esboço de um mapa geológico, porém toma como afloramentos contíguos de rochas foiaíticas uma área de 1450 km², o colocando como segundo maior maciço alcalino do mundo na época.

Teixeira (1961) sugere, a partir dos padrões de drenagem e feições topográficas, a existência de um espesso dique anelar de tinguaíto na região central do maciço, com forma oval e diâmetro de 8 x $9 \mathrm{~km}$.

Penalva (1967) e Ribeiro Filho (1967) apresentam os únicos trabalhos de maior detalhe da ocorrência, caracterizando petrograficamente os litotipos predominantes e apresentando algumas análises modais e geoquímicas. Também discutem sua gênese, evolução e relação com outros maciços vizinhos, Passa Quatro e Morro Redondo, à luz dos conhecimentos da época. Descrevem uma grande variedade textural e mineralógica de nefelina sienitos, sienitos e quartzo sienitos, além de uma ocorrência local de granito no centro do maciço, brechas magmáticas, diques, tanto máficos quanto félsicos, e milonitos. Apresentam o primeiro mapa geológico (Figura 1.4), que até hoje permaneceu sem modificações maiores. Além disso, definiram seus contatos revelando uma forma alongada, com eixo maior de $30 \mathrm{~km}$ segundo orientação NW-SE e com uma área de aproximadamente $215 \mathrm{~km}^{2}$. Entretanto, representaram uma associação formada por apenas quatro grupos de rocha: nefelina sienitos e sienitos, quartzo sienitos, granito e brechas magmáticas.

Brotzu et al. (1997) fizeram um estudo geral sobre a petrogênese do maciço de Itatiaia, apresentando alguma informação petrográfica, análises químicas dos principais tipos de rocha e de minerais, e análises de isótopos de Sr. Além disso, acrescentam algumas informações ao mapa geológico, separando algumas fácies e indicando algumas estruturas. Com base na mineralogia, relações texturais e geoquímica, separaram as rochas sieníticas em quatro grupos distintos, além do granito e das brechas. Além disso, descreveram alguns diques de fonolito e traquito.

Enrich et al. (2005) e Brotzu et al. (2005) apresentam uma revisão com os dados já existentes e alguns dados isotópicos inéditos, descrevendo modelos petrogenéticos e relações com o desenvolvimento do magmatismo alcalino regional.

Melluso et al. (2016) discutem a evolução de magmas feldspáticos félsicos, revendo dados de Brotzu et al. (1997), e apresentam um estudo detalhado sobre os minerais acessórios ricos em ETRs e HFSE, como rinkite, hiortdahlita, låvenite, wöhlerita, chevkinita, allanite, britholite, monazita, dentre outros. 


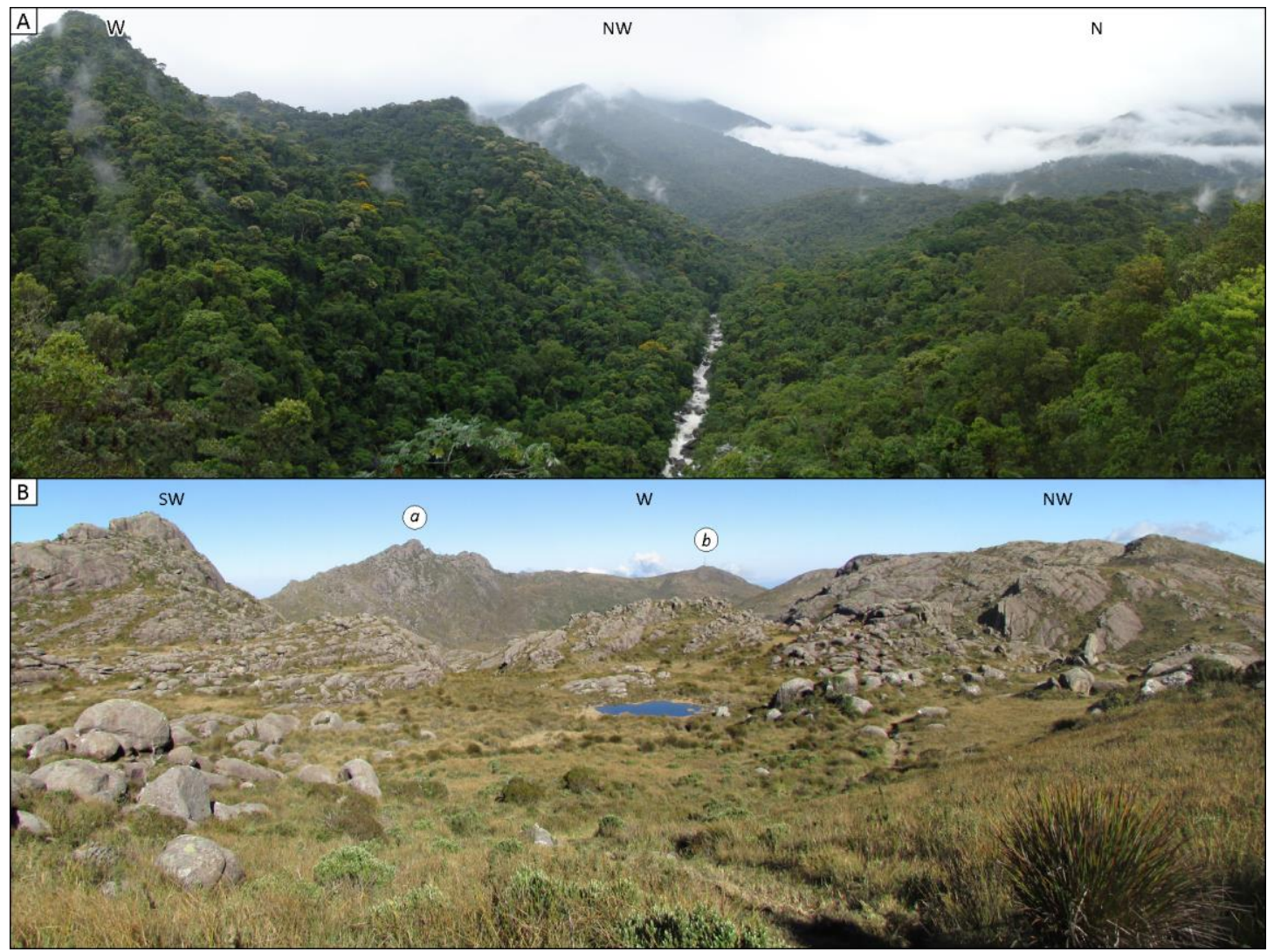

Figura 1.3 - Paisagens representativas do MAI. A) Florestas da região sudeste do maciço, onde ocorrem predominantemente nefelina sienitos. Vista a partir do Mirante do Último Adeus. No centro está o Rio Campo Belo. B) Campos de altitude da região do planalto central do maciço, onde domina sienitos com quartzo. Vista a partir da trilha Rebouças - Rancho Caído próximo à Pedra do Altar. (a) Morro do Couto; (b) Morro da Antena.

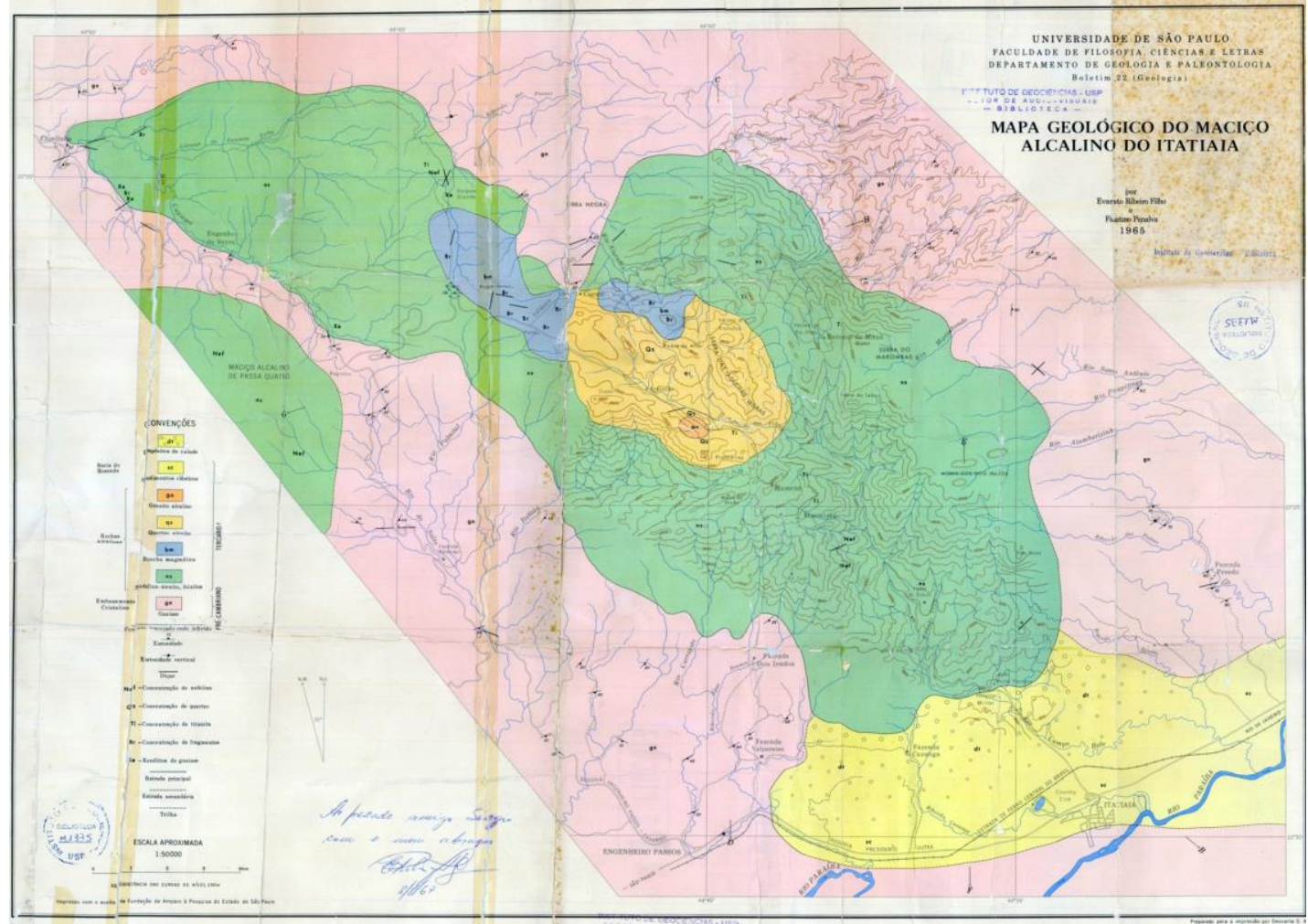

Figura 1.4 - Mapa geológico do Maciço Alcalino de Itatiaia segundo Ribeiro Filho \& Penalva (1965). Legenda: amarelo claro, depósito de talude (com textura de círculos) e sedimentos clásticos; abóbora, granito alcalino; amarelo escuro, quartzo sienito; roxo, brecha magmática; verde, nefelina sienito, foiaítos; rosa, gnaisse. Escala original 1:50.000. 


\section{MATERIAIS E MÉTODOS}

As etapas de trabalho realizadas contaram com estudos bibliográficos, trabalhos de campo, petrografia, análise de química de rocha e mineral, cálculo de parâmetros intensivos, geoquímica isotópica e determinação geocronológica. A seguir são descritos todos os procedimentos adotados na realização deste trabalho.

\subsection{Trabalhos de campo}

Os trabalhos de campo se mostraram muito mais difíceis do que o inicialmente esperado. Além de possuir um grande território $\left(\sim 215 \mathrm{~km}^{2}\right)$, a área de estudo apresenta espessa vegetação, topografia muito acidentada e poucas estradas. Isto exigiu grandes deslocamentos a pé por trilhas, picadas ou caminhos através de lajedos e campos, o que restringiu muito o alcance diário e o respectivo número de afloramentos visitados, principalmente devido ao tempo gasto e ao peso das amostras coletadas. Os trabalhos foram realizados com a valiosa ajuda de um ou dois colegas (estudantes de graduação e pós-graduação) por campo. Foram realizadas dez etapas de seis a doze dias cada, totalizando 86 dias, sendo 66 de trabalho (Tabela 2.1).

O trabalho com veículo em afloramentos na beira da estrada só foi possível no extremo sul do maciço, nas estradas da parte baixa do Parque, ao longo da estrada de acesso ao abrigo Rebouças, na Tabela 2.1 - Etapas de trabalho de campo.

\begin{tabular}{|c|c|c|}
\hline Etapa & Data & Pontos de controle \\
\hline $1 \underline{a}$ & 07 a 17/01/2013 & 001 a 051 \\
\hline $2^{a}$ & $24 / 06$ a 01/07/2013 & 052 a 069 \\
\hline $3 \underline{a}$ & 07 a 14/08/2013 & 070 a 092 \\
\hline $4 \underline{a}$ & 20 a $27 / 08 / 2013$ & 093 a 111 \\
\hline 5 & $24 / 09$ a $01 / 10 / 2013$ & 112 a 130 \\
\hline $6 \underline{a}$ & 16 a $21 / 10 / 2013$ & 131 a 145 \\
\hline $7 \underline{a}$ & $31 / 01$ a 07/02/2014 & 146 a 174 \\
\hline $8^{a}$ & 14 a $21 / 02 / 2014$ & 175 a 200 \\
\hline $9 \underline{a}$ & 22 a 29/05/2014 & 201 a 209 \\
\hline $10^{a}$ & 17 a 28/08/2015 & 210 a 233 \\
\hline
\end{tabular}


região centro-oeste, e em estradas rurais na porção norte. A maior parte do trabalho foi dedicada àparte alta do maciço, onde ocorrem as melhores exposições e as maiores questões petrológicas. Entretanto é uma região com acesso muito difícil, sendo feito quase sempre a pé, caminhando em média de 10 a $15 \mathrm{~km}$ por dia, chegando até $23 \mathrm{~km}$, em muitas vezes com trechos de escalaminhada (caminhada em trilhas de ascensão, onde nos lugares mais difíceis de subir, usa-se as mãos em raízes ou pedras que existem no caminho, sem a necessidade do uso de cordas ou semelhantes). Além disso, algumas trilhas possuem grandes variações altimétricas, sendo comum 200-400 metros de desnível, mas chegando até 1000 metros, ou então ao extremo 1250 metros, na trilha Pico da MarombaCachoeira do Escorrega. A chuva também prejudicou, ou mesmo impossibilitou, alguns dias de trabalho.

Foram visitados 233 pontos de controle, tanto na área aflorante do corpo, como também nas encaixantes e cobertura de tálus, e nominados com o prefixo MAI (Maciço Alcalino de Itatiaia) seguido da numeração sequencial de visitação. Cada afloramento foi devidamente descrito, zelando para o tipo de afloramento, extensão, continuidade, grau de alteração, minerais presentes, estruturas e texturas, e, sempre que possível, feito coleta de amostra para fins de análises laboratoriais. Para maior confiança das informações coletadas foi utilizado um GPS Garmin Oregon 550 (com um erro de 3 a 10 metros) para registrar a localização e altitude dos afloramentos descritos assim como todo o percurso realizado. Como resultado, obteve-se um acervo de 256 amostras representativas. A tabela com as coordenadas de todos os afloramentos visitados, bem como o mapa com suas localizações e as atividades realizadas em cada um encontra-se no ANEXO B (Figura B.1 e Tabela B.1).

Os pontos foram amostrados com pelo menos $~ 500$ metros de distância, salvo em ocasiões de clara mudança litológica ou de relevância petrológica. Ainda assim, quando essas importâncias foram encontradas com menos de 250 metros de distância recebeu uma letra maiúscula sequencial (B, C, D, etc.) ao ponto mais próximo como sufixo. Quando mais de um litotipo foi encontrado dentro de um mesmo ponto (até $~ 50$ metros de raio) adicionou-se apenas um numeral romano como sufixo. Em nenhum lugar foi observado contato direto entre as variações, exceto com alguns diques, sendo notados por mudanças repentinas ou gradativas ao longo de afloramentos.

A metade sul do maciço é marcada por forte desnível com as encaixantes proterozóicas e sedimentos da Bacia de Resende, possuindo praticamente toda a extensão de seu contato coberta por depósitos de tálus. Num primeiro momento foi difícil a identificação de tais depósitos, mas com a percepção da grande variação de litotipos e estruturas sem sentido aparente, aliado às observações geomorfológicas, notou-se realmente não se tratar de rochas in situ. O problema de afloramentos com blocos duvidosamente in situ também ocorreu em alguns lugares no interior do corpo, especialmente na parte baixa onde os desníveis são maiores e a vegetação espessa dificulta uma visão abrangente, no entanto as variações entre esses blocos são poucas ou ausentes, tornado a amostragem 
representativa da área de coleta. Já na parte alta o problema maior deveu-se ao intemperismo das rochas. Há muitos afloramentos na forma de grandes lajedos ou maciços rochosos (como Agulhas Negras e Pedra do Sino), porém quase sempre estão razoavelmente alterados, tornando difícil a coleta de amostra para fins geoquímicos e isotópicos.

Como parte da área de estudo está dentro do Parque Nacional de Itatiaia (PNI), este trabalho obteve autorização de pesquisa e coleta de amostras abióticas concedida pelo Sisbio sob a inscrição № 36806-3. As atividades de campo também contaram com o apoio do PNI. Houve uma recomendação para não abrir novas trilhas e ser cauteloso com a vegetação, especialmente espécies protegidas. A coleta de amostras foi realizada fora do caminho e longe da vista dos turistas, para causar o mínimo de impacto visual, assim como pontos de visitação e formações de interesse turísticos foram poupados.

\subsection{Cartografia e sensoriamento remoto}

O mapa de Ribeiro Filho \& Penalva (1965; Figura 1.4) foi utilizado como base geológica a partir do qual traçou-se as estratégias de reconhecimento de campo, e nas áreas sem informação procurouse respeitar os limites definidos pelos autores. Apesar de ter sido elaborado sem as facilidades tecnológicas contemporâneas, mal contando com uma carta topográfica completa e de detalhe, o mapa apresenta os limites razoavelmente bem alocados, assim como as divisões internas dos grupos petrológicos. Entretanto possui detalhamento e precisão insuficientes para a complexidade do maciço e escala apresentada.

As unidades litológicas foram definidas de acordo com as características petrográficas (textura e mineralogia acessória principalmente) e geoquímica, seguindo as feições estruturais, características geomorfológicas e ocorrência geográfica, de modo que cada uma é interpretada como sendo um pulso e/ou evento magmático distinto. Algumas unidades possuem variações faciológicas internas, porém foram interpretadas como possuindo correlação-genética íntima, e por isso, mantidas unidas. As unidades possuem continuidade mapeável na escala apresentada e muitas mostram diferenças óbvias com as unidades adjacentes. A parte alta do maciço, região central do mapa, está melhor detalhada devido à maior densidade de afloramentos descritos, além de maior exposição de rochas e padrões geomorfológicos bem definidos, o que facilitou as interpretações das imagens de satélite.

O mapa elaborado tem como base o modelo digital de terreno ASTER GDEM ASTGTM2_S23W045 com resolução de 30 metros (ASTER GDEM é um produto de METI e NASA), que possibilitou avaliar os padrões geomorfológicos, gradientes altimétricos, declividades e drenagens utilizando o programa Global Mapper 13. Essas informações têm grande importância devido à extensa amplitude altimétrica, padrões de falhamentos e feições topográficas típicas de complexos anelares, 
sendo essenciais para o reconhecimento de unidades geomorfológicas e os consequentes litotipos associados.

Imagens de satélite obtidas pelo software Google Earth (Google Earth, 2015) também foram de grande valia, pois possuem boa resolução em toda a área de estudo. Na parte alta onde predomina lajedos e maciços rochosos foi possível visualizar alguns possíveis contatos, padrões de fraturamento e estruturas. Também auxiliaram na delimitação de depósitos aluvionares, localidades, e identificação de pontos de referência, estradas e trilhas. Imagens Landsat 8 (Cortesia da U. S. Geological Survey) também foram utilizadas para identificação de algumas feições geomorfológicas e vegetação, ainda com tratamento simples de bandas.

O mapa regional com as ocorrências dos maciços alcalinos da Província Serra do Mar (cf. Almeida, 1983, 1991; Schobbenhaus et al., 1984) (apresentado no item 3.3.1) resultou da compilação, com algumas modificações, a partir de várias fontes bibliográficas: embasamento regional (Leite et al., 2004; Valeriano et al., 2011; Alves et al., 2015; Cioffi et al., 2015; Janasi et al., 2015), tectônica cenozóica (Meisling \& Cob, 2001; Zalán \& Oliveira, 2005), maciços alcalinos (Almeida, 1983, 1991; Motoki, 1986; Bellieni et al., 1990; Ferrari, 2001; Chiessi, 2004; Trouw et al., 2007; Brotzu et al., 2007; Heilbron et al., 2007; Azzone et al., 2009; Enrich et al., 2009; Guarino et al., 2011; Rosa, 2012).

O tratamento das informações cartográficas (dados do aparelho GPS, imagens de satélite, modelo digital de terreno) foi realizado utilizando o programa de georreferenciamento Global Mapper 13 e retrabalhado em um programa de edição gráfica Corel Draw X7.

\subsection{Petrografia}

Inicialmente foram descritas macroscopicamente todas as amostras disponíveis, seguindo-se de uma seleção das variedades representativas para fins de estudos microscópicos pormenorizados. A investigação petrográfica teve por finalidade a identificação e a caracterização das principais feições macro e microscópicas das fácies presentes no maciço. Para tanto foram utilizados critérios de cor, heterogeneidades texturais, estruturas, granularidade, granulação e paragênese. No estudo microscópico, as observações foram direcionadas às paragêneses nos diferentes estágios magmáticos, à diversidade mineralógica e aos aspectos texturais como granularidade e microestruturas.

Foram confeccionadas 120 seções delgadas com $30 \mu \mathrm{m}$ de espessura e coberta com lamínula e descritas em um microscópio Zeiss Axioplan, com objetivas possibilitando aumentos de 2,5, 10, 20 e 40 vezes, pertencente ao Laboratório de Microscopia Petrográfica do Departamento de Mineralogia e Geotectônica do Instituto de Geociências da Universidade de São Paulo. O registro fotomicroscópico das características mineralógicas, texturais e microestruturais mais relevantes foram realizadas em um microscópio Zeiss Axio Imager.A2m acoplado a uma câmera modelo AxioCamMR3 com distância focal 
de $35 \mathrm{~mm}$ e obtidas em um programa dedicado AxioVision 4.9.1 SP1, e tratadas no programa Corel Draw X7.

Análises modais foram realizadas em 21 amostras selecionadas, utilizando-se um Charriot acoplado ao microscópio petrográfico e um contador de pontos. Foram levantados em cada uma das lâminas 30 perfis de 70 pontos cada, totalizando assim 2100 pontos. A distância adotada entre os pontos foi de $0,5 \mathrm{~mm}$, assim como para o espaçamento entre os perfis, abrangendo assim uma área de $5,75 \mathrm{~cm}^{2}$. Os minerais identificados nas lâminas, mas não computados, são marcados como mineral traço (tr). Os minerais ausentes estão em branco. O menor valor modal representado é de 0,048\%, expresso pela contagem de 1 ponto, e foram arredondados para dois algarismos significativos.

As unidades foram denominadas segundo a classificação modal das amostras predominantes (ANEXO C) seguindo-se as recomendações de Le Maitre (2002). Minerais acessórios importantes (> 5\% em teor modal) e/ou texturas características foram adicionadas ao nome como um distintivo. Quando definido o mesmo nome foi adicionado um numeral romano apenas para distinção, sem conotação petrológica. Os termos nordmarkito e pulaskito são utilizados como sinônimos de álcali feldspato sienito, respectivamente com quartzo e com nefelina, assim como alaskito, sinônimo de álkali feldspato granito leucocrático (Le Maitre, 2002).

\subsection{Química mineral}

Foram escolhidas 20 amostras representativas de diversas unidades para a confecção das lâminas polidas (com espessura de $90 \mu \mathrm{m}$ ) e determinação química e caracterização dos minerais. Análises pontuais quantitativas por WDS foram realizadas nos seguintes minerais: feldspato, nefelina, sodalita, analcima, clinopiroxênio, anfibólio, titanita, biotita, ilmenita, espinélio, coríndon e alguns minerais raros. Já as análises por EDS foram direcionadas preferencialmente para a caracterização dos minerais acessórios de ocorrência rara, com vistas à identificação qualitativa da composição mineralógica mais segura, como também do grupo mineral ao qual pertence.

Os trabalhos foram efetuados no Laboratório de Microssonda Eletrônica do Núcleo de Apoio à Pesquisa Geoanalítica - USP, empregando-se instrumental de fabricação JEOL JXA-FE-8530F, com canhão eletrônico suportado por Field Emission (FE). As análises foram realizadas com um potencial de aceleração de $15 \mathrm{kV}$ e corrente do feixe eletrônico de $20 \mathrm{nA}$, com diâmetro do feixe de $5 \mu \mathrm{m}$. Espinélio e ilmenita foram analisados com o diâmetro de $1 \mu \mathrm{m}$, enquanto feldspato alcalino, nefelina sodalita e analcima, com $10 \mu \mathrm{m}$ sempre que possível. Todos os pontos de análise foram realizados com base em imagem composicional (BEI-COMPO) simultânea, possuindo assim um preciso controle textural. Os dados foram corrigidos pelo programa CITZAF (Armstrong, 1991). As configurações utilizadas, os tempos de contagem e os padrões para cada rotina se encontram na Tabela 2.2. 
Tabela 2.2 - Configuração dos espectrômetros da microssonda eletrônica para análise química dos minerais. L, linha; $\mathrm{CH}$, canal; $\mathrm{P}$, tempo de contagem no pico; $\mathrm{Bg}$, tempo de contagem para medida do backgound. * Fe medido como $\mathrm{Fe}_{2} \mathrm{O}_{3}$.

\begin{tabular}{|c|c|c|c|c|c|c|c|c|c|c|c|c|c|c|c|}
\hline Óxido & $\mathbf{L}$ & Cristal & $\mathrm{CH}$ & $\mathbf{P}$ & $\mathrm{Bg}$ & Padrão & $\mathbf{P}$ & $\mathrm{Bg}$ & Padrão & $\mathbf{P}$ & $\mathrm{Bg}$ & Padrão & $\mathbf{P}$ & $\mathrm{Bg}$ & Padrão \\
\hline & & & & \multicolumn{3}{|c|}{ Feldspato e nefelina } & \multicolumn{2}{|c|}{ Piroxênio } & & \multicolumn{2}{|c|}{ Anfibólio } & & \multicolumn{2}{|c|}{ Biotita } & \\
\hline $\mathrm{SiO}_{2}$ & $\mathrm{~K} \alpha$ & TAP & 1 & 10 & 5 & anorthoclase & 10 & 5 & diopside & 10 & 5 & wollastonite & 10 & 5 & diopside \\
\hline $\mathrm{Al}_{2} \mathrm{O}_{3}$ & $\mathrm{~K} \alpha$ & TAP & 1 & 15 & 7.5 & anorthite & 15 & 7.5 & anorthite & 15 & 7.5 & anorthite & 15 & 7.5 & anorthite \\
\hline $\mathrm{Y}_{2} \mathrm{O}_{3}$ & La & TAP & 1 & & & & & & & & & & & & \\
\hline $\mathrm{FeO}$ & $\mathrm{K} \alpha$ & LIFL & 2 & 10 & 5 & fayalite * & 10 & 5 & fayalite & 10 & 5 & fayalite & 10 & 5 & fayalite \\
\hline $\mathrm{MnO}$ & $\mathrm{K} \alpha$ & LIFL & 2 & 40 & 20 & fayalite & 40 & 20 & fayalite & 40 & 20 & fayalite & 40 & 20 & fayalite \\
\hline $\mathrm{ZnO}$ & $\mathrm{K} \alpha$ & LIFL & 2 & & & & & & & & & & 40 & 20 & gahnite \\
\hline $\mathrm{Cl}$ & $\mathrm{K} \alpha$ & PETJ & 3 & & & & & & & 10 & 5 & sodalite & 10 & 5 & sodalite \\
\hline $\mathrm{K}_{2} \mathrm{O}$ & $\mathrm{K} \alpha$ & PETJ & 3 & 10 & 5 & ortoclase & 10 & 5 & ortoclase & 10 & 5 & ortoclase & 10 & 5 & ortoclase \\
\hline $\mathrm{CaO}$ & $\mathrm{K} \alpha$ & PETJ & 3 & 20 & 10 & wollastonite & 20 & 10 & wollastonite & 20 & 10 & wollastonite & 10 & 5 & wollastonite \\
\hline $\mathrm{ZrO}_{2}$ & $\mathrm{~L} \alpha$ & PETJ & 3 & & & & 50 & 25 & zircon & & & & & & \\
\hline SrO & $\mathrm{L} \alpha$ & PETJ & 3 & 40 & 20 & strontianite & & & & & & & & & \\
\hline $\mathrm{TiO}_{2}$ & $\mathrm{~K} \alpha$ & LIFL & 4 & 10 & 5 & rutile & 10 & 5 & rutile & 10 & 5 & rutile & 10 & 5 & rutile \\
\hline $\mathrm{Cr}_{2} \mathrm{O}_{3}$ & $\mathrm{~K} \alpha$ & LIFL & 4 & & & & 10 & 5 & chromite & & & & & & \\
\hline $\mathrm{ZnO}$ & $\mathrm{K} \alpha$ & LIFL & 4 & & & & & & & 40 & 20 & willemite & & & \\
\hline $\mathrm{BaO}$ & $\mathrm{L} \alpha$ & LIFL & 4 & 30 & 15 & benitoite & & & & & & & 30 & 15 & benitoite \\
\hline $\mathrm{F}$ & $\mathrm{K} \alpha$ & TAPH & 5 & & & & & & & 10 & 5 & fluorapatite & 10 & 5 & fluorapatite \\
\hline $\mathrm{Na}_{2} \mathrm{O}$ & $\mathrm{K} \alpha$ & TAPH & 5 & 10 & 5 & albite & 10 & 5 & albite & 10 & 5 & albite & 10 & 5 & albite \\
\hline $\mathrm{MgO}$ & $\mathrm{K} \alpha$ & TAPH & 5 & 10 & 5 & diopside & 10 & 5 & diopside & 10 & 5 & diopside & 10 & 5 & diopside \\
\hline
\end{tabular}

\begin{tabular}{|c|c|c|c|c|c|c|c|c|c|c|c|c|}
\hline Óxido & $\mathbf{L}$ & Cristal & $\mathrm{CH}$ & $\mathbf{P}$ & $\mathrm{Bg}$ & Padrão & $\mathbf{P}$ & $\mathrm{Bg}$ & Padrão & $\mathbf{P}$ & $\mathrm{Bg}$ & Padrão \\
\hline & & & \multicolumn{4}{|c|}{ Titanita e minerais raros } & \multicolumn{2}{|c|}{ Espinélio } & \multicolumn{4}{|c|}{ Ilmenita } \\
\hline $\mathrm{SiO}_{2}$ & $\mathrm{~K} \alpha$ & TAP & 1 & 10 & 5 & diopside & 10 & 5 & diopside & 20 & 10 & diopside \\
\hline $\mathrm{Al}_{2} \mathrm{O}_{3}$ & $\mathrm{~K} \alpha$ & TAP & 1 & 15 & 7.5 & anorthite & 15 & 7.5 & anorthite & 20 & 10 & anorthite \\
\hline $\mathrm{Y}_{2} \mathrm{O}_{3}$ & $\mathrm{~L} \alpha$ & TAP & 1 & 50 & 25 & yttrium-phosphate & & & & & & \\
\hline $\mathrm{FeO}$ & $\mathrm{K} \alpha$ & LIFL & 2 & 10 & 5 & fayalite & 10 & 5 & hematite * & 10 & 5 & ilmenite \\
\hline $\mathrm{MnO}$ & $\mathrm{K} \alpha$ & LIFL & 2 & 40 & 20 & fayalite & 40 & 20 & ilmenite & 40 & 20 & ilmenite \\
\hline $\mathrm{La}_{2} \mathrm{O}_{3}$ & $\mathrm{~L} \alpha$ & LIFL & 2 & 50 & 25 & lanthanium-phosphate & & & & & & \\
\hline $\mathrm{K}_{2} \mathrm{O}$ & $\mathrm{K} \alpha$ & PETJ & 3 & 20 & 10 & ortoclase & 10 & 5 & ortoclase & 20 & 10 & ortoclase \\
\hline $\mathrm{CaO}$ & $\mathrm{K} \alpha$ & PETJ & 3 & 10 & 5 & wollastonite & 20 & 10 & wollastonite & 20 & 10 & wollastonite \\
\hline $\mathrm{Nb}_{2} \mathrm{O}_{5}$ & $\mathrm{~L} \alpha$ & PETJ & 3 & 60 & 30 & magnetite & 40 & 20 & magnetite & 40 & 20 & ilmenite \\
\hline $\mathrm{ZrO}_{2}$ & $\mathrm{~L} \alpha$ & PETJ & 3 & 50 & 25 & zircon & & & & & & \\
\hline $\mathrm{TiO}_{2}$ & $\mathrm{~K} \alpha$ & LIFL & 4 & 10 & 5 & rutile & 5 & 2.5 & ilmenite & 5 & 2.5 & ilmenite \\
\hline $\mathrm{Cr}_{2} \mathrm{O}_{3}$ & Ka & LIFL & 4 & & & & 10 & 5 & chromite & 40 & 20 & chromite \\
\hline $\mathrm{ZnO}$ & $\mathrm{K} \alpha$ & LIFL & 4 & & & & 40 & 20 & willemite & 40 & 20 & willemite \\
\hline $\mathrm{BaO}$ & $\mathrm{L} \alpha$ & LIFL & 4 & 30 & 15 & benitoite & & & & & & \\
\hline $\mathrm{Ce}_{2} \mathrm{O}_{3}$ & $\mathrm{~L} \alpha$ & LIFL & 4 & 30 & 15 & cerium-phosphate & & & & & & \\
\hline $\mathrm{Nd}_{2} \mathrm{O}_{3}$ & $\mathrm{~L} \alpha$ & LIFL & 4 & 50 & 25 & neodymium-phosphate & & & & & & \\
\hline $\mathrm{F}$ & $\mathrm{K} \alpha$ & TAPH & 5 & 10 & 5 & fluorapatite & & & & & & \\
\hline $\mathrm{Na}_{2} \mathrm{O}$ & $\mathrm{K} \alpha$ & TAPH & 5 & 10 & 5 & albite & 10 & 5 & albite & 40 & 20 & albite \\
\hline $\mathrm{MgO}$ & $\mathrm{K} \alpha$ & TAPH & 5 & 10 & 5 & diopside & 10 & 5 & diopside & 40 & 20 & diopside \\
\hline
\end{tabular}


Os padrões utilizados anorthite, anorthoclase, benitoite, cerium-phosphate, chromite, diopside, fayalite, gahnite, ilmenite, lanthanium-phosphate, magnetite, neodymium-phosphate, strontianite e yttrium-phosphate são procedentes da Smithsonian Institution (Jarosewich, 2002), e os padrões albite, fluorapatite, hematite, ortoclase, rutile, sodalite, willemite, wollastonite e zircon são da Geller (disponível em www.gellermicro.com/standards/uhv-el.htm).

O cálculo do número de cátions e fórmulas estruturais para feldspato, nefelina, biotita e titanita foram realizados segundo Deer et al. (1992). O cálculo das proporções de $\mathrm{Fe}^{2+} / \mathrm{Fe}^{3+}$ a partir do $\mathrm{FeO}_{\text {total }}$ para o clinopiroxênio aplicou-se o procedimento de Droop (1987), e a classificação química foi feita segundo Morimoto (1988). Para o anfibólio utilizou-se a planilha de Locock (2014) segundo Hawthorne et al. (2012). E para os óxidos seguiu-se os procedimentos de Carmichael (1967).

Os dados foram tratados no programa Excel 2013 segundo procedimentos recomendados pela IMA (International Mineralogical Association) e amplamente utilizados para cada mineral. Além disso, os diagramas de classificação e variações composicionais foram elaborados no programa GCDkit (Janoušek et al., 2006) e editados no Corel Draw X7.

\subsubsection{Determinação dos parâmetros intensivos}

Os trabalhos de determinação da química mineral para o cálculo dos parâmetros intensivos, e seu conseqüente tratamento e interpretação, foram realizados no Laboratório de Microssonda Eletrônica do Departamento de Geociências da Universidade de Tübingen, Alemanha, em colaboração com o Dr. Michael Marks. Esta atividade foi desenvolvida como parte do programa Bolsa Estágio de Pesquisa no Exterior (BEPE; Proc. 2015/19974-0) da FAPESP no período de 05 de novembro de 2015 a 07 de janeiro de 2016.

Dez amostras com a paragênese bem definida foram escolhidas dentre às analisadas anteriormente. Imagens de elétron retroespalhado (BSE) dos cristais alvo (titanomagnetita, ilmenita, clinopyroxênio e feldspato) foram obtidas em um microscópio eletrônico de varredura (SEM) do tipo bancada do modelo TM3030 Hitachi, no mesmo departamento. Novas microanálises quantitativas por WDS foram realizadas em um equipamento JEOL 8900 Superprobe daquela universidade, em nefelina, feldspato alcalino, plagioclásio, piroxênio, titanomagnetita, ilmenita e andradita. As configurações utilizadas e os tempos de contagem para cada rotina se encontram na Tabela 2.3.

Nos cristais de titanomagnetita com exsoluções finas, realizaram-se três análises por cristal com um diâmetro do feixe de $20 \mu \mathrm{m}$, focado nos locais mais homogêneos possíveis, para obter-se a média como uma composição global do cristal. Nos cristais com lamelas de exsolução mais grossas, analisou-se se três pontos separadamente na magnetita hospedeira e nas lamelas de ilmenita, com um feixe de $1 \mu \mathrm{m}$. A composição de cada cristal foi recalculada considerando-se a proporção da área 
Tabela 2.3 - Configuração dos espectrômetros da microssonda eletrônica para análise química dos minerais com vistas à determinação dos parâmetros intensivos.

\begin{tabular}{|c|c|c|c|c|c|}
\hline & Elemento & Cristal & Canal & Padrão & Condição \\
\hline \multirow{8}{*}{$\begin{array}{l}0 \\
\frac{0}{0} \\
\frac{0}{0} \\
\frac{0}{0} \\
\frac{0}{0} \\
\frac{1}{4}\end{array}$} & Al & TAP & 1 & A_Plagioklas & Al1TBa \\
\hline & $\mathrm{Na}$ & TAP & 2 & A_Albit & Na2TEU \\
\hline & Si & TAP & 2 & A_Plagioklas & $\mathrm{Si} 2 \mathrm{TS} r$ \\
\hline & K & PETJ & 3 & A_Sanidin & K3P \\
\hline & $\mathrm{Ca}$ & PETJ & 3 & A_Plagioklas & Ca3PJ \\
\hline & $\mathrm{Sr}$ & PETH & 4 & A_SrTiO3 & $\mathrm{Sr} 4 \mathrm{PH}$ \\
\hline & $\mathrm{Ba}$ & PETH & 4 & A_Baryt & Ba4PH \\
\hline & $\mathrm{Fe}$ & LIFH & 4 & A_Haematite & $\mathrm{Fe} 4 \mathrm{LH}$ \\
\hline \multirow{10}{*}{ 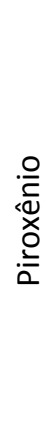 } & $\mathrm{Na}$ & TAP & 1 & A_Albit & $\mathrm{Na1T}$ \\
\hline & $\mathrm{Mg}$ & TAP & 1 & A_Diopsid & Mg1Tox \\
\hline & Al & TAP & 2 & A_Plagioklas & $\mathrm{Al} 2 \mathrm{~T}$ \\
\hline & Si & TAP & 2 & A_Diopsid & $\mathrm{Si} 2 \mathrm{~T}$ \\
\hline & $\mathrm{Ca}$ & PETJ & 3 & A_Diopsid & Ca3PJ \\
\hline & $\mathrm{Mn}$ & PETJ & 3 & A_Rhodonit & Mn3PJ \\
\hline & $\mathrm{Fe}$ & $\mathrm{LiF}$ & 3 & A_Haematit & Fe3Lpy \\
\hline & K & PETH & 4 & A_Sanidin & K4PHmn \\
\hline & $\mathrm{Ti}$ & PETH & 4 & A_SrTiO3 & Ti4P \\
\hline & $\mathrm{Zr}$ & PETH & 4 & A_ZrO2 & ZrP4 \\
\hline \multirow{9}{*}{$\begin{array}{l}\text { on } \\
\frac{0}{x} \\
\text { Oे }\end{array}$} & Si & TAP & 1 & A_Diopsid20 & Si1Tox \\
\hline & Al & TAP & 2 & S_Al2O320 & Al2Tmn \\
\hline & $\mathrm{Mg}$ & TAP & 2 & A_Diopsid20 & $\mathrm{Mg} 2 \mathrm{~T}$ \\
\hline & $\mathrm{Ti}$ & PETJ & 3 & A_SrTiO320 & Ti3P \\
\hline & $\mathrm{Ca}$ & PETJ & 3 & A_Diopsid20 & Cr3PJ \\
\hline & $\mathrm{Nb}$ & PETJ & 3 & S_LiNb0620 & $\mathrm{Nb}$ \\
\hline & $\mathrm{Zn}$ & LIFH & 4 & M_Zn20 & $\mathrm{ZnSp}$ \\
\hline & $\mathrm{Fe}$ & LIFH & 4 & A_Hematit20 & Fe4LH \\
\hline & $\mathrm{Mn}$ & LIFH & 4 & A_Rhodonit20 & Mn4LH \\
\hline
\end{tabular}

e os volumes molares das fases exsolvidas, sendo 31,70 e $44,52 \mathrm{~cm}^{3} / \mathrm{mol}$ para ilmenita e magnetita, respectivamente. No feldspato alcalino pertítico utilizou-se o mesmo processo, considerando os volumes molares de 100,05 e 108,28 cm $3 / \mathrm{mol}$ para albita e ortoclásio, respectivamente. No entanto, as lamelas de albita foram analisadas com um diâmetro do feixe de $10 \mu \mathrm{m}$ (para reduzir o efeito da migração de $\mathrm{Na}$ ) e ortoclásio com $5 \mu \mathrm{m}$. As estimativas de área foram feitas no programa de edição de imagens Corel Photo Paint X7.

As atividades dos membros finais da assembleia QUILF (quartzo, ulvöespinélio, ilmenita e fayalita) nas temperaturas de interesse foram calculadas no programa QUILF (Andersen et al., 1993) baseados no modelo de Davidson \& Mukhopadhyay (1984). Para o cálculo das atividades de nefelina foi aplicado o modelo on-site mixing, e para albita em feldspato alcalino e jadeíta em clinopiroxênio foram aplicados os modelos de atividade de Holland \& Powell (2003) e Holland (1990), respectivamente. A atividade do componente Ca-Tchermak em clinopiroxênio foi calculado segundo o modelo de Wood (1979). O componente andradita em granada foi calculado segundo Locock (2008) e 
sua atividade segundo Cosca et al. (1986). Os valores máximo e mínimo (e eventuais discrepâncias) das atividades foram consideradas para o cálculo para temperaturas de 800 e $900^{\circ} \mathrm{C}$ e pressão de 1 kbar, exceto para nefelina e Ca-Tchermak em clinopiroxênio, que não possuem modelos termodinâmicos desenvolvidos. Para as rochas com quartzo, a atividade de sílica é igual a um, enquanto que para as rochas insaturadas em sílica este valor é menor do que um, tendo sido calculado para cada amostra. A atividade de titanita foi considerada igual a um.

As curvas de atividades de sílica foram calculadas pelo equilíbrio nefelina - albita (em feldspato alcalino) - jadeíta (em clinopiroxênio) e anortita (em plagioclásio) - Ca-Tschermak e as curvas de fugacidade de oxigênio pelo equilíbrio hedenbergita - magnetita - ilmenita - titanita através do programa GEOCALC Berman et al. (1987) e Lieberman \& Petrakakis (1991), com o banco de dados de Berman (1988). O cálculo das curvas de buffer e a estimativa dos parâmetros intensivos foi realizada através do programa QUILF (Andersen et al., 1993).

\subsection{Geoquímica elemental}

Foram realizadas análises químicas de rocha total utilizando-se fluorescência de Raios-X, para determinação dos elementos maiores e alguns traços, e ICP-AES-MS, para a maioria dos elementos traços e terras raras, junto aos laboratórios AcmeLabs, Vancouver, Canadá, Laboratório de Geologia Isotópica do Departamento de Geologia e Recursos Naturais da UNICAMP, e Laboratórios de Fluorescência de Raios-X e de Química e ICP-AES/MS do Núcleo de Apoio à Pesquisa Geoanalítica-USP.

Com base nas descrições petrográficas e no mapa de localização foram selecionadas 82 amostras de litotipos representativos do MAI, além de 3 amostras de encaixantes locais. Desse elenco, 34 amostras foram escolhidas para determinação de elementos traços e terras raras.

\subsubsection{Preparação das amostras}

As amostras foram processadas nos Laboratórios de Tratamento de Amostras (LTA) do Núcleo de Apoio à Pesquisa Geoanalítica-USP, respeitando-se cada procedimento de trabalho e limpeza de utensílios e equipamentos pertinentes, a fim de se evitar contaminações e alterações nos resultados. Em todas as etapas (exceto na separação de minerais para geocronologia) foram preparadas primeiramente uma fração de descarte, prosseguindo com a fração definitiva após nova limpeza dos aparelhos.

Retirou-se das amostras quaisquer superfícies de alteração que pudessem adulterar as condições magmáticas, como capa de intemperismo, fraturas impregnadas de minerais secundários e veios. É importante salientar que também se teve o cuidado de excluir as faces serradas das amostras a fim de diminuir a contaminação causada pela serra, especialmente por chumbo. O volume 
processado foi considerado um sólido com arestas aproximadamente dez vezes maior que o maior cristal da amostra em questão.

As amostras foram: I) fragmentadas com martelo e marreta; II) reduzidas em uma prensa pneumática; III) quarteadas manualmente; IV) e pulverizadas em um moinho de anéis de ágata, por um tempo aproximado de 10 minutos até uma granulação de 200 mesh. As amostras de granulação mais grossa porfiríticas ou com textura heterogênea, assim como aquelas selecionadas para análises isotópicas e geocronológicas, foram preparadas em maior volume, sendo fragmentadas em um britador.

\subsubsection{Análises laboratoriais}

Oitenta e uma amostras em pó foram enviadas ao laboratório Acmelabs em Vancouver, Canadá. Os elementos maiores, menores e alguns traços foram analisados por fluorescência de raios$X$ com fundente $\mathrm{Li}_{2} \mathrm{~B}_{4} \mathrm{O}_{7} / \mathrm{LiBO}_{2}$ através da rotina LF702-EXT do catálogo do laboratório (http://acmelab.com/pdfs/FeeSchedule-2015.pdf). Quarenta elementos traços foram analisados por ICP-AES e ICP-MS com digestão por multi-ácido à quente através da rotina MA270. Inicialmente foi escolhido uma rotina de análise de elementos traço por FRX em pastilha prensada, que incluía apenas 8 elementos. Entretanto, com as amostras já em mãos, o laboratório informou que a rotina tinha sido extinta e sugeriu a utilização dessa última por ICP sem prejuízo ao projeto.

Dessas, trinta amostras foram selecionadas (MAI022BI, MAI030, MAI036, MAI046E, MAI053I, MAI053II, MAI070B, MAI090, MAI092I, MAI092II, MAI097B, MAI107, MAI108II, MAI110, MAI112B, MAI114, MAl122, MAI130, MAI133, MAl136, MAl148, MAI160, MAl16, MAI165, MAI166I, MAl166II, MAI178, MAI182C, MAI199 e MAI204) para a análise dos elementos terras-raras via ICP-MS junto ao Laboratório de Geologia Isotópica do Departamento de Geologia e Recursos Naturais da UNICAMP em Campinas. As amostras foram dissolvidas utilizando uma mistura de ácidos nítrico e fluorídrico em bombas tipo Parr. Todas soluções foram preparadas com água ultra-pura $(18,2 \mathrm{M} \Omega . \mathrm{cm})$, obtida por sistema Milli-Q. $\mathrm{O}$ ácido nítrico $\left(\mathrm{HNO}_{3}\right)$ foi purificado por sub-ebulição. Os frascos utilizados para as diluições foram previamente limpos com $\mathrm{HNO}_{3} 5 \%$ e enxaguados com água ultra-pura. $\mathrm{O}$ limite de detecção (LD) foi determinado como sendo a média (x) mais três desvios-padrão (s) de dez medidas do branco $(L D=x+3 s)$. As medições foram realizadas em ICP-MS $X$ seriesIl (Thermo) equipado com CCT (Collision Cell Technology). Antes das medidas o instrumento foi ajustado, conforme recomendado pelo fabricante. Os isótopos ${ }^{7} \mathrm{Li},{ }^{9} \mathrm{Be},{ }^{45} \mathrm{Sc},{ }^{71} \mathrm{Ga},{ }^{89} \mathrm{Y},{ }^{91} \mathrm{Zr},{ }^{93} \mathrm{Nb},{ }^{95} \mathrm{Mo},{ }^{133} \mathrm{Cs},{ }^{137} \mathrm{Ba},{ }^{139} \mathrm{La},{ }^{140} \mathrm{Ce},{ }^{141} \mathrm{Pr},{ }^{143} \mathrm{Nd}$, ${ }^{147} \mathrm{Sm},{ }^{151} \mathrm{Eu},{ }^{157} \mathrm{Gd},{ }^{159} \mathrm{~Tb},{ }^{163} \mathrm{Dy},{ }^{165} \mathrm{Ho},{ }^{166} \mathrm{Er},{ }^{169} \mathrm{Tm},{ }^{172} \mathrm{Yb},{ }^{175} \mathrm{Lu},{ }^{180} \mathrm{Hf},{ }^{181} \mathrm{Ta},{ }^{182} \mathrm{~W},{ }^{208} \mathrm{~Pb},{ }^{209} \mathrm{Bi}^{232} \mathrm{Th},{ }^{238} \mathrm{U}$ foram medidos na configuração normal. Os isótopos ${ }^{51} \mathrm{~V},{ }^{52} \mathrm{Cr},{ }^{59} \mathrm{Co},{ }^{60} \mathrm{Ni},{ }^{63} \mathrm{Cu},{ }^{66} \mathrm{Zn},{ }^{85} \mathrm{Rb},{ }^{88} \mathrm{Sr},{ }^{114} \mathrm{Cd}$, ${ }^{118} \mathrm{Sn}$ e ${ }^{121} \mathrm{Sb}$ foram medidos com a CCT. A calibração do instrumento foi efetuada com soluções multielementares preparadas gravimetricamente a partir de soluções-padrão monoelementares de 
$100 \mathrm{mg} / \mathrm{L}$ (AccuStandards). O controle de qualidade foi efetuado pela análise dos materiais de referência: GS-N (granito) e BRP-1 (basalto)

Para essas amostras selecionadas também se considerou os resultados dos demais elementos traço, pois entendeu-se que são mais confiáveis (em termos de cuidados metodológicos para fins acadêmicos), além de maior precisão e limites de deteç̧ão menores. Isso é especialmente importante para os elementos $\mathrm{Sr}, \mathrm{Rb}, \mathrm{Sm}, \mathrm{Nd}, \mathrm{U}$, Th e $\mathrm{Pb}$, por serem utilizados como parâmetros dos sistemas isotópicos, bem como mais sensíveis à propagação de erros. Os diagramas da Figura 2.1 comparam os resultados químicos das amostras analisadas nos dois laboratórios, onde no geral há uma boa
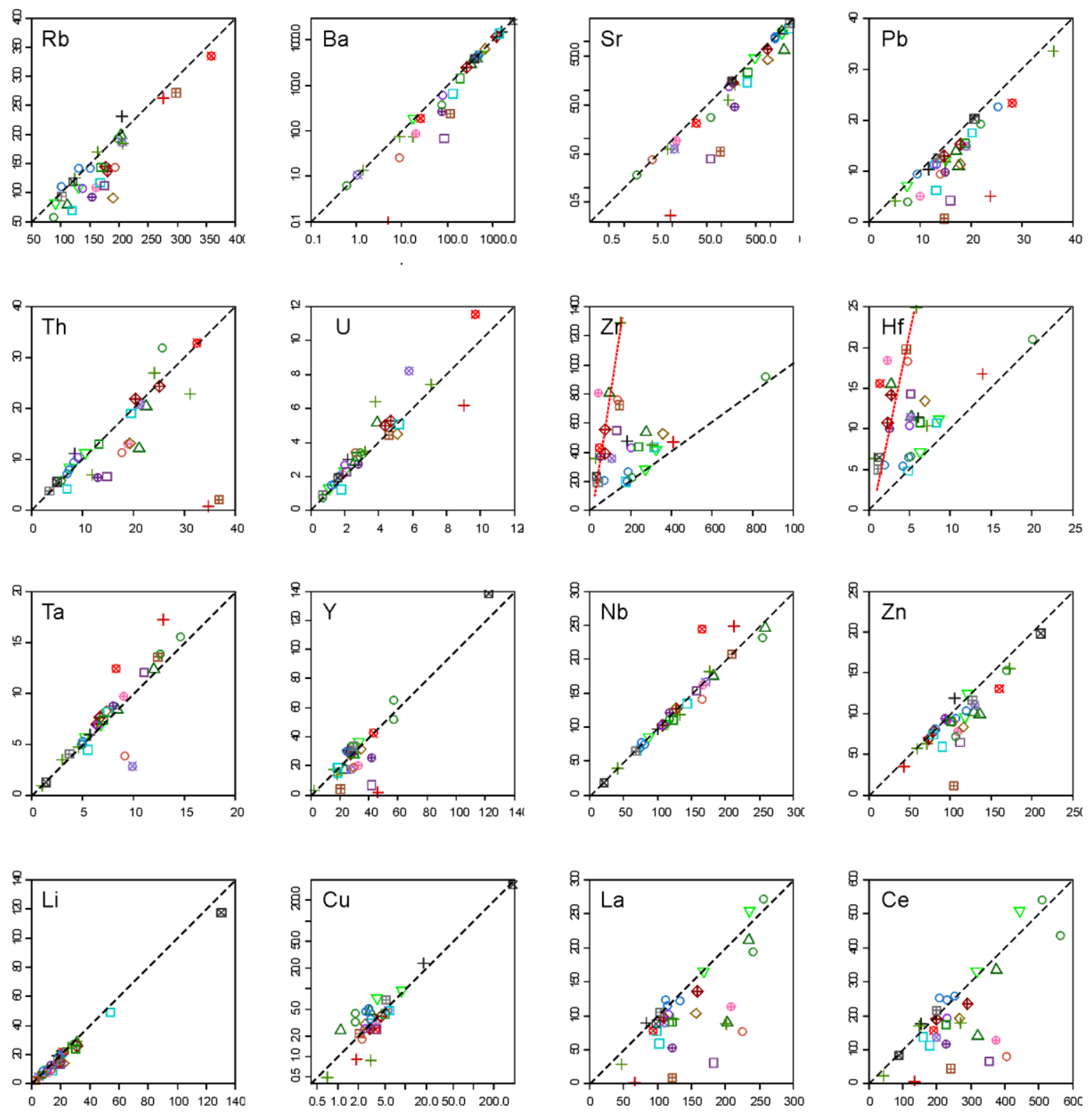

Figura 2.1 - Diagramas confrontando resultados de análises de elementos traços obtidas em dois laboratórios: AcmeLabs (abscissa, X) vs. UNICAMP (ordenada, Y). Algumas escalas são logarítmicas. A linha tracejada representa a proporção 1:1 ideal. A linha vermelha nos elementos $\mathrm{Zr}$ e $\mathrm{Hf}$ representa o trend de discrepância nas rochas supersaturadas em sílica e ricas em zircão. 
correlação 1:1 ideal. Entretanto, vários elementos apresentaram valores mais elevados e dispersos relativos às análises do AcmeLabs, principalmente para aqueles mais baixos. Os elementos $\mathrm{Zr}$ e $\mathrm{Hf}$, obtidos para as rochas com quartzo, mostram uma tendência de valores muito mais altos para as análises da UNICAMP. Essas rochas são ricas em zircão e possivelmente os métodos de digestão ácida da AcmeLabs não foram eficientes em dissolvê-los, sendo assim, os resultados relativos a esses dois elementos obtidos nesse laboratório foram desconsiderados.

Posteriormente, mais 4 amostras (MAI027, MAI168, MAI194C e MAI226) foram analisadas nos Laboratórios de Fluorescência de Raios-X e de Química e ICP-AES/MS do Núcleo de Apoio à Pesquisa Geoanalítica-USP. Essas amostras seguiram exatamente as mesmas rotinas de preparação e foram entregues aos laboratórios para análise.

A utilização de diferentes laboratórios e métodos para a determinação da geoquímica deveuse a fatores circunstanciais, mas não comprometeram a confiabilidade dos resultados. Os elementos analisados com seus limites de detecção encontram-se na Tabela 2.4.

Tabela 2.4 - Limites de detecção (óxidos, em \% de peso; elementos traço, em ppm) para as análises de geoquímica elemental realizadas em diferentes laboratórios. A- AcmeLabs, óxidos via FRX, traço via ICP-AES/ICP-MS; B- UNICAMP, traço via ICPMS; C- Geoanalítica-USP, óxidos via FRX, traço via ICP-MS. (*) elementos analisados via FRX.

\begin{tabular}{|c|c|c|c|c|c|c|c|}
\hline & A & B & C & & A & B & C \\
\hline $\mathrm{SiO}_{2}$ & 0,01 & & 0,030 & $\mathbf{N i}$ & 0,5 & 0,2 & $5 *$ \\
\hline $\mathrm{TiO}_{2}$ & 0,01 & & 0,003 & Sn & 0,5 & 0,08 & \\
\hline $\mathrm{Al}_{2} \mathrm{O}_{3}$ & 0,01 & & 0,02 & Co & 1 & 0,02 & $6 *$ \\
\hline $\mathrm{Fe}_{2} \mathrm{O}_{3}$ & 0,01 & & 0,010 & V & 10 & 0,1 & $9 *$ \\
\hline MnO & 0,01 & & 0,002 & $W$ & 0,5 & 0,01 & \\
\hline MgO & 0,01 & & 0,01 & $\mathbf{G a}$ & & 0,009 & $9 *$ \\
\hline $\mathrm{CaO}$ & 0,01 & & 0,01 & $\mathrm{Zn}$ & 5 & 3,4 & $2^{*}$ \\
\hline $\mathrm{Na}_{2} \mathrm{O}$ & 0,01 & & 0,02 & $\mathrm{Cu}$ & 0,5 & 0,2 & $5^{*}$ \\
\hline $\mathrm{K}_{2} \mathrm{O}$ & 0,01 & & 0,010 & $\mathrm{Ag}$ & 0,5 & & \\
\hline $\mathrm{P}_{2} \mathrm{O}_{5}$ & 0,01 & & 0,003 & As & 5 & & \\
\hline $\mathrm{SO}_{3}$ & 0,002 & & 0,01 & $\mathrm{Se}$ & 5 & & \\
\hline \multirow[t]{2}{*}{ LOI } & & & 0,01 & Mo & 0,5 & 0,02 & \\
\hline & & & & $\mathrm{Bi}$ & 0,5 & 0,006 & \\
\hline Li & 0,5 & 0,03 & & $\mathrm{Cd}$ & 0,5 & 0,02 & \\
\hline Cs & & 0,004 & 0,01 & $\mathrm{Sb}$ & 0,5 & 0,01 & \\
\hline $\mathbf{R b}$ & 0,5 & 0,2 & 0,01 & La & 0,5 & 0,01 & 0,01 \\
\hline $\mathrm{Ba}$ & 5 & 0,08 & 0,50 & $\mathrm{Ce}$ & 5 & 0,02 & 0,01 \\
\hline $\mathrm{Be}$ & 5 & 0,04 & & $\mathrm{Pr}$ & & 0,006 & 0,01 \\
\hline $\mathrm{Sr}$ & 5 & 0,07 & 0,01 & $\mathrm{Nd}$ & & 0,009 & 0,08 \\
\hline $\mathrm{Pb}$ & 0,5 & 0,05 & 0,02 & Sm & & 0,007 & 0,01 \\
\hline Th & 0,5 & 0,003 & 0,01 & Eu & & 0,003 & 0,01 \\
\hline $\mathbf{U}$ & 0,5 & 0,03 & 0,01 & $\mathbf{G d}$ & & 0,006 & 0,01 \\
\hline $\mathbf{Z r}$ & 0,5 & 0,04 & 0,03 & $\mathrm{~Tb}$ & & 0,003 & 0,01 \\
\hline Hf & 0,5 & 0,005 & 0,01 & Dy & & 0,003 & 0,01 \\
\hline Ta & 0,5 & 0,003 & & Ho & & 0,003 & 0,01 \\
\hline $\mathbf{Y}$ & 0,5 & 0,02 & 0,01 & $\mathrm{Er}$ & & 0,004 & 0,01 \\
\hline $\mathrm{Nb}$ & 0,5 & 0,05 & 0,01 & $\mathrm{Tm}$ & & 0,02 & 0,01 \\
\hline Sc & 1 & 0,10 & $14^{*}$ & $\mathrm{Yb}$ & & 0,005 & 0,01 \\
\hline $\mathrm{Cr}$ & 1 & 0,4 & $13^{*}$ & Lu & & 0,002 & 0,01 \\
\hline
\end{tabular}




\subsubsection{Tratamento dos dados e classificação}

A classificação das unidades do MAI seguiu essencialmente critérios petrográficos e geológicos para as rochas faneríticas, como sugerido por Le Maitre (2002). Entretanto, as características químicas também foram levadas em consideração, como variações nos teores de elementos traço e ETRs, índices geoquímicos e mineralogia normativa. Essas informações foram cruciais para o entendimento do comportamento mineralógico de algumas unidades e suas variações. As unidades traquíticas e diques seguiram prioritariamente a classificação química. Os índices petrológicos utilizados encontram-se na Tabela 2.5. Os índices A/NK e A/CNK são de acordo com Shand (1943) e R1-R2 segundo De La Roche et al.(1980). As fórmulas químicas ideais dos minerais estão de acordo com Anthony et al. (2017). Para o cálculo da mineralogia normativa CIPW utilizou-se a razão $\mathrm{FeO} /(\mathrm{FeO}+$ $\mathrm{Fe}_{2} \mathrm{O}_{3}$ ) de acordo com Middlemost (1989), sendo 0,5 para as rochas classificadas como fonolito, traquito e riolito no diagrama TAS, 0,4 para nefelinito e traquiandesito e 0,3 para traquibasalto.

Nos diagramas multi-elementares, os elementos traço foram normalizados pelo modelo de manto pirolítico, Primitive Mantle, e os ETRs pelo condrito $\mathrm{Cl}$, ambos segundo McDonough and Sun (1995). Os resultados foram tratados com o auxílio dos programas Microsoft Excel 2013 e GCDkit 3.00 (Janoušek et al., 2006), seguindo procedimentos e recomendações amplamente utilizados na área da petrologia de rochas ígneas.

\subsection{Geoquímica isotópica}

Dezoito amostras foram selecionadas para análises dos isótopos de $\mathrm{Sr}, \mathrm{Nd}$ e $\mathrm{Pb}$ em rocha total. As análises deram-se em duas etapas, primeiramente foram escolhidas dez amostras (MAI030, MAI036, MAI070B, MAI090, MAI092I, MAI108II, MAl110, MAI114, MAl160 e MAI166I) que representavam os litotipos principais do maciço. Posteriormete, viu-se a necessidade de acrescentar mais oito amostras (MAI046E, MAI053I, MAI122, MAI130, MAI226, MAI027, MAl168 e MAI194C) incluindo diques e encaixantes. Destas últimas, as quatro primeiras foram preparadas no mesmo lote Tabela 2.5 - Fórmulas para cálculo dos índices petrológicos utilizados.

\begin{tabular}{|c|c|c|}
\hline Índice & Nome & Fórmula \\
\hline mg\# & Número de magnésio & $100 * \mathrm{MgO} /(\mathrm{MgO}+\mathrm{FeO}), \mathrm{mol} \%$ \\
\hline IA & Índice de peralcalinidade & $\left(\mathrm{Na}_{2} \mathrm{O}+\mathrm{K}_{2} \mathrm{O}\right) / \mathrm{Al}_{2} \mathrm{O}_{3}, \mathrm{~mol} \%$ \\
\hline $\mathrm{A} / \mathrm{NK}$ & & $\mathrm{Al}_{2} \mathrm{O}_{3} /\left(\mathrm{Na}_{2} \mathrm{O}+\mathrm{K}_{2} \mathrm{O}\right), \mathrm{mol} \%$ \\
\hline $\mathrm{A} / \mathrm{CNK}$ & Saturação de alumina & $\mathrm{Al}_{2} \mathrm{O}_{3} /\left(\mathrm{CaO}+\mathrm{Na}_{2} \mathrm{O}+\mathrm{K}_{2} \mathrm{O}\right), \mathrm{mol} \%$ \\
\hline R1 & & $4 \mathrm{Si}-11(\mathrm{Na}+\mathrm{K})-2(\mathrm{Fe}+\mathrm{Ti}), \mathrm{mol} \%$ \\
\hline $\mathrm{R} 2$ & & $\mathrm{Al}+2 \mathrm{Mg}+6 \mathrm{Ca}, \mathrm{mol} \%$ \\
\hline ID & Índice de diferenciação & $Q+o r+a b+n e+l c+k s, \%$ normativa \\
\hline $\mathrm{Eu} / \mathrm{Eu}^{*}$ & Anomalia de Eu & EuN $/ \sqrt{ }\left(S_{N} * G_{N}\right)$, teores normalizados por C1 \\
\hline $\mathrm{Ce}^{*}$ & Anomalia de $\mathrm{Ce}$ & $\mathrm{Ce}_{\mathrm{N}} / \mathrm{V}\left(\mathrm{La}_{\mathrm{N}} * \operatorname{Pr}_{\mathrm{N}}\right)$, teores normalizados por C1 \\
\hline
\end{tabular}


que as anteriores, e as restantes foram preparadas separadamente seguindo exatamente os mesmos procedimentos (descritos no item 2.5.1).

As amostras em pó foram encaminhadas ao Laboratório de Espectrometria do Centro de Pesquisas Geocronológicas (CPGeo) - USP onde seguiram procedimentos químicos em laboratório limpo classe 10.000, providos de capelas de fluxo laminar classe 100. Toda a água e ácidos empregados nas análises passaram por procedimentos de purificação. A água foi filtrada, destilada, e então purificada num sistema Milli-Q de remoção de íons. Os ácidos utilizados ( $\mathrm{HNO}, \mathrm{HCl}, \mathrm{HF}$ e $\mathrm{HBr}$ ) foram purificados em destiladores de quartzo sub-boiling DST-1000 e/ou garrafas de destilação sub-boiling de teflon. A dissolução das amostras foi realizada por digestão ácida, utilizando-se em etapas distintas $\mathrm{HNO}_{3}+\mathrm{HF}$ e $\mathrm{HCl}$ em um béquer de teflon (SAVILLEX ${ }^{\circledR}$ ), à temperatura de $100^{\circ} \mathrm{C}$ em um "clean box" ou empregadas bombas tipoPARR ${ }^{\circledast}$ inseridas em cápsulas de aço inox, aquecidas à temperatura de $150^{\circ} \mathrm{C}$, em estufa.

As curvas de AFC e mixing foram calculadas com o programa FC-AFC-FCA and mixing modeler (Ersoy \& Helvacl, 2010).

\subsubsection{Método $\mathrm{Sr} / \mathrm{Sr}$}

A separação do $\mathrm{Sr}$ foi realizada utilizando-se a resina específica para $\mathrm{Sr}(\mathrm{Sr} \mathrm{Spec}$ ), e eluído com $\mathrm{HNO}_{3} 0.05 \mathrm{M}$. As amostras de $\mathrm{Sr}$ foram depositadas em filamento simples de tântalo com adição de soluçãode $\mathrm{H}_{3} \mathrm{PO}_{4}$. As razões foram obtidas por espectrometria de massa por ionização térmica (TIMS) em um espectrômetro Thermo Triton. Para cada amostra foram efetuadas 200 medições e a incerteza calculada para $2 \sigma$. As razões isotópicas ${ }^{87} \mathrm{Sr} /{ }^{86} \mathrm{Sr}$ foram normalizadas para o valor de ${ }^{86} \mathrm{Sr} /{ }^{88} \mathrm{Sr}=0,1194$. O branco de Sr medido durante as análises foi de $112 \mathrm{pg}$. Valor médio para a razão ${ }^{87} \mathrm{Sr} /{ }^{86} \mathrm{Sr}$ do padrão NBS-987 foi igual $0.710242 \pm 0.000023$.

As razões iniciais ${ }^{87} \mathrm{Sr} /{ }^{86} \mathrm{Sr}_{i}$ foram calculadas pelo programa GCDkit 3.00 (Janoušek et al., 2006).

\subsubsection{Método $\mathrm{Nd} / \mathrm{Nd}$}

A separação das terras raras foi realizada em duas etapas, a primeira com a resina específica para terras raras (RE spec) e a segunda utilizando a resina $L N$ spec para a separação do $\mathrm{Nd}$ e do $\mathrm{Sm}$. As amostras de Sm foram depositadas em filamento simples de tântalo com adição de $\mathrm{H}_{2} \mathrm{O}$ MilliQ. As razões são obtidas por espectrometria de massa por ionização térmica (TIMS), utilizando-se o espectrômetro Thermo Triton. Para cada amostra foram efetuadas 45 medições e a incerteza é calculada para $2 \sigma$. As amostras de Nd foram depositadas em filamento paralelo de rênio com adição de $\mathrm{H}_{2} \mathrm{O}$ MilliQ. As razões foram obtidas por espectrometria de massa por ionização térmica (TIMS) em um espectrômetro Thermo Triton. Para cada amostra foram efetuadas 150 medições e incerteza calculada para $2 \sigma$. As razões isotópicas ${ }^{143} \mathrm{Nd} /{ }^{144} \mathrm{Nd}$ (medidas como $\mathrm{Nd}+$ ) foram normalizadas para o 
valor de ${ }^{146} \mathrm{Nd} /{ }^{144} \mathrm{Nd}=0,7219$ (DePaolo, 1981). Branco de $\mathrm{Nd}$ medido durante as análises foi de $389 \mathrm{pg}$. Valor médio para a razão ${ }^{143} \mathrm{Nd} /{ }^{144} \mathrm{Nd}$ do padrão JNdi-1 foi de 0,512097 $\pm 0,000008$.

As razões iniciais ${ }^{143} \mathrm{Nd} /{ }^{144} \mathrm{Nd}{ }_{i}$ e os $\varepsilon N d$ e $T_{D M}$ foram calculadas pelo programa GCDkit 3.00 (Janoušek et al., 2006) de acordo com (Liew \& Hofmann, 1988).

\subsubsection{Método $\mathrm{Pb} / \mathrm{Pb}$}

As amostras dissolvidas foram submetidas à purificação de $\mathrm{Pb}$, através da técnica de troca iônica por uma coluna de polietileno Biorad ${ }^{\circledR}$ adaptada para a diminuição do fluxo contendo resina Biorad AG1-X8 ${ }^{\circledast}, 200-400$ mesh, pré-tratada. Após o condicionamento da resina, a amostra foi adicionada e a remoção de outros íons feita com $\mathrm{HBr}$ 0,7 M. A eluição do $\mathrm{Pb}$ foi feita com $\mathrm{HCl}$ 6,0 M. Em seguida, $\mathrm{H}_{3} \mathrm{PO}_{4}$ foi adicionado à solução que levada a secura (Babinski, 1993). As amostras foram depositadas em filamento de rênio de arranjo simples, com adição de sílica-gel ultrapura (Cameron et al., 1969). As razões isotópicas de Pb foram obtidas por espectrometria de massa por ionização térmica (TIMS), utilizando-se o espectrômetro FINNIGAN MAT 262. As composições isotópicas obtidas foram corrigidas para o fracionamento de massa, em função dos valores obtidos para o padrão NBS 981 analisados sob condições similares, com valores \pm desvio padrão $(1 \sigma)$ de: ${ }^{206} \mathrm{~Pb} /{ }^{204} \mathrm{~Pb}=16,898 \pm 0,004$; ${ }^{207} \mathrm{~Pb} /{ }^{204} \mathrm{~Pb}=15,440 \pm 0,005 \mathrm{e}{ }^{208} \mathrm{~Pb} /{ }^{204} \mathrm{~Pb}=36,539 \pm 0,017$. As razões isotópicas foram corrigidas para fracionamento de massa de 0,095\%/u.m.a. Erro $2 \sigma \%$ - Desvio padrão $2 \sigma$ (número médio de medidas = 100). O branco total medido durante as análises foi de $28 \mathrm{pg}$.

\subsection{Geocronologia}

Foram determinadas as idades de zircão correspondentes a sete amostras no Laboratório de Geocronologia de Alta Resolução GEOLAB do Instituto de Geociências da USP via Microssonda lônica de Alta Resolução, do tipo SHRIMP II e/MC.

As alíquotas das amostras destinadas à separação de minerais foram preparadas no Laboratório de Separação do Geoanalítica e do CPEGeo seguindo as seguintes etapas: I) fragmentadas com martelo e marreta; II) processadas em moinho de discos de tungstênio; III) separadas na granulação ideal (0,150 a 0,060 mm) utilizando jogos de peneiras e um peneirador vibratório suspenso; IV) concentradas os minerais pesados em uma mesa vibratória do tipo Wiffley; V) separadas dos minerais magnéticos em um separador magnético tipo Frantz; VI) concentradas os minerais pesados por densidade em bromofórmio $\left(\mathrm{CHBr}_{3}-2,89 \mathrm{~g} / \mathrm{cm}^{3}\right)$ e iodeto de metileno $\left(\mathrm{CH}_{2} \mathrm{I}_{2}-3,32 \mathrm{~g} / \mathrm{cm}^{3}\right)$; VII) os cristais melhores de zircão foram pinçados manualmente utilizando uma lupa binocular; VIII) os grãos foram montados em pastilhas (mounts) de resina epóxi; IX) e obtidos imagens em luz transmitida e por catodoluminescência $(\mathrm{CL})$, bem como imagens por elétrons retroespalhados (BSE), em um microscópio eletrônico de varredura (MEV) modelo Quanta 250 FEG equipado com um XMAS CL 
(catodoluminescência), que operou com potencial de aceleração de $15 \mathrm{kV}$, distância de trabalho de 16,9 mm, detector PMD, emissão do filamento $100 \mu \mathrm{A}$ e magnificação de 95 a 130 vezes; X) e por fim as montagens foram metalizadas com ouro ( $\sim 3 \mu \mathrm{m})$.

As amostras de grãos de zircão foram separadas em dois mounts, A (MAI036, MAI108II e MAI166I) e B (MAI070B, MAI090, MAI092I e MAI110), cada amostra contando com 50 a 70 grãos (15 grãos na amostra MAI036), dos quais foram selecionados de 12 a 16 cristais de tipologia variada para para serem datados. No decorrer das análises, cada quatro medidas na amostra mediu-se um cristal do padrão Temora 2, de idade 416,78 $\pm 0.33 \mathrm{Ma}$ (Black et al., 2004) para o devido controle e correções.

As condições analíticas do feixe primário possuem fenda de Kohler de 120 um, diâmetro do feixe de $30 \mu \mathrm{m}$ e densidade do feixe de $\mathrm{O}_{2}$ de 2,5 a 7 nA. O feixe secundário possui fenda de $80 \mu \mathrm{m}$, resolução paras as massas de ${ }^{196}\left(\mathrm{Zr}_{2} \mathrm{O}\right),{ }^{206} \mathrm{~Pb},{ }^{207} \mathrm{~Pb},{ }^{208} \mathrm{~Pb},{ }^{238} \mathrm{U},{ }^{248}(\mathrm{ThO})$ e ${ }^{254}(\mathrm{UO})$ variando entre 5000 e 5500 (1\%) e resíduos menor que 0,025 e energia da fenda aberta. As características mais detalhadas do aparelho e dos respectivos procedimentos analíticos são descritos em Sato et al. (2014) 


\section{CONTEXTO GEOLÓGICO REGIONAL E MAGMÁTICO}

A região onde se insere o Maciço Alcalino de Itatiaia possui uma história geológica complexa. O maciço está situado no limite entre os Orógenos Brasília e Ribeira, de idade Brasiliana, onde se desenvolveu um sistema de riftes cenozoicos formados pela reativação de antigas zonas de cisalhamento. Essa reativação está relacionada à abertura do oceano Atlântico Sul, resultando no intenso vulcanismo toleítico e alcalino ao redor da bacia do Paraná e na região costeira da região sudeste do Brasil.

\subsection{Embasamento pré-cambriano}

O MAI intrude metapelitos, ortognaisses e granitos da Província Mantiqueira (Figura 3.1). Segundo Heilbron et al. (2004), a Província Mantiqueira é constituída pelos orógenos Araçuaí, Ribeira, Dom Feliciano e São Gabriel, e pela zona de interferência entre os orógenos Brasília e Ribeira. Desta zona de interferência para sul, até a borda norte do maciço cratônico de Luis Alves, estende-se um conjunto de unidades cujas relações geotectônicas com o Orógeno Ribeira são ainda dúbias e que, em parte, poderiam pertencer à extremidade sul do Orógeno Brasília. Em função disto, estas unidades estão agrupadas nos terrenos Apiaí-Guaxupé e Embu.

Heilbron et al. (2004) faz uma síntese da compartimentação tectônica da extremidade sul do Orógeno Brasília e do Orógeno Ribeira, resumida abaixo.

A parte sul do Orógeno Brasília mostra trend estrutural NNW-SSE e é subdividida em nappes com empilhamento tectônico vergente para E-ESE, rumo ao Cráton do São Francisco ou tangente à sua borda meridional. Esta etapa colisional neoproterozóica (Colisão I) é a mais antiga da Orogênese Brasiliana no Segmento Central da Província Mantiqueira, tendo atingido seu ápice em cerca de 630$625 \mathrm{Ma}$. Resultou da colisão entre a borda sul-sudoeste da paleoplaca São Francisco-Congo e outra placa, situada a W-SW, atualmente encoberta pelas sequências deposicionais fanerozóicas da Bacia do Paraná. As nappes da parte sul do Orógeno Brasília podem ser agrupadas em dois conjuntos: as nappes inferiores e as nappes superiores. As nappes inferiores (e.g. Socorro) registram metamorfismo que atinge a fácies granulito de pressão relativamente alta e guardam relação paleogeográfica com o 


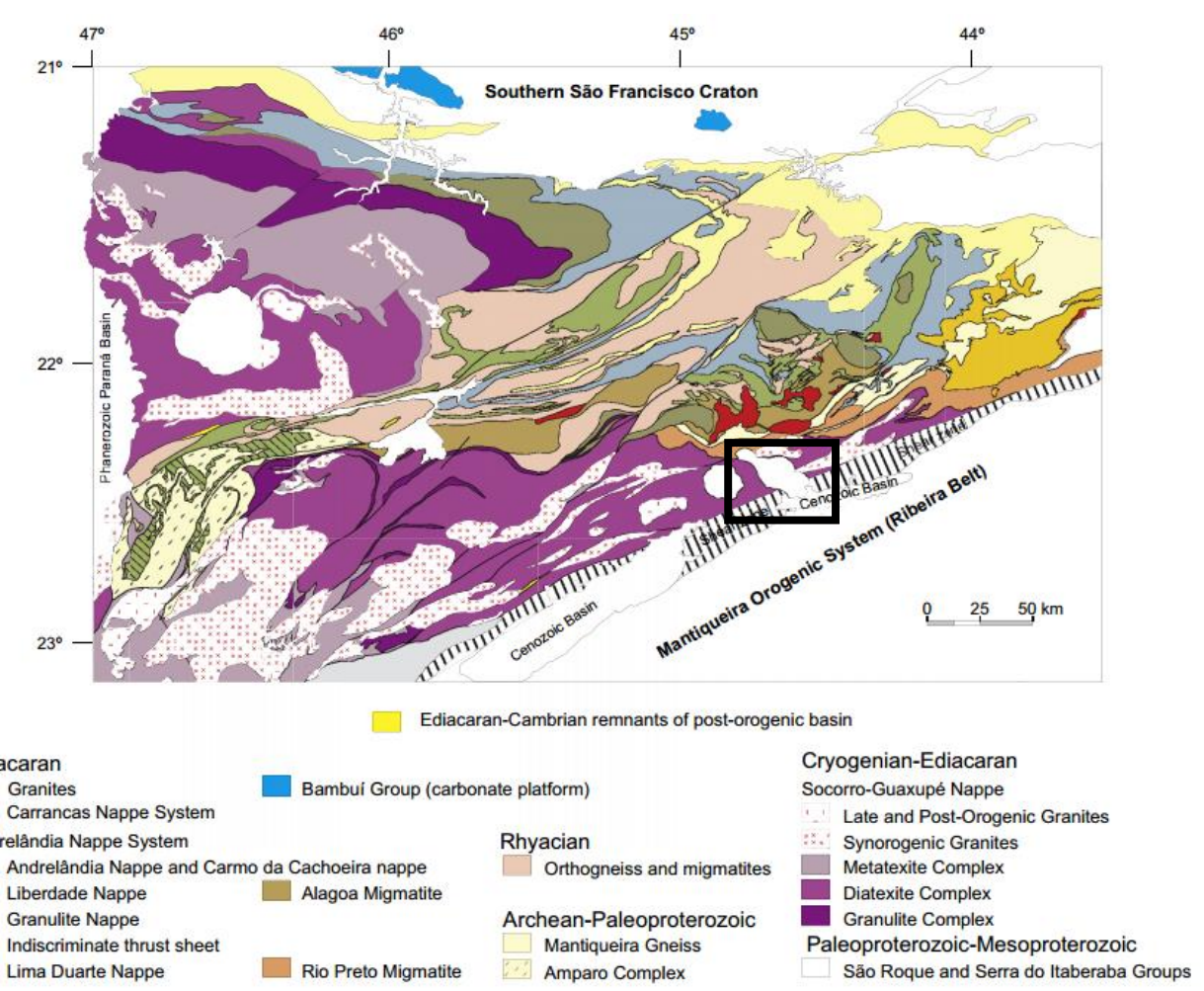

Figura 3.1 - Mapa geológico da porção sul do Orógeno Brasília (Campos Neto et al. 2010). A localização do MAl está marcada pelo retângulo preto.

Cráton do São Francisco. As nappes superiores (e.g. Andrelândia) apresentam metamorfismo de pressão mais baixa e inúmeros corpos granitóides cálcio-alcalinos, em parte interpretados como remanescentes de um arco magmático cordilherano.

O Orógeno Ribeira, que apresenta trend estrutural NE-SW, resulta da interação entre o Cráton do São Francisco e outra (s) placa (s) e/ou microplaca(s) e/ou arco de ilhas situado(s) a sudeste deste cráton, bem como com a porção sudoeste do Cráton do Congo. Esta segunda etapa de colisão continental (Colisão II, cerca de $580 \mathrm{Ma}$ ) resultou no empilhamento de terrenos de leste para oestenoroeste. Como a colisão entre estes terrenos foi oblíqua, a deformação principal exibe clara partição entre zonas com predomínio de encurtamento frontal e zonas com componente transpressivo destral. Assim, contrastando com a extremidade sul do Orógeno Brasília, os limites entre os compartimentos tectônicos são representados por empurrões com mergulhos mais íngremes ( $>30^{\circ}$ ), ou por zonas de cisalhamento oblíquas.

Esses orógenos caracterizam-se por um grande volume de magmatismo granítico cálcioalcalino de alto K pré-, sin- e pós-tectônico. O magmatismo pós-colisional é dominado por granitos metaluminosos e quartzo monzonitos indeformados com abundantes enclaves dioríticos e evidências isotópicas de mistura entre magmas de origens crustais e mantélicas (Valeriano et al., 2011, 2016; Tupinambá et al., 2012; Carvalho et al., 2014; Martins et al., 2016). Ocorrem em faixas de direção NE 
principalmente no Terreno Oriental e Nappe Socorro, como grandes stocks, sills, diques e outros corpos pequenos associados com aplitos e pegmatitos (Valeriano et al., 2016).

A porção sudeste do MAl intrude granada-sillimanita-muscovita xistos do grupo Embú (Terreno Paraíba do Sul) e (granada)-biotita gnaisses bandados e anfibolitos do Grupo Raposo (terreno Ocidental), da Faixa Ribeira (Heilbron et al., 2004, 2016; Mendes et al., 2006; Trouw et al., 2013). Segundo a orientação regional ENE-WSW, granitos ediacaranos do Domínio Andrelândia também ocorrem, localmente representados por biotita granitos porfiríticos e foliados das suítes Serra Selada e do Maromba (Mendes et al., 2006). O limite entre as faixas Ribeira e Brasília é marcado pela Zona de Cizalhamento do Rio Jaguari (Campos Neto et al., 2011), que coincide com o limites do Rifte Continental do Sudeste Brasileiro. A porção noroeste intrude paragnaisses metatexíticos, hornblendabiotita ortognaisses migmetíticos e leucogranitos neoproterozóicos da Nappe Socorro-Guaxupé, Faixa Brasília (Heilbron et al., 2004; Campos Neto et al., 2011; Trouw et al., 2013)

\subsection{Tectônica meso-cenozóica e o Rifte Continental do Sudeste do Brasil}

A partir do Jurássico Superior iniciou-se o processo de abertura do Atlântico Sul após longo período de calma tectônica, Reativação Wealdeniana (Almeida, 1967, 1969), caracterizado pela reativação de antigos falhamentos e surgimento de blocos de falha, soerguimentos de arcos, abatimentos de bacias costeiras e acentuada subsidência da Bacia do Paraná. Como consequência houve intenso magmatismo basáltico toleítico que preencheu toda bacia do Paraná, estendendo-se até onde é hoje a Bacia de Santos. Nas bordas dessas bacias foram geradas, ou reativadas, arcos, flexuras e zonas de falhamentos que possibilitaram a manifestação do vulcanismo alcalino ao redor da Bacia do Paraná (Almeida, 1983).

Durante o Cretáceo Superior (pós vulcanismo Serra Geral) iniciou-se o desenvolvimento do Rifte Continental do Sudeste Brasileiro (RCSB; Riccomini, 1989). Este rifte, ou sistema de riftes, desenvolveu-se sobre o Orógeno Ribeira, aproveitando-se da intensa trama de zonas de cisalhamento com direção preferencial ENE a E, paralelas à costa do Atlântico, que foram reativadas como falhas normais no Paleógeno e transcorrentes no Neógeno (Figura 3.2). Atualmente é representado por uma série de bacias tafrogênicas que ocorrem do Paraná até o norte do Rio de Janeiro (e.g. Bacias de Curitiba, São Paulo e Taubaté, e Baixada Fluminense), inclusive com ocorrência de rochas vulcânicas (ankaramitos) nas bacias de Itaboraí e Volta Redonda (Almeida, 1976; Melo et al., 1985; Riccomini, 1989; Riccomini et al., 2004; Zalán \& Oliveira, 2005).

A reativação desses falhamentos antigos está vinculada à evolução da margem continental, entretanto os mecanismos geradores deste processo ainda não são muito claros (Riccomini et al., 
2004). O desenvolvimento de um megaplanalto de natureza epirogenética, responsável pelo desenvolvimento da Superfície de Aplainamento Japi durante o Cretáceo Superior (Almeida, 1976; Almeida \& Carneiro, 1998), é registrado por espessos pacotes de rochas sedimentares nas Bacias de Santos e Campos. Esse soerguimento teria se desenvolvido em resposta à passagem da Placa SulAmericana sobre uma anomalia térmica (hot spots de Trindade). Tal situação tornou-se isostaticamente instável, e o colapso gravitacional do megaplanalto estendeu-se entre 58 e 20 Ma com a reativação de antigos falhamentos e o abatimento de diversas áreas lineares formando corredores de grábens (rifts) paralelos à costa. A origem dos falhamentos está relacionada com as paleo-tensões locais desencadeadas por esse soerguimento, e são reflexos de anisotropias mecânicas do manto subjacente. Tais anisotropias seriam evidenciadas pela deformação dúctil e orientação preferencial de eixos cristalográficos de olivina encontradas em xenólitos mantélicos e pelas heterogeneidades na propagação de ondas sísmicas sob riftes continentais. Toda essa tectônica teria sido responsável pela colocação de diversos corpos e diques alcalinos de 82 a 52 (Ferrari, 2001; Zalán \& Oliveira, 2005).

\subsection{O magmatismo alcalino meso-cenozóico}

O magmatismo alcalino dominante em toda Plataforma Sul-Americana é de idade mesozóica, com a maioria das ocorrências concentrando-se na região a sul da latitude $15^{\circ} \mathrm{S}$. Apresenta uma grande variação composicional, desde ultrabásico até ácido, sendo que, em alguns complexos extremamente diferenciados, há presença de sienitos insaturados até supersaturados. Conhecem-se mais de cem centros intrusivos alcalinos mesozóicos, simples ou múltiplos, e alguns centros vulcânicos, além de associações de diques ou enxames de diques, na porção meridional da placa Sul-Americana. Estes se dispõem ao longo de arcos e flexuras em torno dos limites da Bacia do Paraná, onde afloram as mais numerosas ocorrências, e da região costeira marginal à Bacia de Santos, nos Estados de São Paulo e Rio de Janeiro (Gomes \& Comin-Chiaramonti, 2005).

A ocorrência dos corpos alcalinos meso-cenozóicos na porção centro-sudeste da Plataforma Sul-Americana mostra um claro controle tectônico por descontinuidades crustais, principalmente por zonas de falhas extensionais ou transcorrentes, ao longo das bordas atuais das bacias sedimentares e riftes (Figura 3.3). A herança de descontinuidades crustais proterozóicas desempenhou um importante papel na colocação desses corpos, pois a mudança nos campos de esforços e reativação de estruturas regionais causadas pelo processo diastrófico iniciado no Jurássico, produziram uma grande variedade de fraquezas estruturais por onde o magma alcalino pôde alojar-se ou chegar à superfície (Almeida, 1971, 1983; Algarte, 1972; Riccomini et al., 2005; Zalán \& Oliveira, 2005). Além disso, as áreas onde se desenvolveram as províncias alcalinas foram mantidas sob uma importante anomalia térmica por um tempo suficiente para a litosfera incorporar uma quantidade de calor necessária para a geração desses 


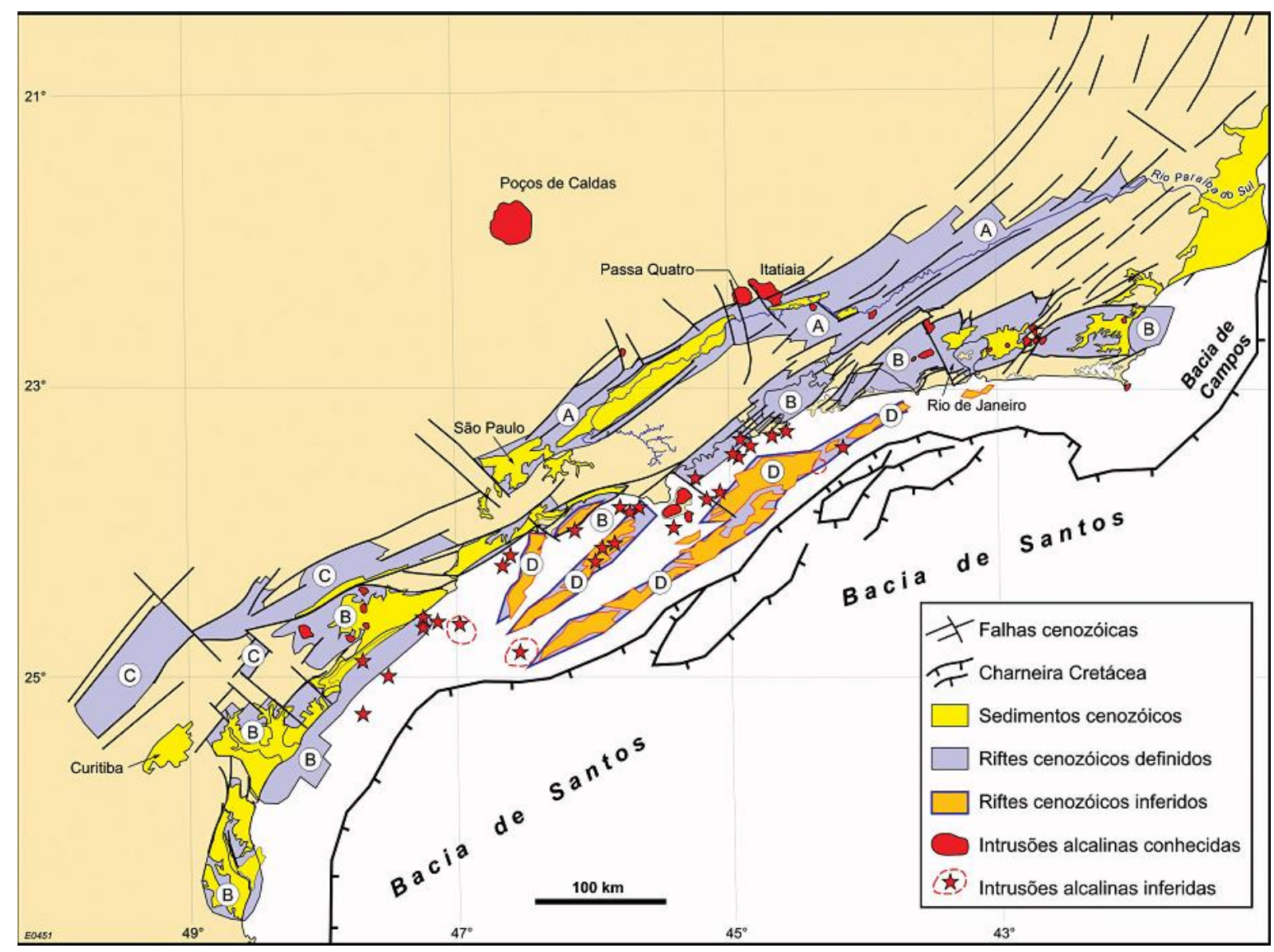

Figura 3.2 - Mapa de distribuição dos quatro riftes do sistema RCSB: (A) Paraíba do Sul, (B) Litorâneo, (C) Ribeira, e (D) Marítimo; de suas falhas limitantes, preenchimentos sedimentares, intrusões/lavas alcalinas, charneira cretácea das bacias de Santos/Campos e o Rio Paraíba do Sul. (Zalán\& Oliveira, 2005).

magmas (Ernesto et al., 2002; Marques \& Ernesto, 2004; Zalán \& Oliveira, 2005). Por outro lado, há autores que relacionam este magmatismo à presença de plumas mantélicas ou hotspots, sendo algumas dessas manifestações tectônicas interpretadas como influências do impacto dessas plumas sob a litosfera (e.g. Gibson et al., 1995; Thompson et al., 1998; Thomaz Filho \& Rodrigues, 1999). Entretanto, esta hipótese esbarra em alguns indícios (isotópicos, geocronológicos e paleomagnéticos) que não corroboram com o modelo proposto (Ernesto et al., 2002; Marques \& Ernesto, 2004; Riccomini et al., 2005).

O magmatismo toleítico e alcalino da Plataforma Sul-Americana mostra uma tendência isotópica Sr-Nd bem definida, compreendendo os componentes EM1 e HIMU. Essa assinatura isotópica é interpretada como originada de um manto litosférico subcontinental com diferentes graus de enriquecimento (e.g. Gibson et al.,1995; Comin-Chiaramonti et al., 1997, 2005; Thompson et al.,1998). Comin-Chiaramonti et al. (2005)chamam a atenção para o enriquecimento da assinatura isotópica de oeste para leste, sugerindo que a origem do magmatismo está relacionado a heterogeneidades no manto litosférico, tanto em grande, quanto em pequena escala, os isótopos de Pb também sustentam 


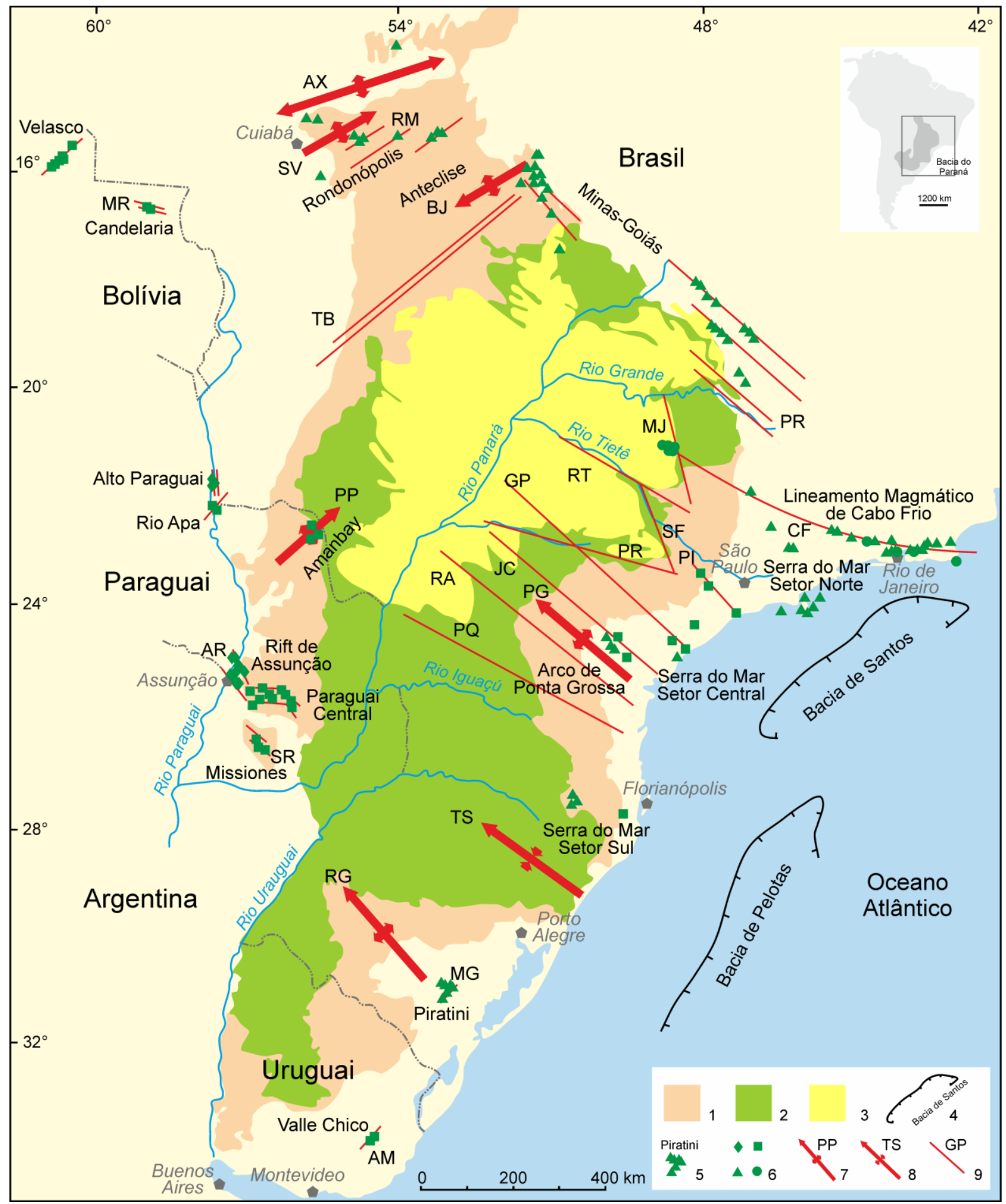

Figura 3.3 - Províncias alcalinas da região centro-sul da Plataforma Sul-Americana e suas relações com as maiores feições estruturais: 1) Bacia do Paraná, Ordoviciano Inferior a Cretáceo Superior; 2) derrames da Formação Serra Geral, Cretáceo Superior; 3) Bacia de Bauru, Cretáceo Superior; 4) limites das bacias marginais; 5) províncias alcalinas; 6) idade das ocorrências alcalinas (losangos, Permo-Triássico; quadrados, Cretáceo Inferior; triângulos, Cretáceo Superior; círculos, Paleógeno); 7) arcos (AX, Alto Xingu; SV, São Vicente; BJ, Bom Jardim de Goiás; PG, Ponta Grossa; RG, Rio Grande; PP, Ponta Porã); 8) Sinclinal de Torres; 9) maiores zonas de fraturas (Rifts: MR, Mercedes; RM, Rio das Mortes; MG, Moirão; SR, Santa Rosa; AR Assunção. Lineamentos: TB, Transbrasiliano; AP, Alto Paranaíba; MJ, Moji-Guaçu; CF, Cabo Frio; RT, Rio Tietê; SL, São Carlos-Leme; PR, Paranapanema; PI, Piedade; GP, Guapiara; JC, São Jerônimo-Curiúva; RA, Rio Alonzo; PQ, Rio Pequiri; AM, Santa Lúcia-Aiguá-Merin). Modificado de Riccomini et al. (2005). 
essa consideração. Nota-se também que a assinatura da llha de Trindade é diferente das províncias que estaria relacionada, Alto Paranaíba, Serra do Mar e Lineamento Magmático de Cabo Frio, o que não corroboraria com o modelo de Thompson et al. (1998).

O magmatismo alcalino de Tristão da Cunha e dos basaltos da Cadeia de Walvis e do Alto do Rio Grande possuem características isotópicas distintas, ou se sobrepõe apenas parcialmente ao magmatismo toleítico e alcalino da Província Paraná-Etendeka. Portanto, também neste caso, a contribuição de componentes mantélicos derivados da Pluma de Tristão da Cunha também é questionável. Sendo assim, esses autores assumem que a hipótese da causa do magmatismo da Província Angola-Etendeka-Paraná não possui contribuição de uma pluma astenosférica, exceto talvez por alguma perturbação termal. Por outro lado, Garda et al. (1995) e Thompson et al. (1998) sugerem a influência da fusão de um manto astenosférico na origem de algumas ocorrências na Província Serra do Mar que possuem composições isotópicas Sr-Nb próximas ao Bulk Earth, ou em um quadrante empobrecido.

No geral, essas informações mostram que a geração desse magmatismo necessita de fontes enriquecidas no manto. Esse enriquecimento poderia estar relacionado aos processos metassomáticos ocorridos durante os eventos colisionais do Brasiliano, já que as idades modelo TDM de Nd variam entre 0,6 e 0,7 Ga (Comin-Chiaramontiet al., 2005).

\subsubsection{O Lineamento Magmático de Cabo Frio}

O Lineamento Magmático do Cabo Frio (LMCF), primeiramente definido por Sadowski \& Dias Neto (1981) como "lineamento sismo-tectônico de Cabo Frio" e posteriormente por Almeida (1991) como "alinhamento magmático de Cabo Frio", foi estabelecido como uma província independente por Riccomini et al. (2005) com pelo menos duas fases de magmatismo alcalino, do Cretáceo Superior ao Paleógeno. Segundo Almeida (1991), representa uma feição estrutural WNW-ESE desenvolvida desde Jaboticabal, no interior do Estado de São Paulo, até a região do limite entre as crostas continental e oceânica, no Banco Almirante Saldanha, no Estado do Rio de Janeiro. Consiste em uma faixa curva de $60 \mathrm{~km}$ de largura por $1150 \mathrm{~km}$ de comprimento que inclui 26 corpos alcalinos intrusivos, como grandes maciços, stocks, plugs, centros efusivos e um grande número de diques (Figura 3.4). A maior parte das ocorrências situa-se entre os maciços de Passa Quatro-Itatiaia (SP-MG-RJ) e Morro de São João (RJ).

É constituída essencialmente de nefelina sienitos, sienitos, fonolitos e traquitos, com característica presença de leucita e, especialmente, pseudoleucita. Rochas máficas ocorrem apenas como diques, sills e lavas. Dentre esses centros inclui-se Poços de Caldas, o maior complexo alcalino do Brasil e um dos maiores do mundo, com $800 \mathrm{~km}^{2}$. Outras intrusões importantes são, de oeste para leste, Passa Quatro, Itatiaia, Morro Redondo, Tinguá, Mendanha, Itaúna, Tanguá, Soarinho, Rio Bonito, Morro de São João e Cabo Frio. 
Uma característica interessante das ocorrências associadas ao RCSB e distribuídas ao longo do LMCF é a aparente progressão de idades de oeste para leste variando de, aproximadamente, 84 a 52 Ma. Este fato chamou atenção de vários pesquisadores e muitos trabalhos foram feitos a seu respeito para explicar essa progressão, associando a círculos mínimos de falhas transformantes (e.g. Marsh, 1973), a plumas mantélicas (e.g. Thompson et al., 1998) e falhas subcrustais (Almeida, 1991; Riccomini et al., 2005; Zalán \& Oliveira, 2005). Apesar disso, as suas rochas não são tão bem conhecidas e à exceção de alguns maciços, carecem de estudos estruturais, geoquímicos, isotópicos e geocronológicos mais detalhados. Ao se examinar os dados geocronológicos com mais cuidado, observa-se que esta variação não é tão linear, por exemplo, Jaboticabal, a ocorrência mais ocidental, possui idade K-Ar de $54 \mathrm{Ma}$ (Gomes \& Valarelli, 1970), indo progressivamente para leste, há Poços de Caldas com idades Ar-Ar entre 84 e 76 Ma (Shea, 1992; Vlach et al., 2003), lavas ankaramíticas de Volta Redonda e Itaboraí com 43 Ma (Riccomini \& Rodrigues-Francisco, 1992), diques associados ao maciço de Mendanha de 82 a 54 Ma (Ferrari, 2001; Smith et al., 2001), Morro de São João de 77 a 56 Ma (Ulbrich \& Gomes, 1981; Sonoki \& Garda, 1988; Sichel et al., 1997; Thomaz Filho \& Rodrigues, 1999) e Cabo Frio com $52 \mathrm{Ma}$ (Ferrari, 2001). Além disso, poucos são os dados que oferecem segurança, sendo grande parte deles obtidos há muito tempo, com técnicas e equipamentos de precisão menor, gerando em alguns casos, erros consideráveis para o intervalo de tempo existente.

Além de estarem dentro ou preferencialmente nas bordas dos rifts do RCSB (com exceção do maciço alcalino de Poços de Caldas), outro fato a ser levado em consideração é que a maioria dos corpos alcalinos da província estão em contato ou intrudindo granitos sin, tardi ou pós-orogênicos. Dentre os granitos orogênicos ocorrem peraluminosos e calcioalcalinos de alto potássio (Tupinambá et al., 2012; Janasi et al., 2015; Alves et al., 2016), sendo esses últimos os que apresentam maior relação com as ocorrências alcalinas meso-cenozóicas na região, também tipicamente potássicas. Já os granitos anorogênicos são tipicamente potássicos e apresentam um certo alinhamento onde se concentram juntamente com as ocorrências meso-cenozóicas, especialmente na Nappe Socorro e Domínio Apiaí e no Terreno Oriental (Valeriano et al., 2011; Carvalho et al., 2014) 


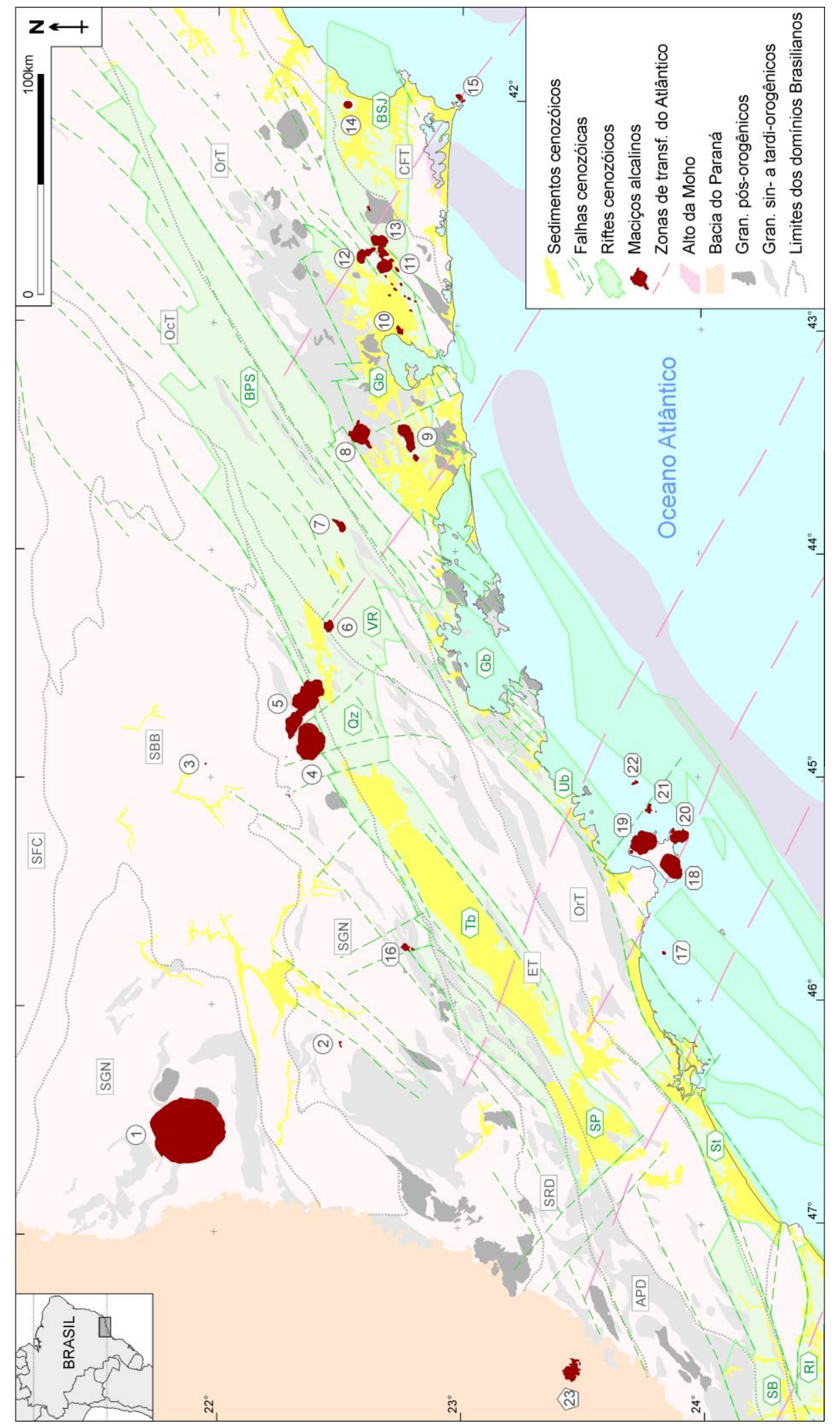

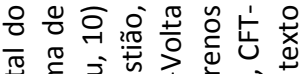

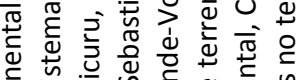

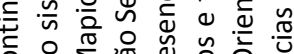
ర人

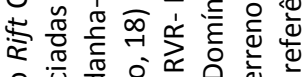
$\circ$ 잉

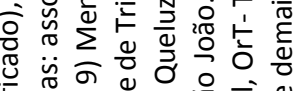

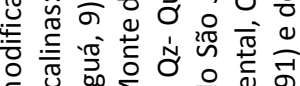

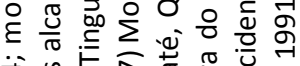

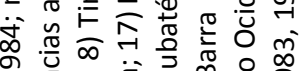
र्ष

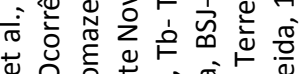

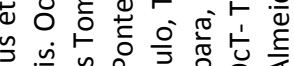

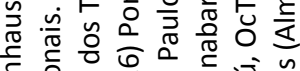

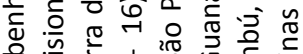

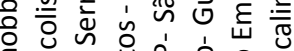

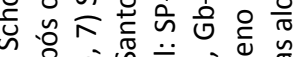

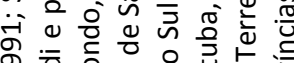
先

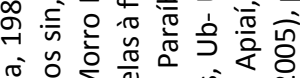

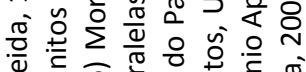

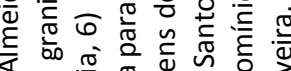

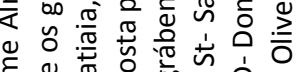
है

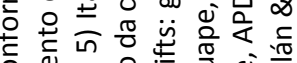

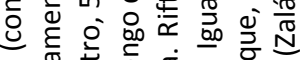
夜

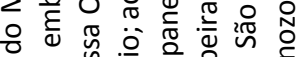

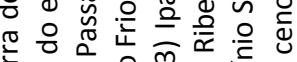

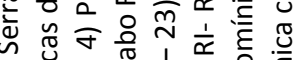
중 记

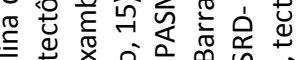

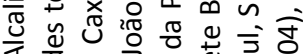
范 苋 ว.

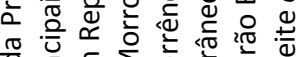
范结

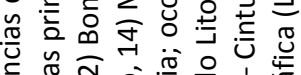
额

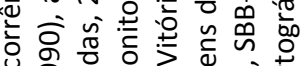
ช

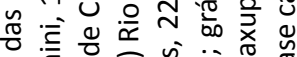


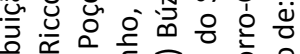

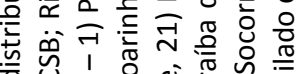
品 ๘

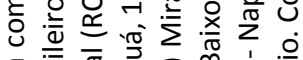

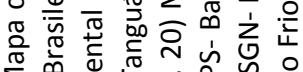

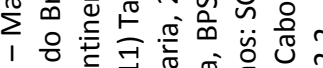

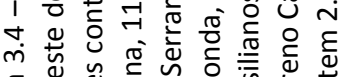

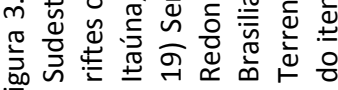





\section{GEOLOGIA E PETROGRAFIA}

Neste capítulo são apresentas uma nova leitura sobre a geologia do MAl, com um mapeamento geológico detalhado e caracterização das unidades magmáticas identificadas, bem ilustrado no mapa geológico no ANEXO D. Essa nova leitura mereceu um artigo científico com todas as informações sobre a geologia e petrografia interpretada segundo um modelo geológico e petrológico evolutivo. Esse artigo, intitulado "Nepheline Syenites to Syenites and Granitic Rocks of the Itatiaia Alkaline Massif, Southeastern Brazil: new geological insights into a migratory ring Complex" foi escrito em inglês e submetido ao Brazilian Journal of Geology com vistas a uma edição dedicada à Província ignea do Paraná e o magmatismo relacionado (ANEXO A). Portanto, é imprescindível sua leitura para a compreensão das informações apresentadas nesta tese.

A seguir encontra-se um resumo do manuscrito.

\subsection{Resumo}

O Maciço Alcalino de Itatiaia (MAl) está dentre as maiores ocorrências alcalinas mesocenozóicas do Brasil, com aproximadamente $215 \mathrm{~km}^{2}$ entre os estados de Minas Gerais e Rio de Janeiro. Ocorre como um corpo alongado com $30 \mathrm{~km}$ de comprimento por 4,5 a 11,5 km de largura orientado segundo SE-NW ao longo de zones de acomodação do Rifte Continental do Sudeste Brasileiro e intrudindo metapelitos, ortognaisses e granitos das faixas Ribeira e Brasília.

Novos dados de mapeamento geológico sugerem que o maciço evoluiu a partir de um centro magmático migratório, manifestando como um complexo anelar com sucessivas intrusões em forma de meia lua de sudeste para noroeste em três setores: Sudeste (S-SE), Central (S-C) e Noroeste (S-NW). Esses setores possuem características litológicas e geomorfológicas distintas, sugerindo diferentes origens e/ou estágios de evolução.

O S-SE não apresenta feições estruturais muito evidentes e é composta exclusivamente por nefelina sienitos, representando variedades miaskíticos a agpaíticos. A fácies mais insaturada está na borda em contato com a encaixante, localmente peraluminosa com a presença de coríndon modal e hercinita. Ocorrem diques fonolíticos afíricos, porfiríticos (alguns com pseudoleucita) ou brechóides, além de um dique de nefelinito. 
O S-C é formado pela estrutura anelar que intrude parcialmente a porção SE, apresentando um anel externo em forma de $\mathrm{C}$ sustentado por nefelina sienitos e fonolitos miaskíticos a agpaíticos. As fácies internas possuem forma de meia lua que migram para NW, sugerindo sucessivas intrusões. São compostas por diferentes unidades de pulaskitos, nordmarkitos e quartzo álcali feldspato sienitos, com tendência a aumentar a saturação em sílica para o centro. Um pequeno corpo de alaskito ocorre próximo ao centro. Diques de fonolito ocorrem nas regiões externas, enquanto que no interior ocorrem diques de traquito a riolito. A transição para o S-NW é feita por um 'pescoço' formado por quartzo sienito glomeroporfirítico com textura anti-rapakivi e enclaves microgranulares máficos. Também ocorrem corpos de traquitos brechóides a porfiríticos de matriz afanítica com fragmentos quase exclusivamente angulosos de granulação fina.

O S-NW aparentemente intrude essa zona de transição e também apresenta algumas estruturas em meia lua. Predomina nefelina sienitos, mas nordmarkitos ocorrem na borda norte. Localmente ocorre melagabro com textura cumulática e biotita monzonito. No centro da área também ocorre um neck vulcânico de traquito porfirítico a brechóide que se destaca na paisagem.

As variedades litológicas nos três setores apresentam-se como diferentes possíveis intrusões, cada uma com diferentes características petrográficas que podem ser divididas em cinco grupos: 1) nefelina sienitos sem plagioclásio, caracterizados por uma forte insaturação em sílica e uma tendência tardi-magmática agpaítica (comumente com låvenita, hiortdahlita, rinkite, dentre outros minerais); 2) nefelina sienitos/pulaskitos com plagioclásio, que mostram-se menos insaturados em sílica e mais máficos, com diopsídio largamente substituído por magnésio-hastingsita e presença de plagioclásio (normalmente com textura anti-rapakivi); 3) série nordmarkito-granito, onde álcali feldspato quartzo sienitos e granito mostram uma variação progressiva nos teores de quartzo, índice de cor e granulação, enquanto os nordmarkitos não mostram uma clara ralação evolutiva; 4) associação anti-rapakivi, caracterizado pela textura porfirítica a glomeroporfirítica anti-rapakivi nas rochas e presença ocasional de enclaves microgranulares máficos arredondados; a 5) rochas básicas representadas pela ocorrência de um melagabro metassomantizado e um traquibasalto com relações geológicas não mostrando relações claras com os sienitos. 


\section{RESULTADOS ANALÍTICOS}

A seguir são descritos de maneira sistemática os resultados das análises laboratoriais e ilustrados através de gráficos e diagramas.

\subsection{Química mineral}

O MAI caracteriza-se pela coexistência de rochas insaturadas e supersaturadas em sílica que variam de hololeucocráticas a melanocráticas, básicas a ácidas, peralcalinas a peraluminosas e sódicas a ultrapotássicas, o que reflete numa grande variação composicional dos minerais principais e diversidade da mineralogia acessória. Neste capítulo são apresentadas as características composicionais dos minerais principais e de alguns acessórios das principais unidades do MAl, com base na determinação química in situ por microssonda eletrônica. Os resultados das análises para todos os minerais estudados, bem como aquelas utilizadas para fins de cálculo dos parâmetros intensivos, encontram-se no ANEXO E.

\subsubsection{Feldspato}

O feldspato alcalino é o mineral predominante em todo o maciço, exceto no MG-mts, onde ocorre apenas plagioclásio, e no BtM, onde o plagioclásio ocorre em igual proporção. Geralmente encontra-se exsolvido, especialmente nas rochas supersaturadas em sílica. Plagioclásio também ocorre em menor proporção em algumas outras unidades, comumente como antecristais sobrecrescidos por feldspato alcalino. O diagrama An-Ab-Or (Figura 5.1) mostra a variação composicional dos feldspatos nas distintas fácies definidas, ilustradas em diagramas separadamente para os setores do Sudeste (S-SE), Central (S-C) e Noroeste (S-NW), e as diferenças existentes entre elas não somente dentro de uma unidade geológica, como também entre esses três (Tabela E.1).

No S-SE, as unidades apresentam composições mais constantes, tanto para o feldspato alcalino (que são mais potássicos), quanto para o plagioclásio. A composição do feldspato alcalino na fácies agpaítico do NeS-I é $\mathrm{An}_{0-0,2} \mathrm{Ab}_{23-28} \mathrm{Or}_{72-77}$ (composição média reintegrada), enquanto na fácies peraluminosa é um pouco mais potássico $A n_{0,2-1} A b_{17-22} \mathrm{Or}_{77-83}$ e o plagioclásio de $A n_{36-40} A b_{59-63} \mathrm{Or}_{0,5-1}$. Já no BtHbINeS o feldspato alcalino possui composição mais intermediária, $A n_{1-6} \mathrm{Ab}_{40-48} \mathrm{Or}_{47-55}$ (composição média reintegrada) e o plagioclásio menos cálcico de $\mathrm{An}_{25-33} \mathrm{Ab}_{66-74} \mathrm{Or}_{1-2}$. De modo geral, 
os valores de $\mathrm{SrO}$ e $\mathrm{BaO}$ chegam no máximo a 0,36 e 0,12\% em peso, respectivamente, sendo o primeiro mais abundante na amostra MAI030 (NeS-I, peraluminosa).

No S-C, o feldspato alcalino tem uma composição média de $\mathrm{An}_{0-6} \mathrm{Ab}_{38-60} \mathrm{Or}_{39-61}$. As composições mais potássicas ou mais sódicas possivelmente estão em desequilíbrio. Nas rochas supersaturadas em sílica são comuns bordas albíticas bem definidas. Na unidade BtHblP possui uma tendência de aumentar o teor de An com o aumento de Ab. O plagioclásio constitui dois grupos composicionais, um com $A n_{39-43}$, formado por núcleos de cristais na unidade BtHblP, e outro com $\mathrm{An}_{23-32}$, formado por regiões de borda e alguns núcleos nesta mesma unidade e núcleos nas unidades arpk-QzS e N I, apresentando em todos $\mathrm{Or}_{1-5}$. De modo geral, SrO chega até $0,28 \%$ em peso no feldspato alcalino e entre 0,17 e 1,11\% no plagioclásio, tendo uma aparente correlação positiva com An. Já o BaO chega até $0,55 \%$.

No S-NW, as rochas com nefelina apresentam um feldspato alcalino de composição média de $\mathrm{An}_{1-4} \mathrm{Ab}_{44-61} \mathrm{Or}_{54-61}$, além de um plagioclásio na amostra MAl160 (HblP), com $\mathrm{An}_{12-15} \mathrm{Ab}_{\text {82-85 }} \mathrm{Or}_{3-4 .}$. No BtM, os feldspatos apresentam três grupos composicionais, cristais de plagioclásio na matriz e em núcleos de fenocristais com $A n_{22-28} A b_{66-76} \mathrm{Or}_{2-6}$, cristais com textura semelhante, porém exibindo feições de reequilíbrio $A n_{14-17} A b_{55-67} \mathrm{Or}_{17-32}$, com feldspato alcalino $A n_{5-8} A b_{32-46} \mathrm{Or}_{45-62}$. Já o $M G-m t s$ possui plagioclásio de composição $A n_{37-44} \mathrm{Ab}_{55-62} \mathrm{Or}_{1}$, com a maioria das análises compreendidas no intervalo An 25-30 com feições de reequilíbrio. Também apresenta algumas porções, em contato com o anfibólio, com $A b_{98-99}$ na forma de cristal tabular e uma textura exsolvida em um emaranhado acicular muito fino de composição média $\mathrm{An}_{11} \mathrm{Ab}_{59} \mathrm{Or}_{30}$. De modo geral, constituem dois grupos quanto aos teores de $\mathrm{SrO}$, um com até $0,13 \%$ e outro variando de 0,22 a 0,45\% (amostras MAl160 e 182C). Já os teores de BaO chegam até $0,63 \%$, apresentando uma correlação negativa com An.

\subsubsection{Nefelina}

Nefelina é o feldspatóide dominante em todas as unidades insaturadas em sílica, à exceção de algumas amostras, onde a sodalita é mais importante e no dique MAI046F onde ocorre pseudoleucita. As unidades BtM e MG-mts apresentam nefelina normativa, porém não foi encontrada em lâmina. 0 diagrama Ne-Qz-Ks (Figura 5.2) mostra a diferença de composição entre as fácies nos distintos setores (Tabela E.2) e as temperaturas de equilíbrio dos cristais.

No S-SE, a nefelina possui uma composição média de $\mathrm{Ne}_{73-79} \mathrm{Ks}_{17-26} \mathrm{Qz}_{2-6}$, sendo a unidade BtHbINeS a mais rica em Qz. As temperaturas de equilíbrio ficam abaixo de $750^{\circ} \mathrm{C}$, provavelmente já reequilibradas. Nas amostras MAI030 e 036 (NeS I e BtNbINeS) apresentam valores de CaO entre 1,16 e 1,83\% em peso, sendo essas amostras com a presença de plagioclásio. Os teores de $\mathrm{Fe}_{2} \mathrm{O}_{3}$ varia entre 0,54 e 1,37\% nos núcleos da amostra MAI058I e 0,45 e 0,73\% na amostra MAI060, ambas da fácies agpaítica da unidade NeS I. Para o restante os valores chegam no máximo a 0,27\%. 
No S-C, possui uma composição mais variada, com Ne ${ }_{73-78} \mathrm{Ks}_{15-29} \mathrm{Qz}_{0-9}$. A amostra MAI208 destoa quanto ao teor de $Q z$, abaixo de $1,5 \%$, enquanto todas as outras análises possuem acima de $4 \%$. Os teores de $\mathrm{CaO}$ apresenta algumas diferenças, sendo significativas apenas nas amostras do BtP (a única com plagioclásio modal). As amostras MAl102 e 114 possuem exatamente a mesma distribuição, variando de 1,24 a 1,66\%, enquanto a amostra MAI092I apresenta valores entre 0,50 e 0,84\%. Já os valores de $\mathrm{Fe}_{2} \mathrm{O}_{3}$ variam entre 0,32 e 0,75\%, exceto para a amostra MAI199, 1,30 a 1,68\%.

No S-NW, a composição média é de $\mathrm{Ne}_{74-77} \mathrm{Ks}_{17-23} \mathrm{Qz}_{3-7}$. Os teores de $\mathrm{CaO}$ variam de 0,87 a 1,23\% no HblP e de 0,36 e 0,55\% no NeS II, sendo esta a única fácies sem plagioclásio com teores significativos. Já os teores de $\mathrm{Fe}_{2} \mathrm{O}_{3}$ variam de 0,07 a $0,54 \%$ e 0,43 a $0,73 \%$ no $\mathrm{HblP}$ e $\mathrm{NeS}$ II, respectivamente.

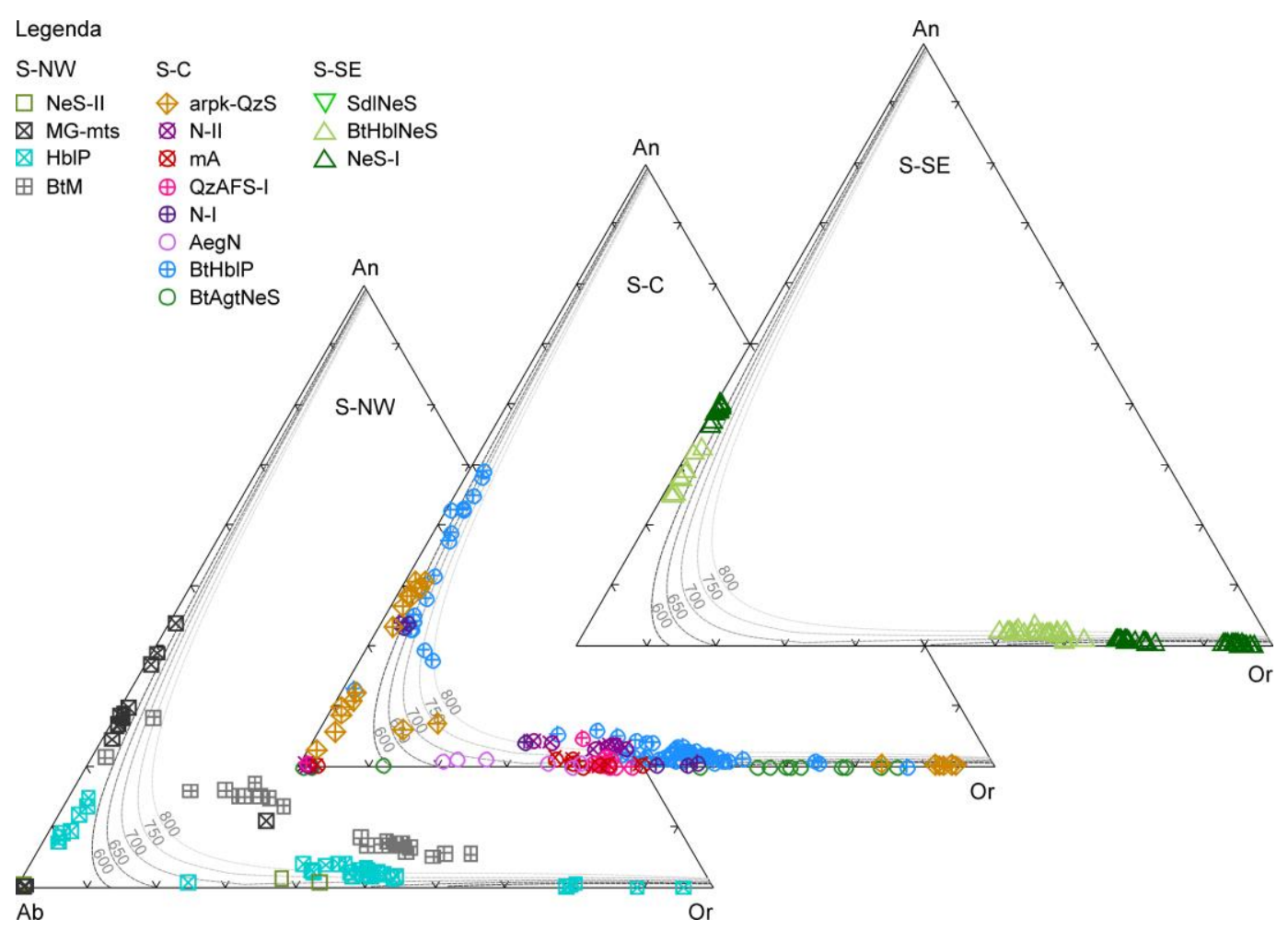

Figura 5.1 - Diagrama dos componentes moleculares Ab - An - Or, em proporção molecular, para feldspatos dos diferentes setores do MAI. As linhas pontilhadas representam os limites de solução sólida de feldspatos ternários para as temperaturas na pressão de 1 kbar, segundo modelo termodinâmico de Elkins \& Grove (1990).
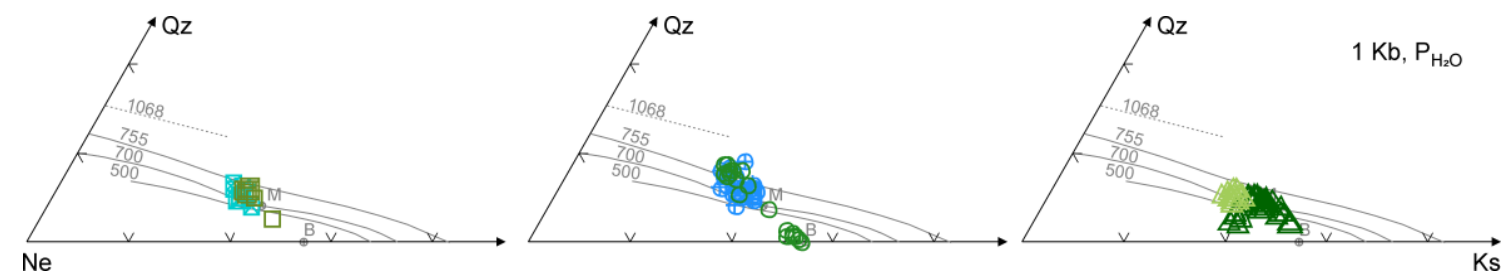

Figura 5.2 - Diagrama dos componentes moleculares $\mathrm{Ne}-\mathrm{Qz}-\mathrm{Ks}$, em proporção molecular, para nefelinas dos diferentes setores do MAI. Temperaturas de equilíbrio segundo Hamilton (1961). Legenda idem Figura 5.1. 


\subsubsection{Clinopiroxênio}

O clinopiroxênio possui uma ampla variação composicional e segue a sequência geral augita, diopsídio, aegirina-augita e aegirina, como pode ser visto no diagrama Mg-Na-[Fe $\left.{ }^{2+}+\mathrm{Mn}\right]$ (Figura 5.3) e na Tabela E.3.

No S-SE apresenta uma curva quase contínua de enriquecimento em $\mathrm{Mg} \rightarrow \mathrm{Fe}^{2+} \rightarrow \mathrm{Na}$, porém formado por grupos de diferentes amostras. O BtHbINeS é composto exclusivamente por diopsídio, enquanto as duas amostras do NeS I variam de diopsídio a aegirina-augita (MAI060) e de aegirinaaugita a aegirina (MAI058I). Os teores de $\mathrm{Al}_{2} \mathrm{O}_{3}$ variam de 0,68 a 4,07\% em peso, com Al tetraédrico até $0,156 \mathrm{apfu}$, sendo ausente em poucas análises. $\mathrm{MnO}$ varia de 0,60 a 4,71\%, enquanto $\mathrm{TiO}_{2}$ e $\mathrm{ZrO}_{2}$ atingem até $4,22 \%$ e $1,26 \%$, respectivamente.

No S-C concentra-se em dois grupos distintos, BtP e arpk-QzS possuem apenas diopsídio, enquanto BtAgtNeS e AegN variam apenas de aegirina-augita a aegirina. Apenas o N I (MAl097B) apresenta uma variação diopsídio $\rightarrow$ aegirina. De modo geral, apresentam um menor enriquecimento em $\mathrm{Fe}^{2+}$, o que deixa uma curva de tendência mais direta do que o S-SE. Os teores de $\mathrm{Al}_{2} \mathrm{O}_{3}$ variam de 0,18 a 4,99\%, sendo que no BtP é superior a 1,17\%, enquanto nas outras unidades atingem no máximo
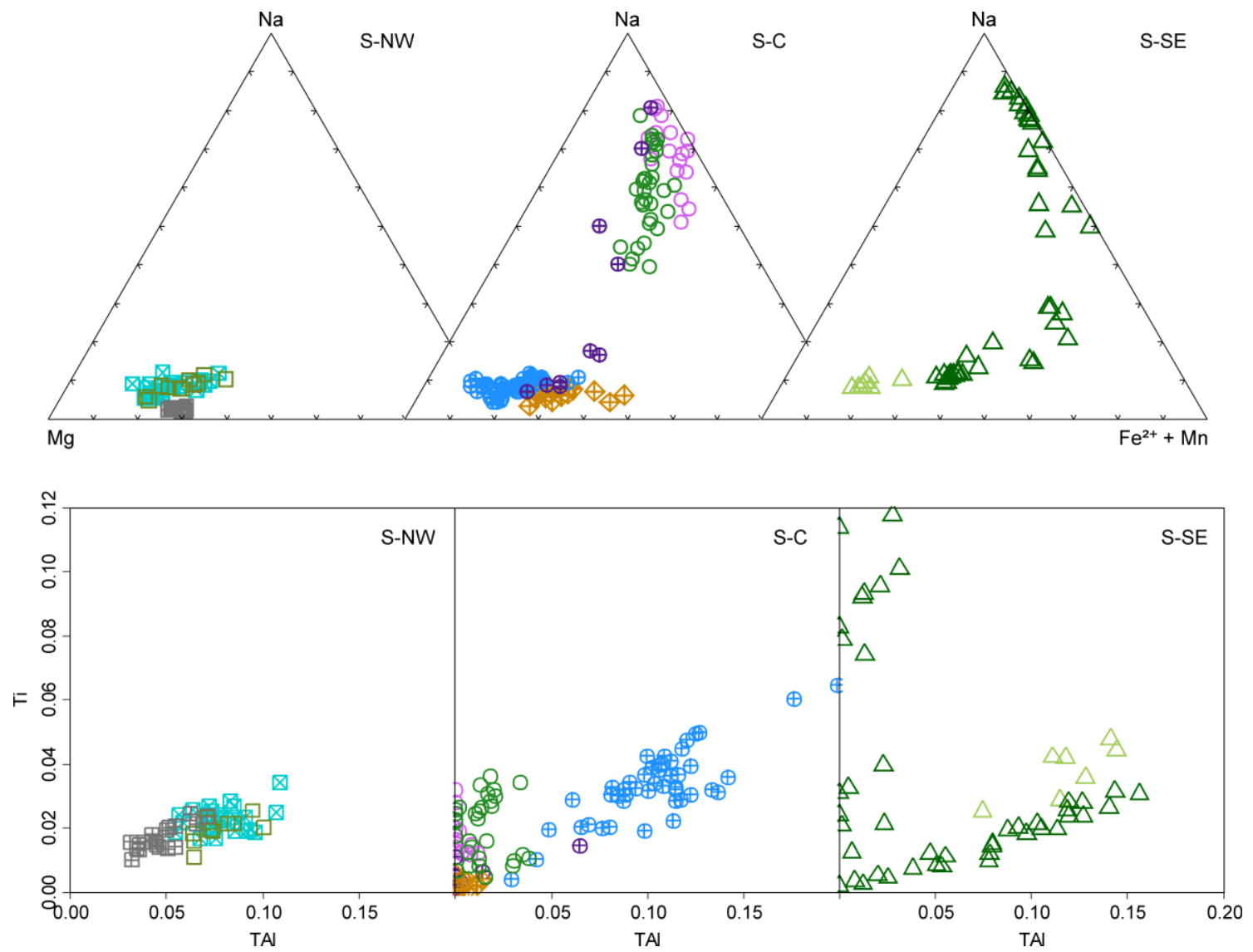

Figura 5.3 - Diagramas $\mathrm{Mg}-\mathrm{Na}-\left(\mathrm{Fe}^{2+}+\mathrm{Mn}\right)$, em a.p.f.u., e $\mathrm{Al}_{\mathrm{T}}$ Vs. Ti, em a.p.f.u., para clinopiroxênios dos diferentes setores do MAl. Legenda idem Figura 5.1. 
1,55\%. Alv chega até 0,199 apfu. $\mathrm{MnO}$ varia de 0,16 a 4,26\%, enquanto $\mathrm{TiO}_{2}$ e $\mathrm{ZrO}_{2}$ atingem no máximo 1,16 e $1,18 \%$, respectivamente.

No S-NW as unidades com nefelina possuem apenas diopsídio, enquanto o BtM a augita. Os teores de $\mathrm{Al}_{2} \mathrm{O}_{3}$ variam de 1,16 a 3,57\%. $\mathrm{MnO}$ e $\mathrm{TiO}_{2}$ variam de 0,75 a 2,04\% e 0,36 a 1,24\%, respectivamente, enquanto $\mathrm{ZrO}_{2}$ atinge até $0,24 \%$.

\subsubsection{Anfibólio}

Em quase todas as litologias onde está presente, verifica-se que é clara a relação de substituição do piroxênio por anfibólio. Nas rochas insaturadas em sílica, o anfibólio é caracteristicamente cálcico, classificando-se como magnésio-hastingsita rica em Ti, à exceção da amostra MAI178 (MG-mts), na maioria ferro-pargasita, e na amostra MAI199 (BtAgtNeS) onde tem natureza sódico-cálcica a sódica, classificado como ferri-katophorita ou magnésio-arfvedsonita. Já nas rochas supersaturadas em sílica, ele é sódico-cálcico e classifica-se como richterita ou ferro-richterita.

Os três segmentos não apresentam diferenças composicionais significativas nos respectivos anfibólios presentes (Figura 5.4 e Tabela E.4). De modo geral, as amostras apresentam pouca variação composicional, tendo alguma importância apenas quanto ao \#Mg, e quanto alguns elementos nas amostras MAI036 (BtHbINeS), 110 (QzAFS-I ) e 178 (MG-mts).

\subsubsection{Titanita}

A titanita, de modo geral, apresenta teores elevados de $\mathrm{Fe}_{2} \mathrm{O}_{3}$ e $\mathrm{Al}_{2} \mathrm{O}_{3}$, com até $5,41 \%$ e 3,96\% de óxido em peso, respectivamente, além de $\mathrm{Ce}_{2} \mathrm{O}_{3}, \mathrm{ZrO}_{2}, \mathrm{Nd}_{2} \mathrm{O}_{3}, \mathrm{Y}_{2} \mathrm{O}_{3}$, e $\mathrm{Na}_{2} \mathrm{O}$ com até 2,81\%, 2,48\%, $1,94 \%, 1,46 \%$ e $1,43 \%$ em peso, respectivamente, sendo o $\mathrm{Y}_{2} \mathrm{O}_{3}$ significativo apenas nas unidades supersaturadas em sílica e $\mathrm{Na}_{2} \mathrm{O}$ no BtAgtNeS e QzAFS-I. Nos três segmentos, a titanita não apresentou diferenças composicionais significativas (Tabela E.5).

$\mathrm{O}$ total integrado entre $\mathrm{Fe}^{3+}, \mathrm{Al}$ e $\mathrm{Zr}$ (em a.p.f.u.) apresenta uma correlação negativa próxima a 1:1 com o Ti, sugerindo uma substituição entre esses elementos. Assim como a soma dos ETRs (La, Ce e Nd, além de Y) apresenta a mesma correlação com Ca (Figura 5.5). Porém, os ETRs não apresentam uma correlação definida com $\mathrm{Fe}^{3+}$ ou Al. A fórmula fixada em 3 cátions e 5 oxigênios apresenta uma certa deficiência no sítio do Ti, que varia de 0,918 a 1,002 a.p.f.u. e excesso no sítio do Ca, variando de 0,986 a 1,072 a.p.f.u., enquanto Si varia de 0,976 a 1,032 a.p.f.u. Isso possivelmente se deve à ausência de elementos importantes na análise, dado pela relativa abundância dos ETRs medidos.

\subsubsection{Biotita}

A maioria dos cristais de biotita apresenta texturas de substituição do anfibólio e, mais raramente, piroxênio. Apenas na unidade BtM e na fácies peraluminosa da unidade NeS-I possivelmente seja primária. 
As análises mostram composições que classificam-se como flogopita a annita (Figura 5.6 e Tabela E.6), com Mg/(Mg + $\left.\mathrm{Fe}^{2+}\right)$ variando de 0,172 a 0,745 e $\mathrm{Al}_{\text {total }}$ entre 0,729 e 1,824 a.p.f.u.. Fe ocorre em várias unidades, especialmente nas do S-C, sendo ausente no S-SE. De modo geral possui teores importantes de $\mathrm{TiO}_{2}, \mathrm{MnO}$ e $\mathrm{BaO}$, chegando até 6,82\%, 3,14\% e 1,53\% em peso, respectivamente, sendo o último significativo apenas no arpk-QzS e BtM.

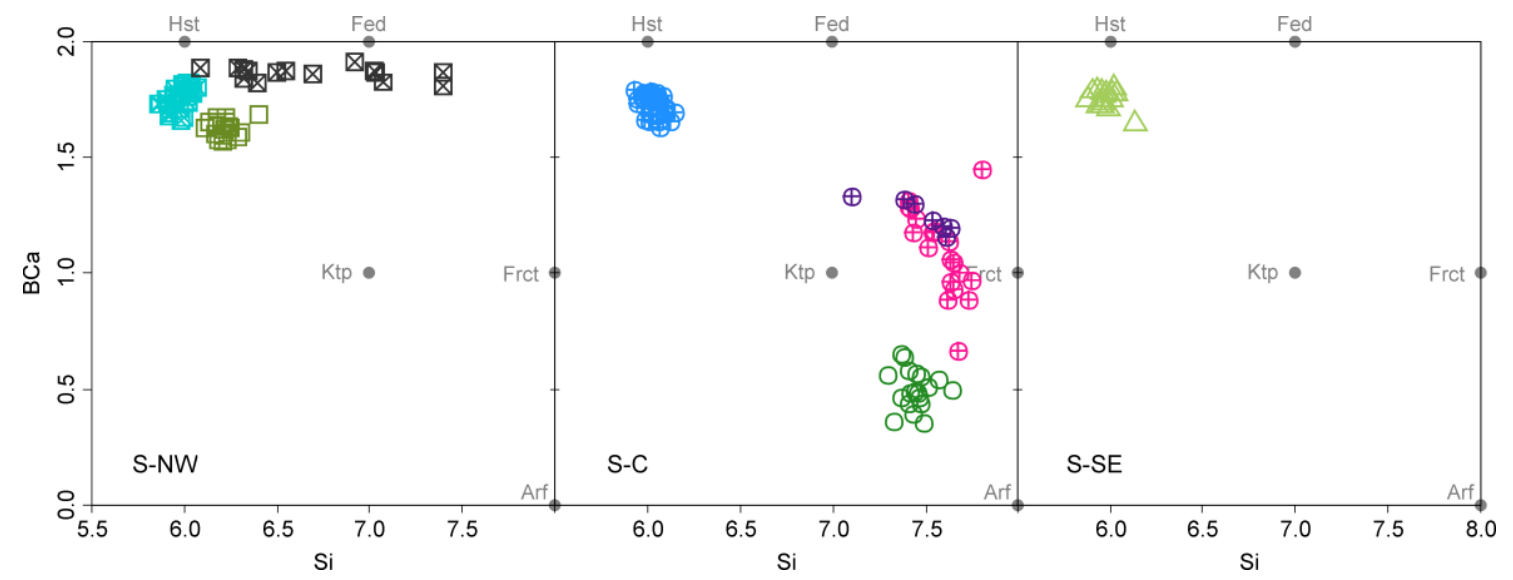

Figura 5.4 - Diagrama Si vs. $\mathrm{Ca}_{\mathrm{B}}$, em a.p.f.u., para anfibólios dos diferentes setores do MAl. Os pontos cinza representam os membros finais hastingsita (Hst), ferro-edenita (Fed), katoforita (Ktp), ferro-richterita (Frct) e arfvedsonita (Arf). Legenda idem Figura 5.1.
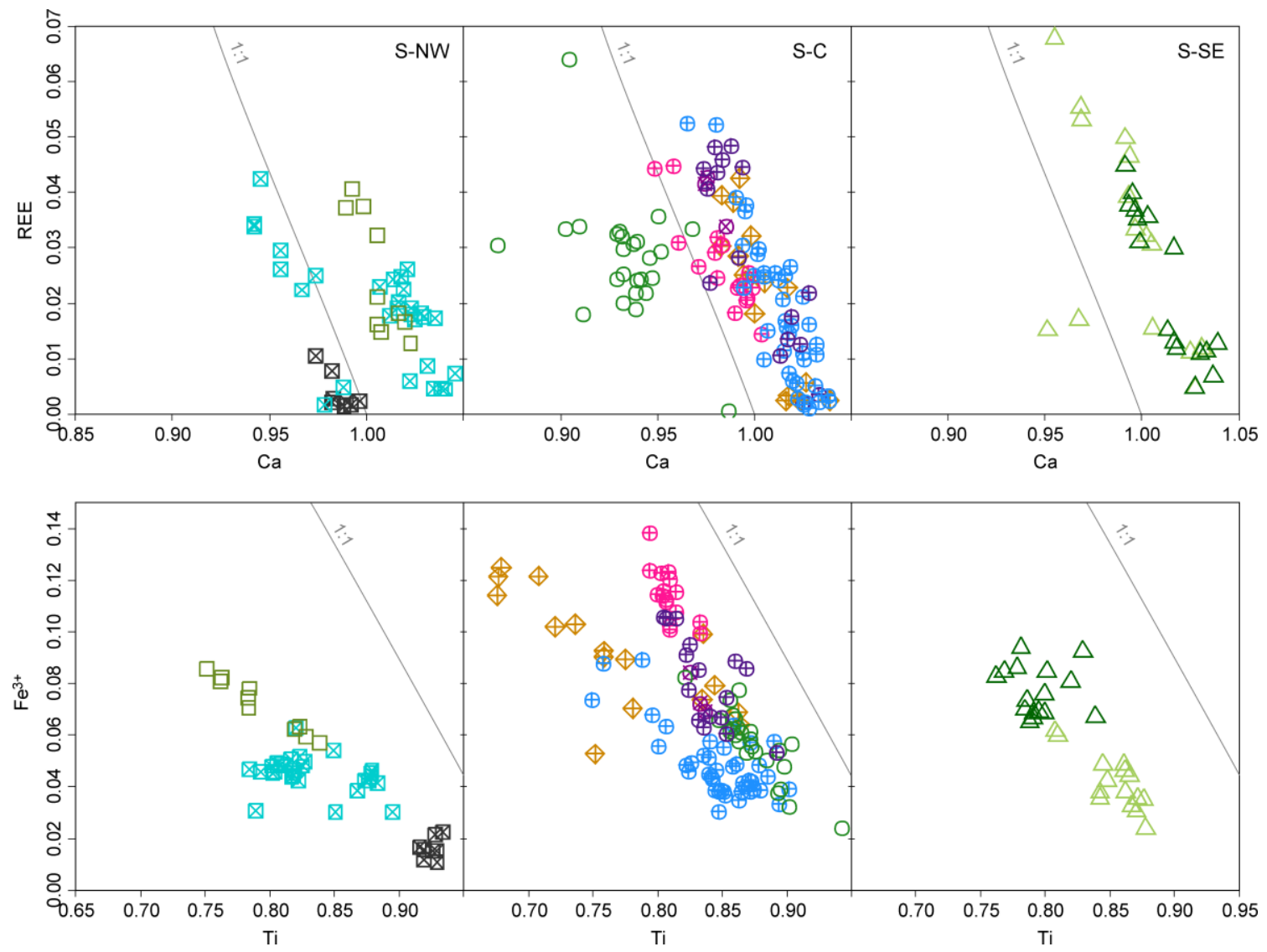

Figura 5.5 - Diagramas Ca vs. REE $(\mathrm{La}+\mathrm{Ce}+\mathrm{Nd}+\mathrm{Y})$ e Ti vs. $\mathrm{Fe}^{3+}$, em a.p.f.u., para titanitas dos diferentes setores do MAl. A linha diagonal representa a proporção catiônica 1:1. Legenda idem Figura 5.1. 


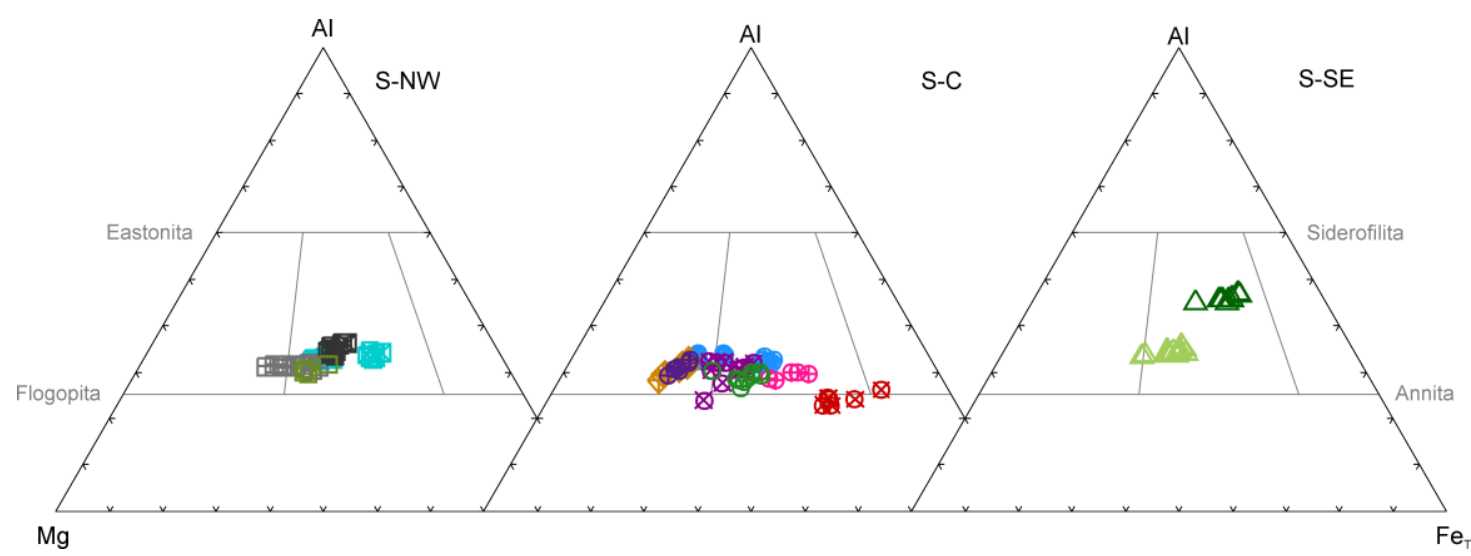

Figura 5.6 - Diagrama $\mathrm{Mg}-\mathrm{Al}-\mathrm{Fe}_{\mathrm{T}}$, em a.p.f.u., com membros finais eastonita, siderofilita, flogopita e annita (Deer et al., 1992) para biotitas dos diferentes setores do MAI. Legenda idem Figura 5.1.

\subsubsection{Ilmenita e espinélios}

Ilmenita ocorre principalmente nas rochas supersaturadas em sílica, mas também pode ocorrer como relictos na titanita no BtP ou como cristais intercrescidos com titanomagnetita no BtM e na amostra MAI199 (peralcalina da unidade BtAgtNeS). Não ocorre nas amostras do S-SE analisadas. Apresenta teores de $\mathrm{MnO}$ significativos, de 3,27 a 24,96\% em peso, sendo mais altos no BtAgtNeS, $\mathrm{N}$ I e QzAFS-I (Tabela E.7a). $\mathrm{Nb}_{2} \mathrm{O}_{5}$, atinge até $1,27 \%$ nas rochas com quartzo, enquanto $\mathrm{ZnO}$ é importante apenas no $\mathrm{N}-\mathrm{I}$, de 0,93 a 1,20\%, e MgO apenas no BtP, de 1,71 a 2,11\%.

Titanomagnetita ocorre em todas as rochas. Os cristais possuem uma composição relativamente constante em cada unidade (Tabela C.7b). De modo geral o $\mathrm{TiO}_{2}$ é variável de $0,46 \mathrm{a}$ $13,94 \%$, enquanto os teores de $\mathrm{MnO}, \mathrm{Al}_{2} \mathrm{O}_{3}$ e $\mathrm{ZnO}$ chegam até $6,58 \%, 1,89 \%$ e $0,61 \%$ (em peso) respectivamente, além de $\mathrm{MgO}$ na amostra MAl114, que varia de 0,29 a 0,85\%.

Hercynita e coríndon ocorrem apenas na fácies peraluminosa do NeS-I e apresentam composição homogênea, com teores significativos de $\mathrm{MnO}$ e $\mathrm{MgO}$, de 2,94 a 3,99\% e 0,82 a 1,50\%, respectivamente, no primeiro, e de $\mathrm{Fe}_{2} \mathrm{O}_{3}$, entre 0,84 e 2,03\% no segundo (Tabela E.7c).

\subsubsection{Minerais acessórios}

Com o auxílio de análises por microssonda eletrônica nos modos WDS e EDS, além da óptica, foram ainda caracterizados ou identificados vários minerais raros (Tabela E.8). Nas unidades insaturadas em sílica, a låvenita, hiortdahlia, kupletskita, hainita e rinkita são acessórios importantes, enquanto a britholita, catapleiita, pirocloro (grupo), scheelita, zirconolita e sulfetos de $\mathrm{Pb}, \mathrm{Zn}$ e Fe, ocorrem como traços. Já nas fácies supersaturadas em sílica chevkinita e fluorcarbonatos de terrasraras são acessórios, enquanto pirocloro e xenotima são traços. 


\subsection{Geoquímica elemental}

Os resultados das análises de química global das variedades litológicas do MAI encontram-se no ANEXO F. Esses dados foram utilizados para fins de cálculo de minerais normativos, classificação química das rochas e definições de índices geoquímicos, ressaltando diferenças importantes entre os litotipos de cada unidade e particularmente entre os três setores. Os teores de $\mathrm{SiO}_{2}$ mostraram uma boa correlação com os outros elementos maiores, alguns traços e as razões isotópicas.

\subsubsection{Elementos maiores e traços}

Os teores de $\mathrm{SiO}_{2}$ variam de 45 a $73 \%$ em peso (sendo a maior parte das amostras entre 58 e 63\%), compreendendo um amplo intervalo composicional que se estende de rochas básicas a ácidas (Figura 5.7). Já os valores de \#mg variam de 2,2 a 42,6 mas em sua maioria entre 18 e 37.

No diagrama TAS (total álcalis vs. sílica), as rochas do S-SE pertencem quase exclusivamente ao campo do fonolito, as do S-C concentram-se no campo de traquito, variando de fonolito a riolito, enquanto as do S-NW distribuem-se quase totalmente no campo do traquito, além do BtM no campo do latito (traquiandesito, onde $\mathrm{Na}_{2} \mathrm{O}-2<\mathrm{K}_{2} \mathrm{O}$ ) e MG-mts e TB no traquibasalto potássico (Figura 5.8).

$\mathrm{Na}$ Figura 5.9, as amostras concentram-se no campo das rochas metaluminosas, variando de peralcalinas (quase exclusivamente as litologias insaturadas em sílica) a peraluminosas

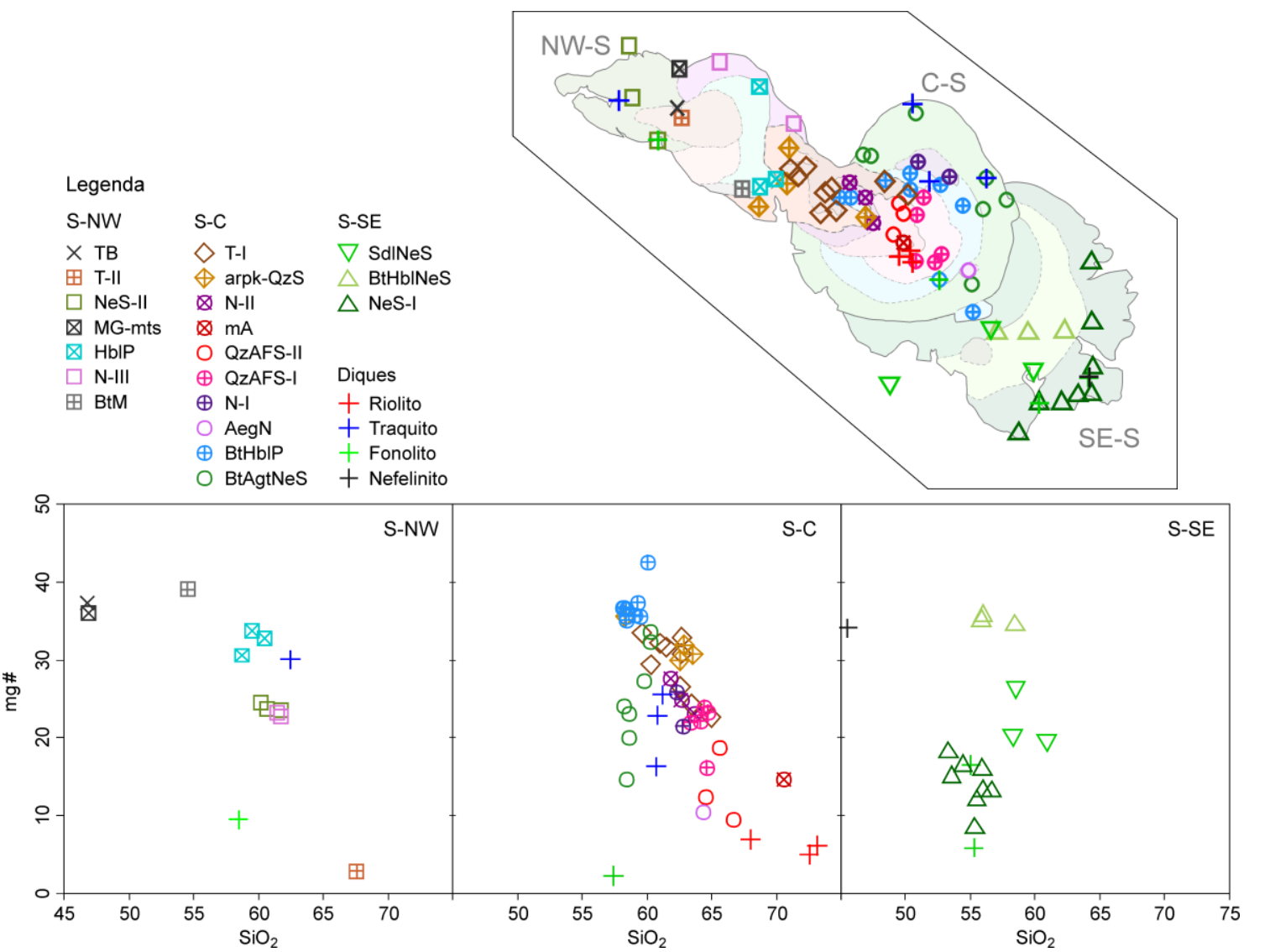

Figura 5.7 - Diagrama $\mathrm{SiO}_{2}$ (\% em peso) vs. mg\# (mol \%), para os litotipos dos distintos setores do MAl. No destaque, a localização das amostras analisadas no mapa geológico simplificado. 
(principalmente diques de traquito e riolito, a unidade T-I e a facies com coríndon do NeS-I). No diagrama $\mathrm{Na}_{2} \mathrm{O}$ vs. $\mathrm{K}_{2} \mathrm{O}$ (Figura 5.10) também apresentam grande dispersão, estendendo-se do campo sódico ao ultra-potássico, mas concentrando-se no campo potássico. As rochas mais peralcalinas tendem a serem mais sódicas, enquanto que as peraluminosas mais potássicas.

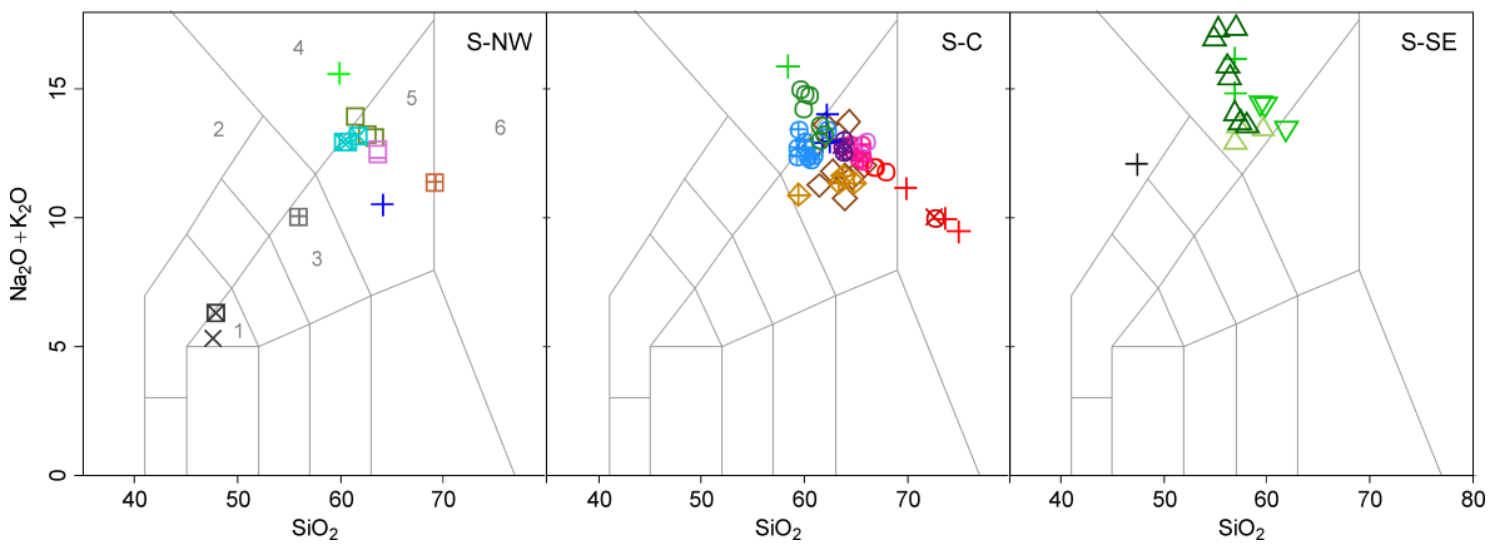

Figura 5.8 - Diagrama TAS (total álcalis vs. $\mathrm{SiO}_{2}$, em \% de peso; Le Maitre, 2002) para as rochas dos diferentes setores do MAI. Os campos numerados são: 1- traquibasalto, 2-foidito, 3- traquiandesito, 4-fonolito, 5 - traquito $(\mathrm{Q}<20 \%)$ e 6 - riolito. Legenda idem Figura 5.7.

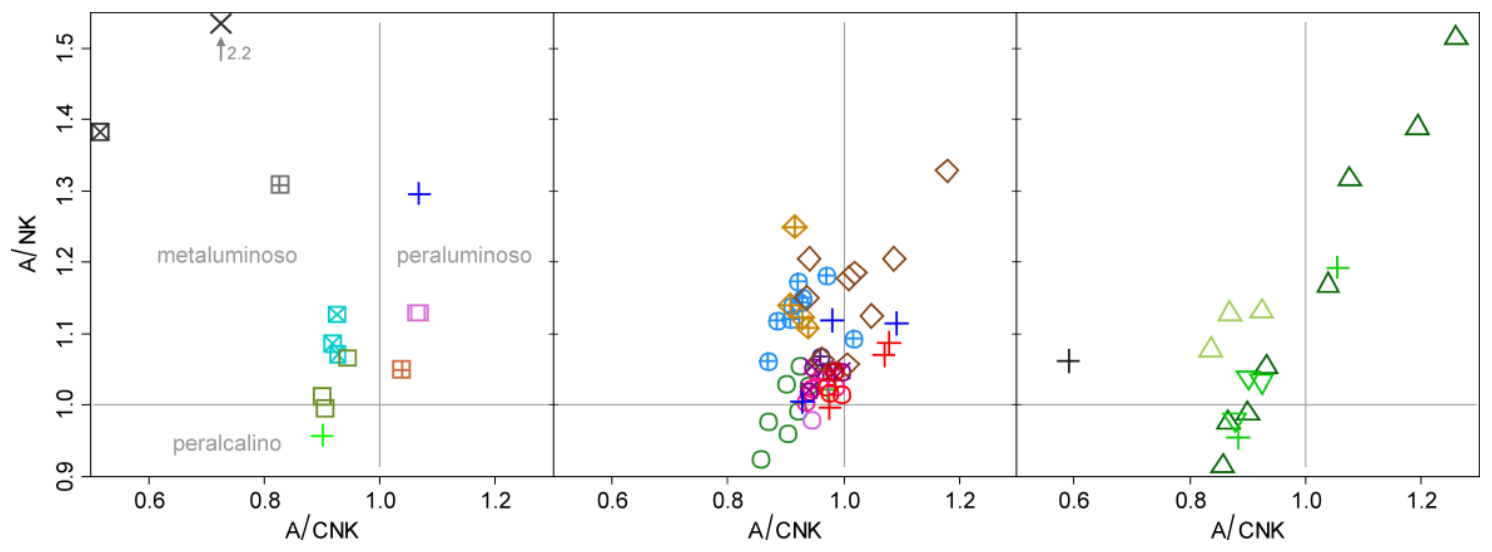

Figura 5.9 - Diagrama A/CNK vs. A/NK (Shand, 1943) para as rochas dos diferentes setores do MAl. Legenda idem Figura 5.7.

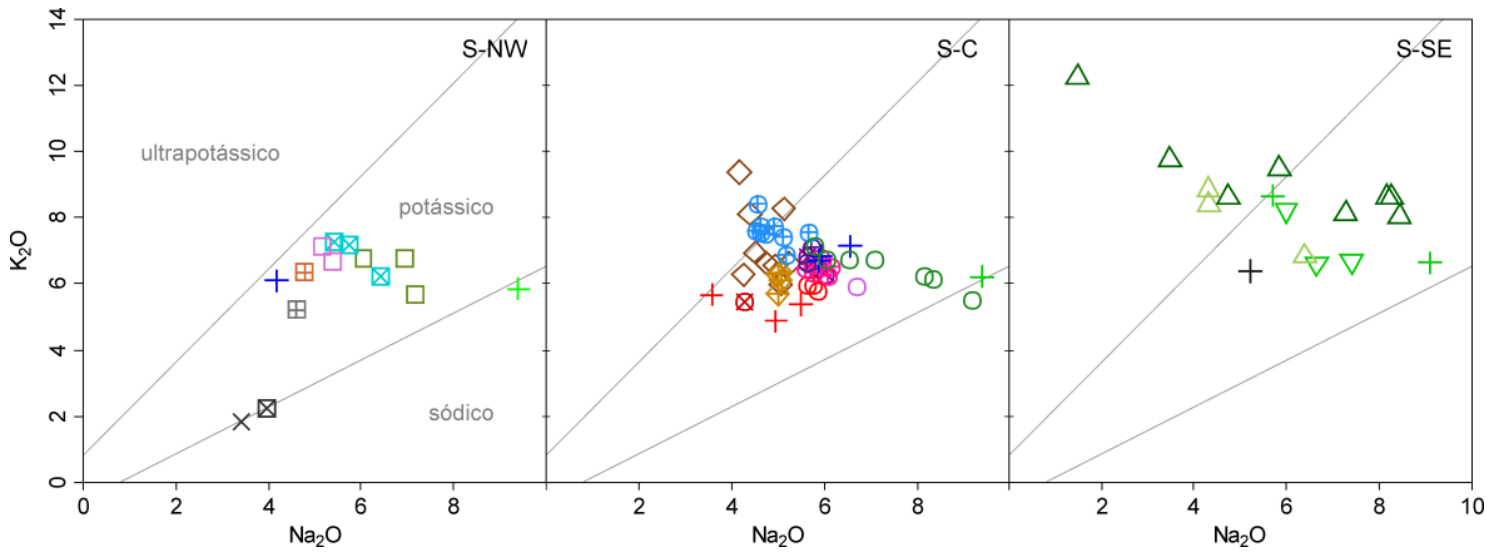

Figura 5.10 - Diagrama $\mathrm{Na}_{2} \mathrm{O}$ vs. $\mathrm{K}_{2} \mathrm{O}$ (Middlemost, 1975) para as rochas dos diferentes setores do MAl. Legenda idem Figura 5.7 . 
Nos diagramas de Harker (Figura 5.11) para os elementos maiores, fica claro o enriquecimento em sílica. $\mathrm{O} \mathrm{Al}_{2} \mathrm{O}_{3}$ possui uma forte correlação negativa com a sílica, enquanto que o $\mathrm{K}_{2} \mathrm{O}$ apresenta algum espalhamento, e o $\mathrm{Na}_{2} \mathrm{O}$ uma grande dispersão. $\mathrm{TiO}_{2}, \mathrm{MgO}, \mathrm{Fe}_{2} \mathrm{O}_{3 \text { total }}, \mathrm{P}_{2} \mathrm{O}_{5}$ e, um pouco menos claro, $\mathrm{CaO}$ apresentam o mesmo padrão, com uma curva principal evidenciando para parte expressiva das litologias uma boa correlação negativa e um grupo mais abaixo representando algumas litologias, com uma tendência oposta, formando um lambda $(\lambda)$.

Visto separadamente, as unidades litológicas de cada um dos três setores possuem tendências diferentes. Apenas o S-C apresenta correlações mais bem definidas entre as unidades, enquanto que o S-SE possui um grande espalhamento (principalmente devido a unidade NeS-I) e uma tendência geral oposta aos outros dois (formando o $\lambda$ ), já o S-NW apresenta uma concentração para alguns elementos e uma fraca correlação linear para outros. Esse padrão em $\lambda$ sugere que o S-SE possui uma origem e/ou evolução diferente do resto do maciço.

Os elementos traço também apresentam grande variação nos teores, com destaques para $\mathrm{Rb}$ (39-358 ppm), Ba (1-2945 ppm), Sr (2-2519ppm), Zr (21-1754 ppm), Nb (21-436 ppm), La (1-271 ppm) e Ce (5-540 ppm). Entretanto, a maioria deles apresenta-se muito disperso, não possuindo clara correlação com a sílica (Figura 5.12) ou \#mg, e mesmo os que possuem não são muito bem definida. Apenas $\mathrm{Rb}$, Th e Sr, além de $\mathrm{U}, \mathrm{Nb}$ e Ta, possuem uma leve correlação positiva para o S-C e S-NW e negativa para o S-SE, enquanto Sr é o único elemento que apresenta uma correlação geral negativa com a sílica.

Essa variação reflete-se na grande dispersão das curvas no diagrama para os elementos incompatíveis normalizados pelo manto primitivo (McDonough \& Sun, 1995), destacando-se as proeminentes anomalias negativas de $\mathrm{Ba}, \mathrm{Sr}$, Eu e Ti (Figura 5.13). Essas anomalias são mais pronunciadas no S-C, enquanto que no S-SE ocorrem principalmente nos diques de fonolito. $O$ nefelinito e o traquibasalto possuem um padrão menos sinuoso, apenas com uma pequena anomalia positiva de Rb para o primeiro e Ba para o segundo.

\subsubsection{Norma CIPW}

As rochas insaturadas em sílica possuem nefelina normativa ( $\mathrm{Ne}$ ) variáveis de 4,49 a 33,65\% no S-SE; 0,01 a 19,29\% no S-C (além do dique MAI092II com 26,47\%) e 0,09 a 9,72\% no S-NW (sendo o dique MAl166II com 21,57\%), e olivina (OI) com variações de 0 a 2,78\% no S-SE; 0,35 a 3,13\% no S-C e 0,42 a 9,88\% no S-NW. No S-SE duas amostras não possuem OI, (MAI060 e 068), enquanto o dique de nefelinito (MAIO46E) é a única do MAI com leucita normativa (Ne 22,93 e Lc 4,15\%). Apesar do dique de fonolito MAIO46F possuir cerca de $25 \%$ de fenocristais de pseudoleucita modal, não possui Lc normativa. 


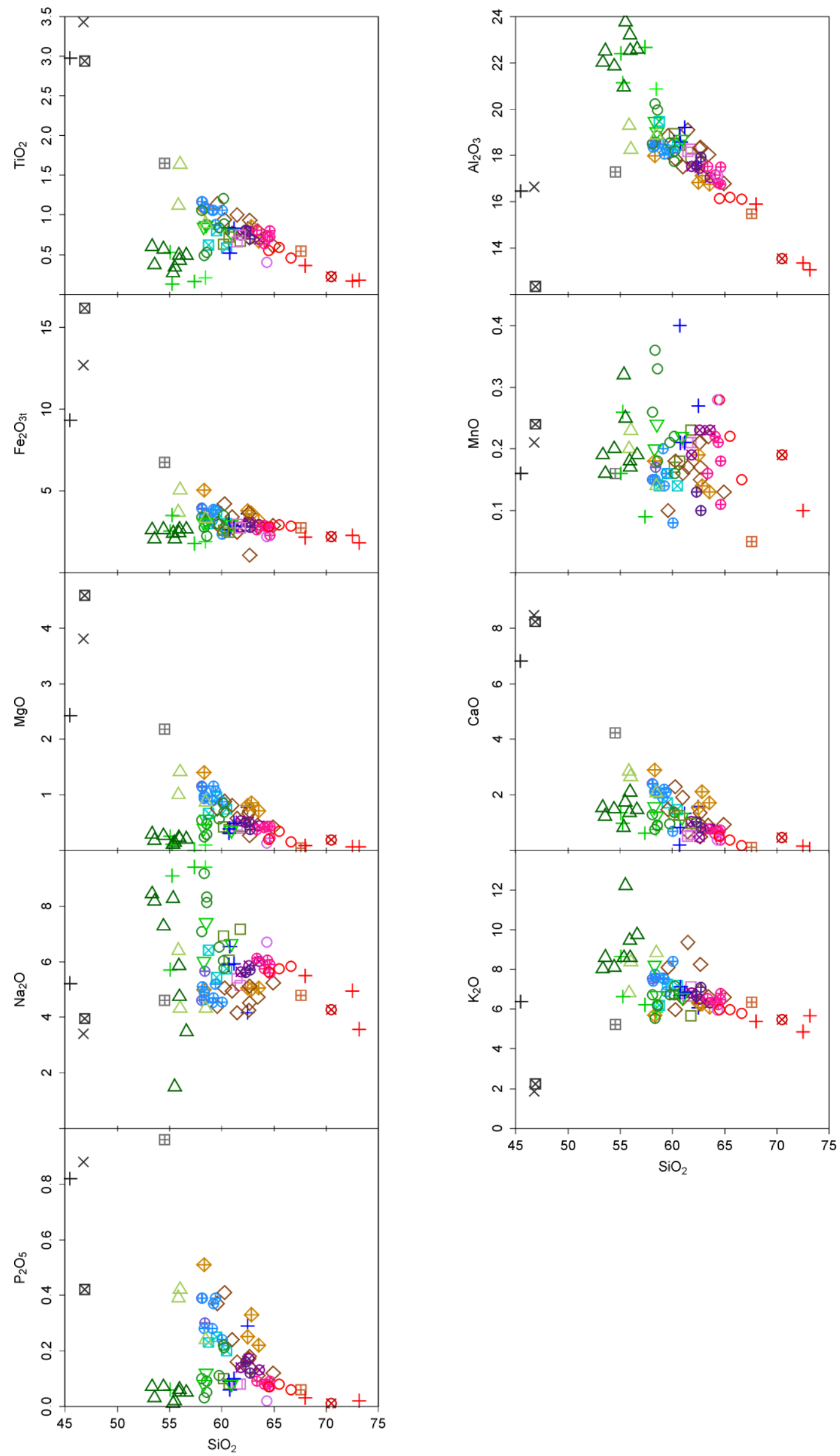

Figura 5.11 - Diagramas de Harker de elementos maiores (\% em peso), para rochas do MAI. Legenda idem Figura 5.7. 

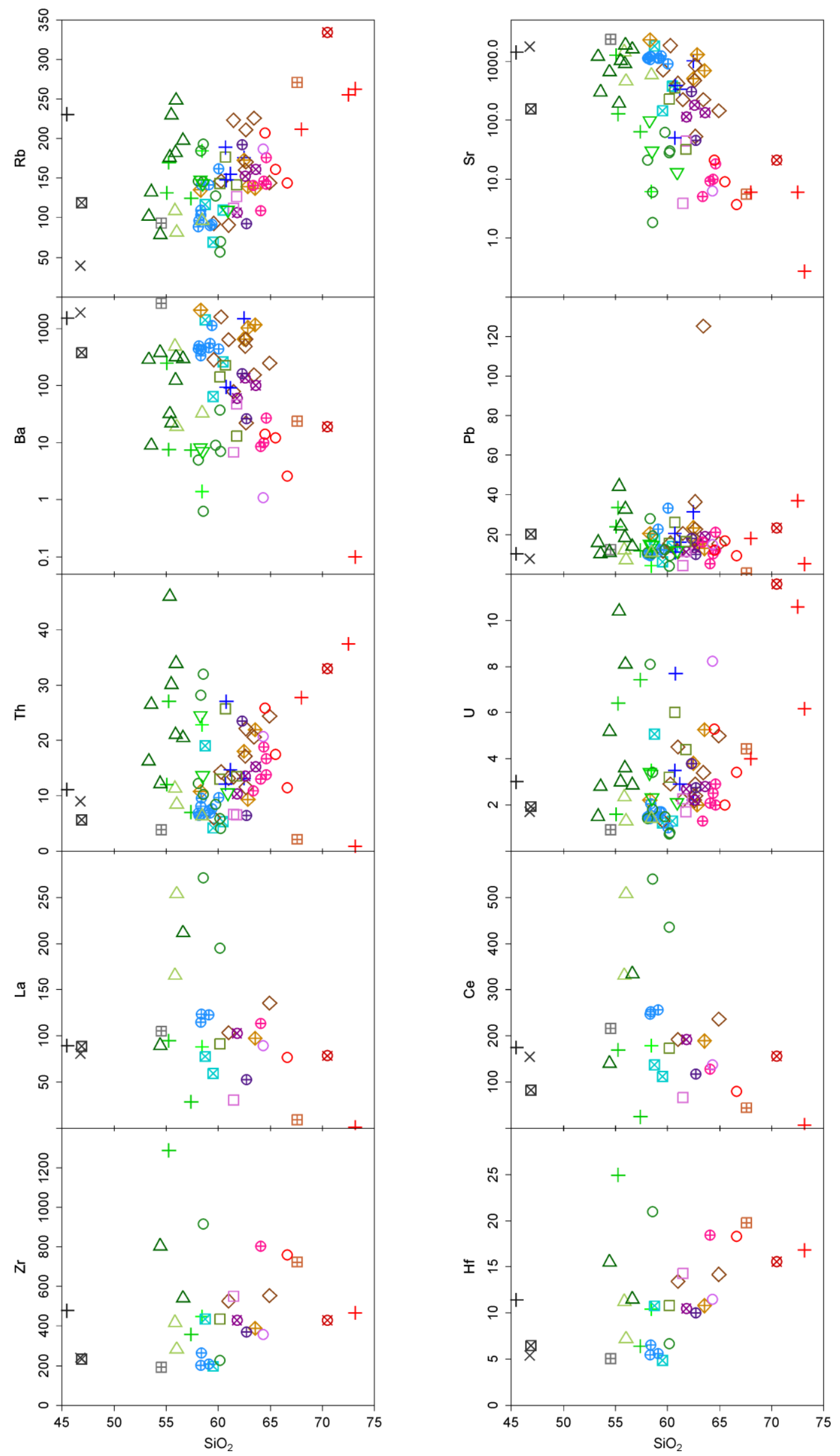

Figura 5.12 - Diagramas de Harker de elementos traço (em ppm) para as rochas do MAl. Legenda idem Figura 5.7. Continua. 

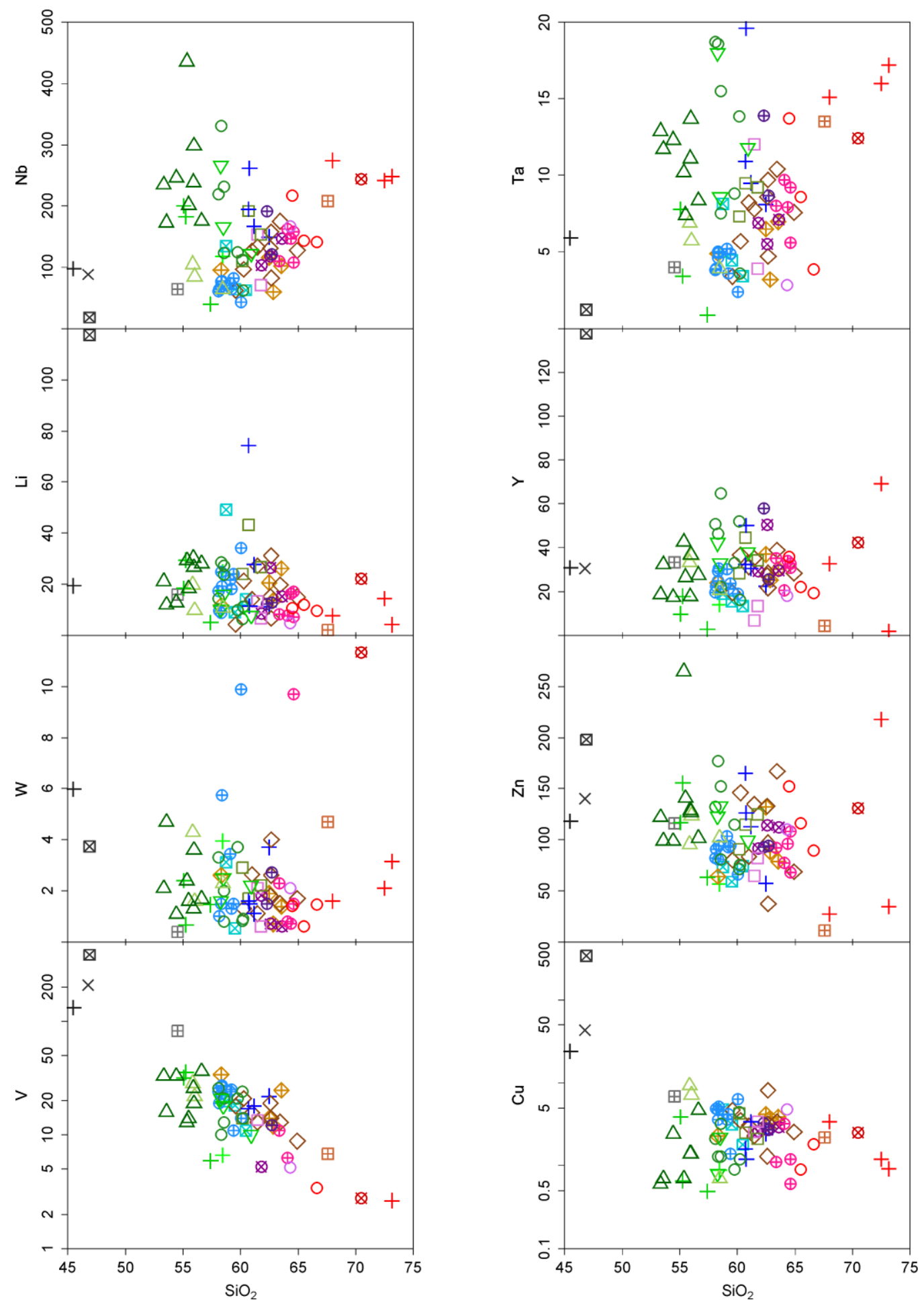

Figura 12 - Continuação.

Três amostras (MAI097B, 189, 144) não possuem Ne nem quartzo (Q), mas possuem Ol $(0,48$ a $1,67 \%)$ e Hy (0,48 a 4,15\%). Entretanto, as duas primeiras apresentam de 2 a $3 \%$ de quartzo modal.

As amostras supersaturadas em sílica no S-C possuem Q entre 0,04 a 29,95\% e Hy entre 0,65 a 4,52\%, enquanto que no S-NW varia entre 2,22 a $14,67 \%$ e 1,70 a 4,25\% respectivamente, sendo $Q$ elevado apenas no dique (MAl171) e no traquito do Picú (MAl165). 
O MAI também possui uma importante quantidade de rochas peraluminosas, com coríndon (C) normativo variando de 0,08 a 5,06\%. Entretanto, coríndon modal (além de hercynita) foi encontrado apenas na fácies peraluminosa do NeSI. As amostras MAl133, 138II, 148 e 149 estão muito sericitizadas, sendo as duas últimas com feições de alteração hidrotermal, o que pode ter levado à saturação de $\mathrm{Al}_{2} \mathrm{O}_{3}$. Por outro lado, as poucas amostras contendo acmita (Ac), apresentaram variações de 0,23 a 3,13\%. Estas são representadas principalmente por rochas pertencentes às fácies-agpaíticas do NeS I e SdINeS, além do AegN e alguns diques de fonolito e riolito.

\subsubsection{Elementos terras-raras}

No diagrama spider de ETRs (Figura 5.14) é possível observar que as amostras que representam cada um dos três setores apresentam um padrão geral da curva semelhante, formando uma rampa empobrecendo nos ETRs leves e intermediários, com $(\mathrm{La} / \mathrm{Sm})_{\mathrm{N}}$ e $(\mathrm{Sm} / \mathrm{Ho})_{\mathrm{N}}$ entre 2,6 a 18,1 e 1,7 a 7,1 respectivamente, e tendendo à horizontalização nos pesados, $(\mathrm{Ho} / \mathrm{Lu})_{N}$ entre 0,80-2,7. A razão geral $(\mathrm{La} / \mathrm{Lu})_{N}$ varia consideravelmente, entre $6,8-78,7$, sendo que as rochas insaturadas apresentam valores mais altos e maior variação.

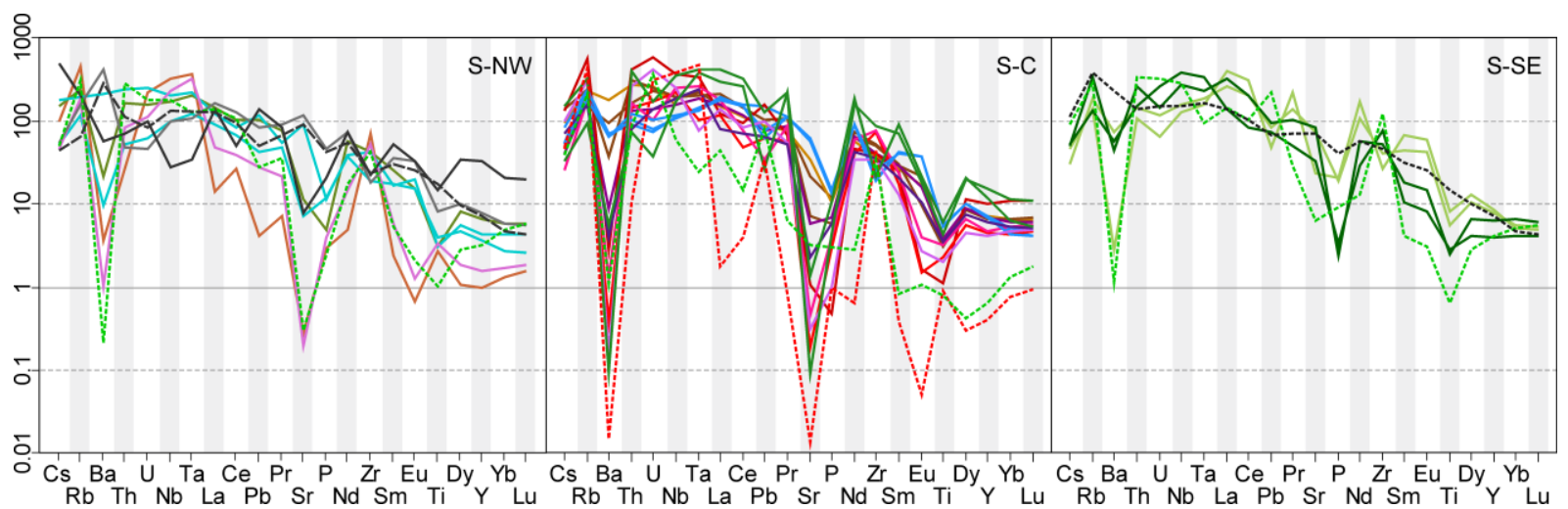

Figura 5.13 - Diagrama tipo spider para os elementos incompatíveis de rochas dos diferentes setores do MAl. Elementos normalizados pelo manto primitivo de McDonough \& Sun (1995). Legenda segue as mesmas cores da Figura 5.7; pontilhado destaca os diques e tracejado o traquibasalto (MAI226).

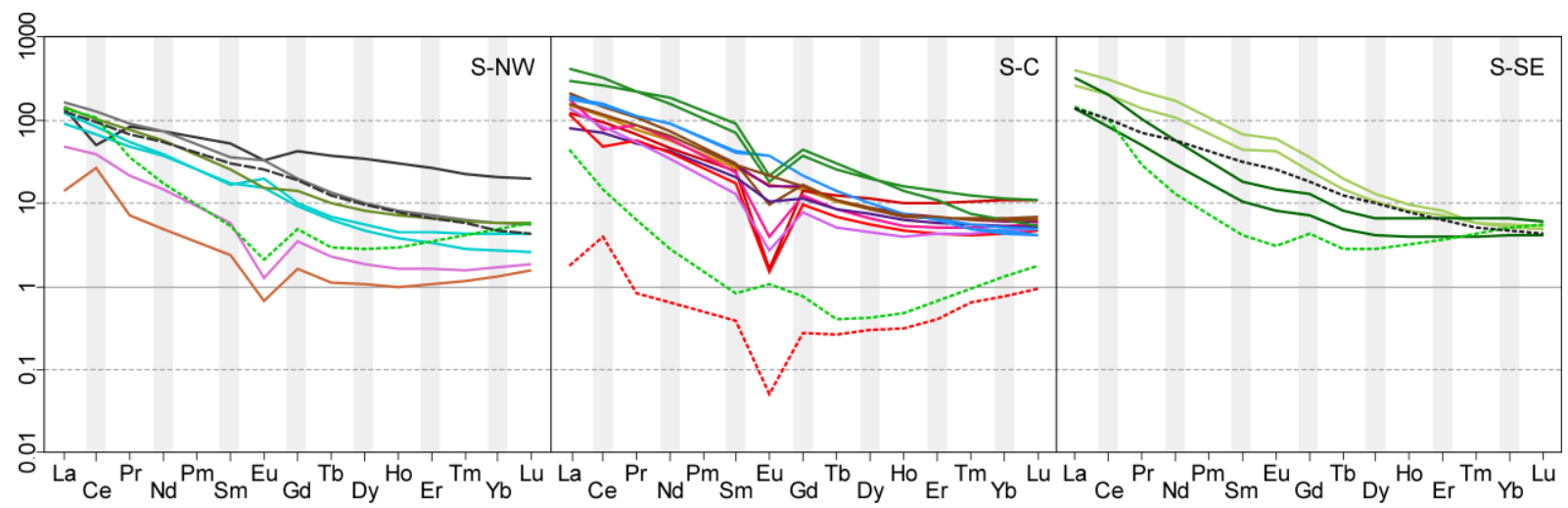

Figura 5.14 - Diagrama tipo spider para os elementos terras raras de rochas dos diferentes setores do MAI. Elementos normalizados pelo condrito de McDonough \& Sun (1995). Legenda segue as mesmas cores da Figura 5.7; pontilhado destaca os diques e tracejado o traquibasalto (MAI226). 
De modo geral, as rochas insaturadas em sílica possuem uma anomalia de Eu quase inexistente a levemente positiva, Eu/Eu* de 0,95 a 1,54, à exceção do BtAgtNeS $(0,33-0,35), \mathrm{MG}-\mathrm{mts}(0,71)$ e NeSII $(0,80)$. Já as rochas supersaturadas em sílica apresentam anomalia negativa, Eu/Eu* de 0,09 a 0,85, exceto a amostra MAI122, T-I (0,99).

Os diques de fonolito e riolito e o traquito do Picú (MAl165) possuem um padrão diferente, sendo no geral bem mais empobrecidos nos ETRs. Apresentam empobrecimento acentuado nos ETRs leves, com a razão (La/Sm) $)_{N}$ variando de 25 a 53 para os fonolitos e 4,6 a 6,0 para os outros dois (pois apresentam uma anomalia negativa de La), e um enriquecimento nos ETRs pesados $(\mathrm{Ho} / \mathrm{Lu})_{\mathrm{N}}$ de 0,27 a 0,64. Também apresentam uma anomalia negativa ou positiva acentuada, Eu/Eu* de 0,16 a 0,75 e 1,4. Os fonolitos também apresentam um enriquecimento maior de $\mathrm{Gd}$ em relação ao Tb.

Considerando os diferentes seguimentos, o S-SW apresenta as litologias mais enriquecidas, principalmente nos ETRs leves. O NeS-I possui uma leve anomalia negativa (Eu/Eu* de 0,95 para as duas amostras), enquanto BtHbINeS apresenta anomalia positiva (Eu/Eu* de 1,19 e 1,28). O dique de fonolito (MAI053II) possui mais uma anomalia positiva de $\mathrm{Gd}$ do que negativa de Eu, enquanto o nefelinito (MAIO46E) apresenta um padrão reto constantemente empobrecendo nos ETRs pesados. Ambos ocorrem no NeS-I.

No S-C quase todas as unidades apresentam anomalia negativa de Eu, exceto o BtP e seu dique (MAI092II) e o T-I. As unidades QzAFS-I e II também possuem uma pequena anomalia negativa de $\mathrm{Ce}$ (com Ce* de 0,62 e 0,58 respectivamente).

O S-NW apresenta diferenças grandes nos padrões. O BtM e o HblP possuem anomalias positivas de $\mathrm{Eu}(\mathrm{Eu} / \mathrm{Eu} *$ de 1,19 a 1,54), enquanto o TB não possui anomalia desse elemento $(1,04)$ e as demais unidades possuem anomalias negativas. Apesar de possuírem composição semelhante nos demais elementos, o MG-mts e o TB apresentam padrões dos ETRs bem diferentes, sendo o primeiro bastante enriquecido nos pesados $\left((\mathrm{La} / \mathrm{Lu})_{\mathrm{N}}\right.$ de 6,8$)$ e formando uma curva bem horizontalizada com anomalias negativas de Eu e $\mathrm{Ce}(\mathrm{Ce} * 4,6)$, enquanto o segundo possui uma curva coincidente com a do nefelinito (MAI046E).

\subsection{Geoquímica isotópica ( $\mathrm{Sr}-\mathrm{Nd}-\mathrm{Pb})$}

Os resultados isotópicos obtidos em rocha total que são descritos a seguir encontram-se no ANEXO G. Os dados isotópicos foram utilizados para fins de modelamentos petrogenéticos e petrológicos e comparações entre as unidades dos três setores (S-SE, S-C e S-NW).

A razão ${ }^{87} \mathrm{Sr} /{ }^{86} \mathrm{Sr}_{(i)}$ apresenta um gap entre as amostras do S-SE $(0,70469$ a 0,70503$)$ com os SC e S-NW $(0,70533$ e 0,70643$)$. Os erros $(2 \sigma)$ são de $\pm 0,00002-8$ para as razões. No S-SE, as duas amostras do NeS-I também apresentam diferenças significativas (de 0,00025), sendo a fácies peraluminosa (MAI030) com o valor mais elevado delas. O dique de nefelinito (MAI046E) possui um 
valor de 0,70484. No S-C e S-NW, o TB (MAI226) possui o menor valor, enquanto que o arpk-QzS (MAI108II) apresenta o maior. As amostras MAI070B, MAI090, MAl110 e MAl130 (todas supersaturadas em sílica) apresentaram valores sem significado geológico $(<0,7)$ e foram descartadas. Essas amostras são muito empobrecidas em $\operatorname{Sr}(0,27$ a 21,14 ppm) e ligeiramente mais enriquecidas em $\mathrm{Rb}$, relativo à média do $\mathrm{MAI}$ (108 a 334 ppm), apresentando uma razão $\mathrm{Rb} / \mathrm{Sr}$ muito elevada (11,8 a 992)

No S-SE os valores da razão ${ }^{143} \mathrm{Nd} /{ }^{144} \mathrm{Nd}_{(\text {(i) }}$ variam de 0,512409 a 0,512362 e $\varepsilon \mathrm{Nd}_{(\text {(i) }}$ de $-3,60$ a 2,97, e exibe um gap para o dique de nefelinito, 0,512457 e -1,75, respectivamente. Nos S-C e S-NW os valores variam de 0,512329 a 0,512223 e -6,37 a -4,28, também apresentando um gap para os valores do TB, 0,512391 e $-3,12$. Os erros $(2 \sigma)$ são de $\pm 0,000003-7$ para as referidas razões. As idades $\operatorname{TDM}_{(i)}$ também refletem essa diferença, sendo que no S-SE varia de 637 a $785 \mathrm{Ma}$, enquanto no restante no maciço varia de 812 a 895 chegando até $1225 \mathrm{Ma}$ (Figura 5.15).

As razões isotópicas de $\mathrm{Pb}$ apresentam variação maior comparado aos isótopos anteriores. No S-SE variam de 18,153 a 18,468 para ${ }^{206} \mathrm{~Pb} /{ }^{204} \mathrm{~Pb}_{(\text {(i) }}, 15,490$ a 15,550 para ${ }^{207} \mathrm{~Pb} /{ }^{204} \mathrm{~Pb}_{(\text {(i) }}$ e 38,333 a 38,808 para ${ }^{208} \mathrm{~Pb} /{ }^{204} \mathrm{~Pb}_{(\mathrm{i})}$, em todos tendo o dique de nefelinito com o maior valor e o BtHblNeS o menor. Nos S-C e S-NW, ${ }^{206} \mathrm{~Pb} /{ }^{204} \mathrm{~Pb}_{(\mathrm{i}) \text { Varia de } 18,195}$ a 18,625, sendo o QzAFS-I (MAI110) discrepante com o menor valor, enquanto ${ }^{207} \mathrm{~Pb} /{ }^{204} \mathrm{~Pb}_{(\mathrm{i})}$ Varia de 15,540 a 15,585 e ${ }^{208} \mathrm{~Pb} /{ }^{204} \mathrm{~Pb}_{(\mathrm{i})}$ de 38,304 a 38,556 . Os erros $(2 \sigma)$ são de $\pm 0,003-7$ para as duas primeiras razões e $\pm 0,004-0,021$ para terceira.

Também foram analisadas amostras das encaixantes locais. A amostra MAI027 é um milonito localizado na região da zona de cisalhamento limite entre as Faixas Ribeira e Brasília, representando uma profunda zona de fraqueza (possivelmente reativada) por onde o líquido gerado poderia ascender

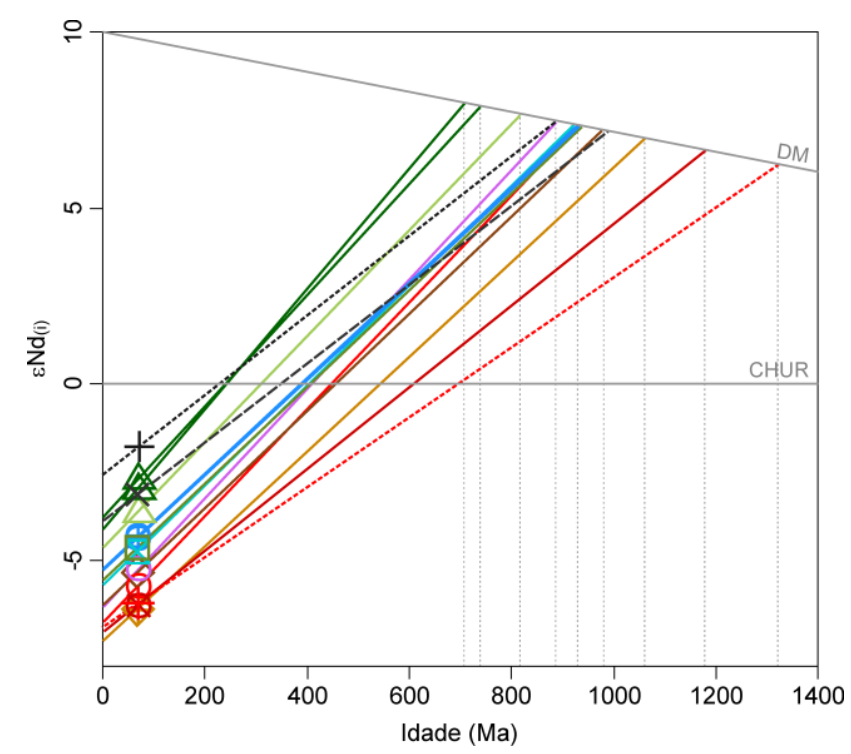

Figura 5.15 - Diagrama Idade (Ma) vs. $\varepsilon \mathrm{Nd}_{(\mathrm{i})}$, para rochas do MAI. Idade modelo $\mathrm{T}_{\mathrm{DM}}$ de acordo com Liew \& Hofmann (1988). Legendas idem Figura 5.7 e 5.13. 
mais facilmente, havendo assim um maior tempo de interação. MAI194C é um leucogranito peralcalino com uma assinatura isotópica inicial ( 600 Ma) de característica mais mantélica, sendo assim, com uma origem relativamente profunda na crosta. Com isto, suas zonas de geração também poderiam influenciar os magmas alcalinos desde a base da crosta. Já a amostra MAl168 é um biotita xisto com características bem mais rasas que as outras duas, tendo mais importância durante seu alojamento.

\subsection{Geocronologia (U-Pb)}

As idades U-Pb SHRIMP em zircão corroboram com o modelo geológico proposto para o MAI, de uma evolução que inicia na porção SE do maciço e migra gradativamente para NW, e ressaltam as diferenças entre os três setores (Figura 5.16). A unidade do S-SE apresenta idade de 71,26 Ma, as do S-C possui duas modas, três idades variando de 69,65 a 69,39 Ma e outras duas idades com 68,65 Ma, enquanto que as do S-NW possui uma idade de 67,5 Ma.

Os resultados das amostras de zircão datadas são descritos a seguir e os cristais correspondentes analisados encontram-se nas Figuras 5.17 e 5.18. A Figura 5.19 mostra os diagramas de Wetherill (1956) para as idades concórdia ${ }^{207} \mathrm{~Pb} /{ }^{235} \mathrm{U} v{ }^{206} \mathrm{~Pb} /{ }^{238} \mathrm{U}$ obtidas. Os resultados das análises encontram-se no ANEXO G.

Os cristais do BtHbINeS (MAI036) exibem estruturas zonadas do tipo oscilatório em imagem de $\mathrm{CL}$, uma típica feição ígnea, e possuem tamanho e morfologia bimodais. Os cristais menores (de 1 a 9) tendem a ser mais equidimensionais e com zonalidade gradativa, já os cristais maiores (de 10 a 13) tendem a ser prismáticos (2:1) e com estrutura zonada mais bem definida, além de apresentarem as idades mais velhas. Foram analisados 14 grãos de zircão, onde os teores de $\mathrm{U}$ e Th variam de 117 a 902 ppm e 2 a 1879 ppm, respectivamente, com razões ${ }^{232} \mathrm{Th} /{ }^{238} \mathrm{U}$ entre 0,011 e $2,462.0{ }^{206} \mathrm{~Pb}_{\text {comum }}$

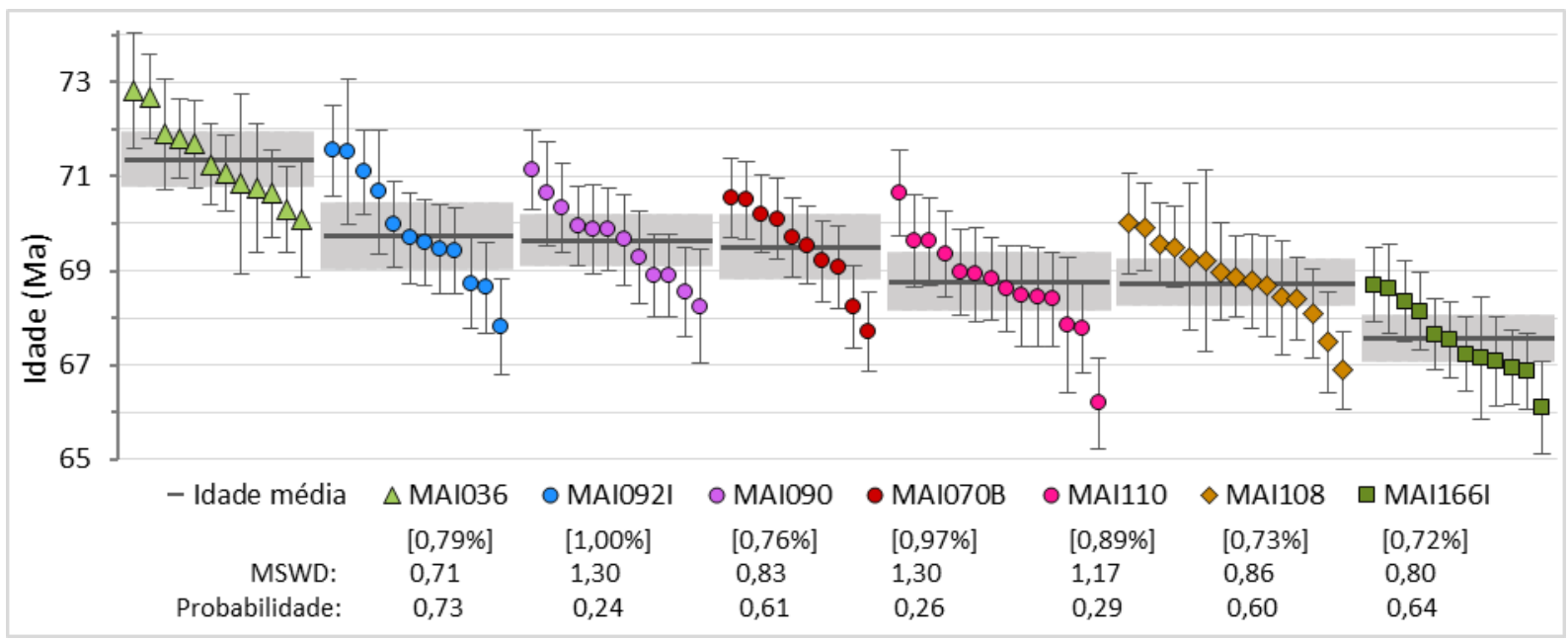

Figura 5.16 - Diagrama de barras com as idades ${ }^{206} \mathrm{~Pb} /{ }^{238} \mathrm{U}$ ( $\mathrm{Pb}$ comum corrigido por ${ }^{204} \mathrm{~Pb}$ medido) de zircão para cada análise $\mathrm{U}-\mathrm{Pb}$, determinada via SHRIMP, das amostras do Maciço Alcalino de Itatiaia. As barras de erro são de $1 \sigma$ para cada análise. As barras cinza escuro representam as idades médias dos cristais de zircão de cada amostra e as áreas cinza claro seus respectivos erros com $95 \%$ de confiança. 
varia de 0,02 a 4,75\%. Duas análises foram rejeitadas para os cálculos finais. A idade concórdia obtida no diagrama ${ }^{207} \mathrm{~Pb} /{ }^{235} \mathrm{U} v{ }^{206} \mathrm{~Pb} /{ }^{238} \mathrm{U}$ foi de $71,26 \pm 0,29 \mathrm{Ma}$ e a idade média ${ }^{206} \mathrm{~Pb} /{ }^{238} \mathrm{U}$ foi de $71,29 \pm 0,57$ Ma.

No BtP (MAI092I) os cristais são prismáticos (2:1) e semelhantes aos maiores da amostra anterior, com estruturas zonadas oscilatórias bem definidas, entretanto, os cristais 5, 6, 9 e 11 possuem um zonamento mais gradativo. Foram analisados 13 grãos, onde os teores de $\mathrm{U}$ e Th variam de 166 a 729 ppm e 469 a 2020 ppm, respectivamente, com razões ${ }^{232} \mathrm{Th} /{ }^{238} \mathrm{U}$ entre 1,223 e 4,697. 0 ${ }^{206} \mathrm{~Pb}_{\text {comum }}$ varia de 0,15 a 3,75\%. Uma análise foi rejeitada para os cálculos finais. A idade concórdia obtida no diagrama ${ }^{207} \mathrm{~Pb} /{ }^{235} \mathrm{U}$ vs. ${ }^{206} \mathrm{~Pb} /{ }^{238} \mathrm{U}$ foi de $69,64 \pm 0,29 \mathrm{Ma}$ e a idade média ${ }^{206} \mathrm{~Pb} /{ }^{238} \mathrm{U}$ foi de $69,65 \pm 0,57 \mathrm{Ma}$.

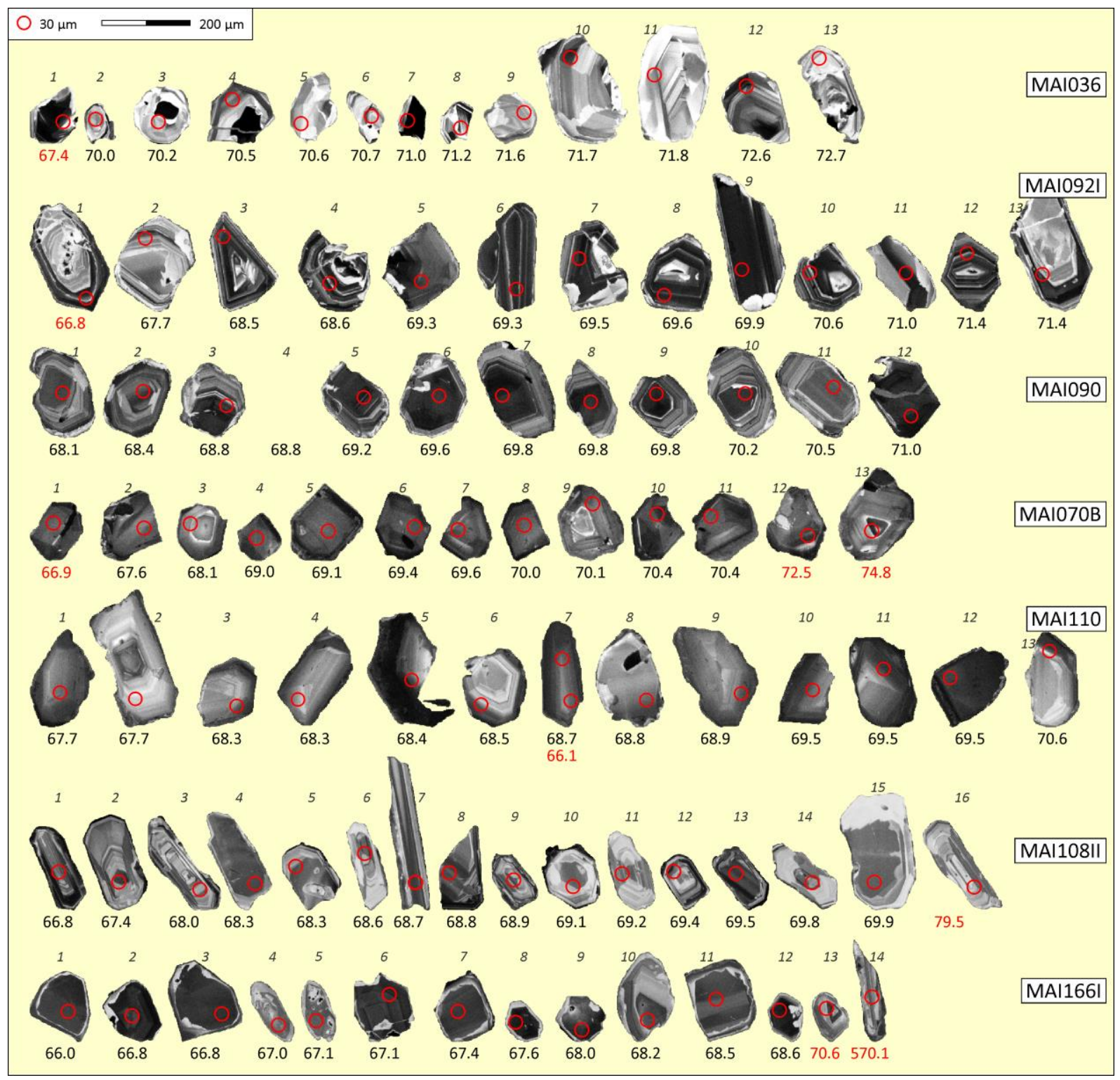

Figura 5.17 - Imagens de catodoluminesência dos cristais de zircão analisados via SHRIMP, de rochas do MAI. Em cada cristal está marcado o spot analisado e sua respectiva idade. As idades em vermelho foram descartadas. Os erros variam de $\pm 0,8$ a $\pm 1,9$ por análise. 
O AegN (MAI090) possui os cristais de zircão homogêneos e prismáticos (3:2), com um núcleo equidimensional escuro e uma borda mais clara, com zonamento oscilatório bem marcado. Os cristais 5,6, 9 e 10 apresentam uma fina zona branca com feições de corrosão, representando uma descontinuidade núcleo-borda. Foram analisados 12 grãos, onde os teores de U e Th variam de 253 a 1037 ppm e 344 a 2498 ppm, respectivamente, com razões ${ }^{232} \mathrm{Th} /{ }^{238} \mathrm{U}$ entre 0,687 e $2,489 . \mathrm{O}^{206} \mathrm{~Pb}_{\text {comum }}$ varia de $-0,02$ a 2,29\%. A idade concórdia obtida no diagrama ${ }^{207} \mathrm{~Pb} /{ }^{235} \mathrm{U}$ vs. ${ }^{206} \mathrm{~Pb} /{ }^{238} \mathrm{U}$ foi de $69,56 \pm 0,27$ Ma e a idade média ${ }^{206} \mathrm{~Pb} /{ }^{238} \mathrm{U}$ foi de $69,53 \pm 0,53 \mathrm{Ma}$.

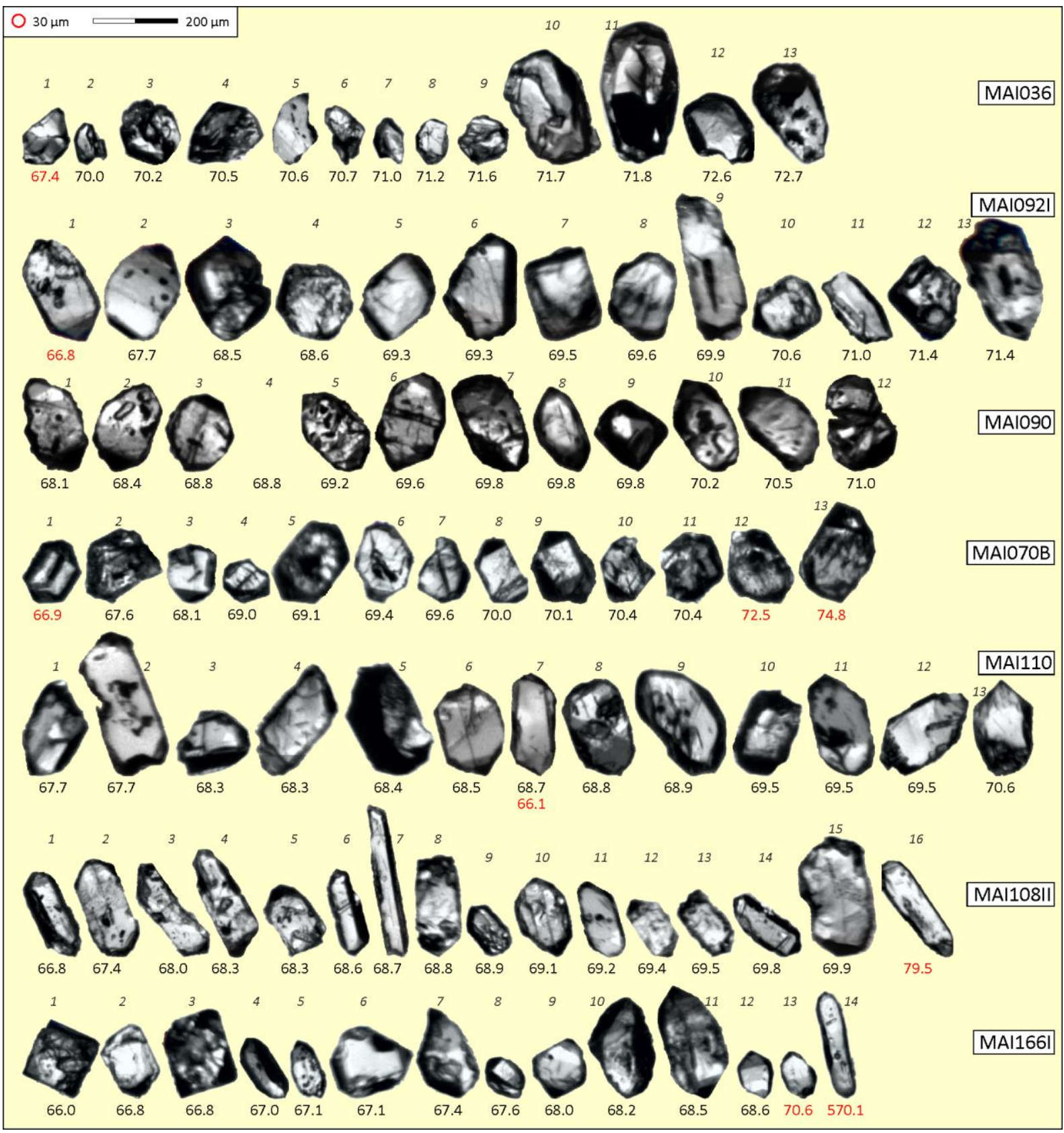

Figura 5.18 - Imagens de luz transmitida dos cristais de zircão analisados via SHRIMP, de rochas do MAI. Em cada cristal está marcado sua respectiva idade. As idades em vermelho foram descartadas. Os erros variam de $\pm 0,8$ a $\pm 1,9$ por análise. 

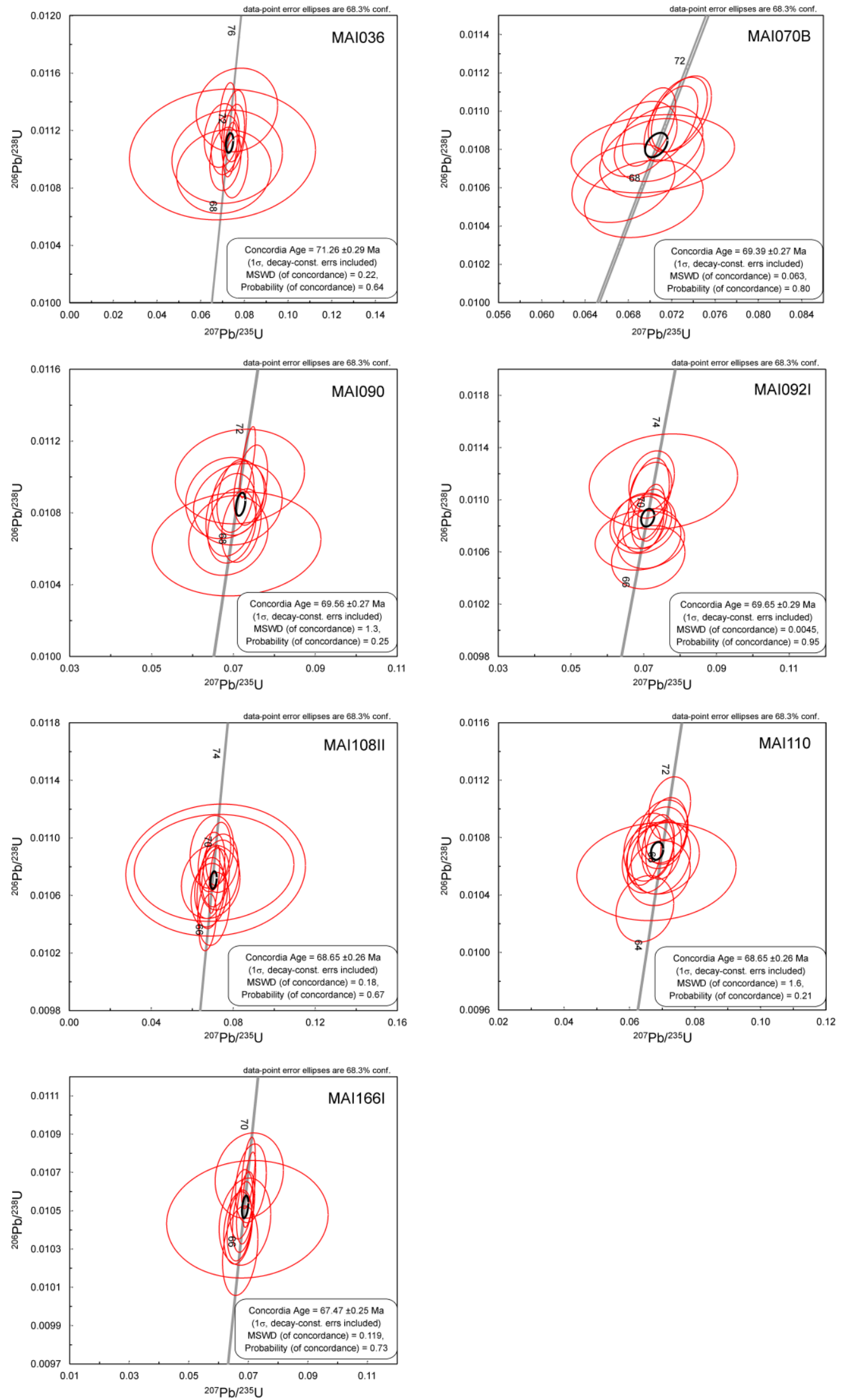

Figura 5.19 - Diagramas concórdia ${ }^{207} \mathrm{~Pb} /{ }^{235} \mathrm{U}$ vs. ${ }^{206} \mathrm{~Pb} /{ }^{238} \mathrm{U}$ de Wetherill (1956) para análises de zircão via SHRIMP, de rochas do MAI. 
Os cristais datados do mA (MAI070B) são equidimensionais e homogêneos, apresentando apenas um zonamento gradativo suave. Os cristais 3, 9 e 13 possuem um núcleo destacado por um anel branco. Cerca de $1 / 3$ dos cristais coletados para o mount apresentaram-se completamente alterado por processos de metamictização. Foram analisados 13 grãos, onde os teores de U e Th variam de 422 a 2145 ppm e 383 a 4307 ppm, respectivamente, com razões ${ }^{232} \mathrm{Th} /{ }^{238} \mathrm{U}$ entre 0,700 e 2,074. 0 ${ }^{206} \mathrm{~Pb}_{\text {comum }}$ varia de 0,01 a $1,03 \%$. Três análises foram rejeitadas para os cálculos finais. A idade concórdia obtida no diagrama ${ }^{207} \mathrm{~Pb} /{ }^{235} \mathrm{U} v$ s. ${ }^{206} \mathrm{~Pb} /{ }^{238} \mathrm{U}$ foi de $69,39 \pm 0,27 \mathrm{Ma}$ e a idade média ${ }^{206} \mathrm{~Pb} /{ }^{238} \mathrm{U}$ foi de $69,40 \pm 0,68 \mathrm{Ma}$.

No QzAFS-I (MAI110), os cristais são prismáticos (3:1 a 2:1) com zonamento gradativo ou fracamente oscilatório, também pode ocorrer um discreto zonamento setorial sobreposto. Foram analisados 14 grãos, onde os teores de $U$ e Th variam de 90 a 493ppm e 136 a 415ppm, respectivamente, com razões ${ }^{232} \mathrm{Th} /{ }^{238} \mathrm{U}$ entre 0,762 e 1,555 . $\mathrm{O}^{206} \mathrm{~Pb}_{\text {comum }}$ varia de 0,34 a 2,57\%. A idade concórdia obtida no diagrama ${ }^{207} \mathrm{~Pb} /{ }^{235} \mathrm{U} v{ }^{206} \mathrm{~Pb} /{ }^{238} \mathrm{U}$ foi de $68,65 \pm 0,26 \mathrm{Ma}$ e a idade média ${ }^{206} \mathrm{~Pb} /{ }^{238} \mathrm{U}$ foi de $68,66 \pm 0,61 \mathrm{Ma}$.

O arpk-QzS (MAl108II) possui a maior diversidade tipológica de zircão, variando de equidimensional a prismático 6:1, com núcleo homogêneo e bordas finas zonadas a zonamento oscilatório bem definido, por vezes com zonamento setorial sobreposto. Alguns cristais (3, 5 e 14) apresentaram um sobrecrescimento ao redor de um núcleo preexistente. Foi a amostra com maior número de cristais analisados, 16 no total, onde os teores de U e Th variam de 104 a 558ppm e 123 a $636 \mathrm{ppm}$, respectivamente, com razões ${ }^{232} \mathrm{Th} /{ }^{238} \mathrm{U}$ entre 0,700 e $2,074.0{ }^{206} \mathrm{~Pb}_{\text {comum }}$ varia de $0,00 \mathrm{a}$ 10,15\%. Uma análise foi rejeitada para os cálculos finais. A idade concórdia obtida no diagrama ${ }^{207} \mathrm{~Pb} /{ }^{235} \mathrm{U} v{ }^{206} \mathrm{~Pb} /{ }^{238} \mathrm{U}$ foi de $68,65 \pm 0,26 \mathrm{Ma}$ e a idade média ${ }^{206} \mathrm{~Pb} /{ }^{238} \mathrm{U}$ foi de $68,65 \pm 0,50 \mathrm{Ma}$.

O NeS-II (MAI166I) possui dois tipos de cristais, um maior, equidimensional com o núcleo homogêneo, ou fracamente zonado, com uma zona com feições de corrosão na borda, e outro tipo menor prismático (3:1 a 2:1), zonado e comumente com feições locais de correção e de alteração por metamictização. Cerca de $15 \%$ dos cristais coletados para o mount apresentaram-se fortemente metamictizados. Foram analisados 14 grãos, onde os teores de U e Th variam de 247 a 1241 ppm e 102 a 1654ppm, respectivamente, com razões ${ }^{232} \mathrm{Th} /{ }^{238} \mathrm{U}$ entre 0,372 e $1,707.0{ }^{206} \mathrm{~Pb}_{\text {comum }}$ varia de 0,02 a $6,17 \%$. Duas análises foram rejeitadas para os cálculos finais. A idade concórdia obtida no diagrama ${ }^{207} \mathrm{~Pb} /{ }^{235} \mathrm{U} v s .{ }^{206} \mathrm{~Pb} /{ }^{238} \mathrm{U}$ foi de $67,47 \pm 0,25 \mathrm{Ma}$ e a idade média ${ }^{206} \mathrm{~Pb} /{ }^{238} \mathrm{U}$ foi de $67,47 \pm 0,48 \mathrm{Ma}$. $\mathrm{O}$ cristal 14 é um xenocristal da encaixante com idade de 570,1 $\pm 6,0 \mathrm{Ma}$. 



\section{EVOLUÇÃO DO MACIÇO ALCALINO DE ITATIAIA}

A história magmática do Maciço Alcalino de Itatiaia é complexa, envolvendo diferentes magmas parentais e diversos processos modificadores no decurso de cristalização, como assimilação e contaminação em graus diversos, mistura de magmas e cristalização fracionada, nos vários eventos ocorridos ao longo de pelo menos $4 \mathrm{Ma}$. Este capítulo integra e discute todos os dados coletados neste trabalho e informações disponíveis na literatura a fim de reconstituir a história magmática e geológica do Maciço Alcalino de Itatiaia.

\subsection{Evolução geológica}

As atividades magmáticas que deram origem ao $\operatorname{MAl}(71,3$ a 67,5 Ma) se iniciaram após o soerguimento regional, que se desenvolveu entre 90 a $75 \mathrm{Ma}$ e cessou antes do colapso tectônico e desenvolvimento do Rifte Continental do Sudeste Brasileiro (RCSB), ocorrido entre 55 e $40 \mathrm{Ma}$ (Riccomini, 1989; Zalán \& Oliveira, 2005; Cogné et al., 2011, 2012; Engelmann de Oliveira et al., 2016; Salgado et al., 2016). O maciço encontra-se alojado na região adjacente à Bacia de Resende e próxima da Zona de Acomodação de Queluz, que divide o Rifte do Paraíba do Sul em dois padrões tectônicos distintos (Zalán \& Oliveira, 2005). O MAl possui uma notável elongação (cerca de 30 km no eixo maior, com largura variável de 4,5 a 11,5 km) orientada segundo a mesma direção das zonas de acomodação tectônica do RCSB e das zonas de transferência da Placa Oceânica do Atlântico Sul (Meisling \& Cob, 2001; Zalán \& Oliveira, 2005; Cogné et al., 2012; Stanton et al., 2014; Negrão et al., 2015). Ressalta-se que o MAl é uma das poucas ocorrências alongadas da Província Alcalina da Serra do Mar e a única com direção discordante dos lineamentos regionais SE.

Essa elongação deve-se à dinâmica de sucessiva migração de um centro magmático alimentador ao longo de pelo menos 4 Ma de SE para NW, registrada claramente nas relações de campo, nas estruturas preservadas e idades U-Pb em zircão (Figura 6.1). O MAl é um dos poucos complexos anelares de intraplaca continental com um centro magmático migratório. Esta característica permitiu uma boa preservação e clara relação dos diferentes pulsos magmáticos, já que durante evolução tiveram uma possibilidade menor de se misturar e/ou de serem descaracterizados ou "apagados" pelas intrusões subsequentes. Os alívios de tensões causados pelo soerguimento 
regional poderiam progressivamente mudar ao longo da zona de acomodação seguindo uma analogia do tipo fecho de correr, assim causando a migração da zona de descompressão e, consequentemente, da zona de fusão parcial para a geração desses magmas. Esse contexto evolutivo permitiu caracterizar na área do maciço três setores claramente definidos no espaço e no tempo, cada um representando distintos estágios magmáticos (Figura 6.1): Setor Sudeste (S-SE), Setor Central (S-C) e Setor Noroeste (S-NW).

O S-SE representa o primeiro estágio magmático, formado há aproximadamente 71,3 Ma, com a intrusão de um nefelina sienito tendo um magma parental de composição ankaratrítica ou basanítica. Este setor dispõe-se quase inteiramente dentro do RCSB. Entretanto, as unidades litológicas não se encontram muito afetadas pelo desenvolvimento do rifte. Nesta região não foram encontradas foliações magmáticas expressivas ou zonas de cisalhamento, sugerindo que o magma não se cristalizou sob tensão tectônica significativa. Aparentemente, os lineamentos radiais na porção norte e leste são pós-magmáticas.

A atividade magmática no S-SE iniciou-se com a intrusão do NeS-I, que representa a unidade mais insaturada em sílica do maciço, e com evidências de pouca contaminação ao longo da ascensão do magma. Localmente, verificou-se efeitos de assimilação da rocha encaixante, com a formação de uma variedade litológica adquirindo um caráter fortemente peraluminoso. Na porção sudeste ocorre um enxame de diques de fonolito, que variam de afírico com tendência agpaítica a porfirítico, com

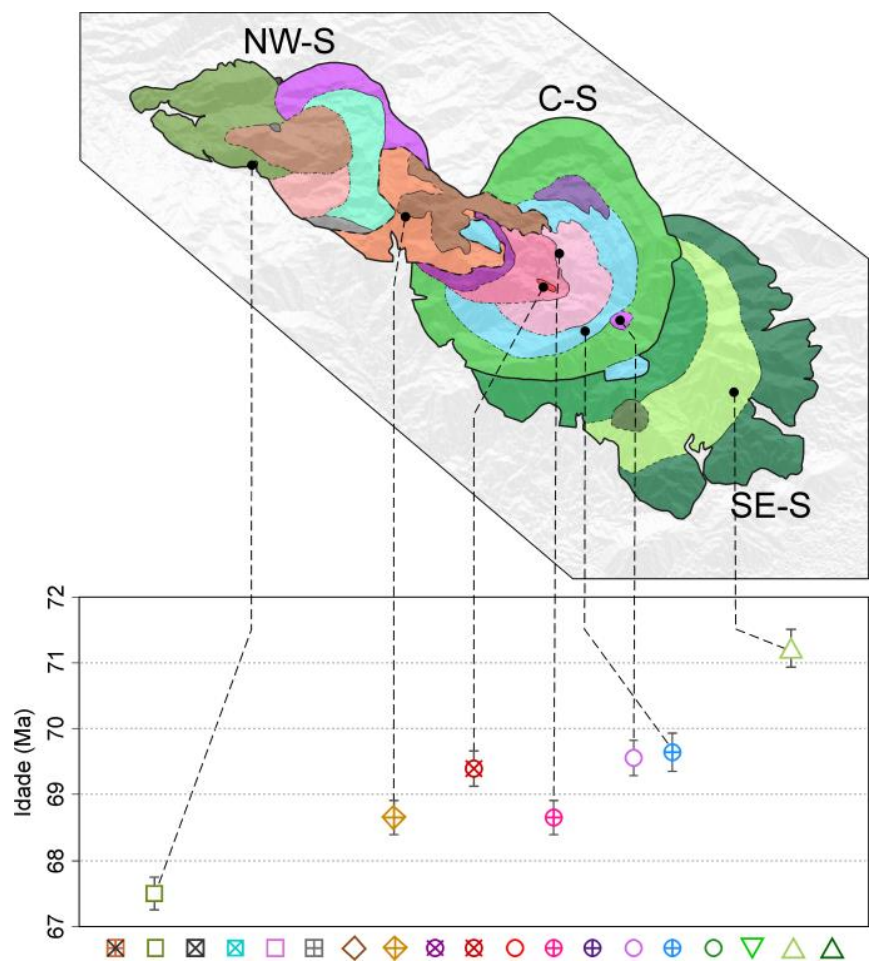

Figura 6.1 - Mapa geológico simplificado do MAI mostrando as localizações das amostras analisadas, associado ao diagrama das unidades (em ordem de colocação) vs. idade (U-Pb em Ma). Legenda idem Figura 5.7. 
fenocristais de feldspato alcalino e/ou pseudo-leucita, e rochas brechóides, com xenólitos sieníticos, máficos com andradita e gnaisse miloníticos. Também ocorrem nefelinitos afíricos. A segunda intrusão no S-SE é representada pelo BtHbINeS, que possivelmente tem a mesma fonte da anterior, mas que em algum momento no estágio inicial de cristalização, ou mesmo antes, é afetada por injeções máficas. O magmatismo segue com a intrusão do NeSdIS, retornando as características petrológicas e petrográficas da primeira intrusão. O SdINeS-foy representa o último pulso magmático do setor, que ocorreu na forma de um plug com forte foliação magmática, como resultado de processos de diferenciação da unidade anterior.

O S-C caracteriza o segundo estágio magmático do MAl, que se formou entre 69,7 a 68,7 Ma com colocação de uma grande intrusão insaturada em sílica, representada pelo BtAgtNeS. A fácies peralcalina dessa unidade está localizada na região externa da crista circular, onde ocorre enxames de diques de traquitos sin-plutônicos paralelos à crista. No entanto, não foram observadas evidências de subsidência gerando a estrutura de caldeira. Em seguida, ocorre a intrusão de um BtHbIP, que, assim como o BtHbINeS, possui indícios injeções máficas. Os pulsos seguintes apresentam um aumento progressivo nos teores de sílica, que permitiu através de processos AFC cruzarem a barreira termal no sistema $\mathrm{Ne}-\mathrm{Q} z$, gerando rochas com quartzo modal. Os dados isotópicos corroboram com esse modelo e mostram evidências de contaminação crustal relacionada ao aumento nos teores de sílica (Brotzu et al., 1997; e este trabalho). Ressalte-se que as primeiras intrusões do S-C são concêntricas, mas a partir do QzAFS-II é retomada a migração para NW.

As rochas com quartzo não mostram uma relação clara entre elas. O AegN e N-I intrudem os limites entre o BtAgtNeS e BtHbIP, sendo as primeiras manifestações supersaturadas em sílica. O N-II ocorre em uma posição similar, entretanto possui uma relação geológica mais jovem. QzAFS-I e II são grandes intrusões supersaturadas em sílica no centro do S-C e mostram um aumento no teor de sílica e redução no índice de cor para NW. Além disso, há também uma redução na granulação e aumento na foliação magmática. O mA, juntamente com os diques de riolito, é a unidade com quartzo mais evoluída do maciço. Essa unidade encontra-se alojada no QzAFS-II, embora seus contatos não tenham sido registrados. Possivelmente, o mA é resultado de um processo de diferenciação interna do QzAFSII e contemporâneo aos diques de riolito. Sua forma e localização sugerem uma relação com o desenvolvimento do VLL, conforme evidenciado por um intenso fraturamento paralelo e veios de quartzo, porém possuem uma estrutura maciça. A presença de cavidade miarolíticas, especialmente no QzAFS-I, sugerem um nível raso de colocação.

A transição do S-C para o S-NW é feita por um "pescoço" onde ocorrem arpk-QzS (68,7 Ma) e T-I. Ocorre uma clara mudança nas características geológicas e associação de rochas, onde a estrutura de caldeira desaparece e retornam as intrusões migratórias similares ao S-SE. O arpk-QzS e o T-I guardam uma provável correlação genética entre si, representando produtos de uma mistura com o 
BtM que, aparentemente, intrudem o N-II e o HblP. As diferentes fácies de T-I formam condutos subvulcânicos exibindo características rasas, como auto-fragmentos afaníticos e deformação fluidal.

O S-NW representa o terceiro estágio magmático, mostrando as relações litológicas menos claras e um controle geológico pobre no centro da área. Aparentemente há uma intercalação de intrusões insaturadas e supersaturadas em sílica. O HbIP exibe um aumento dos teores de nefelina, anfibólio, biotita e titanita para o norte e também mostram evidências de interações precoces com injeções de magmas máficos. O NeS-II representa a última unidade plutônica estabelecida no maciço (67,5 Ma) e possui uma grande similaridade textural e geoquímica com o NeS-I. O MG-mts poderia representar porções mais antigas e/ou profundas da câmara magmática colocada em um nível mais raso por processos tectono-magmáticos.

O T-II intrude o centro do S-NW, tendo a Pedra do Picú como a principal manifestação que possivelmente representa um neck vulcânico bem preservado. Aparentemente, o TB intrude o T-II sendo a última manifestação magmática do MAI. Suas características mineralógicas e geoquímicas comparadas às do MG-mts sugerem alguma conexão petrológica.

Além disso não se descarta algum tipo de ligação genética com o maciço alcalino de Passa Quatro, a oeste do MAl.

\subsection{Aspectos petrogenéticos}

O MAI possui assinaturas isotópicas ( $\mathrm{Sr}-\mathrm{Nd}-\mathrm{Pb}$ ) típicas de magmas de origem mantélica, que evoluíram com alguma participação de processos de contaminação crustal. É um maciço de composição quase exclusivamente sienítica, com ocorrências pontuais de rochas básicas que até então eram desconhecidas. Entretanto, poucas ocorrências da província Serra do Mar, a exemplo de Ponte Nova (Azzone et al., 2009) e Morro de São João (Brotzu et al., 2007), e o enxame de diques da Serra do Mar (e.g. Garda et al., 1995; Thompson et al., 1998), possuem expressões importantes de magmatismo básico e ultrabásico. Essas rochas guardam uma relação temporal e petrológica com as ocorrências sieníticas do Lineamento Magmático de Cabo Frio (LMCF), sendo o material mais primitivo encontrado na região.

\subsubsection{O manto litosférico na região sudeste do Brasil}

No diagrama ${ }^{143} \mathrm{Nd} /{ }^{144} \mathrm{Nd} d_{(i)} v{ }^{8}{ }^{87} \mathrm{Sr} /{ }^{86} \mathrm{Sr}_{(\mathrm{i})}$ (Figura 6.2) as rochas do MAl sobrepõem-se ao campo dos basaltos toleíticos da região nordeste da Província Magmática Paraná-Etendeka (PMPE) e às partes inferiores dos campos das rochas alcalinas do LMCF e da Província Serra do Mar (Brotzu et al., 1989, 2007; Garda et al., 1995; Thompson et al., 1998; Bennio et al., 2002, 2003; Ulbrich et al., 2002; Enrich et al., 2005; Rocha-Júnior et al., 2013; Azzone et al., 2016), bem como às porções superiores dos campos da Província Ígnea do Alto Paranaíba (PIAP;Gibson et al., 1995; Araujo et al., 2001; Guarino et 
al., 2013) e do enxame de diques toleíticos pré-Atlântico da região de Resende-Ilha Grande, oeste do RJ (Guedes et al., 2016). A origem mantélica desses magmas alcalinos e toleíticos com posteriores processos de contaminação crustal são sugeridos por todos esses autores citados. Essas razões isotópicas possuem como polo as rochas das llhas de Trindade e Martín Vaz (Marques et al., 1999; Siebel et al., 2000; Bongiolo et al., 2015), que representariam parâmetros de composições mantélicas sem influência continental. Entretanto, as composições isotópicas formam um trend em direção aos granitoides pós-orogênicos, seguindo para os sin-orogênicos da Faixa Ribeira e Brasília na região (Tupinambá et al., 2012; Carvalho et al., 2014; Janasi et al., 2015; Alves et al., 2016; Martins et al., 2016; Valeriano et al., 2016).

As idades $\operatorname{TDM}_{(50-155)}$ para as rochas meso-cenozóicas apresentam-se majoritariamente entre 600 e 900 Ma (Figura 6.3) e coincide com a Orogênese Brasiliana (800-600 Ma; Neves et al., 2014), que provavelmente foi o evento que provocou matassomatismo junto ao manto liltosférico. As assinaturas isotópicas (calculadas para suas respectivas idades iniciais) e o caráter potássico dos granitoides Brasilianos pós-orogênicos coincidentes com o do magmatismo meso-cenozóico alcalino podem sugerir origem em mesmo manto litosférico enriquecido em flogopita. Além disso, a maior parte dos maciços alcalinos estão nos terrenos Brasilianos onde ocorrem esses granitoides pós-orogênicos, Terreno Oriental e Nappe Socorro-Guaxupé. Além disso, a grosso modo, eles encontram-se alinhados segundo uma direção tectônica preferencial do embasamento, orientada para SW-NE (Figura 3.4).
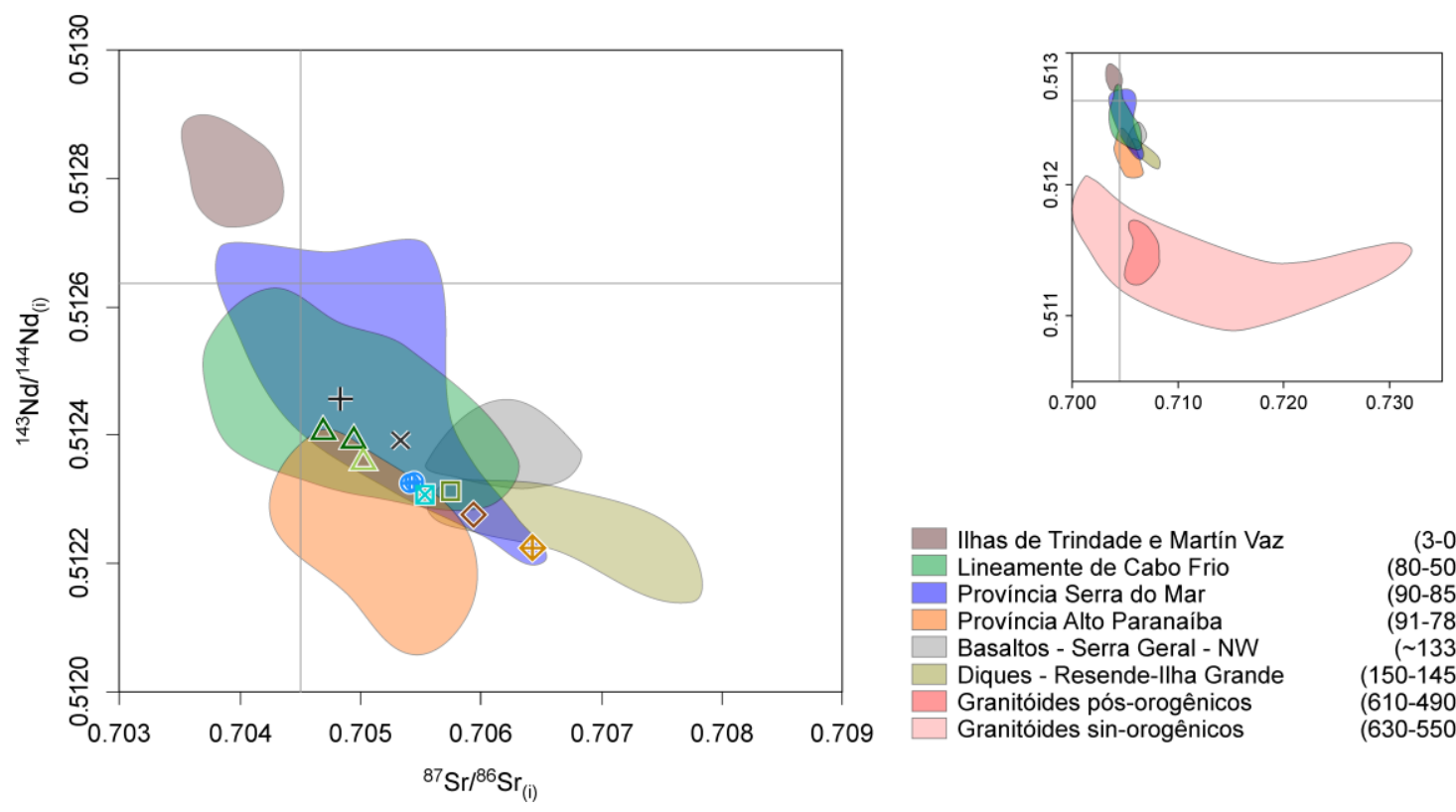

Ilhas de Trindade e Martín Vaz Lineamente de Cabo Frio Província Serra do Mar Província Alto Paranaíba Basaltos - Serra Geral - NW Diques - Resende-Ilha Grande Granitóides pós-orogênicos Granitóides sin-orogênicos

Figura 6.2 - Diagrama ${ }^{143} \mathrm{Nd} /{ }^{144} \mathrm{Nd}_{(\mathrm{i})} v s .{ }^{87} \mathrm{Sr} /{ }^{86} \mathrm{Sr}_{(i)}$ para as rochas do MAl (símbolos idem Figura 5.7), com os campos de variação das Ilhas de Trindade e Martín Vaz (Marques et al., 1999; Siebel et al., 2000; Bongiolo et al., 2015), da Província Serra do Mar e LMCF (Brotzu et al., 1989, 2007; Garda et al., 1995; Thompson et al., 1998; Bennio et al., 2002, 2003; Ulbrich et al., 2002; Enrich et al., 2005; Azzone et al., 2016), porção nordeste da Província Magmática Paraná-Etendeka (RochaJúnior et al., 2013), Província Ígnea do Alto Paranaíba (Gibson et al., 1995; Araujo et al., 2001; Guarino et al., 2013) e dos diques toleíticos pré-Atlântico da região de Resende-Ilha Grande (Guedes et al., 2016). No diagrama suplementar soma-se os campos dos granitoides sin- e pós-orogênicos (Tupinambá et al., 2012; Carvalho et al., 2014; Janasi et al., 2015; Alves et al., 2016; Martins et al., 2016; Valeriano et al., 2016). Razões calculadas para idades iniciais de cada análise (intervalo de variação indicada na figura). 
No diagrama ${ }^{207} \mathrm{~Pb} /{ }^{204} \mathrm{~Pb}$ vs. ${ }^{206} \mathrm{~Pb} /{ }^{204} \mathrm{~Pb}$ com os modelos de reservatórios terrestres (Figura 6.4; Zartman \& Haines, 1988), as amostras do S-SE colocam-se dentro do campo mantélico, enquanto as demais tendem ao campo do orógeno (ou às encaixantes locais no campo da crosta superior), que é correlato ao aumento da sílica. Algumas amostras também mostram uma tendência em direção ao milonito encaixante da porção sudeste do maciço. Já para o diagrama ${ }^{208} \mathrm{~Pb} /{ }^{204} \mathrm{~Pb}$ vs. ${ }^{206} \mathrm{~Pb} /{ }^{204} \mathrm{~Pb}$ as amostras situam-se mais próximas ao campo do orógeno e menos dispersas, não apresentando uma tendência clara.

\subsubsection{Processos AFC-mixing}

As rochas mais primitivas encontradas nas unidades do MAI são um dique de nefelinito (NeSI, MAI046E) no extremo sudeste e um pequeno corpo de traquibasalto potássico (TB, MAI226) no centro do S-NW, além do melagabro metassomatizado (MG-mts, MAl178) que possui características
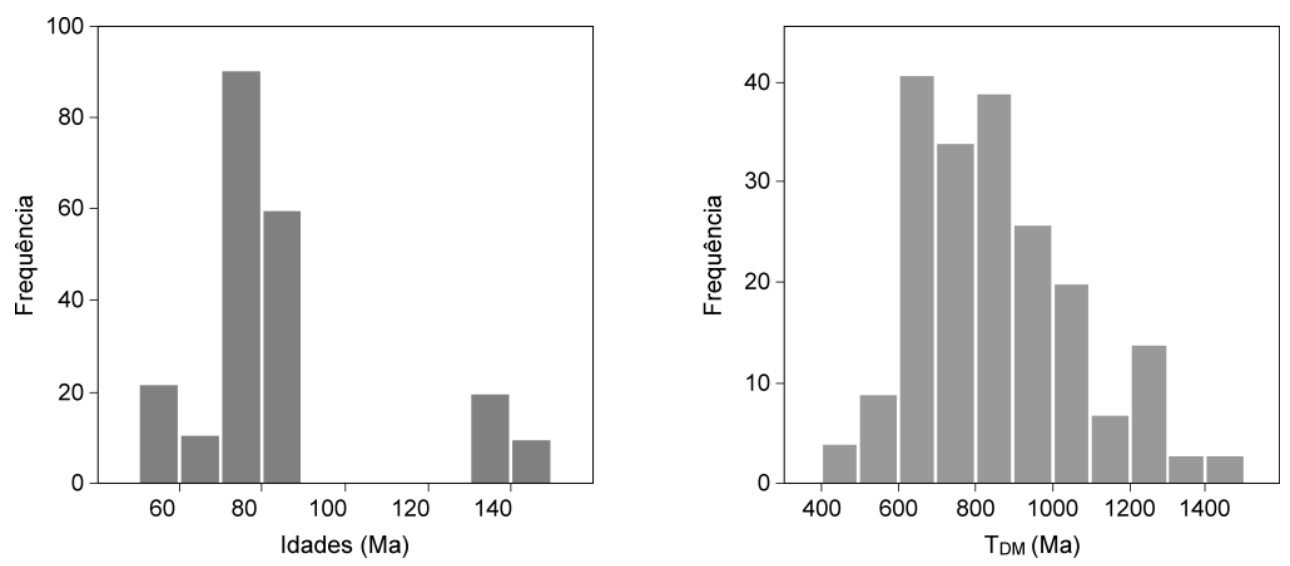

Figura 6.3 - Histograma com a distribuição de frequência das idades do magmatismo alcalino e das idades modelo $T_{D M}$ (em milhões de anos) da Província Serra do Mar, LMCF, porção nordeste da Província Magmática Paraná-Etendeka, Província Ígnea do Alto Paranaíba e dos diques toleíticos pré-Atlântico da região de Resende-llha Grande. Referências conforme a Figura 6.2.
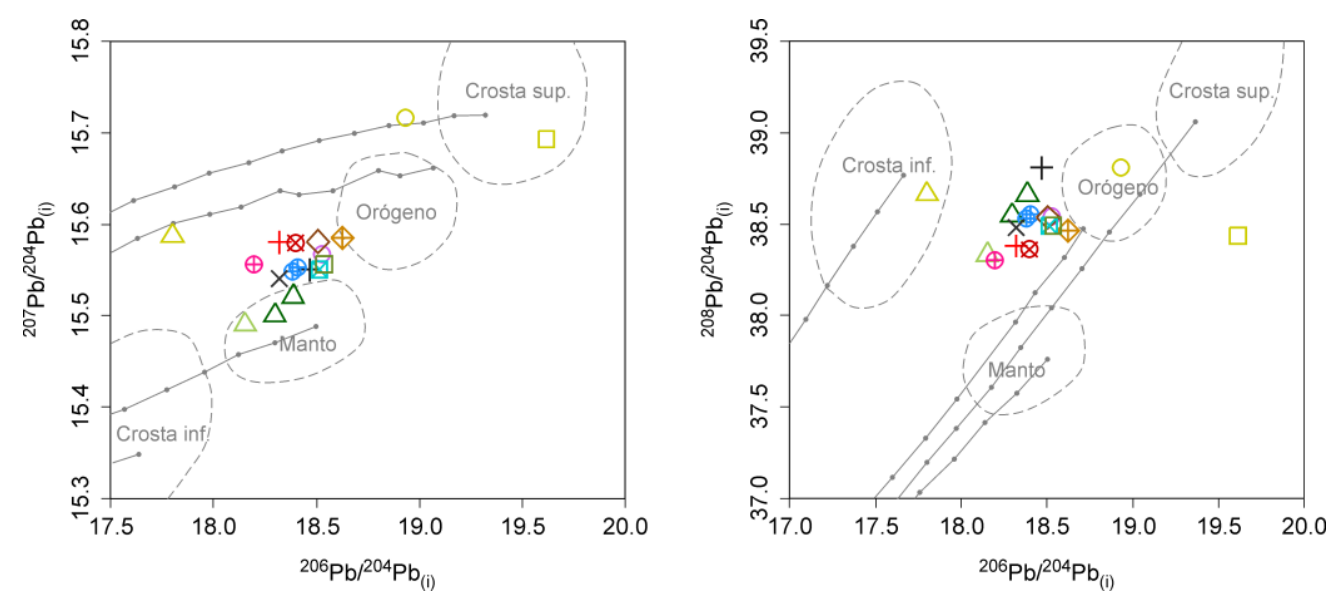

Figura 6.4 - Diagramas ${ }^{206} \mathrm{~Pb} / 204 \mathrm{~Pb}_{(\mathrm{i})} V{ }^{.207} \mathrm{~Pb} /{ }^{204} \mathrm{~Pb}_{(\mathrm{i})}$ e ${ }^{206} \mathrm{~Pb} /{ }^{204} \mathrm{~Pb}_{(\mathrm{i})} V$ s. $^{208} \mathrm{~Pb} /{ }^{204} \mathrm{~Pb}_{(\mathrm{i})}$ para rochas do $\mathrm{MAl}$ e encaixantes regionais adjacentes. Triângulo, milonito (MAI027); círculo, leucogranito (MAI194C); e quadrado, biotita xisto (MAI168). Curvas de evolução isotópica do $\mathrm{Pb}$ (versão IV) para modelo de reservatórios juntos com campos contendo a composição moderna provável. Os incrementos nas curvas indicam intervalos de $100 \mathrm{Ma}$ (Zartman \& Haines, 1988). Legenda idem Figura 5.7. 
químicas semelhantes ao TB. Possuem teores de $\mathrm{SiO}_{2}(\sim 46 \%)$ e $\mathrm{Al}_{2} \mathrm{O}_{3}(\sim 16,5 \%)$ semelhantes porém teores de álcalis $\left(\mathrm{Na}_{2} \mathrm{O}+\mathrm{K}_{2} \mathrm{O}\right.$ de $11,61 \%$ para o nefelinito e 5,25\% para o traquibasalto) e razões $\mathrm{K}_{2} \mathrm{O} / \mathrm{Na}_{2} \mathrm{O}(1,22$ e 0,54$)$ bem diferentes. Consequentemente, o nefelinito apresenta teores normativos de nefelina e leucita respectivamente de 22,93 e 4,15\%, enquanto o traquibasalto possui teores de quartzo e hyperstênio respectivamente de 1,22 e 15,14\%. Essas amostras são também apresentam os teores mais elevados de $\mathrm{CaO}, \mathrm{MgO}, \mathrm{P}_{2} \mathrm{O}_{5}, \mathrm{Ba}, \mathrm{Sc}, \mathrm{Cr}, \mathrm{Ni}, \mathrm{Co} \mathrm{V}$, e $\mathrm{Cu}$ e assinatura de ETRs semelhantes e ausência de anomalia de Eu. A existência desses tipos magmas como possíveis parentais para as rochas do maciço foi sugerida por Brotzu et al. (1997), que indicaram basanito ou ankaratrito para as rochas fortemente insaturadas em sílica (SA) e álcali-basalto/basanito para as rochas menos insaturadas (A), além de basalto pouco insaturado (ou apenas com um pouco de hyperstênio normativo) para as rochas supersaturadas (Q).

A mudança de magmas alcalinos insaturados em sílica para supersaturados é possível apenas em sistemas abertos, quase sempre envolvendo processos de assimilação de rochas ricas em quartzo (Hamilton \& MacKenzie, 1965; Nekvasil et al., 2004; Gupta et al., 2010). Além disso, geralmente os magmas parentais já estão próximos ao limite de saturação, sendo álcali basaltos ou basanitos (Foland et al., 1993; Harris, 1995; Jung et al., 2005; Estrade et al., 2014; Mogahed, 2016), enquanto magmas mais insaturados, e geralmente mais potássicas, e dificilmente geram rochas supersaturas mesmo com significativo grau de assimilação (e.g. Martinez et al., 1996; Azzone et al., 2016).

Os dados isotópicos e geoquímicos descritos nos itens 5.2 e 5.3 apontaram diferentes fontes para as unidades de S-SE e de S-C/S-NW. De modo amplo, as amostras seguem as curvas de mixing estabelecidas nos diagramas de razões isotópicas ( $\mathrm{Nd}-\mathrm{Sr}-\mathrm{Pb})$ vs. $\mathrm{SiO}_{2}$ para as rochas mais primitivas do MAI com as amostras das encaixantes adjacentes (Figura 6.5; especialmente a MAI027 e MAI194C), corroborando com a sugestão da influência de rochas crustais para a transposição da barreira termal no sistema Ne-Ab-Qz e a consequente evolução para um sistema supersaturado em sílica. Entretanto, as curvas do modelo AFC e mixing com as encaixantes a partir dessas amostras (MAIO46E e 226), assim como dos diques de tephritos e basanito encontrados próximo ao maciço (94SOB95, 94SOB97, 94SOB98; Thompson et al., 1998), não se ajustam adequadamente como sendo os magmas parentais para a evolução direta das rochas sieníticas do maciço (Figura 6.5).

A partir da amostra mais primitiva (composicional e isotopicamente) disponível, o dique de tephrito 94SOB97 (Thompson et al., 1998) localizado $8 \mathrm{~km}$ a nordeste do S-SE, na escarpa da Serra da Mantiqueira, seria possível gerar o nefelinito (MAI046E), com apenas $\sim 5-10 \%$ de assimilação crustal para a curva de mixing. Também seria possível gerar o traquibasalto (MAI226) com 13-20\% de mixing. Entretanto, os teores muito mais baixos de $\mathrm{K}_{2} \mathrm{O}(1,41$ contra $6,30 \%$ em peso) sugererem uma fonte diferente e rica em flogopita e/ou anfibólio. 
A llha de Trindade, tomada como parâmetro para a composição isotópica inicial próxima à da mantélica e livre de contaminação da crosta continental para o magmatismo alcalino meso-cenozóico da região (Marques et al., 1999; Siebel et al., 2000; Bongiolo et al., 2015), possui dois grupos de rochas ultrabásicas: ankaratritos/nefelinitos e basanitos/tephritos, com razões $\mathrm{K}_{2} \mathrm{O} / \mathrm{Na}_{2} \mathrm{O}$ de 0,53 a 0,91 e 0,07 a 0,28, respectivamente (Marques et al., 1999). A existência desses dois tipos de magmas primários estaria de acordo com o sugerido por Brotzu et al. (1997) e com os dados obtidos neste trabalho para a geração do nefelinito e do traquibasalto.

Já as rochas sieníticas possivelmente se diferenciaram diretamente desses magmas primários, e das mesmas fontes mantélicas, no entanto com um grau de fusão parcial maior. É evidente a correlação da sílica com as razões isotópicas, que aumenta sempre no sentido de aumentar o componente crustal. De modo geral possui dois grupos com comportamentos diferentes, um com o SSE e outro com os S-C e S-NW.

A razão ${ }^{87} \mathrm{Sr} /{ }^{86} \mathrm{Sr}_{(i)}$ apresenta uma forte correlação positiva com $\mathrm{SiO}_{2}$ (Figura 6.6) exceto pelas amostras básicas (MAI046E e MAl226), enquanto ${ }^{143} \mathrm{Nd} /{ }^{144} \mathrm{Nd} d_{(i)}$ e o $\varepsilon N d_{(i)}$ apresentam boa correlação negativa com a sílica, e assim como para a razão de Sr, as rochas do S-SE também possuem valores menos radiogênicos do que as do restante do maciço. As razões isotópicas de $\mathrm{Pb}$ apresentam variação maior comparado aos isótopos anteriores. O S-SE possui uma correlação negativa com a sílica para as três razões isotópicas de $\mathrm{Pb}\left({ }^{206} \mathrm{~Pb} /{ }^{204} \mathrm{~Pb}_{(\mathrm{i})},{ }^{207} \mathrm{~Pb} /{ }^{204} \mathrm{~Pb}_{(\mathrm{i})} \mathrm{e}^{208} \mathrm{~Pb} /{ }^{204} \mathrm{~Pb}(\right.$ (i) $)$, em todos tendo o dique de nefelinito com o maior valor e o BtHbINeS com o menor. Nos S-C e S-NW, ${ }^{206} \mathrm{~Pb} /{ }^{204} \mathrm{~Pb}_{(\text {(i) }}$ possui uma correlação positiva para as rochas insaturadas e negativa para as supersaturadas em sílica, sendo o QzAFS-I (MAI110) discrepante com o menor valor, enquanto ${ }^{207} \mathrm{~Pb} /{ }^{204} \mathrm{~Pb}_{(i)}$ apresenta uma correlação positiva e ${ }^{208} \mathrm{~Pb} /{ }^{204} \mathrm{~Pb}_{(\text {() }}$ negativa.

A correlação entre a ordem de intrusão das diferentes unidades do MAI, (interpretada com base nas informações geológicas) com os teores de sílica e razões isotópicas (Figura 6.7) sugerem que o grau de assimilação crustal aumentou progressivamente nos sucessivos pulsos até romper a barreira termal (continuando seu curso evolutivo por processos de diferenciação magmática) e depois diminuindo nos pulsos seguintes, mantendo esses magmas finais insaturados.

Aparentemente, as rochas com maiores teores de sílica ocupam geomorfologicamente as posições mais elevadas (Figura 6.7). Isso poderia ser apenas um efeito do intemperismo e erosão mais atuantes nas rochas insaturadas que ocupariam níveis inferiores, porém, o maciço de Passa Quatro (Brotzu et al., 1992)e as porções externas do S-C (e.g. Serra Negra e Morro do Maromba) exibem as mesmas expressões altimétricas e não possuem rochas supersaturadas em seus pontos culminantes.

Este fato poderia ser resultado de um aumento gradativo nas taxas de fusão parcial das encaixantes crustais e assimilação causados pelo incremento de temperatura através de pulsos sucessivos, até atingir um ápice na curva dos solidus. O intervalo temporal entre a formação de S-C e 
S-NW, apesar de pequeno, seria o suficiente para os magmas encontrarem as encaixantes mais frias novamente. Outro fator a ser considerado, é que o maciço corta transversalmente diversas litologias e terrenos tectônicos diferentes, o que poderia interferir significativamente nos processos de geração e ascensão desses magmas e ampliados por outros processos de evolução magmática.
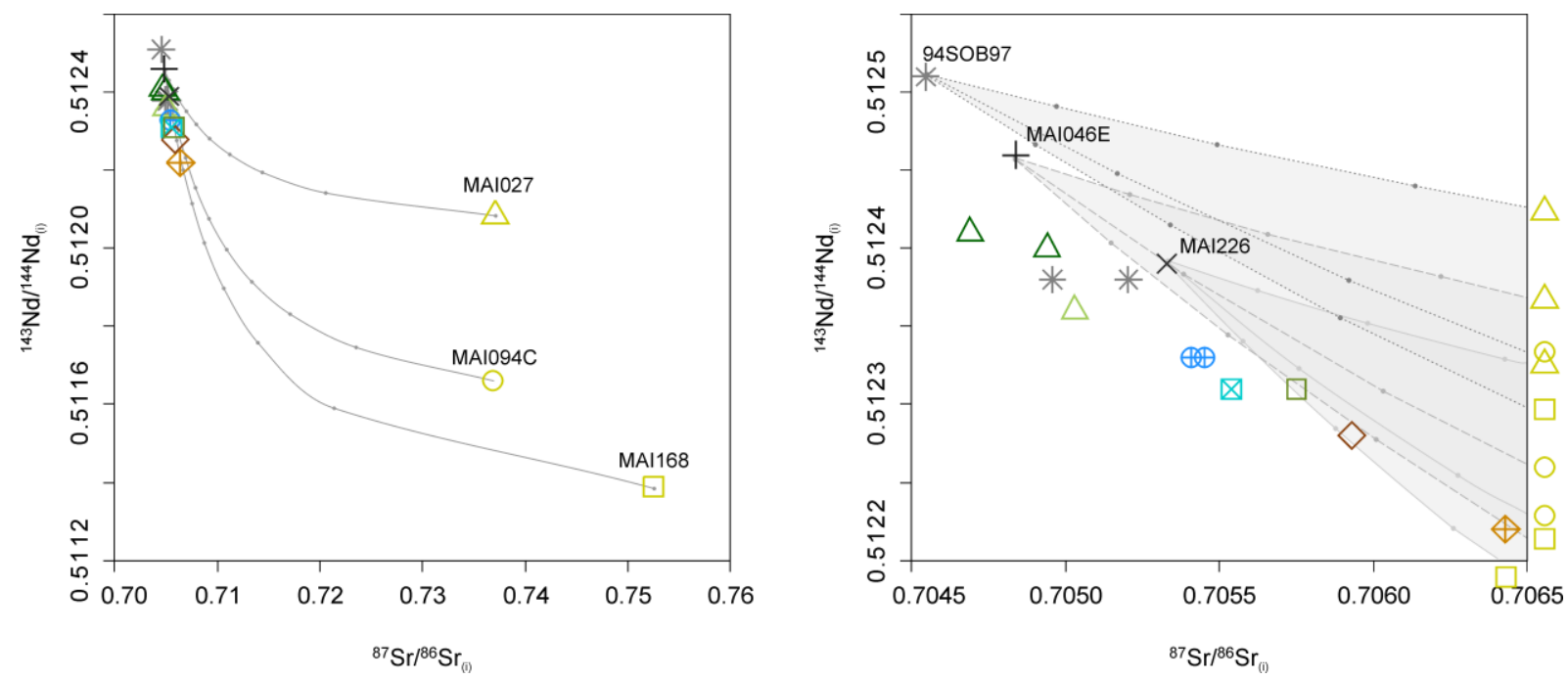

Figura 6.5 - Diagramas ${ }^{143} \mathrm{Nd} /{ }^{144} \mathrm{Nd}_{(i)} v s .{ }^{87} \mathrm{Sr} /{ }^{86} \mathrm{Sr}_{(i)}$ para as rochas do MAl e diques próximos. As curvas representam a tendência de mixing (com incrementos de 10\%) a partir de amostras iniciais primitivas com as encaixantes adjacentes, milonito (triângulo, MAI027), leucogranito (círculo, MAI194C); e biotita xisto (quadrado, MAl168). Os símbolos asterisco cinza são tephitos e basanitos de Thompson et al. (1998). Legenda idem Figura 5.7.
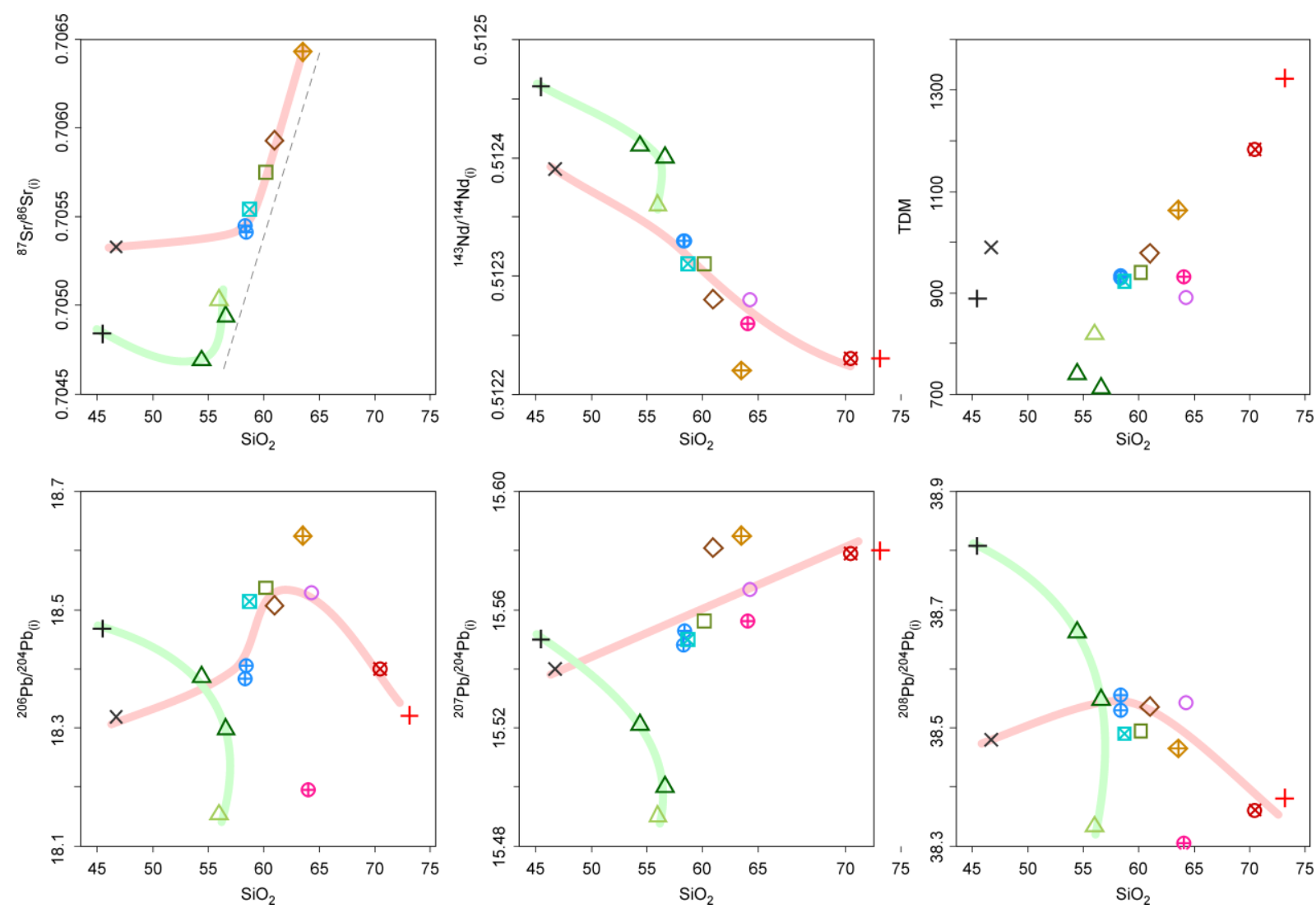

Figura 6.6 - Diagramas $\mathrm{SiO}_{2}$ (em \% de peso) vs. razões isotópicas iniciais e idades modelo $\mathrm{T}_{\mathrm{DM}}$. A Linha verde representa a tendência para o S-SE e a rosa para os S-C e S-NW. Legenda idem Figura 5.7. 

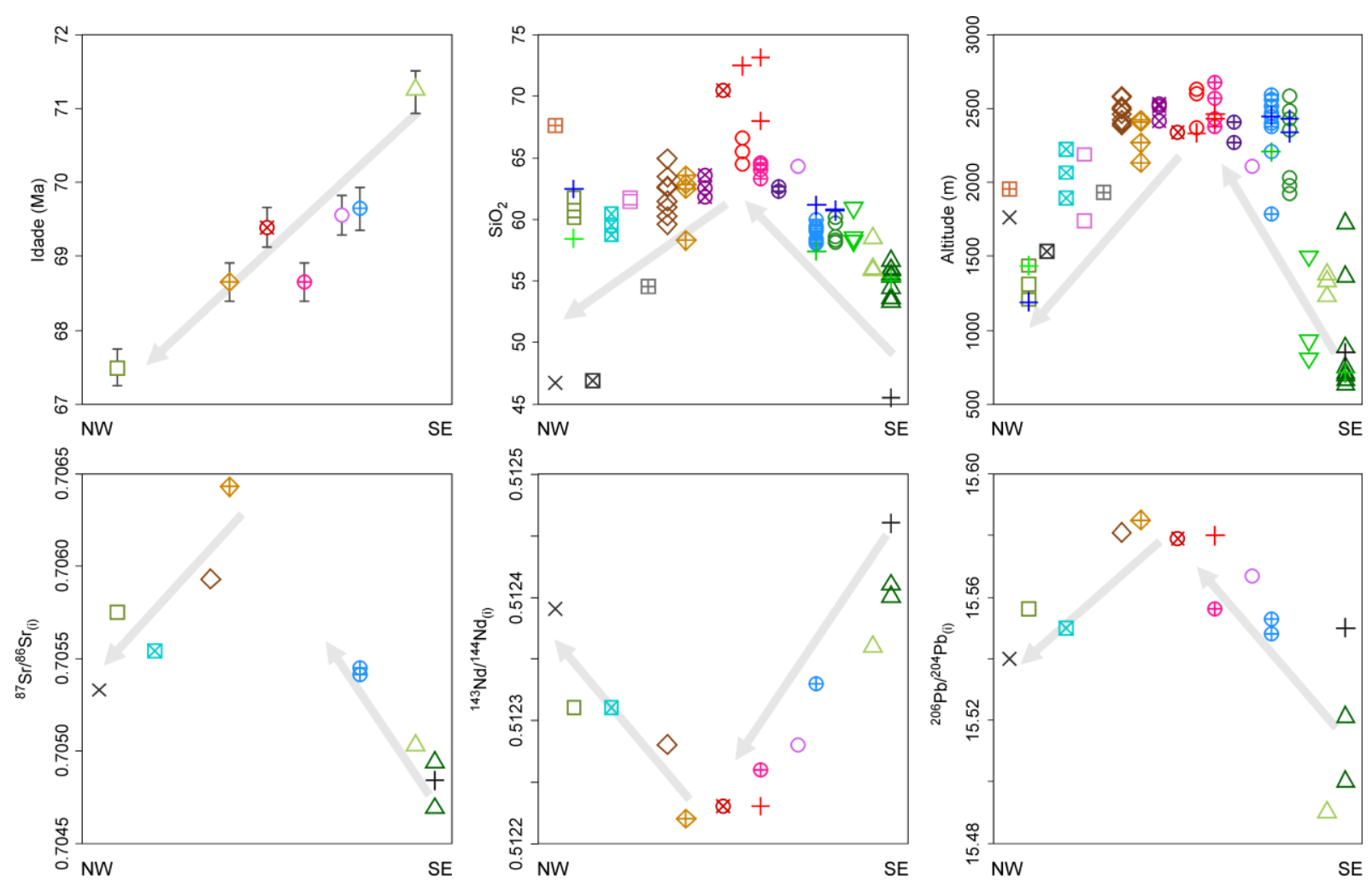

Figura 6.7 - Diagramas mostrando as tendências de variações petrológicas em relação à ordem de intrusão (sem escala) de SE para NW (interpretada a partir de informações geológicas) das unidades do MAI. Legenda idem Figura 5.7.

\subsection{Evolução petrológica}

Os dados geoquímicos e isotópicos sugerem que as rochas do MAl foram geradas através da evolução de dois magmas parentais distintos (Figura 6.8): I) ankaratrito/basanito, que deram origem aos nefelinitos por fracionamento cristal de diopsídio e aos nefelina sienitos do S-SE por fracionamento de diopsídio, apatita e tanfibólio; e II) basanito/álcali basalto que geraram os traquibasaltos por fracionamento de diopsídio e os sienitos dos S-C e S-NW por fracionamento de plagioclásio, diopsídio e apatita, que por sua vez a) evoluíram para nefelina sienitos e b) para sienitos com quartzo ultrapassando a barreira termal por processos assimilação crustal. A Figura 6.9 reproduz esquematicamente as relações petrológicas e petrogenéticas entre as unidades.

O diagrama petrogenético residual (Figura 6.10) mostra que as composições do NeS-I partem do campo da nefelina em direção ao eutético Ne-Ab-Or. As amostras peraluminosas do NeS-I estão dentro do campo da leucita, e isso explica as feições texturais de possíveis pseudoleucitas nessas amostras. As unidades BtHbINeS e NeSdIS têm suas composições no campo de cristalização de feldspato alcalino, mostrando-se um pouco mais evoluídas.

As composições das amostras insaturadas em sílica dos S-C e S-NW estão próximas ao limite de saturação, de modo que uma baixa taxa de assimilação crustal seria suficiente para romper a barreira termal e evoluir em direção ao eutético Ab-Qz-Or por processos de diferenciação e cristalização fracionada. Já os magmas que não tiveram assimilação de encaixantes suficientes para 
ultrapassar a barreira, seguiram uma evolução normal para o eutético Ne-Ab-Or. Os diques de fonolito têm composição muito próxima do eutético nefelina sienítico, enquanto os riolitos e o mA ainda apresentam composições em direção ao eutético granítico.

A razão $\mathrm{Nb} / \mathrm{Ta}$ é relativamente constante $(15,1-18,6$ entre o primeiro e terceiro quartis e mediana 16,7) para todo o maciço e um pouco abaixo do valor do condrito $C 1$ (17,6; McDonough \& Sun, 1995), não possuindo uma relação clara com o incremento de $\mathrm{SiO}_{2}$ ou $\mathrm{Nb}$ (Figura 6.11). Esses valores sugerem uma evolução a partir de um líquido mantélico sem o fracionamento de titanita e titanomagnetita (Green \& Pearson, 1987; Green, 1995). Apenas algumas amostras de tendência mais

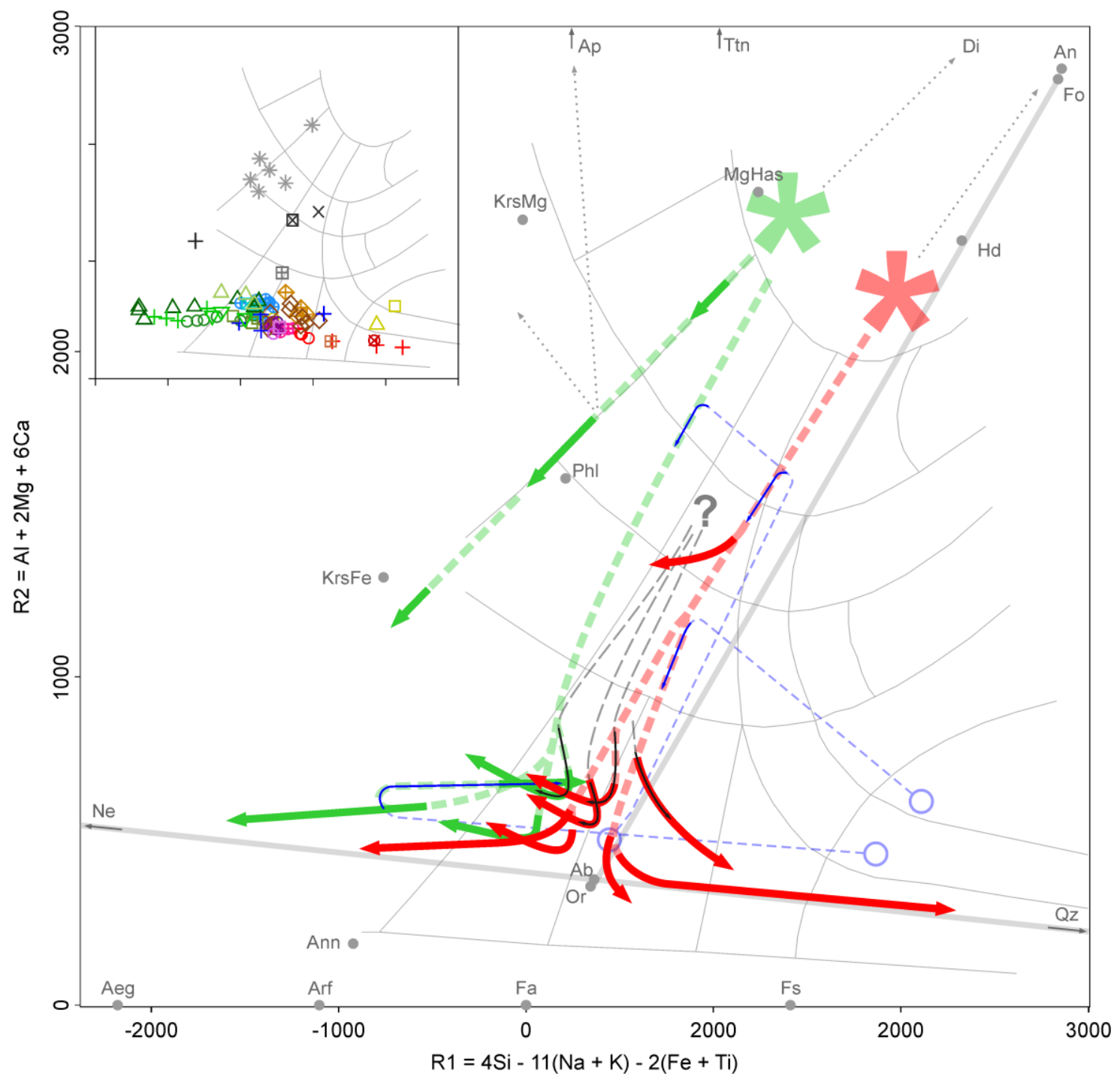

Figura 6.8 - Diagrama R1-R2 (De La Roche et al., 1980) representando as tendências evolutivas das unidades do MAl, as linhas cheias representam as séries das unidades e as tracejadas as possíveis trajetórias evolutivas dos gaps composicionais. As cores representam: verde, unidades do setor S-SE; vermelho, unidades dos setores S-C e S-NW; preto, possíveis injeções máficas nas unidades sieníticas; azul, possíveis processos de assimilação a partir da composição das encaixantes locais. Os asteriscos representam as possíveis composições dos líquidos parentais. Os círculos cinza representam as composições ideais dos minerais e as linhas pontilhadas a direção oposta ao fracionamento dos respectivos minerais. No diagrama (em mesma numérica) estão as distribuições das amostras do MAl (legenda idem Figura 5.7) e dos diques próximos (asteriscos cinza, Thompson et al., 1998). 
evoluída e peralcalina (tanto insaturadas quanto supersaturadas em sílica) possuem valores mais altos (25-59), sugerindo um fracionamento local desses minerais em sua evolução.

A razão $\mathrm{Zr} / \mathrm{Hf}$ apresenta uma variação (37-42,1 entre o primeiro e terceiro quartis e mediana $39,2)$ pouco acima do valor do condrito C1 $(37,6$; McDonough \& Sun, 1995). O aumento dessa razão é controlada principalmente pelo fracionamento de fases máficas como piroxênio e anfibólio magnesiano (e.g. Pfänder et al., 2007; Berger et al., 2014), o que é apoiado pela correlação negativa com mg\#, $\mathrm{A} / \mathrm{NK}$ e $\mathrm{SiO}_{2}$ (Figura 6.11). No entanto, a correlação negativa $\mathrm{Zr} / \mathrm{Hf}$ vs. $\mathrm{SiO}_{2}$ para as rochas supersaturadas significa que elas evoluem diminuindo essa razão, o que não condiz com o fracionamento de máficos.

Os valores do índice Eu/Eu* mostram a variação das anomalias positivas a fortemente negativas de $\mathrm{Eu}(0,09-1,54)$ e possuem uma boa correlação negativa comSiO ${ }_{2}, \pm \mathrm{A} / \mathrm{NK}$ e positiva com $\mathrm{Sr}$ e Ba (Figura 6.12). As rochas consideradas mais primitivas (NeS-I, TB e o nefelinito MAIO46E) não

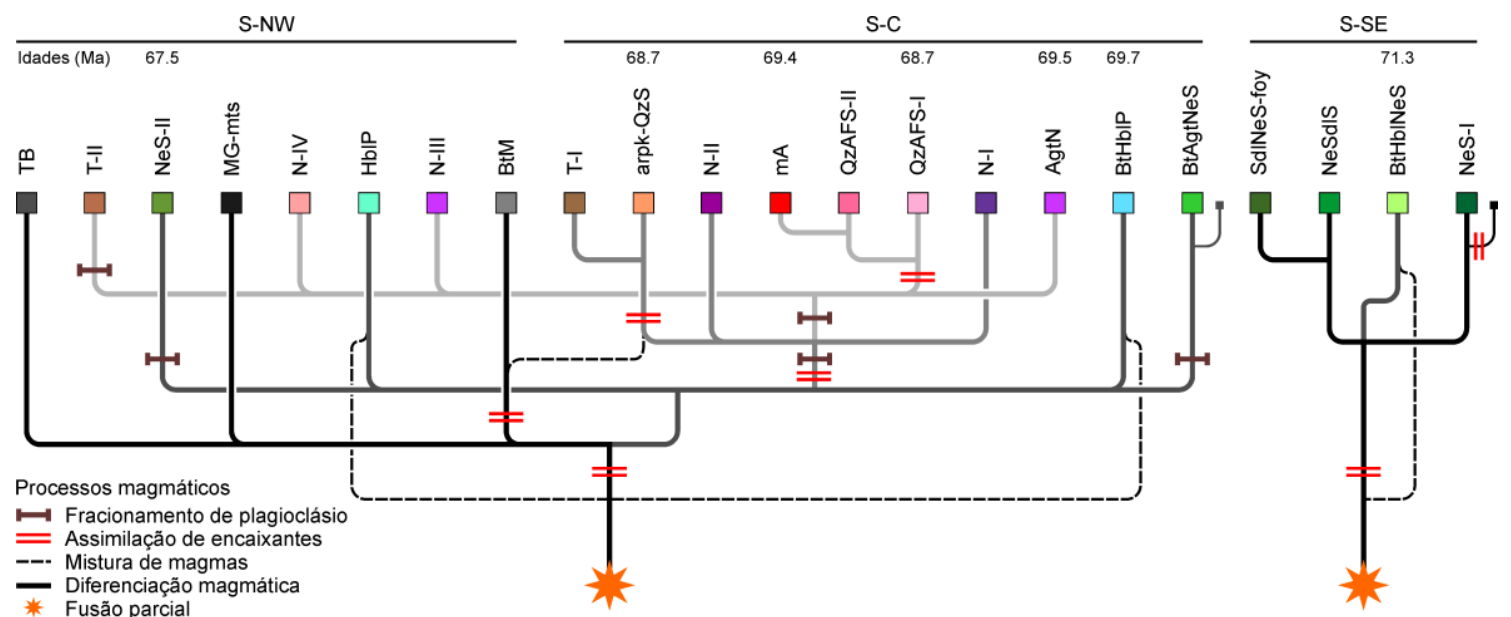

Figura 6.9-Relações petrogenéticas entre as unidades magmáticas do MAI. Os símbolos representam os principais processos petrológicos envolvidos.

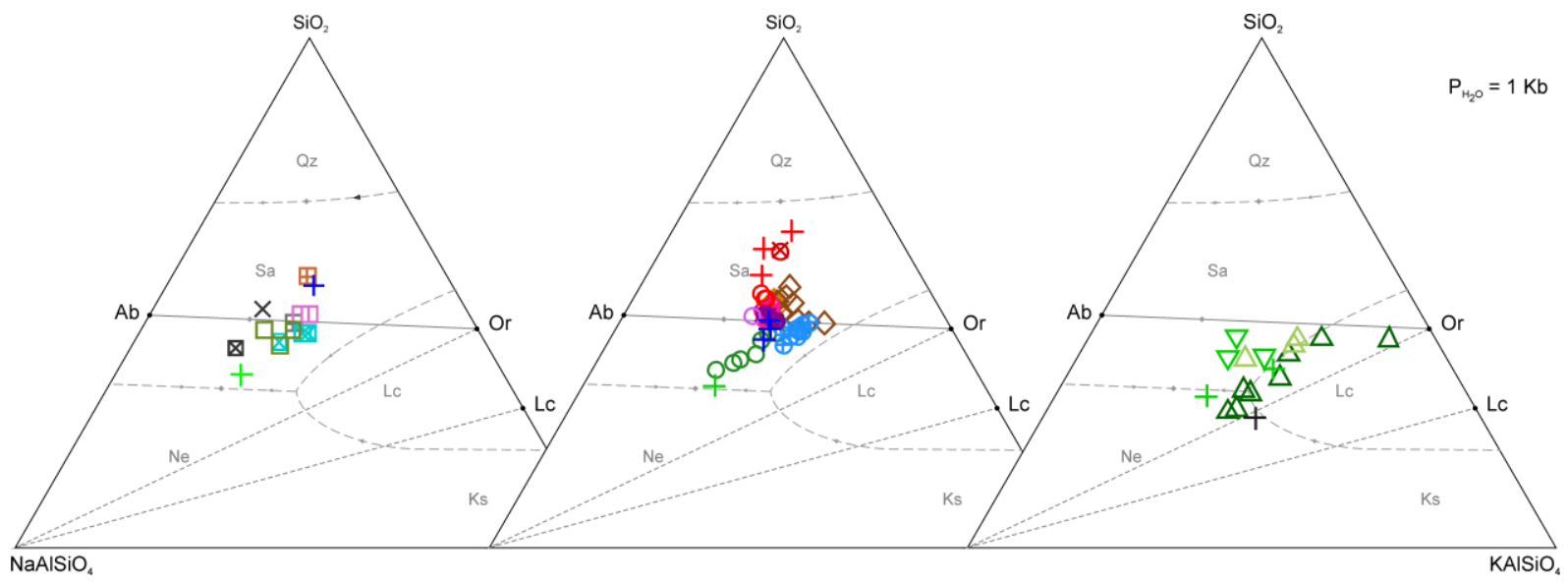

Figura 6.10 - Diagrama de equilíbrio $\mathrm{NaAlSiO}_{4}-\mathrm{SiO}_{2}-\mathrm{KalSiO}_{4}$ (Hamilton \& MacKenzie, 1965) para as rochas dos diferentes setores do MAl. Legenda idem Figura 5.7. 
possuem anomalias significativas (Eu/Eu* 0,96-1,05), enquanto a evolução tanto para as rochas insaturadas quanto supersaturadas se dá com importante fracionamento de plagioclásio, exceto para o SE-E. As rochas com anomalias positivas (Eu/Eu* > 1) possuem plagioclásio e seu significado é discutido a seguir (item 6.4.1.2).
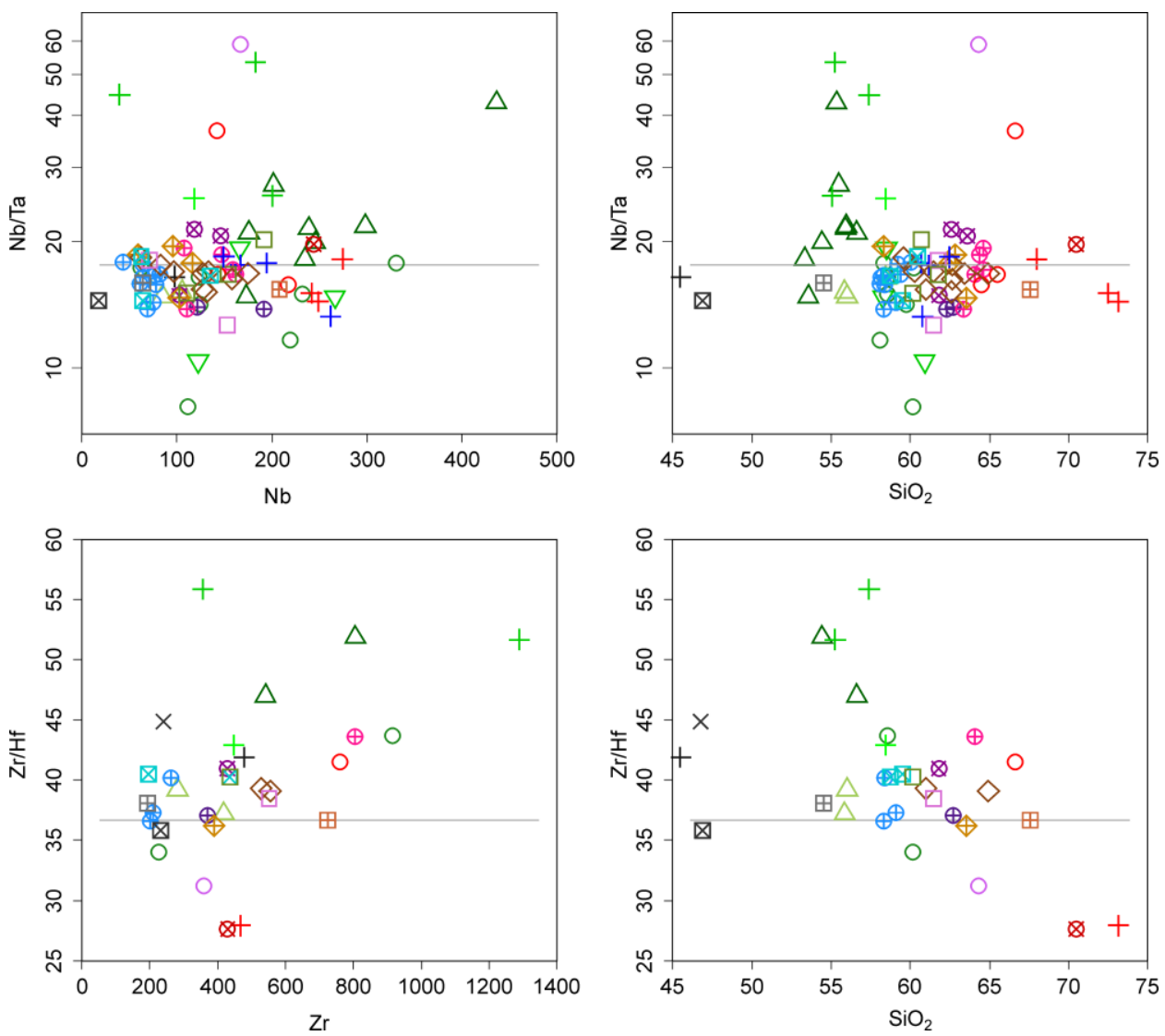

Figura 6.11 - Diagramas de variação das razões $\mathrm{Nb} / \mathrm{Ta}$ e $\mathrm{Zr} / \mathrm{Hf}$ para as rochas do MAl. As linhas horizontais representam a razão condrítica de McDonough \& Sun (1995). Elementos em ppm e $\mathrm{SiO}_{2}$ em \% de peso. Legenda idem Figura 5.7.

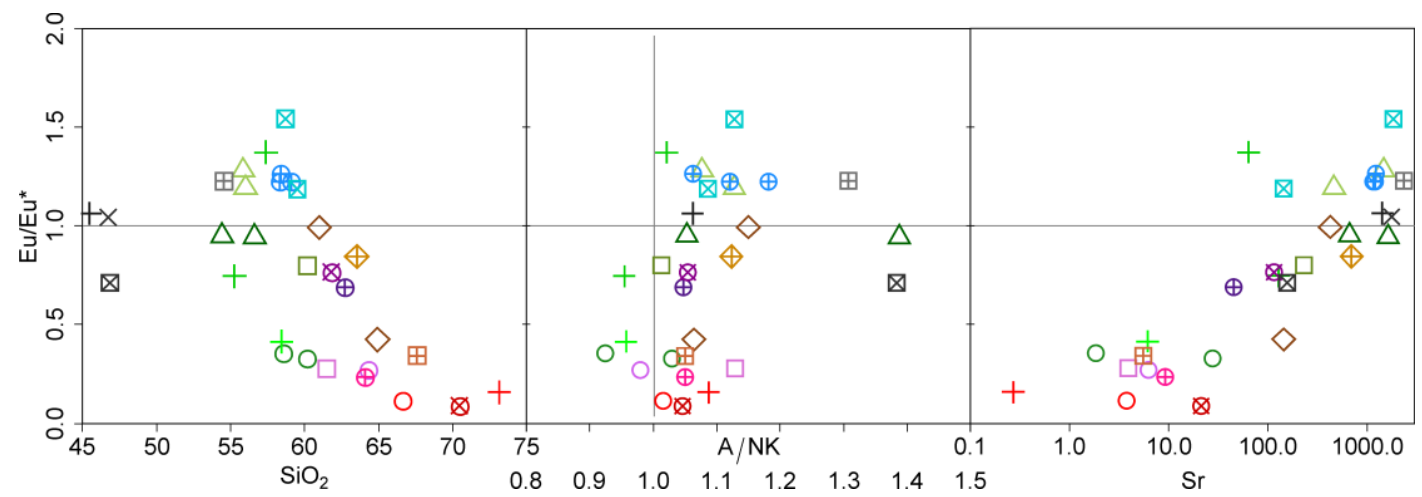

Figura 6.12 - Diagramas de variação da anomalia ed $\mathrm{Eu}\left(\mathrm{Eu} / \mathrm{Eu}^{*}\right)$ vs. $\mathrm{SiO}_{2}$ (em \% de peso), índice A/NK, e $\mathrm{Sr}$ (em ppm) para as rochas do MAI. Legenda idem Figura 5.7. 


\subsubsection{Parâmetros intensivos}

As atividades de albita no álcali feldspato não variam significativamente e quase não diferem entre as temperaturas de 800 e $900^{\circ} \mathrm{C}$, de 0,79 a 0,96 e 0,71 e 0,91, respectivamente. As atividades de nefelina mostram uma variação pouco menor, de 0,38 a 0,53, onde a amostra MAl199 possui os maiores valores. Já o componente jadeíta no clinopiroxênio mostra uma variação significativa e diferença importante entre as temperaturas calculadas, de 0,035 a 0,090 e 0,033 a 0,76. Essa variação deve-se à diferentes estágios de substituição e/ou alteração nos cristais de clinopiroxênio. Além disso, algumas amostras possuem valores bimodais (melhor visto no componente Ca-Tschermak), o que pode representar diferentes estágios de equilíbrio, como antecristais. A variação na atividade de jadeíta é muito crítica pois é muito sensível à mudança de temperatura, o que resulta em uma grande influência no equilíbrio albita-nefelina-jadeíta. Apenas atividades de jadeíta abaixo de 0,040 registram temperaturas mais magmáticas, acima de $700^{\circ} \mathrm{C}$. Com o objetivo de estimar as condições magmáticas iniciais, todos os equilíbrios abaixo de $700^{\circ} \mathrm{C}$ foram considerados com cautela.

Todas as amostras possuem a mesma assembleia inicial (feldspato alcalino, nefelina, clinopiroxênio, magnetita e ilmenita, que pode ser ausente, seguidos então por titanita, anfibólio e Æbiotita), então as suas condições físico-químicas iniciais de equilíbrio devem ser similares. Nessa situação, a temperatura de equilíbrio mais alta pode ser considerada como a condição inicial para esses magmas. A amostra MAl199 mostra temperaturas de $850^{\circ} \mathrm{C}$ e atividades de sílica de $\sim 0,5$, para os valores máximos de atividade de albita e nefelina e mínimo de jadeíta (Figura 6.13A).

O equilíbrio hedenbergite-magnetita-ilmenita-titanita fornece valores de $\mathrm{fO}_{2}$ de 3 a 7 log acima do buffer $F M Q(\triangle F M Q=+3 a+7)$, e abaixo do buffer $H M$, sugerindo condições relativamente altas de fugacidade (Figura 6.13B). Essas condições relativamente altas de oxidação explica a falta de olivina e presença abundante de titanita no maciço.

O equilíbrio anortita (em plagioclásio) - Ca-Tschermak (em clinopiroxênio) possui valores de atividade de sílica muito menores (Figura 6.13C), mostrando um claro desequilíbrio com a assembleia feldspato alcalino-nefelina-clinopiroxênio. Isso corrobora com as observações texturais de que os cristais de plagioclásio são antecristais, ou mesmo xenocristais.

\subsection{Grupos petrológicos}

O MAI compõe-se de um conjunto diversificado de litotipos que pode ser dividido em cinco grupos petrológicos: (1) nefelina sienitos sem plagioclásio, (2) nefelina sienitos/pulaskitos com plagioclásio, (3) série nordmarkito-granito, (4) associação quartzo sienito anti-rapakivi e (5) rochas básicas. A Figura 6.14 mostra a distribuição espacial desses grupos no mapa geológico do MAl e seus respectivos campos de variação no diagrama mg vs. Q-foid. 

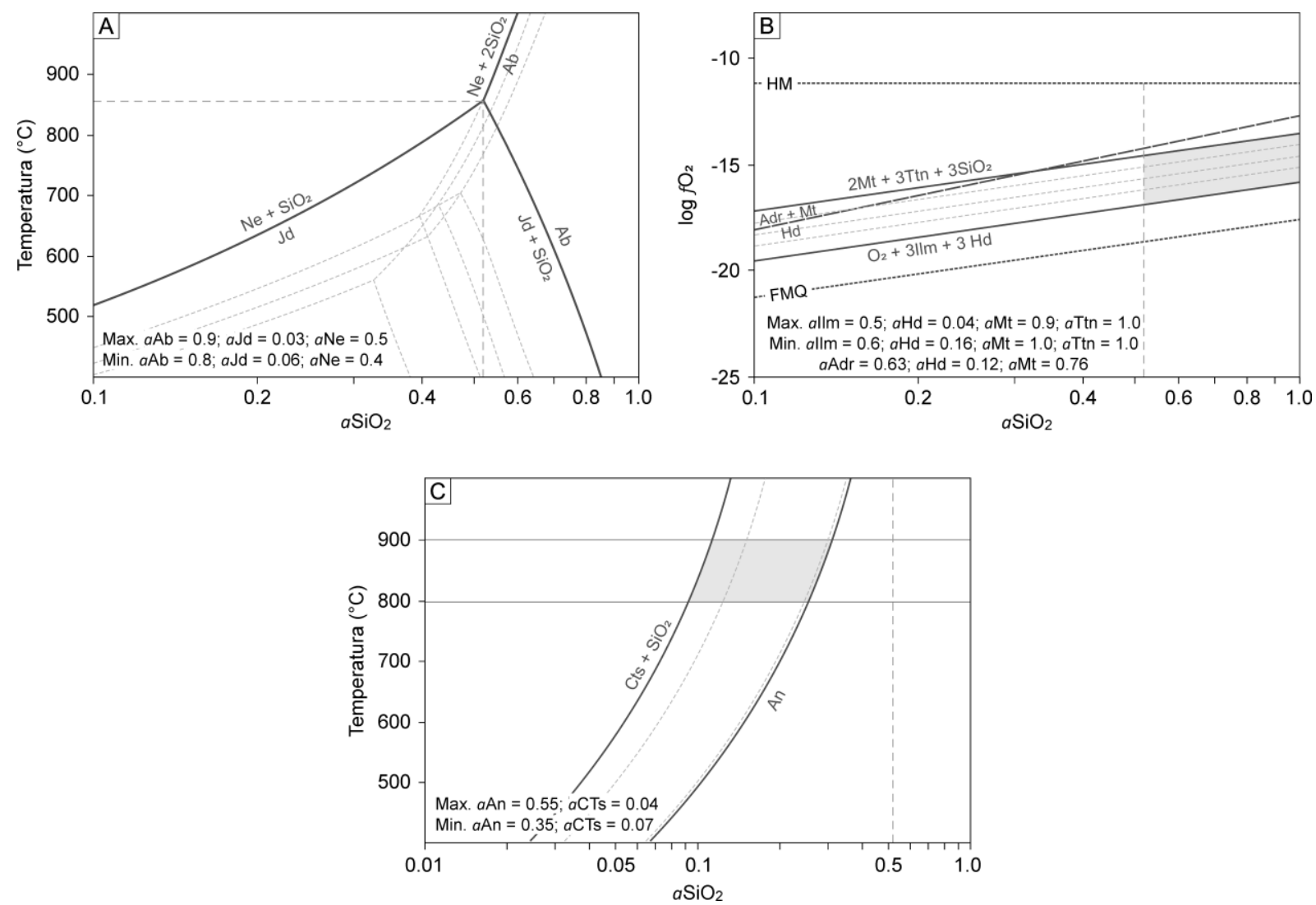

Figura 6.13 - Diagramas de equilíbrio entre as fases minerais das rochas do Maciço Alcalino de Itatiaia calculados para 1 kbar e $900^{\circ} \mathrm{C}$ para as atividades dos componentes minerais. A) Diagrama $a \mathrm{SiO}_{2} v s$. temperatura mostrando o equilíbrio nefelina - jadeíta (em clinopiroxênio) - albita (em feldspato alcalino). Os equilíbrios tracejados são considerados sub solidus (< $700^{\circ} \mathrm{C}$ ), sendo o de maior temperatura registrado na amostra $\mathrm{MAI} 199$, com $a \mathrm{SiO}_{2}$ de $\sim 0,55$. B) Diagrama $a \mathrm{SiO}_{2} v s$. $\log f \mathrm{fO}_{2}$ mostrando os equilíbrios magnetita - titanita - ilmenita - hedenbergita (em clinopiroxênio) e andradita - magnetita hedenbergite (em clinopiroxênio). Em cinza o campo de variação da $a \mathrm{SiO}_{2}$ e $f_{\mathrm{O}}$ do $\mathrm{MAI}$. $\mathrm{HM}$, buffer hematita-magnetita; $\mathrm{FMQ}$, buffer fayalita-magnetita-quartzo. C) Diagrama $a \mathrm{SiO}_{2} v s$. temperatura mostrando o equilíbrio Ca-tschermak (em clinopiroxênio) - anortita (em plagioclásio). Em cinza a área de estabilidade desse equilíbrio, mostrando-se abaixo da $a \mathrm{SiO}_{2}$ mínima do maciço.
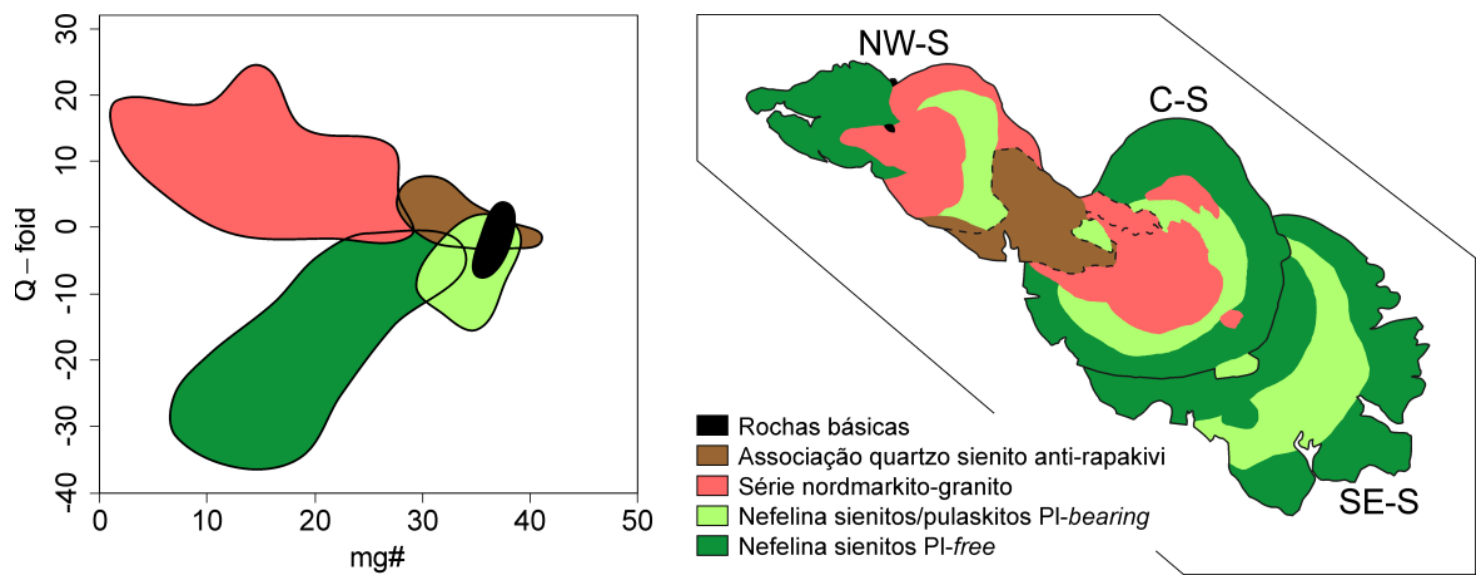

Figura 6.14 - Mapa geológico simplificado com os grupos petrológicos do MAl e o diagrama mg\# vs. Q - foid (em \% normativa) com os campos de variação das rochas do MAI. 


\subsubsection{Rochas sieníticas com nefelina}

Todos os sienitos insaturados em sílica possuem uma paragênese mineral inicial similar: apatita, zircão, titanomagnetita, „ilmenita e diopsídio, além de feldspato potássico e nefelina, contudo eles podem ser divididos em dois grupos distintos (Tabela 6.1): nefelina sienitos sem plagioclásio (PIfree) e nefelina sienitos/pulaskitos com plagioclásio (Pl-bearing).

Esses grupos de rochas sieníticas com nefelina Pl-free e PI-bearing têm similaridades com os tipos SA e A, respectivamente, descritos por Brotzu et al. (1997), e coincide com as áreas de concentração de nefelina e titanita marcadas por Penalva e Ribeiro Filho (1965). O tipo A seria dominante, moderadamente insaturado ( $\mathrm{Ne}_{\text {norm }} 2-16 \%$ ), com plagioclásio ou não, e compondo plugs locais de sienitos com coríndon (subgrupo C) na região sudeste, e o tipo SA seriam intrusões mais tardias fortemente insaturadas ( $\mathrm{Ne}_{\text {norm }} 20-36 \%$ ). Entretanto, as observações geológicas e petrológicas coletadas neste trabalho sugerem relações diferentes. Os nefelina sienitos Pl-free representam as primeiras e últimas intrusões sieníticas dos setores S-SE e S-C/S-NW, intercaladas pelos nefelina sienitos/pulaskitos PI-bearing.

\subsubsection{Nefelina sienitos sem plagioclásio (PI-free)}

As rochas deste grupo são tipicamente mais escuras, devido ao feldspato potássico cinza escuro e teores maiores de nefelina (também escura), porém possuem índice de cor menor. 0 diopsídio segue um zonamento normal, com bordas tipicamente de aegirina-augita a aegirina, exceto na unidade NeS-II, onde é substituída por magnésio-hastingsita e biotita. Esta unidade também é a única onde foi encontrado relictos de andradita (além de xenólitos com melanita nos diques do S-SE). Nos diagramas de Harker (Figura 5.11) $\mathrm{TiO}_{2}, \mathrm{FeO}_{\mathrm{t}}, \mathrm{MgO}$ e $\mathrm{P}_{2} \mathrm{O}_{5}$ não apresentam uma clara correlação com $\mathrm{SiO}_{2}$, mantendo uma tendência horizontal a levemente positiva, que foge da tendência geral do

Tabela 6.1 - Classificação dos grupos petrológicos dos litotipos plagioclásio-free (Pl-free) e plagioclásio-bearing (PI-bearing) das unidades nefelina sieníticas e pulaskíticas do MAI. Não foram consideradas as rochas peraluminosas do NeS-I e do apêndice noroeste da unidade BtHbIP.

\begin{tabular}{|c|c|}
\hline Nefelina sienitos Pl-free & Nefelina sienitos/pulaskitos PI-bearing \\
\hline NeS-I, NeSdIS, SdINeS-foy, BtAgtNeS e NeS-II*) & BtHlbNeS, BtHblP e HblP \\
\hline Mais insaturada em sílica (10-35\% foid modal) & Menos insaturada em sílica (0-15\% foid modal) \\
\hline Rocha cinza escura; M' 5-16\%; mg\# 8-34 & Rocha cinza claro; M' 10-28\%; mg\# 30-43 \\
\hline$\lambda \mathrm{SiO}_{2}$ vs. $\nearrow \rightarrow\left(\mathrm{TiO}_{2}, \mathrm{FeO}_{\mathrm{t}}, \mathrm{MgO}\right.$ e $\left.\mathrm{P}_{2} \mathrm{O}_{5}\right)$ & $\lambda \mathrm{SiO}_{2}$ vs. $\searrow\left(\mathrm{TiO}_{2}, \mathrm{FeO}_{\mathrm{t}}, \mathrm{MgO}\right.$ e $\left.\mathrm{P}_{2} \mathrm{O}_{5}\right)$ \\
\hline $\mathrm{CaO}<1,6 \% ; \mathrm{P}_{2} \mathrm{O}_{5}<0,2 \% ; \mathrm{Eu} / \mathrm{Eu}^{*} 0,33-0,95$ & $\mathrm{CaO}>1,7 \% ; \mathrm{P}_{2} \mathrm{O}_{5}>0,2 \% ; \mathrm{Eu} / \mathrm{Eu}^{*} 1,19-1,54$ \\
\hline$\downarrow f \mathrm{O}_{2} ; \mathrm{A} / \mathrm{NK}<1,07 ; \mathrm{K}_{2} \mathrm{O} / \mathrm{Na}_{2} \mathrm{O} 0,6-1,4$ & $\uparrow \mathrm{fO}_{2} ; \mathrm{A} / \mathrm{NK}>1,06 ; \mathrm{K}_{2} \mathrm{O} / \mathrm{Na}_{2} \mathrm{O} 1,0-2,1$ \\
\hline Diopsídio $\rightarrow$ aegirina-augita $\rightarrow$ aegirina & Diopsídio $\rightarrow$ magnésio-hastingsita $\rightarrow \pm$ biotita \\
\hline$\downarrow$ biotita, titanita, titanomagnetita e apatita & 个 biotita, titanita, titanomagnetita e apatita \\
\hline Presença local de minerais agpaíticos & Presença constante de plagioclásio \\
\hline
\end{tabular}


maciço (formado o $\lambda$ ). Também é característica a tendência mais sódica $\left(\mathrm{K}_{2} \mathrm{O} / \mathrm{Na}_{2} \mathrm{O}\right.$ 0,6 a 1,4) e peralcalina (A/NK 0,91 a 1,07), com a presença comum de minerais agpaíticos. As informações geoquímicas e isotópicas sugerem que as rochas desse grupo foram geradas pela evolução direta de magmas parentais mantélicos, controlada principalmente por processos de fracionamento de plagioclásio e clinopiroxênio.

Os minerais agpaíticos, especialmente låvenita, hiortdahlita e rinkita (além de kupletskita, hainita, rosenbuschita e catapleiita), ocorrem dispersos pela rocha como fases intersticiais ou como cristais aciculares, juntamente com a maior presença de sodalita. As sequências de cristalização dos minerais são:

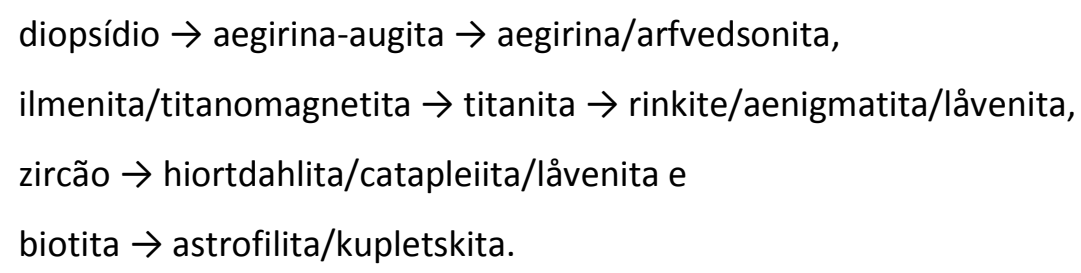

Esse minerais delimitam um estágio transicional de um sistema miaskítico para agpaítico (Sørensen, 1997; Marks et al., 2011; Andersen et al., 2016).

Rochas agpaíticas são geradas por uma extensa diferenciação de magmas nefeliníticos ou álcali basálticos derivados do manto sob baixa $\mathrm{fO}_{2}$ (Sørensen, 1997; Mann et al., 2006; Markl et al., 2010; Marks et al., 2011). Sua evolução e cristalização dependem fortemente das razões A/NK e K/N do líquido, que são favorecidas pelo fracionamento de plagioclásio, clinopiroxênio e hornblenda, e pela cristalização de feldspato potássico, nefelina e biotita, respectivamente, fatores que progressivamente acumulam $\mathrm{Na}$ no líquido. Magmas com baixa $\mathrm{fO}_{2}$ também favorecem o enriquecimento de $\mathrm{Na}, \mathrm{Cl}, \mathrm{Fe}$ outros voláteis devido à menor atividade de $\mathrm{H}_{2} \mathrm{O}$ e $\mathrm{CO}_{2}$. Nesse caso, eles possuem tipicamente $\mathrm{CH}_{4}$ como fase fluída dominante, que por sua vez, tornam-se bastante solúveis para os HFSE resultando na cristalização de minerais agpaíticos (Marks et al., 2011). No caso do líquido não concentrar suficientemente $\mathrm{Na}, \mathrm{Cl}$ e F, minerais como titanita e zircão irão se cristalizar, formando uma assembleia miaskítica. $\mathrm{O}$ excesso de Na favorece a cristalização de aegirina e arfvedsonita, forçando a entrada de $\mathrm{Fe}^{3+}$ nesses minerais e assim reduzindo ainda mais o líquido devido ao consumo de $\mathrm{O}_{2}$. O líquido evolui para condições nas quais nem ilmenita ou magnetita são estáveis (no oxide field), com as condições de oxidação passando então a ser controladas pelo equilíbrio entre aegirina, arfvedsonita e aenigmatita (Markl et al., 2010).

O SdINeS-foy apresenta os maiores teores desses minerais agpaíticos, enquanto na borda sudeste do NeS-I e nas regiões de crista do BtAgtNeS ocorrem fácies onde são mais abundantes. A manifestação de rochas agpaíticas na região externa de complexos anelares (como na unidade BtAgtNeS que forma o anel externo do $\mathrm{S}-\mathrm{C}$ ) também ocorre em outros maciços, como Poços de Caldas 
(Ulbrich, 1993) e Pilanesberg (Andersen et al., 2016). Nesses lugares, as fácies agpaíticas, normalmente fonolitos e tinguaítos, são interpretados como manifestações tardias e relacionadas ao colapso do sistema de caldeira.

As rochas peraluminosas com coríndon modal do NeS-I possuem os teores de $\mathrm{SiO}_{2}, \mathrm{Al}_{2} \mathrm{O}_{3}, \mathrm{~K}_{2} \mathrm{O}$ e $\mathrm{Rb}$ maiores e $\mathrm{Na}_{2} \mathrm{O}$ muito menor do que as demais amostras da unidade. As razões ${ }^{87} \mathrm{Sr} /{ }^{86} \mathrm{Sr}$ e ${ }^{143} \mathrm{Nd} /{ }^{144} \mathrm{Nd}$ também variam um pouco no sentido de enriquecimento de componente crustal. $\mathrm{O}$ aumento de $\mathrm{K}_{2} \mathrm{O}, \mathrm{Al}_{2} \mathrm{O}_{3}$ e $\mathrm{Rb}$ sugere a assimilação de rochas ricas em muscovita e biotita, sendo a encaixante local um sillimanita-granada-muscovita-biotita-xisto do Grupo Embú (Eirado et al., 2006; Heilbron et al., 2016). A assimilação de uma encaixante rica em minerais aluminosos, especialmente muscovita, por um magma peralcalino poderia levar à saturação de $\mathrm{Al}_{2} \mathrm{O}_{3}$ antes da saturação de $\mathrm{SiO}_{2}$, resultando na presença de coríndon e hercynita. Alguns lugares do MAl, como nos Três Picos, a rocha possui uma granulação fina, podendo representar plugs resultado de uma diferenciação interna. A associação plagioclásio, hercynite e coríndon pode sugerir substituição de granada e clinopiroxênio (Mariga et al., 2006).

\subsubsection{Nefelina sienitos/pulaskitos com plagioclásio (PI-bearing)}

As rochas sieníticas com nefelina do grupo Pf-bearing são mais claras e mais máficas, geralmente com o feldspato alcalino esbranquiçado, nefelina rosada e cristais de anfibólio, biotita e titanita bem desenvolvidos. O diopsídio é substituído por magnésio-hastingsita durante o estágio principal de cristalização, que localmente pode ser substituída por biotita. Nos diagramas de Harker (Figura 5.11), a composição química desse grupo de rocha segue a tendência normal do maciço,

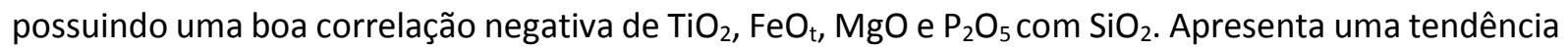
de caráter mais potássica $\left(\mathrm{K}_{2} \mathrm{O} / \mathrm{Na}_{2} \mathrm{O} 1,0-2,1\right)$ e miaskítica $(\mathrm{A} / \mathrm{NK} 1,06-1,17)$. Além disso, possui uma característica anomalia positiva de Eu e presença de plagioclásio, frequentemente zonado, com texturas iniciais ígneas e feições de reequilíbrio/substituição posterior.

Os cristais maiores de plagioclásio possuem teores mais elevados de An (40-50\%), exibindo os seus núcleos menos reequilibrados. Esses teores de An são relativamente altos para nefelina sienitos e pulaskitos de associações tipicamente feldspática. O equilíbrio anortita (em plagioclásio) - CaTschermak (em clinopiroxênio) possui valor de atividade de sílica muito menor do que o estimado para os nefelina sienitos do MAI (Figura 6.13C), mostrando um claro desequilíbrio com a assembleia feldspato alcalino-nefelina-clinopiroxênio.

As razões $\mathrm{A} / \mathrm{NK}$ e $\mathrm{K}_{2} \mathrm{O} / \mathrm{Na}_{2} \mathrm{O}$ maiores e a presença de plagioclásio (ainda instável), tornaram a concentração relativa de $\mathrm{Na}$ no líquido menor, favorecendo a cristalização de uma assembleia miaskítica e mantendo a $\mathrm{fO}_{2}$ elevada ao longo da cristalização pela falta de substituições acoplada $\mathrm{NaFe}^{3+}$. Aliado ao aumento da $a \mathrm{H}_{2} \mathrm{O}$ durante a cristalização, o diopsídio torna-se instável sendo 
substituído pela magnésio-hastingsita, mais estável sob uma maior $\mathrm{fO}_{2}$ e menor disponibilidade de $\mathrm{Na}$ (Figura 6.15).

A presença de plagioclásio e diopsídio com texturas de desequilíbrio (Figure 5D e H, ANEXO A) e maior teor modal de minerais máficos, seguidos de valores maiores de mg\#, $\mathrm{P}_{2} \mathrm{O}_{5}$ e elementos traço tais como $\mathrm{Sc}, \mathrm{Cr}$, $\mathrm{Co}$ e $\mathrm{Cu}$, poderiam sugerir a interação desses magmas com outros de caráter básico durante a sua evolução, seja em um pré-estágio de cristalização ou durante a ascensão. A concentração de Eu no magma sienítico inicial ao longo da cristalização, seguido de mudanças para um ambiente de redução do sistema, devido à essa iteração de magmas, poderia elevar as concentrações de $\mathrm{Eu}^{2+}$ no plagioclásio e consequentemente na rocha. Não foram encontrados enclaves máficos de qualquer tipo, porém os minerais máficos tendem a formarem agregados relativamente maiores do que o grupo $\mathrm{P}$ free.

Uma taxa de fusão parcial do manto um pouco maior e/ou uma pequena diferença no local dessa fusão, assim como diferenças nos graus de assimilação ao longo da ascensão e colocação desses magmas, também poderiam contribuir para as diferenças geoquímicas e petrográficas entre os dois grupos de rochas sieníticas com nefelina PI-bearing e Pl-free. Porém, os dados isotópicos não indicam uma participação expressiva aos trends de evolução geral do maciço.

\subsubsection{Rochas sieníticas com quartzo}

A rochas sieníticas com quartzo ocorrem no centro do S-C, longe do contato com as encaixantes regionais, na região de transição entre o S-NW e sua região central, nesses locais ocorrendo também em contato com as encaixantes. Todas as unidades apresentam anomalias negativas de Eu significativas, sugerindo que o fracionamento de plagioclásio representou um papel importante no processo de evolução e geração dessas rochas. Tipicamente exibem feições de alteração

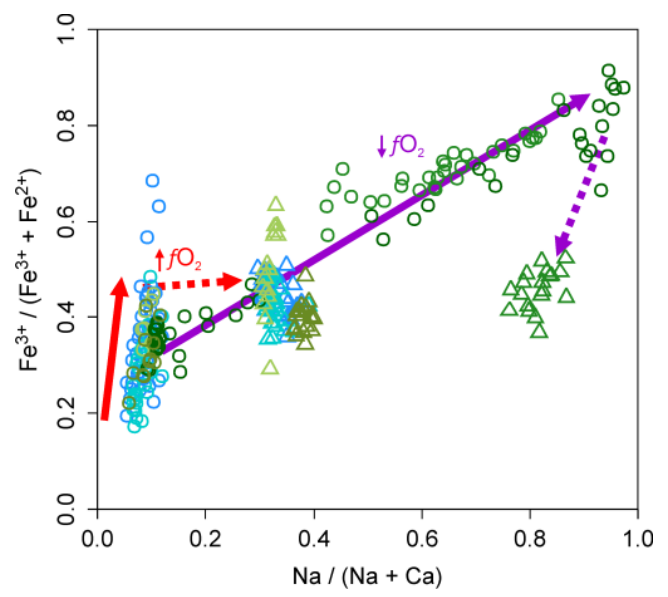

Figura 6.15 - Diagrama $\mathrm{Na} /(\mathrm{Na}+\mathrm{Ca})$ vs. $\mathrm{Fe}^{3+} /\left(\mathrm{Fe}^{3+}+\mathrm{Fe}^{2+}\right)$, em a.p.f.u, para clinopiroxênios e anfibólios das rochas insaturadas em sílica do MAl. Círculos, clinopiroxênio; triângulos, anfibólio. Em vermelho a sequência diopsídio $\rightarrow$ magnésio-hastingsita, onde o aumento do teor de $\mathrm{Fe}^{3+}$ é consequência do aumento progressivo de $\mathrm{fO}_{2}$ e menor dependência da disponibilidade de $\mathrm{Na}$. Em azul a sequência diopsídio $\rightarrow$ aegirina-augita $\rightarrow$ aegirina/arfvedsonita, onde a disponibilidade maior de Na induz à entrada de $\mathrm{Fe}^{3+}$ por substituição acoplada, e aumenta o consumo de $\mathrm{O}_{2}$, diminuindo progressivamente a $f \mathrm{O}_{2}$ do líquido. 
pós-magmática, com as fases máficas parcialmente substituídas por óxidos, carbonatos e fluocarbonatos, e com feldspato bastante sericitizado. Quase todas as unidades exibem cavidades miarolíticas, sugerindo uma colocação relativamente rasa desses corpos.

Foram identificados dois grupos: a série nordmarkito-granito e a associação quartzo sienitotraquito porfirítico.

\subsubsection{Série nordmarkito-granito}

É formada pelas unidades AegN, N-I, N-II, N-III, QzAFS-I, QzAFS-II, QzAFS-III e mA. Essas unidades possuem em comum uma paragênese inicial similar, com tapatita, zircão, „ilmenita, titanomagnetita, \pm augita/aegirina-augita e feldspato alcalino. $O$ teor modal, tamanho dos cristais e a estágio de cristalização do quartzo é correlacionável ao teor de sílica da unidade. A presença de clinopiroxênio e anfibólio é variável, desde unidades sem anfibólio (AegN e N-II), ou apresentando ambos minerais com texturas de substituição (N-I, QzAFS-I, N-III), ou sem clinopiroxênio (QzAFS-II) e até unidades sem estes dois minerais $(\mathrm{mA})$. Não há padrões químicos notáveis que expliquem essas diferenças, sendo então, possivelmente, resultados de variações das condições físico-químicas dos sistemas em que cada unidade foi gerada, particularmente de $\mathrm{fO}_{2}$ e $a \mathrm{H}_{2} \mathrm{O}$. Nas unidades AegN e N-II o clinopiroxênio é substituído por uma associação tardi a pós-magmática de ankerita, carbonatos e fluorcarbonatos de terras raras, ilmenita e fluorita.

Os modelamentos petrológicos com os dados disponíveis para elementos traço e razões isotópicas não são compatíveis com a evolução direta dessas rochas supersaturas a partir de um magma nefelina sienítico, como BtHblP ou BtAgtNeS (S-C) ou HblP e NeS-II (S-NW). Isso sugere que a assimilação local de sílica, especialmente do teto da intrusão, não foi significativa ou determinante para a supersaturar esses magmas.

A correlação com $\mathrm{SiO}_{2}$ para os elementos maiores, $\mathrm{Rb}, \mathrm{Th}, \mathrm{U}, \mathrm{Nb}, \pm \mathrm{Ta}, \pm \mathrm{Hf}$ e Eu/Eu* e as razões isotópicas $\mathrm{Nd}-\mathrm{Sr}-\mathrm{Pb}$ formam uma boa tendência geral para os setores $\mathrm{S}-\mathrm{C}$ e S-NW e sugerem uma relação petrogenética e petrológica entre essas unidades. A partir de um magma parental já pouco insaturado (como um álcali basalto), a assimilação de rochas saturadas a supersaturadas ao longo da acessão pela crosta inferior e superior levaria ao rompimento da barreira termal do sistema Ne-Ab-Qz, assim evoluindo em direção ao eutético do sistema Ab-Qz-Or pela cristalização de feldspato alcalino. Os baixos teores de $\mathrm{MgO}, \mathrm{CaO}, \mathrm{P}_{2} \mathrm{O}_{5}, \mathrm{Ba}$ e $\mathrm{Sr}$ e a forte anomalia de $\mathrm{Eu}$ indicam um importante fracionamento de plagioclásio, diopsídio e apatita a partir de um magma pouco insaturado em $\mathrm{SiO}_{2}$ (como discutido no item 6.2.2). Possivelmente, os estágios iniciais de fracionamento mineral ocorreram em uma câmara em níveis intermediários a inferior da crosta.

Os QzASF-I e II e suas fácies internas possuem uma correlação química mais próxima e possivelmente evoluíram através de sucessivos pulsos magmáticos de caráter similar. São as únicas 
unidades do MAl com anomalia negativa de $\mathrm{Ce}(\mathrm{Ce} * 0,58-0,62)$, além do $\mathrm{MG}-\mathrm{mts}$, o que poderia indicar um fracionamento de zircão sob maior $\mathrm{fO}_{2}$ (Burnham \& Berry, 2014; Smythe \& Brenan, 2015). Entretanto essas rochas são ricas em zircão e o Ce* não apresenta qualquer correlação aparente com qualquer outro elemento ou razões elementares para o conjunto de dados do MAI. Já o dique MAl130, que corta o QzASF-I próximo ao contato com o QzAFS-II, é fortemente empobrecido em ETRs, porém com forte anomalia positiva de $\mathrm{Ce} *(3,22)$ e enriquecimento nos ETRs pesados. O T-II apresenta padrão semelhante, porém pouco menos empobrecido. $0 \mathrm{~mA}$ possui grande semelhança geoquímica e isotópica com os diques de riolito, e possivelmente são resultados de uma diferenciação interna da unidade QzAFS-II.

A relação entre os nordmarkitos não é clara, já que eles não estão em contato entre si. O AegN e N-I estão alojados entre o BtAgtNeS e BtHblP, entretanto, o AegN é a única unidade com quartzo de caráter peralcalino $(\mathrm{A} / \mathrm{NK}=0,98)$, tendo aegirina e albita como fases finais de cristalização e ausência de titanita. $\mathrm{O} \mathrm{N}$-I possui maior afinidade com o $\mathrm{N}$-II, e possuem os teores mais elevados de $\mathrm{P}_{2} \mathrm{O}_{5}, \mathrm{Sr}$ e $\mathrm{Ba}$, anomalias negativas de Eu menores (Eu/Eu* 0,69-0,77), e assinatura de ETRs correspondentes. $\mathrm{O}$ $\mathrm{N}$-II está claramente colocado entre duas unidades mais ricas em sílica. A localização e texturas do NIII e QzAFS-III (foliação magmática do N-III e a textura dos agregados máficos em ambos) sugerem que poderiam ser facies de borda do HblP, com grande assimilação das rochas encaixantes. Entretanto, as unidades insaturadas e supersaturadas do N-NW possuem assinaturas de elementos traço e ETRs bem diferentes. O N-III e T-II possuem curvas de ETRs semelhantes, com forte anomalia negativa de Eu, anomalia positiva de $\mathrm{Ce}$, e leve enriquecimento nos ETRs pesados, porém o T-II é mais empobrecido.

Os T-I(a) e T-II também fazem parte dos trends geoquímicos, porém possuem um contexto geológico um pouco diferente. O comportamento geoquímico de alguns elementos e as características mineralógicas indicam diferenças nos processos evolutivos.

\subsubsection{Associação quartzo sienito anti-rapakivi}

Os dados geoquímicos, as relações de campo e as semelhanças texturais mostram uma afinidade petrológica entre o arpk-QzS, o T-I(b) e o T-I(c). A fácies $T-I$ (c) possui as mesmas texturas, mineralogia e cor que as do arpk-QzS, porém com uma matriz mais fina. Já a fácies T-I(b) possui uma matriz afanítica, com fenocristais exibindo texturas anti-rapakivi semelhantes às do arpk-QzS. No campo é difícil determinar os limites entre essas unidades, ora ocorrendo de forma abrupta, ora gradativa. Essas unidades também se sobrepõem nos diagramas de variação química, sugerindo assim uma mesma origem e evolução.

A presença de textura anti-rapakivi, comumente envolvendo agregados minerais, indica mudança brusca nos teores de $\mathrm{K}_{2} \mathrm{O}$ e $\mathrm{Na}_{2} \mathrm{O}$ durante um estágio de cristalização, enquanto enclaves máficos arredondados ou ovóides e ricos em biotita registram a injeção de um magma mais básico. 
Os diagramas de variação química mostram um deslocamento do trend normal do maciço em direção ao BtM, com o qual faz contato na porção oeste. Nos diagramas das Figura 5.8 e 6.8 o arpkQzS e o T-I saem da tendência geral alinhando-se com o BtM.

As amostras do arpk-QzS e T-I se adequam bem à curva de mistura (Figura 6.16) entre as amostras MAI110 (QzAFS-I), com o qual possui semelhanças mineralógicas e visuais, e MAI182C (BtM), com um grau de mistura de 20 a 65\%. A amostra MAl189 de um arpk-QzS representa a que mais se aproxima quimicamente do BtM, sendo também a que está situada mais próxima geograficamente.

\subsubsection{Rochas básicas}

As unidades Mg-mts e TB possuem pouca expressão na constituição do MAl, tendo sido encontrado apenas um afloramento de cada uma dessas unidades, sem mostrar uma relação geológica clara com as rochas sieníticas. O melagabro possui textura tipicamente cumulática, porém não há resquícios de piroxênio, substituído por uma associação de ferropargasita, magnetita, titanita e biotita. Possui composição química muito semelhante ao TB, diferindo apenas nos menores teores de $\mathrm{Ba}$ e $\mathrm{Sr}$, nas anomalias negativas de Eu e Ce e no maior enriquecimento em ETRs pesados.
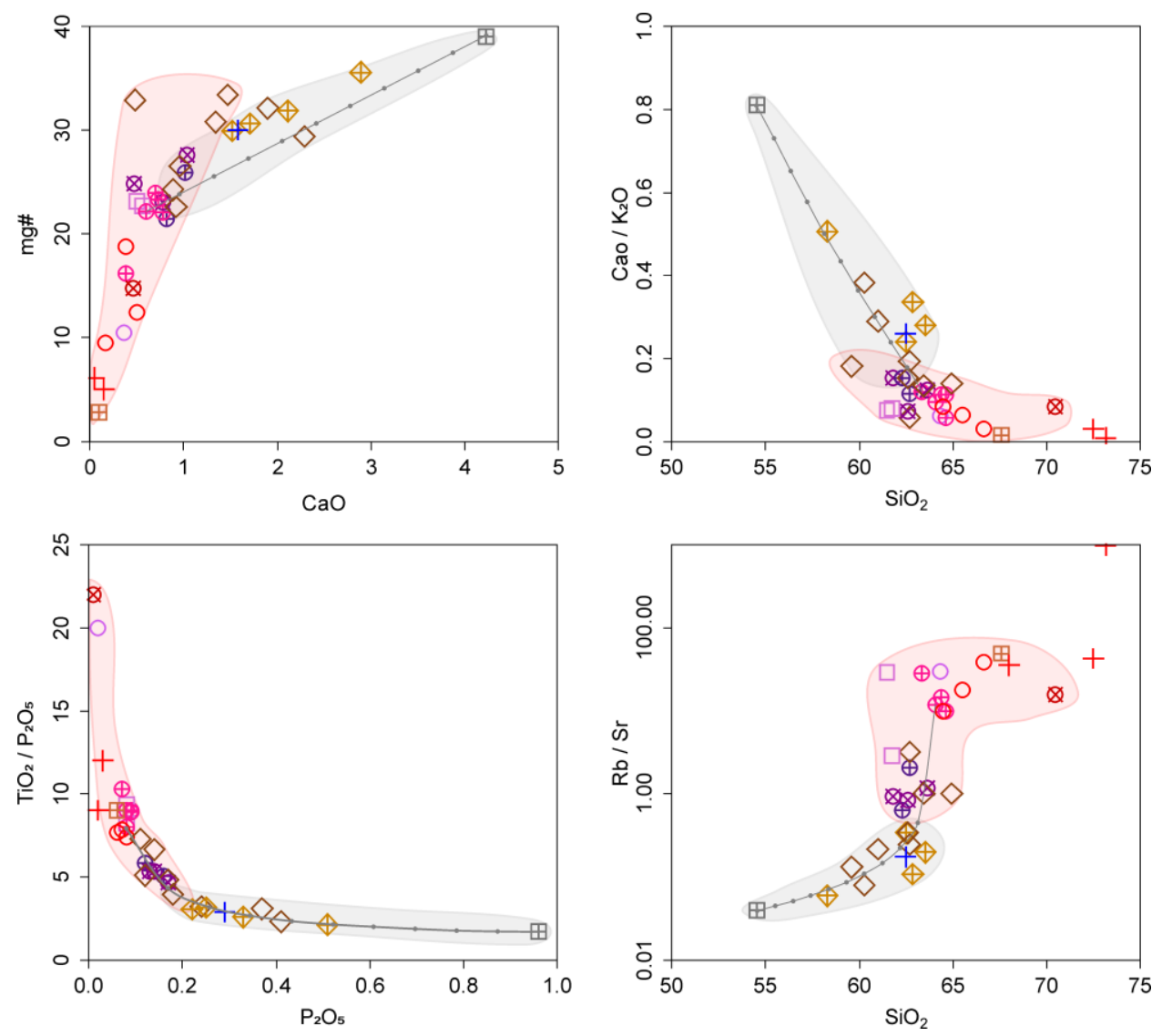

Figura 6.16 - Diagramas de elementos maiores (em \% de óxido) vs. mg\# e razões (elementos maiores em \% de óxido e traços em ppm) para a série nordmarkito-granito (campo em rosa) e associação quartzo sienito anti-rapakivi (em cinza) com as linhas de mixing entre as amostras MAI182C e MAI110. Legenda idem Figura 5.7. 


\section{CONSIDERAÇÕES FINAIS}

A partir das informações coletadas ao longo deste trabalho, que inclui mapeamento geológico de detalhe, petrografia pormenorizada, caracterização química de minerais, estudos com base na geoquímica de rocha e geoquímica isotópica $\mathrm{Sr}-\mathrm{Nd}-\mathrm{Pb}$ e determinação de idade $\mathrm{U} / \mathrm{Pb}$ de zircão por SHRIMP, apresenta-se uma nova leitura geológica e petrológica do Maciço Alcalino de Itatiaia, que culminou com as seguintes conclusões:

- O Maciço Alcalino de Itatiaia (MAI) é uma das maiores ocorrências alcalinas meso-cenozóica do Brasil, com aproximadamente $215 \mathrm{~km}^{2}$. Possui uma forma alongada NW-SE (30 por 4,5 a $11,5 \mathrm{~km}$ ) com uma estrutura anelar na região central. Encontra-se orientado segundo a mesma direção das zonas de acomodação tectônica do Rifte Continental do Sudeste Brasileiro e das zonas de transferência da Placa Oceânica do Atlântico Sul, mostrando uma estreita relação com sua evolução.

- O MAl evoluiu a partir de um centro magmático migratório, com idades que variam de 71,3 a 67,3 Ma. Manifestou-se como um complexo anelar, com sucessivas intrusões em forma de meia lua distribuídas de sudeste para noroeste em três setores: Sudeste (S-SE), Central (S-C) e Noroeste (S-NW). Esses setores possuem características litológicas e geomorfológicas distintas, sugerindo diferentes origens e/ou estágios de evolução

- Apresenta grande variação composicional, formado por rochas insaturadas a supersaturadas em sílica que variam de hololeucocráticas a melanocráticas, básicas a ácidas, peralcalinas a peraluminosas e sódicas a ultrapotássicas. Essas características se refletem numa grande variação composicional dos minerais principais e na diversidade da mineralogia acessória. Foram identificadas 21 unidades petrográficas (além de variações faciológicas internas) de nefelina sienitos a quartzo sienitos, traquitos, granito, monzonito, melagabro, traquibasalto, além de diques de nefelinitos, fonolitos, traquitos e riolitos.

- Essa variedade litológica pode ser dividida em cinco grupos petrológicos:

- nefelina sienitos sem plagioclásio, caracterizados por uma forte insaturação em sílica e uma tendência tardi-magmática agpaítica (comumente com låvenita, hiortdahlita, rinkite, dentre outros minerais); 
- nefelina sienitos/pulaskitos com plagioclásio, que mostram-se menos insaturados em sílica e mais enriquecidos em máficos, com diopsídio largamente substituído por magnésio-hastingsita e presença de plagioclásio (normalmente com textura antirapakivi);

- série nordmarkito-granito, onde álcali feldspato quartzo sienitos e granito mostram uma variação progressiva nos teores de quartzo, índice de cor e granulação, enquanto os nordmarkitos não mostram uma clara ralação evolutiva;

- associação anti-rapakivi, caracterizado pela textura porfirítica a glomeroporfirítica antirapakivi nas rochas e presença ocasional de enclaves microgranulares máficos arredondados;

- rochas básicas representadas pela ocorrência de um melagabro metassomatizado e um traquibasalto, aparentemente não mostrando relações geológicas claras com os sienitos.

- As rochas foram originadas possivelmente através da evolução de dois magmas parentais mantélicos distintos, que evoluíram principalmente por cristalização fracionada, mas contando também com alguma participação de processos de contaminação crustal:

- ankaratrito/basanito, que deram origem aos nefelinitos por fracionamento cristal de diopsídio, e os nefelina sienitos do S-SE por fracionamento de diopsídio, apatita e 士anfibólio;

- basanito/álcali basalto, que geraram os traquibasaltos por fracionamento de diopsídio e os sienitos dos S-C e S-NW por fracionamento de plagioclásio, diopsídio e apatita, que por sua vez a) evoluíram para nefelina sienitos e b) para sienitos com quartzo ultrapassando a barreira termal por processos assimilação crustal. 


\section{REFERÊNCIAS}

Algarte, J. P. (1972). A Influência dos Arqueamentos Cratônicos no Condicionamento das Alcalinas dos Estados de São Paulo e Paraná. Congresso Brasileiro de Geologia, Belém: SBG - Sociedade Brasileira de Geologia, 65-69.

Almeida, F. F. M. de (1967). Origem e evolução da Plataforma Brasileira. DNPM, Divisão de Geologia e Mineralogia, Boletim, 241, 1-36.

Almeida, F. F. M. de (1969). Diferenciação tectônica da plataforma brasileira. Congresso Brasileiro de Geologia, Salvador: SBG - Sociedade Brasileira de Geologia, 29-46.

Almeida, F. F. M. de (1971). Condicionamento tectônico do magmatismo alcalino mesozóico do Sul do Brasil e do Paraguai ocidental. Anais da Academia Brasileira de Ciências, 43, 835-836.

Almeida, F. F. M. de (1976). The system of continental rifts bordering the Santos Basin, Brazil. Anais da Academia Brasileira de Ciências, 48, 15-26.

Almeida, F. F. M. de (1983). Relações tectônicas das rochas alcalinas mesozóicas da região meridional da plataforma sul-americana. Revista Brasileira de Geociências, 13, 139-158.

Almeida, F. F. M. de (1991). O Alinhamento Magmático de Cabo Frio. $2^{\circ}$ Simpósio de Geologia do Sudeste, São Paulo: SBG - Sociedade Brasileira de Geologia/SP-RJ, 423-428.

Almeida, F. F. M. de \& Carneiro (1998). Origem e evolução da Serra do Mar. Revista Brasileira de Geociências, 28, 135-150.

Alves, A., Janasi, V. de A. \& Campos Neto, M. da C. (2016). Sources of granite magmatism in the Embu Terrane (Ribeira Belt, Brazil): Neoproterozoic crust recycling constrained by elemental and isotope ( $\mathrm{Sr}-\mathrm{Nd}-\mathrm{Pb}$ ) geochemistry. Journal of South American Earth Sciences, 68, 205-223.

Alves, A., Pereira, G. de S., Janasi, V. de A., Higgins, M., Polo, L. A., Juriaans, O. S. \& Ribeiro, B. V. (2015). The origin of felsic microgranitoid enclaves: Insights from plagioclase crystal size distributions and thermodynamic models. Lithos, Elsevier B.V. 239, 33-44.

Andersen, D. J., Lindsley, D. H. \& Davidson, P. M. (1993). QUILF: A pascal program to assess equilibria among Fe$\mathrm{Mg}-\mathrm{Mn}$-Ti oxides, pyroxenes, olivine, and quartz. Computers \& Geosciences, 16, 1333-1350.

Andersen, T., Elburg, M. \& Erambert, M. (2016). The miaskitic-to-agpaitic transition in peralkaline nepheline syenite (white foyaite) from the Pilanesberg Complex, South Africa. Chemical Geology, Elsevier B.V.

Anthony, J. W., Bideaux, R. A., Bladh, K. W. \& Nichols, M. C. (2017). Handbook of Mineralogy. Mineralogical Society of America,.

Araujo, A. L. N., Carlson, R. W., Gaspar, J. C. \& Bizzi, L. A. (2001). Petrology of kamafugites and kimberlites from the Alto Paranaíba Alkaline Province, Minas Gerais, Brazil. Contributions to Mineralogy and Petrology, 142, 163-177.

Armstrong, J. T. (1991). Quantitative Elemental Analysis of Individual Microparticles with Electron Beam Instruments. Electron Probe Quantitation, Boston, MA: Springer US, 261-315.

Azzone, R. G., Montecinos Munoz, P., Enrich, G. E. R., Alves, A., Ruberti, E. \& Gomes, C. B. (2016). Petrographic, geochemical and isotopic evidence of crustal assimilation processes in the Ponte Nova alkaline maficultramafic massif, SE Brazil. Lithos, 260, 58-75.

Azzone, R. G., Ruberti, E., Rojas, G. E. E. \& Gomes, C. de B. (2009). Geologia e Geocronologia do Maciço Alcalino Máfico-Ultramáfico Ponte Nova (SP-MG). Geologia USP. Série Científica, 9, 23-46. 
Bellieni, G., Montes-Lauar, C. R., De Min, A., Piccirillo, E. M., Cavazzini, G., Melfi, A. J. \& Pacca, I. G. (1990). Early and Late Cretaceous magmatism from São Sebastião Island (SE-Brazil): geochemistry and petrology. Geochimica Brasiliensis, 4, 59-83.

Bennio, L. et al. (2003). The tholeiitic dyke swarm of the Arraial do Cabo peninsula (SE Brazil): 39Ar/40Ar ages, petrogenesis, and regional significance. Journal of South American Earth Sciences, 16, 163-176.

Bennio, L., Brotzu, P., Gomes, C. B., D’Antonio, M., Lustrino, M., Melluso, L., Morbidelli, L. \& Ruberti, E. (2002). Petrological, geochemical and Sr-Nd isotopic features of alkaline rocks from the Arraial do Cabo Frio Peninsula (southeastern Brasil). Periodico di Mineralogia, 71, 137-158.

Berger, J., Ennih, N. \& Liégeois, J.-P. (2014). Extreme trace elements fractionation in Cenozoic nephelinites and phonolites from the Moroccan Anti-Atlas (Eastern Saghro). Lithos, 210-211, 69-88.

Berman, R. G. (1988). Internally-Consistent Thermodynamic Data for Minerals in the System $\mathrm{Na}_{2} \mathrm{O}-\mathrm{K}_{2} \mathrm{O}-\mathrm{CaO}-\mathrm{MgO}-$ $\mathrm{FeO}-\mathrm{Fe}_{2} \mathrm{O}_{3}-\mathrm{Al}_{2} \mathrm{O}_{3}-\mathrm{SiO}_{2}-\mathrm{TiO}_{2}-\mathrm{H}_{2} \mathrm{O}-\mathrm{CO}_{2}$. Journal of Petrology, 29, 445-522.

Berman, R. G., Bnown, T. H. \& Perkins, E. H. (1987). Geo-Calc: Software for calculation and display of P-T-X phase diagrams. American Mineralogist, 72, 861-862.

Black, L. P. et al. (2004). Improved 206Pb/238U microprobe geochronology by the monitoring of a trace-elementrelated matrix effect; SHRIMP, ID-TIMS, ELA-ICP-MS and oxygen isotope documentation for a series of zircon standards. Chemical Geology, 205, 115-140.

Bongiolo, E. M., Pires, G. L. C., Geraldes, M. C., Santos, A. C. \& Neumann, R. (2015). Geochemical modeling and $\mathrm{Nd}$-Sr data links nephelinite-phonolite successions and xenoliths of Trindade Island (South Atlantic Ocean, Brazil). Journal of Volcanology and Geothermal Research, Elsevier B.V. 306, 58-73.

Brade, A. C. (1956). A Flora do Parque Nacional. Boletim do Parque Nacional do Itatiaia, Itatiaia 5, 1-111.

Brotzu, P. et al. (1989). Petrological and geochemical studies of alkaline rocks from continental Brazil. 8. The syenitic intrusion of Morro Redondo, RJ. Geochimica Brasiliensis, 3, 63-80.

Brotzu, P. et al. (1992). Petrology and geochemistry of the Passa Quatro alkaline complex, southeastern Brazil. Journal of South American Earth Sciences, 6, 237-252.

Brotzu, P. et al. (2007). Petrogenesis of the Early Cenozoic potassic alkaline complex of Morro de São João, southeastern Brazil. Journal of South American Earth Sciences, 24, 93-115.

Brotzu, P., Gomes, C. B., Melluso, L., Morbidelli, L., Morra, V. \& Ruberti, E. (1997). Petrogenesis of coexisting $\mathrm{SiO}_{2}-$ undersaturated to $\mathrm{SiO}_{2}$-oversaturated felsic igneous rocks: The alkaline complex of Itatiaia, southeastern Brazil. Lithos, 40, 133-156.

Brotzu, P., Melluso, L., D’Amelio, F. \& Lustrino, M. (2005). Mafic/ultramafic dykes and felsic intrusions with potassic to ultrapotassic affinity in the Serra do Mar province: a review. In: Comin-Chiaramonti, P. \& Gomes, C. B. (eds) Mesozoic to Cenozoic alkaline magmatism in the Brazilian Platform, São Paulo: EDUSPFAPESP, 443-472.

Buddington, A. F. \& Lindsley, D. H. (1964). Iron-Titanium Oxide Minerals and Synthetic Equivalents. Journal of Petrology, 5, 310-357.

Burnham, A. D. \& Berry, A. J. (2014). The effect of oxygen fugacity, melt composition, temperature and pressure on the oxidation state of cerium in silicate melts. Chemical Geology, Elsevier B.V. 366, 52-60.

Carmichael, I. S. E. (1967). The iron-titanium oxides of salic volcanic rocks and their associated ferromagnesian silicates. Contributions to Mineralogy and Petrology, 14, 36-64.

Carvalho, B. B., Janasi, V. de A. \& Henrique-Pinto, R. (2014). Geochemical and Sr-Nd-Pb isotope constraints on the petrogenesis of the K-rich Pedra Branca Syenite: Implications for the Neoproterozoic post-collisional magmatism in SE Brazil. Lithos, 205, 39-59.

Chiessi, C. M. (2004). Tectônica cenozóica do Maciço Alcalino de Passa Quatro (SP-MG-RJ). S?o Paulo, Universidade de São Paulo.

Cioffi, C. R., Campos Neto, M. C., Moller, A. \& Rocha, B. C. (2015). Paleoproterozoic continental crust generation events at 2.15 and $2.08 \mathrm{Ga}$ in the basement of the southern Brasília Orogen, SE Brazil. Precambrian Research, 275, 176-196. 
Cogné, N., Gallagher, K. \& Cobbold, P. R. (2011). Post-rift reactivation of the onshore margin of southeast Brazil: Evidence from apatite (U-Th)/He and fission-track data. Earth and Planetary Science Letters, 309, 118-130.

Cogné, N., Gallagher, K., Cobbold, P. R., Riccomini, C. \& Gautheron, C. (2012). Post-breakup tectonics in southeast Brazil from thermochronological data and combined inverse-forward thermal history modeling. Journal of Geophysical Research: Solid Earth, 117, n/a-n/a.

Comin-Chiaramonti, P. et al. (1997). Potassic and Sodic Igneous Rocks from Eastern Paraguay: their Origin from the Lithospheric Mantle and Genetic Relationships with the Associated Paraná Flood Tholeiites. Journal of Petrology, 38, 495-528.

Comin-Chiaramonti, P., Gomes, C. B., Censi, P., Gasparon, M. \& Velázquez, V. F. (2005). Alkaline complexes from the Alto Paraguay Province at the border of Brazil (Mato Grosso do Sul state) and Paraguay. In: CominChiaramonti, P. \& Gomes, C. B. (eds) Mesozoic to Cenozoic alkaline magmatism in the Brazilian Platform, São Paulo: EDUSP-FAPESP, 71-148.

Cosca, M. A., Moecher, D. P. \& Essene, E. J. (1986). Activity-composition relations for the join grossular-andradite and application to calc-silicate assemblages. Geological Society of America, Abstracts with Programs, 572.

Curtis, C. G., Harris, C., Trumbull, R. B., De Beer, C. \& Mudzanani, L. (2013). Oxygen Isotope Diversity in the Anorogenic Koegel Fontein Complex of South Africa: a Case for Basement Control and Selective Melting for the Production of Low- 180 Magmas. Journal of Petrology, 54, 1259-1283.

Davidson, P. \& Mukhopadhyay, D. (1984). Ca-Fe-Mg olivines: phase relations and a solution model. Contributions to Mineralogy and Petrology, Springer-Verlag 86, 256-263.

De La Roche, H., Leterrier, J., Grandclaude, P. \& Marchal, M. (1980). A classification of volcanic and plutonic rocks using R1-R2-diagram and major element analyses - its relationships with current nomenclature. Chemical Geology, 29, $183-210$.

Deer, W. A., Howie, R. A. \& Zussman, J. (1992). An Introduction to the Rock-Forming Minerals. Harlow, England: Longman Scientific \& Technical ; New York, NY : Wiley.

DePaolo, D. J. (1981). A neodymium and strontium isotopic study of the Mesozoic calc-alkaline granitic batholiths of the Sierra Nevada and Peninsular Ranges, California. Journal of Geophysical Research: Solid Earth, 86, 10470-10488.

Derby, O. A. (1887). On nepheline rocks in Brazil, with special reference to the association of phonolite and foyaite. Quarterly Journal of the Geological Society, 43, 457-473.

Downes, H. (1984). Sr and Nd isotope geochemistry of coexisting alkaline magma series, Cantal, Massif Central, France. Earth and Planetary Science Letters, 69, 321-334.

Droop, G. T. R. (1987). A General Equation for Estimating Fe3+ Concentrations in Ferromagnesian Silicates and Oxides from Microprobe Analyses, Using Stoichiometric Criteria. Mineralogical Magazine,

Eirado, L. G., Heilbron, M. \& Almeida, J. C. H. (2006). Os Terrenos Tectônicos Da Faixa Ribeira Na Serra Da Bocaina E Na Baía Da Ilha Grande, Sudeste Do Brasil. Revista Brasileira de Geociências, 36, 426-436.

Elburg, M. A. \& Cawthorn, R. G. (2016). Source and evolution of the alkaline Pilanesberg Complex, South Africa. Chemical Geology,

Engelmann de Oliveira, C. H., Jelinek, A. R., Chemale, F. \& Cupertino, J. A. (2016). Thermotectonic history of the southeastern Brazilian margin: Evidence from apatite fission track data of the offshore Santos Basin and continental basement. Tectonophysics, 685, 21-34.

Enrich, G. E. R., Azzone, R. G., Ruberti, E., Gomes, C. B. \& Comin-Chiaramonti, P. (2005). Itatiaia, Passa Quatro and São Sebastião island, the major alkaline syenitic complexes from Serra do Mar region. In: CominChiaramonti, P. \& Gomes, C. B. (eds) Mesozoic to Cenozoic alkaline magmatism in the Brazilian Platform, São Paulo: EDUSP-FAPESP, 419-442.

Enrich, G. E. R., Ruberti, E. \& Gomes, C. B. (2009). Geology and geochronology of Monte de Trigo island alkaline suite, southeasern Brazil. Revista Brasileira de Geociências, 39, 67-80.

Ernesto, M., Marques, L. S., Piccirillo, E. M., Molina, E. C., Ussami, N., Comin-Chiaramonti, P. \& Bellieni, G. (2002). Paraná Magmatic Province-Tristan da Cunha plume system: fixed versus mobile plume, petrogenetic 
considerations and alternative heat sources. Journal of Volcanology and Geothermal Research, 118, 15-36.

Ersoy, Y. \& HelvacI, C. (2010). FC-AFC-FCA and mixing modeler: A Microsoft ${ }^{\circledR}$ Excel@ spreadsheet program for modeling geochemical differentiation of magma by crystal fractionation, crustal assimilation and mixing. Computers \& Geosciences, 36, 383-390.

Estrade, G., Béziat, D., Salvi, S., Tiepolo, M., Paquette, J.-L. \& Rakotovao, S. (2014). Unusual evolution of silicaunder- and -oversaturated alkaline rocks in the Cenozoic Ambohimirahavavy Complex (Madagascar): Mineralogical and geochemical evidence. Lithos, 206-207, 361-383.

Faure, G. (2001). Origin of Igneous Rocks: The Isotopic Evidence. Heidelberg: Springer-Verlag.

Ferrari, A. L. (2001). Evolução Tectônica do Graben da Guanabara. São Paulo, Instituto de Geociências, Universidade de São Paulo, Tese de Doutoramento.

Foland, K. A. \& Henderson, C. M. B. (1976). Application of age and Sr isotope data to the petrogenesis of the Marangudzi ring complex, Rhodesia. Earth and Planetary Science Letters, 29, 291-301.

Foland, K. A., Landoll, J. D., Henderson, C. M. B., Chen, J. \& Jiangfeng, C. (1993). Formation of cogenetic quartz and nepheline syenites. Geochimica et Cosmochimica Acta, 57, 697-704.

Frost, B. R. \& Lindsley, D. H. (1992). Equilibria among Fe-Ti oxides, pyroxenes, olivine, and quartz: part II. Application. American Mineralogist, 77, 1004-1020.

Frost, B. R., Lindsley, D. H. \& Andersen, D. J. (1988). Fe-Ti oxidesilicate equilibria: Assemblages with fayalitic olivine. American Mineralogist, 73, 727-740.

Garda, G., Schorscher, J. H. D., Esperança, S. \& Carlson, R. W. (1995). The petrology and geochemistry of coastal dikes from São Paulo State, Brazil: implication for variable litospheric contributions to alkaline magmas from the Western Margins of the South Atlantic. Anais da Academia Brasileira de Ciências, 67, 191-216.

Gibson, S. A., Thompson, R. N., Leonardos, O. H., Dickin, A. P. \& Mitchell, J. G. (1995). The Late Cretaceous Impact of the Trindade Mantle Plume: Evidence from Large-volume, Mafic, Potassic Magmatism in SE Brazil. Journal of Petrology, 36, 189-229.

Giret, A., Bonin, B. \& Leger, J.-M. (1980). Amphibole compositional trends in oversaturated and undersaturated alkaline plutonic ring complexes. Canadian Mineralogist, 18, 481-495.

Gomes, C. B. \& Comin-Chiaramonti, P. (2005). An introduction to the alkaline and alkaline-carbonatitic magmatism in and around the Paraná-Basin. In: Comin- Chiaramonti, P. \& Gomes, C. . (eds) Mesozoic to Cenozoic alkaline magmatism in the Brazilian Platform, São Paulo: EDUSP-FAPESP, 21-30.

Gomes, C. B. \& Valarelli, J. V. (1970). Nova ocorrência de rochas alcalinas no Estado de São Paulo. $24^{\circ}$ Congresso Brasileiro de Geologia, Brasília: SBG - Sociedade Brasileira de Geologia, 336-337.

Green, T. H. (1995). Significance of $\mathrm{Nb} / \mathrm{Ta}$ as an indicator of geochemical processes in the crust-mantle system. Chemical Geology, Elsevier 120, 347-359.

Green, T. H. \& Pearson, N. J. (1987). An experimental study of Nb and Ta partitioning between Ti-rich minerals and silicate liquids at high pressure and temperature. Geochimica et Cosmochimica Acta, 51, 55-62.

Guarino, V., Azzone, R. G., Brotzu, P., de Barros Gomes, C., Melluso, L., Morbidelli, L., Ruberti, E., Tassinari, C. C. G. \& Brilli, M. (2011). Magmatism and fenitization in the Cretaceous potassium-alkaline-carbonatitic complex of Ipanema São Paulo State, Brazil. Mineralogy and Petrology, 104, 43-61.

Guarino, V., Wu, F.-Y., Lustrino, M., Melluso, L., Brotzu, P., Gomes, C. de B., Ruberti, E., Tassinari, C. C. G. \& Svisero, D. P. (2013). U-Pb ages, Sr-Nd- isotope geochemistry, and petrogenesis of kimberlites, kamafugites and phlogopite-picrites of the Alto Paranaíba Igneous Province, Brazil. Chemical Geology, 353, 65-82.

Guedes, E., Heilbron, M., de Morisson Valeriano, C., de Almeida, J. C. H. \& Szatmari, P. (2016). Evidence of Gondwana early rifting process recorded by Resende-Ilha Grande Dike Swarm, southern Rio de Janeiro, Brazil. Journal of South American Earth Sciences, 67, 11-24.

Gupta, A. K. et al. (2010). Silica-Undersaturated Portion of the System Nepheline-Kalsilite-SiO2 at 2 GPa [P $(\mathrm{H} 2 \mathrm{O})=\mathrm{P}($ Total)]. The Canadian Mineralogist, 48, 1297-1313. 
Hamilton, D. L. \& MacKenzie, W. S. (1965). Phase-equilibrium studies in the system $\mathrm{NaAlSiO}_{4}$ (nepheline)-KAISiO (kalsilite)- $\mathrm{SiO}_{2}-\mathrm{H}_{2} \mathrm{O}$. Mineralogical Magazine, 34, 214-231.

Harris, C. (1983). The petrology of lavas and associated plutonic inclusions of Ascension Island. Journal of Petrology, 24, 424-470.

Harris, C. (1995). Oxygen isotope geochemistry of the Mesozoic anorogenic complexes of Damaraland, northwest Namibia: evidence for crustal contamination and its effect on silica saturation. Contributions to Mineralogy and Petrology, 122, 308-321.

Harris, C., Marsh, J. S. \& Milner, S. C. (1999). Petrology of the alkaline core of the Messum igneous complex, Namibia: evidence for the progressively decreasing effect of crustal contamination. Journal of Petrology, 40, 1377-1397.

Harrison, T. M. \& Watson, E. B. (1984). The behavior of apatite during crustal anatexis: Equilibrium and kinetic considerations. Geochimica et Cosmochimica Acta, 48, 1467-1477.

Hawthorne, F. C., Oberti, R., Harlow, G. E., Maresch, W. V., Martin, R. F., Schumacher, J. C. \& Welch, M. D. (2012). Ima report: Nomenclature of the amphibole supergroup. American Mineralogist, 97, 2031-2048.

Heilbron, M. et al. (2007). Geologia e Recursos Minerais das folhas Santa Rita do Jacutinga, Barra do Piraí, Volta Redonda e Angra dos Reis, escala 1:100.000. Brasília: Companhia de Pesquisa de Recursos Minerais - MME.

Heilbron, M., Eirado, L. G. \& Almeida, J. (2016). Mapa Geológico e de Recursos Minerais do Estado do Rio de Janeiro. Escala 1:400.000. Programa Geologia do Brasil (PGB), Mapas Geológicos Estaduais. CPRM - Serviço Geológico do Brasil, Superintendência Regional de Belo Horizonte.

Heilbron, M., Pedrosa-Soares, A. C., Campos Neto, M. C., Silva, L. C., Trouw, R. A. J. \& Janasi, V. C. (2004). A Província Mantiqueira. In: Mantesso-Neto, V., Bartorelli, A., Carneiro, C. D. R. \& Neves, B. B. B. (eds) Geologia do Continente Sul-Americano: Evolução da Obra de Fernando Flávio Marques de Almeida, São Paulo: Editora Beca, 203-234.

Hofmann, A. W. (1997). Mantle geochemistry: The messagefrom oceanic volcanism. Nature, 385, $219-229$.

Holland, T. J. B. (1990). Activities of components in omphacitic solid solutions. Contributions to Mineralogy and Petrology, 105, 446-453.

Holland, T. \& Powell, R. (2003). Activity-composition relations for phases in petrological calculations: an asymmetric multicomponent formulation. Contributions to Mineralogy and Petrology, Springer-Verlag 145, 492-501.

Instituto Brasileiro de Geografia e Estatística - IBGE (2012a). Anuário Estatístico do Brasil. Rio de Janeiro: IBGE.

Instituto Brasileiro de Geografia e Estatística - IBGE (2012b). Manual Técnico da Vegetação Brasileira. Rio de Janeiro: IBGE.

Janasi, V. de A., Andrade, S., Vasconcellos, A. C. B. C., Henrique-Pinto, R. \& Ulbrich, H. H. G. J. (2015). Timing and sources of granite magmatism in the Ribeira Belt, SE Brazil: Insights from zircon in situ U-Pb dating and $\mathrm{Hf}$ isotope geochemistry in granites from the São Roque Domain. Journal of South American Earth Sciences, Elsevier Ltd 68, 224-247.

Janoušek, V., Farrow, C. M. \& Erban, V. (2006). Interpretation of whole-rock geochemical data in igneous geochemistry: Introducing Geochemical Data Toolkit (GCDkit). Journal of Petrology, 47, 1255-1259.

Jarosewich, E. (2002). Smithsonian Microbeam Standards. Journal of Research of the National Institute of Standards and Technology, 107, 681.

Jung, S., Hoernes, S. \& Hoffer, E. (2005). Petrogenesis of Cogenetic Nepheline and Quartz Syenites and Granites (Northern Damara Orogen, Namibia): Enriched Mantle versus Crustal Contamination. The Journal of Geology, University of Chicago Press 113, 651-672.

Jung, S., Mezger, K. \& Hoernes, S. (2004). Shear zone-related syenites in the Damara belt (Namibia): the role of crustal contamination and source composition. Contributions to Mineralogy and Petrology, 148, $104-121$.

Kogarko, L. N. (1974). Role of volatiles. In: Sørensen, H. (ed.) The Alkaline Rocks, London: John Wiley \& Sons, 622.

Lamego, A. R. (1936). O massiço de Itatiaya e regiões circumdantes. Boletim do Serviço Geológico e Mineralógico/ 
DNPM, 88, 1-93.

Landoll, J. D., Foland, K. A. \& Henderson, C. M. B. (1994). Nd isotopes demonstrate the role of contamination in the formation of coexisting quartz and nepheline syenites at the Abu-Khruq complex, Egypt. Contributions to Mineralogy and Petrology, 117, 305-329.

Lasaulx, A. (1885). Üeber das Vorkommen von Eläeolith-Syeniten und editeri zu diesen gehöringen Eläeolithporphyren aus der Serra d'Itatiaia westlich von Rio de Janeiro, Brasilien. Sitzungsberichte Der Niederrheinischen Gesellschaft Für Natur, 231-231.

Le Maitre, R. W. (2002). Igneous Rocks: A Classification and Glossary of Terms: A Classification and Glossary of Terms: Recommendations of the International Union of Geological Sciences, Subcommission on the Systematics of Igneous Rocks. Cambridge University Press.

Leite, C. A. S. et al. (2004). Folhas SF.23 - Rio de Janeiro / SG.23 - Iguape. In: Schobbenhaus, C., Gonçalves, J. H., Santos, J. O. S., Abram, M. B., Leão Neto, R., Matos, G. M. M., Vitotti, R. M., Ramos, M. A. B. \& Jesus, J. D. A. de (eds) Carta Geológica do Brasil ao Milionésimo, Sistema de Informações Geográficas, Programa Geologia do Brasil. CPRM, Brasília. CD-ROM.

Lieberman, J. \& Petrakakis, K. (1991). TWEEQU thermobarometry; analysis of uncertainties and applications to granulites from western Alaska and Austria. The Canadian mineralogist, 29, 857-887.

Liew, T. C. \& Hofmann, A. W. (1988). Precambrian crustal components, plutonic associations, plate environment of the Hercynian Fold Belt of central Europe: Indications from a $\mathrm{Nd}$ and $\mathrm{Sr}$ isotopic study. Contributions to Mineralogy and Petrology, 98, 129-138.

Locock, A. J. (2008). An Excel spreadsheet to recast analyses of garnet into end-member components, and a synopsis of the crystal chemistry of natural silicate garnets. Computers and Geosciences, 34, 1769-1780.

Locock, A. J. (2014). An Excel spreadsheet to classify chemical analyses of amphiboles following the IMA 2012 recommendations. Computers \& Geosciences, 62, 1-11.

Lurie, J. (2004). The Pilanesberg: Geology, Geochemistry and Economic Potential. Thesis Submitted to Rhodes University in 1973 For Which the PhD Degree was Awarded, Supplemented by More Recent Work. e-book. University of Johannesburg. http://hdl.handle.net/10210/2188.

Mann, U., Marks, M. A. W. \& Markl, G. (2006). Influence of oxygen fugacity on mineral compositions in peralkaline melts: The Katzenbuckel volcano, Southwest Germany. Lithos, 91, 262-285.

Mariga, J., Ripley, E. M., Li, C., McKeegan, K. D., Schmidt, A. \& Groove, M. (2006). Oxygen isotopic disequilibrium in plagioclase-corundum-hercynite xenoliths from the Voisey's Bay Intrusion, Labrador, Canada. Earth and Planetary Science Letters, 248, 263-275.

Markl, G., Marks, M. A. W. \& Frost, B. R. (2010). On the Controls of Oxygen Fugacity in the Generation and Crystallization of Peralkaline Melts. Journal of Petrology, 51, 1831-1847.

Markl, G., Marks, M. A. W., Schwinn, G. \& Sommer, H. (2001). Phase Equilibrium Constraints on Intensive Crystallization Parameters of the Ilimaussaq Complex, South Greenland. Journal of Petrology, 42, 22312257.

Marks, M. A. W. \& Markl, G. (2001). Fractionation and assimilation processes in the alkaline augite syenite unit of the Ilimaussaq Intrusion, South Greenland, as deduced from phase equilibria. Journal of Petrology, 42, 1947-1969.

Marks, M. A. W. W., Hettmann, K., Schilling, J., Frost, B. R. \& Markl, G. (2011). The Mineralogical Diversity of Alkaline Igneous Rocks: Critical Factors for the Transition from Miaskitic to Agpaitic Phase Assemblages. Journal of Petrology, 52, 439-455.

Marques, L. S. \& Ernesto, M. (2004). O magmatismo toleítico da Bacia do Paraná. In: Mantesso-Neto, V., Bartorelli, A., Carneiro, C. D. R. \& Brito-Neves, B. B. B. (eds) Geologia do Continente Sul-Americano: evolução da obra de Fernando Flávio Marques de Almeida, São Paulo: Editora Beca, 245-263.

Marques, L. S., Ulbrich, M. N. ., Ruberti, E. \& Tassinari, C. G. (1999). Petrology, geochemistry and Sr-Nd isotopes of the Trindade and Martin Vaz volcanic rocks (Southern Atlantic Ocean). Journal of Volcanology and Geothermal Research, 93, 191-216. 
Marsh, I. S. (1973). Relationships between transform directions and alkaline igneous rock lineaments in Africa and South America. Earth and Planetary Science Letters, 18, 317-323.

Martinez, I. A., Harris, C., Le Roex, A. P. \& Milner, S. C. (1996). Oxygen isotope evidence for extensive crustal contamination in the Okenyenya igneous complex, Namibia. Geochimica et Cosmochimica Acta, 60, 44974508.

Martins, G. G., Mendes, J. C., Schmitt, R. S., Armstrong, R. \& Valeriano, C. M. (2016). 550-490Ma pre-to postcollisional shoshonitic rocks in the Ribeira Belt (SE Brazil) and their tectonic significance. Precambrian Research, Elsevier B.V. 286, 352-369.

McDonough, W. F. \& Sun, S. -s. (1995). The composition of the Earth. Chemical Geology, 120, $223-253$.

Meisling, K. E. \& Cob, P. R. (2001). Segmentation of an obliquely rifted margin, Campos and Santos basins, southeastern Brazil. AAPG Bulletin, 85, 1903-1924.

Melluso, L., Guarino, V., Lustrino, M., Morra, V. \& De' Gennaro, R. (2016). The REE- and HFSE-bearing phases in the Itatiaia Alkaline Complex (Brazil), and geochemical evolution of feldspar-rich felsic melts. Mineralogical Magazine, 81, 217-250.

Melo, M. D., Riccomini, C., Hasui, Y., Almeida, F. D. \& Coimbra, A. M. (1985). Geologia e evolução do sistema de bacias tafrogênicas continentais do sudeste do Brasil. Revista Brasileira de Geociências, 15, 193-201.

Middlemost, E. A. K. (1975). The basalt clan. Earth Science Reviews, 11, 337-364.

Middlemost, E. A. K. (1989). Iron oxidation ratios, norms and the classification of volcanic rocks. Chemical Geology, 77, 19-26.

Mingram, B., Trumbull, R. . B., Littman, S. \& Gerstenberger, H. (2000). A petrogenetic study of anorogenic felsic magmatism in the Cretaceous Paresis ring complex, Namibia: evidence for mixing of crust and mantlederived components. Lithos, 54, 1-22.

Mogahed, M. M. (2016). Petrogenesis of cogenetic silica-oversaturated and -undersaturated syenites of Abu Khruq ring complex, South Eastern Desert, Egypt. Journal of African Earth Sciences, Elsevier Ltd 124, 4462.

Morimoto, N. (1988). Nomenclature of pyroxenes. Mineralogy and Petrology, 39, 55-76.

Motoki, A. (1986). Geologia e petrologia do maciço alcalino da Ilha de Vitória, SP. São Paulo, Universidade de São Paulo.

Mungall, J. E. \& Martin, R. E. (1995). Petrogenesis of basalt-comendite and basalt-pantellerite suites, Terceira, Azores, and some implications for the origin of ocean island rhyolites. Contributions to Mineralogy and Petrology1, 119, 43-55.

Negrão, A. P., Ramos, R. R. C., Mello, C. L. \& Sanson, M. de S. R. (2015). Mapa geológico do cenozoico da região da bacia de Volta Redonda (RJ, segmento central do Rifte Continental do Sudeste do Brasil): identificação de novos grabens e ocorrências descontínuas, e caracterização de estágios tectonossedimentares. Brazilian Journal of Geology, 45, 273-291.

Nekvasil, H., Dondolini, A., Horn, J., Filiberto, J., Long, H. \& Lindsley, D. H. (2004). The Origin and Evolution of Silica-saturated Alkalic Suites: an Experimental Study. Journal of Petrology, 45, 693-721.

Neves, B. B. de B., Fuck, R. A. \& Pimentel, M. M. (2014). The Brasiliano collage in South America: a review. Brazilian Journal of Geology, 44, 493-518.

Nicholls, J. \& Carmichael, J. S. E. (1969). Peralkaline acid liquids: A petrological study. Contributions to Mineralogy and Petrology, Springer-Verlag 20, 268-294.

Njonfang, E., Tchoneng, G. T., Cozzupoli, D. \& Lucci, F. (2013). Petrogenesis of the Sabongari alkaline complex, cameroon line (central Africa): Preliminary petrological and geochemical constraints. Journal of African Earth Sciences, 83, 25-54.

Pankhurst, R. J., Beckinsale, R. D. \& Brooks, C. K. (1976). Strontium and oxygen isotope evidence relating to the petrogenesis of the Kangerdlugssuaq alkaline intrusion, East Greenland. Contributions to Mineralogy and Petrology, 54, 17-42. 
Penalva, F. (1967). Geologia e Tectónica da Região do Itatiaia (Sudeste do Brasil). Boletim da Faculdade de Filosofia Ciências e Letras, Universidade de São Paulo. Geologia, 302, 99.

Pereira, I. M., Oliveira-Filho, A. T. O., Botelho, S. A., Carvalho, W. A. C., Fontes, M. A. L., Schiavini, I. \& Silva, A. F. (2006). Composição Florística do Compartimento Arbóreo de Cinco Remanescentes Florestais do Maciço do Itatiaia, Minas Gerais e Rio de Janeiro. Rodriguésia, 57, 103-126.

Pfänder, J. a., Münker, C., Stracke, A. \& Mezger, K. (2007). Nb/Ta and Zr/Hf in ocean island basalts - Implications for crust-mantle differentiation and the fate of Niobium. Earth and Planetary Science Letters, 254, 158172.

Pilet, S., Baker, M. B. \& Stolpe, R. E. . (2008). Metasomatized lithosphere and the origin of alkaline lavas. Science, 320, 916-919.

Pinto, O. (1950). Aves do Itatiaia. Boletim do Parque Nacional do Itatiaia, 3, 1-87.

Ribeiro Filho, E. (1967). Geologia e Petrologia dos Maciços Alcalinos do Itatiaia e Passa-Quatro (Sudeste do Brasil). Boletim da Faculdade de Filosofia Ciências e Letras, Universidade de São Paulo. Geologia, 302, 9.

Ribeiro Filho, E. \& Penalva, F. (1965). Mapa Geológico do Maciço Alcalino de Itatiaia. [material cartográfico]. 1:50.000. São Paulo, IBGE.

Riccomini, C. (1989). O Rift Continental do Sudeste do Brasil. São Paulo, Instituto de Geociências, Universidade de São Paulo, Tese de Doutoramento.

Riccomini, C. \& Rodrigues-Francisco, B. H. (1992). Idade potássio-argônio do derrame de ankaramito da Bacia de Itaboraí, Rio de Janeiro, Brasil: implicações tectônicas. $37^{\circ}$ Congresso Brasileiro de Geologia, São Paulo: SBG - Sociedade Brasileira de Geologia, 469-470.

Riccomini, C., Sant'Anna, L. G. \& Ferrari, A. L. (2004). Evolução geológica do Rift Continental do Sudeste do Brasil. In: Mantesso Neto, V., Bartorelli, A., Carneiro, C. D. R. \& Brito-Neves, B. B. (eds) Geologia do Continente Sul-Americano: Evolução da Obra de Fernando Flávio Marques de Almeida, São Paulo: Editora Beca, 383405.

Riccomini, C., Veláquez, V. F. \& Gomes, C. B. (2005). Tectonic controls of the Mesozoic and Cenozoic alkaline magmatism in central-southern Brazilian Plataform. In: Comin-Chiaramonti, P. \& Gomes, C. B. (eds) Mesozoic to Cenozoic alkaline magmatism in the Brazilian Platform, São Paulo: EDUSP-FAPESP, 31-56.

Riishuus, M. S., Peate, D. W., Tegner, C., Wilson, J. R. \& Brooks, C. K. (2008). Petrogenesis of Cogenetic SilicaOversaturated and -Undersaturated Syenites by Periodic Recharge in a Crustally Contaminated Magma Chamber: the Kangerlussuaq Intrusion, East Greenland. Journal of Petrology, 49, 493-522.

Riishuus, M. S., Peate, D. W., Tegner, C., Wilson, J. R., Brooks, C. K. \& Harris, C. (2006). Temporal evolution of a long-lived syenitic centre: the Kangerlussuaq Alkaline Complex, East Greenland. Lithos, 92, 276-299.

Rocha-Júnior, E. R. V., Marques, L. S., Babinski, M., Nardy, A. J. R., Figueiredo, A. M. G. \& Machado, F. B. (2013). $\mathrm{Sr}-\mathrm{Nd}-\mathrm{Pb}$ isotopic constraints on the nature of the mantle sources involved in the genesis of the high-Ti tholeiites from northern Paraná Continental Flood Basalts (Brazil). Journal of South American Earth Sciences, 46, 9-25.

Rosa, P. A. S. (2012). Geologia e Petrologia da suíte alcalina de Bom Repouso, MG. São Paulo, Instituto de Geociências, Universidade de São Paulo, Dissertaçao de Mestrado.

Sadowski, G. R. \& Dias Neto, C. M. (1981). O lineamento sismotectônico do Cabo Frio. Revista Brasileira de Geociências, 11, 209-212.

Salgado, A. A. R., Rezende, E. de A., Bourlès, D., Braucher, R., da Silva, J. R. \& Garcia, R. A. (2016). Relief evolution of the Continental Rift of Southeast Brazil revealed by in situ-produced 10Be concentrations in river-borne sediments. Journal of South American Earth Sciences, 67, 89-99.

Sato, K., Tassinari, C. C. G., Basei, M. A. S., Siga, O., Onoe, A. T. \& De Souza, M. D. (2014). Sensitive High Resolution Ion Microprobe (SHRIMP IIe/MC) of the Institute of Geosciences of the University of São Paulo, Brazil: Analytical method and first results. Geologia USP - Serie Cientifica, 14, 3-18.

Schilling, J., Frost, B. R., Marks, M. A. W., Wenzel, T. \& Markl, G. (2011). Fe-Ti oxide-silicate (QUIIF-type) equilibria in feldspathoid-bearing systems. American Mineralogist, 96, 100-110. 
Shand, S. J. (1943). Eruptive Rocks. Their Genesis Composition. Classification, and Their Relation to Ore-Deposits with a Chapter on Meteorite. New York: John Wiley \& Sons.

Shea, M. E. (1992). Isotopic geochemical characteristics of selected nepheline syenites and phonolites from the Poços de Caldas alkaline complex, Minas Gerais, Brazil. Journal of Geochemical Exploration, 54, 173-214.

Sichel, S. E., Carlson, R. W., Esperança, S., Araújo, A. L. N. \& Valença, J. G. (1997). Preliminary isotopic study of the alkalic intrusive complexes along the Cabo Frio Lineament. South-American Symposium on Isotope Geology, Campos do Jordão, 298-300.

Siebel, W., Becchio, R., Volker, F., Hansen, M. A. F., Viramonte, J., Trumbull, R. B., Haase, G. \& Zimmer, M. (2000). Trindade and Martín Vaz Islands, South Atlantic: Isotopic ( $\mathrm{Sr}, \mathrm{Nd}, \mathrm{Pb})$ and trace element constraints on plume related magmatism. Journal of South American Earth Sciences, 13, 79-103.

Silva, J. F. (1876). Descripção do Itatiaia ou Itatiaio. Revista do Instituto Histórico e Geográfico Brasileiro, 39, 413418.

Silva, J. F. (1882). Panorama do Sul de Minas. Revista do Instituto Histórico e Geográfico Brasileiro, 45, $405-435$.

Smith, P. E., Everson, N. M., York, D., Szatmari, P. \& Custodio, O. (2001). Single-Crystal 40Ar/39Ar dating of pyrite: No fool's clock. Geology, 29, 403-406.

Smythe, D. J. \& Brenan, J. M. (2015). Cerium oxidation state in silicate melts: Combined fO2, temperature and compositional effects. Geochimica et Cosmochimica Acta, Elsevier Ltd 170, 173-187.

Sonoki, I. K. \& Garda, G. (1988). Idades K-Ar de rochas alcalinas do Brasil Meridional e Paraguai Oriental: compilação e adaptação às novas constantes de decaimento. Boletim IGC-USP, 19, 63-85.

Sørensen, H. (1974). The Alkaline Rocks. London: John Wiley \& Sons.

Sørensen, H. (1997). The Agpaitic Rocks - An Overview. Mineralogical Magazine, 61, 485-498.

Stanton, N., Ponte-Neto, C., Bijani, R., Masini, E., Fontes, S. \& Flexor, J. M. (2014). A geophysical view of the Southeastern Brazilian margin at Santos Basin: Insights into rifting evolution. Journal of South American Earth Sciences, 55, 141-154.

Teixeira, D. (1961). Relevo e Padrões de Drenagem na Chaminé Vulcânica de Itatiaia. Boletim Paulista de Geografia, 37, 3-12.

Thomaz Filho, A. \& Rodrigues, L. (1999). O Alinhamento de Rochas Alcalinas Poços de Caldas-Cabo Frio (RJ) e sua continuidade na cadeia Vitória-Trindade. Revista Brasileira de Geociências, 29, 189-194.

Thompson, R. N., Gibson, S. A., Mitchell, J. G., Dickin, A. P., Leonardos, O. H., Brod, J. A. \& Greenwood, J. C. (1998). Migrating Cretaceous-Eocene Magmatism in the Serra do Mar Alkaline Province, SE Brasil: Melts from the Deflected Trindade Mantle Plume? Journal of Petrology, 39, 1493-1526.

Trouw, C. C., Medeiros, F. F. F. de \& Trouw, R. A. J. (2007). Evolução tectônica da Zona de Cisalhamento Caxambu , MG. Revista Brasileira de Geociências, 37, 767-776.

Tupinambá, M., Heilbron, M., Valeriano, C., Júnior, R. P., de Dios, F. B., Machado, N., Silva, L. G. do E. \& de Almeida, J. C. H. (2012). Juvenile contribution of the Neoproterozoic Rio Negro Magmatic Arc (Ribeira Belt, Brazil): Implications for Western Gondwana amalgamation. Gondwana Research, International Association for Gondwana Research 21, 422-438.

Ulbrich, H. H. G. J. \& Gomes, C. B. (1981). Alkaline rocks from continental Brazil. Earth Science Reviews, 17, 135154.

Ulbrich, H. H. G. J., Vlach, S. R. F., Ulbrich, M. N. C. \& Kawashita, K. (2002). Penecontemporaneous syeniticphonolitic and basic-ultrabasic-carbonatitic rocks at the Poços de Caldas alkaline massif, SE Brazil: geologic and geochronologic evidence. Revista Brasileira de Geociências, 32, 15-26.

Ulbrich, M. N. C. (1993). Mineralogy of nepheline syenites from the Poços de Caldas alkaline massif, SE Brazil: chemistry, X-ray data and microtextures of feldspars. Revista Brasileira de Geociências, 23, 388-399.

Upton, B. G. J., Emeleus, C. H., Heaman, L. M., Goodenough, K. M. \& Finch, A. A. (2003). Magmatism of the midProterozoic Gardar Province, South Greenland: chronology, petrogenesis and geological setting. Lithos, 68, 43-65. 
Valeriano, C. de M., Mendes, J. C., Tupinambá, M., Bongiolo, E., Heilbron, M. \& Junho, M. do C. B. (2016). CambroOrdovician post-collisional granites of the Ribeira belt, SE-Brazil: A case of terminal magmatism of a hot orogen. Journal of South American Earth Sciences, 68, 269-281.

Valeriano, C. de M., Tupinambá, M., Simonetti, A., Heilbron, M., de Almeida, J. C. H. \& do Eirado, L. G. (2011). U$\mathrm{Pb}$ LA-MC-ICPMS geochronology of Cambro-Ordovician post-collisional granites of the Ribeira belt, southeast Brazil: Terminal Brasiliano magmatism in central Gondwana supercontinent. Journal of South American Earth Sciences, Elsevier Ltd 32, 416-428.

Vlach, S. R. F., Vilalva, F. C. J., Ulbrich, M. N. C., Ulbrich, H. H. G. J. \& Vasconcelos, P. M. (2003). Phlogopite from carbonatitic veins associated with the Poços de Caldas Alkaline Massif, SE Brazil: Mineralogy and Ar/Ar dating by the laser step heating method. South American Symposium on Isotope Geology, Salvador: SBG Sociedade Brasileira de Geologia, 702-705.

Watson, E. B. \& Harrison, T. M. (1983). Zircon saturation revisited: temperature and composition effects in a variety of crustal magma types. Earth and Planetary Science Letters, 64, 295-304.

Wetherill, G. W. (1956). Discordant uranium-lead ages, I. Transactions, American Geophysical Union, $37,320$.

Wones, D. R. (1981). Mafic Silicates as Indicators of Intensive Variables in Granitic Magmas. Mining Geology, 31, 191-212.

Wood, B. J. (1979). Activity-composition relationships in $\mathrm{Ca}(\mathrm{Mg}, \mathrm{Fe}) \mathrm{Si} 2 \mathrm{O} 6$-CaAl2SiO6 clinopyroxene solid solutions. American Journal of Science, 279, 854-875.

Yang, J.-H. H., Sun, J.-F. F., Zhang, M., Wu, F.-Y. Y. \& Wilde, S. A. (2012). Petrogenesis of silica-saturated and silicaundersaturated syenites in the northern North China Craton related to post-collisional and intraplate extension. Chemical Geology, 328, 149-167.

Zalán, P. V \& Oliveira, J. A. B. (2005). Origem e evolução estrutural do Sistema de Riftes Cenozóicos do Sudeste do Brasil. Boletim de Geociências da Petrobras, 13, 296-300.

Zartman, R. E. \& Haines, S. M. (1988). The plumbotectonic model for Pb isotopic systematics among major terrestrial reservoirs-A case for bi-directional transport. Geochimica et Cosmochimica Acta, 52, 1327-1339. 
ANEXO A

Nepheline Syenites to Syenites and Granitic Rocks of the Itatiaia Alkaline Massif, Southeastern

Brazil: new geological insights into a migratory ring Complex

Rosa, P. A. S ${ }^{1}$. \& Ruberti, E. ${ }^{1}$

${ }^{1}$ Universidade de São Paulo, Instituto de Geociências

Keywords: Alkaline rocks, Nepheline syenite, Quartz syenite, Geological mapping, Itatiaia

\section{Summary}

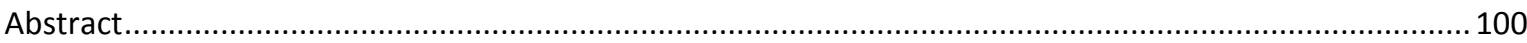

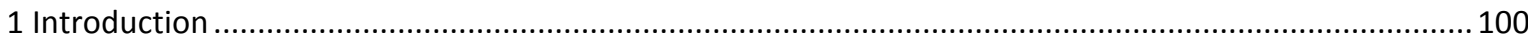

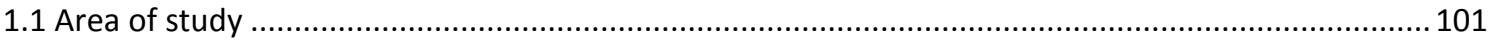

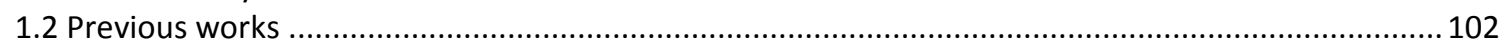

2 Methodology

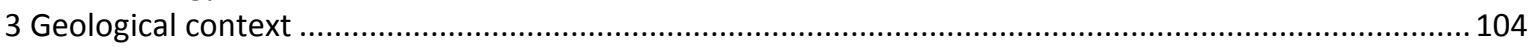

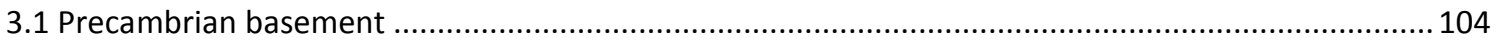

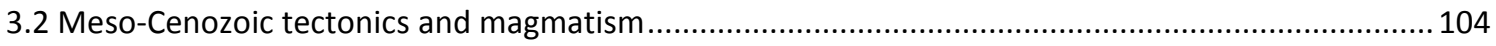

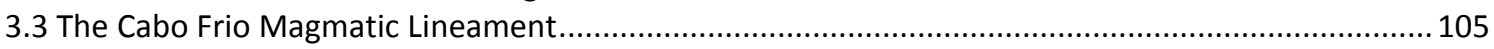

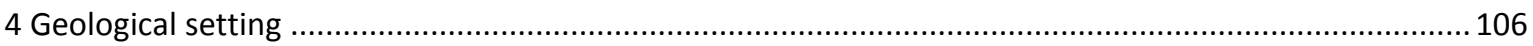

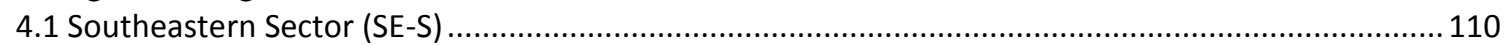

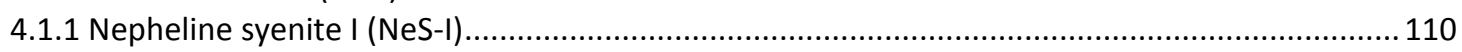

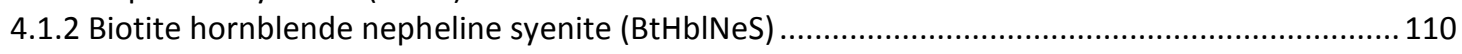

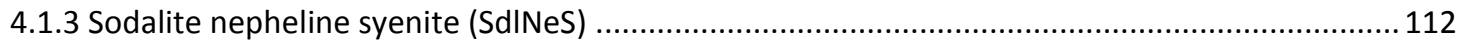

4.1.4 Aegirine nepheline syenite foyaitic (AegNeS-foy) .................................................................. 112

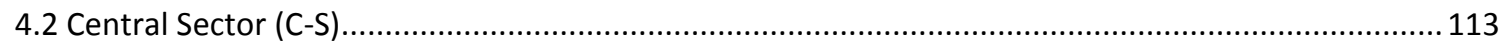

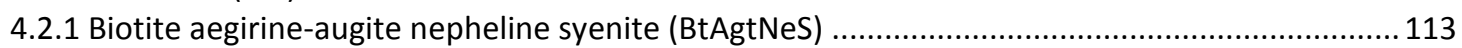

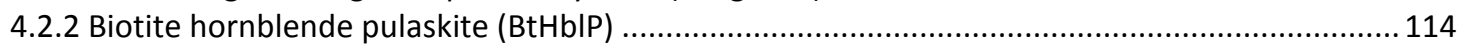

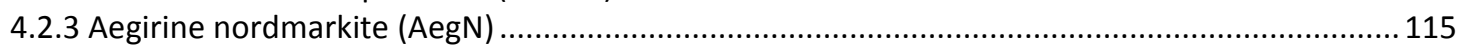

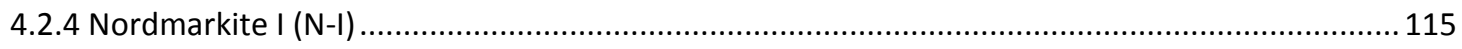

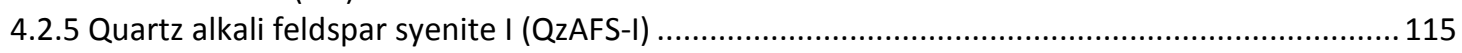

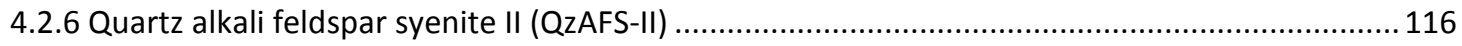

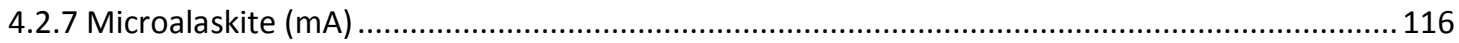

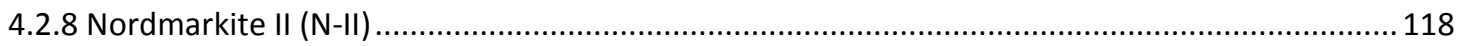

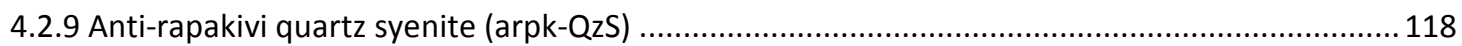

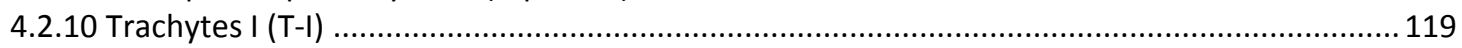

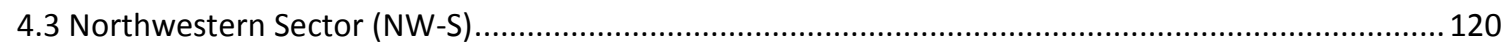

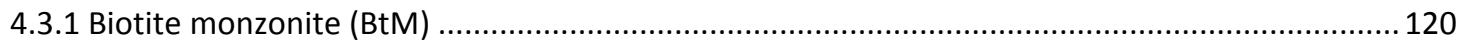

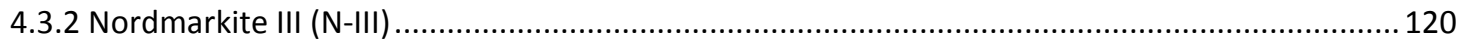

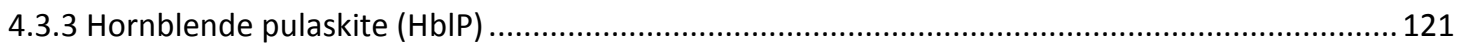




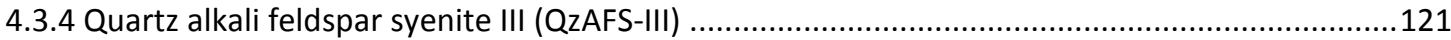

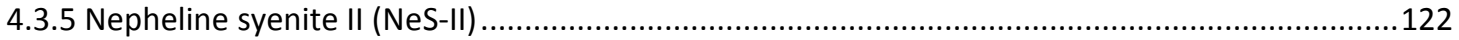

4.3.6 Metasomatized melagabbro (MG-mts) and trachybasalt (TB) .............................................122

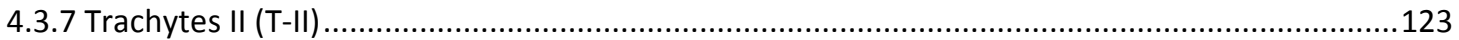

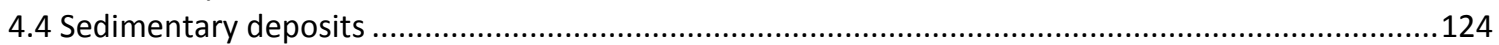

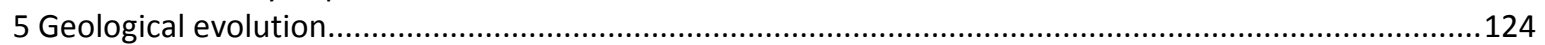

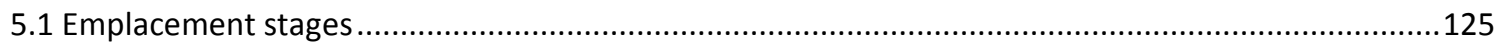

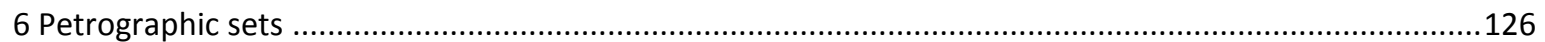

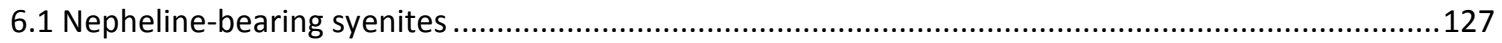

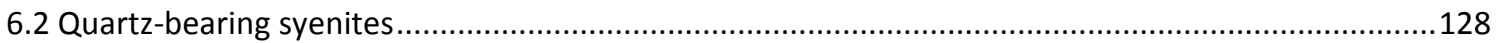

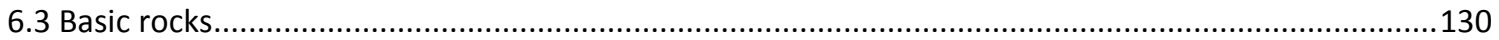

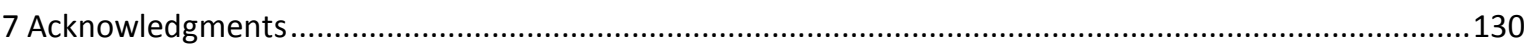

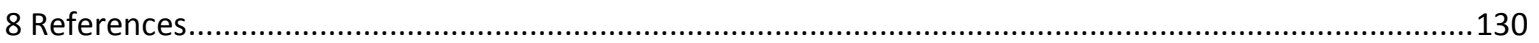

\begin{abstract}
The Itatiaia alkaline massif (IAM) comprises some of the largest Meso-Cenozoic alkaline igneous occurrences in Brazil, covering over 215 km² between Minas Gerais and Rio de Janeiro states. It appears as an elongated, $30 \mathrm{~km}$ long and $4.5-11.5 \mathrm{~km}$ wide SE-NW-trending body emplaced along accommodation zones of the Continental Rift of Southern Brazil, intruding metapelites, orthogneiss and granites of the Brasília and Ribeira fold belts.

New data and geological mapping suggest that the massif evolved from a migratory magmatic center that manifested as ring structures and successive moon-shaped intrusions from SE to NW in three sectors of distinct lithological and geomorphological characteristics: Southeastern (SE-S), Central (C-S) and Northwestern (NW-S).

The lithological variants in the three sectors present themselves as discrete intrusive bodies, comprising feldspathoid-bearing and quartz-bearing syenites, porphyritic to breccioid trachytes, granite, monzonite, gabbro and trachybasalt, that can be grouped into 21 units. These rocks occur in five petrographical sets: plagioclase-free nepheline syenites, plagioclase-bearing nepheline syenite and pulaskites, nordmarkite-granite series, anti-rapakivi associations and basic rocks. Sin- to tardiplutonic dykes of nephelinites, phonolites, trachytes and rhyolites are also present.
\end{abstract}

\title{
1 Introduction
}

Alkaline rocks are defined by the presence of feldspathoids, sodic pyroxene and/or sodic amphibole, thus rocks that can be either undersaturated or oversaturated with silica. A silica-saturated liquid may evolve toward a foid-syenite or a granite eutectic, but it cannot evolve to both terms in the same process (e.g. Hamilton \& MacKenzie, 1965; Sørensen, 1974; Foland et al., 1993; Nekvasil et al., 2004; Gupta et al., 2010). Nevertheless, association of nepheline syenite and quartz syenite is common in many alkaline provinces and in different tectonic contexts. Typically, they form ring complexes that can be categorized into three types of occurrences: a) massifs composed of silica-undersaturated rocks 
in their central portions and quartz-bearing rocks in their border zones, their spatial distribution being either gradual or marked by different intrusions, e.g., Abu Khruq, Egypt (Mogahed, 2016), Ilímaussaq and Kangerlussuaq, Greenland (Marks \& Markl, 2001; Riishuus et al., 2008) and Messum, Namibia (Harris et al., 1999); b) massifs with quartz-bearing rocks only in their central portions, shielded from contact with country rocks (at least at surface level) by silica-undersaturated rocks, e.g., Itatiaia, Brazil (Penalva, 1967; Ribeiro Filho, 1967; Brotzu et al., 1997), Wadi Dib, Egypt (Frisch \& Abdel-Rahman, 1999), Hekanzi, China (Yang et al., 2012) and Pilanesberg, South Africa (Cawthorn, 2015); and c) massifs composed exclusively, or with predominance of, quartz-bearing rocks associated with other silicaundersaturated massifs in the same magmatic province, e.g., Cerro Pedreira and Morro Distante, Alto Paraguay Province, Paraguay (Comin-Chiaramonti et al., 2015), Paresis, Damaraland Province, Namibia (Mingram et al., 2000) and Sabongari, Cameroon Line, Cameroon (Njonfang et al., 2013).

The Itatiaia Alkaline Massif (IAM) is one of the few Meso-Cenozoic alkaline occurrences in Brazil with a variation from $\mathrm{SiO}_{2}$-undersaturated rocks on their borders to silica-oversaturated rocks in their core regions. The massif is notable for its progressively inward increase in $\mathrm{SiO}_{2}$ content, and also for the presence of an alkaline granite body and rhyolitic dykes in its central portions.

The study that is presented here was based on petrographic information, detailed fieldwork and remote sensing, and was aimed at a reevaluation of the IAM geology. The massif shows to be of much higher geological complexity and lithologic variation than described in previous studies. The objective here is to present a new geology reading of the region, with a description of its main structures and lithological diversity and the relations among them. A detailed geological map is also presented, with emphasis on faciology and petrography. Twenty-one different magmatic units (besides internal facies variations) of feldspathoid-bearing and quartz-bearing syenite, trachyte, granite, monzonite, gabbro and dykes of nephelinite, phonolite, trachyte and rhyolite are defined.

\subsection{Area of study}

Covering an area of approximately $215 \mathrm{~km}^{2}$, the Itatiaia Alkaline Massif is one of the largest Meso-Cenozoic alkaline occurrences in Brazil, located between Itatiaia, State of Rio de Janeiro, and Itamonte, State of Minas Gerais $\left(22^{\circ} 18^{\prime} / 22^{\circ} 28^{\prime} \mathrm{S}\right.$; $\left.44^{\circ} 34^{\prime} / 44^{\circ} 49^{\prime} \mathrm{W}\right)$. Access is made by highways BR116, BR-354 and BR-485 (Flores' Highway). About three-quarters of the massif belong to the Itatiaia National Park, the first Brazilian one, established in 1937. Approximately $40 \%$ of its area is above the altitude of 2,000 m. An important landmark in southeastern Brazil, the massif shows a rugged topography and 13 of the 35 highest peaks in the country, among which the famous Agulhas Negras $(2,792 \mathrm{~m})$, the fifth highest one. The lowest altitude point $(560 \mathrm{~m})$ is located near the park entrance. The region presents an astonishing diversity of natural resources, an example being the Atlantic Forest ecoregion. Most of the massif is covered by Serra do Mar coastal forests. Montane rain forest occurs 
above the altitude of 1,500 m, with significant presence of Araucaria trees. Starting between 1,800 and $1,900 \mathrm{~m}$ in the rupestrian grassland of montane savanna, and progressively until disappearing at altitudes above $2,200 \mathrm{~m}$, trees become shorter and more scarce. In the far northwest of the massif, pastures and crops occur.

\subsection{Previous works}

The Itatiaia massif was one of the first regions of scientific interest in Brazil. For its important historical, biological, ecological, geomorphological, touristic, mountaineering and other aspects, it has been studied for almost two centuries. The first scientific work in the region was carried out in 1872 by A. F. M. Glaziou, who collected a large number of new plant species, in an expedition of which Isabel, Imperial Princess of Brazil took part (Brade, 1956). E. Ule was the first one to mention the local fauna in 1894 (Pinto, 1950). Despite its broad extension, lithologic diversity and historical importance, the IAM has been subject of only a few geological studies.

In the first geological study of the IAM, Silva (1876) suggested that the Itatiaia Mountain had been formed by volcanic processes in an igneous terrain. Later, Silva (1882) presented petrographic information on a granite body and some vague aspects of other rock types. Silva, also known as Massena, was an important personality in the region and the first one to climb the Agulhas Negras Peak in 1856.

Lasaulx (1885) recorded the first occurrence of alkaline rocks in the Brazil. He described a finegrained nepheline syenite with orthoclase, plagioclase, augite with hornblende rims, idiomorphic nepheline, abundant titanite and biotite and a porphyritic nepheline syenite with intergrown of orthoclase and nepheline, idiomorphic nepheline, augite, hornblende and titanite.

Lamego (1936) described some nepheline and quartz-bearing lithotypes with their approximate localization, photomicrography and geochemistry. He delimited the foyaite body in the region, including the Passa Quatro and Morro Redondo massifs, the nearest alkaline occurrences, as one. He also associated the local magmatism to the formation of Tertiary basins. From geomorphologic observations, he assigned an Upper Cretaceous age to the massif.

Penalva (1967) and Ribeiro Filho (1967) carried out the most detailed geological studies on the massif, describing a great variety of lithotypes and drawing its first geological map (Ribeiro Filho \& Penalva, 1965). Four lithological associations were mapped: nepheline syenites and syenites, quartz syenites, magmatic breccia and granite. They also discussed the massif genesis and evolution and its relations to Passa Quatro and Morro Redondo.

Brotzu et al. (1997) presented important mineral chemical, geochemical and isotopic data and also discussed petrological and petrogenetic aspects of the massif. Modifications to the previous map were proposed, with individualization of some internal variations and structural features. 
Enrich et al. (2005) and Brotzu et al. (2005) revised all the previous data in a discussion of petrogenetic models, contrasting the massif with the Passa Quatro and São Sebastião stocks.

Finally, Melluso et al. (2016) presented new mineral chemical data on the main lithologies of the IAM, especially on accessory phases of peralkaline syenites and granites and their genetic relationships with evolved lithotypes.

\section{Methodology}

In the study presented here, 233 outcrops were visited and 256 rock samples collected. The coordinates of outcrops, in addition to landmarks, buildings and sites used as references in the text, are given in Supplementary data (see appendix). Many areas of the massif are inaccessible due to topography and/or exposure constraints.

Lithological units were individualized based on fieldwork information and petrographical (texture and accessory mineralogy of 120 thin sections), geochemical, structural and geomorphological features. All units are interpreted as corresponding to distinct pulses and/or correlated magmatic events. They are cartographically continuous at the working scale 1:75,000 (present here at the scale $\sim 1: 143,000$ ) and were drawn based Google Earth (Google Earth, 2015) and Landsat 8 LC82180752013189LGNO0 (Image courtesy of the U.S. Geological Survey) satellite imagery and ASTER GDEM ASTGTM2_S23W045 (ASTER GDEM is a product of METI and NASA). Some units show significant internal variation, but there is currently not enough information based on which to individualize them. Owing to the larger number of outcrops described and better exposure and geomorphology, mapping is more detailed in the central parts of the massif. Preliminary data on elemental and isotopic geochemistry, mineral chemistry and geochronology, yet not presented here, were also considered in the individualization of units. Country rock units were compiled from Trouw et al. (2003) and Heilbron et al. (2016). The map of Fig. 1 was compiled from: Leite et al. (2004), Valeriano et al. (2011), Alves et al. (2015), Cioffi et al. (2015) and Janasi et al. (2015) for regional basement; Riccomini (1989), Meisling \& Cob (2001) and Zalán \& Oliveira (2005) for Cenozoic tectonic; and Almeida (1983, 1991) Schobbenhaus et al. (1984), Motoki (1986), Bellieni et al. (1990) Ferrari (2001), Chiessi (2004), Trouw et al. (2007), Brotzu et al. (2007), Heilbron et al. (2007), Azzone et al. (2009), Enrich et al. (2009), Guarino et al. (2011) and Rosa (2012) for alkaline provinces and massifs.

Geological contacts were categorized as: known, when a sudden geological change was directly noticed in field (direct contacts were not observed) and/or satellite imagery observation with good fieldwork control; inferred, when change was unclear or fieldwork control was insufficient; and supposed, when based only on some indication, with insufficient or missing fieldwork control. Internal facies were also individualized, based on a sector, unit and facies hierarchy. 
Phaneritic rocks were identified according to their modal QAPF plots and aphanitic rocks were identified according to their geochemical TAS diagrams (Le Maitre, 2002). Except for fine-grained types, modal analyses of thin sections were performed for representative samples of each unit. Pulaskite and nordmarkite are synonyms for nepheline-bearing alkali feldspar syenite and quartzbearing alkali feldspar syenite, respectively. Alaskite is synonym for leucocratic alkali feldspar granite (Le Maitre, 2002).

\section{Geological context}

The Itatiaia Alkaline Massif is emplaced in region of complex geological history in the limits of Brasília and Ribeira orogenic belts, where a continental rift system was developed by reactivation of old shear zones. The same reactivation and all its associated tholeiitic and alkaline magmatism accounted for the opening of the South Atlantic Ocean.

\subsection{Precambrian basement}

The southeastern portion of the Itatiaia Alkaline Massif intrudes garnet-sillimanite-muscoviteschists of the Embú Group (Paraíba do Sul Terrain) and banded (garnet)-biotite-gneiss and amphibolites of the Raposo Group (Occidental Terrain), Ribera Belt (Heilbron et al., 2004, 2016; Mendes et al., 2006; Trouw et al., 2013). Following the ENE-WSW trend of the Ribeira Belt, Ediacaran granites of the Andrelândia Domain are also present, locally represented by foliated porphyritic biotite granites of the Serra Selada and Maromba suits (Mendes et al., 2006). The limits between Ribeira and Brasília fold belts are market by the Rio Jaguari Shear Zone (Campos Neto et al., 2011), that roughly coincides with the limits of the Continental Rift of Southeastern Brazil. The northwestern portion intrudes Neoproterozoic rocks of the Socorro-Guaxupé Nappe, Brasília Belt (Heilbron et al., 2004; Campos Neto et al., 2011; Trouw et al., 2013) represented by a paragneiss-metatexite unit with banded paragneiss and subordinated layers of amphibolite, muscovite-quartz schist and quartzite, and also by an orthogneiss-diatexite unit with hornblende-biotite migmatitic orthogneiss and leucogranites.

\subsection{Meso-Cenozoic tectonics and magmatism}

An extensional tectonic event in the Upper Jurassic started the opening of the South Atlantic Ocean. In the Brazilian Platform, the event, named Wealdenian Reactivation (Almeida, 1967, 1969), was characterized by reactivation of faults, arc uplift, subsidence of the Paraná Basin and development of coastal basins and intense tholeiitic magmatism in the Paraná-Etendeka Magmatic Province (134131 Ma.; e.g. Thiede \& Vasconcelos, 2010; Janasi et al., 2011). Such processes allowed for the manifestation of repeated alkaline magmatic activity as highs, arcs and flexures surrounding the Paraná Basin and on the coasts adjacent to the Santos Basin (Almeida, 1971, 1983; Algarte, 1972; 
Almeida et al., 1996; Riccomini et al., 2005). Their large compositional variations resulted, according to the magmatic associations, in ultrabasic to acid and ultrapotassic to sodic rocks that occur as large to small alkaline bodies, plugs, swarms of dykes and lava flows (Gomes \& Comin-Chiaramonti, 2005).

One of the most important tectonic events in the Upper Cretaceous was the development of the Continental Rift of Southeastern Brazil (CRSB; Riccomini, 1989; Riccomini et al., 2004), which resulted in several tafrogenic basins from Paraná to the north of Rio de Janeiro states. The rift system developed over the Ribeira Belt, leveraging the intense plot of shear zones reactivated as normal faults parallel to coastlines in the Paleogene and as transcurrent faults in the Neogene (Almeida, 1976; Melo et al., 1985; Riccomini, 1989; Riccomini et al., 2004; Zalán \& Oliveira, 2005). The development of an epirogenetic mega plateau in the Upper Cretaceous caused by a thermal anomaly (e.g. Ernesto et al., 2002; Rocha et al., 2011) is recorded as the Japi Planation Surface and recorded as thick sedimentary rock layers in the Santos and Campos basins (e.g. Zalán \& Oliveira, 2005; Cogné et al., 2012). The uplift that developed in response to the passage of the South American Plate through a thermal anomaly became isostatically unstable, and its gravitational collapse extended between 58 and $20 \mathrm{Ma}$. A connection among the magmatic activity along the Serra do Mar range and several alkaline intrusions and dikes from 82 to $52 \mathrm{Ma}$ and the development of the CRSB seems clear.

\subsection{The Cabo Frio Magmatic Lineament}

The Cabo Frio Magmatic Lineament (CFLM; Sadowski \& Dias Neto, 1981; Almeida, 1991; Thomaz Filho \& Rodrigues, 1999; Riccomini et al., 2005) is a curved, $60 \mathrm{~km}$ wide and 1,150 km long belt that extends from Jaboticabal to the coastal banks of Almirante Saldanha. About 30 alkaline intrusive bodies as large as massifs, stocks, plugs, lava flows and dike swarms are arranged along the lineament. These rock bodies, of potassic affinity, are essentially composed of nepheline syenite, syenite, phonolite and trachyte. Except for the Poços de Caldas Massif $\left(\sim 800 \mathrm{~km}^{2}\right)$, Bom Repouso and Caxambú stocks (both $\sim 1 \mathrm{~km}^{2}$ ) and some dikes, these occurrences took place inside or at the edge of CRSB (Fig. 1).

The CFML age apparently ranges eastward, from 84 to $52 \mathrm{Ma}$. Many studies aimed at an explanation of this progression, linking it to transform faults (e.g. Marsh, 1973), mantle plumes (e.g. Thompson et al, 1998) and subcrustal faulting (e.g. Almeida, 1991; Ferrari, 2001; Riccomini et al., 2005; Zalán \& Oliveira, 2005). However, the progression is not linear, and more detailed geochronological studies are necessary, e.g., Jaboticabal is 54 Ma (Gomes \& Valarelli, 1970), Poços de Caldas is 84-76 Ma (Shea, 1992; Vlach et al., 2003), Bom Repouso is 79-76 Ma (Rosa et al., 2014), dikes in the Resende and Volta Redonda basins are 82-59 Ma (Guedes et al., 2005), the ankaramitic lavas in Volta Redonda and Itaboraí basins are 43 Ma (Riccomini \& Rodrigues-Francisco, 1992), the dikes associated to Mendanha massif are 82 to 54 Ma (Ferrari, 2001; Smith et al., 2001), Morro de São João is 77-56 Ma (Ulbrich \& 
Gomes, 1981; Sonoki \& Garda, 1988; Sichel et al., 1997; Thomaz Filho \& Rodrigues, 1999) and Cabo Frio is $52 \mathrm{Ma}$ (Ferrari, 2001).

It is remarkable that most of the CFML alkaline bodies tend to be in contact or intruding Neoproterozoic sin-, late- or post-orogenic K-high calc-alkaline granites and syenites of the Ribeira and Brasília fold belts, especially in the Socorro Nappe, Apiaí Domain and Oriental Terrain (e. g. Valeriano et al., 2011; Tupinambá et al., 2012; Carvalho et al., 2014; Janasi et al., 2015; Alves et al., 2016). The post-orogenic granitoids also have mantellic isotopic signatures (e.g. Janasi et al., 2009; Valeriano et al., 2011; Carvalho et al., 2014) and are oriented to NE-SW (the same trend of Brasiliano faults) with Cenozoic alkaline massifs.

\section{Geological setting}

The Itatiaia Alkaline Massif is an elongated, $30 \mathrm{~km}$ long and 4.5 to $11.5 \mathrm{~km}$ wide SE-NWtrending feature. Most of its units are moon-shaped and align successively to the Northwest (Fig. 2). Its structures and lithotype associations suggest three sectors whose characteristics could represent distinct origin and/or evolution stages.

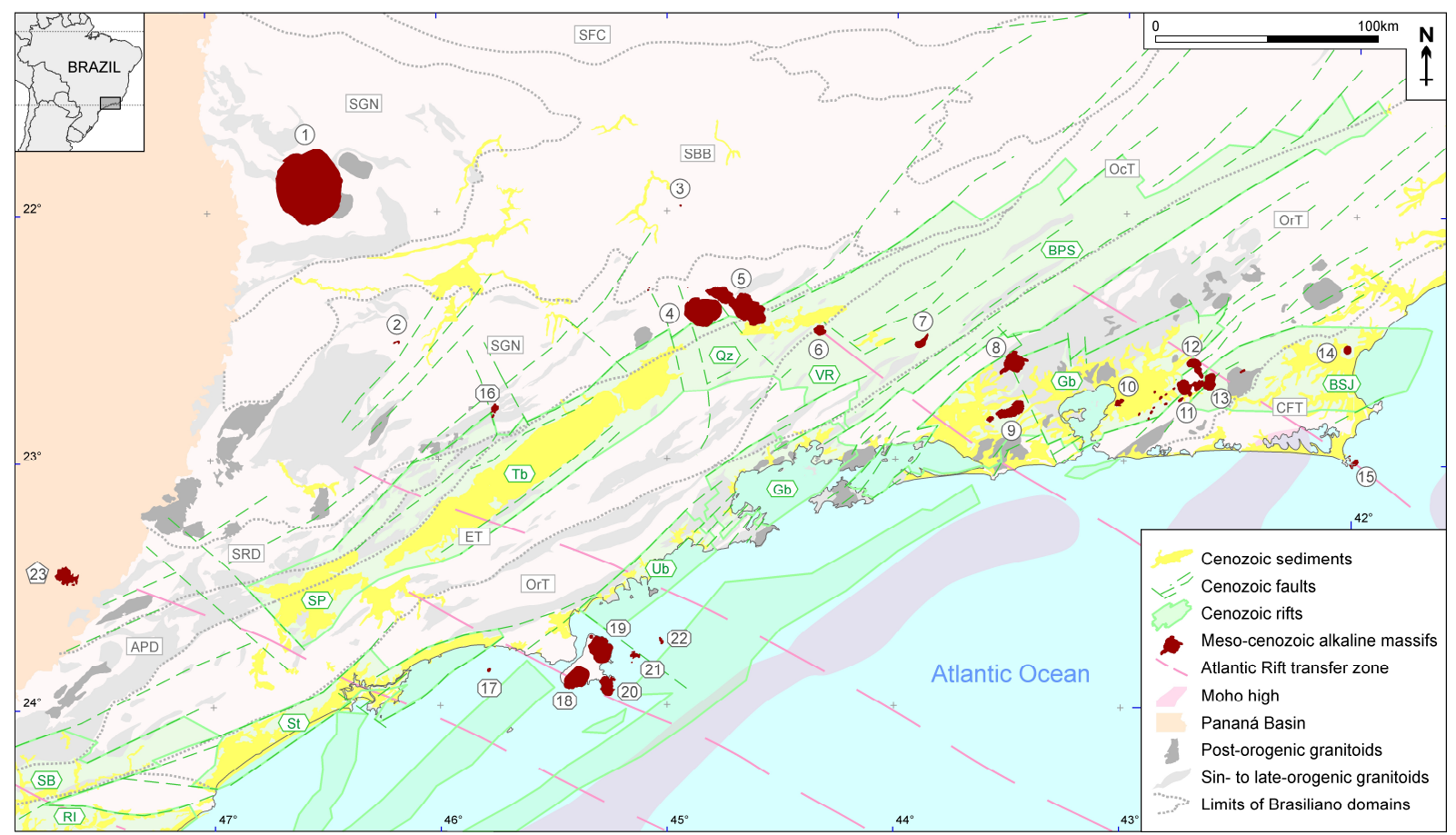

Figure 1 - Distribution of the Meso-Cenozoic alkaline occurrences of Serra do Mar Province (modified after Almeida, 1983, 1991; Schobbenhaus et al., 1984), with the CRSB (Riccomini, 1989), the main Brasiliano tectonic domains and sin- to postorogenic granitoids. Alkaline occurrences: Poços de Caldas (1), Bom Repouso (2), Caxambú (3), Passa Quatro (4), Itatiaia (5), Morro Redondo (6), Serra dos Tomazes (7), Tinguá (8), Mendanha-Mapicuru (9), Itaúna (10), Tanguá (11), Soarinho (12), Rio Bonito (13), Morro de São João (14), Cabo Frio (15), Ponte Nova (16), Monte de Trigo (17), São Sebastião (18), Serraria (19), Mirante (20), Búzios (21), Vitória (22) and another occurrence near SMP Ipanema (23). Rifts: Paraíba do Sul, São Paulo (SP), Taubaté (Tb), Queluz (Qz), Resende-Volta Redonda (RVR), Baixo Paraíba do Sul (BPS); Coastal: Sete Barras (SB), Ribeira de Iguape (RI), Santos (St), Ubatuba (Ub), Guanabara (Gb), Barra do São João (BSJ). Brasiliano domains: Socorro-Guaxupé Nappe (SGN), South Brasília Belt (SBB), São Roque Domain (SRD), Apiaí Domain (APD), Embú Terrain (ET), Ocidental Terrain (OcT), Oriental Terrain (OrT), Cabo Frio Terrain (CFT). Compiled from: cartographic base (Leite et al., 2004), Cenozoic tectonics (Riccomini, 1989; Zalán \& Oliveira, 2005), and therein references (See text for other references). 


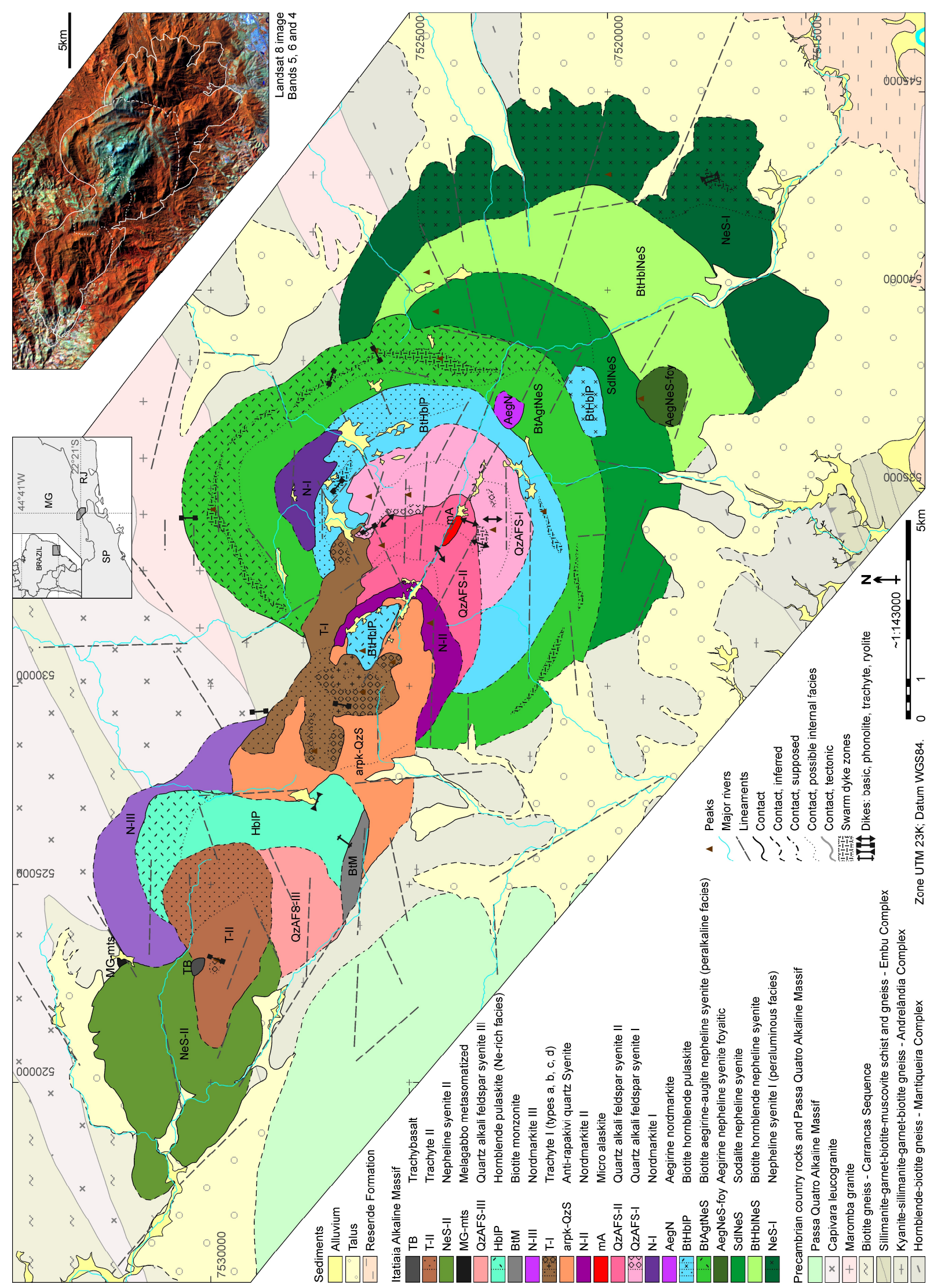

Figure 2 - Geological map of the Itatiaia Alkaline Massif. Insert: Landsat 8 image bands 5, 6 and 4 (Image courtesy of the U.S. Geological Survey) for the same delimitated area. Zone UTM 23K; Datum WGS84. 
The Southeastern Sector (SE-S) consists of miaskitic to agpaitic nepheline syenite bodies cut by dykes of aphiric, porphyritic (some of them with pseudoleucite) and breccioid phonolites and nephelinites. The most silica-undersaturated units are on the edge, in contact with basement, being locality peraluminous with modal hercynite and corundum.

The Central Sector (C-S) corresponds to a ring-like structure with a 9.5 to $11.5 \mathrm{~km}$ diameter (Fig. 3), that partially intrudes the SE-S. It shows an external C-shape ridge with well-defined topographic expressions in its northern and eastern parts, lower in the south and almost absent in the west, consisting of miaskitic to agpaitic nepheline syenites with a 60 to $200 \mathrm{~m}$ wide belt of sin-plutonic swarm of trachyte dykes that sustains its external parts. The inner units are composed of different pulaskites, nordmarkites and quartz alkali feldspar syenites whose silica saturation tends to increase inward. A small intrusive body of alaskite occurs next to the center of the ring, where dykes of trachyte and rhyolite occur. In the transition area to the Northwestern Sector, a 'neck' is formed by anti-rapakivi glomeroporphyritic quartz syenite and porphyritic to breccioid aphanitic trachyte.

The Northwest Sector (NW-S) also shows some moon-shaped structures in nepheline syenites and nordmarkites. Locality, cumulatic melagabbro and biotite monzonite occur. In the central parts of the area, porphyritic to breccioid trachyte and trachybasalt are present.

Remarkable in the entire massif, the structural setting is evidenced by the drainage pattern (Fig. 3), lineaments and faults that shape the relief (Fig. 4A and 4B) and also by the great number of conjugate shear joints in slabs and walls (Fig. 4B). Three preferential direction of lineaments are evident: NW-SE, ENE-WSW and W-E. The first one is clearly observed in the Southeast and Central sectors and coincides with the elongation of the massif. Its main manifestation is the Vale dos Lírios Lineament (VLL). The second is ubiquitous and concordant with the tectonic setting of the basement and CRSB. The third group of lineaments is also ubiquitous, but less expressive and more visible in the Central Sector, being even denser in some belts. Secondary radial lineaments are also present in the external ridge of this sector.

The VLL is longitudinal to the massif, with some magmatic manifestations (microalaskite and aegirine-augite nordmarkite units, the Picu's Rock and the Pedra Furada Hill). It appears as a straight valley in the Central Sector, having some expressiveness in the rest of the massif and outside. However its kinematics is yet to be clarified, it separates two different geomorphological domains: a plateau with the highest elevations to the north and a scarp and ring features of lesser visible structural pattern to the south. Apparently, the lineament does not mark any lithological change.

Talus deposits occur across the massif and are expressive over the Southeastern and Central sectors borders. Alluvia-formed bogs are present in the high valleys of the Central Sector. 


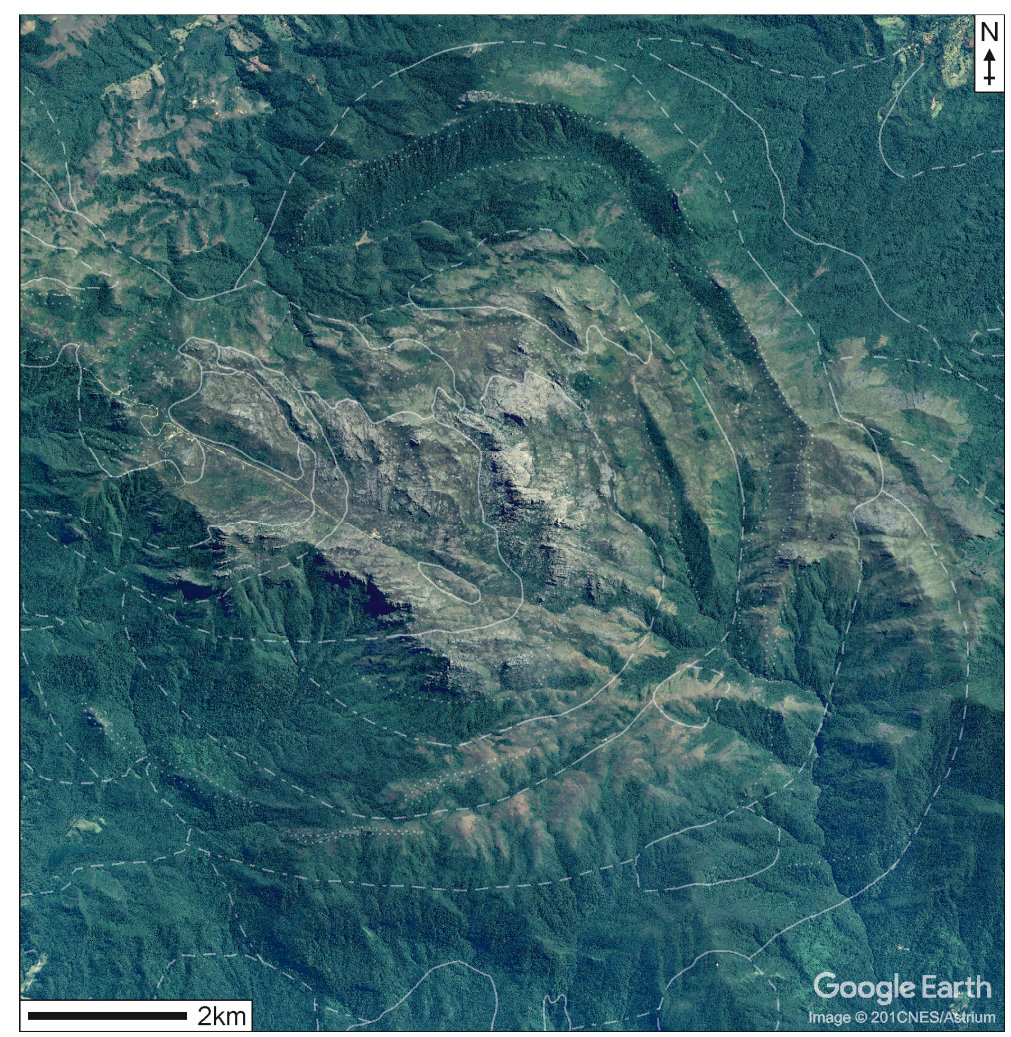

Figure 3 - Geomorphological features of the C-S ring, Itatiaia Alkaline Massif; the Vale dos Lírios Lineament with WNW direction in the center. Google Earth (2015). Whitish lines represent contacts in Figure 2.

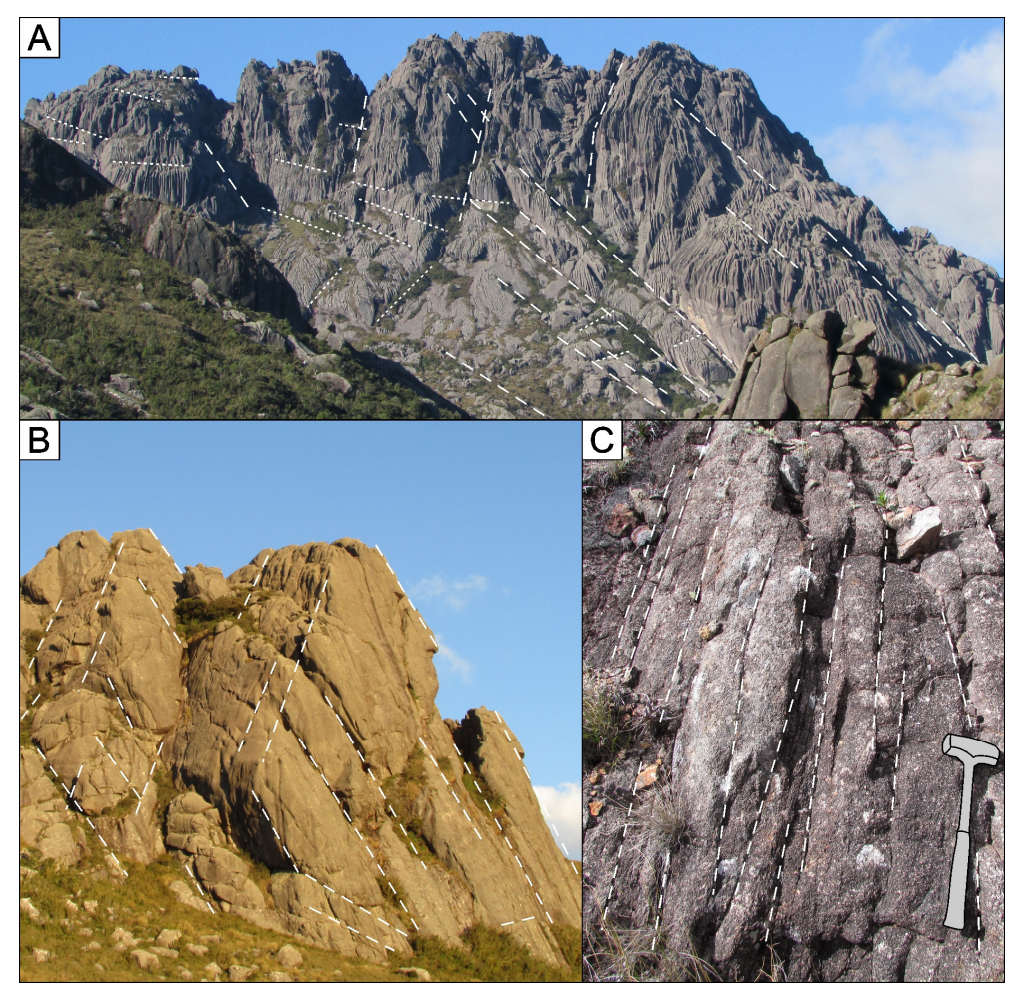

Figure 4 - Field aspects of the Itatiaia Alkaline Massif. A) Fracture plans on the Agulhas Negras Peak, very thin vertical lines corresponding to fluted erosion, which appears as black needles, hence the toponym. B) Fracture plans on the Pedra do Altar. C) Conjugate shear joints on the Vale dos Lírios Lineament overlying the $\mathrm{mA}$ unit. Dashed lines highlight structural planes. 


\subsection{Southeastern Sector (SE-S)}

\subsubsection{Nepheline syenite I (NeS-I)}

This unit occurs in the southeastern border of the massif, partially covered by talus deposits. Outcropping as rocky hills, small massifs or decametric boulders covered by the dense Atlantic Forest, it probably represents the oldest emplaced and most silica-undersaturated rocks of the massif, with more than $30 \%$ of modal nepheline. This unit shows the strong textural and mineralogical variation that characterizes internal and border facies.

The predominant internal facies possibly represents the original magma. The best outcrops are found along the road from the park entrance to the museum area. The typical rock is a massive, coarse to medium-grained, inequigranular to equigranular gray to dark gray nepheline syenite (IC 4-8\%). Titanomagnetite, titanite and apatite are early phases. Nepheline is idiomorphic to subidiomorphic, whereas perthitic alkali feldspar is subidiomorphic to interstitial. Xenomorphic to subidiomorphic aegirine-augite is the main mafic mineral, normally zoned with aegirine rims (Fig. 5A). Hiortdahlite is subidiomorphic, sometimes intergrown with titanite and pyroxene. Sodalite, analcime, biotite, carbonate, \pm amphibole, \pm cancrinite and occasional astrophyllite and pyrochlore are late to post magmatic phases. Locally, an association of amphibole biotite replaces clinopyroxene.

The border facies is well observed along the road to Vista Linda Inn and on the Três Picos Hill. The rocks show saccharoidal to oriented, fine to medium-grained texture and gray to dark gray color domains with whitish portions and mafic enclaves. They consist of aluminous assemblages of significant plagioclase, biotite and muscovite, and also hercynite, corundum and rutile (Fig. 5B). An increasing amount of these minerals is followed by a decrease or absence of pyroxene, amphibole, titanite and magnetite. Plagioclase, hercynite and corundum usually appear in association. Centimetric angular mafic microgranular enclaves seldom occur (Figs. 6A and B).

A swarm of phonolite dykes spreads for over $1.5 \mathrm{~km}$ along the road to Vista Linda Inn. The dykes vary from aphyric with an agpaitic tendency to porphyritic with phenocrysts of alkali feldspar and/or pseudo-leucite (Fig. 6C), but are also breccioid with fragments of syenitic, melanite-bearing mafic, and mylonitic gneissic rocks (Fig. 6D). Aphyric nephelinite also occurs.

\subsubsection{Biotite hornblende nepheline syenite (BtHbINeS)}

This unit, that outcrops as a crescent-moon shaped body, is easily recognized on the road from the museum to the Véu da Noiva Waterfall and on the trail to the Três Picos Hill. It is less silicaundersaturated (5-15 vol\% nepheline) and more mafic (IC 8 to 20\%) than NeS-I. The rocks are medium to coarse-grained, with an inequigranular, slightly oriented texture and a light-gray color, sometimes with rosy smudges due to the presence of nepheline. Texture is dominated by tabular to lathlike perthitic alkali feldspar. Carlsbad twinning is common. Interstitial nepheline and aggregates of mafic 
minerals (Fig. 5C) such as magnesio-hastingsite (up to 8 vol\%) associated with biotite (up to 6 vol\%), titanomagnetite (with titanite rims), xenomorphic titanite (up to 5 vol\%, up to $5 \mathrm{~mm}$ in size, rarely $>10$ $\mathrm{mm})$, apatite and \pm zircon are also present. Plagioclase $\left(\mathrm{An}_{25-32}\right)$ appears as tabular to rounded xenomorphic crystals, usually with oscillatory zoning and/or overgrown alkali feldspar and xenomorphic inclusions of sodalite, nepheline and bluish-green amphibole (Fig. 5D). Diopside occurs in almost all samples, in association with amphibole. Weakly zoned magnesio-hastingsite almost completely replaces diopside on the rims, leaving irregular relicts associated with thin veins of titanite in the amphibole cleavage. Subidiomorphic to interstitial biotite is as abundant as amphibole in some places, usually with inclusions of apatite, titanomagnetite, titanite and zircon. Locally, it replaces

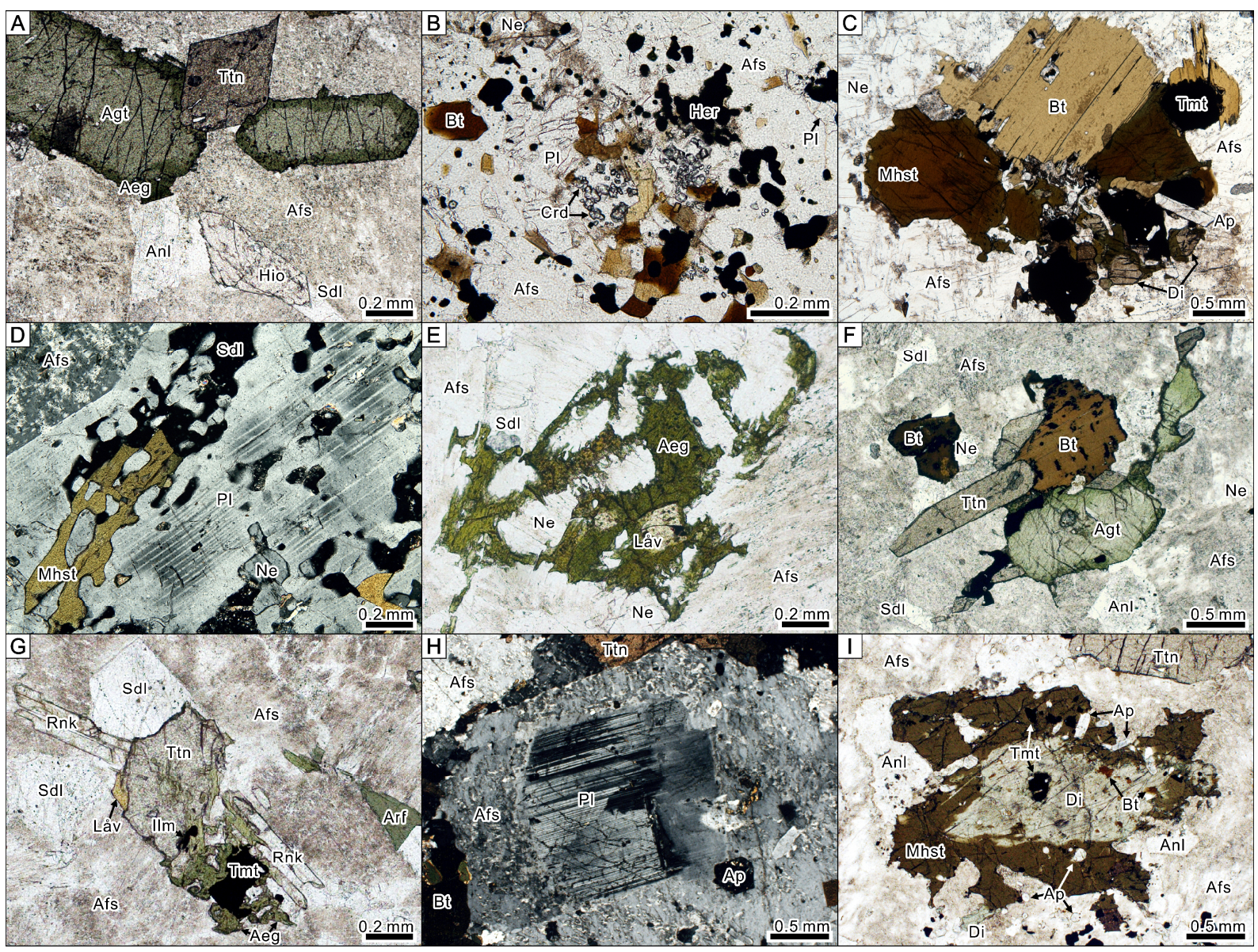

Figure 5 - Representative microtextures of rock varieties in the Itatiaia Alkaline Massif. A) NeS-I, MAI060. Titanite and aegirine-augite with aegirine border and interstitial hiortdahlite, sodalite and analcime. B) NeS-I peraluminous facies, MAI030. Aggregate of plagioclase, biotite, hercynite and corundum; note also alkali feldspar and nepheline. C) BtHbINeS, MAI033. Typical mafic aggregate of magnesio-hastingsite with diopside relicts, biotite, titanomagnetite and apatite; notice the consertal contacts of alkali feldspar and nepheline. D) BtHbINeS, MAI040. Plagioclase with xenomorphic inclusions of sodalite, nepheline and blueish amphibole. E) AegNeS-foy, MAI215. Poiquilitic aegirine replaced by låvenite and enclosing nepheline and alkali feldspar; note also nepheline, alkali feldspar and sodalite. F) BtAgtNeS, MAI206I.Typical mafic aggregate of idiomorphic aegirine-augite and titanite and xenomorphic biotite; notice also alkali feldspar, nepheline, analcime and sodalite. G) BtAgtNeS peralkaline facies, MAI199. Replacement textures of aegirine with arfvedsonite and titanite by låvenite; notice also xenomorphic titanomagnetite (intergrown with ilmenite), prismatic rinkite, subidiomorphic sodalite and tabular alkali feldspar. H) BtHbIP, MAI092I. Idiomorphic plagioclase overgrown by alkali feldspar (anti-rapakivi); notice the consertal contact of alkali feldspar with biotite and apatite inclusions. I) BtHbIP, MAl114. Typical rreplacement texture of diopside with magnesio-hastingsite, in consertal contact with alkali feldspar and analcime; notice xenomorphic inclusions of titanomagnetite and abundant apatite. See Table 2 for abbreviations. 
magnesio-hastingsite. Titanite, biotite and titanomagnetite are usually idiomorphic, while sodalite fills cracks or is included in alkali feldspar. Cancrinite locally replaces nepheline in the final to post magmatic stage.

\subsubsection{Sodalite nepheline syenite (SdINeS)}

This unit is largely exposed on the trail from the Maromba's Station to the Água Branca Shelter and in talus boulders to the west of the region. The rocks are gray to locally rosy in color and medium to coarse inequigranular in texture. They are similar to those of NeS-I and are characterized by the predominance of slightly oriented tabular mesoperthitic alkali feldspar, usually with Carlsbad twinning and interstitial nepheline (7-15\% vol\%) and sodalite (2-5 vol\%). Subidiomorphic to xenomorphic zoned diopside to aegirine-augite is always associated with biotite (which locally replaces it), titanomagnetite and \pm titanite (IC 5-12\%). Sodic amphibole also occurs replacing aegirine-augite. Biotite, titanite and låvenite are the main accessories, while idiomorphic pyrochlore, apatite, \pm fluorite and $\pm z i r c o n$ are less common. Carbonate is an interstitial late- to post-magmatic phase that locally replaces biotite.

\subsubsection{Aegirine nepheline syenite foyaitic (AegNeS-foy)}

This unit only occurs on the Água Branca Shelter Hill, intruding the boundaries of BtHblNeS and SdINeS. Its rocks are characterized by a medium-grained foyaitic texture and a high nepheline content ( 30 vol\%), abundant låvenite and the presence of sodic amphibole. Idiomorphic to subidiomorphic nepheline and interstitial sodalite (both up to $1 \mathrm{~mm}$ long) occur among oriented tabular to lathlike mesoperthitic alkali feldspar crystals, which may present Carlsbad and, more rarely, microcline

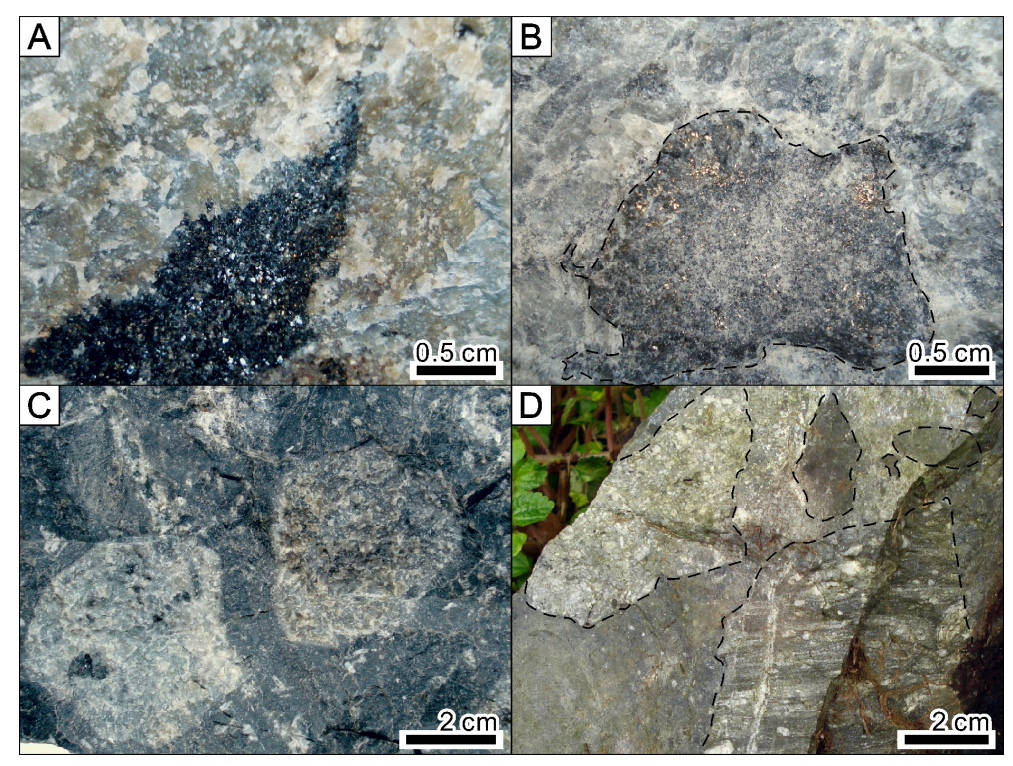

Figure 6 - Structural and textural macroscopic aspects of rocks from NeS-I unit in the Itatiaia Alkaline Massif. A) MAI042. Mafic biotite-rich microgranular enclave. B) MAI043. Mafic pyrite-rich microgranular enclave. C) MAI046F. Porphyritic phonolite with pseudoleucite phenocrysts. D) MAI046G. Breccioid phonolite with syenitic (left), mafic (upper right) and mylonite (lower right) fragments. Dashed lines highlight contacts. 
twinning. Interstitial to slightly poikilitic aegirine (Fig. 5E) locally replaced with biotite, låvenite or \pm tarfvedsonite, idiomorphic to subidiomorphic låvenite and interstitial arfvedsonite are the main accessories. Minor accessories are titanomagnetite, interstitial ilmenite (replaced with aenigmatite), fluorite, apatite, zircon and idiomorphic titanite.

\subsection{Central Sector (C-S)}

\subsubsection{Biotite aegirine-augite nepheline syenite (BtAgtNeS)}

This unit forms the external C-shaped ring of the Central Sector and shows a transition from miaskitic to agpaitic tendency, which occurs in the highest levels. Along the ridge's crest, trachyte dyke swarms occur, in sin-plutonic intrusive contact (Fig. 7A).

The predominant facies is medium to coarse-grained, with a slightly oriented to massive inequigranular structure and gray to light-gray color (IC 12-20\%). Locally, it can be fine to mediumgrained and/or strongly oriented. Caramel titanite crystals (1-3 $\mathrm{mm}$, up to $10 \mathrm{~mm})$ stand out. Perthitic, tabular alkali feldspar with consertal texture and Carlsbad twinning is the main phase, followed by nepheline and sodalite, which occur as subidiomorphic to interstitial crystals. Aegirine-augite to aegirine is the most abundant mafic phase, showing subidiomorphic to interstitial, occasionally idiomorphic forms (Fig. 5F). Accessory are titanite (with ilmenite relicts), subidiomorphic biotite, titanomagnetite, apatite and \pm zircon.

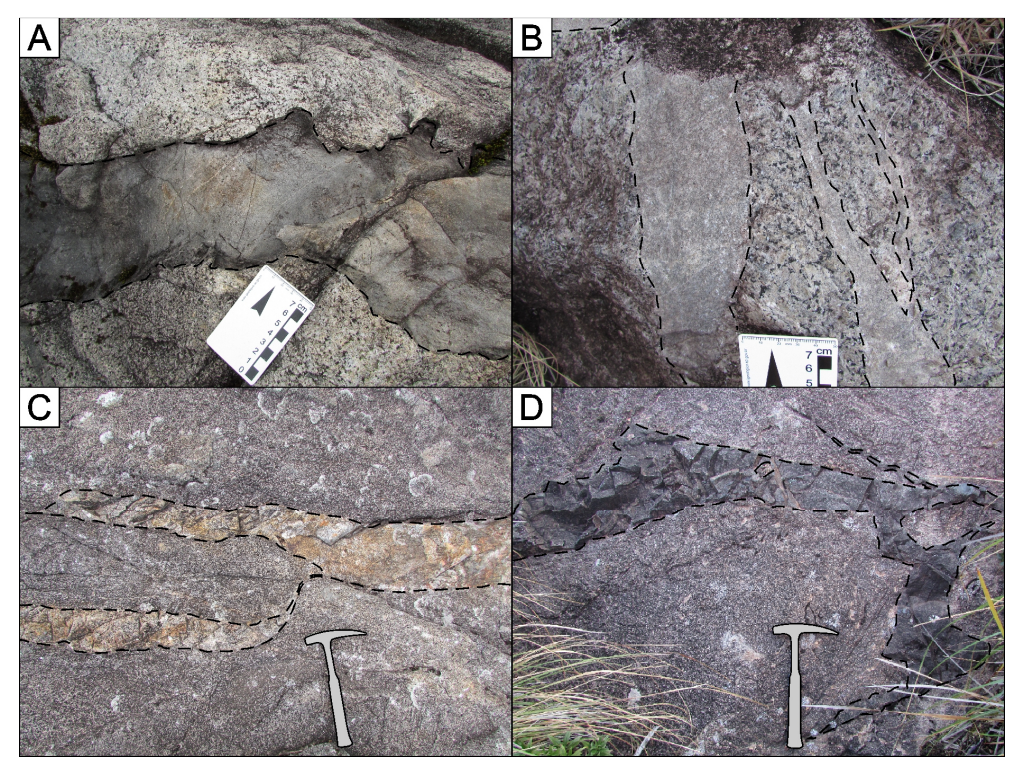

Figure 7 - Representative field aspects of Itatiaia Alkaline Massif dikes. A) Spot close to Maromba's Hill summit. Trachyte showing sinuous sin-plutonic intrusive contacts in the crest of external C-shape ridge. B) MAI092II. Agpaitic phonolite. C) MAI100, dike swarm in a slab. Trachyte with sin-plutonic displacement. D) MAI111. Rhyolite with tardi-plutonic angular contacts. Dashed line highlights contacts. 
In the Serra Negra Hill and to the east of the Maromba's Hill, a transition from miaskitic to agpaitic paragenesis occurs, with replacement of titanite by låvenite and aegirine by arfvedsonite, and abundant presence of sodalite, rinkite, \pm rosenbuschite and small amounts of biotite (Fig. 5G).

Dikes of dark gray aphyric, fine-grained and strongly orientated trachyte are present (Fig. 7A), with the same paragenesis as the main facies, but with amphibole as an important late magmatic phase.

\subsubsection{Biotite hornblende pulaskite (BtHbIP)}

This unit forms a second C-ring shaped structure, but with remarkable topographic expression only in the eastern part of the massif. Its rocks outcrop around the Aiuruoca River Bog, on the crest of the Urubu's Hill near the Massena Shelter and in other two disconnected parts: in the southeast, apparently intruding SdINeS outside the external ring and in the northwest supporting Massena's Hill. In the Massena Shelter region, 2 to $10 \mathrm{~cm}$ wide phonolite dikes outcrop (Fig. 7B). To the east of Ovos da Galinha Boulders, a swarm of up to 1 meter wide and 20 meters long trachyte dikes can be observed in slabs (Fig. 7C). Both groups of occurrences show sin-plutonic intrusive contacts.

The rocks are similar to the predominant facies of BtAgtNeS, but are characterized by a lower feldspathoid content (up to 5 vol\%) and a slight porphyritic tendency, with some discrepant tabular feldspar crystals and disequilibrium textures. Locally, crystals show strong magmatic orientation. A border facies with a more prominent medium to fine-grained porphyritic texture occurs in the northern (on the Aiuruoca Waterfall) to eastern portion.

Apatite, titanomagnetite, ilmenite, diopside and zircon form the early magmatic assemblage. Perthitic alkali feldspar occurs as subidiomorphic to xenomorphic crystals, the biggest than $5 \mathrm{~mm}$ ones being tabular, with Carlsbad twinning. Amoeboid to idiomorphic cores of plagioclase $\left(\mathrm{An}_{40-50} ; \mathrm{Fig} .5 \mathrm{H}\right)$ are usually seen. Magnesio-hastingsite is subidiomorphic to xenomorphic and largely replaces diopside (Fig. 5I). Apatite and titanomagnetite inclusions are common. Titanite is subidiomorphic and replaces titanomagnetite and ilmenite. Nepheline, sodalite, biotite (locally mantling amphibole) and fluorite are late phases. Analcime represents a late- to post magmatic phase. Locally, an association of small, scattered subidiomorphic crystals of diopside, zirconolite and pyrite occurs, their crystallization relations being yet unclear.

The rocks from the southeastern appendix are slightly different from the unit's main facies in texture, with local polygonal contact, common Carlsbad twinning and a less perthitic intergrowth of alkali feldspar, scarce amphibole and the presence of pyrite and \pm chevkinite. The rocks from the northwest appendix are similar to this unit in texture, but significantly different in mineralogy. They show post magmatic re-equilibration, with microfaults and potassic alteration zones. Pyroxene and/or 
amphibole are almost totally replaced with biotite, which in turn is replaced with chlorite and carbonate. Neither feldspathoid nor quartz were observed in both appendices.

The trachytes dykes are porphyritic, with an aphanitic matrix and gray color. Well-oriented acicular feldspar and amphibole, idiomorphic magnetite and some unidentified minerals compose the matrix $(<0.2 \mathrm{~mm}$ crystal size). Tabular alkali feldspar $(2-10 \mathrm{~mm})$ and biotite occur as phenocrysts. Phonolites are aphyric, with saccharoidal texture and light gray in color. Texture is granular, with xenomorphic alkali feldspar, nepheline, sodalite, amphibole, magnetite, biotite and zircon (up to 0.4 mm crystal size).

\subsubsection{Aegirine nordmarkite (AegN)}

This unit outcrops as metric boulders at the Rui Braga trail between the two external rings of the Central Sector and locally interrupting the VLL. It has almost the same relative position of N-I and $\mathrm{N}-\mathrm{II}$, intruding BtAgtNeS at the borders with BtHblP. The rocks are medium-grained, massive, with inequigranular texture and leaden to light gray in color, with polygonal ochre smudges. Mafic minerals form aggregates (IC 9-11\%). Texture is dominated by tabular mesoperthitic alkali feldspar with Carlsbad twinning, interstitial aegirine-augite to aegirine and quartz (3-4 vol\%; Fig. 8A). Associated are subidiomorphic titanomagnetite intergrown with ilmenite, zircon, chevkinite, \pm apatite. Pyroxene is moderately homogeneous, however showing instability texture, with sectored exsolutions associated to fluorite. Ankerite, fluorite, REE-fluorcarbonates and ilmenite replace titanite.

\subsubsection{Nordmarkite I (N-I)}

These rocks correspond to the first silica-oversaturated unit, outcropping as a moon-shaped body among the silica-undersaturated units. They can be found to the north and northeast of the Ovos da Galinha Boulders. The rocks are massive, inequigranular, medium- to coarse-grained, leaden-gray in color, with cream-whitish smudges. Texture is dominated by consertal subidiomorphic alkali feldspar, seldom showing Carlsbad twinning. Mafic minerals aggregates (IC 9-11\%) are present. Quartz ( $<4$ vol.\%) is interstitial, commonly showing a mirmequitic texture. Xenomorphic richterite, occasionally with augite to aegirine relicts (amphibole is absent in one sample), idiomorphic titanomagnetite (commonly with corona of titanite), titanite, \pm ilmenite, \pm zircon (up to $0.5 \mathrm{~mm}$ ) and tapatite compose the mafic aggregates. Biotite is xenomorphic, locally intergrown with alkali feldspar. Xenomorphic plagioclase $\left(\mathrm{An}_{22^{-25}}\right)$ crystals with reabsorption texture and cracked alteration are rare and probably antecrysts.

\subsubsection{Quartz alkali feldspar syenite I (QzAFS-I)}

This unit of greatest topographic expression forms the Agulhas Negras Peak and Asa de Hermes, Pedra do Sino, Pedra Assentada and the Prateleiras Hills. It consist of a moon-shaped structure that outcrops as rocky massifs, big slabs and decametric boulders. Fluted and pitted-like erosion 
structures are typical (Fig. 4A). Millimetric to centimetric miarolitic cavities are common, normally with quartz druses (Fig. 9A).

Its rocks are inequigranular medium- to coarse-grained and light rosy brown in color, with whitish smudges (IC 9-11\%). Tabular microperthitic alkali feldspar predominates, reaching up to 10 $\mathrm{mm}$, mainly with interstitial growth of other minerals. Seldom subidiomorfic, faceted quartz (5-8 vol\%) appears mainly in contact with amphibole. Ferro-richterite is the main mafic mineral, with relics of aegirine-augite in some samples (Fig. 8B). Associated are also prismatic ilmenite, subidiomorphic magnetite, titanite, zircon, chevkinite and apatite, as important accessories. Biotite is uncommon and replaces amphibole. In the western border of the Agulhas Negras Peak, centimetric, rounded and finegrained felsic enclaves that highlight on the surface are common, with more abundant interstitial amphibole and magnetite.

Dikes of aphanitic, aphyric, dark gray rhyolite up to $40 \mathrm{~cm}$ wide with flow-banding texture and angular sharp contacts occur throughout this unit. Occasionally, they are sinuous with sin-plutonic displacement. Some porphyritic dykes with alkali feldspar phenocrysts (up to $5 \mathrm{~mm}$ size) and similar matrix also occur.

\subsubsection{Quartz alkali feldspar syenite II (QzAFS-II)}

This unit outcrops near Rebouças Shelter as large rock slabs forming small hills (e.g., the Pedra do Altar Hill), following a moon-shape sequence and representing the resumption of the northwestward migration of the magmatic center. It comprises three successive facies of little textural and mineralogical differences among them, but brownish to light gray in color with a characteristic medium-grained massif oriented structure and granular texture. These rocks differ from QzAFS-I ones for their higher quartz content (12-18 vol\%), lower IC (7-10\%) and absence of clinopyroxene.

Tabular to xenomorphic mesoperthitic alkali feldspar is the predominant mineral. These rocks also show interstitial to granophyric quartz, zoned amphibole (brown core to pale green to greenish dark blue rim), biotite (locally replacing amphibole) and chevkinite. Apatite, zircon, titanomagnetite and ilmenite, the early magmatic phases, are the main accessories. The central variant facies shows a slightly higher quartz content (graphic texture) and subidiomorphic to interstitial fluorite and allanite. These rocks have been more subject to weathering, with partial replacement of minerals with carbonate. Their internal, mafic facies are slightly oriented.

Rhyolite dikes similar to those of QzAFS-I occur throughout the area (Fig. 7D).

\subsubsection{Microalaskite ( $m A)$}

These rocks outcrop as an elongated low hill that rises above the VLL in QzAFS-II. They show a massive equigranular medium-grained structure and light creamy gray color (IC 5\%). 
Early mineral phases are apatite, zircon and titanomagnetite. Perthitic to mesoperthitic subidiomorphic tabular alkali feldspar predominates, with a consertal texture and often albitic borders. Quartz (26 vol\%) is commonly intergrown with alkali feldspar, occasionally with granophyric or

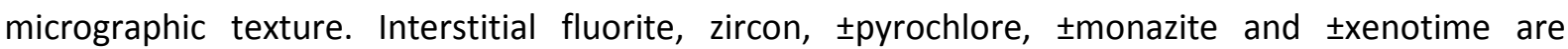
associated to subidiomorphic to xenomorphic titanomagnetite. Interstitial biotite apparently replaces amphibole and/or pyroxene, but with no relicts of such minerals and is associated with late- to postmagmatic carbonates, REE-fluorcarbonates and phosphates (Fig. 8C). Prismatic quartz, ankerite and 土albite fill miarolitic cavities.

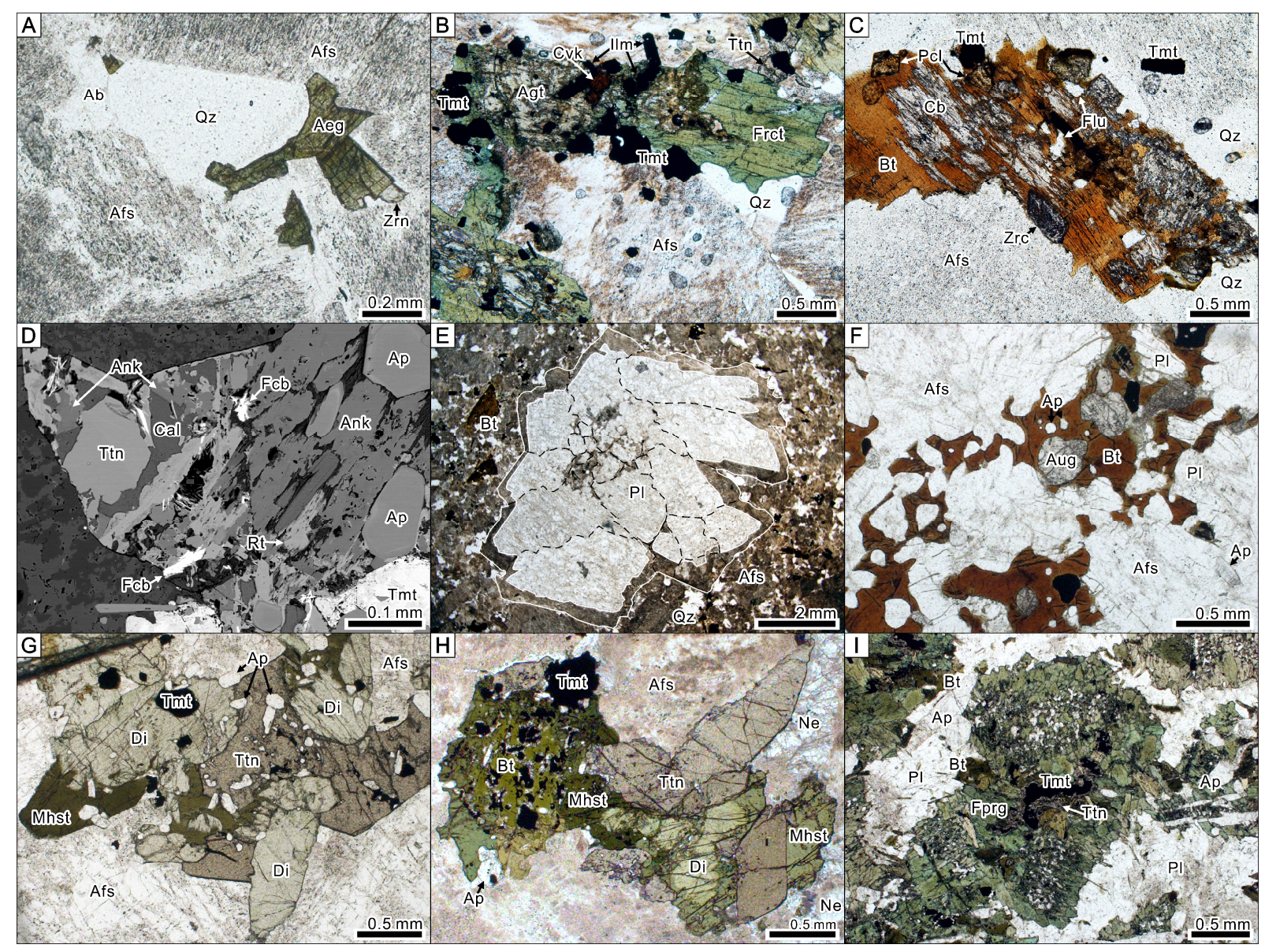

Figure 8 - Representative microtextures of rock varieties in the Itatiaia Alkaline Massif. A) AegN, MAI090. Interstitial quartz and aegirine and albite border in alkali feldspar; notice zircon crystal. B) QzAFS-I, MAI079. Typical mafic aggregates of ferrorichterite with aegirine-augite relicts and inclusions of titanomagnetite, ilmenite and chevkinite; notice titanite replacement titanomagnetite and interstitial quartz. C) $\mathrm{mA}$, MAI070B. Replacement texture in biotite by carbonates and fluorcarbonates; note the inclusions of pyrochlore, fluorite, zircon and titanomagnetite. D) N-II, MAl136 (BSE image). Association of titanite partially replaced by calcite, ankerite, rutile and REE-fluorcarbonate; notice inclusions of titanomagnetite and apatite. E) arpk-QzS, MAI108II. Plagioclase aggregate (dashed black lines) overgrown by alkali feldspar (white line); notice the fine groundmass composed by alkali feldspar and quartz. F) BtM, MAl182C. Poiquilitc biotite enclosing augite, plagioclase, titanomagnetite and apatite. G) HbIP, MAI190. Typical mafic aggregate of diopside partially replaced by magnesio-hastingsite, titanite, titanomagnetite and abundant apatite; note the sharp contact with alkali feldspar. H) NeS-II, MAI166I. Typical mafic aggregate of diopside, magnesio-hastingsite and biotite in replacement relation between them and titanite, titanomagnetite and apatite; notice nepheline and alkali feldspar. I) MG-mts, MAI178. Pseudomorph of pyroxene composed by ferro-pargasite aggregate, biotite, titanomagnetite with titanite corona and alkali feldspar; note apatite inclusions and plagioclase intercumulus. See Table 2 for abbreviations. 


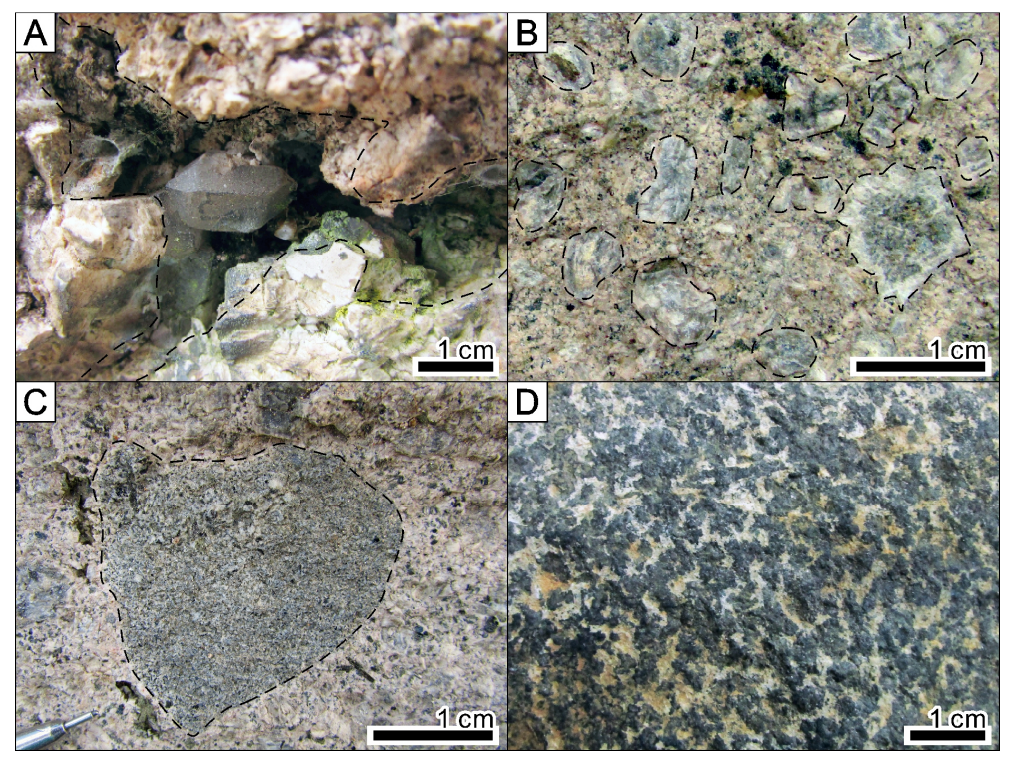

Figure 9 - Macroscopic aspects of rock-types in the Itatiaia Alkaline Massif. A) QzAFS-I, MAI128. Miarolitic cavity with quartz crystals. B) arpk-QzS, MAI122B. Porphyritic texture with fine-grained groundmass and plagioclase antecrysts; notice remarkable anti-rapakive texture to the right. C) arpk-QzS, MAl152. Rounded mafic microgranular enclave. D) MG-mts, MAl178. Cumulatic texture. Dashed lines highlight contacts.

\subsubsection{Nordmarkite II (N-II)}

This unit occurs as a C-shape that follows successive intrusions to NW, outcropping as big slabs and rocky massifs, including the Pedra do Couto Hill. The rocks are dark gray in color (IC 6-8\%) inequigranular, medium-grained, with a slightly oriented structure. Triangular miarolitic cavities are present in some samples. Tabular perthitic to mesoperthitic alkali feldspar is predominant, usually with Carlsbad twinning and albitic borders. Quartz (2-3 vol\%) is interstitial, the largest crystals occasionally bearing mafic inclusions. Idiomorphic magnetite and ilmenite, biotite, titanite and zircon are associated and apatite is rare. Subidiomorphic to idiomorphic amphibole (greenish blue to bluish gray) occurs in some samples, partially replaced with biotite and carbonate. All mafic minerals show some post-magmatic alteration, titanite being replaced with calcite, ankerite, rutile and Ca-REEfluorcarbonates (Fig. 8D). The same association fills miarolitic cavities.

\subsubsection{Anti-rapakivi quartz syenite (arpk-QzS)}

This unit represents the neck-shape transition from the ring structure of the C-S to the NW-S, outcropping mainly as metric rounded boulders and small rocky hills and slabs. The rocks are rosy to brownish gray in color and medium to coarse-grained, being characterized by a massive anti-rapakivi porphyritic to glomeroporphyritic texture (Fig. 9B). Rounded biotite-rich enclaves (up to $30 \mathrm{~mm}$ ) occur to the southeast (Fig. 9C).

Plagioclase antecrysts $\left(\mathrm{An}_{25-30}\right)$ up to $20 \mathrm{~mm}$ wide are rounded to tabular. They are gray in color and usually mantled by white rims of alkali feldspar (Fig. 8E), and occasionally oscillatory zoned. Rounded, dark brown biotite (up to $10 \mathrm{~mm}$ ) with magnetite exsolution also occurs as possible antecrysts. The matrix is composed of subidiomorphic to idiomorphic mesoperthitic alkali feldspar that 
is interstitial to granophyric quartz (6-12 vol\%), biotite and aggregates of augite, titanomagnetite and titanite. Zircon, apatite and chevkinite are also associated. Ilmenite occurs as relicts partially replaced with titanite or associated with titanomagnetite.

\subsubsection{Trachytes I (T-I)}

Trachytes occur in the transition from the C-S ring structure of to NW-S, locally intercalated with arpk-QzS. On the basis of textural and mineralogical relationship, they can be grouped into four rock variants: a) aphyric to porphyritic with aphanitic groundmass; b) biotite-rich anti-rapakivi porphyritic with aphanitic groundmass; c) porphyritic with fine-grained groundmass; and d) breccioid with aphanitic matrix. Although the contact between these variants is not clear, some domains are topographically highlighted, with no lateral continuity among them. Changes are sudden or gradual over a few meters.

Type (a) outcrops in the eastern part of the unit, from the north of the 5 Lagos Trail to Aiuruoca River Bog and, locally, to the west of the Morro da Antena Hill. These rocks are typically porphyritic with idiomorphic alkali feldspar (2-10 mm), \pm plagioclase $(1-6 \mathrm{~mm}), \pm$ biotite $(1-2 \mathrm{~mm})$ and rare amphibole phenocrysts, with an aphanitic dark gray groundmass (Fig. 10A). To the west of Morro da Antena Hill and in easternmost part of the area, they occur as a fine-grained aphyric gray rock with rare alkali feldspar phenocrysts, cut by whitish veins.

Type (b) outcrops in the western and northern parts of the unit, especially on the trail to the Pedra Furada Hill. Typically, the rocks present aphanitic gray groundmass with rounded to idiomorphic

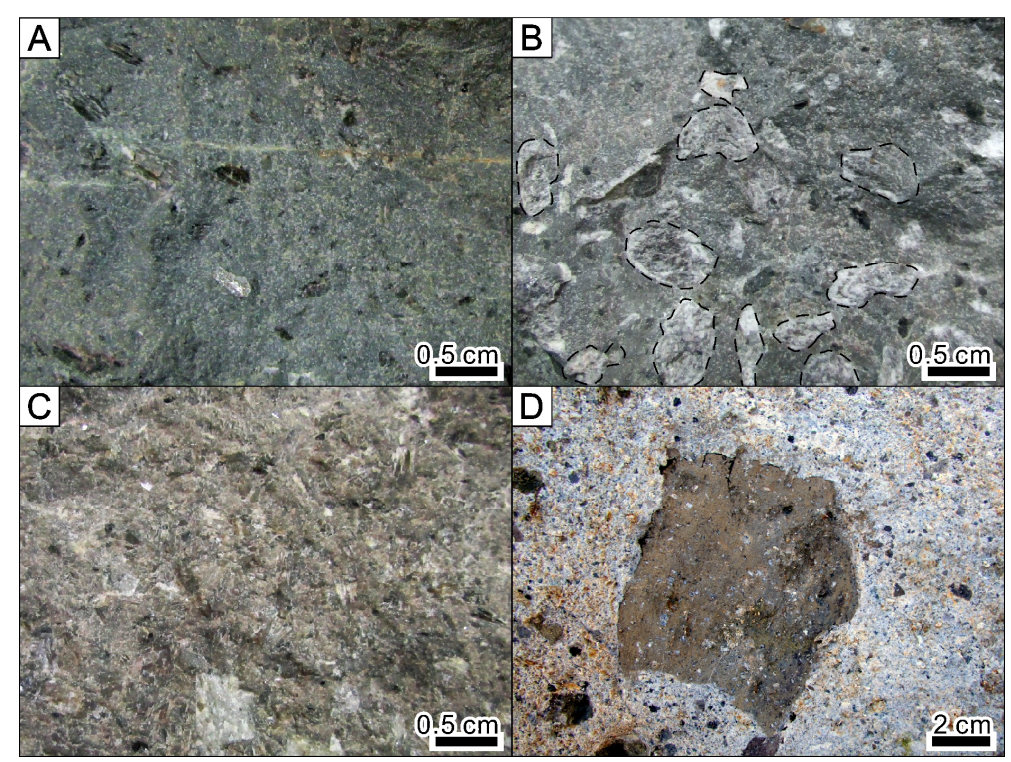

Figure 10 - Representative macroscopic aspects of T-I rock facies in the Itatiaia Alkaline Massif. A) Facies (a), MAI231. Porphyritic texture with alkali feldspar phenocrysts in aphanitic groundmass. B) Facies (b), MAI118B. Porphyritic texture with plagioclase anti-rapakivi phenocrysts (highlighted by dashed lines) in aphanitic groundmass. C) Facies (c), MAI113B. Porphyritic texture with fine-grained groundmass. D) Facies (c), trail between MAI117C and 118. Aphanitic fragment in a breccioid rock with aphanitic matrix. 
zoned anti-rapakivi alkali feldspar (5-20 mm; very similar to arpk-QzS) and biotite (2-5 mm; Fig. 10B). Locally, it is aphyric, with rare alkali feldspar megacrysts.

Type (c) outcrops on a hill to the northeast of the Camelo's Rock and on the trail to the Pedra Furada Hill. The light brown rock resemble a fine variety of arpk-QzS, with the same anti-rapakivi texture. Mineralogy is similar, but with a presence of alkali feldspar megacrysts and reduced amount of plagioclase (Fig. 10C).

Type (d) is associated to (and sometimes intercalated with) Type (b). It outcrops near the Camelo's Rock and along Carvoeiro Road and Flores' Highway to the south of the Pedra Furada Hill, on the Pedra Furada Hill summit, making up the Morro da Antena Hill, on the top of a hill to the east portion and locally to the northwest portion. These rocks show an aphanitic matrix with millimetric to centimetric (locally more than 10 or $15 \mathrm{~cm}$ ) angular fragments of aphanitic to fine-grained rock, autofragments and alkali feldspar megacrysts (Fig. 10D). Fragments of coarse-grained rock are very rare. Notably, these variants can sometimes show fluidal textures with deformed fragments.

\subsection{Northwestern Sector (NW-S)}

\subsubsection{Biotite monzonite (BtM)}

These rocks were observed only in a small quarry at km 3.8 on Flores' Highway and as some rare centimetric angular xenoliths in arpk-QzS. They are massive, greenish gray in color and inequigranular, medium-grained (IC 23\%). They are characterized by their significant amount of poikilitic biotite, with cleavage planes but no preferential orientation.

Texture shows predominance of granular alkali feldspar and plagioclase ( $\mathrm{An}_{28-35}$; locally with partial reequilibration) in equal proportions, with augite and plagioclase enclosed in poikilitic dark brown biotite (Fig. 8F). Plagioclase crystals larger than $2 \mathrm{~mm}$ usually show consertal texture, zoning, exsolution and inclusions of idiomorphic titanomagnetite and apatite. Subidiomorphic titanomagnetite and ilmenite usually intergrown. IImenite also occurs, as isolated xenomorphic crystals. Augite appears as subidiomorphic to xenomorphic grains, occasionally poikilitic (up to $1 \mathrm{~mm}$ ) and intergrown with plagioclase. Accessory phases include idiomorphic apatite ( 3.2 vol.\%) with fluid inclusions in core and xenomorphic zircon. Chlorite locally replaces biotite.

\subsubsection{Nordmarkite III ( $N$-III)}

This unit occurs on the northeastern border of NW-S, from the north of Pedra Furada Hill to the east of Fazenda Velha Town. The rocks are inequigranular, coarse to fine-grained with massive to oriented structure. The mafic minerals usually are concentrated in patches and IC is about $8-9 \%$. Millimetric miarolitic cavities seldom occur. 
Perthitic to mesoperthitic alkali feldspar (frequently with albitic border) is the most important mineral, showing a consertal texture of tabular to xenomorphic crystals, usually with polygonal interstices. Quartz (3-4 vol\%) is interstitial, seldom showing granophyric intergrowth. Subidiomorphic amphibole and idiomorphic ilmenite (commonly with a titanite corona) form irregular aggregates, which also contain biotite and \pm zircon. Biotite can form isolated subidiomorphic crystals in feldspar. Chevkinite and magnetite usually appear as xenomorphic to interstitial grains associated to quartz. Carbonate may fill cavities.

\subsubsection{Hornblende pulaskite (HblP)}

This unit occurs along part of Flores' Highway and to the west of the road to Vargem Grande Town. It represents the first manifestation of silica undersaturated rock from outer C-S inward. The rocks are inequigranular, slightly oriented and coarse-grained and are characterized by their light gray color (IC 5-25\%) with aggregates of mafic minerals (up to $10 \mathrm{~mm}$ ) and titanite crystals (up to $5 \mathrm{~mm}$; up to 2 vol\%).

These rocks are similar to those of $\mathrm{BtHbINeS}$ and $\mathrm{BtHbIP}$ and are characterized by the presence of tabular mesoperthitic alkali feldspar, with local foyaitic texture. Nepheline is interstitial and reaches $12 \%$ modal volume in the northern region, while in the southern region (only up to 3 vol\%) it is almost completely replaced with analcime. Sodalite is interstitial. Plagioclase occurs locally, partially resorbed and re-equilibrated. Associated mafic minerals are idiomorphic to subidiomorphic diopside, which in the northern region occurs just as relics rimmed by magnesio-hastingsite, magnesio-hastingsite, titanite and titanomagnetite (Fig. 8G). Subidiomorphic biotite also occurs, as isolated crystals with feldspar. Main accessory minerals are zircon and apatite.

\subsubsection{Quartz alkali feldspar syenite III (QzAFS-III)}

This is the unit with less information available, as access to the occurrence area is very limited. However, it is important for apparently forming a moon-shaped body emplaced between two nepheline-bearing units. It outcrops to the northeast of the Capivara River, between Garganta do Registro Pass and Engenho da Serra Town. These coarse-grained rocks are massive, brownish-gray (IC $\sim 9 \%)$ and inequigranular. Mesoperthitic alkali feldspars are present as subidiomorphic to xenomorphic grains with consertal texture, along with interstitial to granophyric quartz (11 vol\%) and biotite in subordinate amounts, with abundant apatite inclusions and magnetite exsolution, respectively. Subidiomorphic titanomagnetite with idiomorphic zircon, apatite and \pm biotite appear as milimetersized aggregates. Carbonates, chlorite and magnetite completely replace and/or alter subidiomorphic to interstitial pyroxene pseudomorphs. 


\subsubsection{Nepheline syenite II (NeS-II)}

This unit represents the last emplacement in the far northwest side of the plutonic units. It forms the Colina and Picú ridges, which are separated from each other by the Furnas River valley (Fazenda Velha Town), outcropping mainly as boulders.

These rocks are massive, coarse-grained, dark-gray (IC 6-10\%) and inequigranular, with tabular perthitic to mesoperthitic alkali feldspar, consertal texture and interstitial nepheline as main minerals. Locally, nepheline appears as aggregates of idiomorphic grains (up to $0.3 \mathrm{~mm}$ ) with polygonal texture (recrystallized?). Magnesio-hastingsite is present in some samples, with cores of diopside or biotite, clearly showing a complex instability relation, and subidiomorphic titanite (Fig. 8H). Locally, diopside appears as subidiomorphic or zoned grains, sometimes with thin rims of hedenbergite. A single grain of xenomorphic andradite associated with amphibole was found. Titanomagnetite is present as subidiomorphic rounded grains hosting very thin ilmenite exsolution lamellae, along with idiomorphic to subidiomorphic titanite. Accessory phases include sodalite, analcime, thainite and \pm fluorite associated with small crystals of zircon (less than $0.05 \mathrm{~mm}$ ). Sphalerite, britholite, wöhlerite, allanite and scheelite are trace minerals.

Fine-grained to aphanitic aphyric dikes of trachytes and agpaitic phonolites also occur in this unit.

\subsubsection{Metasomatized melagabbro (MG-mts) and trachybasalt (TB)}

These rocks represent the first record of mafic rocks in the Itatiaia massif along with nephelinite dykes in the southeastern border and rare xenoliths. They occur at two different spots, the first one as a few decimetric, rounded blocks in lower relief areas on the road that connects the Fazenda Velha and Colina towns, along NeS-II blocks to the west, mylonitic amphibolite to the north and covered by alluvium to the east. The second spot comprises abundant decimetric to metric tabular blocks on the northern hillside of the trail to Pedra do Picú.

MG-mts shows massive cumulatic texture, with color index of about 77\% (Fig. 9D). However, these rocks have been altered by metasomatism and the original paragenesis appears to have been overprinted by post-magmatic replacement and/or recrystallization of the original phases. The cumulus consists of pyroxene pseudomorphs formed by aggregates of granular to xenomorphic ferropargasite, with interstitial magnetite, titanite, biotite and plagioclase (Fig. 8I). Locally, rounded cores of actinolite rimmed by high concentration ring of fine crystals of biotite, titanite, idiomorphic magnetite and amoeboid albite occur. IImenite is also present as xenomorphic grains rimmed by titanite and idiomorphic apatite (up to $2 \mathrm{~mm}$ ). The intercumulus is represented by xenomorphic plagioclase (relicts $A n_{37-44}$ and re-equilibrated $A n_{24-29}$ ) and albite with consertal texture, the latter locally and close to mafic minerals. Alkali feldspar is rare and occurs as idiomorphic crystals (up to 2 
$\mathrm{mm}$ ) completely exsolved as very thin albite needles and a K-feldspar mass. Pyrite occurs as an accessory mineral.

TB is porphyritic, with idiomorphic phenocrysts (1-4 mm) of plagioclase $\left(A n_{45-50}\right)$, titanomagnetite and pseudomorph of pyroxene (replaced with chlorite and other unidentified minerals). The matrix is dark gray and very fine-grained, composed of acicular feldspar and pyroxene $(<0.2 \mathrm{~mm})$.

\subsubsection{Trachytes II (T-II)}

These rocks occur in central NW-S and form the crest of the Picú Ridge. Its area of occurrence is possible overestimated because of the very limited access. The Pedra do Picú rock (a $120 \mathrm{~m}$ high landmark in the shape of a shark fin; Fig. 11A) consists of porphyritic trachyte, with alkali feldspar phenocrysts and a brownish aphanitic groundmass (Fig. 11B). A few sin-magmatic, irregular subhorizontal aphyric dykes cut through their walls. About 100 meters to west, breccia is present with centimetric to decimetric angular fragments and auto-fragments. The fragments are aphanitic to fine-

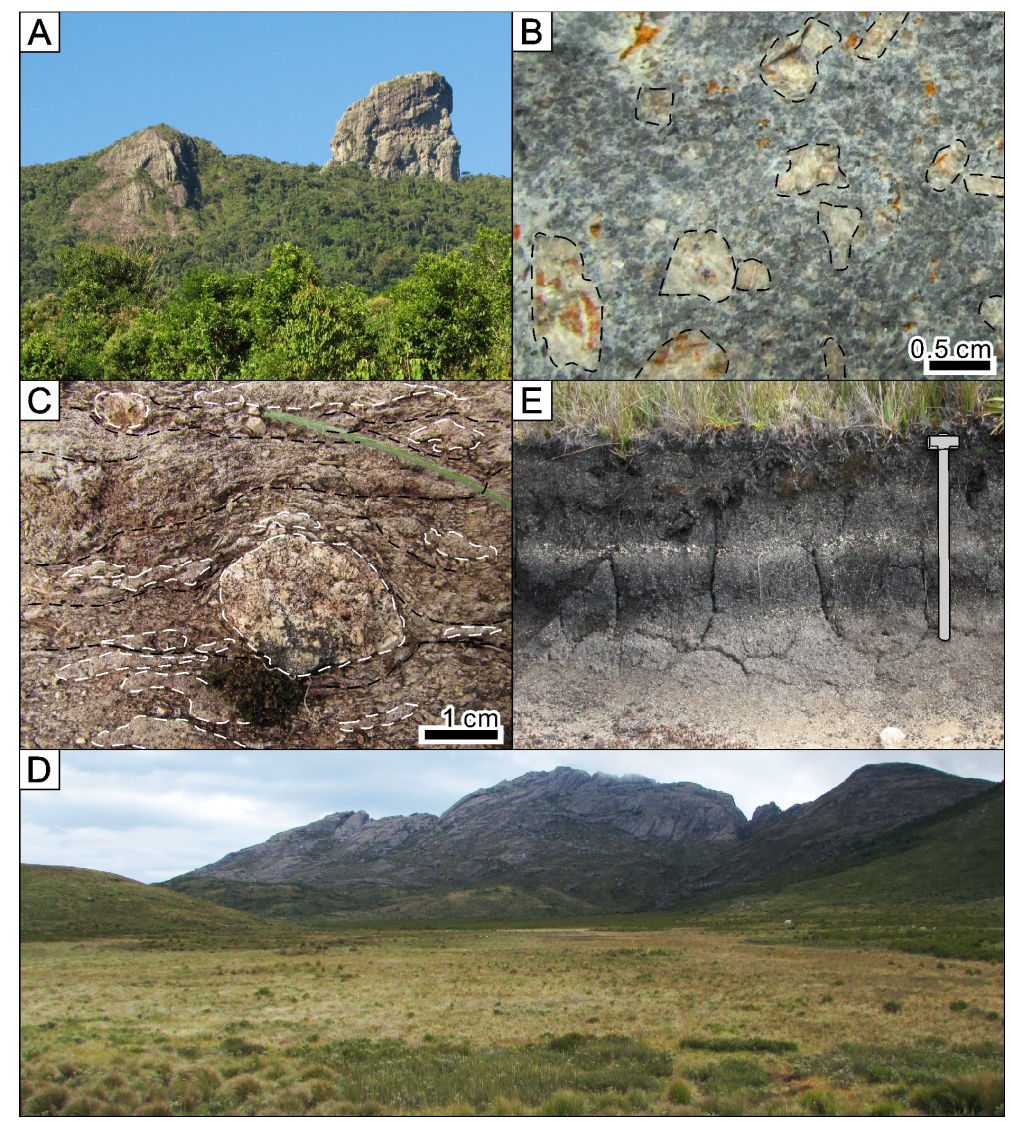

Figure 11 - A) Panoramic view to Pedra do Picú, right. B) T-II, MAl165. Porphyritic texture with aphanitic groundmass and alkali feldspar phenocrysts. dashed lines. C) Rocky hill at left of Pedra do Picú in A. Breccia with a very orientated groundmass and deformed fragments. Dashed lines highlight structure and contacts. D) Panoramic View from Rancho Caído Trail. Preto River Bog in the C-S. Note the Agulhas Negras Peak (center) and Pedra do Sino Hill (right). E) West side of the Aiuruoca River Bog. Typical alluvium deposit. 
grained, while in some places the matrix is strongly orientated, with plastically deformed fragments (Fig. 11C).

In the eastern part of this unit, a different moon-shaped geomorphological feature showing rugged terrain and rocky hills is exposed. The only sample collected from the northern edge is characterized by a massive white variant, by the small grain size and by the porphyritic tendency. Large idiomorphic alkali feldspar crystals (up to $5 \mathrm{~mm}$ ) stand out in a fine-grained groundmass composed of alkali feldspar, quartz and opaque minerals.

\subsection{Sedimentary deposits}

Talus deposits occur in almost the entire massif border, especially in the southwestern region due to the steeper topographic gradient. The deposits are heterogeneous, ranging from decametric angular breccias boulders to conglomerates with centimetric clasts in the distal parts. Bauxite is also present, associated to talus and in vegetation-covered slopes in the nepheline-bearing units. At the Alambari River, the ramp of deposits extends for over $11 \mathrm{~km}$, with fluted erosion on some of the largest boulders. Three SW-NE elongated hills with $360 \mathrm{~m}$ thick talus are concentrated between the City of Itatiaia and the park entrance. At C-S foothills, there are evident piles of rolled blocks. Rolled boulders also occur throughout the massif.

Alluvium deposits occur mainly over C-S form bogs in valleys and depressions (Fig. 11D). Such deposits are composed mainly of mud and peat, with coarser grains and centimetric clasts in the more proximal areas. The largest alluvia have its edges two to three meters above the current water level (Fig. 11E).

\section{Geological evolution}

Magmatism in the Itatiaia Alkaline Massif (71.3 to $67.5 \mathrm{Ma}$, unpublished data) followed a regional uplift that took place from 90 to $75 \mathrm{Ma}$ and finished before tectonic collapse and development of the Continental Rift of Southeastern Brazil 55 to 40 Ma ago (Riccomini, 1989; Zalán \& Oliveira, 2005; Cogné et al., 2011, 2012; Engelmann de Oliveira et al., 2016; Salgado et al., 2016). The massif is adjacent to the Resende Basin and was emplaced near the Queluz Accommodation Zone, which separates the Paraíba do Sul Rift into two different tectonic patterns (Zalán \& Oliveira, 2005). It stands out as a remarkable elongated topographic structure, one of the few elongated ones in the province and the only one oriented to WNW (Fig. 2), which is in accordance with the accommodation zones of the rift system and the transfer zones of the South Atlantic Ocean Plate (Meisling et al., 2001; Zalán \& Oliveira, 2005; Cogné et al., 2012; Stanton et al., 2014; Negrão et al., 2015).

A tension relief due to regional uplift could have progressively changed the accommodation zone (like a zip fastening), causing migration of the decompression zone and the partial melting that 
resulted in magma generation. The IAM then formed as a result of the evolution a migratory magmatic center, as successive moon-shape intrusions for over $30 \mathrm{~km}$ along an axis oriented from southeast to northwest, with ring structures arranged into three sectors with distinct lithological and geomorphological characteristics: Southeastern, (SE-S), Central (C-S) and Northwestern (NW-S). Itatiaia Alkaline Massif is one of the few ring complexes whose origin involved migration of a magmatic center (e.g. Wadi Dib, Egypt; Frisch \& Abdel-Rahman, 1999; Ras ed Dom, Sudan, O’Halloran, 1985). This characteristic of the massif permitted good preservation and clear distinction of magmatic pulses, since previous intrusions were not mixed and/or erased.

\subsection{Emplacement stages}

The lithological variants can be divided into several clearly identifiable facies based on mineralogical and petrographical features, such as texture and modal variation of felsic and mafic mineral content. They include feldspathoid-bearing or quartz-bearing syenites, trachytes, granite, monzonite, gabbro and trachybasalt, resulting in 21 units that represent the different magmatic pulses. Sin- to tardi-plutonic dykes of nephelinites, phonolites, trachytes and rhyolites are also present.

The early magmatic intrusions (first stage) are represented by alkaline rock-types in SE-S and are almost entirely emplaced into CRSB. Apparently, SE-S was not strongly affected by the development of the rift system, as its rocks in do not show expressive magmatic foliation nor have been deformed into shear zones, which suggests that they intruded their hosts as most liquid magma, without undergoing crystallization under significant stress conditions. Apparently, the radial lineament pattern in the northern and eastern regions is post-magmatic. Although migration to NW was already present, it is not clear if a temporal gap occurred between the emplacement of SE-S and C-S, although suggested by the morphological and petrographical setting.

$\mathrm{NeS}-\mathrm{I}$ is the most silica-undersaturated unit and it has garnet-sillimanite-muscovite-biotite schists of the Embú Group in Ribeira Belt as wall rocks (Eirado et al., 2006; Heilbron et al., 2016). Assimilation of peraluminous minerals could have led to crystallization of corundum and hercynite in such a silica deficient magma. The association of plagioclase, hercynite and corundum found in these rocks could suggest garnet rebalancing (Mariga et al., 2006). Mafic microgranular enclaves also is common in the peraluminous samples (Figs. 6A and B).The fine-grained inner varieties of this facies could represent small stocks, but their fieldwork control is very difficult due to vegetation and topography. Evidence of assimilation from wall rock units was not found in other plutonic units.

The second stage emplaced a large silica-undersaturated intrusion of BtAgtNeS in Central IAM. The peralkaline facies makes up the crest of the circular ridge. This variant, that could correspond to a late magmatic stage, do not show any evidence of caldera subsidence. The trachytic sin-plutonic dikes could be related to the intrusion of BtHbIP. This magma pulse is similar to the SE-S cluster, but the 
subsequent one evolved with an increase in silica content and, in some way, crossed the thermal barrier of nepheline-quartz to the silica-oversaturated types. Isotopic data shows crustal contamination in quartz-bearing rocks (Brotzu et al., 1997; Rosa, unpublished data). The first C-S intrusions are concentric, but QzASF-II resumed migration to NW.

The quartz-bearing rocks do not show clear evolutive relations among themselves. AegN and $\mathrm{N}-\mathrm{I}$ intrude between $\mathrm{BtAgtNeS}$ and $\mathrm{BtHbIP}$ and are possibly the first $\mathrm{SiO}_{2}$-supersaturated manifestation. $\mathrm{N}-$ II occurs in a similar location, although in a certainly younger geological relation. QzAFS-I and -II and their internal facies apparently show a weak gradational increase in quartz content and orientation with a decrease in granulation and color index to the northwest. $\mathrm{mA}$ is the most evolved quartz-bearing unit of the massif. It intrudes QzAFS-II, although no contact has been observed between them. It is possibly a product of QzAFS-II internal differentiation contemporary to the rhyolite dikes. mA shape and location suggest development linked to the VLL, as evidenced by the strong parallel fracturing and the frequent quartz veins, however it has a massif structure. On the other hand, the presence of miarolitic cavities, especially in QzAFS-I, may suggest relatively shallow crystallization.

The transition between C-S and NW-S is marked by arpk-QzS and T-I, but their temporal relation is not clear and they apparently intrude part of N-III. NW-S represents a third stage, since geological features and lithotype associations change in both sectors, the caldera-shaped structure fades away and the magmatic center resumes migration, with intrusions similar to SE-S. There is no sufficient information on the quartz-bearing rocks of NW-S. The location and some textures of N-III and QzAFS-III (e.g. magmatic orientation of $\mathrm{N}$-III and both presenting mafic agglomerates) could suggest that they are border facies of HbIP with large country rock assimilation. But this is unlikely, since they are similar in extension and HbIP gradates (increase in the nepheline, amphibole and titanite content) northward. NeS-II was the last plutonic unit to emplace and bears great textural similarities with NeS-I, although it has amphibole as a late magmatic phase instead of aegirine.

$\mathrm{T}-\mathrm{I}(\mathrm{d}), \mathrm{T}-\mathrm{II}$ and TB could represent a fourth magmatic stage, corresponding to subvolcanic conducts with epigenetic characteristics, as suggested by aphanitic auto-fragments and locally fluidal deformation.

\section{Petrographic sets}

The lithological variants of Itatiaia Alkaline Massif can be divided into several clearly identifiable units based on mineralogical and petrographical features such as texture and modal variation of felsic and mafic minerals. A summary of crystallization sequence and paragenesis in the magmatic stages for each unit of the IAM are in Tab. 1. They comprise three main lithological variants: feldspathoid-bearing syenites, quartz-bearing syenites and basic rocks. These rocks can be 
distinguished in five petrographic sets (Fig. 12): (1) plagioclase-free nepheline syenites, (2) plagioclasebearing nepheline syenite and pulaskites, (3) nordmarkite-granite series, (4) anti-rapakivi association and (5) basic rocks.

\subsection{Nepheline-bearing syenites}

In general, the comparative mineralogy among nepheline-bearing syenites of all the IAM sectors indicates that all variants have similar paragenesis, with apatite, zircon, titanomagnetite, tilmenite and diopside, alkali feldspar and nepheline. The textural and mineralogical variations permit to conclude that two crystallization pathways led to the generation of two sets:

Plagioclase-free (1) - for units NeS-I, SdINeS, AegNeS-foy, SdINeS and NeS-II, which are of sodic tendency, more silica-undersaturated (10-35\% foid modal) and more felsic (IC 5-16\%), pyroxene variation is represented by diopside $\rightarrow$ aegirine-augite $\rightarrow$ aegirine (except in NeS-II), low content of biotite, titanite, titanomagnetite and apatite and local presence of agpaitic minerals (låvenite, hiortdahlite and hainite, besides astrophyllite, rinkite, rosenbuschite and catapleiite). These minerals are dispersed throughout the rocks as interstitial phases and/or aggregates of acicular crystals associated or replacing miaskitic minerals (aegirine-augite, ilmenite/titanomagnetite, zircon and biotite), which with the presence of abundant sodalite, indicate a transitional system from miaskitic to agpaitic rocks (Sørensen, 1997; Marks et al., 2011; Andersen et al., 2016; Melluso et al., 2016). AegNeSfoy shows the highest levels of agpaitic minerals, while in facies of the southeastern border of NeS-I and crest areas of BtAgtNeS they are more abundant. Agpaitic rocks in the external areas of ring complexes also occur in other localities, e.g., Poços de Caldas (Ulbrich, 1993) and Pilanesberg (Andersen et al., 2016), interpreted as late manifestations and related to caldera system collapse.

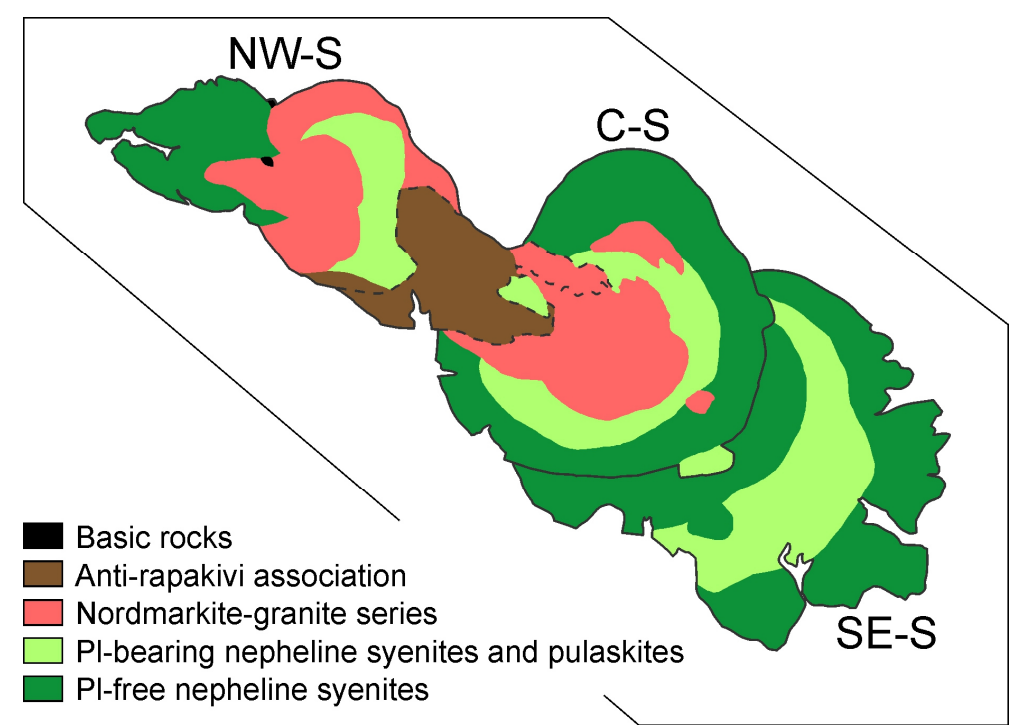

Figure 12 - Simplified map of the Itatiaia alkaline massif (Figure 2) showing its Southeastern, Central and Northwestern sectors and their petrological sets. 
Plagioclase-bearing (2) - BtHbINeS, BtHbIP and HbIP show a potassic-calcic tendency, lower silica-undersaturation (0-15\% foid modal), higher mafic content (IC 10-28\%), diopside relics rimmed by magnesio-hastingsite, high content of biotite, titanite, titanomagnetite and apatite and presence of plagioclase, usually with anti-rapakivi texture. The largest plagioclase crystals show the highest An (40$50 \%)$ and their cores are less re-equilibrated. The presence of plagioclase and diopside with replacement textures, lower foid content and higher IC could indicate interaction with a more basic magma in an early stage. However, mafic enclaves or any suggestive texture were not found.

Alternation of nepheline syenite types indicates changes in intensive parameters $\left(\mathrm{fO}_{2}, a \mathrm{H}_{2} \mathrm{O}\right.$, $\left.a \mathrm{SiO}_{2}\right)$ and magmatic process such as magma mixing, different degrees of contamination and fractioning of mafic minerals in a resident chamber. These rock sets bear similarities with SA and $A$ types, respectively, as described by Brotzu et al. (1997), who interpreted A type as predominant and SA-types as later intrusions. In the present study we observed that in SE-S both these types are intercalated. In C-S, Pl-free composes the external ring and the PI-bearing internally, while in the NW$\mathrm{S}$ they do not have contact relations, but PI-bearing occurs first and the Pl-free is the youngest plutonic unit of the massif.

\subsection{Quartz-bearing syenites}

Quartz-bearing rocks occur in inner C-S without contact with the country rocks, in the transition from C-S to NW-S and across NW-S. They typically exhibit post-magmatic replacement features, with largely sericitized feldspar and mafic phases replaced with oxides, carbonates or fluorcarbonates. Almost all units show miarolitic cavities. Two sets were identified based on mineralogy and texture:

Nordmarkite-granite series (3) - AegN, N-I, N-II, N-III, QzAFS-I, QzAFS-II, QzAFS-III and mA had similar initial paragenesis, with \pm apatite, zircon, \pm ilmenite, titanomagnetite, augite/aegirine-augite and alkali feldspar. In these units, quartz initiates the crystallization in different magmatic stages, with variations in modal volume, grain size and texture. The presence of clinopyroxene and amphibole is variable, with units in which amphibole is absent (AegN and $\mathrm{N}-\mathrm{II}$ ), or clinopyroxene is replaced ( $\mathrm{N}-\mathrm{I}$, QzAFS-I and N-III), or clinopyroxene lacks (QZAFS-II) or are both absent ( $\mathrm{MA})$, probably resulting from particular variation of $\mathrm{fO}_{2}$ and $a \mathrm{H}_{2} \mathrm{O}$ during evolution. The nordmarkite occurrences do not show a clear evolutive relation among themselves, since they are not in contact with each other, while QzAFS-I, QzAFS-II and $\mathrm{mA}$ are apparently in direct connection. T-I(a) and T-II also bear mineralogical similarities with this series, although they formed in a different geological context. T-II intrudes the central part of NW-S and constitutes the Pedra do Picú, possibly representing a well-preserved volcanic neck. 
Table 1 - Crystallization sequence of plutonic units and paragenesis of magmatic stages of the Itatiaia Alkaline Massif. Volume percent of feldspathoid or quartz, respectively (Foid or Qz), index color, total mafic mineral volume percent (IC). Character formatting denotes modal content: principal (>10\%, bold); accessory $(1<\%<10$, normal case); trace $(<1$, italics). Local paragenesis [ ]; replacement associations ( ); antecrysts \{\}; absence of clinopyroxene (Cp*, striked). Unit abbreviations are the same as those of Figure 2.

\begin{tabular}{|c|c|c|c|c|c|c|c|}
\hline & Unit & Foid or Qz & IC & Early & Main & Late & Post \\
\hline \multirow{4}{*}{ 岂 } & NeS-I & $30-35$ & $5-6$ & Tmt, Ttn, $A p$ & Agt, Ne, Afs [Cpx, PI, Her, Crd, Rt] & Aeg, Sdl, Hio, $[K u p], P c l,(A m p, B t)$, Anl & $C c n, C a t, C b, M s$ \\
\hline & BtHbINeS & $5-15$ & $8-20$ & $\{\mathrm{Pl}\}, \mathrm{Ap}, \mathrm{Zrn}, \mathrm{Tmt}, \mathrm{Di}$ & Afs, Ttn, Ne, Mhst & $\mathrm{Bt}, \mathrm{sdl}$ & Ccn \\
\hline & SdINeS & $10-15$ & $5-12$ & $A p, Z r n, T m t, D i$ & Ttn, Ne, Afs, Agt, Sdl & Bt, Låv, Pcl, Flu, Amp & $\mathrm{Cb}$ \\
\hline & AegNeS-foy & 30 & 9 & $A p, \mathrm{Zrn}, \mathrm{Tmt}, \mathbf{N e}$ & Afs, Ttn, Aeg, IIm, Bt & Låv, Arf, Sdl, Ang, Ast, Flu & \\
\hline \multirow{9}{*}{ ù } & BtAgtNeS & $8-25$ & $12-20$ & $A p, Z r n, T m t, I I m$ & Afs, Ttn, Ne, Agt & Aeg, Bt, Sdl, [Låv, Arf, Rnk, Rsb, Sp] & \\
\hline & BtP & $0-5$ & $11-22$ & $\{\mathrm{Pl}\}, A p, \mathrm{Tmt}, \| l m, \mathrm{Di}, \mathrm{Zrn}$ & Afs, Mhst, Ttn & $Z c l, P y, G n, \mathrm{Ne}, S d l, \mathrm{Bt}, \mathrm{Hst}, \mathrm{Flu}, \mathrm{Anl}$ & \\
\hline & AegN & $3-4$ & $9-10$ & $\mathrm{Zrn}, \mathrm{Tmt}, \mathrm{IIm}$ & Afs, Agt, $C v k$ & $\mathrm{Qz}, A e g, A b, P y, P c l$ & (Ank, Flu, REE-Fcb, IIm) \\
\hline & $\mathrm{N}-\mathrm{I}$ & $2-4$ & $9-11$ & $\{P I\}, A p, Z r n, T m t, I I m, A u g$ & Afs, Ttn, Agt & Rct, Bt, Qz & \\
\hline & QZAFS-I & $5-8$ & $9-11$ & $Z r n, I I m, A p, A g t$ & Tmt, Frct, $C v k$, Afs, Ttn & Qz, Bt & \\
\hline & QzAFS-II & $12-18$ & $7-10$ & $A p, Z r n, T m t, I I m$ & Amp, Afs, Bt, Cvk & $\mathrm{Qz}, \mathrm{Bt},[F / u, A l n], A b$ & {$[C b]$} \\
\hline & $\mathrm{mA}$ & 26 & 5 & Ap, Zrn, Tmt & Afs, $P c l, Q z$, Flu & $C v k, \mathrm{Bt}, \mathrm{Mnz}, X t m, A b$ & $\mathrm{Cb}$ \\
\hline & $\mathrm{N}-\mathrm{II}$ & $2-3$ & $6-8$ & $A p, Z r n, I I m, T m t$ & Di, Ttn, Afs & $\mathrm{Qz}, \mathrm{Bt}, C_{v k}, A b, A n k$ & (Cal, Ank, Rt, REE-Cb) \\
\hline & arpk-QzS & $6-12$ & $6-10$ & $\{\mathrm{PI}, \mathrm{Bt}\}, A p, \mathrm{Zrn}, \mathrm{IIm}, \mathrm{Tmt}, \mathrm{Di}$ & Cvk, Afs, Aug, Ttn & Bt, $\mathbf{Q z}$ & \\
\hline \multirow{5}{*}{$\sum_{z}^{n}$} & $\mathrm{~N}-\mathrm{III}$ & $3-4$ & $8-9$ & $Z r n, I I m$, Aug & Afs, Tmt, Ttn, Amp, Bt & $C v k, Q z, A b$ & $C b$ \\
\hline & BtM & - & 23 & Ap, IIm, Tmt & $Z r n$, Aug, PI, Afs & $\mathrm{Bt}$ & Chl \\
\hline & MG-mts & - & 77 & Ap, IIm & Ep*, PI & Py, Ttn & (Fprg, Mt, Ttn, Bt)? \\
\hline & HblP & $3-12$ & $9-18$ & $\{P l\}, A p, Z r n, T m t, D i$ & Afs, Ttn, Ne, Mhst & $\mathrm{Bt}, \mathrm{Hst}, \mathrm{Sdl}, \mathrm{Anl}$ & Cen \\
\hline & QzASF-III & 9 & 11 & $A p, Z r n$ & Ttn, Cpx, Afs, Bt & Qz & \\
\hline
\end{tabular}
NeS-II
10-15
6-10
$A p, A d r$, Tmt, $A l n, D i$
Afs, $\mathrm{Ne}, \mathrm{Hd}$, Mhst, Ttn
Bt, Hst, Hai, Sdl, Zrn, Flu, Brt, Sp, Shl, Anl

Abbreviations: Ab, albite; Adr, andradite; Aeg, aegirine; Afs, alkali feldspar; Agt, aegirine-augite; Aln, allanite; Amp, amphibole; Ang, aenigmatite; Ank, ankerite; Anl, analcime; Ap, apatite; Arf arfvedsonite; Ast, astrophyllite; Aug, augite; Brt, britholite; Bt, biotite; Cal, calcite; Cat, catapleiite; Cb, carbonate; Ccn, cancrinite; Chl, chlorite; Cpx, clinopyroxene; Crd, corundum; Cvk, chevkinite; Di, diopside; Flu, fluorite; Fprg, ferro-pargasite; Frct, ferro-richterite; Gn, galene; Hai, hainite; Hst, hastingsite; Hbl, hornblende; Her, hercynite; Hio, hiortdahlite; Ilm, ilmenite; Kup, kupletskite; Låv, låvenite; Mhst, magnesio-hastingsite; Mnz, monazite; Ms, muscovite; Mt, magnetite; Ne, nepheline; Pcl, pyrochlore; Pl, plagioclase; Py, pyrite; Qz, quartz; Rct, riebeckite; REE$\mathrm{Cb}$, REE-carbonate; REE-Fcb, REE-fluorcarbonate; Rnk, rinkite; Rsb, rosenbuschite; Rt, rutile; Sdl, sodalite; Shl, scheelite; Sp, sphalerite; Tmt, titanomagnetite; Ttn, titanite; Xtm, xenotime; Zcl, zirconolite; Zrn, zircon. 
Anti-rapakivi association (4) - the relation among arpk-QzS, T-I(b) and T-I(c) is a very close one: all of them exhibit the same anti-rapakivi porphyritic tendency in appearance and mineralogy (Figs. 9B and 10B). In the field, in most cases it is very difficult to establish their limits, that are sometimes either abrupt or gradual. arpk-QzS has a characteristic glomeroporphyritic anti-rapakivi texture, locally containing two types of mafic enclaves: a rounded one, very fine-grained and aphyric, similar to that of $\mathrm{T}-\mathrm{I}(\mathrm{b})$ and an rounded to irregular fine-grained one that resembles BtM xenoliths (Fig. 9C), given that their petrography is the same (biotite inclusion in plagioclase renders the same poikilitic texture of BtM). These structural and textural features suggest magma mixing adjacent to the west portion, where one of the components could be BtM.

\subsection{Basic rocks}

Melagabbric to trachybasaltic rocks (5) - Other minor rock types of the Itatiaia Alkaline Massif (MG-mts and TB) show unclear geological connections with the syenitic rocks. MG-mts could stand for an older and/or deeper portion of the chamber brought to a shallow level by tectonic-magmatic processes, although field relations do not allow such an assertion. Cumulatic gabbros occur in a few localities in the Serra do Mar Province, e.g., Ponte Nova (Azzone et al., 2009) and Morro de São João (Brotzu et al., 2007), but this is their first description in IAM. TB is the last magmatic manifestation of the IAM and apparently intrudes the T-II. It bears mineral similarities to MG-mts and they could be connected.

\section{Acknowledgments}

Thank you Michael Marks, Rogério Guitarrari Azzone and Gaston Eduardo Enrich Rojas for the discussions! Thanks a lot for the fieldworks help, Bruna Miraya, Caio Santos (2x!), Claudio Mora, Emanuel Amorer, Geovanne Moreira, Igor Barboza, Julio Cauhy, Lucaz Inglez, Ludmila Teixeira, Maria Paula Ramos, Matheus Caseri, Pedro Angelini, Rafael Capelle, Rafaela Gengo and Saulo Vieira! Thanks to FAPESP for the financial support (Processes 2012/19184-1, 2012/06082-6 and 2015/19974-0). Thanks to the Itatiaia National Park for the logistical support, permissions and directions, especially to Gustavo Tomzhinski, Léo Nascimento, Leonardo Cândido and Marcão's station staff.

Congratulations to the Itatiaia National Park for its 80 years of existence!

\section{References}

Algarte, J. P. (1972). A Influência dos Arqueamentos Cratônicos no Condicionamento das Alcalinas dos Estados de São Paulo e Paraná. Congresso Brasileiro de Geologia. Belém: SBG - Sociedade Brasileira de Geologia, 65-69.

Almeida, F. F. M. de (1967). Origem e evolução da Plataforma Brasileira. DNPM, Divisão de Geologia e Mineralogia, Boletim 241, 1-36. 
Almeida, F. F. M. de (1969). Diferenciação tectônica da plataforma brasileira. Congresso Brasileiro de Geologia. Salvador: SBG - Sociedade Brasileira de Geologia, 29-46.

Almeida, F. F. M. de (1971). Condicionamento tectônico do magmatismo alcalino mesozóico do Sul do Brasil e do Paraguai ocidental. Anais da Academia Brasileira de Ciências 43, 835-836.

Almeida, F. F. M. de (1976). The system of continental rifts bordering the Santos Basin, Brazil. Anais da Academia Brasileira de Ciências 48, 15-26.

Almeida, F. F. M. de (1983). Relações tectônicas das rochas alcalinas mesozóicas da região meridional da plataforma sul-americana. Revista Brasileira de Geociências 13, 139-158.

Almeida, F. F. M. de (1991). O Alinhamento Magmático de Cabo Frio. $2^{\circ}$ Simpósio de Geologia do Sudeste. São Paulo: SBG - Sociedade Brasileira de Geologia/SP-RJ, 423-428.

Almeida, F. F. M. de, Carneiro, C. D. R. \& Mizusaki, A. M. P. (1996). Correlação do magmatismo das bacias da margem continental brasileira com o das áreas emersas adjacentes. Revista Brasileira de Geociências26, 125-138.

Alves, A., Janasi, V. de A. \& Campos Neto, M. da C. (2016). Sources of granite magmatism in the Embu Terrane (Ribeira Belt, Brazil): Neoproterozoic crust recycling constrained by elemental and isotope ( $\mathrm{Sr}-\mathrm{Nd}-\mathrm{Pb})$ geochemistry. Journal of South American Earth Sciences 68, 205-223. doi: 10.1016/j.jsames.2015.10.014.

Alves, A., Pereira, G. de S., Janasi, V. de A., Higgins, M., Polo, L. A., Juriaans, O. S. \& Ribeiro, B. V. (2015). The origin of felsic microgranitoid enclaves: Insights from plagioclase crystal size distributions and thermodynamic models. Lithos. Elsevier B.V. 239, 33-44. doi: 10.1016/j.lithos.2015.09.027.

Andersen, T., Elburg, M. \& Erambert, M. (2016). The miaskitic-to-agpaitic transition in peralkaline nepheline syenite (white foyaite) from the Pilanesberg Complex, South Africa. Chemical Geology. Elsevier B.V. doi: 10.1016/j.chemgeo.2016.08.020.

Azzone, R. G., Ruberti, E., Rojas, G. E. E. \& Gomes, C. de B. (2009). Geologia e Geocronologia do Maciço Alcalino Máfico-Ultramáfico Ponte Nova (SP-MG). Geologia USP. Série Científica 9, 23-46. doi: 10.5327/Z1519-874X2009000200002.

Bellieni, G., Montes-Lauar, C. R., De Min, A., Piccirillo, E. M., Cavazzini, G., Melfi, A. J. \& Pacca, I. G. (1990). Early and Late Cretaceous magmatism from São Sebastião Island (SE-Brazil): geochemistry and petrology. Geochimica Brasiliensis 4, 59-83. doi: 10.21715/gb.v1i4.31.

Brade, A. C. (1956). A Flora do Parque Nacional. Boletim do Parque Nacional do Itatiaia. Itatiaia 5, 1111.

Brotzu, P. et al. (2007). Petrogenesis of the Early Cenozoic potassic alkaline complex of Morro de São João, southeastern Brazil. Journal of South American Earth Sciences 24, 93-115. doi: 10.1016/j.jsames.2007.02.006.

Brotzu, P., Gomes, C. B., Melluso, L., Morbidelli, L., Morra, V. \& Ruberti, E. (1997). Petrogenesis of coexisting SiO2-undersaturated to $\mathrm{SiO} 2$-oversaturated felsic igneous rocks: The alkaline complex of Itatiaia, southeastern Brazil. Lithos 40, 133-156. doi: 10.1016/S0024-4937(97)00007-8.

Brotzu, P., Melluso, L., D'Amelio, F. \& Lustrino, M. (2005). Mafic/ultramafic dykes and felsic intrusions with potassic to ultrapotassic affinity in the Serra do Mar province: a review. In: CominChiaramonti, P. \& Gomes, C. B. (eds) Mesozoic to Cenozoic alkaline magmatism in the Brazilian Platform. São Paulo: EDUSP-FAPESP, 443-472.

Campos Neto, M. D. C., Basei, M. A. S., Assis Janasi, V. De \& Moraes, R. (2011). Orogen migration and tectonic setting of the Andrelândia Nappe system: An Ediacaran western Gondwana collage, south of São Francisco craton. Journal of South American Earth Sciences. Elsevier Ltd 32, 393406. doi: 10.1016/j.jsames.2011.02.006. 
Carvalho, B. B., Janasi, V. de A. \& Henrique-Pinto, R. (2014). Geochemical and Sr-Nd-Pb isotope constraints on the petrogenesis of the K-rich Pedra Branca Syenite: Implications for the Neoproterozoic post-collisional magmatism in SE Brazil. Lithos 205, 39-59. doi: 10.1016/j.lithos.2014.06.016.

Cawthorn, R. G. (2015). The geometry and emplacement of the Pilanesberg Complex, South Africa. Geological Magazine 152, 802-812. doi: 10.1017/S0016756814000764.

Chiessi, C. M. (2004). Tectônica cenozóica do Maciço Alcalino de Passa Quatro (SP-MG-RJ). S?o Paulo, Universidade de São Paulo. doi: 10.11606/D.44.2004.tde-10042014-161924.

Cioffi, C. R., Campos Neto, M. C., Moller, A. \& Rocha, B. C. (2015). Paleoproterozoic continental crust generation events at 2.15 and $2.08 \mathrm{Ga}$ in the basement of the southern Brasília Orogen, SE Brazil. Precambrian Research 275, 176-196. doi: 10.1017/СВ09781107415324.004.

Cogné, N., Gallagher, K. \& Cobbold, P. R. (2011). Post-rift reactivation of the onshore margin of southeast Brazil: Evidence from apatite (U-Th)/He and fission-track data. Earth and Planetary Science Letters 309, 118-130. doi: 10.1016/j.epsl.2011.06.025.

Cogné, N., Gallagher, K., Cobbold, P. R., Riccomini, C. \& Gautheron, C. (2012). Post-breakup tectonics in southeast Brazil from thermochronological data and combined inverse-forward thermal history modeling. Journal of Geophysical Research: Solid Earth 117, B11413. doi: 10.1029/2012JB009340.

Comin-Chiaramonti, P., Gomes, C. B., De Min, A., Ernesto, M. \& Gasparon, M. (2015). Magmatism along the high Paraguay River at the border of Brazil and Paraguay: A review and new constraints on emplacement ages. Journal of South American Earth Sciences 58, 72-81. doi: 10.1016/j.jsames.2014.12.010.

Eirado, L. G., Heilbron, M. \& Almeida, J. C. H. (2006). Os Terrenos Tectônicos Da Faixa Ribeira Na Serra Da Bocaina E Na Baía Da Ilha Grande, Sudeste Do Brasil. Revista Brasileira de Geociências 36, 426-436.

Engelmann de Oliveira, C. H., Jelinek, A. R., Chemale, F. \& Cupertino, J. A. (2016). Thermotectonic history of the southeastern Brazilian margin: Evidence from apatite fission track data of the offshore Santos Basin and continental basement. Tectonophysics 685, 21-34. doi: 10.1016/j.tecto.2016.07.012.

Enrich, G. E. R., Azzone, R. G., Ruberti, E., Gomes, C. B. \& Comin-Chiaramonti, P. (2005). Itatiaia, Passa Quatro and São Sebastião island, the major alkaline syenitic complexes from Serra do Mar region. In: Comin-Chiaramonti, P. \& Gomes, C. B. (eds) Mesozoic to Cenozoic alkaline magmatism in the Brazilian Platform. São Paulo: EDUSP-FAPESP, 419-442.

Enrich, G. E. R., Ruberti, E. \& Gomes, C. B. (2009). Geology and geochronology of Monte de Trigo island alkaline suite, southeasern Brazil. Revista Brasileira de Geociências39, 67-80.

Ernesto, M., Marques, L. S., Piccirillo, E. M., Molina, E. C., Ussami, N., Comin-Chiaramonti, P. \& Bellieni, G. (2002). Paraná Magmatic Province-Tristan da Cunha plume system: fixed versus mobile plume, petrogenetic considerations and alternative heat sources. Journal of Volcanology and Geothermal Research 118, 15-36. doi: 10.1016/S0377-0273(02)00248-2.

Ferrari, A. L. (2001). Evolução Tectônica do Graben da Guanabara. São Paulo, Instituto de Geociências, Universidade de São Paulo, Tese de Doutoramento. doi: 10.11606/T.44.2001.tde-29082013152530.

Foland, K. A., Landoll, J. D., Henderson, C. M. B., Chen, J. \& Jiangfeng, C. (1993). Formation of cogenetic quartz and nepheline syenites. Geochimica et Cosmochimica Acta 57, 697-704. doi: 10.1016/0016-7037(93)90380-F. 
Frisch, W. \& Abdel-Rahman, A. M. (1999). Petrogenesis of the Wadi Dib alkaline ring complex, Eastern Desert of Egypt. Mineralogy and Petrology 65, 249-275. doi: 10.1007/BF01161963.

Gibson, S. A., Thompson, R. N., Leonardos, O. H., Dickin, A. P. \& Mitchell, J. G. (1995). The Late Cretaceous Impact of the Trindade Mantle Plume: Evidence from Large-volume, Mafic, Potassic Magmatism in SE Brazil. Journal of Petrology 36, 189-229. doi: 10.1093/petrology/36.1.189.

Gibson, S. A., Thompson, R. N., Weska, R. K., Dickin, A. P. \& Leonardos, O. H. (1997). Late Cretaceous rift-related upwelling and melting of the Trindade starting mantle plume head beneath western Brazil. Contributions to Mineralogy and Petrology 126, 303-314. doi: 10.1007/s004100050252.

Gomes, C. B. \& Comin-Chiaramonti, P. (2005). An introduction to the alkaline and alkaline-carbonatitic magmatism in and around the Paraná-Basin. In: Comin- Chiaramonti, P. \& Gomes, C. . (eds) Mesozoic to Cenozoic alkaline magmatism in the Brazilian Platform. São Paulo: EDUSP-FAPESP, 21-30.

Gomes, C. B. \& Valarelli, J. V. (1970). Nova ocorrência de rochas alcalinas no Estado de São Paulo. $24^{\circ}$ Congresso Brasileiro de Geologia. Brasília: SBG - Sociedade Brasileira de Geologia, 336-337.

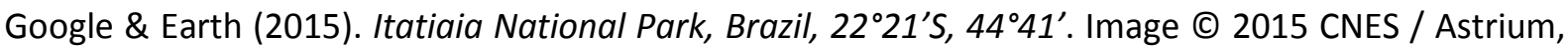
8/30/2013. http://www.earth.google.com [Acessed in 6/30/2015].

Guarino, V., Azzone, R. G., Brotzu, P., de Barros Gomes, C., Melluso, L., Morbidelli, L., Ruberti, E., Tassinari, C. C. G. \& Brilli, M. (2011). Magmatism and fenitization in the Cretaceous potassiumalkaline-carbonatitic complex of Ipanema São Paulo State, Brazil. Mineralogy and Petrology 104, 43-61. doi: 10.1007/s00710-011-0168-4.

Guedes, E., Heilbron, M., Vasconcelos, P. M., de Morisson Valeriano, C., César Horta de Almeida, J., Teixeira, W. \& Thomaz Filho, A. (2005). K-Ar and 40Ar/39Ar ages of dikes emplaced in the onshore basement of the Santos Basin, Resende area, SE Brazil: implications for the south Atlantic opening and Tertiary reactivation. Journal of South American Earth Sciences 18, 371-382. doi: 10.1016/j.jsames.2004.11.008.

Gupta, A. K. et al. (2010). Silica-Undersaturated Portion of the System Nepheline-Kalsilite-SiO2 at 2 $\mathrm{GPa} \quad[\mathrm{P} \quad(\mathrm{H} 2 \mathrm{O})=\mathrm{P} \quad($ Total) $]$. The Canadian Mineralogist 48, 1297-1313. doi: 10.3749/canmin.48.5.1297.

Hamilton, D. L. \& MacKenzie, W. S. (1965). Phase-equilibrium studies in the system NaAlSiO4 (nepheline)-KAISiO4 (kalsilite)-SiO2-H2O. Mineralogical Magazine 34, 214-231. doi: 10.1180/minmag.1965.034.268.17.

Harris, C., Marsh, J. S. \& Milner, S. C. (1999). Petrology of the alkaline core of the Messum igneous complex, Namibia: evidence for the progressively decreasing effect of crustal contamination. Journal of Petrology 40, 1377-1397. doi: 10.1093/petroj/40.9.1377.

Heilbron, M. et al. (2007). Geologia e Recursos Minerais das folhas Santa Rita do Jacutinga, Barra do Piraí, Volta Redonda e Angra dos Reis, escala 1:100.000. Brasília: Companhia de Pesquisa de Recursos Minerais - MME.

Heilbron, M., Eirado, L. G. \& Almeida, J. (2016). Mapa Geológico e de Recursos Minerais do Estado do Rio de Janeiro. Escala 1:400.000. Programa Geologia do Brasil (PGB), Mapas Geológicos Estaduais. CPRM - Serviço Geológico do Brasil, Superintendência Regional de Belo Horizonte.

Heilbron, M., Pedrosa-Soares, A. C., Campos Neto, M. C., Silva, L. C., Trouw, R. A. J. \& Janasi, V. C. (2004). A Província Mantiqueira. In: Mantesso-Neto, V., Bartorelli, A., Carneiro, C. D. R. \& Neves, B. B. B. (eds) Geologia do Continente Sul-Americano: Evolução da Obra de Fernando Flávio Marques de Almeida. São Paulo: Editora Beca, 203-234.

Janasi, V. de A., Andrade, S., Vasconcellos, A. C. B. C., Henrique-Pinto, R. \& Ulbrich, H. H. G. J. (2015). 
Timing and sources of granite magmatism in the Ribeira Belt, SE Brazil: Insights from zircon in situ $\mathrm{U}-\mathrm{Pb}$ dating and $\mathrm{Hf}$ isotope geochemistry in granites from the São Roque Domain. Journal of South American Earth Sciences. Elsevier Ltd 68, 224-247. doi: 10.1016/j.jsames.2015.11.009.

Janasi, V. de A., de Freitas, V. A. \& Heaman, L. H. (2011). The onset of flood basalt volcanism, Northern Paraná Basin, Brazil: A precise U-Pb baddeleyite/zircon age for a Chapecó-type dacite. Earth and Planetary Science Letters. Elsevier B.V. 302, 147-153. doi: 10.1016/j.epsl.2010.12.005.

Janasi, V. de A., Vlach, S. R. F., Campos Neto, M. da C. \& Ulbrich, H. H. G. J. (2009). Associated A-type subalkaline and high-K calc-alkaline granites in the Itu Granite Province, southeastern Brazil: Petrological and tectonic significance. The Canadian Mineralogist 47, 1505-1526. doi: 10.3749/canmin.47.6.1505.

Lamego, A. R. (1936). O massiço de Itatiaya e regiões circumdantes. Boletim do Serviço Geológico e Mineralógico/ DNPM 88, 1-93.

Lasaulx, A. (1885). Üeber das Vorkommen von Eläeolith-Syeniten und editeri zu diesen gehöringen Eläeolith-porphyren aus der Serra d'Itatiaia westlich von Rio de Janeiro, Brasilien. Sitzungsberichte Der Niederrheinischen Gesellschaft Für Natur 231-231.

Le Maitre, R. W. (2002). Igneous Rocks: A Classification and Glossary of Terms: A Classification and Glossary of Terms: Recommendations of the International Union of Geological Sciences, Subcommission on the Systematics of Igneous Rocks. Cambridge University Press.

Leite, C. A. S. et al. (2004). Folhas SF.23 - Rio de Janeiro / SG.23 - Iguape. In: Schobbenhaus, C., Gonçalves, J. H., Santos, J. O. S., Abram, M. B., Leão Neto, R., Matos, G. M. M., Vitotti, R. M., Ramos, M. A. B. \& Jesus, J. D. A. de (eds) Carta Geológica do Brasil ao Milionésimo, Sistema de Informações Geográficas. Programa Geologia do Brasil. CPRM, Brasília. CD-ROM.

Mariga, J., Ripley, E. M., Li, C., McKeegan, K. D., Schmidt, A. \& Groove, M. (2006). Oxygen isotopic disequilibrium in plagioclase-corundum-hercynite xenoliths from the Voisey's Bay Intrusion, Labrador, Canada. Earth and Planetary Science Letters 248, 263-275. doi: 10.1016/j.epsl.2006.05.031.

Marks, M. A. W. \& Markl, G. (2001). Fractionation and assimilation processes in the alkaline augite syenite unit of the llimaussaq Intrusion, South Greenland, as deduced from phase equilibria. Journal of Petrology 42, 1947-1969. doi: https://doi.org/10.1093/petrology/42.10.1947.

Marks, M. A. W. W., Hettmann, K., Schilling, J., Frost, B. R. \& Markl, G. (2011). The Mineralogical Diversity of Alkaline Igneous Rocks: Critical Factors for the Transition from Miaskitic to Agpaitic Phase Assemblages. Journal of Petrology 52, 439-455. doi: 10.1093/petrology/egq086.

Marsh, I. S. (1973). Relationships between transform directions and alkaline igneous rock lineaments in Africa and South America. Earth and Planetary Science Letters18, 317-323.

Meisling, K. E. \& Cob, P. R. (2001). Segmentation of an obliquely rifted margin, Campos and Santos basins, southeastern Brazil. AAPG Bulletin 85, 1903-1924. doi: 10.1306/8626D0A9-173B-11D78645000102C1865D.

Melluso, L., Guarino, V., Lustrino, M., Morra, V. \& De' Gennaro, R. (2016). The REE- and HFSE-bearing phases in the Itatiaia Alkaline Complex (Brazil), and geochemical evolution of feldspar-rich felsic melts. Mineralogical Magazine 81, 217-250. doi: 10.1180/minmag.2016.080.122.

Melo, M. D., Riccomini, C., Hasui, Y., Almeida, F. D. \& Coimbra, A. M. (1985). Geologia e evolução do sistema de bacias tafrogênicas continentais do sudeste do Brasil. Revista Brasileira de Geociências 15, 193-201.

Mendes, J. C., Ávila, C. A., Pereira, R. M., Heilbron, M. P. L. \& Moura, C. A. V (2006). 207Pb/ 206Pb-ages of zircons from syn-collisional I-type porphyritic granites of the central Ribeira belt, SE Brazil. 
Gondwana Research 9, 326-336. doi: 10.1016/j.gr.2005.11.004.

Mingram, B., Trumbull, R. . B., Littman, S. \& Gerstenberger, H. (2000). A petrogenetic study of anorogenic felsic magmatism in the Cretaceous Paresis ring complex, Namibia: evidence for mixing of crust and mantle-derived components. Lithos 54, 1-22. doi: 10.1016/S00244937(00)00033-5.

Mogahed, M. M. (2016). Petrogenesis of cogenetic silica-oversaturated and -undersaturated syenites of Abu Khruq ring complex, South Eastern Desert, Egypt. Journal of African Earth Sciences 124, 44-62. doi: 10.1016/j.jafrearsci.2016.09.010.

Motoki, A. (1986). Geologia e petrologia do maciço alcalino da llha de Vitória, SP. São Paulo, Universidade de São Paulo. doi: 10.11606/T.44.1986.tde-30062015-101540.

Negrão, A. P., Ramos, R. R. C., Mello, C. L. \& Sanson, M. de S. R. (2015). Mapa geológico do cenozoico da região da bacia de Volta Redonda (RJ, segmento central do Rifte Continental do Sudeste do Brasil): identificação de novos grabens e ocorrências descontínuas, e caracterização de estágios tectonossedimentares. Brazilian Journal of Geology 45, 273-291. doi: 10.1590/23174889201500020007.

Nekvasil, H., Dondolini, A., Horn, J., Filiberto, J., Long, H. \& Lindsley, D. H. (2004). The Origin and Evolution of Silica-saturated Alkalic Suites: an Experimental Study. Journal of Petrology 45, 693721. doi: $10.1093 /$ petrology/egg103.

Njonfang, E., Tchoneng, G. T., Cozzupoli, D. \& Lucci, F. (2013). Petrogenesis of the Sabongari alkaline complex, cameroon line (central Africa): Preliminary petrological and geochemical constraints. Journal of African Earth Sciences 83, 25-54. doi: 10.1016/j.jafrearsci.2013.03.004.

O'Halloran, D. A. (1985). Ras ed Dom migrating ring complex: A-type granites and syenites from the Bayuda Desert, Sudan. Journal of African Earth Sciences3, 61-75. doi: 10.1016/08995362(85)90023-5.

Penalva, F. (1967). Geologia e Tectónica da Região do Itatiaia (Sudeste do Brasil). Boletim da Faculdade de Filosofia Ciências e Letras, Universidade de São Paulo. Geologia 302, 99. doi: 10.11606/issn.2526-3862.bffcluspgeologia.1967.121904.

Pinto, O. (1950). Aves do Itatiaia. Boletim do Parque Nacional do Itatiaia3, 1-87.

Ribeiro Filho, E. (1967). Geologia e Petrologia dos Maciços Alcalinos do Itatiaia e Passa-Quatro (Sudeste do Brasil). Boletim da Faculdade de Filosofia Ciências e Letras, Universidade de São Paulo. Geologia 302, 9. doi: 10.11606/issn.2526-3862.bffcluspgeologia.1967.121901.

Ribeiro Filho, E. \& Penalva, F. (1965). Mapa Geológico do Maciço Alcalino de Itatiaia. [material cartográfico]. 1:50.000. São Paulo, IBGE.

Riccomini, C. (1989). O Rift Continental do Sudeste do Brasil. São Paulo, Instituto de Geociências, Universidade de São Paulo, Tese de Doutoramento. doi: 10.11606/T.44.1990.tde-18032013105507.

Riccomini, C. \& Rodrigues-Francisco, B. H. (1992). Idade potássio-argônio do derrame de ankaramito da Bacia de Itaboraí, Rio de Janeiro, Brasil: implicações tectônicas. $37^{\circ}$ Congresso Brasileiro de Geologia. São Paulo: SBG - Sociedade Brasileira de Geologia, 469-470.

Riccomini, C., Sant'Anna, L. G. \& Ferrari, A. L. (2004). Evolução geológica do Rift Continental do Sudeste do Brasil. In: Mantesso Neto, V., Bartorelli, A., Carneiro, C. D. R. \& Brito-Neves, B. B. (eds) Geologia do Continente Sul-Americano: Evolução da Obra de Fernando Flávio Marques de Almeida. São Paulo: Editora Beca, 383-405.

Riccomini, C., Veláquez, V. F. \& Gomes, C. B. (2005). Tectonic controls of the Mesozoic and Cenozoic alkaline magmatism in central-southern Brazilian Plataform. In: Comin-Chiaramonti, P. \& Gomes, 
C. B. (eds) Mesozoic to Cenozoic alkaline magmatism in the Brazilian Platform. São Paulo: EDUSPFAPESP, 31-56.

Riishuus, M. S., Peate, D. W., Tegner, C., Wilson, J. R. \& Brooks, C. K. (2008). Petrogenesis of Cogenetic Silica-Oversaturated and -Undersaturated Syenites by Periodic Recharge in a Crustally Contaminated Magma Chamber: the Kangerlussuaq Intrusion, East Greenland. Journal of Petrology 49, 493-522. doi: 10.1093/petrology/egm090.

Rocha, M. P., Schimmel, M. \& Assumpção, M. (2011). Upper-mantle seismic structure beneath SE and Central Brazil from P- and S-wave regional traveltime tomography. Geophysical Journal International 184, 268-286. doi: 10.1111/j.1365-246X.2010.04831.x.

Rosa, P. A. S. (2012). Geologia e Petrologia da suíte alcalina de Bom Repouso, MG. São Paulo, Instituto de Geociências, Universidade de São Paulo, Dissertaçao de Mestrado. doi: 10.11606/D.44.2012.tde-11112013-133338.

Rosa, P. A. S., Ruberti, E., Vasconcelos, P. M. \& Thiede, D. S. (2014). 40Ar/39Ar Ages of Bom Repouso Alkaline Suite, MG State. 9th South American Symposium on Isotope Geology, 2014, São Paulo. São Paulo: Program and Abstracts, 184.

Sadowski, G. R. \& Dias Neto, C. M. (1981). O lineamento sismotectônico do Cabo Frio. Revista Brasileira de Geociências 11, 209-212.

Salgado, A. A. R., Rezende, E. de A., Bourlès, D., Braucher, R., da Silva, J. R. \& Garcia, R. A. (2016). Relief evolution of the Continental Rift of Southeast Brazil revealed by in situ-produced 10Be concentrations in river-borne sediments. Journal of South American Earth Sciences 67, 89-99. doi: 10.1016/j.jsames.2016.02.002.

Schobbenhaus, F. C., Campos, P. A., Derze, G. R. \& Asmus, H. E. (1984). Geologia do Brasil. Brasília: DNPM.

Shea, M. E. (1992). Isotopic geochemical characteristics of selected nepheline syenites and phonolites from the Poços de Caldas alkaline complex, Minas Gerais, Brazil. Journal of Geochemical Exploration 54, 173-214. doi: 10.1016/0375-6742(92)90125-R.

Sichel, S. E., Carlson, R. W., Esperança, S., Araújo, A. L. N. \& Valença, J. G. (1997). Preliminary isotopic study of the alkalic intrusive complexes along the Cabo Frio Lineament. South-American Symposium on Isotope Geology. Campos do Jordão, 298-300.

Silva, J. F. (1876). Descripção do Itatiaia ou Itatiaio. Revista do Instituto Histórico e Geográfico Brasileiro 39, 413-418.

Silva, J. F. (1882). Panorama do Sul de Minas. Revista do Instituto Histórico e Geográfico Brasileiro 45, 405-435.

Smith, P. E., Everson, N. M., York, D., Szatmari, P. \& Custodio, O. (2001). Single-Crystal 40Ar/39Ar dating of pyrite: No fool's clock. Geology 29, 403-406.

Sonoki, I. K. \& Garda, G. (1988). Idades K-Ar de rochas alcalinas do Brasil Meridional e Paraguai Oriental: compilação e adaptação às novas constantes de decaimento. Boletim IGC-USP 19, 63-85.

Sørensen, H. (1974). The Alkaline Rocks. London: John Wiley \& Sons.

Sørensen, H. (1997). The Agpaitic Rocks - An Overview. Mineralogical Magazine 61, 485-498. doi: 10.1180/minmag.1997.061.407.02.

Stanton, N., Ponte-Neto, C., Bijani, R., Masini, E., Fontes, S. \& Flexor, J. M. (2014). A geophysical view of the Southeastern Brazilian margin at Santos Basin: Insights into rifting evolution. Journal of South American Earth Sciences 55, 141-154. doi: 10.1016/j.jsames.2014.07.003.

Thiede, D. S. \& Vasconcelos, P. M. (2010). Paraná flood basalts: Rapid extrusion hypothesis confirmed 
by new 40Ar/39Ar results. Geology 38, 747-750. doi: 10.1130/G30919.1.

Thomaz Filho, A. \& Rodrigues, L. (1999). O Alinhamento de Rochas Alcalinas Poços de Caldas-Cabo Frio (RJ) e sua continuidade na cadeia Vitória-Trindade. Revista Brasileira de Geociências 29, 189-194.

Thompson, R. N., Gibson, S. A., Mitchell, J. G., Dickin, A. P., Leonardos, O. H., Brod, J. A. \& Greenwood, J. C. (1998). Migrating Cretaceous-Eocene Magmatism in the Serra do Mar Alkaline Province, SE Brasil: Melts from the Deflected Trindade Mantle Plume? Journal of Petrology 39, 1493-1526. doi: doi.org/10.1093/petroj/39.8.1493.

Trouw, C. C., Medeiros, F. F. F. de \& Trouw, R. A. J. (2007). Evolução tectônica da Zona de Cisalhamento Caxambu , MG. Revista Brasileira de Geociências 37, 767-776.

Trouw, R. A. J., Peternel, R., Ribeiro, A., Heilbron, M., Vinagre, R., Duffles, P., Trouw, C. C., Fontainha, M. \& Kussama, H. H. (2013). A new interpretation for the interference zone between the southern Brasília belt and the central Ribeira belt, SE Brazil. Journal of South American Earth Sciences 48, 43-57. doi: 10.1016/j.jsames.2013.07.012.

Trouw, R. A. J., Ribeiro, A. \& Paciullo, F. V. P. (2003). Geologia da Folha Pouso Alto 1:100.000. In: Pedrosa Soares, C. A., Noce, M. A., Trouw, R. A. J. \& Heilbron, M. (eds) Geologia e Recursos Minerais do Sudeste Mineiro, Projeto Sul de Minas e Etapa I (COMIG, UFMG, UFRJ, UERJ), first ed., 2. Companhia Mineradora de Minas Gerais e COMIG, Belo Horizonte, MG.

Tupinambá, M., Heilbron, M., Valeriano, C., Júnior, R. P., de Dios, F. B., Machado, N., Silva, L. G. do E. \& de Almeida, J. C. H. (2012). Juvenile contribution of the Neoproterozoic Rio Negro Magmatic Arc (Ribeira Belt, Brazil): Implications for Western Gondwana amalgamation. Gondwana Research. International Association for Gondwana Research 21, 422-438. doi: 10.1016/j.gr.2011.05.012.

Ulbrich, H. H. G. J. \& Gomes, C. B. (1981). Alkaline rocks from continental Brazil. Earth Science Reviews 17, 135-154.

Ulbrich, M. N. C. (1993). Mineralogy of nepheline syenites from the Poços de Caldas alkaline massif, SE Brazil: chemistry, X-ray data and microtextures of feldspars. Revista Brasileira de Geociências 23, 388-399.

Valeriano, C. de M., Tupinambá, M., Simonetti, A., Heilbron, M., de Almeida, J. C. H. \& do Eirado, L. G. (2011). U-Pb LA-MC-ICPMS geochronology of Cambro-Ordovician post-collisional granites of the Ribeira belt, southeast Brazil: Terminal Brasiliano magmatism in central Gondwana supercontinent. Journal of South American Earth Sciences 32, 416-428. doi: 10.1016/j.jsames.2011.03.003.

Vlach, S. R. F., Vilalva, F. C. J., Ulbrich, M. N. C., Ulbrich, H. H. G. J. \& Vasconcelos, P. M. (2003). Phlogopite from carbonatitic veins associated with the Poços de Caldas Alkaline Massif, SE Brazil: Mineralogy and Ar/Ar dating by the laser step heating method. South American Symposium on Isotope Geology. Salvador: SBG - Sociedade Brasileira de Geologia, 702-705.

Yang, J.-H. H., Sun, J.-F. F., Zhang, M., Wu, F.-Y. Y. \& Wilde, S. A. (2012). Petrogenesis of silica-saturated and silica-undersaturated syenites in the northern North China Craton related to post-collisional and intraplate extension. Chemical Geology 328, 149-167. doi: 10.1016/j.chemgeo.2011.09.011.

Zalán, P. V \& Oliveira, J. A. B. (2005). Origem e evolução estrutural do Sistema de Riftes Cenozóicos do Sudeste do Brasil. Boletim de Geociências da Petrobras 13, 296-300. 
Tabela de coordenada e mapa dos afloramentos decritos

\section{ANEXO B}


ANEXO B - Tabela B.1 - Coordenadas de todos os afloramentos descritos e acidentes geográficos, construção e lugares usados como referência na tese. A altitude dos pontos (em metros acima do mar) foi baseada em medidas de GPS e ASTER GDEM ASTGTM2_S23W045 (ASTER GDEM is a product of METI and NASA). ${ }^{1}$ - medidas oficiais; ${ }^{2}$ - ponto médio do caminho.

\begin{tabular}{|c|c|c|c|c|c|c|c|}
\hline Aflor. & Longitude & Latitude & Altitude & Aflor. & Longitude & Latitude & Altitude \\
\hline MAI001 & 545925 & 7521568 & 734 & MAI058B & 542894 & 7516535 & 633 \\
\hline MAI002 & 547628 & 7520540 & 519 & MAI059 & 542793 & 7516061 & 608 \\
\hline MAI003 & 550979 & 7521617 & 501 & MAI060 & 539357 & 7514647 & 749 \\
\hline MAI004 & 550870 & 7522084 & 529 & MAI061 & 540065 & 7517733 & 929 \\
\hline MAI005 & 550097 & 7522472 & 552 & MAI062 & 539727 & 7518825 & 1040 \\
\hline MAI006 & 549093 & 7522589 & 600 & MAI063 & 538021 & 7519773 & 1501 \\
\hline MAI007 & 544491 & 7523095 & 1056 & MAI064 & 537807 & 7519974 & 1525 \\
\hline MAI008 & 544341 & 7522947 & 1091 & MAI065 & 537636 & 7520350 & 1618 \\
\hline MAI009 & 544042 & 7522990 & 1140 & MAI066 & 537171 & 7520525 & 1789 \\
\hline MAI010 & 543175 & 7522810 & 1247 & MAI067 & 539828 & 7519475 & 1228 \\
\hline MAI011 & 543026 & 7522880 & 1301 & MAI068 & 541449 & 7516115 & 693 \\
\hline MAI012 & 542870 & 7522879 & 1363 & MAI069 & 541144 & 7516160 & 708 \\
\hline MAI013 & 517490 & 7532277 & 1057 & MAI070 & 533820 & 7523864 & 2337 \\
\hline MAI014 & 518710 & 7532217 & 1035 & MAI071 & 534267 & 7523613 & 2307 \\
\hline MAI015 & 518752 & 7531823 & 1015 & MAI072 & 535098 & 7523548 & 2315 \\
\hline MAI016 & 516876 & 7530887 & 989 & MAI073 & 535641 & 7523307 & 2376 \\
\hline MAI017 & 539114 & 7519736 & 1098 & MAI074 & 534147 & 7523479 & 2335 \\
\hline MAI018 & 539264 & 7519887 & 1152 & MAI075 & 535568 & 7522855 & 2315 \\
\hline MAI019 & 539105 & 7519617 & 1125 & MAI076 & 535303 & 7522938 & 2434 \\
\hline MAI020 & 538484 & 7518863 & 1227 & MAI077 & 533927 & 7523449 & 2406 \\
\hline MAI021 & 538333 & 7519132 & 1325 & MAI078 & 533955 & 7522960 & 2491 \\
\hline MAI022 & 538316 & 7519525 & 1378 & MAI079 & 534400 & 7522993 & 2435 \\
\hline MAI023 & 534977 & 7513904 & 500 & MAI080 & 534740 & 7522955 & 2404 \\
\hline MAI024 & 534582 & 7515272 & 559 & MAI081 & 533342 & 7524230 & 2372 \\
\hline MAI025 & 534844 & 7515575 & 628 & MAI082 & 532764 & 7524335 & 2520 \\
\hline MAI026 & 534991 & 7516187 & 655 & MAI083 & 530382 & 7525685 & 2466 \\
\hline MAI027 & 535513 & 7517677 & 965 & MAI084 & 531423 & 7524467 & 2646 \\
\hline MAI028 & 535286 & 7517164 & 743 & MAI085 & 530920 & 7524770 & 2581 \\
\hline MAI029 & 535024 & 7517099 & 822 & MAI086 & 530637 & 7524998 & 2570 \\
\hline MAI030 & 542911 & 7519981 & 1725 & MAI087 & 530571 & 7525412 & 2578 \\
\hline MAI031 & 542899 & 7520044 & 1684 & MAI088 & 536781 & 7521026 & 1945 \\
\hline MAI032 & 542769 & 7520124 & 1641 & MAI089 & 537333 & 7521707 & 2013 \\
\hline MAI033 & 542377 & 7520267 & 1620 & MAI089B & 537091 & 7521833 & 2035 \\
\hline MAI034 & 542048 & 7520286 & 1574 & MAI090 & 536941 & 7522500 & 2107 \\
\hline MAI035 & 541869 & 7519837 & 1453 & MAI091 & 536157 & 7522001 & 2189 \\
\hline MAI036 & 541568 & 7519568 & 1334 & MAI092 & 535522 & 7522062 & 2207 \\
\hline MAI037 & 541375 & 7519435 & 1289 & MAI093 & 533612 & 7525740 & 2630 \\
\hline MAI038 & 541131 & 7519318 & 1266 & MAI094 & 534059 & 7525808 & 2551 \\
\hline MAI039 & 540903 & 7519329 & 1241 & MAI095 & 534415 & 7525814 & 2659 \\
\hline MAI040 & 540422 & 7519364 & 1210 & MAI096 & 534687 & 7526891 & 2396 \\
\hline MAI041 & 543232 & 7514339 & 543 & MAI096B & 534842 & 7527101 & 2398 \\
\hline MAI042 & 542631 & 7517634 & 902 & MAI097 & 536030 & 7527018 & 2412 \\
\hline MAI043 & 542941 & 7517814 & 883 & MAI097C & 535859 & 7526923 & 2430 \\
\hline MAI044 & 543641 & 7517573 & 874 & MAI098 & 535615 & 7526653 & 2513 \\
\hline MAI045 & 543111 & 7517516 & 890 & MAI099 & 534794 & 7526027 & 2679 \\
\hline MAI046E & 542766 & 7517376 & 851 & MAI100 & 535061 & 7526809 & 2449 \\
\hline MAI046F & 542733 & 7517355 & 850 & MAI101 & 535018 & 7527561 & 2411 \\
\hline MAI047 & 542613 & 7517034 & 805 & MAI102 & 534128 & 7527221 & 2377 \\
\hline MAI048 & 542548 & 7516996 & 816 & MAI103 & 534541 & 7527778 & 2273 \\
\hline MAI049 & 542307 & 7516726 & 730 & MAI104 & 527139 & 7529620 & 1961 \\
\hline MAI050 & 542220 & 7516469 & 660 & MAI105 & 527252 & 7528987 & 2086 \\
\hline MAI051 & 542020 & 7516252 & 636 & MAI106 & 527207 & 7527818 & 2159 \\
\hline MAI052 & 540372 & 7516027 & 682 & MAI107 & 527643 & 7526948 & 2227 \\
\hline MAI053 & 540357 & 7516116 & 710 & MAI108 & 528197 & 7526700 & 2268 \\
\hline MAI054 & 540494 & 7515689 & 695 & MAI109 & 534649 & 7525011 & 2642 \\
\hline MAI055 & 540113 & 7515192 & 648 & MAI110 & 534453 & 7525193 & 2569 \\
\hline MAI056 & 539831 & 7515258 & 717 & MAI111 & 534182 & 7525553 & 2533 \\
\hline MAI057 & 539872 & 7514811 & 609 & MAI112 & 529939 & 7526336 & 2354 \\
\hline MAI058 & 542896 & 7516446 & 601 & MAI112B & 530028 & 7526274 & 2400 \\
\hline
\end{tabular}


ANEXO B - Tabela B.1 - Continuação...

\begin{tabular}{|c|c|c|c|c|c|c|c|}
\hline Aflor. & Longitude & Latitude & Altitude & Aflor. & Longitude & Latitude & Altitude \\
\hline MAl113 & 530344 & 7526477 & 2498 & MAI158 & 529937 & 7527077 & 2274 \\
\hline MAl113B & 530543 & 7526476 & 2572 & MAI159 & 527425 & 7530881 & 1815 \\
\hline MAl114 & 534122 & 7526442 & 2447 & MAI160 & 526868 & 7531390 & 1897 \\
\hline MAl115 & 534015 & 7526170 & 2461 & MAI161 & 526134 & 7532389 & 1883 \\
\hline MAI115B & 533970 & 7526021 & 2494 & MAI162 & 525653 & 7532685 & 1843 \\
\hline MAI116 & 529526 & 7526693 & 2367 & MAI163 & 524937 & 7532582 & 1738 \\
\hline MAl117 & 529335 & 7526867 & 2426 & MAI164 & 527091 & 7527334 & 2149 \\
\hline MAI117C & 529102 & 7526886 & 2402 & MAl165 & 523109 & 7529867 & 1955 \\
\hline MAI118 & 528711 & 7527057 & 2422 & MAI166 & 521965 & 7528801 & 1437 \\
\hline MAl119 & 528766 & 7527626 & 2451 & MAI167 & 517858 & 7529885 & 1157 \\
\hline MAI120 & 528366 & 7527407 & 2586 & MAI168 & 517203 & 7530729 & 969 \\
\hline MAl121 & 528441 & 7527777 & 2540 & MAI169 & 517827 & 7531005 & 1001 \\
\hline MAl122 & 529128 & 7527524 & 2510 & MAI170 & 519529 & 7530689 & 1111 \\
\hline MAI122B & 529142 & 7527693 & 2492 & MAI171 & 520087 & 7530727 & 1190 \\
\hline MAl123 & 525690 & 7525789 & 1835 & MAI172 & 520450 & 7530670 & 1257 \\
\hline MAl123B & 525597 & 7525929 & 1780 & MAl173 & 521586 & 7530739 & 1459 \\
\hline MAl124 & 524087 & 7526301 & 1630 & MAI174 & 521032 & 7531004 & 1345 \\
\hline MAl124B & 523978 & 7526549 & 1620 & MAI174B & 520754 & 7530854 & 1313 \\
\hline MAI125 & 522740 & 7527189 & 1567 & MAI175 & 520731 & 7528111 & 1401 \\
\hline MAl126 & 521822 & 7527729 & 1490 & MAI176 & 522851 & 7534275 & 1429 \\
\hline MAl127 & 521609 & 7528388 & 1374 & MAI177 & 522854 & 7531837 & 1510 \\
\hline MAI127B & 521913 & 7528240 & 1364 & MAI178 & 523029 & 7532258 & 1534 \\
\hline MAI128 & 534405 & 7523218 & 2481 & MAI178B & 522866 & 7532237 & 1545 \\
\hline MAl129 & 534218 & 7522902 & 2429 & MAI178C & 523006 & 7532408 & 1546 \\
\hline MAl130 & 533594 & 7523218 & 2463 & MAI179 & 522705 & 7532643 & 1577 \\
\hline MAl131 & 534033 & 7524544 & 2422 & MAI180 & 520599 & 7533361 & 1207 \\
\hline MAl132 & 533145 & 7525758 & 2541 & MAI181 & 519543 & 7532866 & 1135 \\
\hline MAI132C & 532998 & 7525806 & 2543 & MAI182 & 526084 & 7526628 & 1935 \\
\hline MAl133 & 533826 & 7525241 & 2601 & MAI182C & 526016 & 7526458 & 1932 \\
\hline MAl134 & 533486 & 7523701 & 2546 & MAI183 & 528052 & 7524095 & 1619 \\
\hline MAl135 & 532943 & 7524231 & 2475 & MAI184 & 527750 & 7523698 & 1597 \\
\hline MAl136 & 532358 & 7524820 & 2418 & MAI185 & 527688 & 7524275 & 1524 \\
\hline MAl137 & 532003 & 7525081 & 2421 & MAI186 & 526923 & 7524298 & 1561 \\
\hline MAl138 & 531974 & 7526030 & 2531 & MAI187 & 526335 & 7524173 & 1562 \\
\hline MAl139 & 532436 & 7526051 & 2513 & MAI188 & 526820 & 7525951 & 2170 \\
\hline MAI140 & 532625 & 7525837 & 2598 & MAI189 & 526821 & 7525611 & 2135 \\
\hline MAI140B & 532729 & 7525801 & 2590 & MAI190 & 526882 & 7526564 & 2067 \\
\hline MAl141 & 533838 & 7526836 & 2434 & MAI191 & 533167 & 7517526 & 865 \\
\hline MAI142 & 533641 & 7527213 & 2425 & MAI192 & 533140 & 7517086 & 810 \\
\hline MAl143 & 533328 & 7526870 & 2509 & MAI193 & 528432 & 7520976 & 1090 \\
\hline MAl143B & 533271 & 7526626 & 2546 & MAI194 & 531558 & 7528338 & 1864 \\
\hline MAl144 & 532917 & 7526818 & 2496 & MAl195 & 533081 & 7528187 & 2009 \\
\hline MAl144B & 532953 & 7526883 & 2466 & MAI196 & 532268 & 7528064 & 1979 \\
\hline MAl145 & 533066 & 7526280 & 2475 & MAI197 & 531859 & 7528115 & 1928 \\
\hline MAl146 & 531090 & 7526658 & 2515 & MAI198 & 534251 & 7530569 & 2336 \\
\hline MAI146C & 531240 & 7526768 & 2518 & MAI199 & 534428 & 7530111 & 2485 \\
\hline MAl146D & 530940 & 7526610 & 2536 & MAI200 & 533225 & 7531065 & 1894 \\
\hline MAI147 & 531633 & 7526678 & 2468 & MAI201 & 536619 & 7526735 & 2339 \\
\hline MAI147B & 531503 & 7526743 & 2470 & MAI202 & 536682 & 7525628 & 2404 \\
\hline MAl148 & 531259 & 7526021 & 2595 & MAI203 & 537315 & 7525976 & 2302 \\
\hline MAI149 & 530745 & 7526032 & 2562 & MAI204 & 537628 & 7525482 & 2352 \\
\hline MAI150 & 529550 & 7525200 & 2413 & MAI205 & 537676 & 7526358 & 2356 \\
\hline MAI150B & 529821 & 7525301 & 2388 & MAI206 & 537800 & 7526962 & 2430 \\
\hline MAI151 & 530106 & 7525431 & 2475 & MAI207 & 538388 & 7525826 & 2572 \\
\hline MAl152 & 531497 & 7525361 & 2426 & MAI207B & 538550 & 7525862 & 2614 \\
\hline MAl153 & 528954 & 7526733 & 2333 & MAI208 & 538794 & 7525914 & 2582 \\
\hline MAI154 & 528283 & 7528436 & 2412 & MAI209 & 538402 & 7527615 & 1953 \\
\hline MAl155 & 528500 & 7529619 & 2190 & MAI210 & 539349 & 7524827 & 2361 \\
\hline MAl156 & 530616 & 7527650 & 2208 & MAI211 & 539793 & 7524997 & 2252 \\
\hline MAl156B & 530679 & 7527436 & 2229 & MAI212 & 540121 & 7524994 & 2221 \\
\hline MAl157 & 530474 & 7527259 & 2256 & MAI213 & 539097 & 7525452 & 2415 \\
\hline
\end{tabular}


ANEXO B - Tabela B.1 - Continuação...

\begin{tabular}{|c|c|c|c|c|c|c|c|}
\hline Aflor. & Longitude & Latitude & Altitude & Picos & Longitude & Latitude & Altitude \\
\hline MAI214 & 535475 & 7527087 & 2527 & Agulhas Negras & 534842 & 7525036 & $2792^{1}$ \\
\hline MAI215 & 537270 & 7519161 & 1733 & Asa de Hermes & 534581 & 7525596 & 2600 \\
\hline MAI215B & 537048 & 7519412 & 1760 & Brejo do Aiuruoca & 534261 & 7526938 & 2367 \\
\hline MAI216 & 536702 & 7519453 & 1773 & Brejo do Rio Preto & 536495 & 7526660 & 2320 \\
\hline MAI217 & 536857 & 7519975 & 1812 & Cachoeira do Aiuruoca & 534124 & 7527228 & 2355 \\
\hline MAI218 & 539978 & 7516906 & 795 & Cachoeira Véu da Noiva & 539309 & 7519902 & 1194 \\
\hline MAI219 & 524640 & 7527355 & 1675 & Morro da Antena & 530621 & 7525401 & 2584 \\
\hline MAI220 & 525282 & 7527525 & 1749 & Morro do Couto & 531601 & 7524484 & $2680^{1}$ \\
\hline MAI221 & 529560 & 7529058 & 2289 & Morro do Maromba & 538475 & 7525870 & $2619^{1}$ \\
\hline MAI222 & 529276 & 7528733 & 2287 & Morro do Massena & 530897 & 7526187 & $2609^{1}$ \\
\hline MAI222B & 529361 & 7528787 & 2266 & Morro do Urubu & 534413 & 7521625 & $2270^{1}$ \\
\hline MAI222C & 529133 & 7528687 & 2305 & Ovos da Galinha & 534883 & 7526830 & 2466 \\
\hline MAI223 & 528935 & 7528266 & 2340 & Pedra Assentada & 534766 & 7522921 & $2453^{1}$ \\
\hline MAI224 & 528638 & 7528157 & 2410 & Pedra do Altar & 533552 & 7525703 & $2665^{1}$ \\
\hline MAI225 & 519025 & 7529790 & 1352 & Pedra do Camelo & 529784 & 7526183 & 2318 \\
\hline MAI226 & 522922 & 7530354 & 1763 & Pedra do Picú & 523087 & 7529872 & 1970 \\
\hline MAI227 & 522580 & 7530892 & 1526 & Pedra do Sino & 534791 & 7526030 & $2670^{1}$ \\
\hline MAI228 & 522372 & 7531398 & 1408 & Pedra Furada & 528370 & 7527406 & $2589^{1}$ \\
\hline MAI229 & 523898 & 7532352 & 1595 & Prateleiras & 533955 & 7522898 & 2458 \\
\hline MAI230 & 530632 & 7526863 & 2488 & Serra da Colina & 522146 & 7532348 & 1731 \\
\hline MAI231 & 532052 & 7526717 & 2455 & Serra Negra & 534462 & 7529964 & $2572^{1}$ \\
\hline MAI232 & 524195 & 7530998 & 1830 & Três Picos & 542916 & 7519993 & 1675 \\
\hline \multirow[t]{21}{*}{ MAI233 } & 523221 & 7530811 & 1570 & & & & \\
\hline & & & & Lugares & Longitude & Latitude & Altitude \\
\hline & & & & Abrigo Agua Branca & 533069 & 7524470 & 2392 \\
\hline & & & & Abrigo Massena & 535907 & 7521950 & 2190 \\
\hline & & & & Abrigo Rebouças & 533069 & 7524470 & 2392 \\
\hline & & & & Bairro da Colina & 521844 & 7533772 & 1276 \\
\hline & & & & Bairro Engenho da Serra & 521852 & 7528362 & 1333 \\
\hline & & & & Bairro Fazeda Velha & 523112 & 7532137 & 1493 \\
\hline & & & & Bairro Vargem Grande & 528495 & 7531708 & 1748 \\
\hline & & & & Entrada do Parque & 541936 & 7515888 & 614 \\
\hline & & & & Estrada do Carvoeiro & 531603 & 7528123 & 1889 \\
\hline & & & & Garganta do Registro & 524605 & 7525480 & $1669^{1}$ \\
\hline & & & & Hotel Vista Linda & 542733 & 7517470 & 861 \\
\hline & & & & Museu & 540115 & 7517269 & 856 \\
\hline & & & & Posto do Marcão & 530500 & 7525869 & 2436 \\
\hline & & & & Posto do Maromba & 539111 & 7519636 & 1102 \\
\hline & & & & Rancho Caído & 537597 & 7526148 & 2299 \\
\hline & & & & Rodovia das Flores ${ }^{2}$ & 526547 & 7526978 & 1948 \\
\hline & & & & Travesia Rui Braga ${ }^{2}$ & 536299 & 7520981 & 1946 \\
\hline & & & & Travessia do Rancho Caíc & 537893 & 7527588 & 2073 \\
\hline & & & & Trilha dos 5 Lagos $^{2}$ & 531734 & 7526360 & 2447 \\
\hline
\end{tabular}


MAPA DE AFLORAMENTOS DESCRITOS E ETAPAS ANALÍTICAS

Tese de Doutoramento - ANEXO B - Pedro A. S. Rosa

2017

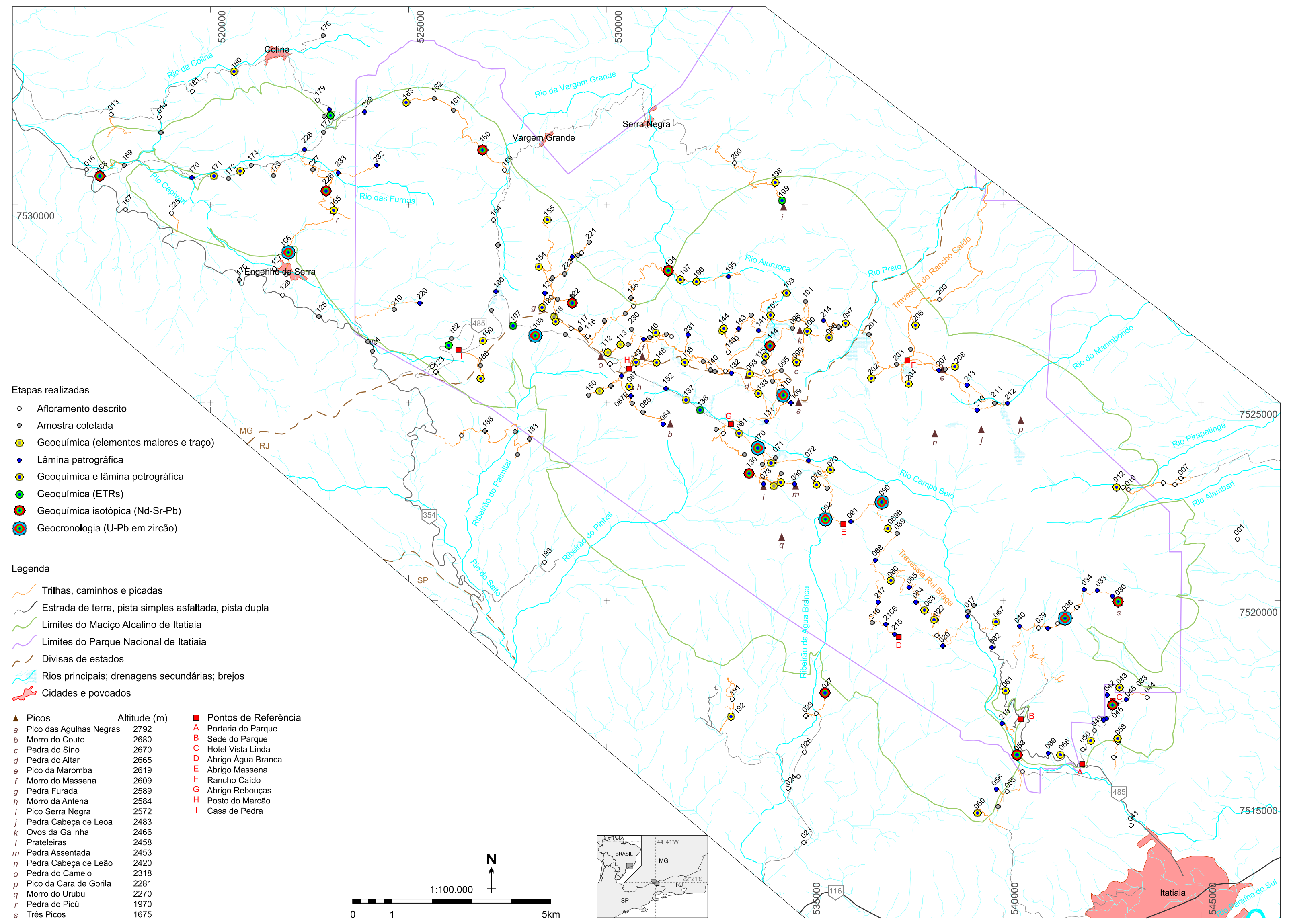


Tabela de análise modal de amostras representativas

ANEXO C 
ANEXO C - Análise modal (em \% de volume) de amostras representativas das principais unidades descritas no MAI. Contagem de 2100 pontos em seção delgada. Cada ponto representa $0,048 \%$, arredondado para 2 casas decimais. Os minerais decritos em lâmina

\begin{tabular}{|c|c|c|c|c|c|c|c|c|c|c|c|}
\hline Amostra & MAI060 & MAI030 & MAI036 & MAl199 & MAI092I & MAl102 & MAl114 & MAl148 & MAI090 & MAI097B & MAl110 \\
\hline Unidade & NeS-I & NeS-I & $\mathrm{BtHblNeS}$ & BtAgtNeS & BtHblP & BtHblP & BtHblP & BtHblP & AegN & $\mathrm{N}-\mathrm{I}$ & QzAFS-I \\
\hline$\overline{\mathrm{M}^{\prime}}$ & 5,95 & 14,14 & 18,86 & 14,67 & 16,00 & 16,62 & 21,10 & 10,57 & 9,33 & 9,05 & 8,90 \\
\hline Q & & & & & & & & & 3,74 & 2,11 & 7,36 \\
\hline A & 62,96 & 65,58 & 88,74 & 76,41 & 96,05 & 95,35 & 89,13 & 97,95 & 96,26 & 97,89 & 92,64 \\
\hline$P$ & & 26,37 & 1,01 & & 2,48 & 0,58 & 5,31 & 2,05 & & & \\
\hline $\mathrm{F}$ & 37,04 & 8,06 & 10,25 & 23,59 & 1,47 & 4,07 & 5,56 & & & & \\
\hline Feldspato & 58,52 & 55,43 & 68,52 & 64,33 & 77,57 & 78,14 & 69,48 & 86,52 & 87,05 & 88,57 & 83,33 \\
\hline Plagioclásio & & 22,29 & 3,19 & & 2,00 & 0,48 & 4,14 & 1,81 & & & \\
\hline Nefelina & 25,00 & 6,48 & 7,62 & 14,62 & 0,38 & 1,90 & 2,52 & & & & \\
\hline Analcima & 9,43 & & & & & & 1,67 & & & & \\
\hline Sodalita & & 0,33 & 0,57 & 5,24 & 0,81 & 1,43 & 0,14 & & & & \\
\hline Quartzo & & & & & & & & & 3,38 & 1,90 & 6,62 \\
\hline Anfibólio & & & 6,81 & 6,00 & 6,52 & & 5,52 & & & 2,62 & 3,86 \\
\hline Biotita & 0,14 & 6,52 & 5,81 & & 4,38 & 7,19 & 6,81 & 1,90 & & 1,57 & 0,86 \\
\hline Opaco & 0,71 & 0,19 & 2,10 & 0,86 & 1,00 & 3,57 & 3,62 & 2,86 & 1,19 & 3,05 & 2,81 \\
\hline Clinopiroxê & 3,33 & & 0,10 & 5,19 & 0,81 & 4,38 & 2,52 & 0,10 & 6,05 & 0,29 & 0,14 \\
\hline Titanita & 1,76 & & 3,90 & 1,38 & 3,10 & 1,29 & 2,38 & 1,24 & 1,38 & 1,19 & 0,76 \\
\hline Apatita & & & 1,05 & & 0,95 & 1,43 & 0,95 & 1,05 & 0,24 & 0,48 & 0,10 \\
\hline Zircão & & 0,14 & 0,14 & & 0,19 & 0,19 & 0,24 & 0,24 & 0,62 & 0,33 & 0,48 \\
\hline Låvenita & & & & 1,24 & & & & & & & \\
\hline Hiordahlita & 1,10 & & & 1,10 & & & & & & & \\
\hline Rosenbuschi & & & & 0,05 & & & & & & & \\
\hline Hercinita & & 7,24 & & & & & & & & & \\
\hline Corindon & & 1,05 & & & & & & & & & \\
\hline Muscovita & & 0,24 & 0,19 & & 0,10 & & & & & & \\
\hline $\begin{array}{l}\text { Fluorita } \\
\text { Fluorita+zircã }\end{array}$ & & & & & & & & 0,05 & & & \\
\hline Rutilo & & 0,05 & & & & & & & & & \\
\hline Clorita & & & & & & & & 4,24 & & & \\
\hline Agregados & & & & & 2,14 & & & & & & \\
\hline Carbonato & & 0,05 & & & & & & & & & \\
\hline \multicolumn{2}{|c|}{ Cavidade miarolítica } & & & & & & & & & & 1,05 \\
\hline
\end{tabular}


ANEXO C - Análise modal (em \% de volume) de amostras representativas das principais unidades descritas no MAI. Contagem de 2100 pontos em seção delgada. Cada ponto representa 0,048\%, arredondado para 2 casas decimais. Os minerais decritos em lâmina e não computados são

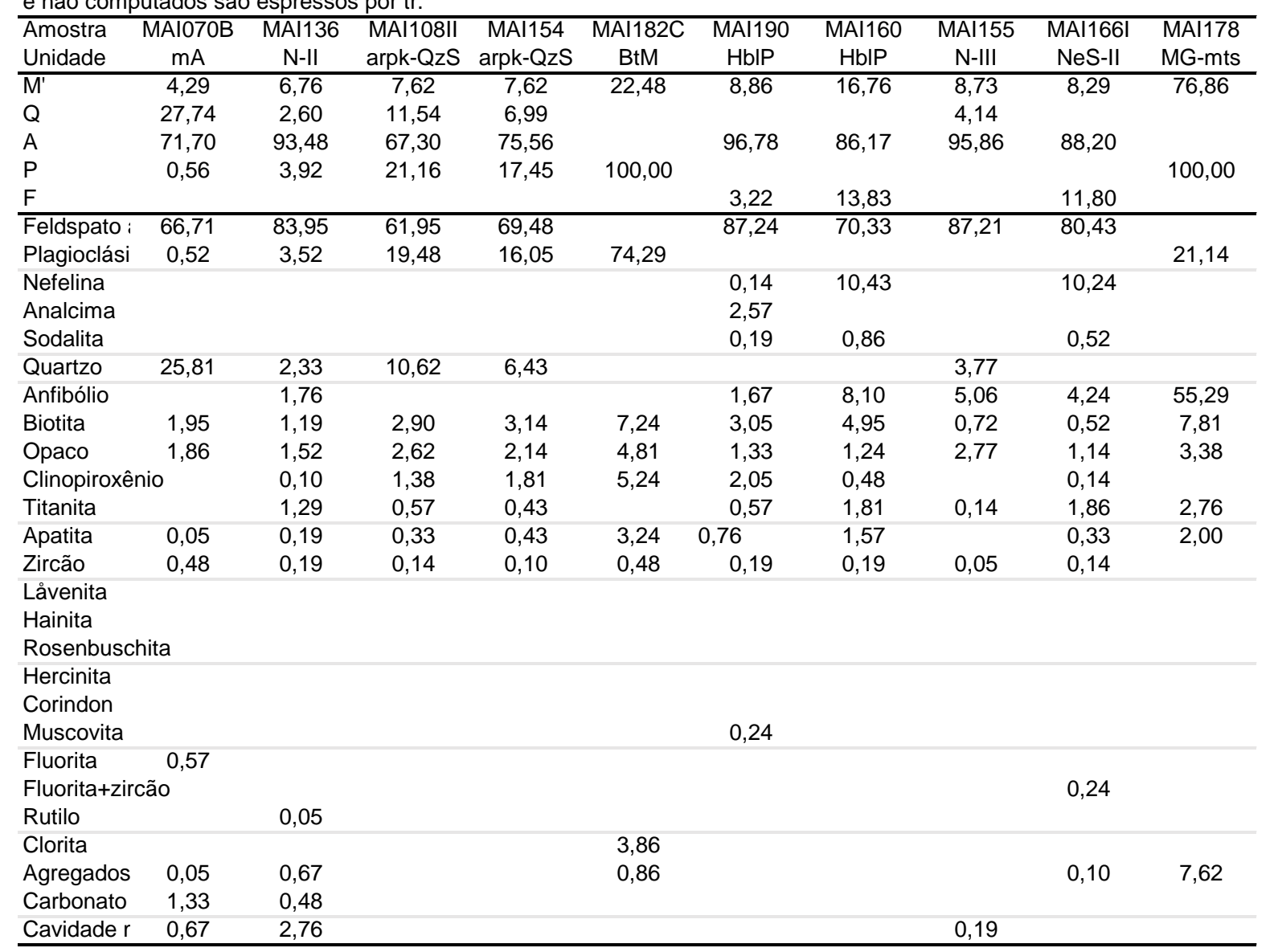


Mapa geológico

\section{ANEXO D}


MAPA GEOLÓGICO DO MACIÇO ALCALINO DE ITATIAIA, MG-RJ

Tese de Doutoramento - ANEXO D - Pedro A. S. Rosa

2017

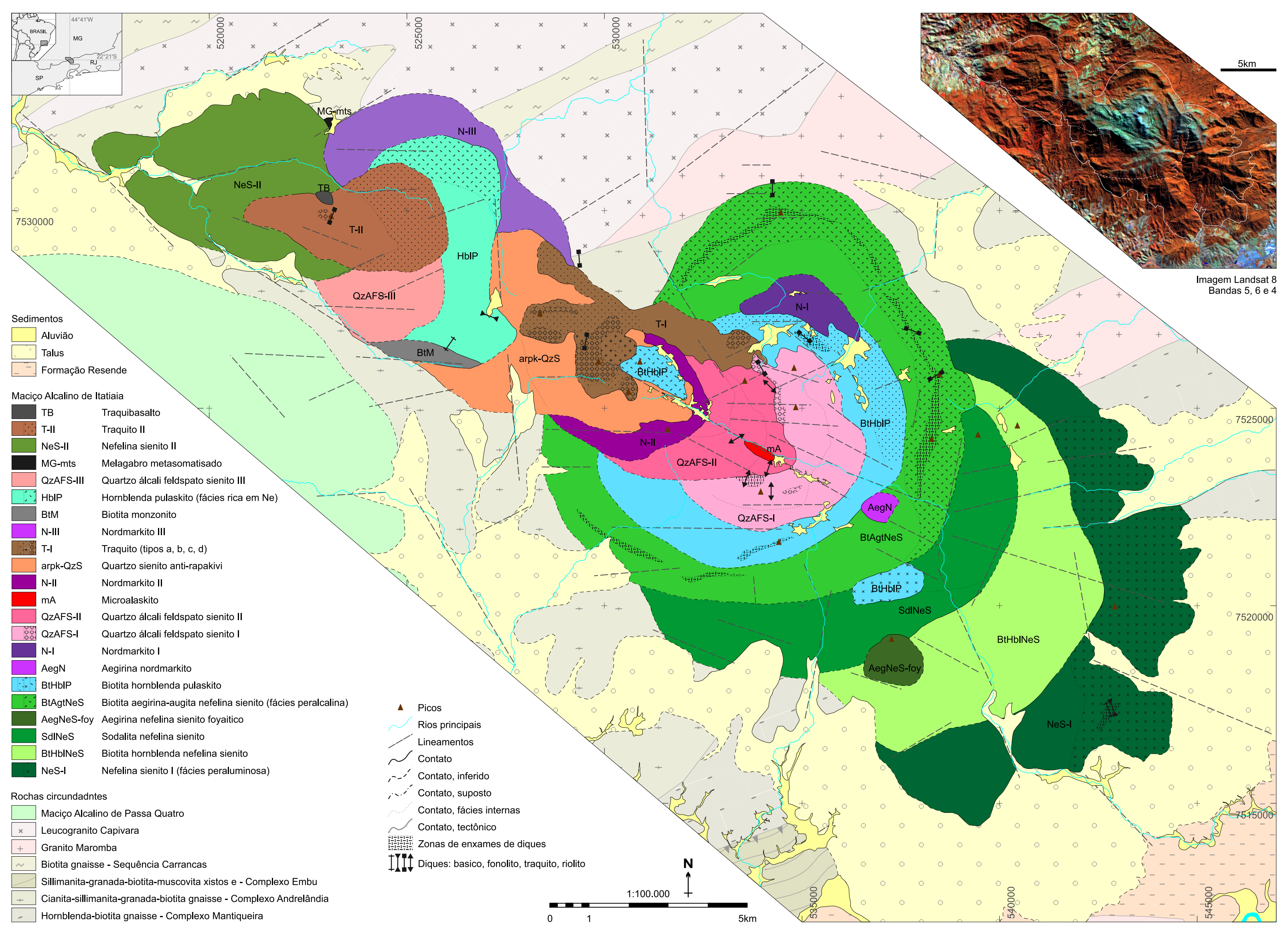


Tabelas de análises de química mineral

ANEXO E 
ANEXO E - Tabela E.1 - Composição química de feldspatos de rochas do Maciço Alcalino de Itatiaia. Continua

\section{Unidade BtHbNeS}

\begin{tabular}{|c|c|c|c|c|c|c|c|c|c|c|c|c|c|c|c|c|c|c|c|c|c|c|c|c|c|}
\hline Cristal & 1 & 1 & 2 & 2 & 3 & 4 & 4 & 5 & 6 & 7 & 7 & 8 & 8 & 9 & 9 & 10 & 10 & 11 & 11 & 12 & 12 & 13 & 13 & 14 & 14 \\
\hline Textura $^{1}$ & $\mathrm{kfln}$ & $\mathrm{kfl} \mathrm{b}$ & plkkfl & $\mathrm{kfl}$ & $\mathrm{kfl}$ & $\mathrm{kfl} \mathrm{n}$ & $\mathrm{kfl} \mathrm{b}$ & kfl b & $\mathrm{pl}$ & $\mathrm{kfl} \mathrm{b}$ & $\mathrm{kfln}$ & $\mathrm{kfl} \mathrm{n}$ & $\mathrm{kfl} b$ & $\mathrm{kfln}$ & $\mathrm{kflb}$ & $\mathrm{kfln}$ & $\mathrm{kflb}$ & $\mathrm{pln}$ & $\mathrm{plb}$ & $\mathrm{pln}$ & $\mathrm{pl} \mathrm{b}$ & $\mathrm{pln}$ & $\mathrm{plb}$ & $\mathrm{kfln}$ & kfl t \\
\hline $\mathrm{SiO}_{2}$ & 66,00 & 66,05 & 61,31 & 65,82 & 65,74 & 65,57 & 65,45 & 65,54 & 65,85 & 64,71 & 65,93 & 66,37 & 65,67 & 65,98 & 65,86 & 66,14 & 65,10 & 60,33 & 62,29 & 60,19 & 62,29 & 60,77 & 61,96 & 65,78 & 65,89 \\
\hline $\mathrm{Al}_{2} \mathrm{O}_{3}$ & 19,60 & 19,62 & 25,03 & 19,45 & 19,23 & 19,20 & 19,24 & 19,38 & 19,34 & 18,91 & 19,54 & 18,98 & 19,30 & 19,56 & 19,31 & 19,52 & 19,00 & 25,35 & 24,07 & 25,57 & 24,19 & 24,70 & 24,04 & 19,34 & 19,35 \\
\hline $\mathrm{TiO}_{2}$ & 0,04 & 0,08 & 0,06 & 0,06 & 0,01 & 0,05 & 0,04 & & 0,04 & 0,13 & 0,05 & 0,07 & 0,10 & 0,13 & & 0,01 & 0,02 & 0,02 & 0,09 & 0,08 & 0,01 & 0,10 & 0,04 & 0,12 & $0, c$ \\
\hline $\mathrm{Fe}_{2} \mathrm{O}_{3}$ & 0,08 & 0,10 & 0,14 & 0,04 & 0,07 & 0,03 & 0,14 & 0,03 & 0,11 & 0,23 & 0,08 & 0,14 & 0,09 & 0,03 & 0,13 & 0,08 & 0,17 & 0,13 & 0,09 & 0,11 & 0,28 & 0,14 & 0,09 & 0,07 & 0,06 \\
\hline $\mathrm{MnO}$ & 0,00 & 0,01 & & 0,01 & & 0,02 & 0,00 & & & 0,02 & & 0,00 & & 0,00 & & 0,01 & 0,02 & & 0,01 & 0,01 & & 0,01 & 0,01 & 0,01 & \\
\hline MgO & 0,00 & & 0,00 & 0,01 & & & 0,00 & 0,01 & 0,01 & & 0,00 & & & 0,02 & 0,01 & 0,00 & 0,02 & 0,01 & & & & & & & \\
\hline $\mathrm{CaO}$ & 0,40 & 0,52 & 5,64 & 0,45 & 0,41 & 0,21 & 0,41 & 0,44 & 0,47 & 0,43 & 0,49 & 0,10 & 0,42 & 0,45 & 0,38 & 0,49 & 0,45 & 6,54 & 5,19 & 6,66 & 5,15 & 5,94 & 5,01 & 0,42 & 0,39 \\
\hline $\mathrm{Na}_{2} \mathrm{O}$ & 4,05 & 3,97 & 8,01 & 3,25 & 3,89 & 3,01 & 3,55 & 3,68 & 4,15 & 3,65 & 4,35 & 3,33 & 3,50 & 3,65 & 4,01 & 4,08 & 3,36 & 7,64 & 8,34 & 7,42 & 8,43 & 7,93 & 8,28 & 3,79 & 3,24 \\
\hline $\mathrm{K}_{2} \mathrm{O}$ & 10,41 & 10,64 & 0,17 & 11,79 & 10,72 & 12,45 & 11,46 & 11,04 & 10,29 & 11,62 & 10,28 & 11,82 & 11,55 & 11,36 & 10,67 & 10,30 & 11,64 & 0,15 & 0,25 & 0,27 & 0,17 & 0,23 & 0,24 & 11,01 & 11,92 \\
\hline SrO & 0,09 & 0,08 & 0,08 & 0,08 & 0,12 & 0,09 & 0,10 & 0,08 & 0,07 & 0,10 & 0,11 & 0,08 & 0,04 & 0,07 & 0,07 & 0,05 & 0,05 & 0,08 & 0,07 & 0,07 & 0,06 & 0,07 & 0,13 & 0,09 & $0,1 c$ \\
\hline $\mathrm{BaO}$ & 0,01 & & 0,00 & & 0,03 & 0,05 & & & 0,02 & 0,07 & & & & 0,04 & & & & 0,03 & & & & 0,03 & & 0,06 & \\
\hline
\end{tabular}

\section{Número de cátions calculado na base de 32 oxigênios.}

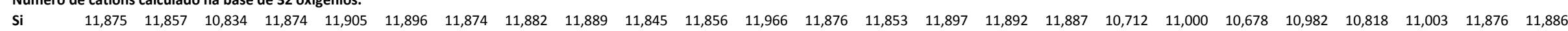

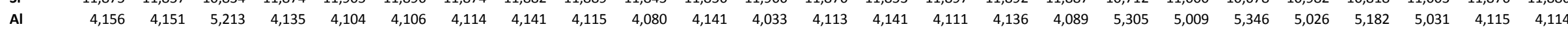
$\begin{array}{lllllllllllllllllllllllllll}\mathrm{Ti} & 0,005 & 0,011 & 0,009 & 0,009 & 0,001 & 0,007 & 0,005 & 0,000 & 0,006 & 0,018 & 0,007 & 0,010 & 0,014 & 0,017 & 0,000 & 0,001 & 0,003 & 0,003 & 0,012 & 0,011 & 0,001 & 0,013 & 0,005 & 0,016 & 0,011 \\ \mathrm{Fe}^{3+} & 0,011 & 0,013 & 0,09 & 0,005 & 0,010 & 0,005 & 0,019 & 0,004 & 0,014 & 0,032 & 0,011 & 0,019 & 0,013 & 0,004 & 0,017 & 0,010 & 0,024 & 0,018 & 0,012 & 0,014 & 0,037 & 0,018 & 0,012 & 0,009 & 0,008\end{array}$ $\begin{array}{lllllllllllllllllllllllllll}\mathrm{Fe}^{3+} & 0,011 & 0,013 & 0,019 & 0,005 & 0,010 & 0,005 & 0,019 & 0,004 & 0,014 & 0,032 & 0,011 & 0,019 & 0,013 & 0,004 & 0,017 & 0,010 & 0,024 & 0,018 & 0,012 & 0,014 & 0,037 & 0,018 & 0,012 & 0,009 & 0,008\end{array}$ $\begin{array}{llllllllllllllllllllllllllllll}M n & 0,000 & 0,001 & 0,000 & 0,001 & 0,000 & 0,003 & 0,001 & 0,000 & 0,000 & 0,002 & 0,000 & 0,000 & 0,000 & 0,001 & 0,000 & 0,001 & 0,003 & 0,000 & 0,001 & 0,001 & 0,000 & 0,001 & 0,001 & 0,002 & 0,000\end{array}$ $\begin{array}{llllllllllllllllllllllllllll}\text { Mg } & 0,000 & 0,000 & 0,001 & 0,003 & 0,000 & 0,000 & 0,001 & 0,002 & 0,003 & 0,000 & 0,001 & 0,000 & 0,000 & 0,005 & 0,003 & 0,001 & 0,006 & 0,002 & 0,000 & 0,000 & 0,000 & 0,000 & 0,000 & 0,000 & 0,000\end{array}$ $\begin{array}{llllllllllllllllllllllllllll}\text { Ca } & 0,078 & 0,100 & 1,068 & 0,086 & 0,080 & 0,041 & 0,080 & 0,085 & 0,091 & 0,084 & 0,094 & 0,020 & 0,082 & 0,087 & 0,073 & 0,095 & 0,089 & 1,244 & 0,982 & 1,266 & 0,973 & 1,133 & 0,953 & 0,081 & 0,075\end{array}$

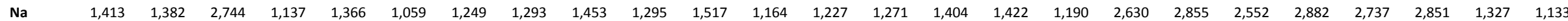
\begin{tabular}{lllllllllllllllllllllllllll}
$\mathbf{K}$ & 2,389 & 2,436 & 0,039 & 2,713 & 2,476 & 2,881 & 2,652 & 2,553 & 2,370 & 2,713 & 2,358 & 2,719 & 2,664 & 2,603 & 2,459 & 2,362 & 2,711 & 0,034 & 0,056 & 0,062 & 0,038 & 0,052 & 0,054 & 2,536 & 2,743 \\
\hline
\end{tabular} $\begin{array}{lllllllllllllllllllllllllllll}\text { Sr } & 0,010 & 0,008 & 0,008 & 0,009 & 0,012 & 0,009 & 0,011 & 0,008 & 0,008 & 0,011 & 0,012 & 0,008 & 0,004 & 0,008 & 0,007 & 0,005 & 0,006 & 0,008 & 0,008 & 0,007 & 0,006 & 0,007 & 0,014 & 0,010 & 0,010\end{array}$

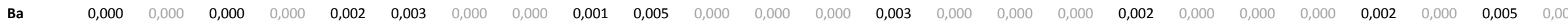

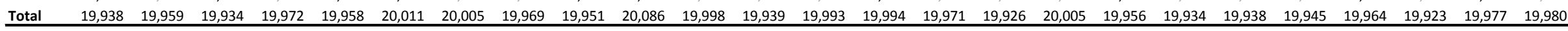

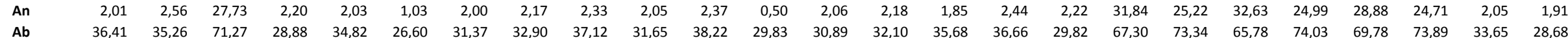

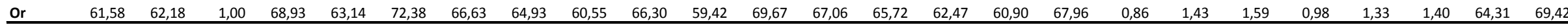
Albite Activity

\section{$800^{\circ} \mathrm{C}$}

$900^{\circ} \mathrm{C}$

Anortite Activity

$800^{\circ} \mathrm{C}$

\section{$900^{\circ} \mathrm{C}$}

n, núcleo; b, borda; <, incluso em; ints, intersticial; fen, fenocristal; idio, idiomórfico; lam, lamela de exsolução;

TÜ - análises realizadas na Universidade de Tübingen 
ANEXO E - Tabela E.1 - Composição química de feldspatos de rochas do Maciço Alcalino de Itatiaia. Continua.

\begin{tabular}{|c|c|c|c|c|c|c|c|c|c|c|c|c|c|c|c|c|c|c|c|c|c|c|c|c|c|}
\hline \multicolumn{9}{|c|}{$\begin{array}{l}\text { Unidade BtHbNeS } \\
\text { Amostra MAI036 }\end{array}$} & \multicolumn{17}{|c|}{\begin{tabular}{|l|} 
NeS-I \\
MAI060 \\
\end{tabular}} \\
\hline Cristal & 15 & 15 & 16 & 16 & 17 & 17 & $1 R^{*}$ & $2 \mathrm{R}^{*}$ & 3 & $3 \mathrm{R}^{*}$ & $4 R^{*}$ & $5 \mathrm{R}^{*}$ & 23 & 25 & 27 & 34 & 18 & 18 & 19 & 19 & 20 & 21 & 22 & 23 & 23 \\
\hline Textura $^{1}$ & $\mathrm{pln}$ & $\mathrm{plb}$ & kfl b & $\mathrm{kfln}$ & $\mathrm{kfln}$ & kfl b & TÜ & TÜ & тÜ & тÜ & TÜ & тÜ & тÜ & тÜ & TÜ & TÜ & $\mathrm{kfln}$ & kfl b & $\mathrm{kfln}$ & $\mathrm{kflb}$ & $\mathrm{kfln}$ & kfl ints & $\mathrm{kfl}$ & $\mathrm{kfln}$ & $\mathrm{kfl} b$ \\
\hline$\overline{\mathrm{SiO}_{2}}$ & 61,08 & 60,78 & 65,98 & 66,08 & $\begin{array}{l}65,94 \\
\end{array}$ & 66,11 & 65,50 & 65,40 & 61,31 & 63,83 & 63,51 & 65,13 & 60,33 & 60,19 & 60,77 & 61,08 & 65,18 & 65,15 & 65,22 & 64,78 & 65,37 & 65,37 & $\begin{array}{l}65,54 \\
\end{array}$ & 65,48 & 65,77 \\
\hline $\mathrm{Al}_{2} \mathrm{O}_{3}$ & 24,79 & 24,90 & 19,62 & 19,14 & 19,53 & 19,29 & 18,88 & 19,59 & 25,03 & 19,68 & 19,46 & 19,97 & 25,35 & 25,57 & 24,70 & 24,79 & 18,99 & 18,66 & 18,80 & 18,49 & 18,73 & 18,56 & 18,77 & 18,64 & 18,99 \\
\hline $\mathrm{TiO}_{2}$ & 0,04 & 0,02 & 0,07 & 0,06 & 0,03 & 0,02 & & & 0,06 & & & & 0,02 & 0,08 & 0,10 & 0,04 & 0,06 & & 0,07 & 0,08 & 0,02 & 0,03 & & 0,07 & 0,03 \\
\hline $\mathrm{Fe}_{2} \mathrm{O}_{3}$ & 0,08 & 0,11 & 0,06 & 0,15 & 0,06 & 0,07 & 0,04 & 0,04 & 0,13 & 0,06 & 0,05 & 0,04 & 0,12 & 0,10 & 0,12 & 0,07 & 0,03 & 0,38 & 0,16 & 0,18 & 0,19 & 0,19 & 0,19 & 0,14 & 0,02 \\
\hline MnO & & & 0,00 & 0,00 & 0,01 & & & & & & & & & & & & 0,00 & 0,02 & & 0,03 & 0,00 & 0,01 & 0,00 & & \\
\hline MgO & 0,02 & & & & 0,01 & 0,00 & & & & & & & & & & & & & & 0,01 & & & 0,00 & 0,01 & 0,00 \\
\hline $\mathrm{CaO}$ & 5,69 & 5,92 & 0,67 & 0,16 & 0,52 & 0,33 & 0,25 & 1,04 & 5,64 & 0,95 & 0,57 & 1,37 & 6,54 & 6,66 & 5,94 & 5,69 & & 0,01 & 0,06 & 0,05 & 0,05 & 0,04 & 0,04 & & \\
\hline $\mathrm{Na}_{2} \mathrm{O}$ & 8,13 & 7,96 & 3,69 & 3,36 & 4,07 & 3,37 & 5,03 & 5,40 & 8,01 & 5,23 & 4,75 & 4,60 & 7,64 & 7,42 & 7,93 & 8,13 & 0,31 & 0,53 & 0,80 & 0,49 & 0,65 & 0,61 & 0,56 & 0,48 & 0,47 \\
\hline $\mathrm{K}_{2} \mathrm{O}$ & 0,20 & 0,22 & 11,01 & 12,02 & 10,69 & 11,53 & 9,39 & 8,12 & 0,17 & 8,49 & 9,46 & 9,10 & 0,15 & 0,27 & 0,23 & 0,20 & 16,43 & 16,01 & 15,70 & 16,13 & 15,88 & 16,20 & 16,07 & 16,19 & 16,57 \\
\hline SrO & 0,08 & 0,05 & 0,05 & 0,07 & 0,11 & 0,06 & 0,00 & 0,02 & 0,08 & 0,01 & 0,01 & 0,02 & 0,08 & 0,07 & 0,07 & 0,08 & 0,01 & 0,01 & 0,06 & 0,10 & 0,06 & 0,07 & 0,05 & 0,01 & 0,01 \\
\hline $\mathrm{BaO}$ & 0,06 & & & & 0,00 & 0,02 & 0,01 & 0,00 & 0,00 & 0,00 & 0,03 & 0,01 & 0,03 & & 0,03 & 0,06 & 0,01 & 0,03 & & & 0,09 & & 0,02 & & \\
\hline Total & 100,17 & 99,97 & 101,15 & 101,04 & 100,98 & 100,80 & 99,10 & 99,62 & 100,44 & 98,25 & 97,85 & 100,24 & 100,26 & 100,37 & 99,90 & 100,16 & 101,03 & 100,81 & 100,87 & 100,35 & 101,05 & 101,08 & 101,26 & 101,02 & 101,87 \\
\hline \multicolumn{26}{|c|}{ Número de cátions calculado na base de 32 oxigênios. } \\
\hline $\mathrm{Si}$ & 10,838 & 10,807 & 11,851 & 11,920 & 11,859 & 11,922 & 2,985 & 2,956 & 2,710 & 2,934 & 2,941 & 2,938 & 2,679 & 2,671 & 2,706 & 2,711 & 11,928 & 11,947 & 11,937 & 11,948 & 11,955 & 11,965 & 11,959 & 11,974 & 11,943 \\
\hline Al & 5,184 & 5,218 & 4,153 & 4,069 & 4,140 & 4,100 & 1,014 & 1,043 & 1,304 & 1,066 & 1,062 & 1,062 & 1,327 & 1,337 & 1,296 & 1,297 & 4,096 & 4,033 & 4,055 & 4,019 & 4,037 & 4,004 & 4,037 & 4,017 & 4,064 \\
\hline $\mathrm{Ti}$ & 0,005 & 0,003 & 0,009 & 0,008 & 0,004 & 0,002 & 0,000 & 0,000 & 0,002 & 0,000 & 0,000 & 0,000 & 0,001 & 0,003 & 0,003 & 0,001 & 0,009 & 0,000 & 0,010 & 0,011 & 0,003 & 0,005 & 0,000 & 0,010 & 0,005 \\
\hline $\mathrm{Fe}^{3+}$ & 0,011 & 0,015 & 0,008 & 0,020 & 0,008 & 0,009 & 0,002 & 0,001 & 0,005 & 0,002 & 0,002 & 0,002 & 0,004 & 0,004 & 0,005 & 0,003 & 0,005 & 0,053 & 0,022 & 0,025 & 0,027 & 0,026 & 0,026 & 0,020 & 0,003 \\
\hline $\mathrm{Mn}$ & 0,000 & 0,000 & 0,001 & 0,000 & 0,002 & 0,000 & & & & & & & & & & & 0,001 & 0,003 & 0,000 & 0,004 & 0,000 & 0,001 & 0,000 & 0,000 & 0,000 \\
\hline Mg & 0,005 & 0,000 & 0,000 & 0,000 & 0,003 & 0,000 & & & & & & & & & & & 0,000 & 0,000 & 0,000 & 0,004 & 0,000 & 0,000 & 0,001 & 0,002 & 0,001 \\
\hline $\mathrm{Ca}$ & 1,082 & 1,128 & 0,130 & 0,032 & 0,101 & 0,064 & 0,012 & 0,051 & 0,267 & 0,047 & 0,028 & 0,066 & 0,311 & 0,317 & 0,283 & 0,271 & 0,000 & 0,002 & 0,012 & 0,009 & 0,009 & 0,008 & 0,009 & 0,000 & 0,000 \\
\hline $\mathrm{Na}$ & 2,797 & 2,744 & 1,285 & 1,175 & 1,419 & 1,178 & 0,444 & 0,474 & 0,686 & 0,467 & 0,427 & 0,402 & 0,658 & 0,638 & 0,685 & 0,700 & 0,110 & 0,190 & 0,283 & 0,177 & 0,230 & 0,217 & 0,199 & 0,169 & 0,165 \\
\hline K & 0,045 & 0,051 & 2,523 & 2,766 & 2,452 & 2,652 & 0,546 & 0,468 & 0,010 & 0,498 & 0,559 & 0,524 & 0,008 & 0,015 & 0,013 & 0,011 & 3,836 & 3,745 & 3,665 & 3,795 & 3,705 & 3,782 & 3,741 & 3,777 & 3,838 \\
\hline $\mathrm{Sr}$ & 0,009 & 0,005 & 0,005 & 0,007 & 0,012 & 0,007 & 0,000 & 0,000 & 0,000 & 0,000 & 0,000 & 0,000 & 0,000 & 0,000 & 0,000 & 0,000 & 0,001 & 0,001 & 0,006 & 0,011 & 0,007 & 0,008 & 0,005 & 0,001 & 0,001 \\
\hline Ba & 0,004 & 0,000 & 0,000 & 0,000 & 0,000 & 0,001 & 0,000 & 0,000 & 0,000 & 0,000 & 0,001 & 0,000 & 0,000 & 0,000 & 0,001 & 0,001 & 0,001 & 0,003 & 0,000 & 0,000 & 0,007 & 0,000 & 0,002 & 0,000 & 0,000 \\
\hline Total & 19,980 & 19,971 & 19,964 & 19,998 & 19,999 & 19,936 & 5,003 & 4,993 & 4,984 & 5,015 & 5,020 & 4,994 & 4,990 & 4,985 & 4,992 & 4,995 & 19,985 & 19,977 & 19,989 & 20,004 & 19,978 & 20,015 & 19,979 & 19,970 & 20,021 \\
\hline An & 27,57 & 28,75 & 3,29 & 0,80 & 2,53 & 1,64 & 44,33 & 47,73 & 71,27 & 46,12 & 42,08 & 40,54 & 67,30 & 65,78 & 69,78 & 71,28 & 0,00 & 0,06 & 0,29 & 0,22 & 0,23 & 0,19 & 0,22 & 0,00 & 0,00 \\
\hline$A b$ & 71,28 & 69,96 & 32,64 & 29,58 & 35,73 & 30,26 & 1,24 & 5,10 & 27,73 & 4,65 & 2,80 & 6,65 & 31,84 & 32,63 & 28,88 & 27,57 & 2,78 & 4,82 & 7,14 & 4,44 & 5,84 & 5,40 & 5,04 & 4,29 & 4,13 \\
\hline or & 1,15 & 1,29 & 64,07 & 69,62 & 61,74 & 68,11 & 54,43 & 47,18 & 1,00 & 49,23 & 55,12 & 52,81 & 0,86 & 1,59 & 1,33 & 1,15 & 97,22 & 95,12 & 92,56 & 95,33 & 93,93 & 94,41 & 94,74 & 95,71 & 95,87 \\
\hline \multicolumn{26}{|c|}{ Albite Activity } \\
\hline $800^{\circ} \mathrm{C}$ & & & & & & & 0,93 & 0,85 & - & 0,86 & 0,89 & 0,80 & - & - & - & - & & & & & & & & & \\
\hline $900^{\circ} \mathrm{C}$ & & & & & & & 0,88 & 0,81 & - & 0,81 & 0,84 & 0,76 & - & - & - & - & & & & & & & & & \\
\hline \multicolumn{26}{|c|}{ Anortite Activity } \\
\hline $800^{\circ} \mathrm{C}$ & & & & & & & - & - & 0,38 & - & - & - & 0,44 & 0,45 & 0,40 & 0,38 & & & & & & & & & \\
\hline $900^{\circ} \mathrm{C}$ & & & & & & & - & & 0,36 & - & - & & 0,41 & 0,42 & 0,37 & 0,35 & & & & & & & & & \\
\hline
\end{tabular}

${ }^{1}$ - $n$, núcleo; $b$, borda; <, incluso em; ints, intersticial; fen, fenocristal; idio, idiomórfico; lam, lamela de exsolução;

TÜ - análises realizadas na Universidade de Tübingen 
ANEXO E - Tabela E.1 - Composição química de feldspatos de rochas do Maciço Alcalino de Itatiaia. Continua.

\begin{tabular}{|c|c|c|c|c|c|c|c|c|c|c|c|c|c|c|c|c|c|c|c|c|c|c|c|c|c|}
\hline \multicolumn{13}{|c|}{$\begin{array}{l}\text { Unidade NeS-I } \\
\text { Amostra MAI060 }\end{array}$} & \multicolumn{8}{|c|}{\begin{tabular}{|l|}
$\mathrm{mA}$ \\
$\mathrm{MAI070B}$
\end{tabular}} & \multicolumn{5}{|l|}{$\begin{array}{l}\text { AegN } \\
\text { MAlO90 } \\
\end{array}$} \\
\hline Cristal & 24 & 24 & 25 & 25 & 26 & 26 & 27 & 28 & $1 \mathrm{R}^{*}$ & $2 \mathrm{R}^{*}$ & $3 R^{*}$ & $4 R^{*}$ & 29 & 29 & 29 & 30 & 31 & 32 & 33 & 34 & 35 & 36 & 37 & 37 & 38 \\
\hline Textura $^{1}$ & $\mathrm{kfln}$ & $\mathrm{kfl} b$ & $\mathrm{kfln}$ & kfl b & $\mathrm{kfln}$ & $\mathrm{kfl} \mathrm{b}$ & $\mathrm{kfl}$ & $\mathrm{kfl}$ & TÜ & тÜ & TÜ & TÜ & $\mathrm{kfl} \mathrm{n}$ & $\mathrm{kflb}$ & $a b b$ & $\mathrm{kfl}$ & $\mathrm{kfl}$ & $\mathrm{kfl}$ & $\mathrm{kfl}$ & $\mathrm{kfl}$ & $\mathrm{kfl}$ & $\mathrm{kfl}$ & $\mathrm{kfl} \mathrm{n}$ & kfl b & $\mathrm{kfl}$ \\
\hline$\overline{\mathrm{SiO}_{2}}$ & 65,31 & 65,24 & 64,95 & 66,27 & 64,95 & 65,89 & 65,19 & 65,54 & 66,80 & 66,43 & 65,80 & 66,10 & 66,99 & 67,40 & 68,72 & 66,75 & 67,02 & 67,28 & 66,40 & 66,38 & 67,30 & $\begin{array}{l}68,04 \\
\end{array}$ & 67,49 & 67,47 & 67,57 \\
\hline $\mathrm{Al}_{2} \mathrm{O}_{3}$ & 18,66 & 18,66 & 18,87 & 18,82 & 18,57 & 19,02 & 18,71 & 18,78 & 18,57 & 18,56 & 18,59 & 18,52 & 18,99 & 18,59 & 19,44 & 19,19 & 18,93 & 19,08 & 18,95 & 18,69 & 19,11 & 19,44 & 19,48 & 18,71 & 19,25 \\
\hline $\mathrm{TiO}_{2}$ & 0,00 & 0,03 & 0,01 & & 0,03 & 0,01 & 0,08 & 0,05 & & & & & & 0,01 & & 0,03 & 0,03 & 0,00 & 0,07 & & 0,02 & 0,00 & 0,03 & & 0,02 \\
\hline $\mathrm{Fe}_{2} \mathrm{O}_{3}$ & 0,14 & 0,05 & 0,13 & 0,24 & 0,14 & 0,23 & 0,17 & 0,27 & 0,23 & 0,16 & 0,03 & 0,03 & 0,36 & 0,46 & 0,22 & 0,39 & 0,25 & 0,30 & 0,39 & 0,24 & 0,28 & 0,20 & 0,26 & 0,57 & 0,30 \\
\hline $\mathrm{MnO}$ & & 0,00 & & & 0,00 & 0,01 & & 0,02 & & & & & 0,00 & 0,01 & 0,03 & & & & & 0,00 & & 0,00 & 0,00 & & \\
\hline $\mathrm{MgO}$ & 0,00 & 0,01 & & 0,01 & & 0,00 & 0,00 & & & & & & 0,01 & & 0,01 & 0,00 & 0,01 & & 0,01 & 0,00 & & 0,00 & 0,00 & 0,01 & 0,00 \\
\hline $\mathrm{CaO}$ & 0,01 & 0,00 & 0,07 & 0,05 & 0,03 & 0,04 & 0,00 & & 0,04 & 0,01 & 0,01 & 0,04 & 0,13 & 0,02 & 0,09 & 0,29 & 0,06 & 0,32 & 0,11 & 0,11 & 0,13 & 0,23 & 0,31 & 0,04 & 0,18 \\
\hline $\mathrm{Na}_{2} \mathrm{O}$ & 0,44 & 0,38 & 0,59 & 0,74 & 0,63 & 0,70 & 0,44 & 0,36 & 2,92 & 2,88 & 2,59 & 3,15 & 6,79 & 6,72 & 11,24 & 6,80 & 6,39 & 7,01 & 5,72 & 6,19 & 6,70 & 9,05 & 8,26 & 6,87 & 7,31 \\
\hline $\mathrm{K}_{2} \mathrm{O}$ & 16,26 & 16,30 & 16,04 & 15,81 & 16,02 & 15,80 & 16,26 & 16,47 & 12,81 & 12,96 & 13,26 & 12,35 & 6,67 & 7,03 & 0,43 & 6,65 & 7,38 & 6,16 & 8,42 & 7,52 & 6,93 & 3,51 & 4,52 & 6,75 & 6,13 \\
\hline Sro & 0,09 & 0,03 & 0,06 & 0,03 & 0,10 & 0,11 & 0,06 & 0,03 & 0,01 & 0,00 & 0,02 & 0,01 & 0,01 & 0,02 & & 0,06 & 0,03 & 0,06 & 0,04 & 0,06 & 0,02 & & 0,01 & 0,01 & \\
\hline $\mathrm{BaO}$ & & & & 0,03 & & 0,07 & 0,02 & & 0,01 & 0,00 & 0,02 & 0,02 & 0,04 & 0,06 & & 0,01 & 0,04 & & 0,03 & 0,02 & 0,00 & 0,03 & & 0,07 & \\
\hline Total & 100,91 & 100,71 & 100,72 & 101,99 & 100,49 & 101,89 & 100,94 & 101,52 & 101,39 & 101,01 & 100,32 & 100,23 & 99,99 & 100,31 & 100,17 & 100,18 & 100,13 & 100,20 & 100,13 & 99,21 & 100,49 & 100,51 & 100,36 & 100,50 & 100,77 \\
\hline \multicolumn{26}{|c|}{ Número de cátions calculado na base de 32 oxigênios. } \\
\hline Si & 11,968 & 11,972 & 11,922 & 11,983 & 11,954 & 11,940 & 11,946 & 11,947 & 3,008 & 3,004 & 3,000 & 3,005 & 11,977 & 12,032 & 11,993 & 11,927 & 11,992 & 11,979 & 11,943 & 11,999 & 11,978 & 11,966 & 11,933 & 12,013 & 11,964 \\
\hline Al & 4,030 & 4,036 & 4,082 & 4,011 & 4,028 & 4,062 & 4,041 & 4,035 & 0,986 & 0,990 & 0,999 & 0,993 & 4,002 & 3,911 & 3,999 & 4,041 & 3,992 & 4,004 & 4,017 & 3,982 & 4,008 & 4,029 & 4,059 & 3,926 & 4,017 \\
\hline $\mathrm{Ti}$ & 0,000 & 0,004 & 0,002 & 0,000 & 0,005 & 0,002 & 0,011 & 0,007 & 0,000 & 0,000 & 0,000 & 0,000 & 0,000 & 0,001 & 0,000 & 0,003 & 0,004 & 0,001 & 0,010 & 0,000 & 0,002 & 0,000 & 0,004 & 0,000 & 0,003 \\
\hline $\mathrm{Fe}^{3+}$ & 0,020 & 0,007 & 0,019 & 0,032 & 0,020 & 0,031 & 0,023 & 0,037 & 0,009 & 0,006 & 0,001 & 0,001 & 0,049 & 0,061 & 0,029 & 0,052 & 0,034 & 0,040 & 0,052 & 0,033 & 0,038 & 0,027 & 0,035 & 0,076 & 0,040 \\
\hline $\mathrm{Mn}$ & 0,000 & 0,000 & 0,000 & 0,000 & 0,001 & 0,001 & 0,000 & 0,003 & & & & & 0,000 & 0,001 & 0,004 & 0,000 & 0,000 & 0,000 & 0,000 & 0,000 & 0,000 & 0,001 & 0,001 & 0,000 & 0,000 \\
\hline Mg & 0,001 & 0,003 & 0,000 & 0,001 & 0,000 & 0,000 & 0,001 & 0,000 & & & & & 0,003 & 0,000 & 0,002 & 0,000 & 0,001 & 0,000 & 0,001 & 0,001 & 0,000 & 0,000 & 0,000 & 0,003 & 0,000 \\
\hline $\mathrm{Ca}$ & 0,002 & 0,001 & 0,013 & 0,009 & 0,006 & 0,007 & 0,001 & 0,000 & 0,002 & 0,001 & 0,000 & 0,002 & 0,026 & 0,003 & 0,016 & 0,056 & 0,012 & 0,060 & 0,021 & 0,021 & 0,025 & 0,044 & 0,058 & 0,008 & 0,035 \\
\hline $\mathrm{Na}$ & 0,156 & 0,135 & 0,209 & 0,261 & 0,224 & 0,247 & 0,156 & 0,126 & 0,255 & 0,253 & 0,229 & 0,277 & 2,354 & 2,326 & 3,803 & 2,356 & 2,217 & 2,420 & 1,995 & 2,169 & 2,312 & 3,086 & 2,832 & 2,372 & 2,509 \\
\hline K & 3,801 & 3,816 & 3,756 & 3,647 & 3,761 & 3,652 & 3,801 & 3,830 & 0,736 & 0,748 & 0,772 & 0,716 & 1,521 & 1,601 & 0,096 & 1,516 & 1,684 & 1,399 & 1,932 & 1,734 & 1,573 & 0,787 & 1,019 & 1,533 & 1,385 \\
\hline Sr & 0,010 & 0,003 & 0,007 & 0,003 & 0,011 & 0,011 & 0,007 & 0,003 & 0,000 & 0,000 & 0,000 & 0,000 & 0,001 & 0,002 & 0,000 & 0,007 & 0,003 & 0,006 & 0,004 & 0,006 & 0,002 & 0,000 & 0,001 & 0,001 & 0,000 \\
\hline $\mathrm{Ba}$ & 0,000 & 0,000 & 0,000 & 0,002 & 0,000 & 0,005 & 0,001 & 0,000 & 0,000 & 0,000 & 0,000 & 0,000 & 0,003 & 0,004 & 0,000 & 0,001 & 0,002 & 0,000 & 0,002 & 0,001 & 0,000 & 0,002 & 0,000 & 0,005 & 0,000 \\
\hline Total & 19,986 & 19,977 & 20,008 & 19,949 & 20,010 & 19,961 & 19,989 & 19,988 & 4,995 & 5,001 & 5,001 & 4,995 & 19,935 & 19,944 & 19,943 & 19,959 & 19,942 & 19,908 & 19,976 & 19,946 & 19,939 & 19,943 & 19,942 & 19,938 & 19,952 \\
\hline An & 0,04 & 0,02 & 0,33 & 0,23 & 0,16 & 0,19 & 0,02 & 0,00 & 25,71 & 25,25 & 22,85 & 27,85 & 0,66 & 0,08 & 0,41 & 1,43 & 0,32 & 1,55 & 0,53 & 0,53 & 0,64 & 1,13 & 1,48 & 0,20 & 0,89 \\
\hline$A b$ & 3,94 & 3,41 & 5,25 & 6,66 & 5,60 & 6,33 & 3,95 & 3,19 & 0,20 & 0,06 & 0,04 & 0,19 & 60,34 & 59,18 & 97,13 & 59,98 & 56,64 & 62,38 & 50,53 & 55,28 & 59,12 & 78,77 & 72,44 & 60,62 & 63,87 \\
\hline Or & 96,02 & 96,57 & 94,42 & 93,12 & 94,23 & 93,48 & 96,03 & 96,81 & 74,09 & 74,70 & 77,11 & 71,96 & 39,00 & 40,74 & 2,46 & 38,59 & 43,04 & 36,07 & 48,94 & 44,19 & 40,23 & 20,10 & 26,08 & 39,19 & 35,24 \\
\hline \multicolumn{26}{|c|}{ Albite Activity } \\
\hline $800^{\circ} \mathrm{C}$ & & & & & & & & & 0,83 & 0,82 & 0,79 & 0,85 & & & & & & & & & & & & & \\
\hline $900^{\circ} \mathrm{C}$ & & & & & & & & & 0,75 & 0,74 & 0,71 & 0,78 & & & & & & & & & & & & & \\
\hline \multicolumn{26}{|c|}{ Anortite Activity } \\
\hline $800^{\circ} \mathrm{C}$ & & & & & & & & & - & - & - & - & & & & & & & & & & & & & \\
\hline $900^{\circ} \mathrm{C}$ & & & & & & & & & & & & & & & & & & & & & & & & & \\
\hline
\end{tabular}

${ }^{1}$ - n, núcleo; b, borda; <, incluso em; ints, intersticial; fen, fenocristal; idio, idiomórfico; lam, lamela de exsolução;

TÜ - análises realizadas na Universidade de Tübingen 
ANEXO E - Tabela E.1 - Composição química de feldspatos de rochas do Maciço Alcalino de Itatiaia. Continua

\begin{tabular}{|c|c|c|c|c|c|c|c|c|c|c|c|c|c|c|c|c|c|c|c|c|c|c|c|c|c|}
\hline \multicolumn{2}{|c|}{$\begin{array}{l}\text { Unidade AegN } \\
\text { Amostra MAl090 }\end{array}$} & \multicolumn{24}{|l|}{\begin{tabular}{|l} 
BtHblP \\
MAI092I
\end{tabular}} \\
\hline Cristal & 39 & 40 & 41 & 42 & 42 & 43 & 43 & 44 & 44 & 45 & 45 & 46 & 46 & 47 & 47 & 48 & 48 & 49 & 49 & 50 & 50 & 9 & 15 & 17 & 24 \\
\hline Textura ${ }^{1}$ & $\mathrm{kfl}$ & $\mathrm{kfl}$ & $\mathrm{kfl}$ & $\mathrm{kfln}$ & $\mathrm{kfl} \mathrm{b}$ & plant n & plant b & $\mathrm{kfl} \mathrm{b}$ & $\mathrm{kfl} \mathrm{b}$ & $\mathrm{kfln}$ & $\mathrm{kfl} \mathrm{b}$ & $\mathrm{kfln}$ & $\mathrm{kfl} b$ & $\mathrm{kfln}$ & $\mathrm{kflb}$ & $\mathrm{kfln}$ & $\mathrm{kflb}$ & $\mathrm{kfln}$ & $\mathrm{kflb}$ & $\mathrm{kfl} \mathrm{n}$ & $\mathrm{kfl} \mathrm{b}$ & TÜ & TÜ & TÜ & TÜ \\
\hline $\mathrm{SiO}_{2}$ & 67,49 & 64,78 & 65,27 & 65,77 & 66,67 & 57,28 & 65,31 & 65,73 & 66,68 & 66,60 & 66,35 & 66,40 & 66,23 & 66,42 & 66,47 & 66,42 & 65,48 & 66,28 & 66,53 & 66,58 & 66,59 & 57,28 & 66,60 & 66,40 & 66,42 \\
\hline $\mathrm{Al}_{2} \mathrm{O}_{3}$ & 19,40 & 20,81 & 18,76 & 19,22 & 19,43 & 27,48 & 22,05 & 19,38 & 19,65 & 19,38 & 19,31 & 19,42 & 19,50 & 19,64 & 19,60 & 19,52 & 19,01 & 19,54 & 19,41 & 19,47 & 19,54 & 27,48 & 19,38 & 19,42 & 19,64 \\
\hline $\mathrm{TiO}_{2}$ & 0,04 & 0,09 & & 0,02 & 0,07 & 0,14 & 0,06 & & 0,12 & 0,06 & & & 0,03 & 0,08 & 0,02 & 0,00 & 0,05 & 0,04 & 0,04 & & & 0,14 & 0,06 & & 0,08 \\
\hline $\mathrm{Fe}_{2} \mathrm{O}_{3}$ & 0,22 & 0,18 & 0,20 & 0,14 & 0,26 & 0,12 & 0,15 & 0,14 & 0,30 & 0,14 & 0,18 & 0,14 & 0,13 & 0,16 & 0,10 & 0,15 & 0,15 & 0,19 & 0,30 & 0,15 & 0,11 & 0,11 & 0,13 & 0,13 & 0,15 \\
\hline MnO & 0,01 & & & & 0,00 & 0,02 & 0,01 & & & 0,01 & & 0,02 & 0,00 & & & 0,00 & 0,03 & & 0,04 & 0,00 & & & & & \\
\hline MgO & 0,00 & & 0,00 & 0,00 & 0,02 & 0,00 & & & 0,00 & 0,01 & 0,02 & & 0,02 & 0,02 & & 0,00 & & & 0,01 & & & & & & \\
\hline $\mathrm{CaO}$ & 0,32 & 1,13 & 0,04 & 0,16 & 0,25 & 8,62 & 2,73 & 0,30 & 0,32 & 0,28 & 0,17 & 0,22 & 0,33 & 0,47 & 0,32 & 0,35 & 0,23 & 0,44 & 0,20 & 0,27 & 0,30 & 8,62 & 0,28 & 0,22 & 0,47 \\
\hline $\mathrm{Na}_{2} \mathrm{O}$ & 8,80 & 6,60 & 1,41 & 2,77 & 5,12 & 6,31 & 9,81 & 3,94 & 5,65 & 5,24 & 4,50 & 5,01 & 5,79 & 5,81 & 5,53 & 5,32 & 2,82 & 5,92 & 4,32 & 5,42 & 5,07 & 6,31 & 5,24 & 5,01 & 5,81 \\
\hline $\mathrm{K}_{2} \mathrm{O}$ & 3,83 & 5,72 & 14,90 & 12,59 & 9,10 & 0,08 & 0,22 & 10,55 & 8,41 & 8,90 & 10,13 & 9,39 & 8,14 & 7,92 & 8,37 & 8,91 & 12,48 & 7,72 & 10,21 & 8,78 & 9,13 & 0,08 & 8,90 & 9,39 & 7,92 \\
\hline Sro & 0,02 & 0,92 & 0,10 & 0,24 & 0,19 & 0,72 & 0,30 & 0,26 & 0,18 & 0,21 & 0,22 & 0,15 & 0,21 & 0,23 & 0,22 & 0,22 & 0,21 & 0,22 & 0,21 & 0,24 & 0,22 & 0,72 & 0,21 & 0,15 & 0,23 \\
\hline $\mathrm{BaO}$ & & 0,55 & 0,05 & 0,15 & 0,14 & 0,03 & 0,01 & 0,07 & & & 0,08 & 0,00 & 0,02 & 0,01 & 0,06 & & 0,07 & 0,07 & 0,06 & 0,10 & 0,18 & 0,03 & & 0,00 & 0,01 \\
\hline Total & 100,14 & 100,78 & 100,74 & 101,07 & 101,24 & 100,79 & 100,65 & 100,36 & 101,30 & 100,84 & 100,96 & 100,75 & 100,40 & 100,76 & 100,70 & 100,90 & 100,53 & 100,41 & 101,34 & 101,01 & 101,14 & 100,78 & 100,82 & 100,74 & 100,74 \\
\hline \multicolumn{26}{|c|}{ Número de cátions calculado na base de 32 oxigênios. } \\
\hline Si & 11,936 & 11,601 & 11,940 & 11,904 & 11,898 & 10,222 & 11,444 & 11,889 & 11,861 & 11,912 & 11,912 & 11,905 & 11,877 & 11,860 & 11,888 & 11,883 & 11,911 & 11,871 & 11,901 & 11,898 & 11,897 & 2,562 & 2,981 & 2,979 & 2,968 \\
\hline Al & 4,044 & 4,392 & 4,045 & 4,100 & 4,087 & 5,779 & 4,554 & 4,131 & 4,119 & 4,085 & 4,086 & 4,104 & 4,122 & 4,133 & 4,131 & 4,116 & 4,075 & 4,125 & 4,092 & 4,101 & 4,114 & 1,449 & 1,022 & 1,027 & 1,034 \\
\hline $\mathrm{Ti}$ & 0,005 & 0,012 & 0,000 & 0,002 & 0,010 & 0,018 & 0,008 & 0,000 & 0,016 & 0,008 & 0,000 & 0,000 & 0,003 & 0,011 & 0,002 & 0,000 & 0,007 & 0,005 & 0,005 & 0,000 & 0,000 & 0,005 & 0,002 & 0,000 & 0,003 \\
\hline $\mathrm{Fe}^{3+}$ & 0,030 & 0,024 & 0,028 & 0,019 & 0,034 & 0,016 & 0,020 & 0,018 & 0,040 & 0,019 & 0,024 & 0,019 & 0,018 & 0,022 & 0,014 & 0,020 & 0,020 & 0,026 & 0,041 & 0,020 & 0,015 & 0,004 & 0,005 & 0,005 & 0,005 \\
\hline$M n$ & 0,002 & 0,000 & 0,000 & 0,000 & 0,000 & 0,002 & 0,002 & 0,000 & 0,000 & 0,002 & 0,000 & 0,003 & 0,000 & 0,000 & 0,000 & 0,001 & 0,004 & 0,000 & 0,006 & 0,001 & 0,000 & & & & \\
\hline Mg & 0,001 & 0,000 & 0,000 & 0,000 & 0,004 & 0,000 & 0,000 & 0,000 & 0,001 & 0,003 & 0,005 & 0,000 & 0,004 & 0,006 & 0,000 & 0,000 & 0,000 & 0,000 & 0,003 & 0,000 & 0,000 & & & & \\
\hline $\mathrm{Ca}$ & 0,061 & 0,216 & 0,009 & 0,032 & 0,047 & 1,648 & 0,513 & 0,058 & 0,060 & 0,053 & 0,034 & 0,042 & 0,063 & 0,089 & 0,062 & 0,067 & 0,044 & 0,084 & 0,038 & 0,052 & 0,058 & 0,413 & 0,013 & 0,010 & 0,022 \\
\hline $\mathrm{Na}$ & 3,018 & 2,292 & 0,500 & 0,972 & 1,772 & 2,183 & 3,333 & 1,382 & 1,949 & 1,817 & 1,566 & 1,742 & 2,013 & 2,011 & 1,918 & 1,845 & 0,995 & 2,056 & 1,498 & 1,878 & 1,756 & 0,547 & 0,455 & 0,436 & 0,503 \\
\hline K & 0,864 & 1,307 & 3,477 & 2,907 & 2,072 & 0,019 & 0,050 & 2,434 & 1,908 & 2,031 & 2,320 & 2,148 & 1,862 & 1,804 & 1,910 & 2,033 & 2,896 & 1,764 & 2,330 & 2,001 & 2,081 & 0,005 & 0,508 & 0,537 & 0,452 \\
\hline $\mathrm{Sr}$ & 0,003 & 0,096 & 0,011 & 0,025 & 0,020 & 0,074 & 0,031 & 0,027 & 0,018 & 0,022 & 0,023 & 0,015 & 0,022 & 0,024 & 0,023 & 0,023 & 0,023 & 0,022 & 0,022 & 0,025 & 0,022 & 0,000 & 0,000 & 0,000 & 0,000 \\
\hline Ba & 0,000 & 0,038 & 0,004 & 0,011 & 0,010 & 0,002 & 0,001 & 0,005 & 0,000 & 0,000 & 0,006 & 0,000 & 0,001 & 0,001 & 0,004 & 0,000 & 0,005 & 0,005 & 0,005 & 0,007 & 0,012 & 0,001 & 0,000 & 0,000 & 0,000 \\
\hline Total & 19,963 & 19,978 & 20,013 & 19,973 & 19,953 & 19,964 & 19,953 & 19,944 & 19,972 & 19,952 & 19,976 & 19,978 & 19,987 & 19,960 & 19,951 & 19,988 & 19,980 & 19,958 & 19,941 & 19,982 & 19,957 & 4,985 & 4,987 & 4,995 & 4,989 \\
\hline An & 1,56 & 5,67 & 0,22 & 0,82 & 1,21 & 42,81 & 13,16 & 1,49 & 1,54 & 1,36 & 0,86 & 1,07 & 1,59 & 2,28 & 1,60 & 1,71 & 1,12 & 2,16 & 0,98 & 1,32 & 1,50 & 56,71 & 46,58 & 44,30 & 51,51 \\
\hline$A b$ & 76,53 & 60,07 & 12,55 & 24,86 & 45,54 & 56,71 & 85,56 & 35,67 & 49,74 & 46,58 & 39,96 & 44,30 & 51,12 & 51,51 & 49,30 & 46,76 & 25,28 & 52,66 & 38,75 & 47,77 & 45,09 & 42,81 & 1,36 & 1,07 & 2,28 \\
\hline Or & 21,91 & 34,25 & 87,23 & 74,33 & 53,25 & 0,48 & 1,28 & 62,84 & 48,71 & 52,06 & 59,18 & 54,63 & 47,29 & 46,20 & 49,10 & 51,53 & 73,60 & 45,18 & 60,26 & 50,91 & 53,42 & 0,48 & 52,06 & 54,63 & 46,20 \\
\hline \multicolumn{26}{|c|}{ Albite Activity } \\
\hline $800^{\circ} \mathrm{C}$ & & & & & & & & & & & & & & & & & & & & & & - & 0,92 & 0,93 & 0,90 \\
\hline $900^{\circ} \mathrm{C}$ & & & & & & & & & & & & & & & & & & & & & & - & 0,87 & 0,87 & 0,86 \\
\hline \multirow{2}{*}{\multicolumn{26}{|c|}{ Anortite Activity }} \\
\hline & & & & & & & & & & & & & & & & & & & & & & & & & - \\
\hline $900^{\circ} \mathrm{C}$ & & & & & & & & & & & & & & & & & & & & & & 0,54 & & & \\
\hline
\end{tabular}

- n, núcleo; b, borda; <, incluso em; ints, intersticial; fen, fenocristal; idio, idiomórfico; lam, lamela de exsolução;

TÜ - análises realizadas na Universidade de Tübingen 
ANEXO E - Tabela E.1 - Composição química de feldspatos de rochas do Maciço Alcalino de Itatiaia. Continua

\begin{tabular}{|c|c|c|c|c|c|c|c|c|c|c|c|c|c|c|c|c|c|c|c|c|c|c|c|c|c|}
\hline \multicolumn{4}{|c|}{$\begin{array}{l}\text { Unidade BtHblP } \\
\text { Amostra MAI0921 }\end{array}$} & \multicolumn{13}{|c|}{$\begin{array}{l}\mathrm{N}-\mathrm{I} \\
\text { MAl097B }\end{array}$} & \multicolumn{9}{|l|}{$\begin{array}{l}\text { BtHblP } \\
\text { MAI102 } \\
\end{array}$} \\
\hline Cristal & 27 & 29 & 33 & 51 & 52 & 53 & 53 & 54 & 55 & 56 & 56 & 8 & 10 & 11 & 12 & 13 & 57 & 57 & 58 & 59 & 59 & 60 & 61 & 61 & 62 \\
\hline Textura $^{1}$ & TÜ & TÜ & TÜ & $\mathrm{kfl}$ & $\mathrm{kfl}$ & plkkfl b & $\mathrm{plkkfln}$ & $\mathrm{kfl}$ & $\mathrm{kfl}$ & $\mathrm{pl}<\mathrm{kfl}$ & $\mathrm{kfl}$ & TÜ & тÜ & TÜ & TÜ & TÜ & $\mathrm{kfl}$ fen $\mathrm{n}$ & $\mathrm{kfl}$ fen b & kfl idio & $\mathrm{kfl}$ fen $\mathrm{n}$ & kfl fen b & kfl idio & $\mathrm{kfl}$ fen $\mathrm{n}$ & $\mathrm{kfl}$ fen b & kfl idio \\
\hline $\mathrm{SiO}_{2}$ & 66,42 & 66,28 & 66,58 & 67,14 & 66,13 & 61,66 & 61,82 & 66,90 & 66,65 & 61,58 & 66,43 & 61,82 & 66,90 & 66,65 & 61,58 & 66,43 & 66,45 & 65,69 & 66,07 & 65,68 & 65,44 & 66,11 & 66,45 & 65,59 & 66,16 \\
\hline $\mathrm{Al}_{2} \mathrm{O}_{3}$ & 19,52 & 19,54 & 19,47 & 19,07 & 19,92 & 23,70 & 23,96 & 18,84 & 18,76 & 23,73 & 19,04 & 23,96 & 18,84 & 18,76 & 23,73 & 19,04 & 19,36 & 19,89 & 19,63 & 19,95 & 19,75 & 19,61 & 19,54 & 20,33 & 19,40 \\
\hline $\mathrm{TiO}_{2}$ & 0,00 & 0,04 & & 0,01 & 0,15 & 0,15 & 0,07 & 0,01 & 0,09 & 0,04 & 0,08 & 0,07 & 0,01 & 0,09 & 0,04 & 0,08 & 0,04 & 0,16 & & 0,07 & 0,03 & 0,11 & 0,05 & 0,22 & 0,16 \\
\hline $\mathrm{Fe}_{2} \mathrm{O}_{3}$ & 0,13 & 0,17 & 0,13 & 0,21 & 0,21 & 0,18 & 0,42 & 0,34 & 0,30 & 0,17 & 0,23 & 0,38 & 0,30 & 0,27 & 0,15 & 0,20 & 0,20 & 0,20 & 0,16 & 0,16 & 0,19 & 0,15 & 0,14 & 0,23 & 0,16 \\
\hline MnO & & & & 0,01 & & & 0,03 & & 0,01 & & 0,02 & & & & & & 0,01 & & & & 0,02 & 0,02 & 0,02 & 0,01 & \\
\hline MgO & & & & & & & 0,00 & 0,01 & & & 0,01 & & & & & & & 0,01 & 0,01 & 0,00 & 0,02 & 0,00 & 0,00 & 0,01 & 0,02 \\
\hline $\mathrm{CaO}$ & 0,35 & 0,44 & 0,27 & 0,11 & 0,88 & 4,88 & 4,88 & 0,06 & 0,10 & 4,70 & 0,17 & 4,88 & 0,06 & 0,10 & 4,70 & 0,17 & 0,34 & 0,68 & 0,56 & 0,89 & 0,72 & 0,40 & 0,39 & 1,07 & 0,42 \\
\hline $\mathrm{Na}_{2} \mathrm{O}$ & 5,32 & 5,92 & 5,42 & 5,44 & 7,43 & 8,25 & 8,20 & 4,92 & 5,42 & 8,19 & 4,75 & 8,20 & 4,92 & 5,42 & 8,19 & 4,75 & 4,44 & 4,97 & 4,86 & 5,55 & 4,89 & 4,61 & 4,50 & 5,82 & 4,83 \\
\hline $\mathrm{K}_{2} \mathrm{O}$ & 8,91 & 7,72 & 8,78 & 8,77 & 5,25 & 0,43 & 0,65 & 9,45 & 8,72 & 0,60 & 9,66 & 0,65 & 9,45 & 8,72 & 0,60 & 9,66 & 10,28 & 9,05 & 9,38 & 7,92 & 9,22 & 9,98 & 9,91 & 7,39 & 9,39 \\
\hline SrO & 0,22 & 0,22 & 0,24 & & 0,10 & 0,43 & 0,60 & 0,00 & 0,03 & 0,50 & 0,09 & 0,60 & 0,00 & 0,03 & 0,50 & 0,09 & 0,16 & 0,19 & 0,20 & 0,19 & 0,17 & 0,15 & 0,17 & 0,23 & 0,14 \\
\hline BaO & & 0,07 & 0,10 & 0,03 & 0,13 & 0,08 & 0,10 & 0,03 & 0,05 & 0,22 & 0,08 & 0,10 & 0,03 & 0,05 & 0,22 & 0,08 & 0,11 & 0,13 & 0,09 & 0,09 & 0,09 & 0,06 & 0,09 & 0,04 & 0,06 \\
\hline Total & 100,88 & 100,39 & 101,00 & 100,79 & 100,19 & 99,76 & 100,73 & 100,55 & 100,13 & 99,72 & 100,55 & 100,69 & 100,51 & 100,10 & 99,71 & 100,53 & 101,39 & 100,96 & 100,96 & 100,49 & 100,54 & 101,19 & 101,26 & 100,92 & 100,75 \\
\hline \multicolumn{26}{|c|}{ Número de cátions calculado na base de 32 oxigênios. } \\
\hline Si & 2,974 & 2,971 & 2,978 & 11,986 & 11,787 & 10,997 & 10,954 & 12,001 & 11,989 & 11,003 & 11,945 & 2,746 & 3,002 & 2,999 & 2,756 & 2,989 & 11,894 & 11,777 & 11,846 & 11,779 & 11,789 & 11,845 & 11,884 & 11,701 & 11,874 \\
\hline Al & 1,030 & 1,032 & 1,026 & 4,012 & 4,185 & 4,982 & 5,004 & 3,983 & 3,977 & 4,997 & 4,035 & 1,254 & 0,997 & 0,995 & 1,252 & 1,010 & 4,084 & 4,203 & 4,148 & 4,217 & 4,193 & 4,141 & 4,119 & 4,275 & 4,103 \\
\hline $\mathrm{Ti}$ & 0,000 & 0,001 & 0,000 & 0,001 & 0,020 & 0,020 & 0,009 & 0,002 & 0,012 & 0,005 & 0,010 & 0,002 & 0,000 & 0,003 & 0,001 & 0,003 & 0,005 & 0,021 & 0,000 & 0,009 & 0,005 & 0,014 & 0,007 & 0,030 & 0,022 \\
\hline $\mathrm{Fe}^{3+}$ & 0,005 & 0,006 & 0,005 & 0,028 & 0,028 & 0,025 & 0,057 & 0,046 & 0,040 & 0,023 & 0,031 & 0,014 & 0,011 & 0,010 & 0,006 & 0,008 & 0,027 & 0,027 & 0,022 & 0,022 & 0,025 & 0,020 & 0,019 & 0,030 & 0,022 \\
\hline Mn & & & & 0,001 & 0,000 & 0,000 & 0,005 & 0,000 & 0,001 & 0,000 & 0,003 & & & & & & 0,002 & 0,000 & 0,000 & 0,000 & 0,003 & 0,003 & 0,003 & 0,001 & 0,000 \\
\hline Mg & & & & 0,000 & 0,000 & 0,000 & 0,001 & 0,001 & 0,000 & 0,000 & 0,003 & & & & & & 0,000 & 0,003 & 0,003 & 0,001 & 0,005 & 0,000 & 0,001 & 0,002 & 0,005 \\
\hline $\mathrm{Ca}$ & 0,017 & 0,021 & 0,013 & 0,022 & 0,167 & 0,932 & 0,926 & 0,011 & 0,019 & 0,900 & 0,034 & 0,232 & 0,003 & 0,005 & 0,225 & 0,008 & 0,065 & 0,130 & 0,107 & 0,170 & 0,140 & 0,077 & 0,074 & 0,204 & 0,082 \\
\hline $\mathrm{Na}$ & 0,462 & 0,515 & 0,470 & 1,883 & 2,568 & 2,853 & 2,817 & 1,711 & 1,890 & 2,837 & 1,656 & 0,706 & 0,428 & 0,473 & 0,711 & 0,414 & 1,541 & 1,728 & 1,689 & 1,930 & 1,708 & 1,601 & 1,560 & 2,013 & 1,681 \\
\hline K & 0,509 & 0,441 & 0,501 & 1,997 & 1,194 & 0,098 & 0,147 & 2,163 & 2,001 & 0,136 & 2,216 & 0,037 & 0,541 & 0,501 & 0,034 & 0,554 & 2,347 & 2,070 & 2,145 & 1,812 & 2,119 & 2,281 & 2,261 & 1,682 & 2,150 \\
\hline Sr & 0,000 & 0,000 & 0,000 & 0,000 & 0,010 & 0,044 & 0,061 & 0,000 & 0,003 & 0,052 & 0,009 & 0,000 & 0,000 & 0,000 & 0,000 & 0,000 & 0,017 & 0,019 & 0,021 & 0,019 & 0,018 & 0,016 & 0,017 & 0,023 & 0,015 \\
\hline Ba & 0,000 & 0,001 & 0,002 & 0,002 & 0,009 & 0,005 & 0,007 & 0,002 & 0,003 & 0,015 & 0,005 & 0,002 & 0,000 & 0,001 & 0,004 & 0,001 & 0,008 & 0,009 & 0,006 & 0,006 & 0,006 & 0,004 & 0,007 & 0,003 & 0,004 \\
\hline Total & 4,997 & 4,989 & 4,995 & 19,933 & 19,968 & 19,956 & 19,988 & 19,920 & 19,936 & 19,968 & 19,947 & 4,996 & 4,983 & 4,987 & 4,989 & 4,988 & 19,990 & 19,986 & 19,987 & 19,964 & 20,011 & 20,002 & 19,951 & 19,964 & 19,957 \\
\hline An & 46,76 & 52,66 & 47,77 & 0,55 & 4, & 24,01 & 23,81 & 7 & 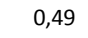 & 23,23 & 0,86 & 72,41 & 44,05 & 48,34 & 73,26 & 42,40 & 1,63 & 3,31 & 2,71 & 4,36 & 3,52 & 1,94 & 1,90 & 5,23 & 2,09 \\
\hline$A b$ & 1,71 & 2,16 & 1,31 & 48,26 & 65,36 & 73,46 & 72,41 & 44,05 & 48,34 & 73,26 & 42,40 & 23,81 & 0,27 & 0,49 & 23,23 & 0,86 & 38,98 & 43,99 & 42,86 & 49,33 & 43,06 & 40,45 & 40,06 & 51,63 & 42,96 \\
\hline Or & 51,53 & 45,18 & 50,92 & 51,19 & 30,38 & 2,52 & 3,78 & 55,67 & 51,17 & 3,51 & 56,74 & 3,78 & 55,67 & 51,17 & 3,51 & 56,74 & 59,38 & 52,70 & 54,43 & 46,31 & 53,42 & 57,61 & 58,04 & 43,13 & 54,95 \\
\hline \multicolumn{26}{|c|}{ Albite Activity } \\
\hline $800^{\circ} \mathrm{C}$ & 0,91 & 0,91 & 0,93 & & & & & & & & & - & 0,95 & 0,95 & - & 0,93 & & & & & & & & & \\
\hline $900^{\circ} \mathrm{C}$ & 0,86 & 0,87 & 0,87 & & & & & & & & & & 0,89 & 0,89 & - & 0,87 & & & & & & & & & \\
\hline \multicolumn{26}{|c|}{ Anortite Activity } \\
\hline $800^{\circ} \mathrm{C}$ & - & - & - & & & & & & & & & 0,33 & 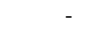 & - & 0,32 & 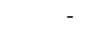 & & & & & & & & & \\
\hline $900^{\circ} \mathrm{C}$ & - & - & 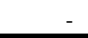 & & & & & & & & & 0,30 & - & - & 0,30 & - & & & & & & & & & \\
\hline
\end{tabular}

TÜ - análises realizadas na Universidade de Tübingen 
ANEXO E - Tabela E.1 - Composição química de feldspatos de rochas do Maciço Alcalino de Itatiaia. Continua.

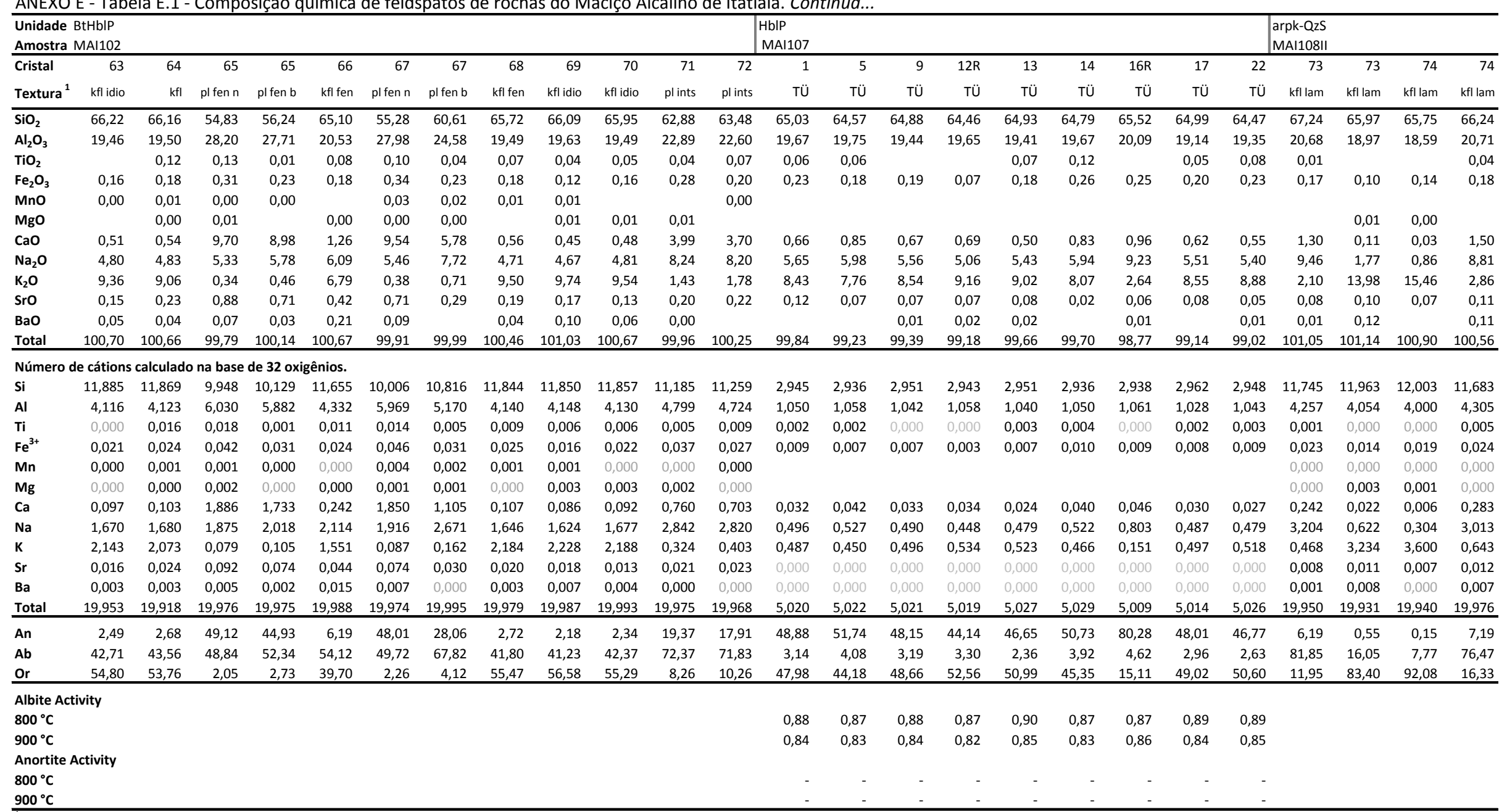

${ }^{1}$ - n, núcleo; b, borda; <, incluso em; ints, intersticial; fen, fenocristal; idio, idiomórfico; lam, lamela de exsolução;

TÜ - análises realizadas na Universidade de Tübingen 
ANEXO E - Tabela E.1 - Composição química de feldspatos de rochas do Maciço Alcalino de Itatiaia. Continua.

\begin{tabular}{|c|c|c|c|c|c|c|c|c|c|c|c|c|c|c|c|c|c|c|c|c|c|c|c|c|c|}
\hline \multicolumn{24}{|c|}{$\begin{array}{l}\text { Unidade arpk-QzS } \\
\text { Amostra MAI108II } \\
\end{array}$} & \multicolumn{2}{|l|}{\begin{tabular}{|l|} 
QzAFS-I \\
MAI110 \\
\end{tabular}} \\
\hline Cristal & 75 & 76 & 76 & 77 & 77 & 78 & 78 & 78 & 79 & 79 & 80 & 80 & 81 & 81 & 82 & 82 & 83 & 83 & 5 & 6 & 10 & 17 & 19 & 84 & 84 \\
\hline Textura $^{1}$ & $\mathrm{pl}<\mathrm{kfl}$ & $\mathrm{plkkfln}$ & $\mathrm{plkfflb}$ & $\mathrm{ffl}>\mathrm{pl} \mathrm{lam}$ & kfl>pl lam & $\mathrm{plkkfln}$ & $\mathrm{pl}<\mathrm{kfl} \mathrm{nb}$ & $\mathrm{plkkfl} \mathrm{b}$ & $\mathrm{ffl}>\mathrm{pl} \mathrm{lam}$ & kfl>pl lam & kff<pl lam & kfl<pl lam & $\mathrm{plkffl}$ & $\mathrm{plkkfl}$ & $\mathrm{plkkf|n}$ & $\mathrm{plkkflb}$ & $\mathrm{kfl}>\mathrm{pl} \mathrm{lam}$ & $\mathrm{kfl}>\mathrm{pl} \mathrm{lam}$ & TÜ & TÜ & TÜ & TÜ & TÜ & fen $n 1$ & fen $n 2$ \\
\hline$\overline{\mathrm{SiO}_{2}}$ & 60,62 & 62,62 & 61,46 & 67,11 & 65,01 & 60,73 & 60,82 & 65,95 & 65,09 & 66,82 & 65,60 & 66,65 & 61,72 & 66,13 & 60,68 & 61,62 & 68,84 & 65,83 & 60,62 & 62,62 & 60,73 & 61,72 & 60,68 & 65,01 & 66,35 \\
\hline $\mathrm{Al}_{2} \mathrm{O}_{3}$ & 25,27 & 23,88 & 24,79 & 21,30 & 19,18 & 24,85 & 24,95 & 21,43 & 18,79 & 21,12 & 18,77 & 21,33 & 24,75 & 21,84 & 25,11 & 24,63 & 20,35 & 18,65 & 25,27 & 23,88 & 24,85 & 24,75 & 25,11 & 19,97 & 18,99 \\
\hline $\mathrm{TiO}_{2}$ & & 0,05 & 0,01 & & 0,02 & & 0,05 & 0,06 & & 0,05 & & & 0,01 & 0,05 & 0,07 & 0,02 & 0,01 & 0,02 & & 0,05 & & 0,01 & 0,07 & 0,16 & 0,13 \\
\hline $\mathrm{Fe}_{2} \mathrm{O}_{3}$ & 0,16 & 0,24 & 0,18 & 0,13 & 0,12 & 0,30 & 0,27 & 0,26 & 0,13 & 0,27 & 0,17 & 0,19 & 0,24 & 0,26 & 0,28 & 0,16 & 0,04 & 0,11 & 0,14 & 0,22 & 0,27 & 0,22 & 0,25 & 0,22 & 0,29 \\
\hline $\mathrm{MnO}$ & 0,01 & & 0,00 & & 0,00 & 0,00 & 0,00 & & 0,01 & & & & & 0,02 & 0,00 & 0,01 & 0,01 & 0,01 & & & & & & & 0,00 \\
\hline $\mathrm{MgO}$ & & 0,01 & & 0,03 & 0,01 & 0,00 & 0,01 & & 0,00 & & & & & 0,01 & 0,01 & & & & & & & & & & \\
\hline $\mathrm{CaO}$ & 6,31 & 4,74 & 5,74 & 1,80 & 0,05 & 6,01 & 5,99 & 2,28 & 0,03 & 1,21 & 0,06 & 2,06 & 5,81 & 2,51 & 6,25 & 5,40 & 0,61 & 0,07 & 6,31 & 4,74 & 6,01 & 5,81 & 6,25 & 0,97 & 0,31 \\
\hline $\mathrm{Na}_{2} \mathrm{O}$ & 7,69 & 8,40 & 7,80 & 10,23 & 0,60 & 7,55 & 7,64 & 10,01 & 0,80 & 10,52 & 0,66 & 10,23 & 7,90 & 9,66 & 7,43 & 8,08 & 10,99 & 0,93 & 7,69 & 8,40 & 7,55 & 7,90 & 7,43 & 6,20 & 6,12 \\
\hline $\mathrm{K}_{2} \mathrm{O}$ & 0,27 & 0,34 & 0,35 & 0,32 & 15,56 & 0,46 & 0,36 & 0,41 & 15,56 & 0,42 & 15,69 & 0,23 & 0,26 & 0,38 & 0,46 & 0,28 & 0,19 & 15,35 & 0,27 & 0,34 & 0,46 & 0,26 & 0,46 & 6,34 & 7,52 \\
\hline Sro & 0,24 & 0,19 & 0,29 & 0,14 & 0,17 & 0,44 & 0,49 & 0,17 & 0,15 & 0,11 & 0,17 & 0,19 & 0,26 & 0,16 & 0,38 & 0,37 & 0,08 & 0,10 & 0,24 & 0,19 & 0,44 & 0,26 & 0,38 & 0,28 & \\
\hline $\mathrm{BaO}$ & 0,20 & 0,00 & 0,15 & 0,02 & 0,31 & 0,18 & 0,07 & 0,05 & 0,30 & 0,02 & 0,37 & & 0,15 & 0,03 & 0,16 & 0,16 & & 0,06 & 0,20 & 0,00 & 0,18 & 0,15 & 0,16 & 0,44 & 0,06 \\
\hline Total & 100,76 & 100,48 & 100,77 & 101,09 & 101,03 & 100,52 & 100,66 & 100,62 & 100,86 & 100,54 & 101,49 & 100,88 & 101,11 & 101,06 & 100,83 & 100,73 & 101,12 & 101,12 & 100,75 & 100,45 & 100,49 & 101,09 & 100,80 & 99,59 & 99,77 \\
\hline \multicolumn{26}{|c|}{ Número de cátions calculado na base de 32 oxigênios. } \\
\hline Si & 10,735 & 11,049 & 10,858 & 11,658 & 11,895 & 10,790 & 10,781 & 11,551 & 11,937 & 11,672 & 11,959 & 11,616 & 10,867 & 11,521 & 10,748 & 10,890 & 11,895 & 11,994 & 2,687 & 2,765 & 2,703 & 2,720 & 2,692 & 11,737 & 11,937 \\
\hline Al & 5,274 & 4,966 & 5,162 & 4,361 & 4,136 & 5,203 & 5,213 & 4,424 & 4,061 & 4,348 & 4,033 & 4,381 & 5,136 & 4,484 & 5,242 & 5,130 & 4,144 & 4,005 & 1,320 & 1,243 & 1,304 & 1,286 & 1,313 & 4,249 & 4,026 \\
\hline $\mathrm{Ti}$ & 0,000 & 0,006 & 0,002 & 0,000 & 0,003 & 0,000 & 0,007 & 0,008 & 0,000 & 0,007 & 0,000 & 0,000 & 0,001 & 0,006 & 0,009 & 0,002 & 0,001 & 0,003 & 0,000 & 0,001 & 0,000 & 0,000 & 0,002 & 0,021 & 0,017 \\
\hline $\mathrm{Fe}^{3+}$ & 0,021 & 0,032 & 0,024 & 0,017 & 0,016 & 0,040 & 0,036 & 0,034 & 0,018 & 0,036 & 0,023 & 0,025 & 0,032 & 0,034 & 0,037 & 0,021 & 0,006 & 0,015 & 0,005 & 0,008 & 0,010 & 0,008 & 0,009 & 0,030 & 0,039 \\
\hline$M n$ & 0,001 & 0,000 & 0,000 & 0,000 & 0,000 & 0,000 & 0,000 & 0,000 & 0,001 & 0,000 & 0,000 & 0,000 & 0,000 & 0,003 & 0,000 & 0,001 & 0,001 & 0,001 & & & & & & 0,000 & 0,000 \\
\hline Mg & 0,000 & 0,002 & 0,000 & 0,009 & 0,002 & 0,001 & 0,003 & 0,000 & 0,001 & 0,000 & 0,000 & 0,000 & 0,000 & 0,002 & 0,004 & 0,000 & 0,000 & 0,000 & & & & & & 0,000 & 0,000 \\
\hline $\mathrm{Ca}$ & 1,197 & 0,896 & 1,086 & 0,335 & 0,010 & 1,144 & 1,138 & 0,428 & 0,007 & 0,226 & 0,012 & 0,385 & 1,096 & 0,469 & 1,186 & 1,022 & 0,113 & 0,013 & 0,300 & 0,224 & 0,287 & 0,274 & 0,297 & 0,188 & 0,059 \\
\hline $\mathrm{Na}$ & 2,640 & 2,874 & 2,672 & 3,445 & 0,213 & 2,601 & 2,626 & 3,399 & 0,284 & 3,563 & 0,234 & 3,457 & 2,697 & 3,263 & 2,552 & 2,769 & 3,682 & 0,327 & 0,661 & 0,719 & 0,652 & 0,675 & 0,639 & 2,170 & 2,135 \\
\hline K & 0,061 & 0,077 & 0,079 & 0,071 & 3,632 & 0,104 & 0,082 & 0,092 & 3,640 & 0,093 & 3,649 & 0,051 & 0,059 & 0,085 & 0,104 & 0,063 & 0,043 & 3,568 & 0,015 & 0,019 & 0,026 & 0,015 & 0,026 & 1,460 & 1,726 \\
\hline $\mathrm{Sr}$ & 0,024 & 0,020 & 0,030 & 0,014 & 0,018 & 0,046 & 0,050 & 0,017 & 0,016 & 0,011 & 0,018 & 0,019 & 0,027 & 0,017 & 0,039 & 0,038 & 0,008 & 0,011 & 0,000 & 0,000 & 0,000 & 0,000 & 0,000 & 0,030 & 0,000 \\
\hline $\mathrm{Ba}$ & 0,014 & 0,000 & 0,010 & 0,001 & 0,023 & 0,012 & 0,005 & 0,004 & 0,021 & 0,001 & 0,026 & 0,000 & 0,011 & 0,002 & 0,011 & 0,011 & 0,000 & 0,004 & 0,003 & 0,000 & 0,003 & 0,003 & 0,003 & 0,031 & 0,004 \\
\hline Total & 19,968 & 19,922 & 19,923 & 19,912 & 19,948 & 19,941 & 19,941 & 19,957 & 19,986 & 19,957 & 19,954 & 19,934 & 19,926 & 19,887 & 19,931 & 19,948 & 19,892 & 19,941 & 4,991 & 4,981 & 4,984 & 4,981 & 4,982 & 19,917 & 19,944 \\
\hline An & 30,71 & 23,30 & 28,32 & 8,70 & 0,26 & 29,73 & 29,59 & 10,92 & 0,17 & 5,82 & 0,32 & 9,88 & 28,45 & 12,28 & 30,88 & 26,53 & 2,94 & 0,33 & 67,72 & 74,71 & 67,58 & 70,01 & 66,43 & 4,93 & 1,52 \\
\hline$A b$ & 67,72 & 74,71 & 69,63 & 89,46 & 5,52 & 67,58 & 68,29 & 86,74 & 7,23 & 91,79 & 6,00 & 88,81 & 70,01 & 85,50 & 66,43 & 71,84 & 95,95 & 8,36 & 30,71 & 23,30 & 29,73 & 28,45 & 30,88 & 56,83 & 54,46 \\
\hline Or & 1,57 & 2,00 & 2,05 & 1,85 & 94,22 & 2,70 & 2,13 & 2,34 & 92,59 & 2,39 & 93,68 & 1,31 & 1,53 & 2,23 & 2,70 & 1,63 & 1,11 & 91,31 & 1,57 & 2,00 & 2,70 & 1,53 & 2,70 & 38,24 & 44,03 \\
\hline \multicolumn{26}{|c|}{ Albite Activity } \\
\hline $800^{\circ} \mathrm{C}$ & & & & & & & & & & & & & & & & & & & & - & - & & & & \\
\hline $900^{\circ} \mathrm{C}$ & & & & & & & & & & & & & & & & & & & & - & - & - & & & \\
\hline \multicolumn{26}{|c|}{ Anortite Activity } \\
\hline $800^{\circ} \mathrm{C}$ & & & & & & & & & & & & & & & & & & & 0,42 & 0,32 & 0,41 & 0,39 & 0,42 & & \\
\hline $900^{\circ} \mathrm{C}$ & & & & & & & & & & & & & & & & & & & 0,39 & 0,30 & 0,38 & 0,37 & 0,39 & & \\
\hline
\end{tabular}

-n, núcleo; b, borda; <, incluso em; ints, intersticial; fen, fenocristal; idio, idiomórfico; lam, lamela de exsolução;

TÜ - análises realizadas na Universidade de Tübingen 
\begin{tabular}{l} 
ANEXO E - Tabela E.1 - Composição química de feldspatos de rochas do Maciço Alcalino de Itatiaia. Continua.. \\
\hline Unidade QzAFS-I
\end{tabular}

\begin{tabular}{|c|c|c|c|c|c|c|c|c|c|c|c|c|c|c|c|c|c|c|c|c|c|c|c|c|c|}
\hline \multicolumn{3}{|c|}{ Amostra MAl110 } & \multicolumn{23}{|c|}{ MAl114 } \\
\hline Cristal & 85 & 85 & 86 & 87 & 88 & 88 & 89 & 89 & 4 & 10 & 14 & 16 & 20 & 90 & 90 & 90 & 91 & 92 & 92 & 93 & 93 & 94 & 94 & 95 & 95 \\
\hline Textura $^{1}$ & fen $n$ & fen $b$ & fen & $\mathrm{ab} / \mathrm{cav}$ & $\mathrm{kfln}$ & $\mathrm{kflb}$ & $\mathrm{kfln}$ & $\mathrm{kflb}$ & TÜ & TÜ & TÜ & TÜ & TÜ & plkkfln & $\mathrm{plkkflnb}$ & $\mathrm{plkkflb}$ & $\mathrm{kfl}$ & $\mathrm{kfln}$ & $\mathrm{kflb}$ & $\mathrm{kfln}$ & $\mathrm{kflb}$ & $\mathrm{pln}$ & $\mathrm{plb}$ & $\mathrm{kfln}$ & $\mathrm{kflb}$ \\
\hline$\overline{\mathrm{SiO}_{2}}$ & 66,64 & 66,99 & 66,81 & 69,87 & 66,86 & 67,21 & 67,14 & 67,06 & 65,01 & 66,64 & 66,81 & 66,86 & 67,14 & 57,89 & 59,12 & 61,47 & 65,42 & 65,64 & 65,90 & 65,49 & 66,83 & 62,43 & 62,00 & 65,84 & 62,42 \\
\hline $\mathrm{Al}_{2} \mathrm{O}_{3}$ & 19,01 & 18,29 & 19,01 & 20,00 & 18,75 & 18,30 & 18,90 & 18,43 & 19,97 & 19,01 & 19,01 & 18,75 & 18,90 & 26,41 & 25,27 & 23,99 & 19,83 & 19,40 & 19,90 & 19,14 & 19,95 & 23,68 & 23,58 & 19,53 & 23,48 \\
\hline $\mathrm{TiO}_{2}$ & 0,05 & & 0,05 & 0,05 & & 0,01 & 0,02 & 0,03 & 0,16 & 0,05 & 0,05 & & 0,02 & 0,07 & 0,05 & 0,15 & 0,12 & 0,01 & 0,05 & 0,04 & 0,08 & & & 0,03 & 0,05 \\
\hline $\mathrm{Fe}_{2} \mathrm{O}_{3}$ & 0,30 & 0,63 & 0,31 & 0,05 & 0,31 & 0,65 & 0,36 & 0,72 & 0,20 & 0,27 & 0,27 & 0,28 & 0,33 & 0,20 & 0,17 & 0,18 & 0,13 & 0,16 & 0,16 & 0,18 & 0,17 & 0,18 & 0,26 & 0,10 & 0,22 \\
\hline $\mathrm{MnO}$ & & & 0,00 & & 0,02 & & 0,01 & & & & & & & 0,01 & 0,01 & & & 0,01 & 0,01 & & 0,01 & & & & \\
\hline $\mathrm{MgO}$ & & 0,02 & 0,00 & 0,00 & 0,01 & & 0,00 & 0,01 & & & & & & 0,00 & 0,00 & 0,00 & 0,00 & & 0,03 & & 0,01 & 0,02 & 0,01 & 0,00 & \\
\hline $\mathrm{CaO}$ & 0,13 & 0,01 & 0,35 & 0,16 & 0,05 & 0,02 & 0,08 & 0,00 & 0,97 & 0,13 & 0,35 & 0,05 & 0,08 & 7,50 & 6,40 & 5,14 & 0,82 & 0,45 & 0,85 & 0,38 & 0,60 & 4,73 & 4,90 & 0,44 & 4,68 \\
\hline $\mathrm{Na}_{2} \mathrm{O}$ & 6,51 & 5,85 & 6,23 & 11,08 & 6,31 & 6,24 & 6,38 & 6,14 & 6,20 & 6,51 & 6,23 & 6,31 & 6,38 & 6,58 & 7,20 & 7,99 & 5,37 & 4,80 & 5,29 & 4,57 & 4,85 & 8,28 & 8,02 & 4,81 & 8,26 \\
\hline $\mathrm{K}_{2} \mathrm{O}$ & 7,20 & 8,16 & 7,37 & 0,12 & 7,37 & 7,59 & 7,48 & 7,78 & 6,34 & 7,20 & 7,37 & 7,37 & 7,48 & 0,44 & 0,60 & 0,66 & 8,11 & 9,20 & 8,31 & 9,97 & 8,65 & 0,82 & 0,74 & 9,42 & 0,78 \\
\hline Sro & 0,02 & & 0,01 & 0,01 & 0,02 & 0,01 & 0,03 & 0,04 & 0,28 & 0,02 & 0,01 & 0,02 & 0,03 & 0,86 & 0,80 & 0,34 & 0,22 & 0,17 & 0,20 & 0,17 & 0,16 & 0,23 & 0,18 & 0,22 & 0,17 \\
\hline BaO & 0,03 & & & 0,06 & & & & 0,03 & 0,44 & 0,03 & & & & 0,05 & 0,13 & 0,06 & 0,02 & 0,04 & 0,14 & 0,07 & 0,03 & & & 0,19 & 0,04 \\
\hline Total & 99,90 & 99,94 & 100,14 & 101,40 & 99,71 & 100,03 & 100,41 & 100,25 & 99,57 & 99,87 & 100,11 & 99,68 & 100,37 & 100,03 & 99,75 & 99,99 & 100,06 & 99,88 & 100,84 & 100,00 & 101,34 & 100,37 & 99,70 & 100,58 & 100,08 \\
\hline \multicolumn{26}{|c|}{ Número de cátions calculado na base de 32 oxigênios. } \\
\hline Si & 11,955 & 12,048 & 11,959 & 12,004 & 12,010 & 12,053 & 11,989 & 12,020 & 2,938 & 2,991 & 2,992 & 3,005 & 3,000 & 10,405 & 10,633 & 10,948 & 11,785 & 11,874 & 11,794 & 11,881 & 11,866 & 11,055 & 11,046 & 11,855 & 11,079 \\
\hline Al & 4,019 & 3,877 & 4,010 & 4,050 & 3,969 & 3,868 & 3,978 & 3,893 & 1,064 & 1,006 & 1,003 & 0,993 & 0,995 & 5,594 & 5,356 & 5,036 & 4,210 & 4,136 & 4,198 & 4,092 & 4,175 & 4,942 & 4,951 & 4,145 & 4,912 \\
\hline $\mathrm{Ti}$ & 0,007 & 0,000 & 0,007 & 0,007 & 0,000 & 0,002 & 0,003 & 0,004 & 0,005 & 0,002 & 0,002 & 0,000 & 0,001 & 0,010 & 0,007 & 0,020 & 0,016 & 0,001 & 0,006 & 0,005 & 0,010 & 0,000 & 0,000 & 0,004 & 0,006 \\
\hline $\mathrm{Fe}^{3+}$ & 0,041 & 0,085 & 0,041 & 0,006 & 0,043 & 0,088 & 0,049 & 0,098 & 0,007 & 0,010 & 0,010 & 0,011 & 0,012 & 0,027 & 0,023 & 0,024 & 0,018 & 0,022 & 0,022 & 0,024 & 0,023 & 0,024 & 0,035 & 0,013 & 0,029 \\
\hline$M n$ & 0,000 & 0,000 & 0,000 & 0,000 & 0,003 & 0,000 & 0,001 & 0,000 & & & & & & 0,002 & 0,002 & 0,000 & 0,000 & 0,001 & 0,002 & 0,000 & 0,002 & 0,000 & 0,000 & 0,000 & 0,000 \\
\hline $\mathrm{Mg}$ & 0,000 & 0,005 & 0,000 & 0,000 & 0,003 & 0,000 & 0,001 & 0,002 & & & & & & 0,001 & 0,001 & 0,000 & 0,000 & 0,000 & 0,008 & 0,000 & 0,001 & 0,006 & 0,004 & 0,001 & 0,000 \\
\hline $\mathrm{Ca}$ & 0,026 & 0,001 & 0,066 & 0,030 & 0,010 & 0,004 & 0,015 & 0,000 & 0,047 & 0,006 & 0,017 & 0,003 & 0,004 & 1,444 & 1,233 & 0,981 & 0,159 & 0,087 & 0,162 & 0,074 & 0,114 & 0,897 & 0,935 & 0,085 & 0,890 \\
\hline $\mathrm{Na}$ & 2,264 & 2,040 & 2,162 & 3,691 & 2,198 & 2,170 & 2,209 & 2,134 & 0,543 & 0,566 & 0,541 & 0,550 & 0,553 & 2,293 & 2,511 & 2,759 & 1,876 & 1,684 & 1,836 & 1,607 & 1,670 & 2,843 & 2,770 & 1,679 & 2,843 \\
\hline K & 1,648 & 1,872 & 1,683 & 0,026 & 1,689 & 1,736 & 1,704 & 1,779 & 0,366 & 0,412 & 0,421 & 0,423 & 0,426 & 0,101 & 0,138 & 0,150 & 1,864 & 2,123 & 1,897 & 2,307 & 1,959 & 0,184 & 0,168 & 2,164 & 0,176 \\
\hline $\mathrm{Sr}$ & 0,002 & 0,000 & 0,001 & 0,001 & 0,002 & 0,001 & 0,003 & 0,004 & 0,000 & 0,000 & 0,000 & 0,000 & 0,000 & 0,090 & 0,083 & 0,035 & 0,023 & 0,018 & 0,021 & 0,018 & 0,017 & 0,024 & 0,019 & 0,023 & 0,017 \\
\hline $\mathrm{Ba}$ & 0,002 & 0,000 & 0,000 & 0,004 & 0,000 & 0,000 & 0,000 & 0,002 & 0,008 & 0,001 & 0,000 & 0,000 & 0,000 & 0,004 & 0,009 & 0,004 & 0,002 & 0,003 & 0,010 & 0,005 & 0,002 & 0,000 & 0,000 & 0,013 & 0,003 \\
\hline Total & 19,964 & 19,927 & 19,930 & 19,819 & 19,927 & 19,921 & 19,951 & 19,936 & 4,979 & 4,994 & 4,986 & 4,985 & 4,991 & 19,971 & 19,995 & 19,957 & 19,954 & 19,949 & 19,956 & 20,013 & 19,839 & 19,976 & 19,930 & 19,983 & 19,954 \\
\hline An & 0,65 & 0,03 & 1,69 & 0,79 & 0,27 & 0,10 & 0,39 & 0,01 & 56,83 & 57,50 & 55,28 & 56,39 & 56,23 & 37,63 & 31,77 & 25,22 & 4,08 & 2,23 & 4,16 & 1,85 & 3,05 & 22,87 & 24,14 & 2,15 & 22,77 \\
\hline$A b$ & 57,51 & 52,13 & 55,28 & 98,51 & 56,39 & 55,49 & 56,23 & 54,53 & 4,93 & 0,65 & 1,69 & 0,27 & 0,39 & 59,75 & 64,68 & 70,93 & 48,11 & 43,24 & 47,13 & 40,30 & 44,61 & 72,44 & 71,51 & 42,76 & 72,73 \\
\hline Or & 41,85 & 47,84 & 43,03 & 0,70 & 43,34 & 44,41 & 43,37 & 45,46 & 38,24 & 41,85 & 43,03 & 43,34 & 43,38 & 2,62 & 3,56 & 3,85 & 47,81 & 54,53 & 48,71 & 57,85 & 52,34 & 4,69 & 4,35 & 55,09 & 4,50 \\
\hline \multicolumn{26}{|c|}{ Albite Activity } \\
\hline $800^{\circ} \mathrm{C}$ & & & & & & & & & 0,85 & 0, & 0, & 0,95 & 0, & & & & & & & & & & & & \\
\hline $900^{\circ} \mathrm{C}$ & & & & & & & & & 0,82 & 0,90 & 0,88 & 0,90 & 0,90 & & & & & & & & & & & & \\
\hline \multicolumn{26}{|c|}{ Anortite Activity } \\
\hline $800^{\circ} \mathrm{C}$ & & & & & & & & & - & - & - & - & & & & & & & & & & & & & \\
\hline $900^{\circ} \mathrm{C}$ & & & & & & & & & & - & - & - & & & & & & & & & & & & & \\
\hline
\end{tabular}

-n, núcleo; b, borda; <, incluso em; ints, intersticial; fen, fenocristal; idio, idiomórfico; lam, lamela de exsolução;

TÜ - análises realizadas na Universidade de Tübingen 
ANEXO E - Tabela E.1 - Composição química de feldspatos de rochas do Maciço Alcalino de Itatiaia. Continua.

\begin{tabular}{|c|c|c|c|c|c|c|c|c|c|c|c|c|c|c|c|c|c|c|c|c|c|c|c|c|c|}
\hline \multicolumn{11}{|c|}{$\begin{array}{l}\text { Unidade BtHblP } \\
\text { Amostra MAl114 }\end{array}$} & \multicolumn{15}{|c|}{$\begin{array}{l}\text { N-II } \\
\text { MAI136 }\end{array}$} \\
\hline Cristal & 96 & 97 & 97 & 97 & 97 & 98 & 99 & 99 & 1 & $5 R$ & 6 & 7 & 10 & 14 & 17 & 21 & 29 & 100 & 101 & 102 & 103 & 104 & 105 & 106 & 107 \\
\hline Textura $^{1}$ & $\mathrm{pl}<\mathrm{kfl}$ & $\mathrm{plkkfln}$ & $\mathrm{pl}<\mathrm{kfl} \mathrm{nb}$ & $\mathrm{plkkflb}$ & $\mathrm{p} \mid \mathrm{kffl} \mathrm{b}$ & $\mathrm{kfl}$ & $\mathrm{kfln}$ & kfl b & TÜ & TÜ & TÜ & TÜ & TÜ & TÜ & TÜ & TÜ & TÜ & $a b b$ & $\mathrm{kfln}$ & $\mathrm{kfl}$ & $a b b$ & kfl & $\mathrm{kfl}$ & $a b b$ & $\mathrm{kfl}$ \\
\hline$\overline{\mathrm{SiO}_{2}}$ & 65,94 & 56,66 & 56,81 & 58,00 & 61,54 & 65,92 & 66,60 & 66,02 & 57,89 & 66,09 & 65,42 & 65,64 & 65,49 & 65,84 & 56,66 & 65,92 & 66,60 & 68,74 & 65,63 & 65,69 & 67,56 & 65,79 & 66,14 & 68,29 & 66,33 \\
\hline $\mathrm{Al}_{2} \mathrm{O}_{3}$ & 19,69 & 27,36 & 27,37 & 26,43 & 23,91 & 19,31 & 19,36 & 19,25 & 26,41 & 19,93 & 19,83 & 19,40 & 19,14 & 19,53 & 27,36 & 19,31 & 19,36 & 19,55 & 19,47 & 19,54 & 18,96 & 19,32 & 19,36 & 19,40 & 20,03 \\
\hline $\mathrm{TiO}_{2}$ & 0,09 & 0,08 & 0,07 & 0,06 & 0,06 & & 0,04 & 0,02 & 0,07 & & 0,12 & 0,01 & 0,04 & 0,03 & 0,08 & & 0,04 & & 0,10 & 0,02 & 0,01 & 0,06 & 0,04 & & 0,16 \\
\hline $\mathrm{Fe}_{2} \mathrm{O}_{3}$ & 0,15 & 0,16 & 0,15 & 0,20 & 0,20 & 0,16 & 0,22 & 0,14 & 0,18 & 0,03 & 0,12 & 0,15 & 0,16 & 0,09 & 0,15 & 0,14 & 0,19 & 0,12 & 0,34 & 0,33 & 0,28 & 0,33 & 0,34 & 0,09 & 0,39 \\
\hline $\mathrm{MnO}$ & 0,01 & & 0,02 & 0,02 & 0,00 & & 0,03 & & & & & & & & & & & 0,01 & & & 0,01 & 0,01 & 0,02 & 0,00 & 0,00 \\
\hline $\mathrm{MgO}$ & 0,00 & 0,01 & & & & 0,01 & & & & & & & & & & & & & & 0,00 & & 0,01 & & 0,00 & \\
\hline $\mathrm{CaO}$ & 0,49 & 8,43 & 8,59 & 7,79 & 5,14 & 0,38 & 0,23 & 0,24 & 7,50 & 0,57 & 0,82 & 0,45 & 0,38 & 0,44 & 8,43 & 0,38 & 0,23 & 0,06 & 0,73 & 0,76 & 0,11 & 0,66 & 0,69 & 0,09 & 0,90 \\
\hline $\mathrm{Na}_{2} \mathrm{O}$ & 5,02 & 6,00 & 6,06 & 6,50 & 8,00 & 4,56 & 4,37 & 4,24 & 6,58 & 6,31 & 5,37 & 4,80 & 4,57 & 4,81 & 6,00 & 4,56 & 4,37 & 11,09 & 5,83 & 5,95 & 11,60 & 5,82 & 6,09 & 11,21 & 7,22 \\
\hline $\mathrm{K}_{2} \mathrm{O}$ & 8,82 & 0,36 & 0,34 & 0,37 & 0,69 & 9,76 & 10,43 & 10,45 & 0,44 & 6,77 & 8,11 & 9,20 & 9,97 & 9,42 & 0,36 & 9,76 & 10,43 & 0,20 & 7,32 & 7,25 & 0,14 & 7,79 & 7,26 & 0,24 & 5,39 \\
\hline Sro & 0,18 & 1,11 & 0,84 & 0,47 & 0,26 & 0,13 & 0,08 & 0,09 & 0,86 & 0,26 & 0,22 & 0,17 & 0,17 & 0,22 & 1,11 & 0,13 & 0,08 & & 0,07 & 0,02 & 0,03 & 0,02 & 0,04 & 0,03 & 0,02 \\
\hline $\mathrm{BaO}$ & 0,10 & 0,02 & 0,04 & & 0,08 & 0,03 & 0,05 & 0,05 & 0,05 & 0,03 & 0,02 & 0,04 & 0,07 & 0,19 & 0,02 & 0,03 & 0,05 & 0,04 & 0,01 & & 0,04 & 0,02 & 0,06 & 0,10 & 0,05 \\
\hline Total & 100,51 & 100,18 & 100,30 & 99,85 & 99,88 & 100,26 & 101,41 & 100,49 & 100,01 & 99,97 & 100,04 & 99,86 & 99,98 & 100,57 & 100,17 & 100,24 & 101,39 & 99,80 & 99,51 & 99,56 & 98,73 & 99,83 & 100,03 & 99,45 & 100,51 \\
\hline \multicolumn{26}{|c|}{ Número de cátions calculado na base de 32 oxigênios. } \\
\hline Si & 11,842 & 10,201 & 10,207 & 10,414 & 10,968 & 11,897 & 11,909 & 11,912 & 2,610 & 2,962 & 2,949 & 2,971 & 2,973 & 2,967 & 2,560 & 2,977 & 2,979 & 12,011 & 11,840 & 11,840 & 11,980 & 11,857 & 11,872 & 11,997 & 11,779 \\
\hline Al & 4,168 & 5,806 & 5,796 & 5,593 & 5,022 & 4,107 & 4,080 & 4,093 & 1,403 & 1,053 & 1,054 & 1,035 & 1,024 & 1,037 & 1,457 & 1,028 & 1,021 & 4,026 & 4,140 & 4,151 & 3,962 & 4,104 & 4,096 & 4,017 & 4,192 \\
\hline $\mathrm{Ti}$ & 0,013 & 0,011 & 0,009 & 0,008 & 0,007 & 0,000 & 0,006 & 0,002 & 0,002 & 0,000 & 0,004 & 0,000 & 0,001 & 0,001 & 0,003 & 0,000 & 0,001 & 0,000 & 0,014 & 0,003 & 0,002 & 0,009 & 0,005 & 0,000 & 0,022 \\
\hline $\mathrm{Fe}^{3+}$ & 0,021 & 0,022 & 0,021 & 0,027 & 0,027 & 0,021 & 0,029 & 0,019 & 0,007 & 0,001 & 0,005 & 0,006 & 0,006 & 0,003 & 0,006 & 0,005 & 0,007 & 0,016 & 0,046 & 0,044 & 0,038 & 0,045 & 0,046 & 0,012 & 0,052 \\
\hline$M n$ & 0,002 & 0,000 & 0,002 & 0,003 & 0,000 & 0,000 & 0,004 & 0,000 & & & & & & & & & & 0,001 & 0,000 & 0,000 & 0,001 & 0,001 & 0,003 & 0,001 & 0,001 \\
\hline Mg & 0,001 & 0,003 & 0,000 & 0,000 & 0,000 & 0,002 & 0,000 & 0,000 & & & & & & & & & & 0,000 & 0,000 & 0,000 & 0,000 & 0,002 & 0,000 & 0,000 & 0,000 \\
\hline $\mathrm{Ca}$ & 0,095 & 1,626 & 1,654 & 1,499 & 0,982 & 0,074 & 0,044 & 0,046 & 0,362 & 0,027 & 0,040 & 0,022 & 0,018 & 0,021 & 0,408 & 0,018 & 0,011 & 0,011 & 0,142 & 0,147 & 0,021 & 0,128 & 0,133 & 0,017 & 0,172 \\
\hline $\mathrm{Na}$ & 1,748 & 2,094 & 2,111 & 2,263 & 2,764 & 1,596 & 1,515 & 1,483 & 0,575 & 0,548 & 0,469 & 0,421 & 0,402 & 0,420 & 0,526 & 0,399 & 0,379 & 3,757 & 2,039 & 2,079 & 3,988 & 2,034 & 2,119 & 3,818 & 2,486 \\
\hline K & 2,021 & 0,082 & 0,079 & 0,086 & 0,157 & 2,247 & 2,379 & 2,405 & 0,025 & 0,387 & 0,466 & 0,531 & 0,577 & 0,541 & 0,021 & 0,562 & 0,595 & 0,044 & 1,685 & 1,667 & 0,031 & 1,791 & 1,662 & 0,053 & 1,221 \\
\hline $\mathrm{Sr}$ & 0,019 & 0,116 & 0,088 & 0,049 & 0,027 & 0,014 & 0,008 & 0,009 & 0,000 & 0,000 & 0,000 & 0,000 & 0,000 & 0,000 & 0,000 & 0,000 & 0,000 & 0,000 & 0,007 & 0,002 & 0,003 & 0,003 & 0,004 & 0,003 & 0,003 \\
\hline $\mathrm{Ba}$ & 0,007 & 0,001 & 0,003 & 0,000 & 0,006 & 0,002 & 0,004 & 0,003 & 0,001 & 0,000 & 0,000 & 0,001 & 0,001 & 0,003 & 0,000 & 0,000 & 0,001 & 0,003 & 0,001 & 0,000 & 0,003 & 0,001 & 0,004 & 0,007 & 0,004 \\
\hline Total & 19,935 & 19,962 & 19,970 & 19,942 & 19,961 & 19,960 & 19,978 & 19,974 & 4,986 & 4,979 & 4,988 & 4,987 & 5,004 & 4,995 & 4,981 & 4,990 & 4,996 & 19,868 & 19,914 & 19,933 & 20,028 & 19,973 & 19,943 & 19,925 & 19,931 \\
\hline An & 2,46 & 42,77 & 43,02 & 38,95 & 25,15 & 1,88 & 1,12 & 1,16 & 59,75 & 56,94 & 48,11 & 43,24 & 40,30 & 42,75 & 55,08 & 40,74 & 38,47 & 0,29 & 3,67 & 3,77 & 0,53 & 3,23 & 3,39 & 0,44 & 4,43 \\
\hline$A b$ & 45,24 & 55,08 & 54,93 & 58,82 & 70,83 & 40,74 & 38,47 & 37,70 & 37,63 & 2,85 & 4,08 & 2,23 & 1,85 & 2,15 & 42,77 & 1,88 & 1,12 & 98,57 & 52,75 & 53,41 & 98,72 & 51,46 & 54,14 & 98,19 & 64,09 \\
\hline Or & 52,30 & 2,15 & 2,05 & 2,23 & 4,03 & 57,37 & 60,41 & 61,14 & 2,62 & 40,21 & 47,81 & 54,53 & 57,85 & 55,09 & 2,15 & 57,38 & 60,41 & 1,14 & 43,58 & 42,82 & 0,76 & 45,31 & 42,47 & 1,37 & 31,48 \\
\hline \multicolumn{26}{|c|}{ Albite Activity } \\
\hline $800^{\circ} \mathrm{C}$ & & & & & & & & & & 0 & $0, \varepsilon$ & 0,90 & 0,90 & 0,9 & - & 0,90 & 0,91 & & & & & & & & \\
\hline $900^{\circ} \mathrm{C}$ & & & & & & & & & & 0,86 & 0,82 & 0,84 & 0,84 & 0,84 & - & 0,84 & 0,84 & & & & & & & & \\
\hline \multicolumn{26}{|c|}{ Anortite Activity } \\
\hline $800^{\circ} \mathrm{C}$ & & & & & & & & & 0,51 & - & - & - & - & & 0,58 & - & - & & & & & & & & \\
\hline $900^{\circ} \mathrm{C}$ & & & & & & & & & 0,48 & - & - & - & - & - & 0,54 & 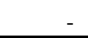 & - & & & & & & & & \\
\hline
\end{tabular}

${ }^{1}$ - n, núcleo; b, borda; <, incluso em; ints, intersticial; fen, fenocristal; idio, idiomórfico; lam, lamela de exsolução;

TÜ - análises realizadas na Universidade de Tübingen 


\begin{tabular}{|c|c|c|c|c|c|c|c|c|c|c|c|c|c|c|c|c|c|c|c|c|c|c|c|c|c|}
\hline \multicolumn{3}{|c|}{$\begin{array}{l}\text { Unidade N-II } \\
\text { Amostra MAl136 }\end{array}$} & \multicolumn{20}{|l|}{$\begin{array}{l}\text { HblP } \\
\text { MAI160 }\end{array}$} & \multicolumn{3}{|l|}{$\begin{array}{l}\text { NeS-II } \\
\text { MAI166I }\end{array}$} \\
\hline Cristal & 108 & 109 & 110 & 110 & 110 & 110 & 110 & 111 & 111 & 112 & 113 & 113 & 114 & 115 & 3 & $8 \mathrm{R}$ & 10 & 17 & 25 & 32 & 35 & $37 \mathrm{R}$ & 116 & 117 & 118 \\
\hline Textura $^{1}$ & $\mathrm{kfl}$ & $\mathrm{kfl}$ & $\mathrm{kfln} 1$ & $\mathrm{kfl} \mid \mathrm{n}$ & $\mathrm{kfln} 3$ & ffl lam n4 & $\mathrm{kflb}$ & $\mathrm{kfln}$ & $\mathrm{kflb}$ & $\mathrm{kfl}$ & $\mathrm{kfln}$ & $\mathrm{kfl} \mathrm{b}$ & $k f \mid n$ & $\mathrm{kflb}$ & TÜ & TÜ & TÜ & TÜ & TÜ & TÜ & TÜ & TÜ & $a b$ & $\mathrm{kfln}$ & $\mathrm{kfln}$ \\
\hline $\mathrm{SiO}_{2}$ & 66,25 & 66,37 & 64,88 & 65,47 & 64,59 & 64,84 & 64,34 & 66,27 & 66,72 & 66,19 & 66,30 & 66,19 & 66,18 & 66,18 & 64,88 & 66,01 & 66,27 & 66,19 & 66,30 & 66,18 & 66,18 & 65,87 & 68,66 & 66,61 & 66,99 \\
\hline $\mathrm{Al}_{2} \mathrm{O}_{3}$ & 19,83 & 19,61 & 22,15 & 21,97 & 22,42 & 18,81 & 18,96 & 19,96 & 19,73 & 19,77 & 19,97 & 19,47 & 19,78 & 19,90 & 22,15 & 19,58 & 19,96 & 19,77 & 19,97 & 19,78 & 19,90 & 20,30 & 20,38 & 19,34 & 19,50 \\
\hline $\mathrm{TiO}_{2}$ & 0,15 & 0,11 & & 0,04 & 0,05 & & & 0,03 & 0,02 & 0,08 & 0,02 & & 0,02 & 0,00 & & & 0,03 & 0,08 & 0,02 & 0,02 & 0,00 & & & 0,02 & 0,07 \\
\hline $\mathrm{Fe}_{2} \mathrm{O}_{3}$ & 0,31 & 0,32 & 0,10 & 0,09 & 0,12 & 0,01 & 0,05 & 0,12 & 0,16 & 0,10 & 0,15 & 0,10 & 0,13 & 0,14 & 0,09 & 0,03 & 0,11 & 0,09 & 0,14 & 0,11 & 0,13 & 0,12 & 0,02 & 0,15 & 0,20 \\
\hline MnO & & 0,00 & 0,00 & 0,01 & & & 0,01 & & 0,01 & 0,00 & & 0,00 & 0,00 & 0,02 & & & & & & & & & 0,03 & & 0,01 \\
\hline $\mathrm{MgO}$ & 0,03 & & 0,00 & 0,01 & & 0,00 & & & & 0,01 & & 0,01 & & 0,00 & & & & & & & & & & & \\
\hline $\mathrm{CaO}$ & 0,86 & 0,61 & 2,74 & 2,53 & 3,08 & 0,02 & 0,02 & 0,58 & 0,39 & 0,45 & 0,50 & 0,39 & 0,35 & 0,51 & 2,74 & 0,39 & 0,58 & 0,45 & 0,50 & 0,35 & 0,51 & 0,94 & 0,15 & 0,20 & 0,32 \\
\hline $\mathrm{Na}_{2} \mathrm{O}$ & 7,03 & 6,28 & 9,38 & 9,67 & 9,45 & 1,18 & 0,43 & 6,36 & 5,40 & 5,44 & 6,27 & 4,98 & 5,67 & 5,72 & 9,38 & 5,75 & 6,36 & 5,44 & 6,27 & 5,67 & 5,72 & 5,40 & 11,43 & 6,42 & 7,02 \\
\hline $\mathrm{K}_{2} \mathrm{O}$ & 5,91 & 6,96 & 0,61 & 0,51 & 0,53 & 14,89 & 15,75 & 7,09 & 8,57 & 8,43 & 7,05 & 9,17 & 8,05 & 7,96 & 0,61 & 7,96 & 7,09 & 8,43 & 7,05 & 8,05 & 7,96 & 7,93 & 0,12 & 7,54 & 6,52 \\
\hline SrO & 0,03 & 0,04 & 0,38 & 0,33 & 0,36 & 0,22 & 0,24 & 0,36 & 0,30 & 0,31 & 0,39 & 0,27 & 0,29 & 0,35 & 0,38 & 0,28 & 0,36 & 0,31 & 0,39 & 0,29 & 0,35 & 0,31 & 0,10 & 0,10 & 0,05 \\
\hline $\mathrm{BaO}$ & & 0,08 & 0,10 & 0,08 & 0,03 & 0,32 & 0,32 & 0,26 & 0,12 & 0,24 & 0,39 & 0,03 & 0,15 & 0,27 & 0,10 & 0,17 & 0,26 & 0,24 & 0,39 & 0,15 & 0,27 & 0,18 & & 0,04 & 0,09 \\
\hline Total & 100,39 & 100,38 & 100,35 & 100,70 & 100,62 & 100,30 & 100,14 & 101,04 & 101,41 & 101,03 & 101,05 & 100,61 & 100,61 & 101,06 & 100,34 & 100,17 & 101,03 & 101,02 & 101,03 & 100,60 & 101,05 & 101,04 & 100,89 & 100,42 & 100,77 \\
\hline \multicolumn{26}{|c|}{ Número de cátions calculado na base de 32 oxigênios. } \\
\hline Si & 11,798 & 11,853 & 11,425 & 11,474 & 11,354 & 11,934 & 11,899 & 11,805 & 11,870 & 11,833 & 11,813 & 11,887 & 11,849 & 11,817 & 2,860 & 2,970 & 2,955 & 2,962 & 2,958 & 2,966 & 2,959 & 2,942 & 11,891 & 11,912 & 11,898 \\
\hline Al & 4,162 & 4,128 & 4,597 & 4,538 & 4,645 & 4,080 & 4,133 & 4,190 & 4,137 & 4,166 & 4,193 & 4,121 & 4,174 & 4,188 & 1,151 & 1,038 & 1,049 & 1,043 & 1,050 & 1,045 & 1,048 & 1,068 & 4,160 & 4,076 & 4,082 \\
\hline $\mathrm{Ti}$ & 0,020 & 0,015 & 0,000 & 0,005 & 0,006 & 0,000 & 0,000 & 0,005 & 0,002 & 0,011 & 0,003 & 0,000 & 0,002 & 0,000 & 0,000 & 0,000 & 0,001 & 0,003 & 0,001 & 0,001 & 0,000 & 0,000 & 0,000 & 0,003 & 0,009 \\
\hline $\mathrm{Fe}^{3+}$ & 0,042 & 0,043 & 0,014 & 0,012 & 0,015 & 0,001 & 0,007 & 0,017 & 0,022 & 0,014 & 0,021 & 0,013 & 0,017 & 0,019 & 0,003 & 0,001 & 0,004 & 0,003 & 0,005 & 0,004 & 0,005 & 0,004 & 0,002 & 0,021 & 0,027 \\
\hline $\mathrm{Mn}$ & 0,000 & 0,000 & 0,000 & 0,002 & 0,000 & 0,000 & 0,002 & 0,000 & 0,002 & 0,001 & 0,000 & 0,000 & 0,000 & 0,003 & & & & & & & & & 0,005 & 0,000 & 0,002 \\
\hline Mg & 0,007 & 0,000 & 0,001 & 0,002 & 0,000 & 0,001 & 0,000 & 0,000 & 0,000 & 0,002 & 0,000 & 0,003 & 0,000 & 0,001 & & & & & & & & & 0,000 & 0,000 & 0,000 \\
\hline $\mathrm{Ca}$ & 0,164 & 0,117 & 0,517 & 0,475 & 0,580 & 0,003 & 0,004 & 0,111 & 0,074 & 0,087 & 0,096 & 0,075 & 0,067 & 0,098 & 0,129 & 0,019 & 0,028 & 0,022 & 0,024 & 0,017 & 0,025 & 0,045 & 0,027 & 0,039 & 0,062 \\
\hline $\mathrm{Na}$ & 2,427 & 2,175 & 3,203 & 3,286 & 3,221 & 0,422 & 0,156 & 2,197 & 1,863 & 1,886 & 2,166 & 1,734 & 1,968 & 1,980 & 0,802 & 0,502 & 0,550 & 0,472 & 0,542 & 0,493 & 0,496 & 0,468 & 3,838 & 2,226 & 2,418 \\
\hline K & 1,343 & 1,586 & 0,136 & 0,113 & 0,119 & 3,496 & 3,716 & 1,611 & 1,945 & 1,922 & 1,602 & 2,101 & 1,839 & 1,813 & 0,034 & 0,457 & 0,403 & 0,481 & 0,401 & 0,460 & 0,454 & 0,452 & 0,026 & 1,720 & 1,477 \\
\hline Sr & 0,003 & 0,005 & 0,039 & 0,034 & 0,037 & 0,024 & 0,026 & 0,037 & 0,031 & 0,032 & 0,041 & 0,028 & 0,031 & 0,036 & 0,000 & 0,000 & 0,000 & 0,000 & 0,000 & 0,000 & 0,000 & 0,000 & 0,010 & 0,010 & 0,005 \\
\hline $\mathrm{Ba}$ & 0,000 & 0,005 & 0,007 & 0,006 & 0,002 & 0,023 & 0,023 & 0,018 & 0,008 & 0,017 & 0,027 & 0,002 & 0,010 & 0,019 & 0,002 & 0,003 & 0,005 & 0,004 & 0,007 & 0,003 & 0,005 & 0,003 & 0,000 & 0,003 & 0,006 \\
\hline Total & 19,965 & 19,926 & $\begin{array}{r}19,939 \\
\end{array}$ & 19,945 & 19,979 & 19,985 & 19,966 & 19,991 & 19,953 & 19,970 & 19,962 & 19,964 & 19,957 & 19,976 & 4,982 & 4,990 & 4,996 & 4,991 & 4,988 & 4,988 & 4,992 & 4,983 & 19,960 & 20,010 & 19,986 \\
\hline An & 4,16 & 3,02 & 13,41 & 12,26 & 14,80 & 0,09 & 0,1 & 2,84 & $1, \mathrm{c}$ & 23 & 2,4 & 1,9 & 1,72 & 2,53 & 83,05 & 51,33 & 56,05 & 48,41 & 56,05 & 50,81 & 50,88 & 48,49 & 0,70 & 0,97 & 1,56 \\
\hline$A b$ & 61,71 & 56,08 & 83,05 & 84,82 & 82,17 & 10,77 & 4,02 & 56,05 & 47,98 & 48,41 & 56,05 & 44,35 & 50,81 & 50,88 & 13,41 & 1,90 & 2,84 & 2,23 & 2,49 & 1,72 & 2,53 & 4,66 & 98,63 & 55,86 & 61,10 \\
\hline Or & 34,13 & 40,89 & 3,54 & 2,92 & 3,03 & 89,14 & 95,88 & 41,11 & 50,10 & 49,36 & 41,46 & 53,73 & 47,47 & 46,59 & 3,54 & 46,77 & 41,11 & 49,36 & 41,46 & 47,47 & 46,59 & 46,84 & 0,66 & 43,17 & 37,34 \\
\hline \multicolumn{26}{|c|}{ Albite Activity } \\
\hline $800^{\circ} \mathrm{C}$ & & & & & & & & & & & & & & & - & 0,91 & 0,89 & 0,90 & 0,90 & 0,92 & 0,90 & 0,85 & & & \\
\hline $900^{\circ} \mathrm{C}$ & & & & & & & & & & & & & & & - & 0,87 & 0,86 & 0,86 & 0,86 & 0,87 & 0,86 & 0,81 & & & \\
\hline \multicolumn{26}{|c|}{ Anortite Activity } \\
\hline $800^{\circ} \mathrm{C}$ & & & & & & & & & & & & & & & 0,18 & - & & & & - & - & & & & \\
\hline $900^{\circ} \mathrm{C}$ & & & & & & & & & & & & & & & 0,17 & & & & & & & & & & \\
\hline
\end{tabular}

${ }^{1}$ - n, núcleo; b, borda; <, incluso em; ints, intersticial; fen, fenocristal; idio, idiomórfico; lam, lamela de exsolução;

TÜ - análises realizadas na Universidade de Tübingen 
ANEXO E - Tabela E.1 - Composição química de feldspatos de rochas do Maciço Alcalino de Itatiaia. Continua

\begin{tabular}{|c|c|c|c|c|c|c|c|c|c|c|c|c|c|c|c|c|c|c|c|c|c|c|c|c|c|}
\hline \multicolumn{3}{|c|}{$\begin{array}{l}\text { Unidade NeS-II } \\
\text { Amostra MAI166I }\end{array}$} & \multicolumn{23}{|c|}{\begin{tabular}{|l|} 
BtM \\
MAl182C \\
\end{tabular}} \\
\hline Cristal & 11 & 14 & 119 & 120 & 121 & 121 & 122 & 123 & 123 & 124 & 125 & 126 & 126 & 127 & 128 & 129 & 130 & 131 & 132 & 133 & 134 & 135 & 136 & 137 & 138 \\
\hline Textura $^{1}$ & TÜ & TÜ & $\mathrm{pln}$ & $\mathrm{kfl}$ & $\mathrm{pln}$ & $\mathrm{plb}$ & $\mathrm{kfl}$ & fen lam $n$ & fen lam b & kfl & $\mathrm{pl}$ & pl lam n & $\mathrm{pln}$ & $\mathrm{kfl}$ & kfl & $\mathrm{kfl}$ & kfl & kfl<bt & kfl & $\mathrm{pl}$ & $\mathrm{pl} \mathrm{lam} \mathrm{n}$ & $\mathrm{pln}$ & kfl & $\mathrm{kfl}$ & $\mathrm{pl}$ \\
\hline $\mathrm{SiO}_{2}$ & 66,61 & 66,99 & 62,82 & 64,29 & 63,36 & 63,20 & 64,38 & 60,20 & 63,42 & 63,99 & 62,62 & 64,29 & 62,94 & 64,50 & 64,13 & 64,15 & 64,87 & 64,31 & 64,83 & 63,73 & 64,20 & 63,55 & 64,77 & 64,55 & 63,55 \\
\hline $\mathrm{Al}_{2} \mathrm{O}_{3}$ & 19,34 & 19,50 & 23,50 & 20,47 & 22,36 & 21,81 & 20,31 & 24,46 & 21,78 & 20,67 & 22,10 & 20,21 & 22,29 & 20,50 & 19,89 & 20,37 & 20,55 & 20,76 & 20,26 & 22,24 & 20,19 & 22,02 & 20,62 & 20,61 & 22,14 \\
\hline $\mathrm{TiO}_{2}$ & 0,02 & 0,07 & 0,09 & 0,04 & 0,10 & 0,04 & 0,18 & 0,11 & 0,10 & 0,11 & 0,01 & 0,13 & 0,07 & 0,20 & 0,04 & 0,06 & 0,07 & 0,17 & 0,03 & 0,15 & 0,00 & 0,10 & 0,18 & 0,13 & 0,08 \\
\hline $\mathrm{Fe}_{2} \mathrm{O}_{3}$ & 0,14 & 0,18 & 0,31 & 0,17 & 0,21 & 0,17 & 0,15 & 0,25 & 0,25 & 0,16 & 0,24 & 0,24 & 0,26 & 0,19 & 0,21 & 0,22 & 0,21 & 0,18 & 0,13 & 0,21 & 0,13 & 0,21 & 0,20 & 0,16 & 0,25 \\
\hline MnO & & & 0,01 & & 0,01 & & & & 0,02 & 0,01 & 0,01 & 0,00 & & 0,00 & 0,02 & & 0,00 & & & & & & 0,00 & 0,00 & \\
\hline $\mathrm{MgO}$ & & & & & & & 0,00 & 0,01 & 0,06 & 0,02 & 0,01 & & 0,01 & 0,00 & 0,01 & 0,01 & & 0,00 & 0,03 & 0,01 & 0,01 & 0,01 & & 0,02 & 0,01 \\
\hline $\mathrm{CaO}$ & 0,20 & 0,32 & 4,49 & 1,48 & 3,08 & 3,02 & 1,34 & 5,66 & 2,73 & 1,54 & 3,27 & 1,09 & 3,49 & 1,40 & 1,03 & 1,43 & 1,42 & 1,68 & 1,17 & 3,04 & 1,15 & 3,04 & 1,46 & 1,50 & 3,25 \\
\hline $\mathrm{Na}_{2} \mathrm{O}$ & 6,42 & 7,02 & 8,73 & 4,52 & 6,79 & 6,32 & 4,40 & 7,32 & 6,09 & 4,75 & 7,50 & 3,46 & 6,35 & 4,69 & 4,11 & 4,85 & 5,16 & 5,12 & 4,52 & 6,63 & 3,96 & 6,29 & 4,58 & 4,61 & 6,86 \\
\hline $\mathrm{K}_{2} \mathrm{O}$ & 7,54 & 6,52 & 0,35 & 8,70 & 4,16 & 4,60 & 8,89 & 0,94 & 5,35 & 8,28 & 2,91 & 10,28 & 4,35 & 8,31 & 9,56 & 8,23 & 7,99 & 7,63 & 8,86 & 4,24 & 9,92 & 4,91 & 8,69 & 8,57 & 3,71 \\
\hline SrO & 0,10 & 0,05 & 0,32 & 0,40 & 0,41 & 0,42 & 0,36 & 0,30 & 0,45 & 0,36 & 0,37 & 0,43 & 0,37 & 0,40 & 0,38 & 0,38 & 0,45 & 0,41 & 0,39 & 0,38 & 0,38 & 0,41 & 0,41 & 0,40 & 0,36 \\
\hline $\mathrm{BaO}$ & 0,04 & 0,09 & 0,07 & 0,50 & 0,35 & 0,26 & 0,57 & 0,08 & 0,34 & 0,52 & 0,19 & 0,54 & 0,29 & 0,51 & 0,63 & 0,58 & 0,52 & 0,54 & 0,50 & 0,27 & 0,58 & 0,26 & 0,53 & 0,45 & 0,20 \\
\hline Total & 100,41 & 100,75 & 100,69 & 100,57 & 100,83 & 99,84 & 100,59 & 99,34 & 100,59 & 100,41 & 99,23 & 100,68 & 100,42 & 100,70 & 100,00 & 100,28 & 101,26 & 100,80 & 100,73 & 100,90 & 100,51 & 100,79 & 101,45 & 100,99 & 100,41 \\
\hline \multicolumn{26}{|c|}{ Número de cátions calculado na base de 32 oxigênios. } \\
\hline $\mathrm{Si}$ & 2,980 & 2,976 & 11,083 & 11,625 & 11,292 & 11,371 & 11,644 & 10,818 & 11,368 & 11,578 & 11,287 & 11,668 & 11,270 & 11,626 & 11,700 & 11,624 & 11,629 & 11,571 & 11,693 & 11,332 & 11,666 & 11,345 & 11,612 & 11,612 & 11,333 \\
\hline Al & 1,020 & 1,021 & 4,886 & 4,362 & 4,696 & 4,625 & 4,329 & 5,180 & 4,601 & 4,408 & 4,695 & 4,323 & 4,704 & 4,355 & 4,277 & 4,350 & 4,342 & 4,402 & 4,307 & 4,661 & 4,324 & 4,633 & 4,357 & 4,370 & 4,653 \\
\hline $\mathrm{Ti}$ & 0,001 & 0,002 & 0,011 & 0,006 & 0,013 & 0,006 & 0,025 & 0,015 & 0,014 & 0,015 & 0,001 & 0,018 & 0,010 & 0,027 & 0,005 & 0,008 & 0,010 & 0,023 & 0,005 & 0,020 & 0,000 & 0,013 & 0,024 & 0,017 & 0,010 \\
\hline $\mathrm{Fe}^{3+}$ & 0,005 & 0,007 & 0,041 & 0,023 & 0,029 & 0,023 & 0,021 & 0,034 & 0,033 & 0,022 & 0,033 & 0,033 & 0,035 & 0,026 & 0,029 & 0,030 & 0,029 & 0,024 & 0,018 & 0,027 & 0,018 & 0,028 & 0,027 & 0,021 & 0,034 \\
\hline $\mathrm{Mn}$ & & & 0,002 & 0,000 & 0,002 & 0,000 & 0,000 & 0,000 & 0,004 & 0,001 & 0,002 & 0,000 & 0,000 & 0,000 & 0,003 & 0,000 & 0,000 & 0,000 & 0,000 & 0,000 & 0,000 & 0,000 & 0,001 & 0,000 & 0,000 \\
\hline Mg & & & 0,000 & 0,000 & 0,000 & 0,000 & 0,000 & 0,002 & 0,016 & 0,006 & 0,003 & 0,000 & 0,004 & 0,001 & 0,003 & 0,003 & 0,000 & 0,001 & 0,007 & 0,002 & 0,001 & 0,002 & 0,000 & 0,005 & 0,004 \\
\hline $\mathrm{Ca}$ & 0,010 & 0,015 & 0,849 & 0,287 & 0,588 & 0,582 & 0,260 & 1,090 & 0,524 & 0,299 & 0,631 & 0,212 & 0,670 & 0,270 & 0,202 & 0,278 & 0,273 & 0,324 & 0,226 & 0,579 & 0,224 & 0,581 & 0,280 & 0,289 & 0,621 \\
\hline $\mathrm{Na}$ & 0,557 & 0,605 & 2,986 & 1,585 & 2,346 & 2,205 & 1,543 & 2,550 & 2,117 & 1,666 & 2,621 & 1,217 & 2,205 & 1,639 & 1,454 & 1,704 & 1,793 & 1,786 & 1,581 & 2,286 & 1,395 & 2,177 & 1,592 & 1,608 & 2,372 \\
\hline $\mathrm{K}$ & 0,430 & 0,370 & 0,078 & 2,007 & 0,946 & 1,056 & 2,051 & 0,216 & 1,223 & 1,911 & 0,669 & 2,380 & 0,994 & 1,911 & 2,225 & 1,902 & 1,827 & 1,751 & 2,038 & 0,962 & 2,300 & 1,118 & 1,987 & 1,967 & 0,844 \\
\hline $\mathrm{Sr}$ & 0,000 & 0,000 & 0,033 & 0,042 & 0,042 & 0,044 & 0,038 & 0,032 & 0,046 & 0,038 & 0,039 & 0,046 & 0,038 & 0,042 & 0,040 & 0,040 & 0,047 & 0,043 & 0,041 & 0,039 & 0,040 & 0,043 & 0,043 & 0,042 & 0,038 \\
\hline $\mathrm{Ba}$ & 0,001 & 0,002 & 0,005 & 0,035 & 0,024 & 0,018 & 0,040 & 0,005 & 0,024 & 0,037 & 0,013 & 0,038 & 0,020 & 0,036 & 0,045 & 0,041 & 0,037 & 0,038 & 0,035 & 0,019 & 0,041 & 0,018 & 0,037 & 0,031 & 0,014 \\
\hline Total & 5,003 & 4,998 & 19,975 & 19,972 & 19,978 & 19,930 & 19,952 & 19,943 & 19,971 & 19,981 & 19,994 & 19,935 & 19,949 & 19,932 & 19,982 & 19,981 & 19,987 & 19,962 & 19,950 & 19,927 & 20,010 & 19,959 & 19,961 & 19,963 & 19,922 \\
\hline An & 55,86 & 61,10 & 21,69 & 7,39 & 15,16 & 15,15 & 6,75 & 28,26 & 13,57 & 7,70 & 16,10 & 5,57 & 17,31 & 7,08 & 5,20 & 7,15 & 7,01 & 8,39 & 5,88 & 15,13 & 5,71 & 15,00 & 7,27 & 7,48 & 16,18 \\
\hline$A b$ & 0,97 & 1,56 & 76,31 & 40,86 & 60,47 & 57,37 & 40,03 & 66,13 & 54,77 & 42,99 & 66,84 & 31,96 & 57,00 & 42,91 & 37,46 & 43,87 & 46,07 & 46,26 & 41,11 & 59,73 & 35,61 & 56,16 & 41,25 & 41,62 & 61,82 \\
\hline Or & 43,17 & 37,34 & 2,00 & 51,75 & 24,37 & 27,48 & 53,22 & 5,61 & 31,66 & 49,31 & 17,06 & 62,47 & 25,69 & 50,02 & 57,33 & 48,98 & 46,93 & 45,35 & 53,02 & 25,13 & 58,68 & 28,84 & 51,49 & 50,90 & 22,00 \\
\hline \multicolumn{26}{|c|}{ Albite Activity } \\
\hline $800^{\circ} \mathrm{C}$ & 0,93 & 0,91 & & & & & & & & & & & & & & & & & & & & & & & \\
\hline $900^{\circ} \mathrm{C}$ & 0,89 & 0,88 & & & & & & & & & & & & & & & & & & & & & & & \\
\hline \multicolumn{26}{|c|}{ Anortite Activity } \\
\hline $800^{\circ} \mathrm{C}$ & & 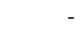 & & & & & & & & & & & & & & & & & & & & & & & \\
\hline $900^{\circ} \mathrm{C}$ & & & & & & & & & & & & & & & & & & & & & & & & & \\
\hline
\end{tabular}

-n, núcleo; b, borda; <, incluso em; ints, intersticial; fen, fenocristal; idio, idiomórfico; lam, lamela de exsolução;

TÜ - análises realizadas na Universidade de Tübingen 
ANEXO E - Tabela E.1 - Composição química de feldspatos de rochas do Maciço Alcalino de Itatiaia. Continua

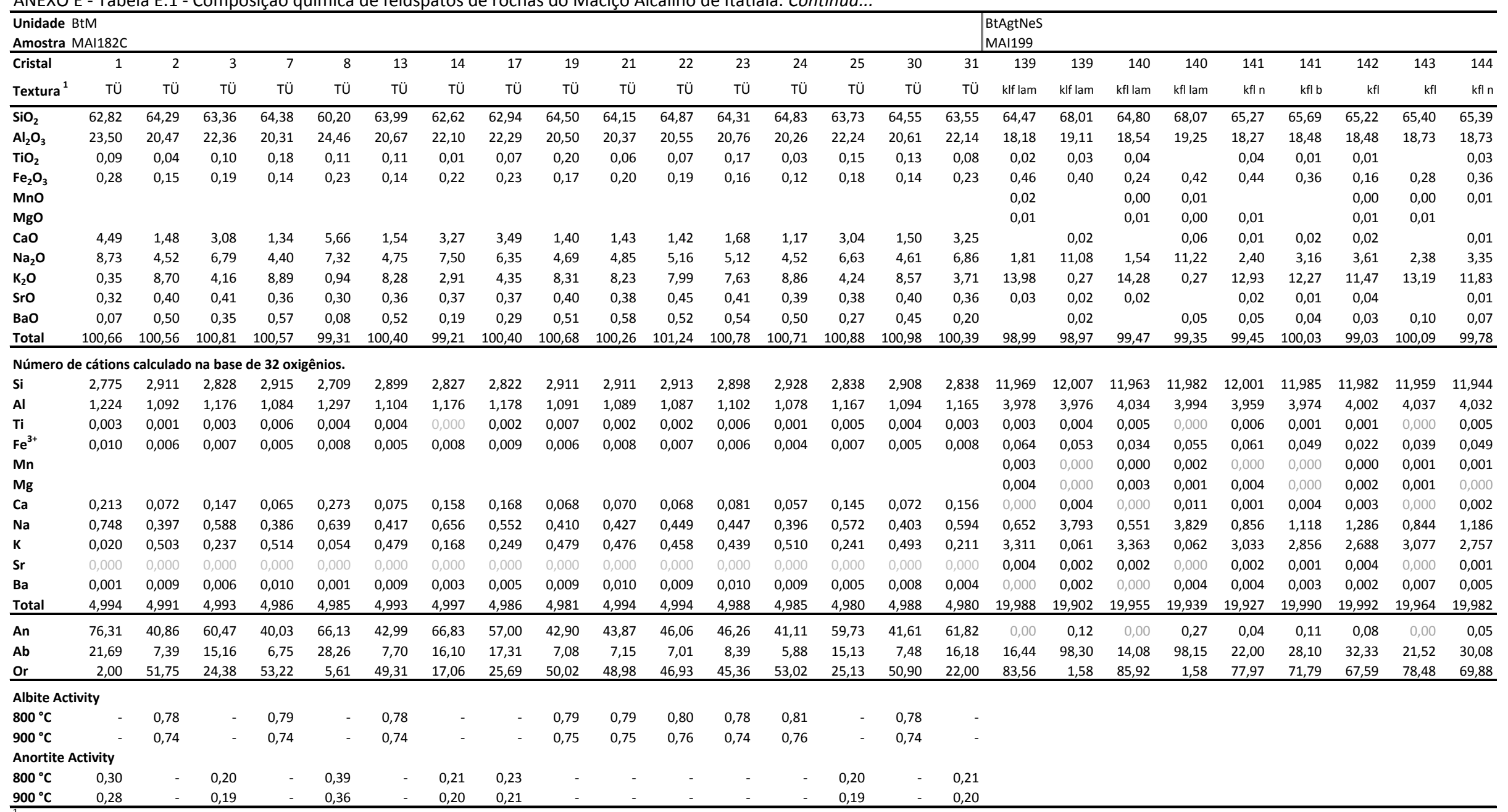

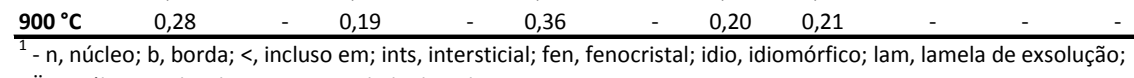

TÜ - análises realizadas na Universidade de Tübingen 
ANEXO E - Tabela E.1 - Composição química de feldspatos de rochas do Maciço Alcalino de Itatiaia. Continua.. Unidade BtAgtNeS

\begin{tabular}{|c|c|c|c|c|c|c|c|c|}
\hline Cristal & 144 & 144 & $6 R$ & $10 \mathrm{R}$ & $13 R$ & $16 \mathrm{R}$ & $26-28$ & $30 R$ \\
\hline Textura $^{1}$ & kfl n2 & kfln3 & TÜ & TÜ & TÜ & TÜ & TÜ & TÜ \\
\hline$\overline{\mathrm{SiO}_{2}}$ & 65,51 & 64,88 & 66,96 & 66,95 & 66,80 & 66,97 & 65,26 & 66,48 \\
\hline $\mathrm{Al}_{2} \mathrm{O}_{3}$ & 18,43 & 18,63 & 19,01 & 18,65 & 18,88 & 18,94 & 18,60 & 18,73 \\
\hline $\mathrm{TiO}_{2}$ & 0,07 & 0,01 & & & & & 0,04 & \\
\hline $\mathrm{Fe}_{2} \mathrm{O}_{3}$ & 0,31 & 0,36 & 0,32 & 0,41 & 0,23 & 0,33 & 0,31 & 0,28 \\
\hline MnO & 0,01 & & & & & & & \\
\hline MgO & 0,00 & 0,01 & & & & & & \\
\hline $\mathrm{CaO}$ & & & 0,04 & 0,00 & 0,02 & 0,02 & 0,01 & 0,01 \\
\hline $\mathrm{Na}_{2} \mathrm{O}$ & 3,28 & 2,37 & 7,93 & 6,64 & 7,48 & 7,09 & 3,00 & 5,91 \\
\hline $\mathrm{K}_{2} \mathrm{O}$ & 11,97 & 13,09 & 5,04 & 6,74 & 5,71 & 6,33 & 12,30 & 8,03 \\
\hline SrO & & 0,03 & 0,01 & 0,01 & 0,02 & 0,00 & 0,02 & 0,03 \\
\hline $\mathrm{BaO}$ & & & 0,03 & 0,03 & 0,03 & 0,05 & 0,07 & 0,07 \\
\hline Total & 99,58 & 99,38 & 99,33 & 99,44 & 99,16 & 99,73 & 99,61 & 99,54 \\
\hline \multicolumn{9}{|c|}{ Número de cátions calculado na base de 32 oxigênios. } \\
\hline Si & 11,987 & 11,946 & 2,997 & 3,010 & 3,001 & 2,999 & 2,992 & 3,002 \\
\hline Al & 3,974 & 4,043 & 1,003 & 0,988 & 0,999 & 0,999 & 1,005 & 0,997 \\
\hline $\mathrm{Ti}$ & 0,010 & 0,001 & 0,000 & 0,000 & 0,000 & 0,000 & 0,001 & 0,000 \\
\hline $\mathrm{Fe}^{3+}$ & 0,043 & 0,050 & 0,012 & 0,016 & 0,009 & 0,012 & 0,012 & 0,011 \\
\hline Mn & 0,001 & 0,000 & & & & & & \\
\hline Mg & 0,001 & 0,003 & & & & & & \\
\hline Ca & 0,000 & 0,000 & 0,002 & 0,000 & 0,001 & 0,001 & 0,000 & 0,000 \\
\hline $\mathrm{Na}$ & 1,164 & 0,846 & 0,688 & 0,579 & 0,651 & 0,616 & 0,267 & 0,517 \\
\hline K & 2,794 & 3,075 & 0,288 & 0,387 & 0,327 & 0,362 & 0,719 & 0,463 \\
\hline $\mathrm{Sr}$ & 0,000 & 0,004 & 0,000 & 0,000 & 0,000 & 0,000 & 0,000 & 0,000 \\
\hline Ba & 0,000 & 0,000 & 0,001 & 0,000 & 0,000 & 0,001 & 0,001 & 0,001 \\
\hline Total & 19,974 & 19,967 & 4,990 & 4,979 & 4,989 & 4,990 & 4,998 & 4,990 \\
\hline An & 0,00 & 0,00 & 70,40 & 59,93 & 66,51 & 62,95 & 27,04 & 52,77 \\
\hline $\mathbf{A b}$ & 29,40 & 21,58 & 0,18 & 0,02 & 0,09 & 0,08 & 0,05 & 0,03 \\
\hline or & 70,60 & 78,42 & 29,42 & 40,05 & 33,40 & 36,96 & 72,92 & 47,21 \\
\hline \multicolumn{9}{|c|}{ Albite Activity } \\
\hline $800^{\circ} \mathrm{C}$ & & & 0,92 & 0,94 & 0,93 & 0,94 & 0,85 & 0,96 \\
\hline $900^{\circ} \mathrm{C}$ & & & 0,90 & 0,91 & 0,90 & 0,91 & 0,77 & 0,91 \\
\hline \multicolumn{9}{|c|}{ Anortite Activity } \\
\hline $800^{\circ} \mathrm{C}$ & & & - & - & - & - & & \\
\hline $900^{\circ} \mathrm{C}$ & & & - & - & & - & & \\
\hline
\end{tabular}

- $n$, núcleo; b, borda; <, incluso em; ints, intersticial; fen, fenocristal; idio, idiomórfico; lam, lamela de exsolução;

TÜ - análises realizadas na Universidade de Tübingen 
ANEXO E - Tabela E.2 - Composição química de nefelinas de rochas do Maciço Alcalino de Itatiaia. Continua..

\begin{tabular}{|c|c|c|c|c|c|c|c|c|c|c|c|c|c|c|c|c|c|c|c|c|c|c|c|}
\hline $\begin{array}{l}\text { Unidade } \\
\text { Amostra }\end{array}$ & $\begin{array}{l}\text { BtHbNeS } \\
\text { MAIO36 }\end{array}$ & & & & & & & & & & & & & & $\begin{array}{l}\text { NeS-I } \\
\text { MAI058I }\end{array}$ & & & & & & & & \\
\hline Cristal & 1 & 2 & 2 & 3 & 4 & 4 & 5 & 5 & 6 & 6 & 7 & 7 & 8 & 8 & 9 & 9 & 10 & 10 & 11 & 11 & 12 & 12 & 13 \\
\hline Textura ${ }^{1}$ & $\mathrm{n}$ & b & $\mathrm{n}$ & $\mathrm{n}$ & $\mathrm{n}$ & $\mathrm{b}$ & $\mathrm{n}$ & $\mathrm{b}$ & $\mathrm{n}$ & $b$ & $\mathrm{n}$ & $b$ & $\mathrm{n}$ & $\mathrm{b}$ & $\mathrm{n}$ & $b$ & $\mathrm{n}$ & b & $\mathrm{n}$ & $b$ & $\mathrm{n}$ & b & $\mathrm{n}$ \\
\hline $\mathrm{SiO}_{2}$ & 44,41 & 44,31 & 44,01 & 43,45 & 44,08 & 44,37 & 43,88 & 43,67 & 44,41 & 44,33 & 44,00 & 44,15 & 43,93 & 43,97 & 43,87 & 43,11 & 43,50 & 42,68 & 44,03 & 44,22 & 43,72 & 42,64 & 44,01 \\
\hline $\mathrm{Al}_{2} \mathrm{O}_{3}$ & 34,24 & 33,70 & 33,72 & 33,69 & 33,87 & 34,16 & 33,75 & 33,84 & 33,85 & 33,99 & 33,77 & 34,17 & 34,08 & 34,12 & 32,80 & 34,23 & 33,04 & 34,66 & 32,68 & 32,21 & 32,74 & 34,44 & 32,78 \\
\hline $\mathrm{TiO}_{2}$ & & 0,06 & & 0,04 & 0,04 & 0,01 & 0,02 & & 0,02 & 0,01 & & 0,00 & 0,03 & 0,03 & & & 0,01 & 0,03 & & & & 0,03 & 0,04 \\
\hline $\mathrm{Fe}_{2} \mathrm{O}_{3}$ & 0,19 & 0,21 & 0,19 & 0,21 & 0,20 & 0,17 & 0,20 & 0,19 & 0,20 & 0,26 & 0,26 & 0,25 & 0,22 & 0,24 & 1,12 & 0,19 & 0,70 & 0,19 & 1,07 & 1,37 & 1,01 & 0,11 & 1,06 \\
\hline $\mathrm{MnO}$ & 0,01 & 0,00 & & & 0,01 & & 0,00 & & & 0,01 & 0,00 & & 0,01 & & 0,00 & & 0,01 & & 0,02 & 0,03 & & 0,01 & \\
\hline MgO & 0,03 & & 0,00 & & 0,00 & 0,00 & & 0,01 & & & & & & & & & & & 0,00 & 0,02 & 0,01 & 0,01 & 0,02 \\
\hline $\mathrm{CaO}$ & 1,35 & 1,17 & 1,16 & 47 & 1,53 & 1,55 & 1,55 & 1,83 & 1,44 & 1,51 & 1,29 & 1,32 & 1,54 & 1,48 & 0,02 & & 0,01 & & & & & & \\
\hline $\mathrm{Na}_{2} \mathrm{O}$ & 15,75 & 15,50 & 15,53 & 15,24 & 15,37 & 15,33 & 15,19 & 15,19 & 15,26 & 15,14 & 15,33 & 15,18 & 15,33 & 15,33 & 15,86 & 15,66 & 15,80 & 15,66 & 15,86 & 15,89 & 15,93 & 15,64 & 15,98 \\
\hline $\mathrm{K}_{2} \mathrm{O}$ & 4,78 & 5,36 & 5,09 & 5,02 & 4,96 & 4,80 & 4,86 & 4,99 & 4,85 & 4,82 & 5,17 & 5,01 & 4,93 & 5,13 & 5,99 & 6,94 & 6,17 & 7,04 & 5,86 & 5,74 & 5,98 & 7,17 & 5,79 \\
\hline SrO & & 0,04 & 0,03 & 0,02 & 0,01 & 0,00 & & & 0,05 & & & 0,00 & 0,00 & 0,02 & 0,04 & 0,05 & & & & 0,06 & 0,05 & 0,04 & 0,02 \\
\hline BaO & & 0,03 & & & 0,01 & & 0,02 & & & 0,04 & 0,08 & & 0,06 & 0,02 & 0,02 & & 0,03 & & & & 0,08 & 0,00 & \\
\hline Total & 100,75 & 100,37 & 99,73 & 99,13 & 100,08 & 100,40 & 99,48 & 99,72 & 100,08 & 100,11 & 99,90 & 100,09 & 100,14 & 100,35 & 99,72 & 100,18 & 99,26 & 100,26 & 99,52 & 99,53 & 99,52 & 100,09 & 99,69 \\
\hline \multicolumn{24}{|c|}{ itions calculado na base de 32 oxigênios. } \\
\hline Si & 8,390 & 8,427 & 8,412 & 8,360 & 8,394 & 8,405 & 8,399 & 8,355 & 8,440 & 8,421 & 8,402 & 8,393 & 8,363 & 8,359 & 8,445 & 8,281 & 8,412 & 8,200 & 8,479 & 8,520 & 8,439 & 8,214 & 8,461 \\
\hline Al & 24 & 7,554 & 7,596 & 7,6 & 01 & 26 & 7,613 & 7,630 & 7,582 & 7,610 & 7,600 & 7 , & 7,646 & 7,645 & 7,441 & 7,749 & 7,530 & 7,848 & 7,417 & 7,315 & 7,448 & 819 & 7,428 \\
\hline $\mathrm{Ti}$ & 0,000 & 0,008 & 0,000 & 0,006 & 0,006 & 0,002 & 0,003 & 0,000 & 0,002 & 0,001 & 0,000 & 0,001 & 0,005 & 0,005 & 0,000 & 0,000 & 0,001 & 0,004 & 0,000 & 0,000 & 0,000 & 0,005 & 0,006 \\
\hline $\mathrm{Fe}^{3+}$ & 0,027 & 0,030 & 0,028 & 0,030 & 0,029 & 0,025 & 0,029 & 0,027 & 0,029 & 0,037 & 0,038 & 0,036 & 0,031 & 0,035 & 0,162 & 0,028 & 0,101 & 0,028 & 0,155 & 0,198 & 0,146 & 0,017 & 0,153 \\
\hline$M n$ & & 1 & 0,000 & 0 & & 0,000 & 0,000 & 0,000 & 0,000 & 0,002 & 0,000 & 0,000 & 0 & 0,000 & 0,001 & 0,000 & 0,001 & 0,000 & 0,003 & 0,005 &, 000 & 0,002 & 0,000 \\
\hline $\mathrm{Mg}$ & 07 & 0,000 & 0,001 & 0,000 & 0,001 & 0,000 & 0,000 & 0,003 & 0,000 & 0,000 & 0,000 & 0,000 & 0,000 & 0,000 & 0,000 & 0,000 & 0,000 & 0,000 & 0,001 & 0,005 & 0,002 & 0,002 & 0,004 \\
\hline $\mathrm{Ca}$ & 74 & 0,239 & 0 & & & & & 0,375 & 0,293 & 0,307 & 0,264 & 0 & 0 & 0,301 & 0,004 & 0,000 & 0,002 & 0,000 & 0,000 & 0,000 & 00 & 0,000 & 0,000 \\
\hline $\mathrm{Na}$ & 69 & 5 & 5, & & & 5 & & 5,634 & 3 & 5 & 6 & 5 & 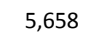 & 5,651 & 5,919 & 5,832 & 5,924 & 5,833 & 5,922 & 36 & 62 & 5,841 & 5,957 \\
\hline 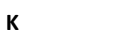 & 152 & 1,300 & 1,241 & 1,2 & 1,205 & 1,160 & 1,187 & 1,218 & 1,176 & 1,168 & 1,259 & 1,215 & 1,197 & 1,244 & 1,471 & 1,701 & 1,522 & 1,725 & 1,439 & 1,411 & 472 & ,762 & 1,420 \\
\hline $\mathrm{Sr}$ & 000 & 0,0 & 0,0 & 0,0 & & 0,000 & 0 & 0,000 & 0,006 & 0,000 & 0 & 0,000 & 0 & 0,002 & 0,005 & 0,006 & 0,000 & 0,000 & 0,000 & 0,007 & 06 & 004 & 0,002 \\
\hline Ba & 0,000 & 0,002 & 0,000 & 0,000 & 0,001 & 0,000 & 0,001 & 0,000 & 0,000 & 0,003 & 0,006 & 0,000 & 0,004 & 0,002 & 0,002 & 0,000 & 0,003 & 0,000 & 0,000 & 0,000 & 0,006 & 0,000 & 0,000 \\
\hline Tot: & 245 & & 23,274 & 23,258 & 23,225 & 23,163 & 23,188 & 23,243 & 23,151 & 23,126 & 23,246 & 23,165 & 23,221 & 23,244 & 23,449 & 23,597 & 23,495 & 23,638 & 23,416 & 23,397 & 23,481 & 23,665 & 23,431 \\
\hline $\mathrm{Ne}$ & $\begin{array}{ll}72,07 \\
\end{array}$ & 70,95 & 71,70 & 70,76 & 70,64 & 70,56 & 70,39 & 69,81 & 70,45 & 70,01 & 70,68 & 70,35 & 70,64 & 70,41 & 72,45 & 72,27 & 72,85 & 72,43 & 72,63 & 72,37 & 72,94 & 72,31 & 73,09 \\
\hline $\mathrm{FeNe}$ & 0,51 & 0 , & & & 0, & 0,48 & 0,57 & م & 6 & 0,72 & 0,73 & 0,70 & 0,61 & 0,67 & 3,07 & 0,53 & 1,93 & 0,54 & 2,95 & 3,74 & 2,77 & 0,32 & 2,90 \\
\hline Ks & 16,02 & 17 & $1 /$ & 17,0 & 16,70 & 16,18 & 16,50 & 16,80 & 16,40 & 16,33 & 17,46 & 17,01 & 16,64 & 17,26 & 20,05 & 23,46 & 20,84 & 23,85 & 19,66 & 19,15 & 20,06 & 24,29 & 19,40 \\
\hline An & 6 , & 5, & 5 & 7, & 7,61 & 7,72 & 7,77 & 9, & 7,19 & 7,56 & 6,44 & 6,63 & 7,68 & 7,36 & 0,09 & 0,00 & 0,05 & 0,00 & 0,00 & 0,00 & 0,00 & 0,00 & 0,00 \\
\hline $\mathrm{Qzz}$ & 4,69 & 4,70 & 4,78 & 4,20 & 4,49 & 5,05 & 4,76 & 3,76 & 5,39 & 5,39 & 4,69 & 5,31 & 4,43 & 4,31 & 4,34 & 3,73 & 4,32 & 3,18 & 4,76 & 4,74 & 4,23 & 3,09 & 4,61 \\
\hline
\end{tabular}


ANEXO E - Tabela E.2 - Composição química de nefelinas de rochas do Maciço Alcalino de Itatiaia. Continua...

\begin{tabular}{|c|c|c|c|c|c|c|c|c|c|c|c|c|c|c|c|c|c|c|c|c|c|c|c|}
\hline $\begin{array}{l}\text { Unidade } \\
\text { Amostra }\end{array}$ & $\begin{array}{l}\text { NeS-I } \\
\text { MAI058I }\end{array}$ & & & & & & MA1060 & & & & & & & & & & & & & & & & \\
\hline Cristal & 14 & 14 & 15 & 16 & 17 & 17 & 18 & 18 & 19 & 19 & 20 & 20 & 21 & 21 & 22 & 22 & 23 & 23 & 24 & 24 & 25 & 25 & 26 \\
\hline Textura ${ }^{1}$ & $\mathrm{n}$ & $b$ & $\mathrm{n}$ & $<\mathrm{kfl}$ & $n$ & b & $\mathrm{n}$ & b & $\mathrm{n}$ & b & $\mathrm{n}$ & $n$ & $\mathrm{n}$ & $\mathrm{n}$ & $\mathrm{n}$ & b & 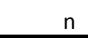 & b & $\mathrm{n}$ & $b$ & $\mathrm{n}$ & b & \\
\hline $\mathrm{SiO}_{2}$ & 42,55 & 44,08 & 43,45 & 41,85 & 43,95 & 41,75 & 43,31 & 43,49 & 43,76 & 44,05 & 43,58 & 43,87 & 43,77 & 43,59 & 44,10 & 44,22 & 43,57 & 43,34 & 43,75 & 43,55 & 43,64 & 43,14 & 43,92 \\
\hline $\mathrm{Al}_{2} \mathrm{O}_{3}$ & 33,76 & 32,41 & 32,96 & 34,68 & 32,60 & 34,66 & 33,79 & 33,42 & 33,58 & 33,58 & 33,59 & 33,69 & 33,54 & 33,69 & 33,17 & 33,54 & 33,48 & 33,79 & 33,57 & 33,54 & 33,53 & 33,67 & 33,61 \\
\hline $\mathrm{TiO}_{2}$ & 0,02 & 0,02 & 0,02 & & & & 0,06 & & 0,02 & & & 0,00 & & 0,02 & 0,03 & & & & & 0,07 & & 0,04 & 0,00 \\
\hline $\mathrm{Fe}_{2} \mathrm{O}_{3}$ & 0,54 & 1,23 & 0,98 & 0,10 & 1,11 & 0,13 & 0,62 & 0,73 & 0,66 & 0,68 & 0,67 & 0,66 & 0,62 & 0,67 & 0,67 & 0,58 & 0,65 & 0,59 & 0,63 & 0,64 & 0,63 & 0,45 & 0,71 \\
\hline Mno & 0,03 & 0,02 & & & 0,01 & & 0,00 & 0,02 & & 0,02 & & & 0,01 & & & 0,00 & 0,01 & & 0,02 & 0,01 & & & 0,00 \\
\hline MgO & & 0,01 & 0,00 & & & 0,00 & & 0,00 & & & & 0,00 & & & & & & & 0,00 & & & & \\
\hline $\mathrm{CaO}$ & 0,01 & & & 0,03 & & & 0,08 & 0,04 & 0,05 & 0,04 & 0,06 & 0,06 & 0,07 & 0,03 & 0,11 & 0,05 & 0,06 & 0,03 & 0,09 & 0,06 & 0,07 & 0,03 & 0,07 \\
\hline $\mathrm{Na}_{2} \mathrm{O}$ & 15,74 & 15,76 & 16,00 & 15,69 & 15,72 & 15,55 & 15,92 & 15,97 & 15,87 & 15,82 & 15,89 & 15,73 & 15,95 & 15,83 & 15,86 & 15,95 & 15,89 & 15,50 & 15,82 & 15,95 & 15,93 & 15,65 & 16,14 \\
\hline 0 & 95 & 5,91 & 6,27 & 7,55 & 5,93 & 7,44 & 6,48 & 6,34 & 6,27 & 6,36 & 6,31 & 6,41 & 6,30 & 6,47 & 6,01 & 6,24 & 6,42 & 6,48 & 6,32 & 6,33 & 6,18 & 6,54 & 6,20 \\
\hline 0 & 0,00 & 0,01 & & 0,03 & 0,01 & & & 0,04 & 0,00 & 0,01 & & 0,00 & 0,06 & 0,06 & 0,03 & & 0,06 & & 0,00 & 0,01 & 0,01 & 0,03 & 0,02 \\
\hline $\mathrm{BaO}$ & 0,04 & & 0,01 & & 0,03 & & & 0,03 & 0,01 & 0,02 & 0,04 & & 0,01 & & & 0,05 & & & & & 0,02 & 0,02 & 0,01 \\
\hline Total & 99,65 & 99,45 & 99,69 & 99,93 & 99,36 & 99,53 & 100,26 & 100,08 & 100,22 & 100,59 & 100,13 & 100,43 & 100,33 & 100,36 & 99,98 & 100,64 & 100,14 & 99,73 & 100,20 & 100,16 & 100,00 & 99,58 & 100,68 \\
\hline \multicolumn{24}{|c|}{ Número de cátions calculado na base de 32 oxigênios. } \\
\hline$S i$ & 8,243 & 8,500 & 8,385 & 8,107 & 8,481 & 8,110 & 8,309 & 8,358 & 8,380 & 8,405 & 8,361 & 8,383 & 8,380 & 8,349 & 8,451 & 8,427 & 8,365 & 8,341 & 8,381 & 8,355 & 8,375 & 8,327 & 8,378 \\
\hline Al & 708 & 7,365 & 7,496 & 7,918 & 7,414 & 7,935 & 7,640 & 7,570 & 7,579 & 7,552 & 7,595 & 7,588 & 7,568 & 7,605 & 7,492 & 7,533 & 7,576 & 7,664 & 7,580 & 7,584 & 7,584 & 660 & 7,557 \\
\hline 11 & 0,003 & 0,003 & 0,003 & 0,000 & 0,000 & 0,000 & 0,008 & 0,000 & 0,003 & 0,000 & 0,000 & 0,000 & 0,000 & 0,003 & 0,004 & 0,000 & 0,000 & 0,000 & 0,000 & 0,010 & 0,000 & 0,007 & 0,000 \\
\hline $\mathrm{Fe}^{3+}$ & 0,079 & 0,178 & 0,143 & 0,014 & 0,161 & 0,019 & 0,089 & 0,106 & 0,096 & 0,098 & 0,096 & 0,095 & 0,090 & 0,097 & 0,097 & 0,084 & 0,094 & 0,085 & 0,091 & 0,092 & 0,091 & 0,065 & 0,101 \\
\hline $\mathrm{Mn}$ & 0,004 & 0,003 & 0,000 & 0,000 & 0,002 & 0,000 & 0,000 & 0,003 & 0,000 & 0,003 & 0,000 & 0,000 & 0,001 & 0,000 & 0,000 & 0,000 & 0,001 & 0,000 & 0,003 & 0,002 & 0,000 & 0,000 & 0,000 \\
\hline $\mathrm{Mg}$ & 00 & 0,003 & 0,000 & 0,000 & 0,000 & 0,000 & 0,000 & 0,000 & 0,000 & 0,000 & 0,000 & 0,001 & 0,000 & 0,000 & 0,000 & 0,000 & 0,000 & 0,000 & ,000 & 0,000 & 0,000 & 0,000 & 0,000 \\
\hline $\mathrm{Ca}$ & 0,003 & 0,000 & 0,000 & 0,006 & 0,000 & 0,000 & 0,017 & 0,008 & 0,010 & 0,008 & 0,012 & 0,013 & 0,014 & 0,007 & 0,022 & 0,010 & 0,013 & 0,006 & 0,018 & 0,012 & 0,014 & 0,007 & 0,013 \\
\hline $\mathrm{Na}$ & 5,912 & 5,892 & 5,987 & 5,893 & 5,881 & 5,856 & 5,922 & 5,951 & 5,892 & 5,853 & 5,911 & 5,828 & 5,921 & 5,879 & 5,893 & 5,894 & 5,915 & 5,784 & 5,876 & 5,933 & 5,928 & 5,857 & 5,970 \\
\hline K & 1,718 & 1,454 & 1,543 & 1,866 & 1,460 & 1,844 & 1,586 & 1,554 & 1,532 & 1,548 & 1,544 & 1,563 & 1,539 & 1,581 & 1,469 & 1,517 & 1,572 & 1,591 & 1,544 & 1,549 & 1,513 & 1,610 & 1,509 \\
\hline $\mathrm{Sr}$ & 0,001 & 0,001 & 0,000 & 0,004 & 0,001 & 0,000 & 0,000 & 0,004 & 0,000 & 0,002 & 0,000 & 0,000 & 0,007 & 0,006 & 0,004 & 0,000 & 0,007 & 0,000 & 0,001 & 0,001 & 0,001 & 0,003 & 0,003 \\
\hline Ba & 0,003 & 0,000 & 0,001 & 0,000 & 0,002 & 0,000 & 0,000 & 0,002 & 0,000 & 0,002 & 0,003 & 0,000 & 0,001 & 0,000 & 0,000 & 0,004 & 0,000 & 0,000 & 0,000 & 0,000 & 0,001 & 0,001 & 0,001 \\
\hline Total & 23,675 & 23,399 & 23,558 & 23,807 & 23,402 & 23,763 & 23,572 & 23,557 & 23,492 & 23,470 & 23,521 & 23,471 & 23,521 & 23,527 & 23,432 & 23,470 & 23,544 & 23,472 & 23,494 & 23,538 & 23,507 & 23,538 & 23,533 \\
\hline $\mathrm{Ne}$ & 72,39 & 72,05 & 72,91 & 72,41 & 72,16 & 72,28 & 72,79 & 72,95 & 72,66 & 72,18 & 72,76 & 71,98 & 72,84 & 72,39 & 72,65 & 72,68 & 72,61 & 71,79 & 72,42 & 72,94 & 73,05 & 72,42 & 73,27 \\
\hline $\mathrm{FeNe}$ & 1,50 & 3,38 & 2,70 & 0,27 & 3,07 & 0,37 & 1,69 & 2,01 & 1,83 & 1,88 & 1,84 & 1,81 & 1,71 & 1,85 & 1,85 & 1,60 & 1,79 & 1,64 & 1,73 & 1,76 & 1,74 & 1,25 & 1,93 \\
\hline Ks & 23,42 & 19,79 & 20,93 & 25,53 & 19,94 & 25,34 & 21,71 & 21,22 & 21,03 & 21,26 & 21,17 & 21,49 & 21,08 & 21,68 & 20,17 & 20,83 & 21,49 & 21,99 & 21,20 & 21,21 & 20,76 & 22,17 & 20,62 \\
\hline An & 0,06 & 0,0 & $0, \mathrm{c}$ & 0,14 & $0, \mathrm{c}$ & 0,00 & 0,41 & 0 & 0 , & 0,18 & 0,28 & 0,31 & 0,33 & 0,17 & 0,53 & 0,25 & 0,31 & 0,15 & 0,44 & 0,30 & 0,33 & 0,17 & 0,32 \\
\hline $\mathrm{Qz}$ & 2,62 & 4,78 & 3,46 & 1,66 & 4,84 & 2,01 & 3,39 & 3,63 & 4,24 & 4,50 & 3,95 & 4,42 & 4,05 & 3,91 & 4,80 & 4,63 & 3,79 & 4,43 & 4,21 & 3,79 & 4,12 & 3,99 & 3,86 \\
\hline
\end{tabular}




\begin{tabular}{|c|c|c|c|c|c|c|c|c|c|c|c|c|c|c|c|c|c|c|c|c|c|c|c|}
\hline $\begin{array}{l}\text { Unidade } \\
\text { Amostra }\end{array}$ & $\begin{array}{l}\text { NeS-I } \\
\text { MAIO60 }\end{array}$ & \begin{tabular}{|l|} 
BtHbIP \\
MAI092I
\end{tabular} & & & & & & & & & & & & \begin{tabular}{|l|} 
BtHblP \\
MAI102
\end{tabular} & & & & & & & & & \\
\hline Cristal & 26 & 27 & 28 & 29 & 29 & 30 & 31 & 32 & 32 & 33 & 33 & 34 & 34 & 35 & 36 & 37 & 38 & 39 & 40 & 41 & 41 & 42 & 43 \\
\hline Textura ${ }^{1}$ & b & $\mathrm{n}$ & $<\mathrm{kfl}$ & $b$ & $b$ & $n$ & $n$ & n & $b$ & $n$ & $\mathrm{~b}$ & $\mathrm{n}$ & ] & $\mathrm{n}$ & $\mathrm{n}$ & $n$ & $\mathrm{n}$ & $n$ & $\mathrm{n}$ & $\mathrm{n}$ & b & $n$ & $\mathrm{n}$ \\
\hline $\mathrm{SiO}_{2}$ & 43,74 & 45,16 & 45,00 & 44,17 & 44,63 & 44,52 & 44,42 & 44,63 & 44,30 & 44,08 & 44,68 & 44,87 & 44,20 & 45,44 & 45,61 & 44,76 & 45,45 & 44,56 & 45,67 & 45,22 & 44,42 & 45,62 & 46,19 \\
\hline $\mathrm{Al}_{2} \mathrm{O}_{3}$ & 33,90 & 33,04 & 33,77 & 33,41 & 33,23 & 33,46 & 33,35 & 33,14 & 33,52 & 33,66 & 33,16 & 32,82 & 33,10 & 32,76 & 32,64 & 33,02 & 32,93 & 33,18 & 32,80 & 32,61 & 33,23 & 32,71 & 32,32 \\
\hline $\mathrm{TiO}_{2}$ & & 0,01 & & & 0,02 & & 0,04 & 0,02 & & 0,07 & 0,01 & 0,02 & 0,03 & 0,03 & 0,04 & 0,01 & & & & 0,03 & & 0,03 & 0,01 \\
\hline $\mathrm{Fe}_{2} \mathrm{O}_{3}$ & 0,60 & 0,39 & 0,45 & 0,35 & 0,44 & 0,45 & 0,33 & 0,38 & 0,39 & 0,43 & 0,41 & 0,38 & 0,43 & 0,49 & 0,51 & 0,58 & 0,54 & 0,53 & 0,58 & 0,59 & 0,50 & 0,47 & 0,46 \\
\hline MnO & & 0,02 & & 0,01 & & & 0,00 & & & & & & & 0,00 & 0,00 & 0,00 & 0,00 & & 0,00 & 0,01 & & 0,01 & \\
\hline MgO & & & & 0,00 & & 0,00 & & 0,00 & 0,01 & & 0,03 & & 0,00 & & & 0,00 & 0,02 & 0,01 & 0,00 & & & 0,01 & \\
\hline $\mathrm{CaO}$ & 0,04 & 0,84 & 0,52 & 0,70 & 0,63 & 0,58 & 0,71 & 0,68 & 0,66 & 0,58 & 0,53 & 0,50 & 0,58 & 1,43 & 1,30 & 1,52 & 1,41 & 1,51 & 1,33 & 1,32 & 1,58 & 1,38 & 1,24 \\
\hline $\mathrm{Na}_{2} \mathrm{O}$ & 15,81 & 15,65 & 15,75 & 15,68 & 15,55 & 15,69 & 15,56 & 15,52 & 15,58 & 15,76 & 15,72 & 15,66 & 15,79 & 15,58 & 15,11 & 15,25 & 15,09 & 15,36 & 15,33 & 15,79 & 15,08 & 15,38 & 15,58 \\
\hline $\mathrm{K}_{2} \mathrm{O}$ & 6,42 & 5,07 & 5,40 & 5,53 & 5,48 & 5,52 & 5,48 & 5,40 & 5,52 & 5,66 & 5,53 & 5,38 & 5,51 & 4,48 & 4,17 & 4,69 & 4,46 & 4,78 & 4,22 & 4,39 & 4,63 & 4,22 & 4,06 \\
\hline SrO & 0,06 & 0,01 & 0,01 & 0,01 & 0,03 & 0,02 & 0,04 & 0,06 & 0,05 & 0,04 & 0,02 & & & 0,01 & 0,04 & 0,04 & 0,01 & & 0,04 & 0,00 & 0,06 & & \\
\hline BaO & 0,00 & & & & & & 0,07 & & 0,01 & 0,09 & 0,03 & 0,01 & 0,08 & 0,04 & 0,03 & 0,02 & & & & & 0,01 & & \\
\hline Total & 100,57 & 100,20 & 100,91 & 99,87 & 100,00 & 100,24 & 99,99 & 99,83 & 100,04 & 100,35 & 100,13 & 99,63 & 99,72 & 100,27 & 99,45 & 99,90 & 99,92 & 99,93 & 99,97 & 99,96 & 99,51 & 99,81 & 99,86 \\
\hline \multicolumn{24}{|c|}{ Número de cátions calculado na base de 32 oxigênios. } \\
\hline $\mathrm{Si}$ & 8,352 & 8,575 & 8,496 & 8,449 & 8,512 & 8,477 & 8,480 & 8,523 & 8,454 & 8,406 & 8,517 & 8,579 & 8,474 & 8,608 & 8,672 & 8,525 & 8,619 & 8,490 & 8,649 & 8,596 & 8,489 & 8,652 & 8,742 \\
\hline Al & 7,629 & 7,394 & 7,514 & 7,532 & 7,469 & 7,508 & 7,504 & 7,459 & 7,540 & 7,565 & 7,450 & 7,396 & 7,479 & 7,314 & 7,315 & 7,412 & 7,360 & 7,451 & 7,321 & 7,306 & 7,484 & 7,311 & 7,210 \\
\hline $\mathrm{Ti}$ & 0,000 & 0,002 & 0,000 & 0,000 & 0,002 & 0,000 & 0,006 & 0,003 & 0,000 & 0,010 & 0,002 & 0,003 & 0,004 & 0,005 & 0,006 & 0,001 & 0,000 & 0,000 & 0,000 & 0,004 & 0,000 & 0,004 & 0,001 \\
\hline $\mathrm{Fe}^{3+}$ & 0,086 & 0,056 & 0,065 & 0,050 & 0,063 & 0,064 & 0,047 & 0,055 & 0,056 & 0,061 & 0,059 & 0,054 & 0,062 & 0,070 & 0,073 & 0,083 & 0,078 & 0,076 & 0,082 & 0,084 & 0,072 & 0,067 & 0,066 \\
\hline$M n$ & 0,000 & 0,003 & 0,000 & 0,002 & 0,000 & 0,000 & 0,000 & 0,000 & 0,000 & 0,000 & 0,000 & 0,000 & 0,000 & 0,001 & 0,000 & 0,000 & 0,000 & 0,000 & 0,000 & 0,001 & 0,000 & 0,001 & 0,000 \\
\hline Mg & 0,000 & 0,000 & 0,000 & 0,001 & 0,000 & 0,001 & 0,000 & 0,001 & 0,002 & 0,000 & 0,009 & 0,000 & 0,001 & 0,000 & 0,000 & 0,001 & 0,006 & 0,003 & 0,001 & 0,000 & 0,000 & 0,002 & 0,000 \\
\hline $\mathrm{Ca}$ & 0,007 & 0,171 & 0,105 & 0,143 & 0,128 & 0,119 & 0,145 & 0,139 & 0,136 & 0,118 & 0,108 & 0,102 & 0,118 & 0,290 & 0,264 & 0,310 & 0,286 & 0,308 & 0,270 & 0,270 & 0,324 & 0,280 & 0,252 \\
\hline $\mathrm{Na}$ & 5,853 & 5,762 & 5,766 & 5,815 & 5,750 & 5,792 & 5,760 & 5,747 & 5,765 & 5,827 & 5,810 & 5,805 & 5,869 & 5,723 & 5,571 & 5,632 & 5,548 & 5,674 & 5,629 & 5,820 & 5,587 & 5,656 & 5,717 \\
\hline K & 1,564 & 1,228 & 1,301 & 1,349 & 1,333 & 1,341 & 1,335 & 1,316 & 1,344 & 1,377 & 1,345 & 1,312 & 1,347 & 1,083 & 1,011 & 1,140 & 1,079 & 1,162 & 1,019 & 1,065 & 1,129 & 1,021 & 0,980 \\
\hline $\mathrm{Sr}$ & 0,007 & 0,001 & 0,001 & 0,001 & 0,003 & 0,002 & 0,004 & 0,006 & 0,005 & 0,004 & 0,003 & 0,000 & 0,000 & 0,002 & 0,005 & 0,004 & 0,001 & 0,000 & 0,004 & 0,000 & 0,006 & 0,000 & 0,000 \\
\hline Ba & 0,000 & 0,000 & 0,000 & 0,000 & 0,000 & 0,000 & 0,005 & 0,000 & 0,001 & 0,007 & 0,002 & 0,001 & 0,006 & 0,003 & 0,002 & 0,002 & 0,000 & 0,000 & 0,000 & 0,000 & 0,001 & 0,000 & 0,000 \\
\hline Total & 23,499 & 23,193 & 23,247 & 23,343 & 23,261 & 23,304 & 23,285 & 23,248 & 23,302 & 23,374 & 23,304 & 23,252 & 23,361 & 23,098 & 22,919 & 23,111 & 22,976 & 23,164 & 22,974 & 23,146 & 23,091 & 22,993 & 22,968 \\
\hline$\overline{\mathrm{Ne}}$ & 72,40 & 71,60 & 72,07 & 72,05 & 71,47 & 71,95 & 71,64 & 71,48 & 71,73 & 72,29 & 72,05 & 72,10 & 72,50 & 70,79 & 70,09 & 69,77 & 69,45 & 70,17 & 70,42 & 71,73 & 69,62 & 70,64 & 71,29 \\
\hline $\mathrm{FeNe}$ & 1,64 & 1,08 & 1,25 & 0,97 & 1,22 & 1,23 & 0,91 & 1,06 & 1,07 & 1,17 & 1,14 & 1,04 & 1,19 & 1,33 & 1,42 & 1,60 & 1,51 & 1,45 & 1,59 & 1,61 & 1,39 & 1,30 & 1,28 \\
\hline Ks & 21,54 & 16,99 & 18,10 & 18,62 & 18,45 & 18,54 & 18,48 & 18,22 & 18,62 & 19,02 & 18,57 & 18,15 & 18,53 & 14,91 & 14,17 & 15,72 & 15,04 & 16,00 & 14,20 & 14,61 & 15,66 & 14,20 & 13,61 \\
\hline An & 0,18 & 4,17 & 2,56 & 3,47 & 3,12 & 2,90 & 3,52 & 3,38 & 3,31 & 2,86 & 2,62 & 2,47 & 2,86 & 7,03 & 6,51 & 7,53 & 7,02 & 7,47 & 6,62 & 6,51 & 7,89 & 6,84 & 6,14 \\
\hline$Q_{z}$ & 4,24 & 6,15 & 6,01 & 4,89 & 5,73 & 5,37 & 5,45 & 5,85 & 5,28 & 4,66 & 5,61 & 6,24 & 4,92 & 5,93 & 7,82 & 5,38 & 6,98 & 4,92 & 7,17 & 5,55 & 5,45 & 7,03 & 7,68 \\
\hline
\end{tabular}


ANEXO E - Tabela E.2 - Composição química de nefelinas de rochas do Maciço Alcalino de Itatiaia. Continua...

\begin{tabular}{|c|c|c|c|c|c|c|c|c|c|c|c|c|c|c|c|c|c|c|c|c|c|c|c|}
\hline $\begin{array}{l}\text { Unidade } \\
\text { Amostra }\end{array}$ & $\begin{array}{l}\text { BtHblP } \\
\text { MAl102 }\end{array}$ & MAl114 & & & & & & \begin{tabular}{|l|} 
HblP \\
MAl160
\end{tabular} & & & & & & & & & & \begin{tabular}{|l|} 
NeS-II \\
MAI166I
\end{tabular} & & & & & \\
\hline Cristal & 44 & 45 & 45 & 46 & 46 & 47 & 47 & 48 & 48 & 49 & 50 & 50 & 51 & 51 & 52 & 52 & 53 & 54 & 54 & 55 & 56 & 57 & 58 \\
\hline Textura $^{1}$ & $\mathrm{n}$ & $\mathrm{n}$ & b & $n$ & b & $\mathrm{n}$ & b & $n$ & $b$ & $n$ & $n$ & $b$ & $\mathrm{n}$ & b & $\mathrm{n}$ & $b$ & $<\mathrm{kfl} \mid$ & idio $n$ & idio b & idio & idion & idio $n$ & b \\
\hline $\mathrm{SiO}_{2}$ & 43,99 & 44,99 & 44,35 & 45,56 & 45,51 & 44,41 & 44,09 & 44,78 & 43,73 & 44,26 & 44,71 & 44,16 & 45,21 & 44,47 & 43,44 & 44,48 & 44,15 & 44,79 & 44,66 & 45,02 & 44,35 & 44,81 & 43,85 \\
\hline $\mathrm{Al}_{2} \mathrm{O}_{3}$ & 33,29 & 32,76 & 33,65 & 32,66 & 33,17 & 33,03 & 33,15 & 33,08 & 33,37 & 33,69 & 33,51 & 33,65 & 32,98 & 33,72 & 34,35 & 33,68 & 33,36 & 33,27 & 32,93 & 33,24 & 32,98 & 33,23 & 33,33 \\
\hline $\mathrm{TiO}_{2}$ & 0,01 & 0,01 & 0,03 & & & 0,01 & & & 0,03 & 0,05 & & 0,03 & 0,02 & & & & 0,00 & & & & & & 0,05 \\
\hline $\mathrm{Fe}_{2} \mathrm{O}_{3}$ & 0,52 & 0,42 & 0,39 & 0,47 & 0,54 & 0,46 & 0,44 & 0,36 & 0,30 & 0,35 & 0,30 & 0,25 & 0,54 & 0,35 & 0,07 & 0,38 & 0,32 & 0,58 & 0,59 & 0,58 & 0,50 & 0,64 & 0,43 \\
\hline no & 0,01 & & 0,01 & 0,01 & & 0,01 & & 0,01 & & 0,01 & & 0,00 & 0,00 & & & & 0,02 & 0,01 & 0,00 & & & & 0,01 \\
\hline MgO & & 0,00 & & 0,01 & 0,00 & & & & 0,00 & 0,01 & 0,03 & & 0,05 & 0,01 & 0,01 & & 0,01 & 0,01 & 0,00 & & 0,01 & & \\
\hline $\mathrm{CaO}$ & 1,66 & 1,31 & 1,52 & 1,24 & 1,36 & 1,50 & 1,60 & 1,00 & 1,15 & 1,23 & 0,87 & 0,87 & 0,93 & 1,04 & 1,12 & 1,00 & 0,99 & 0,38 & 0,36 & 0,39 & 0,43 & 0,41 & 0,43 \\
\hline $\mathrm{Na}_{2} \mathrm{O}$ & 15,40 & 15,30 & 14,90 & 14,63 & 15,19 & 15,37 & 15,16 & 15,62 & 15,45 & 15,39 & 15,53 & 15,80 & 15,57 & 15,48 & 15,43 & 15,42 & 15,58 & 15,77 & 15,81 & 15,91 & 15,86 & 15,64 & 15,68 \\
\hline $\mathrm{K}_{2} \mathrm{O}$ & 1 & 59 & 4,79 & 4,42 & 51 & 4,68 & 4,93 & 4,97 & 5,15 & 5,18 & 5,13 & 5,32 & 4,81 & 5,32 & 5,68 & 5,42 & 5,25 & 5,61 & 5,44 & 5,61 & 5,50 & 5,48 & 5,78 \\
\hline SrO & 0,01 & 0,03 & & 0,01 & 0,02 & 0,01 & & 0,03 & 0,06 & 0,02 & 0,03 & 0,01 & 0,02 & 0,03 & 0,04 & 0,02 & 0,08 & & 0,00 & 0,02 & 0,03 & 0,02 & \\
\hline $\mathrm{BaO}$ & & 0,00 & & & 0,02 & & & & & 0,02 & 0,07 & & 0,01 & & 0,02 & & 0,11 & & & & 0,02 & & 0,05 \\
\hline Total & 99,79 & 99,43 & 99,64 & 99,01 & 100,32 & 99,49 & 99,37 & 99,85 & 99,25 & 100,20 & 100,18 & 100,10 & 100,15 & 100,43 & 100,16 & 100,40 & 99,87 & 100,42 & 99,79 & 100,77 & 99,67 & 100,23 & 99,61 \\
\hline \multicolumn{24}{|c|}{ Número de cátions calculado na base de 32 oxigênios. } \\
\hline Si & 8,415 & 8,591 & 8,457 & 8,691 & 8,599 & 8,496 & 8,457 & 8,537 & 8,411 & 8,424 & 8,499 & 8,422 & 8,579 & 8,445 & 8,298 & 8,451 & 8,446 & 8,514 & 8,538 & 8,530 & 8,501 & 8,525 & 8,425 \\
\hline Al & 7,506 & 7,373 & 7,563 & 7,343 & 7,387 & 7,447 & 7,494 & 7,432 & 7,564 & 7,557 & 7,507 & 7,564 & 7,376 & 7,547 & 7,734 & 7,542 & 7,522 & 7,453 & 7,420 & 7,423 & 7,451 & 7,451 & 7,547 \\
\hline$\pi$ & 0,001 & 0,002 & 0,004 & 0,000 & 0,000 & 0,002 & 0,000 & 0,000 & 0,005 & 0,008 & 0,000 & 0,004 & 0,003 & 0,000 & 0,000 & 0,000 & 0,001 & 0,000 & 0,000 & 0,000 & 0,000 & 0,000 & 0,008 \\
\hline $\mathrm{Fe}^{3+}$ & 0,074 & 0,061 & 0,056 & 0,068 & 0,076 & 0,067 & 0,064 & 0,052 & 0,043 & 0,050 & 0,043 & 0,037 & 0,077 & 0,050 & 0,011 & 0,054 & 0,046 & 0,083 & 0,084 & 0,083 & 0,072 & 0,092 & 0,062 \\
\hline Mn & 01 & 0,000 & 0,001 & 0,001 & 0,000 & 0,001 & 0,000 & 0,001 & 0,000 & 0,002 & 0,000 & 0,001 & 0,000 & 0,000 & 0,000 & 0,000 & 0,003 & 0,002 & 0,000 & 0,000 & 0,000 & 0,000 & 0,002 \\
\hline g & 0,000 & 0,001 & 0,002 & 0,002 & 0,001 & 0,000 & 0,000 & 0,000 & 0,001 & 0,002 & 0,009 & 0,000 & 0,014 & 0,004 & 0,002 & 0,000 & 0,002 & 0,002 & 0,001 & 0,000 & 0,002 & 0,000 & 0,000 \\
\hline $\mathrm{Ca}$ & 0,340 & 0,268 & 0,311 & 0,253 & 0,275 & 0,307 & 0,329 & 0,205 & 0,237 & 0,250 & 0,176 & 0,178 & 0,190 & 0,212 & 0,229 & 0,203 & 0,202 & 0,078 & 0,073 & 0,078 & 0,087 & 0,083 & 0,088 \\
\hline $\mathrm{Na}$ & & 5,664 & 5,509 & 5,411 & 5,565 & 5,701 & & & 5,762 & 5,679 & 5,724 & 5,842 & 5,729 & 5,700 & 5 & 5,681 & 5,779 & 5,812 & 5,860 & 5,845 & 5,894 & 5,769 & 5,841 \\
\hline n & 98 & 1,118 & 1,165 & 1,076 & 1,087 & 1,142 & 1,206 & 1,209 & 1,264 & 1,258 & 1,244 & 1,294 & 1,164 & 1,289 & 34 & 1,314 & 1,281 & 1,360 & 1,327 & 1,356 & 1,345 & 1,330 & 1,417 \\
\hline Sr & 0,001 & 0,004 & 0,000 & 0,002 & 0,002 & 0,001 & 0,000 & 0,003 & 0,007 & 0,002 & 0,003 & 0,001 & 0,002 & 0,004 & 0,005 & 0,002 & 0,009 & 0,000 & 0,000 & 0,003 & 0,004 & 0,002 & 0,000 \\
\hline $\mathrm{Ba}$ & 0,000 & 0,000 & 0,000 & 0,000 & 0,002 & 0,000 & 0,000 & 0,000 & 0,000 & 0,001 & 0,005 & 0,000 & 0,001 & 0,000 & 0,001 & 0,000 & 0,008 & 0,000 & 0,000 & 0,000 & 0,001 & 0,000 & 0,004 \\
\hline Total & 23,249 & 23,082 & 23,067 & 22,847 & 22,995 & 23,166 & 23,187 & 23,212 & 23,293 & 23,233 & 23,210 & 23,344 & 23,137 & 23,250 & 23,379 & 23,248 & 23,299 & 23,304 & 23,304 & 23,317 & 23,357 & 23,253 & 23,392 \\
\hline 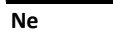 & 70,20 & 70,51 & 69,19 & 68,58 & 69,72 & 70,55 & 69,66 & 71,66 & 71,47 & 70,66 & 71,59 & 72,47 & 71,36 & 70,92 & 71,18 & 70,65 & 71,67 & 72,07 & 72,57 & 72,26 & 72,81 & 71,77 & 72,36 \\
\hline $\mathrm{Ne}$ & 1, & 1,17 & 1, & 1, & 1, & 8 & 1,22 & 9 & 0 & 0,97 & 0,83 & 70 & 1,49 & 97 & 20 & 1,05 & 0,89 & 1,60 & 1,62 & 1,60 & 1,37 & 1,78 & 1,19 \\
\hline Ks & 16,40 & 15,50 & 16,30 & 15,18 & 15,17 & 15,74 & 16,60 & 16,70 & 17,45 & 17,42 & 17,32 & 17,88 & 16,15 & 17,86 & 19,20 & 18,19 & 17,69 & 18,78 & 18,29 & 18,67 & 18,50 & 18,42 & 19,54 \\
\hline An & 8,19 & 6,54 & 7,6 & 6,27 & 6 , & 7, & 7,96 & 4,99 & 5, & 6, & 4 & 4,32 & 4, & 5,16 & 5, & 4,95 & 4,91 & 1,89 & 1,78 & 1,90 & 2,11 & 2,02 & 2,13 \\
\hline $\mathrm{uz}$ & 3,79 & 6,28 & 5,79 & 8,64 & 6,88 & 4,98 & 4,56 & 5,66 & 4,50 & 4,86 & 5,95 & 4,63 & 6,36 & 5,10 & 3,84 & 5,16 & 4,84 & 5,66 & 5,74 & 5,57 & 5,20 & 6,01 & 4,78 \\
\hline
\end{tabular}


ANEXO E - Tabela E.2 - Composição química de nefelinas de rochas do Maciço Alcalino de Itatiaia. Continua...

\begin{tabular}{|c|c|c|c|c|c|c|c|c|c|c|c|c|c|c|c|c|}
\hline $\begin{array}{l}\text { Unidade } \\
\text { Amostra }\end{array}$ & $\begin{array}{l}\text { NeS-II } \\
\text { MAI166I }\end{array}$ & & & & $\begin{array}{l}\text { BtAgtNeS } \\
\text { MAl199 }\end{array}$ & & & & & & & & & & & \\
\hline Cristal & 58 & 59 & 60 & 61 & 62 & 63 & 63 & 64 & 64 & 65 & 65 & 66 & 66 & 67 & 67 & 68 \\
\hline Textura ${ }^{1}$ & $n$ & idio & idio & idiol & $\mathrm{n}$ & $\mathrm{n}$ & b & $\mathrm{n}$ & b & b & $\mathrm{n}$ & $\mathrm{n}$ & b & $n$ & b & \\
\hline $\mathrm{SiO}_{2}$ & 42,70 & 44,81 & 44,67 & 44,76 & 45,17 & 46,05 & 44,23 & 45,26 & 44,85 & 45,93 & 45,75 & 45,90 & 45,71 & 46,49 & 45,82 & 45,82 \\
\hline $\mathrm{Al}_{2} \mathrm{O}_{3}$ & 34,33 & 33,22 & 33,01 & 33,11 & 31,46 & 30,92 & 31,07 & 31,42 & 31,37 & 31,24 & 31,42 & 31,29 & 31,78 & 30,74 & 31,45 & 30,99 \\
\hline $\mathrm{TiO}_{2}$ & 0,01 & & 0,01 & & 0,03 & & & & & & 0,09 & 0,01 & 0,01 & & 0,02 & \\
\hline $\mathrm{Fe}_{2} \mathrm{O}_{3}$ & 0,47 & 0,67 & 0,69 & 0,73 & 1,39 & 1,30 & 1,68 & 1,32 & 1,31 & 1,35 & 1,31 & 1,31 & 1,32 & 1,36 & 1,35 & 1,40 \\
\hline $\mathrm{MnO}$ & 0,01 & 0,01 & 0,02 & & 0,01 & 0,00 & 0,02 & 0,01 & & 0,00 & 0,00 & 0,01 & & 0,01 & 0,01 & \\
\hline MgO & & 0,01 & 0,00 & 0,01 & & 0,01 & & 0,02 & & 0,01 & 0,04 & 0,03 & & 0,01 & 0,00 & 0,01 \\
\hline $\mathrm{CaO}$ & 0,46 & 0,37 & 0,55 & 0,48 & 0,01 & 0,00 & 0,01 & & 0,01 & 0,00 & 0,02 & & 0,03 & 0,02 & 0,00 & 0,01 \\
\hline $\mathrm{Na}_{2} \mathrm{O}$ & 15,58 & 15,72 & 15,72 & 15,79 & 15,85 & 15,94 & 15,97 & 16,01 & 15,76 & 16,14 & 15,96 & 15,91 & 15,71 & 16,11 & 15,91 & 16,02 \\
\hline $\mathrm{K}_{2} \mathrm{O}$ & 6,63 & 5,54 & 5,31 & 5,42 & 4,72 & 4,27 & 5,06 & 4,43 & 5,18 & 4,37 & 4,48 & 4,50 & 4,84 & 4,20 & 4,62 & 4,56 \\
\hline SrO & & & 0,02 & 0,01 & & 0,05 & 0,04 & 0,02 & 0,03 & & 0,02 & 0,00 & 0,00 & 0,02 & 0,06 & 0,01 \\
\hline BaO & 0,01 & & & 0,04 & 0,03 & 0,04 & 0,04 & 0,07 & 0,00 & 0,00 & 0,05 & 0,03 & 0,03 & 0,02 & & 0,08 \\
\hline Total & 100,19 & 100,34 & 100,00 & 100,35 & 98,68 & 98,58 & 98,12 & 98,55 & 98,51 & 99,05 & 99,14 & 98,99 & 99,42 & 98,98 & 99,25 & 98,91 \\
\hline \multicolumn{17}{|c|}{ Número de cátions calculado na base de 32 oxigênios. } \\
\hline i & 8,208 & 8,521 & 8,522 & 8,516 & 8,708 & 8,852 & 8,627 & 8,726 & 8,685 & 8,798 & 8,761 & 8,797 & 8,735 & 8,897 & 8,769 & 8,805 \\
\hline 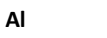 & 7,778 & 7,445 & 7,422 & 7,424 & 7,148 & 7,005 & 7,143 & 7,140 & 7,160 & 7,052 & 7,091 & 7,068 & 7,158 & 6,933 & 7,093 & 7,019 \\
\hline & 0,002 & 0,000 & 0,002 & 0,000 & 0,005 & 0,000 & 0,000 & 0,000 & 0,000 & 0,000 & 0,013 & 0,001 & 0,001 & 0,000 & 0,002 & 0,000 \\
\hline $\mathrm{Fe}^{3+}$ & 0,067 & 0,095 & 0,099 & 0,105 & 0,202 & 0,188 & 0,247 & 0,191 & 0,191 & 0,195 & 0,189 & 0,189 & 0,189 & 0,195 & 0,195 & 0,203 \\
\hline $\mathrm{Mn}$ & 0,001 & 0,001 & 0,003 & 0,000 & 0,002 & 0,001 & 0,003 & 0,001 & 0,000 & 0,000 & 0,000 & 0,001 & 0,000 & 0,002 & 0,002 & 0,000 \\
\hline $\mathrm{Mg}$ & 0,000 & 0,001 & 0,001 & 0,003 & & 0,003 & 0,000 & 0,005 & 0,000 & 0,003 & 0,011 & 0,008 & 0,000 & 0,004 & 0,001 & 0,004 \\
\hline $\mathrm{Ca}$ & 0,095 & 0,076 & 0,112 & 0,097 & 0,003 & 0,001 & 0,002 & 0,000 & 0,001 & 0,000 & 0,004 & 0,000 & 0,005 & 0,003 & 0,001 & 0,003 \\
\hline $\mathrm{Na}$ & 5,807 & 5,796 & 5,815 & 5,825 & 5,924 & 5,941 & 6,040 & 5,985 & 5,917 & 5,994 & 926 & 5,912 & 821 & 5,977 & 5,903 & 5,969 \\
\hline & 1,626 & 1,344 & 1,292 & 1,315 & 1,161 & 1,047 & 1,259 & 1,090 & 1,280 & 1,068 & 1,094 & 1,100 & 180 & 1,025 & 1,128 & 1,118 \\
\hline Sr & 000 & 0,000 & 0,003 & 0,002 & 0,000 & 0,005 & 0,005 & 0,002 & 0,004 & 0,000 & 0,002 & 0,000 & 0,000 & 0,002 & 0,007 & 0,001 \\
\hline Ва & 0,000 & 0,000 & 0,000 & 0,003 & 0,002 & 0,003 & 0,003 & 0,005 & 0,000 & 0,000 & 0,003 & 0,002 & 0,002 & 0,002 & 0,000 & 0,006 \\
\hline Total & 23,584 & 23,279 & 23,269 & 23,290 & 23,155 & 23,045 & 23,328 & 23,145 & 23,238 & 23,110 & 23,096 & 23,080 & 23,091 & 23,041 & 23,100 & 23,127 \\
\hline $\mathrm{Ne}$ & 71,52 & 71,94 & 72,00 & 72,04 & 73,06 & 73,48 & 73,17 & 73,99 & 72,47 & 73,88 & 73,38 & 73,15 & 72,18 & 73,61 & 72,96 & 73,26 \\
\hline $\mathrm{FeNe}$ & 1, & 1, & & 2,01 & & 3,60 & 4,63 & 3,67 & 3,63 & 3,72 & 3,63 & 3,62 & 3,64 & 3,72 & 3,73 & 3,86 \\
\hline Ks & 22,30 & 18,57 & 17,82 & 18,12 & 15,94 & 14,42 & 16,98 & 15,00 & 17,45 & 14,65 & 15,09 & 15,16 & 16,29 & 14,06 & 15,52 & 15,28 \\
\hline An & 2,3 & 1,8 & 2 & 2,36 & 0 , & 0 , & $0, c$ & 0,00 & 0,03 & 0,01 & 0,10 & 0,00 & 0,12 & 0,08 & 0,02 & 0,07 \\
\hline 12 & , & 81 & 5,51 & 5,47 & 08 & 3,48 & 5,16 & 7,35 & 6,42 & 7,74 & 7,80 & 8,07 & 7,76 & 8,52 & 7,77 & 7,54 \\
\hline
\end{tabular}

${ }^{1}$ - n, núcleo; b, borda; <, incluso em; idio, idiomórfico. 
ANEXO E - Tabela E.3 - Composição química de clinopiroxênios de rochas do Maciço Alcalino de Itatiaia. Continua...

\begin{tabular}{|c|c|c|c|c|c|c|c|c|c|c|c|c|c|c|c|c|c|c|c|c|c|c|c|c|c|}
\hline $\begin{array}{l}\text { Unidade } \\
\text { Amostra }\end{array}$ & $\begin{array}{l}\text { BtHbNeS } \\
\text { MAIO36 }\end{array}$ & & & & & & & & & & & & \begin{tabular}{|l|} 
NeS-I \\
MAI058I
\end{tabular} & & & & & & & & & & & & \\
\hline Cristal & & 1 & 2 & 2 & 3 & 4 & 5 & 1 & 2 & 3 & 4 & 5 & 6 & 6 & 7 & 7 & 8 & 9 & 9 & 10 & 11 & 11 & 12 & 13 & $\overline{13}$ \\
\hline Textura $^{1}$ & $<-\operatorname{anf} n$ & $<-a n f b$ & $<-\operatorname{anf} n$ & $<-\operatorname{anf} b$ & $<-\operatorname{anf} n$ & $<-\operatorname{anf} n$ & $<-\operatorname{anf} n$ & TÜ & TÜ & TÜ & TÜ & TÜ & $\mathrm{n}$ & b & $n$ & b & aci & n & b & aci & $n$ & b & aci & $n$ & \\
\hline $\mathrm{SiO}_{2}$ & 50,83 & 50,44 & 50,45 & 50,22 & 50,05 & 50,95 & 52,41 & 48,87 & 51,56 & 51,13 & 49,82 & 50,76 & 51,63 & 52,77 & 51,35 & 51,98 & 52,21 & 52,86 & 52,69 & 52,72 & 52,53 & 51,85 & 51,69 & 51,06 & 51,57 \\
\hline $\mathrm{TiO}_{2}$ & 1,50 & 1,03 & 1,29 & 1,72 & 1,59 & 1,51 & 0,90 & 1,33 & 0,40 & 0,90 & 1,24 & 1,02 & 1,17 & 4,08 & 0,45 & 2,66 & 2,83 & 1,11 & 2,97 & 0,86 & 0,75 & 3,30 & 3,34 & 1,42 & 4,22 \\
\hline $\mathrm{Al}_{2} \mathrm{O}_{3}$ & 3,01 & 3,43 & 4,02 & 4,06 & 4,07 & 3,01 & 2,04 & 3,87 & 2,20 & 1,97 & 2,64 & 2,23 & 0,97 & 1,26 & 0,76 & 0,87 & 0,96 & 1,15 & 1,09 & 1,35 & 0,98 & 1,20 & 1,25 & 1,01 & 0,93 \\
\hline $\mathrm{Cr}_{2} \mathrm{O}_{3}$ & 0,02 & & 0,02 & & 0,00 & & 0,01 & & & & & & & 0,02 & 0,01 & & & & & 0,00 & 0,02 & & 0,03 & 0,04 & \\
\hline $\mathrm{ZrO}_{2}$ & 0,11 & 0,09 & 0,08 & 0,01 & 0,08 & & 0,05 & 0,08 & 0,04 & 0,02 & 0,03 & 0,05 & 0,49 & 0,64 & 0,56 & 1,13 & 1,03 & 0,41 & 0,93 & 0,23 & 0,55 & 0,69 & 0,57 & 0,59 & 0,39 \\
\hline $\mathrm{FeO}_{\mathrm{T}}$ & 8,16 & 10,43 & 8,03 & 7,51 & 8,46 & 7,36 & 7,14 & 7,21 & 6,73 & 6,72 & 7,01 & 6,97 & 25,72 & 23,81 & 24,42 & 25,93 & 24,93 & 26,81 & 25,28 & 27,33 & 27,38 & 25,46 & 25,44 & 25,66 & 22,94 \\
\hline Mno & 1,11 & 1,11 & 0,91 & 0,85 & 0,91 & 0,95 & 1,06 & 0,81 & 0,91 & 1,10 & 1,10 & 0,99 & 1,72 & 2,39 & 2,28 & 1,41 & 1,89 & 0,90 & 1,55 & 0,60 & 1,05 & 1,28 & 1,27 & 1,57 & 2,82 \\
\hline $\mathrm{MgO}$ & 12,70 & 10,80 & 12,39 & 12,33 & 11,74 & 12,98 & 13,79 & 12,52 & 13,22 & 13,71 & 13,04 & 13,19 & 1,11 & 0,23 & 1,83 & 0,16 & 0,27 & 0,65 & 0,22 & 0,48 & 0,66 & 0,21 & 0,21 & 1,02 & 0,30 \\
\hline $\mathrm{CaO}$ & 21,64 & 21,82 & 21,99 & 22,60 & 22,18 & 22,20 & 22,12 & 21,73 & 23,13 & 21,74 & 21,53 & 22,07 & 6,17 & 1,60 & 9,12 & 1,17 & 1,60 & 1,06 & 1,35 & 0,68 & 1,20 & 2,12 & 2,32 & 5,52 & 1,39 \\
\hline $\mathrm{Na}_{2} \mathrm{O}$ & 1,30 & 1,33 & 1,08 & 1,10 & 1,39 & 1,12 & 1,15 & 1,20 & 0,94 & 1,09 & 1,13 & 1,15 & 9,48 & 11,86 & 7,90 & 12,75 & 12,36 & 12,81 & 12,27 & 12,95 & 12,65 & 12,00 & 11,84 & 10,04 & 12,92 \\
\hline $\mathrm{K}_{2} \mathrm{O}$ & 0,03 & & & 0,02 & & & 0,00 & 0,00 & 0,00 & 0,01 & 0,01 & 0,01 & 0,00 & 0,02 & 0,01 & & 0,01 & & 0,00 & 0,02 & 0,02 & 0,01 & & 0,00 & \\
\hline Soma & 100,42 & 100,48 & 100,25 & 100,42 & 100,47 & 100,07 & 100,68 & 97,63 & 99,14 & 98,39 & 97,55 & 98,43 & 98,47 & 98,68 & 98,69 & 98,07 & 98,08 & 97,76 & 98,36 & 97,23 & 97,79 & 98,12 & 97,95 & 97,94 & 97,47 \\
\hline $\mathrm{Fe}_{2} \mathrm{O}_{3}$ & 3,96 & 4,01 & 2,98 & 3,15 & 4,23 & 3,09 & 3,28 & 4,55 & 3,52 & 3,62 & 3,93 & 3,86 & 19,27 & 17,64 & 17,21 & 24,06 & 22,17 & 26,14 & 20,70 & 26,73 & 26,97 & 21,20 & 20,86 & 21,07 & 23,34 \\
\hline $\mathrm{FeO}$ & 4,60 & 6,82 & 5,35 & 4,68 & 4,66 & 4,58 & 4,19 & 3,11 & 3,56 & 3,46 & 3,48 & 3,50 & 8,38 & 7,93 & 8,94 & 4,28 & 4,99 & 3,29 & 6,65 & 3,28 & 3,12 & 6,39 & 6,67 & 6,71 & 1,94 \\
\hline Total & 100,69 & 100,80 & 100,45 & 100,72 & 100,81 & 100,38 & 100,95 & 98,08 & 99,49 & 98,76 & 97,95 & 98,82 & 99,91 & 99,79 & 99,85 & 99,35 & 99,28 & 99,98 & 99,50 & 99,67 & 99,92 & 99,55 & 99,44 & 99,42 & 99,43 \\
\hline \multicolumn{26}{|c|}{ Número de cátions calculado na base de 6 oxigênios. } \\
\hline $\mathrm{Si}$ & 1,882 & 1,885 & 1,872 & 1,859 & 1,856 & 1,889 & 1,925 & 1,853 & 1,924 & 1,919 & 1,891 & 1,908 & 1,995 & 2,017 & 1,993 & 1,987 & 1,998 & 2,006 & 2,013 & 2,008 & 1,999 & 1,988 & 1,987 & 1,977 & 1,972 \\
\hline Al & 0,118 & 0,115 & 0,128 & 0,141 & 0,144 & 0,111 & 0,075 & 0,147 & 0,076 & 0,081 & 0,109 & 0,092 & 0,005 & 0,000 & 0,007 & 0,013 & 0,002 & 0,000 & 0,000 & 0,000 & 0,001 & 0,012 & 0,013 & 0,023 & 0,028 \\
\hline $\mathrm{Fe}^{3+}$ & 0,000 & 0,000 & 0,000 & 0,000 & 0,000 & 0,000 & 0,000 & 0,000 & 0,000 & 0,000 & 0,000 & 0,000 & 0,000 & 0,000 & 0,000 & 0,000 & 0,000 & 0,000 & 0,000 & 0,000 & 0,000 & 0,000 & 0,000 & 0,000 & 0,000 \\
\hline Soma $T$ & 2,000 & 2,000 & 2,000 & 2,000 & 2,000 & 2,000 & 2,000 & 2,000 & 2,000 & 2,000 & 2,000 & 2,000 & 2,000 & 2,017 & 2,000 & 2,000 & 2,000 & 2,006 & 2,013 & 2,008 & 2,000 & 2,000 & 2,000 & 2,000 & 2,000 \\
\hline Al & 0,014 & 0,036 & 0,048 & 0,036 & 0,033 & 0,020 & 0,014 & 0,026 & 0,021 & 0,007 & 0,009 & 0,007 & 0,039 & 0,057 & 0,028 & 0,026 & 0,042 & 0,052 & 0,049 & 0,061 & 0,043 & 0,042 & 0,044 & 0,023 & 0,014 \\
\hline $\mathrm{Ti}$ & 0,042 & 0,029 & 0,036 & 0,048 & 0,044 & 0,042 & 0,025 & 0,037 & 0,011 & 0,025 & 0,035 & 0,028 & 0,033 & 0,114 & 0,013 & 0,074 & 0,079 & 0,031 & 0,083 & 0,024 & 0,021 & 0,092 & 0,093 & 040 & 0,118 \\
\hline $\mathrm{Fe}^{3+}$ & 0,110 & 0,113 & 0,083 & 0,088 & 0,118 & 0,086 & 0,091 & 0,129 & 0,098 & 0,101 & 0,111 & 0,108 & 0,560 & 0,507 & 0,503 & 0,692 & 0,638 & 0,747 & 0,595 & 0,766 & 0,772 & 0,612 & 0,604 & 0,614 & 0,672 \\
\hline $\mathrm{zr}$ & 0,002 & 0,002 & 0,001 & 0,000 & 0,001 & 0,000 & 0,001 & 0,001 & 0,001 & 0,000 & 0,001 & 0,001 & 0,009 & 0,012 & 0,011 & 0,021 & 0,019 & 0,008 & 0,017 & 0,004 & 0,010 & 0,013 & 0,011 & 0,011 & 0,007 \\
\hline $\mathrm{Mg}$ & 0,701 & 0,602 & 0,685 & 0,680 & 0,649 & 0,717 & 0,755 & 0,708 & 0,735 & 0,767 & 0,738 & 0,739 & 0,064 & 0,013 & 0,106 & 0,009 & 0,015 & 0,037 & 0,013 & 0,027 & 0,037 & 0,012 & 0,012 & 0,059 & 0,017 \\
\hline $\mathrm{Fe}^{2+}$ & 0,131 & 0,213 & 0,147 & 0,145 & 0,144 & 0,134 & 0,114 & 0,099 & 0,112 & 0,099 & 0,107 & 0,111 & 0,271 & 0,254 & 0,290 & 0,137 & 0,160 & 0,104 & 0,213 & 0,104 & 0,099 & 0,205 & 0,214 & 0,217 & 0,062 \\
\hline $\mathrm{Mn}$ & 0,000 & 0,006 & 0,000 & 0,003 & 0,009 & 0,000 & 0,000 & 0,000 & 0,022 & 0,000 & 0,000 & 0,005 & 0,024 & 0,043 & 0,050 & 0,041 & 0,047 & 0,022 & 0,030 & 0,013 & 0,017 & 0,024 & 0,023 & 0,036 & 0,091 \\
\hline Soma M1 & 1,000 & 1,000 & 1,000 & 1,000 & 1,000 & 1,000 & 1,000 & 1,000 & 1,000 & 1,000 & 1,000 & 1,000 & 1,000 & 1,000 & 1,000 & 1,000 & 1,000 & 1,000 & 1,000 & 1,000 & 1,000 & 1,000 & 1,000 & 1,000 & 0,981 \\
\hline $\mathrm{Mg}$ & & & & & & & & 0,000 & 0,000 & 0,000 & 0,000 & 0,000 & & & & & & & & & & & & & \\
\hline $\mathrm{Fe}^{2+}$ & 0,012 & 0,000 & 0,019 & 0,000 & 0,000 & 0,008 & 0,014 & 0,002 & 0,000 & 0,010 & 0,004 & 0,000 & 0,000 & 0,000 & 0,000 & 0,000 & 0,000 & 0,000 & 0,000 & 0,000 & 0,000 & 0,000 & 0,000 & 0,000 & 0,000 \\
\hline $\mathrm{Mn}$ & 0,035 & 0,030 & 0,029 & 0,024 & 0,019 & 0,030 & 0,033 & 0,026 & 0,007 & 0,035 & 0,035 & 0,026 & 0,033 & 0,034 & 0,025 & 0,005 & 0,014 & 0,007 & 0,020 & 0,006 & 0,016 & 0,017 & 0,019 & 0,015 & 0,000 \\
\hline $\mathrm{Ca}$ & 0,859 & 0,874 & 0,874 & 0,896 & 0,881 & 0,882 & 0,871 & 0,883 & 0,925 & 0,874 & 0,876 & 0,889 & 0,255 & 0,066 & 0,379 & 0,048 & 0,066 & 0,043 & 0,055 & 0,028 & 0,049 & 0,087 & 0,096 & 0,229 & 0,057 \\
\hline $\mathrm{Na}$ & 0,094 & 0,097 & 0,078 & 0,079 & 0,100 & 0,080 & 0,082 & 0,089 & 0,068 & 0,079 & 0,083 & 0,084 & 0,710 & 0,879 & 0,595 & 0,945 & 0,917 & 0,943 & 0,909 & 0,956 & 0,933 & 0,892 & 0,883 & 0,754 & 0,958 \\
\hline K & 0,002 & 0,000 & 0,000 & 0,001 & 0,000 & 0,000 & 0,000 & 0,000 & 0,000 & 0,001 & 0,000 & 0,000 & 0,000 & 0,001 & 0,000 & 0,000 & 0,000 & 0,000 & 0,000 & 0,001 & 0,001 & 0,001 & 0,000 & 0,000 & 0,000 \\
\hline Soma M2 & 1,000 & 1,000 & 1,000 & 1,000 & 1,000 & 1,000 & 1,00 & 0,999 & 1,000 & 1,000 & 0,999 & 1,000 & 0,999 & 0,980 & 0,999 & 0,998 & 0,998 & 0,993 & 0,984 & 0,991 & 0,999 & 0,997 & 0,997 & 0,998 & 1,015 \\
\hline Total & 4,000 & 4,000 & 4,000 & 4,000 & 4,000 & 4,000 & 4,000 & 3,999 & 4,000 & 4,000 & 3,999 & 4,000 & 3,999 & 3,997 & 3,999 & 3,998 & 3,998 & 3,999 & 3,998 & 3,999 & 3,999 & 3,997 & 3,997 & 3,998 & 3,996 \\
\hline \multicolumn{26}{|c|}{ Jadeite activity } \\
\hline $800^{\circ} \mathrm{C}$ & & & & & & & & 0,097 & 0,057 & 0,061 & 0,076 & 0,06 & & & & & & & & & & & & & \\
\hline $900^{\circ} \mathrm{C}$ & & & & & & & & 0,08 & 0,047 & 0,05 & 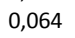 & , & & & & & & & & & & & & & \\
\hline \multicolumn{26}{|c|}{ Hednbergite activity } \\
\hline $800^{\circ} \mathrm{C}$ & & & & & & & & 0,092 & 0,115 & 0,103 & 0,108 & 0,114 & & & & & & & & & & & & & \\
\hline $900^{\circ} \mathrm{C}$ & & & & & & & & 0,098 & 0,12 & 0,109 & 0,113 & 0,118 & & & & & & & & & & & & & \\
\hline
\end{tabular}

$\frac{1}{1}$-n, núcleo; b, borda; <- sendo substituído por; -> substituindo; < incluso em; /, em contato com; aci, acicular; cav, em cavidade; idio, idiomórfico; ints, intersticial; poiq, poiquilítico 
ANEXO E - Tabela E.3 - Composição química de clinopiroxênios de rochas do Maciço Alcalino de Itatiaia. Continua..

\begin{tabular}{|c|c|c|c|c|c|c|c|c|c|c|c|c|c|c|c|c|c|c|c|c|c|c|c|c|c|}
\hline \begin{tabular}{l|} 
Unidade \\
Amostra
\end{tabular} & $\begin{array}{l}\text { NeS-I } \\
\text { MAI058I } \\
\end{array}$ & & & MAI060 & & & & & & & & & & & & & & & & & & & & & \\
\hline Cristal & 14 & 14 & 14 & & 15 & 16 & 16 & 16 & 17 & 17 & 17 & 18 & 18 & 18 & 19 & 19 & 20 & 20 & 20 & 21 & 21 & 21 & 21 & 21 & 21 \\
\hline Textura ${ }^{1}$ & $\mathrm{n}$ & $\mathrm{nb}$ & b & $<-\operatorname{anf} n$ & $<-\operatorname{anf} b$ & $<-\operatorname{anf} n$ & $<-\operatorname{anf} \mathrm{nb}$ & $<-\operatorname{anf} b$ & $<-\operatorname{anf} n$ & $<-a n f n b$ & $<$-anf b & $<-\operatorname{anf} n$ & $<$-anf nb & $<-a n f b$ & $<-\operatorname{anf} n$ & $<-a n f b$ & $<-\operatorname{anf} n$ & $<$-anf nb & $<-\operatorname{anf} b$ & $<-\operatorname{anf} n 1$ & $<-\operatorname{anfn} 2$ & $<-\operatorname{anf} n$ & $<-\operatorname{anf} n 4$ & $<-\operatorname{anf} n 5$ & $<$-anf n6 \\
\hline$\overline{\mathrm{SiO}_{2}}$ & 50,93 & 51,53 & 52,05 & 50,19 & 50,12 & 49,60 & 48,82 & 50,29 & 51,16 & 51,03 & 52,26 & 50,10 & 49,85 & 49,82 & 50,42 & 50,93 & 49,32 & 49,34 & 49,75 & 50,22 & 48,22 & 49,48 & 48,67 & 48,92 & 49,61 \\
\hline $\mathrm{TiO}_{2}$ & 0,77 & 3,62 & 3,43 & 0,66 & 0,29 & 0,93 & 0,43 & 0,26 & 0,19 & 0,13 & 0,09 & 0,77 & 0,72 & 0,30 & 0,70 & 0,43 & 1,01 & 0,71 & 0,40 & 0,73 & 1,10 & 0,85 & 1,14 & 0,95 & 1,00 \\
\hline $\mathrm{Al}_{2} \mathrm{O}_{3}$ & 0,68 & 1,16 & 0,90 & 2,55 & 1,36 & 3,17 & 1,69 & 1,33 & 0,93 & 0,95 & 1,08 & 2,70 & 2,61 & 1,44 & 2,32 & 1,38 & 3,07 & 2,86 & 1,40 & 2,62 & 3,84 & 2,97 & 3,58 & 3,56 & 3,18 \\
\hline $\mathrm{Cr}_{2} \mathrm{O}_{3}$ & & & 0,02 & & 0,00 & & 0,01 & 0,03 & & & & & 0,01 & & 0,01 & 0,02 & & & & & & 0,06 & & & \\
\hline $\mathrm{ZrO}_{2}$ & 1,26 & 0,58 & 0,64 & 0,09 & 0,07 & 0,16 & 0,08 & 0,08 & 0,17 & 0,18 & 0,11 & 0,12 & 0,11 & 0,12 & 0,13 & 0,09 & 0,14 & 0,15 & 0,08 & 0,04 & 0,24 & 0,23 & 0,21 & 0,23 & 0,14 \\
\hline $\mathrm{FeO}_{\mathrm{T}}$ & 25,49 & 25,65 & 24,86 & 13,21 & 19,67 & 13,33 & 19,89 & 19,67 & 23,17 & 25,77 & 28,82 & 13,37 & 13,92 & 19,21 & 12,39 & 15,19 & 13,13 & 15,18 & 20,07 & 12,60 & 14,07 & 13,26 & 13,94 & 13,66 & 12,67 \\
\hline Mno & 2,23 & 1,32 & 2,07 & 2,28 & 4,38 & 2,16 & 4,67 & 4,34 & 3,35 & 3,16 & 1,46 & 2,34 & 2,37 & 4,66 & 2,21 & 3,83 & 2,12 & 2,66 & 4,71 & 2,10 & 2,10 & 2,21 & 2,23 & 2,16 & 1,90 \\
\hline MgO & 1,02 & 0,28 & 0,28 & 8,81 & 3,58 & 8,69 & 3,45 & 3,59 & 2,13 & 0,51 & 0,08 & 8,61 & 8,30 & 3,68 & 9,27 & 6,61 & 8,65 & 7,39 & 3,20 & 9,13 & 7,99 & 8,76 & 7,95 & 8,24 & 9,09 \\
\hline $\mathrm{CaO}$ & 6,97 & 2,54 & 1,79 & 21,34 & 17,01 & 21,04 & 18,46 & 16,35 & 11,76 & 9,75 & 3,38 & 21,37 & 21,22 & 17,36 & 21,77 & 19,07 & 21,19 & 20,51 & 16,91 & 21,57 & 21,12 & 21,27 & 21,32 & 21,40 & 21,71 \\
\hline $\mathrm{Na}_{2} \mathrm{O}$ & 9,24 & 11,91 & 12,52 & 1,45 & 3,75 & 1,48 & 2,62 & 3,84 & 6,64 & 7,58 & 11,57 & 1,45 & 1,52 & 3,26 & 1,21 & 2,64 & 1,42 & 1,72 & 3,57 & 1,25 & 1,45 & 1,38 & 1,43 & 1,45 & 1,39 \\
\hline $\mathrm{K}_{2} \mathrm{O}$ & 0,02 & & 0,05 & 0,00 & 0,02 & & & 0,00 & 0,00 & 0,01 & 0,00 & & 0,01 & & 0,01 & 0,04 & 0,01 & 0,02 & & 0,01 & 0,02 & 0,02 & & 0,00 & 0,02 \\
\hline Soma & 98,62 & 98,59 & 98,60 & 100,58 & 100,25 & 100,55 & 100,12 & 99,79 & 99,50 & 99,07 & 98,86 & 100,83 & 100,63 & 99,85 & 100,43 & 100,23 & 100,06 & 100,54 & 100,10 & 100,27 & 100,15 & 100,49 & 100,46 & 100,57 & 100,71 \\
\hline $\mathrm{Fe}_{2} \mathrm{O}_{3}$ & 20,11 & 21,79 & 23,27 & 5,08 & 10,28 & 5,04 & 8,45 & 9,55 & 15,77 & 17,31 & 26,71 & 4,96 & 5,55 & 8,63 & 4,04 & 6,90 & 4,92 & 6,18 & 9,62 & 4,10 & 6,00 & 5,22 & 5,46 & 5,70 & 5,27 \\
\hline $\mathrm{FeO}$ & 7,39 & 6,05 & 3,92 & 8,64 & 10,42 & 8,79 & 12,29 & 11,08 & 8,98 & 10,19 & 4,79 & 8,90 & 8,93 & 11,44 & 8,76 & 8,98 & 8,70 & 9,62 & 11,42 & 8,92 & 8,67 & 8,57 & 9,03 & 8,53 & 7,92 \\
\hline Total & 99,37 & 100,19 & 100,28 & 101,00 & 101,21 & 100,90 & 100,87 & 100,64 & 100,91 & 100,62 & 101,42 & 101,21 & 101,07 & 100,60 & $.00,69$ & 100,81 & 100,41 & 101,01 & 100,98 & 100,64 & 100,51 & 100,72 & 100,80 & 100,91 & 101,10 \\
\hline \multicolumn{26}{|c|}{ Número de cátions calculado na base de 6 oxigênios. } \\
\hline Si & 1,976 & 1,969 & 1,979 & 1,903 & 1,947 & 1,881 & 1,919 & 1,962 & 1,980 & 1,992 & 1,988 & 1,897 & 1,895 & 1,949 & 1,912 & 1,953 & 880 & 1,886 & 1,945 & 1,907 & 844 & 1,881 & 857 & 1,860 & 1,874 \\
\hline Al & 0,024 & 0,031 & 0,021 & 0,097 & 0,053 & 0,119 & 0,078 & 0,038 & 0,020 & 0,008 & 0,012 & 0,103 & 0,105 & 0,051 & 0,088 & 0,047 & 0,120 & 0,114 & 0,055 & 0,093 & 0,156 & 0,119 & 0,143 & 0,140 & 0,126 \\
\hline $\mathrm{Fe}^{3+}$ & 0,000 & 0,000 & 0,000 & 0,000 & 0,000 & 0,000 & 0,003 & 0,000 & 0,000 & 0,000 & 0,000 & 0,000 & 0,000 & 0,000 & 0,000 & 0,000 & 0,000 & 0,000 & 0,000 & 0,000 & 0,000 & 0,000 & 0,000 & 0,000 & 0,000 \\
\hline Soma $T$ & 2,000 & 2,000 & 2,000 & 2,000 & 2,000 & 2,000 & 2,000 & 2,000 & 2,000 & 2,000 & 2,000 & 2,000 & 2,000 & 2,000 & 2,000 & 2,000 & 2,000 & 2,000 & 2,000 & 2,000 & 2,000 & 2,000 & 2,000 & 2,000 & 2,000 \\
\hline Al & 0,008 & 0,021 & 0,019 & 0,016 & 0,009 & 0,023 & 0,000 & 0,023 & 0,022 & 0,036 & 0,036 & 0,018 & 0,012 & 0,016 & 0,016 & 0,015 & 0,018 & 0,015 & 0,009 & 0,024 & 0,017 & 0,014 & 0,018 & 0,019 & 0,015 \\
\hline $\mathrm{Ti}$ & 0,022 & 0,101 & 0,096 & 0,018 & 0,008 & 0,026 & 0,012 & 0,007 & 0,005 & 0,004 & 0,003 & 0,021 & 0,020 & 0,008 & 0,019 & 0,012 & 0,028 & 0,020 & 0,011 & 0,020 & 0,031 & 0,024 & 0,032 & 0,026 & 0,028 \\
\hline $\mathrm{Fe}^{3+}$ & 0,587 & 0,626 & 0,666 & 0,145 & 0,301 & 0,144 & 0,247 & 0,280 & 0,459 & 0,509 & 0,764 & 0,141 & 0,159 & 0,254 & 0,115 & 0,199 & 0,141 & 0,178 & 0,283 & 0,117 & 0,173 & 0,149 & 0,157 & 0,163 & 0,150 \\
\hline $\mathrm{Zr}$ & 0,024 & 0,011 & 0,012 & 0,002 & 0,001 & 0,003 & 0,001 & 0,002 & 0,003 & 0,004 & 0,002 & 0,002 & 0,002 & 0,002 & 0,002 & 0,002 & 0,003 & 0,003 & 0,002 & 0,001 & 0,004 & 0,004 & 0,004 & 0,004 & 0,003 \\
\hline Mg & 0,059 & 0,016 & 0,016 & 0,498 & 0,207 & 0,491 & 0,202 & 0,209 & 0,123 & 0,030 & 0,004 & 0,486 & 0,470 & 0,215 & 0,524 & 0,378 & 0,492 & 0,421 & 0,186 & 0,517 & 0,455 & 0,496 & 0,452 & 0,467 & 0,512 \\
\hline $\mathrm{Fe}^{2+}$ & 0,240 & 0,193 & 0,125 & 0,274 & 0,338 & 0,279 & 0,404 & 0,361 & 0,291 & 0,333 & 0,152 & 0,282 & 0,284 & 0,375 & 0,278 & 0,288 & 0,277 & 0,308 & 0,373 & 0,283 & 0,277 & 0,272 & 0,288 & 0,271 & 0,250 \\
\hline $\mathrm{Mn}$ & 0,060 & 0,032 & 0,067 & 0,047 & 0,136 & 0,034 & 0,133 & 0,118 & 0,096 & 0,086 & 0,038 & 0,049 & 0,053 & 0,130 & 0,045 & 0,106 & 0,040 & 0,055 & 0,135 & 0,038 & 0,043 & 0,040 & 0,050 & 0,049 & 0,042 \\
\hline Soma M1 & 1,000 & 1,000 & 0,999 & 1,000 & 1,000 & 1,000 & 1,000 & 1,000 & 1,000 & 1,000 & 1,000 & 1,000 & 1,000 & 1,000 & 1,000 & 1,000 & 1,000 & 1,000 & 1,000 & 1,000 & 1,000 & 1,000 & 1,000 & 1,000 & 1,000 \\
\hline \multicolumn{26}{|l|}{ Mg } \\
\hline $\mathrm{Fe}^{2+}$ & 0,000 & 0,000 & 0,000 & 0,000 & 0,000 & 0,000 & 0,000 & 0,000 & 0,000 & 0,000 & 0,000 & 0,000 & 0,000 & 0,000 & 0,000 & 0,000 & 0,000 & 0,000 & 0,000 & 0,000 & 0,000 & 0,000 & 0,000 & 0,000 & 0,000 \\
\hline $\mathrm{Mn}$ & 0,013 & 0,011 & 0,000 & 0,026 & 0,008 & 0,036 & 0,022 & 0,026 & 0,014 & 0,018 & 0,009 & 0,026 & 0,023 & 0,024 & 0,026 & 0,018 & 0,028 & 0,031 & 0,021 & 0,030 & 0,026 & 0,031 & 0,022 & 0,021 & 0,018 \\
\hline $\mathrm{Ca}$ & 0,290 & 0,104 & 0,073 & 0,867 & 0,708 & 0,855 & 0,777 & 0,683 & 0,488 & 0,408 & 0,138 & 0,867 & 0,864 & 0,728 & 0,885 & 0,783 & 0,866 & 0,840 & 0,708 & 0,878 & 0,865 & 0,866 & 0,871 & 0,872 & 0,878 \\
\hline $\mathrm{Na}$ & 0,695 & 0,882 & 0,923 & 0,107 & 0,282 & 0,109 & 0,200 & 0,290 & 0,498 & 0,574 & 0,853 & 0,106 & 0,112 & 0,247 & 0,089 & 0,196 & 0,105 & 0,128 & 0,271 & 0,092 & 0,108 & 0,102 & 0,106 & 0,107 & 0,102 \\
\hline K & 0,001 & 0,000 & 0,002 & 0,000 & 0,001 & 0,000 & 0,000 & 0,000 & 0,000 & 0,000 & 0,000 & 0,000 & 0,000 & 0,000 & 0,000 & 0,002 & 0,000 & 0,001 & 0,000 & 0,001 & 0,001 & 0,001 & 0,000 & 0,000 & 0,001 \\
\hline Soma M2 & 0,999 & 0,997 & 0,998 & 1,000 & 1,000 & 0,999 & 0,999 & 1,000 & 1,000 & 1,000 & 1,000 & 1,000 & 1,000 & 1,000 & 1,000 & 1,000 & 0,999 & 0,999 & 0,999 & 1,000 & 0,999 & 0,999 & 0,999 & 0,999 & 1,000 \\
\hline Total & 3,999 & 3,997 & 3,998 & 4,000 & 4,000 & 3,999 & 3,999 & 4,000 & 4,000 & 4,000 & 4,000 & 4,000 & 4,000 & 4,000 & 4,000 & 4,000 & 3,999 & 3,999 & 3,999 & 4,000 & 3,999 & 3,999 & 3,999 & 3,999 & 4,000 \\
\hline \multicolumn{26}{|c|}{$\begin{array}{l}\text { Jadeite activity } \\
800^{\circ} \mathrm{C} \\
900^{\circ} \mathrm{C}\end{array}$} \\
\hline \multirow{2}{*}{\multicolumn{26}{|c|}{$\begin{array}{l}\text { Hednbergite activity } \\
800^{\circ} \mathrm{C}\end{array}$}} \\
\hline & & & & & & & & & & & & & & & & & & & & & & & & & \\
\hline $900^{\circ} \mathrm{C}$ & & & & & & & & & & & & & & & & & & & & & & & & & \\
\hline
\end{tabular}

\footnotetext{
${ }^{1}$-n, núcleo; b, borda; <- sendo substituído por; - > substituindo; < incluso em; /, em contato com; aci, acicular; cav, em cavidade; idio, idiomórfico; ints, intersticial; poiq, poiquilítico
} 
ANEXO E - Tabela E.3 - Composição química de clinopiroxênios de rochas do Maciço Alcalino de Itatiaia. Continua...

\begin{tabular}{|c|c|c|c|c|c|c|c|c|c|c|c|c|c|c|c|c|c|c|c|c|c|c|c|c|c|}
\hline $\begin{array}{l}\text { Unidade } \\
\text { Amostra }\end{array}$ & $\begin{array}{l}\text { NeS-I } \\
\text { MAI060 }\end{array}$ & & & & & & & & & & & \begin{tabular}{|l|} 
AegN \\
MAl090
\end{tabular} & & & & & & & & & & & & & \\
\hline Cristal & 21 & 21 & 21 & 22 & 22 & 22 & 1 & 2 & 3 & 4 & 5 & 23 & 23 & 23 & 24 & 24 & 24 & 25 & 25 & 25 & 26 & 26 & 26 & 27 & 27 \\
\hline Textura $^{1}$ & $<-\operatorname{anf} n 7$ & $<-\operatorname{anfn} n$ & $<$-anf b & $<-a n f n$ & $<-a n f n b$ & $<-a n f b$ & TÜ & TÜ & TÜ & TÜ & TÜ & /cav n & /cav b1 & /cav b2 & idion & idio nb & idio b & idion & idio nb & idio b & ints n & ints nb & ints b & ints $n$ & ints b \\
\hline$\overline{\mathrm{SiO}_{2}}$ & 49,35 & 49,34 & 49,22 & 50,45 & 50,71 & 52,85 & 49,29 & 49,20 & 49,38 & 49,21 & 49,80 & 51,56 & 52,04 & 52,26 & 51,86 & 51,61 & 51,66 & 51,68 & 51,88 & 52,12 & 51,29 & 52,24 & 52,41 & 52,12 & 52,42 \\
\hline $\mathrm{TiO}_{2}$ & 0,86 & 0,54 & 0,35 & 0,52 & 0,17 & 0,07 & 0,72 & 0,71 & 0,82 & 0,68 & 0,71 & 0,43 & 0,47 & 0,07 & 0,72 & 0,51 & 0,21 & 0,69 & 0,59 & 0,15 & 0,44 & 0,44 & 0,55 & 0,54 & 0,79 \\
\hline $\mathrm{Al}_{2} \mathrm{O}_{3}$ & 3,12 & 2,24 & 2,11 & 2,01 & 1,03 & 1,93 & 2,60 & 2,51 & 2,81 & 2,47 & 2,54 & 0,28 & 0,26 & 0,19 & 0,26 & 0,22 & 0,18 & 0,26 & 0,25 & 0,28 & 0,25 & 0,71 & 0,66 & 0,43 & 0,37 \\
\hline $\mathrm{Cr}_{2} \mathrm{O}_{3}$ & 0,01 & & & 0,01 & 0,03 & & & & & & & 0,01 & & 0,01 & 0,03 & & & & & 0,01 & 0,01 & & 0,03 & 0,02 & \\
\hline $\mathrm{ZrO}_{2}$ & 0,14 & 0,10 & 0,09 & 0,15 & 0,18 & 0,12 & 0,16 & 0,16 & 0,18 & 0,10 & 0,09 & 0,12 & 0,32 & & 0,55 & 0,15 & & 0,37 & 0,11 & 0,03 & 0,29 & 0,04 & 0,02 & & 0,01 \\
\hline $\mathrm{FeO}_{T}$ & 13,20 & 17,55 & 17,13 & 14,58 & 26,19 & 28,29 & 13,00 & 13,24 & 13,01 & 11,98 & 11,61 & 24,17 & 23,99 & 25,29 & 26,86 & 26,12 & 28,59 & 26,23 & 26,22 & 26,60 & 26,23 & 28,67 & 27,74 & 28,86 & 27,23 \\
\hline Mno & 2,14 & 3,64 & 3,62 & 2,68 & 3,87 & 0,92 & 2,31 & 2,36 & 2,29 & 2,07 & 2,06 & 3,70 & 3,90 & 2,70 & 3,02 & 4,26 & 2,83 & 3,14 & 2,81 & 1,78 & 3,28 & 1,09 & 1,03 & 0,97 & 1,51 \\
\hline $\mathrm{MgO}$ & 8,68 & 5,35 & 5,28 & 7,76 & 0,26 & 0,14 & 8,71 & 8,57 & 8,63 & 9,44 & 9,53 & 2,37 & 1,74 & 2,09 & 0,68 & 0,34 & 0,05 & 0,91 & 1,15 & 1,66 & 1,26 & 0,50 & 0,56 & 0,70 & 1,29 \\
\hline CaO & 21,52 & 19,47 & 19,95 & 20,20 & 11,02 & 2,62 & 21,45 & 21,31 & 21,44 & 21,87 & 21,65 & 9,33 & 7,79 & 5,84 & 4,26 & 4,66 & 3,68 & 5,20 & 4,91 & 4,59 & 6,16 & 2,20 & 2,07 & 2,50 & 3,16 \\
\hline $\mathrm{Na}_{2} \mathrm{O}$ & 1,44 & 1,92 & 1,93 & 2,12 & 6,81 & 11,67 & 1,57 & 1,60 & 1,55 & 1,34 & 1,41 & 7,41 & 8,15 & 9,80 & 10,33 & 10,20 & 10,65 & 9,91 & 10,19 & 10,56 & 9,34 & 11,95 & 11,81 & 11,81 & 11,16 \\
\hline $\mathrm{K}_{2} \mathrm{O}$ & & 0,01 & 0,02 & 0,00 & & & 0,01 & 0,00 & 0,00 & 0,00 & 0,01 & 0,01 & 0,00 & & 0,00 & & 0,03 & 0,00 & & 0,04 & 0,00 & 0,01 & & 0,03 & 0,04 \\
\hline Soma & 100,46 & 100,17 & 99,70 & 100,49 & 100,27 & 98,60 & 99,82 & 99,66 & 100,11 & 99,16 & 99,41 & 99,38 & 98,67 & 98,26 & 98,58 & 98,08 & 97,88 & 98,39 & 98,11 & 97,82 & 98,55 & 97,85 & 96,88 & 97,97 & 97,98 \\
\hline $\mathrm{Fe}_{2} \mathrm{O}_{3}$ & 5,73 & 5,60 & 6,10 & 6,52 & 16,39 & 24,60 & 6,63 & 6,74 & 6,09 & 6,25 & 5,29 & 17,40 & 16,99 & 23,14 & 22,53 & 23,05 & 24,73 & 22,05 & 23,03 & 24,82 & 22,13 & 26,97 & 24,97 & 27,21 & 24,56 \\
\hline $\mathrm{FeO}$ & 8,05 & 12,51 & 11,64 & 8,72 & 11,45 & 6,16 & 7,03 & 7,18 & 7,53 & 6,35 & 6,85 & 8,52 & 8,70 & 4,47 & 6,59 & 5,38 & 6,34 & 6,39 & 5,49 & 4,27 & 6,31 & 4,41 & 5,28 & 4,38 & 5,13 \\
\hline Total & 100,88 & 100,63 & 100,22 & 100,98 & 101,70 & 100,95 & 100,49 & 100,34 & 100,72 & 99,78 & 99,94 & 101,00 & 100,05 & 100,56 & 100,25 & 100,24 & 100,36 & 100,24 & 100,31 & 100,26 & 100,47 & 100,52 & 99,33 & 100,69 & 100,43 \\
\hline \multicolumn{26}{|c|}{ Número de cátions calculado na base de 6 oxigênios. } \\
\hline $\mathrm{Si}$ & 1,873 & 1,920 & 1,922 & 1,921 & 1,975 & 2,007 & 1,881 & 1,882 & 1,880 & 1,882 & 1,898 & 1,992 & 2,022 & 2,003 & 2,002 & 2,003 & 2,005 & 1,999 & 2,001 & 2,000 & 1,985 & 1,997 & 2,023 & 1,992 & 2,006 \\
\hline Al & 0,127 & 0,080 & 0,078 & 0,079 & 0,025 & 0,000 & 0,117 & 0,113 & 0,120 & 0,111 & 0,102 & 0,008 & 0,000 & 0,000 & 0,000 & 0,000 & 0,000 & 0,001 & 0,000 & 0,000 & 0,011 & 0,003 & 0,000 & 0,008 & 0,000 \\
\hline $\mathrm{Fe}^{3+}$ & 0,000 & 0,000 & 0,000 & 0,000 & 0,000 & 0,000 & 0,002 & 0,005 & 0,000 & 0,006 & 0,000 & 0,000 & 0,000 & 0,000 & 0,000 & 0,000 & 0,000 & 0,000 & 0,000 & 0,000 & 0,004 & 0,000 & 0,000 & 0,000 & 0,000 \\
\hline Soma $T$ & 2,000 & 2,000 & 2,000 & 2,000 & 2,000 & 2,007 & 2,000 & 2,000 & 2,000 & 2,000 & 2,000 & 2,000 & 2,022 & 2,003 & 2,002 & 2,003 & 2,005 & 2,000 & 2,001 & 2,000 & 2,000 & 2,000 & 2,023 & 2,000 & 2,006 \\
\hline Al & 0,013 & 0,023 & 0,019 & 0,011 & 0,022 & 0,086 & 0,000 & 0,000 & 0,006 & 0,000 & 0,012 & 0,005 & 0,012 & 0,009 & 0,012 & 0,010 & 0,008 & 0,011 & 0,011 & 0,012 & 0,000 & 0,029 & 0,030 & 0,012 & 0,017 \\
\hline $\mathrm{Ti}$ & 0,024 & 0,015 & 0,010 & 0,015 & 0,005 & 0,002 & 0,020 & 0,020 & 0,023 & 0,019 & 0,020 & 0,012 & 0,013 & 0,002 & 0,020 & 0,014 & 0,006 & 0,019 & 0,016 & 0,004 & 0,012 & 0,012 & 0,015 & 0,015 & 0,022 \\
\hline $\mathrm{Fe}^{3+}$ & 0,164 & 0,164 & 0,179 & 0,187 & 0,480 & 0,703 & 0,185 & 0,186 & 0,172 & 0,172 & 0,150 & 0,506 & 0,497 & 0,667 & 0,654 & 0,673 & 0,722 & 0,642 & 0,668 & 0,717 & 0,641 & 0,776 & 0,725 & 0,783 & 0,707 \\
\hline $\mathrm{Zr}$ & 0,003 & 0,002 & 0,002 & 0,003 & 0,003 & 0,002 & 0,003 & 0,003 & 0,003 & 0,002 & 0,002 & 0,002 & 0,006 & 0,000 & 0,010 & 0,003 & 0,000 & 0,007 & 0,002 & 0,001 & 0,005 & 0,001 & 0,000 & 0,000 & 0,000 \\
\hline $\mathrm{Mg}$ & 0,491 & 0,310 & 0,307 & 0,440 & 0,015 & 0,008 & 0,495 & 0,489 & 0,490 & 0,538 & 0,541 & 0,137 & 0,101 & 0,119 & 0,039 & 0,020 & 0,003 & 0,053 & 0,066 & 0,095 & 0,073 & 0,029 & 0,032 & 0,040 & 0,074 \\
\hline $\mathrm{Fe}^{2+}$ & 0,255 & 0,407 & 0,380 & 0,277 & 0,373 & 0,196 & 0,227 & 0,233 & 0,242 & 0,205 & 0,220 & 0,275 & 0,283 & 0,143 & 0,213 & 0,175 & 0,206 & 0,207 & 0,177 & 0,137 & 0,204 & 0,141 & 0,170 & 0,140 & 0,164 \\
\hline $\mathrm{Mn}$ & 0,050 & 0,078 & 0,102 & 0,067 & 0,102 & 0,003 & 0,069 & 0,069 & 0,064 & 0,064 & 0,056 & 0,063 & 0,089 & 0,059 & 0,051 & 0,105 & 0,055 & 0,062 & 0,058 & 0,034 & 0,064 & 0,013 & 0,027 & 0,011 & 0,016 \\
\hline Soma M1 & 1,000 & 1,000 & 1,000 & 1,000 & 1,000 & 1,000 & 1,000 & 1,000 & 1,000 & 1,000 & 1,000 & 1,000 & 1,000 & 1,000 & 1,000 & 1,000 & 1,000 & 1,000 & 1,000 & 1,000 & 1,000 & 1,000 & 1,000 & 1,000 & 1,000 \\
\hline $\mathrm{Mg}$ & & & & & & & 0,000 & 0,000 & 0,000 & 0,000 & 0,000 & & & & & & & & & & & & & & \\
\hline $\mathrm{Fe}^{2+}$ & 0,000 & 0,000 & 0,000 & 0,000 & 0,000 & 0,000 & 0,000 & 0,000 & 0,000 & 0,000 & 0,000 & 0,000 & 0,000 & 0,000 & 0,000 & 0,000 & 0,000 & 0,000 & 0,000 & 0,000 & 0,000 & 0,000 & 0,000 & 0,000 & 0,000 \\
\hline$M n$ & 0,018 & 0,042 & 0,017 & 0,019 & 0,026 & 0,026 & 0,006 & 0,007 & 0,010 & 0,003 & 0,011 & 0,058 & 0,040 & 0,028 & 0,047 & 0,035 & 0,038 & 0,040 & 0,034 & 0,024 & 0,043 & 0,023 & 0,007 & 0,021 & 0,033 \\
\hline $\mathrm{Ca}$ & 0,875 & 0,812 & 0,835 & 0,824 & 0,460 & 0,107 & 0,877 & 0,873 & 0,875 & 0,897 & 0,884 & 0,386 & 0,324 & 0,240 & 0,176 & 0,194 & 0,153 & 0,215 & 0,203 & 0,189 & 0,255 & 0,090 & 0,086 & 0,102 & 0,130 \\
\hline $\mathrm{Na}$ & 0,106 & 0,145 & 0,146 & 0,156 & 0,514 & 0,859 & 0,116 & 0,119 & 0,114 & 0,099 & 0,104 & 0,555 & 0,614 & 0,728 & 0,773 & 0,768 & 0,802 & 0,743 & 0,762 & 0,786 & 0,701 & 0,886 & 0,884 & 0,875 & 0,828 \\
\hline $\mathrm{K}$ & 0,000 & 0,001 & 0,001 & 0,000 & 0,000 & 0,000 & 0,000 & 0,000 & 0,000 & 0,000 & 0,001 & 0,000 & 0,000 & 0,000 & 0,000 & 0,000 & 0,002 & 0,000 & 0,000 & 0,002 & 0,000 & 0,001 & 0,000 & 0,001 & 0,002 \\
\hline Soma M2 & 0,999 & 0,999 & 0,999 & 1,000 & 1,000 & 0,993 & 0,999 & 0,999 & 0,999 & 0,999 & 0,999 & 1,000 & 0,978 & 0,997 & 0,997 & 0,996 & 0,994 & 0,999 & 0,999 & 1,000 & 0,999 & 1,000 & 0,976 & 1,000 & 0,993 \\
\hline Total & 3,999 & 3,999 & 3,999 & 4,000 & 4,000 & 4,000 & 3,999 & 3,999 & 3,999 & 3,999 & 3,999 & 4,000 & 3,999 & 4,000 & 3,999 & 3,999 & 4,000 & 3,999 & 3,999 & 4,000 & 3,999 & 4,000 & 3,999 & 4,000 & 3,999 \\
\hline \multicolumn{26}{|c|}{ Jadeite activity } \\
\hline $800^{\circ} \mathrm{C}$ & & & & & & & 0,079 & 0,078 & 0,08 & 0,069 & 0,07 & & & & & & & & & & & & & & \\
\hline $900^{\circ} \mathrm{C}$ & & & & & & & 0,06 & 0,067 & 0,07 & & & & & & & & & & & & & & & & \\
\hline \multicolumn{26}{|c|}{ Hednbergite activity } \\
\hline $800^{\circ} \mathrm{C}$ & & & & & & & 0,27 & 0,281 & 0,291 & 0,238 & 0,261 & & & & & & & & & & & & & & \\
\hline $900^{\circ} \mathrm{C}$ & & & & & & & 0,273 & 0,283 & 0,294 & 0,241 & 263 & & & & & & & & & & & & & & \\
\hline
\end{tabular}

$\frac{1}{1}$ - n, núcleo; b, borda; <- sendo substituído por; -> substituindo; < incluso em; /, em contato com; aci, acicular; cav, em cavidade; idio, idiomórfico; ints, intersticial; poiq, poiquilítico 
ANEXO E - Tabela E.3 - Composição química de clinopiroxênios de rochas do Maciço Alcalino de Itatiaia. Continua..

\begin{tabular}{|c|c|c|c|c|c|c|c|c|c|c|c|c|c|c|c|c|c|c|c|c|c|c|c|c|c|}
\hline $\begin{array}{l}\text { Unidade } \\
\text { Amostra }\end{array}$ & $\begin{array}{l}\text { AegN } \\
\text { MAl090 }\end{array}$ & & & \begin{tabular}{|l|l|} 
BtHblP \\
MAI092I \\
\end{tabular} & & & & & & & & & & & & & & & & & $\begin{array}{l}\mathrm{N}-\mathrm{I} \\
\text { MAI097B }\end{array}$ & & & & \\
\hline Cristal & 28 & 28 & 29 & 30 & 30 & 31 & 31 & 31 & 32 & 33 & 34 & 34 & 35 & 35 & 1 & 2 & 3 & 4 & 5 & 6 & 36 & 37 & 37 & 38 & 38 \\
\hline Textura ${ }^{1}$ & $\mathrm{n}$ & b & b & $<-\operatorname{anf} n$ & $<-$ anf b & $<-a n f n$ & $<-$ anf b & $<-a n f b b$ & $<-\operatorname{anf} n$ & $<-\operatorname{anf} n$ & $<-\operatorname{anf} n$ & $<-$ anf b & $<-\operatorname{anf} n$ & $<-$ anf b & TÜ & TÜ & TÜ & TÜ & TÜ & Tü| & /cav & $\mathrm{n}$ & $\mathrm{b}$ & $\rightarrow \operatorname{ann} n$ & $\rightarrow$ anf b \\
\hline$\overline{\mathrm{SiO}_{2}}$ & 51,35 & 52,36 & 52,53 & 50,50 & 50,54 & 52,49 & 51,75 & 50,14 & 51,66 & 51,47 & 51,60 & 51,16 & 51,68 & 49,71 & 49,66 & 50,28 & 50,68 & 50,66 & 51,19 & 50,43 & 53,07 & 53,59 & 51,71 & 53,61 & 53,17 \\
\hline $\mathrm{TiO}_{2}$ & 0,46 & 1,01 & 1,16 & 1,30 & 1,32 & 0,70 & 1,03 & 1,09 & 1,19 & 1,16 & 1,14 & 0,69 & 1,09 & 1,13 & 1,22 & 1,15 & 1,23 & 1,24 & 0,68 & 1,01 & 0,41 & 0,20 & 0,53 & 0,12 & 0,23 \\
\hline $\mathrm{Al}_{2} \mathrm{O}_{3}$ & 0,23 & 0,25 & 0,48 & 3,52 & 3,17 & 1,27 & 2,43 & 3,19 & 2,96 & 2,79 & 2,75 & 2,93 & 2,68 & 3,57 & 2,65 & 2,70 & 2,83 & 3,11 & 1,26 & 2,52 & 0,25 & 0,48 & 1,49 & 0,38 & 0,37 \\
\hline $\mathrm{Cr}_{2} \mathrm{O}_{3}$ & 0,03 & & & & & 0,06 & & & 0,02 & & & 0,01 & 0,01 & & & & & & & & 0,01 & & 0,02 & 0,03 & \\
\hline $\mathrm{ZrO}_{2}$ & 0,20 & 0,27 & 0,13 & 0,01 & 0,02 & 0,03 & & 0,01 & 0,00 & & 0,05 & 0,08 & & 0,06 & 0,04 & 0,04 & 0,00 & 0,01 & 0,07 & 0,00 & 0,02 & 0,04 & 0,02 & 0,05 & 0,02 \\
\hline $\mathrm{FeO}_{T}$ & 24,52 & 26,78 & 25,89 & 7,13 & 8,52 & 8,16 & 7,18 & 9,92 & 6,61 & 7,26 & 7,05 & 9,90 & 7,14 & 11,02 & 7,64 & 6,94 & 6,26 & 6,41 & 7,11 & 6,79 & 26,06 & 9,98 & 9,45 & 10,55 & 9,94 \\
\hline MnO & 3,68 & 2,25 & 2,86 & 0,78 & 0,92 & 1,46 & 0,99 & 1,03 & 0,92 & 0,84 & 0,78 & 1,12 & 0,78 & 1,10 & 0,95 & 0,74 & 0,83 & 0,82 & 1,42 & 0,79 & 0,62 & 2,46 & 1,88 & 2,82 & 2,74 \\
\hline MgO & 1,79 & 0,68 & 0,97 & 13,96 & 12,36 & 13,13 & 14,11 & 11,42 & 14,13 & 14,27 & 14,43 & 11,42 & 13,69 & 10,47 & 13,24 & 14,86 & 14,09 & 13,84 & 13,37 & 14,19 & 2,32 & 11,99 & 12,83 & 12,07 & 12,51 \\
\hline $\mathrm{CaO}$ & 7,93 & 2,89 & 4,69 & 21,54 & 22,16 & 21,90 & 21,55 & 22,27 & 21,34 & 21,38 & 21,70 & 22,31 & 22,31 & 22,02 & 21,42 & 21,91 & 22,03 & 22,16 & 21,21 & 22,67 & 4,60 & 20,34 & 20,80 & 19,72 & 19,91 \\
\hline $\mathrm{Na}_{2} \mathrm{O}$ & 8,25 & 11,25 & 9,91 & 1,32 & 0,94 & 1,01 & 0,95 & 1,02 & 1,48 & 0,72 & 0,83 & 1,17 & 0,79 & 1,30 & 1,38 & 0,70 & 1,38 & 1,40 & 1,14 & 0,75 & 10,53 & 1,32 & 1,05 & 1,46 & 1,33 \\
\hline $\mathrm{K}_{2} \mathrm{O}$ & 0,01 & 0,04 & & 0,00 & 0,06 & & 0,01 & 0,03 & 0,05 & & & & 0,01 & 0,03 & 0,01 & 0,00 & 0,01 & 0,00 & 0,01 & 0,02 & & 0,01 & 0,04 & & 0,09 \\
\hline Soma & 98,44 & 97,78 & 98,62 & 100,06 & 100,02 & 100,20 & 99,99 & 100,12 & 100,36 & 99,89 & 100,34 & 100,80 & 100,17 & 100,41 & 98,21 & 99,31 & 99,34 & 99,66 & 97,45 & 99,17 & 97,89 & 100,40 & 99,81 & 100,81 & 100,31 \\
\hline $\mathrm{Fe}_{2} \mathrm{O}_{3}$ & 18,98 & 23,57 & 19,58 & 5,44 & 3,08 & 2,61 & 2,85 & 4,14 & 4,65 & 1,87 & 2,69 & 3,90 & 2,00 & 5,11 & 6,21 & 4,81 & 5,72 & 5,66 & 3,33 & 4,74 & 22,74 & 1,96 & 3,89 & 3,00 & 3,47 \\
\hline $\mathrm{FeO}$ & 7,44 & 5,57 & 8,27 & 2,23 & 5,75 & 5,81 & 4,61 & 6,20 & 2,43 & 5,58 & 4,63 & 6,39 & 5,34 & 6,42 & 2,05 & 2,61 & 1,11 & 1,32 & 4,12 & 2,52 & 5,60 & 8,22 & 5,95 & 7,85 & 6,81 \\
\hline Total & 100,12 & 99,87 & 100,45 & 100,60 & 100,30 & 100,38 & 100,28 & 100,53 & 100,80 & 100,08 & $.00,55$ & 101,09 & 100,37 & 100,86 & 98,83 & 99,79 & 99,91 & 100,22 & 97,78 & 99,64 & $.00,14$ & 100,56 & 100,16 & 101,03 & 100,64 \\
\hline \multicolumn{26}{|c|}{ Número de cátions calculado na base de 6 oxigênios. } \\
\hline Si & 1,997 & 2,017 & 2,024 & 1,858 & 1,885 & 1,952 & 1,913 & 1,878 & 1,892 & 1,906 & 1,900 & 1,902 & 912 & 1,863 & 869 & 1,866 & 874 & 1,869 & 948 & 1,878 & ,025 & 2,004 & 936 & 1,998 & 1,986 \\
\hline Al & 0,003 & 0,000 & 0,000 & 0,142 & 0,115 & 0,048 & 0,087 & 0,122 & 0,108 & 0,094 & 0,100 & 0,098 & 0,088 & 0,137 & 0,118 & 0,118 & 0,123 & 0,131 & 0,052 & 0,111 & 0,000 & 0,000 & 0,064 & 0,002 & 0,014 \\
\hline $\mathrm{Fe}^{3+}$ & 0,000 & 0,000 & 0,000 & 0,000 & 0,000 & 0,000 & 0,000 & 0,000 & 0,000 & 0,000 & 0,000 & 0,000 & 0,000 & 0,000 & 0,014 & 0,015 & 0,003 & 0,000 & 0,000 & 0,012 & 0,000 & 0,000 & 0,000 & 0,000 & 0,000 \\
\hline Soma $T$ & 2,000 & 2,017 & 2,024 & 2,000 & 2,000 & 2,000 & 2,000 & 2,000 & 2,000 & 2,000 & 2,000 & 2,000 & 2,000 & 2,000 & 2,000 & 2,000 & 2,000 & 2,000 & 2,000 & 2,000 & 2,025 & 2,004 & 2,000 & 2,000 & 2,000 \\
\hline Al & 0,007 & 0,012 & 0,022 & 0,011 & 0,024 & 0,007 & 0,019 & 0,019 & 0,020 & 0,028 & 0,019 & 0,030 & 0,028 & 0,021 & 0,000 & 0,000 & 0,000 & 0,004 & 0,005 & 0,000 & 0,011 & 0,021 & 0,001 & 0,015 & 0,002 \\
\hline $\mathrm{Ti}$ & 0,013 & 0,028 & 0,032 & 0,036 & 0,037 & 0,020 & 0,029 & 0,030 & 0,033 & 0,032 & 0,032 & 0,019 & 0,030 & 0,031 & 0,034 & 0,032 & 0,034 & 0,035 & 0,019 & 0,028 & 0,011 & 0,006 & 0,015 & 0,003 & 0,006 \\
\hline $\mathrm{Fe}^{3+}$ & 0,555 & 0,683 & 0,568 & 0,151 & 0,086 & 0,073 & 0,079 & 0,117 & 0,128 & 0,052 & 0,075 & 0,109 & 0,056 & 0,144 & 0,160 & 0,118 & 0,154 & 0,155 & 0,092 & 0,120 & 0,653 & 0,055 & 0,110 & 0,084 & 0,098 \\
\hline $\mathrm{Zr}$ & 0,004 & 0,005 & 0,002 & 0,000 & 0,000 & 0,000 & 0,000 & 0,000 & 0,000 & 0,000 & 0,001 & 0,001 & 0,000 & 0,001 & 0,001 & 0,001 & 0,000 & 0,000 & 0,001 & 0,000 & 0,000 & 0,001 & 0,000 & 0,001 & 0,000 \\
\hline $\mathrm{Mg}$ & 0,104 & 0,039 & 0,056 & 0,766 & 0,687 & 0,728 & 0,778 & 0,638 & 0,772 & 0,788 & 0,792 & 0,633 & 0,755 & 0,585 & 0,743 & 0,822 & 0,777 & 0,761 & 0,759 & 0,788 & 0,132 & 0,668 & 0,716 & 0,671 & 0,697 \\
\hline $\mathrm{Fe}^{2+}$ & 0,242 & 0,179 & 0,267 & 0,036 & 0,165 & 0,172 & 0,096 & 0,194 & 0,047 & 0,099 & 0,082 & 0,199 & 0,131 & 0,201 & 0,063 & 0,028 & 0,034 & 0,043 & 0,124 & 0,065 & 0,179 & 0,249 & 0,158 & 0,227 & 0,197 \\
\hline $\mathrm{Mn}$ & 0,075 & 0,053 & 0,053 & 0,000 & 0,000 & 0,000 & 0,000 & 0,002 & 0,000 & 0,000 & 0,000 & 0,008 & 0,000 & 0,016 & 0,000 & 0,000 & 0,000 & 0,002 & 0,000 & 0,000 & 0,013 & 0,000 & 0,000 & 0,000 & 0,000 \\
\hline Soma M1 & 1,000 & 1,000 & 1,000 & 1,000 & 1,000 & 1,000 & 1,000 & 1,000 & 1,000 & 1,000 & 1,000 & 1,000 & 1,000 & 1,000 & 1,000 & 1,000 & 1,000 & 1,000 & 1,000 & 1,000 & 1,000 & 1,000 & 1,000 & 1,000 & 1,000 \\
\hline Mg & & & & & & & & & & & & & & & 0,000 & 0,000 & 0,000 & 0,000 & 0,000 & 0,000 & & & & & \\
\hline $\mathrm{Fe}^{2+}$ & 0,000 & 0,000 & 0,000 & 0,033 & 0,014 & 0,009 & 0,047 & 0,000 & 0,027 & $0, \mathrm{C}$ & 0,061 & 0,000 & 0,0 & 0,000 & 0,004 & 0,055 & 0,002 & 0,000 & 0,010 & 0,015 & 0,000 & 0,008 & 0,028 & 0,018 & 0,016 \\
\hline $\mathrm{Mn}$ & 0,046 & 0,020 & 0,040 & 0,024 & 0,029 & 0,046 & 0,031 & 0,030 & 0,028 & 0,026 & 0,024 & 0,027 & 0,025 & 0,019 & 0,030 & 0,023 & 0,026 & 0,024 & 0,046 & 0,025 & 0,007 & 0,078 & 0,060 & 0,089 & 0,087 \\
\hline $\mathrm{Ca}$ & 0,330 & 0,119 & 0,194 & 0,849 & & 0,872 & 0,853 & 0,894 & 0,837 & 0,848 & 0,856 & 0,889 & 088 & 0,884 & 0,864 & 0,871 & 0,873 & 0,876 & & 0,904 & 0,188 & 0,815 & 0,834 & 0,787 & 0,797 \\
\hline $\mathrm{Na}$ & 0,622 & 0,840 & 0,741 & 0,094 & 0,068 & 0,073 & 0,068 & 0,074 & 0,105 & 0,052 & 0,059 & 0,084 & 0,056 & 0,095 & 0,101 & 0,051 & 0,099 & 0,100 & 0,084 & 0,054 & 0,779 & 0,096 & 0,076 & 0,105 & 0,096 \\
\hline $\mathrm{k}$ & 0,000 & 0,002 & 0,000 & 0,000 & 0,003 & 0,000 & 0,000 & 0,002 & 0,002 & 0,000 & 0,000 & 0,000 & 0,000 & 0,001 & 0,001 & 0,000 & 0,000 & 0,000 & 0,003 & 0,001 & 0,000 & 0,000 & 0,002 & 0,000 & 0,004 \\
\hline Soma M2 & 0,999 & 0,982 & 0,974 & 1,000 & 1,000 & 1,000 & 1,000 & 1,000 & 1,000 & 1,000 & 1,000 & 1,000 & 1,000 & 1,000 & 1,000 & 1,000 & 1,000 & 1,000 & 1,000 & 1,000 & 0,974 & 0,996 & 1,000 & 1,000 & 1,000 \\
\hline Total & 3,999 & 3,999 & 3,999 & 4,000 & 4,000 & 4,000 & 4,000 & 4,000 & 4,000 & 4,000 & 4,000 & 4,000 & 4,000 & 4,000 & 4,000 & 4,000 & 4,000 & 4,000 & 4,000 & 4,000 & 4,000 & 4,000 & 4,000 & 4,000 & 4,000 \\
\hline \multicolumn{26}{|c|}{ Jadeite activity } \\
\hline $800^{\circ} \mathrm{C}$ & & & & & & & & & & & & & & & 0,075 & 0,048 & 0,080 & 0,086 & 0,046 & 0,048 & & & & & \\
\hline $900^{\circ} \mathrm{C}$ & & & & & & & & & & & & & & & 0,064 & 0,040 & 0,068 & 0,073 & 0,038 & 0,040 & & & & & \\
\hline \multicolumn{26}{|c|}{ Hednbergite activity } \\
\hline $800^{\circ} \mathrm{C}$ & & & & & & & & & & & & & & & 0,055 & 0,051 & 0,03 & 0,036 & 0,128 & 0,062 & & & & & \\
\hline $900^{\circ} \mathrm{C}$ & & & & & & & & & & & & & & & 0,061 & 0,059 & 0,034 & 0,04 & 0,132 & 0,069 & & & & & \\
\hline
\end{tabular}

$\frac{900}{1}$-n, núcleo; b, borda; <- sendo substituído por; -> substituindo; < incluso em; /, em contato com; aci, acicular; cav, em cavidade; idio, idiomórfico; ints, intersticial; poiq, poiquilítico 
ANEXO E - Tabela E.3 - Composição química de clinopiroxênios de rochas do Maciço Alcalino de Itatiaia. Continua...

\begin{tabular}{|c|c|c|c|c|c|c|c|c|c|c|c|c|c|c|c|c|c|c|c|c|c|c|c|c|c|}
\hline $\begin{array}{l}\text { Unidade } \\
\text { Amostra }\end{array}$ & $\begin{array}{l}\mathrm{N}-\mathrm{I} \\
\text { MAl097B }\end{array}$ & & & & & & & & & \begin{tabular}{|l|} 
BtHblP \\
MAl102
\end{tabular} & & & & & & & & & & & & & & & \\
\hline Cristal & 39 & 39 & 40 & 41 & 41 & 1 & 2 & 3 & 4 & 42 & 42 & 43 & 43 & 44 & 44 & 45 & 45 & 46 & 46 & 46 & 46 & 46 & 47 & 47 & 47 \\
\hline Textura ${ }^{1}$ & $->\operatorname{anf} n$ & $\rightarrow$ anf b & $\rightarrow$ anf $b$ & $<\operatorname{ann} n$ & $<\operatorname{anf} n$ & TÜ & TÜ & TÜ & Tü| & $n$ & $\mathrm{~b}$ & $n$ & $b$ & $n$ & b & $n$ & $\mathrm{~b}$ & n1 & $\mathrm{n} 2$ & n3 & $\mathrm{n} 4$ & $\mathrm{~b}$ & $n$ & $\mathrm{nb}$ & b \\
\hline $\mathrm{SiO}_{2}$ & 52,58 & 53,13 & 52,74 & 53,29 & 53,65 & 52,67 & 52,93 & 51,80 & 51,18 & 51,15 & 50,64 & 51,54 & 53,28 & 51,49 & 51,41 & 51,71 & 50,78 & 51,59 & 50,86 & 50,83 & 51,27 & 51,27 & 51,47 & 48,12 & 48,53 \\
\hline $\mathrm{TiO}_{2}$ & 0,05 & 0,18 & 0,07 & 0,08 & 0,06 & 0,07 & 0,24 & 0,53 & 0,69 & 1,71 & 1,03 & 1,52 & 0,15 & 1,44 & 0,73 & 1,40 & 0,81 & 1,52 & 1,79 & 1,78 & 1,48 & 1,62 & 1,43 & 2,32 & 2,17 \\
\hline $\mathrm{Al}_{2} \mathrm{O}_{3}$ & 0,35 & 0,26 & 0,42 & 0,28 & 0,40 & 0,24 & 0,30 & 1,33 & 2,96 & 3,19 & 3,63 & 2,80 & 1,17 & 2,47 & 2,35 & 2,76 & 3,31 & 2,76 & 3,40 & 3,39 & 3,02 & 3,23 & 2,95 & 4,99 & 4,71 \\
\hline $\mathrm{Cr}_{2} \mathrm{O}_{3}$ & & 0,03 & & & 0,01 & & & & & 0,02 & & & & 0,02 & & 0,00 & 0,01 & 0,01 & 0,01 & & & 0,03 & 0,01 & & 0,00 \\
\hline $\mathrm{ZrO}_{2}$ & & 0,02 & & 0,00 & 0,02 & 0,01 & 0,00 & 0,00 & 0,02 & & 0,13 & & 0,05 & 0,02 & 0,07 & & 0,11 & 0,02 & 0,03 & 0,04 & & 0,05 & 0,03 & 0,25 & 0,20 \\
\hline $\mathrm{FeO}_{\mathrm{T}}$ & 13,54 & 13,60 & 29,09 & 19,23 & 18,55 & 16,77 & 25,21 & 9,19 & 9,20 & 6,89 & 10,16 & 7,13 & 10,04 & 6,45 & 10,00 & 6,64 & 9,64 & 6,87 & 6,92 & 7,12 & 6,96 & 6,66 & 6,43 & 10,05 & 9,57 \\
\hline $\mathrm{MnO}$ & 2,88 & 3,13 & 0,16 & 2,09 & 2,44 & 2,32 & 0,70 & 2,06 & 1,80 & 0,67 & 0,92 & 0,62 & 0,98 & 0,61 & 0,96 & 0,64 & 0,93 & 0,68 & 0,65 & 0,65 & 0,64 & 0,73 & 0,68 & 0,76 & 0,77 \\
\hline MgO & 9,31 & 9,70 & 0,85 & 5,92 & 6,27 & 7,25 & 2,79 & 12,75 & 17,54 & 13,91 & 11,10 & 14,81 & 11,98 & 14,89 & 11,44 & 14,45 & 11,46 & 14,75 & 13,94 & 14,24 & 14,50 & 13,81 & 14,23 & 10,50 & 10,84 \\
\hline $\mathrm{CaO}$ & 18,23 & 17,06 & 1,69 & 10,77 & 12,23 & 13,01 & 4,47 & 21,30 & 8,87 & 21,52 & 21,52 & 21,60 & 21,56 & 21,43 & 21,55 & 21,53 & 22,09 & 21,46 & 21,47 & 21,43 & 21,60 & 21,86 & 21,60 & 21,86 & 21,53 \\
\hline $\mathrm{Na}_{2} \mathrm{O}$ & 2,60 & 2,58 & 12,09 & 7,30 & 6,05 & 6,61 & 11,52 & 1,09 & 3,91 & 1,29 & 1,41 & 0,66 & 1,59 & 1,19 & 1,52 & 1,17 & 1,37 & 0,66 & 1,16 & 0,79 & 0,79 & 1,24 & 1,20 & 1,45 & 1,38 \\
\hline $\mathrm{K}_{2} \mathrm{O}$ & & & & 0,01 & 0,02 & 0,01 & 0,00 & 0,00 & 1,00 & & 0,04 & & 0,05 & & 0,06 & & 0,03 & & 0,01 & 0,00 & 0,00 & 0,03 & 0,01 & 0,03 & 0,04 \\
\hline Soma & 99,54 & 99,68 & 97,10 & 98,97 & 99,70 & 98,97 & 98,16 & 100,05 & 97,16 & 100,36 & 100,58 & 100,69 & 100,85 & 100,01 & 100,09 & 100,30 & 100,55 & 100,32 & 100,23 & 100,27 & 100,26 & 100,52 & 100,03 & 100,33 & 99,75 \\
\hline $\mathrm{Fe}_{2} \mathrm{O}_{3}$ & 6,08 & 4,59 & 26,75 & 16,81 & 12,66 & 18,16 & 0,00 & 4,37 & 0,00 & 3,56 & 3,92 & 2,10 & 4,03 & 4,08 & 4,43 & 3,27 & 4,68 & 1,50 & 3,20 & 2,10 & 2,41 & 3,36 & 3,18 & 5,05 & 4,05 \\
\hline $\mathrm{FeO}$ & 8,07 & 9,47 & 5,02 & 4,10 & 7,16 & 0,43 & 25,21 & 5,26 & 9,20 & 3,68 & 6,63 & 5,24 & 6,42 & 2,78 & 6,02 & 3,70 & 5,43 & 5,52 & 4,04 & 5,23 & 4,79 & 3,63 & 3,57 & 5,50 & 5,93 \\
\hline Total & 100,15 & 100,10 & 99,79 & 100,66 & 100,93 & 100,79 & 98,16 & 100,49 & 97,16 & 100,69 & 100,84 & 100,90 & 101,20 & 100,38 & 100,46 & 100,63 & 100,90 & 100,45 & 100,52 & 100,44 & 100,50 & 100,78 & 100,32 & 100,59 & 99,95 \\
\hline \multicolumn{26}{|c|}{ Número de cátions calculado na base de 6 oxigênios. } \\
\hline $\mathrm{Si}$ & 1,998 & 2,017 & 2,023 & 2,010 & 2,025 & 1,977 & 1,989 & 1,934 & 1,879 & 1,880 & 1,886 & 1,892 & 1,971 & 1,892 & 1,920 & 1,898 & 1,887 & 1,900 & 1,873 & 1,875 & 1,888 & 1,882 & 1,894 & 1,801 & 1,824 \\
\hline Al & 0,002 & 0,000 & 0,000 & 0,000 & 0,000 & 0,011 & 0,011 & 0,059 & 0,121 & 0,120 & 0,114 & 0,108 & 0,029 & 0,107 & 0,080 & 0,102 & 0,113 & 0,100 & 0,127 & 0,125 & 0,112 & 0,118 & 0,106 & 0,199 & 0,176 \\
\hline $\mathrm{Fe}^{3+}$ & 0,000 & 0,000 & 0,000 & 0,000 & 0,000 & 0,013 & 0,000 & 0,007 & 0,000 & 0,000 & 0,000 & 0,000 & 0,000 & 0,001 & 0,000 & 0,000 & 0,000 & 0,000 & 0,000 & 0,000 & 0,000 & 0,000 & 0,000 & 0,000 & 0,000 \\
\hline Soma $T$ & 2,000 & 2,017 & 2,023 & 2,010 & 2,025 & 2,000 & 2,000 & 2,000 & 2,000 & 2,000 & 2,000 & 2,000 & 2,000 & 2,000 & 2,000 & 2,000 & 2,000 & 2,000 & 2,000 & 2,000 & 2,000 & 2,000 & 2,000 & 2,000 & 2,000 \\
\hline Al & 0,014 & 0,011 & 0,019 & 0,012 & 0,018 & 0,000 & 0,003 & 0,000 & 0,007 & 0,018 & 0,045 & 0,013 & 0,022 & 0,000 & 0,023 & 0,017 & 0,032 & 0,020 & 0,021 & 0,023 & 0,019 & 0,022 & 0,022 & 0,022 & 0,033 \\
\hline $\mathrm{Ti}$ & 0,001 & 0,005 & 0,002 & 0,002 & 0,002 & 0,002 & 0,007 & 0,015 & 0,019 & 0,048 & 0,029 & 0,043 & 0,004 & 0,040 & 0,020 & 0,039 & 0,023 & 0,043 & 0,050 & 0,050 & 0,041 & 0,045 & 0,040 & 0,065 & 0,061 \\
\hline $\mathrm{Fe}^{3+}$ & 0,174 & 0,131 & 0,772 & 0,477 & 0,360 & 0,478 & 0,776 & 0,114 & 0,282 & 0,099 & 0,110 & 0,058 & 0,112 & 0,111 & 0,124 & 0,090 & 0,131 & 0,042 & 0,089 & 0,058 & 0,067 & 0,093 & 0,088 & 0,142 & 0,115 \\
\hline $\mathrm{zr}$ & 0,000 & 0,000 & 0,000 & 0,000 & 0,000 & 0,000 & 0,000 & 0,000 & 0,000 & 0,000 & 0,002 & 0,000 & 0,001 & 0,000 & 0,001 & 0,000 & 0,002 & 0,000 & 0,000 & 0,001 & 0,000 & 0,001 & 0,000 & 0,005 & 0,004 \\
\hline $\mathrm{Mg}$ & 0,527 & 0,549 & 0,048 & 0,333 & 0,353 & 0,406 & 0,156 & 0,710 & 0,691 & 0,762 & 0,616 & 0,810 & 0,661 & 0,816 & 0,637 & 0,791 & 0,635 & 0,810 & 0,765 & 0,783 & 0,796 & 0,756 & 0,781 & 0,586 & 0,607 \\
\hline $\mathrm{Fe}^{2+}$ & 0,257 & 0,301 & 0,158 & 0,129 & 0,226 & 0,035 & 0,016 & 0,162 & 0,000 & 0,073 & 0,198 & 0,076 & 0,198 & 0,032 & 0,188 & 0,063 & 0,169 & 0,085 & 0,075 & 0,085 & 0,076 & 0,083 & 0,068 & 0,172 & 0,181 \\
\hline $\mathrm{Mn}$ & 0,027 & 0,002 & 0,000 & 0,046 & 0,042 & 0,074 & 0,022 & 0,000 & 0,000 & 0,000 & 0,000 & 0,000 & 0,002 & 0,000 & 0,006 & 0,000 & 0,009 & 0,000 & 0,000 & 0,000 & 0,000 & 0,000 & 0,000 & 0,008 & 0,000 \\
\hline Soma M1 & 1,000 & 1,000 & 1,000 & 1,000 & 1,000 & 0,995 & 0,980 & 1,000 & 1,000 & 1,000 & 1,000 & 1,000 & 1,000 & 1,000 & 1,000 & 1,000 & 1,000 & 1,000 & 1,000 & 1,000 & 1,000 & 1,000 & 1,000 & 1,000 & 1,000 \\
\hline Mg & & & & & & 0,000 & 0,000 & 0,000 & 0,269 & & & & & & & & & & & & & & & & \\
\hline $\mathrm{Fe}^{2+}$ & 0,000 & 0,000 & 0,003 & 0,000 & 0,000 & 0,000 & 0,000 & 0,004 & 0,000 & 0,040 & 0,009 & 0,085 & 0,000 & 0,053 & 0,000 & 0,051 & 0,000 & 0,085 & 0,050 & 0,076 & 0,071 & 0,029 & 0,042 & 0,000 & 0,005 \\
\hline $\mathrm{Mn}$ & 0,066 & 0,098 & 0,005 & 0,021 & 0,036 & 0,000 & 0,000 & 0,065 & 0,056 & 0,021 & 0,029 & 0,019 & 0,029 & 0,019 & 0,025 & 0,020 & 0,020 & 0,021 & 0,020 & 0,020 & 0,020 & 0,023 & 0,021 & 0,016 & 0,025 \\
\hline $\mathrm{Ca}$ & 0,742 & 0,694 & 0,069 & 0,435 & 0,495 & 0,523 & 0,180 & 0,852 & 0,349 & 0,847 & 0,859 & 0,849 & 0,855 & 0,844 & 0,862 & 0,847 & 0,879 & 0,847 & 0,847 & 0,847 & 0,852 & 0,860 & 0,852 & 0,877 & 0,867 \\
\hline $\mathrm{Na}$ & 0,192 & 0,190 & 0,899 & 0,534 & 0,443 & 0,481 & 0,840 & 0,079 & 0,278 & 0,092 & 0,102 & 0,047 & 0,114 & 0,085 & 0,110 & 0,083 & 0,099 & 0,047 & 0,083 & 0,057 & 0,057 & 0,088 & 0,085 & 0,105 & 0,101 \\
\hline K & 0,000 & 0,000 & 0,000 & 0,000 & 0,001 & 0,000 & 0,000 & 0,000 & 0,048 & 0,000 & 0,002 & 0,000 & 0,002 & 0,000 & 0,003 & 0,000 & 0,002 & 0,000 & 0,001 & 0,000 & 0,000 & 0,001 & 0,000 & 0,002 & 0,002 \\
\hline Soma M2 & 1,000 & 0,982 & 0,977 & 0,990 & 0,975 & 1,005 & 1,020 & 1,000 & 1,000 & 1,000 & 1,000 & 1,000 & 1,000 & 1,000 & 1,000 & 1,000 & 1,000 & 1,000 & 1,000 & 1,000 & 1,000 & 1,000 & 1,000 & 0,999 & 0,999 \\
\hline & 4,000 & 4,000 & 4,000 & 4,000 & 4,000 & 4,000 & 4,000 & 4,000 & 4,000 & 4,000 & 4,000 & 4,000 & 4,000 & 4,000 & 4,000 & 4,000 & 4,000 & 4,000 & 4,000 & 4,000 & 4,000 & 4,000 & 4,000 & 3,999 & 3,999 \\
\hline \multicolumn{26}{|c|}{ Jadeite activity } \\
\hline $800^{\circ} \mathrm{C}$ & & & & & & 0 , & 0,0 & 0, & 0,178 & & & & & & & & & & & & & & & & \\
\hline $900^{\circ} \mathrm{C}$ & & & & & & 0,010 & 0,018 & 0,035 & 0,157 & & & & & & & & & & & & & & & & \\
\hline \multicolumn{26}{|c|}{ Hednbergite activity } \\
\hline $800^{\circ} \mathrm{C}$ & & & & & & 0,033 & 0 & 144 & o & & & & & & & & & & & & & & & & \\
\hline $900^{\circ} \mathrm{C}$ & & & & & & 0,035 & 0 & 0,151 & 0 & & & & & & & & & & & & & & & & \\
\hline
\end{tabular}

${ }^{\top}$ - n, núcleo; b, borda; <- sendo substituído por; - > substituindo; < incluso em; /, em contato com; aci, acicular; cav, em cavidade; idio, idiomórfico; ints, intersticial; poiq, poiquilítico 
ANEXO E - Tabela E.3 - Composição química de clinopiroxênios de rochas do Maciço Alcalino de Itatiaia. Continua...

\begin{tabular}{|c|c|c|c|c|c|c|c|c|c|c|c|c|c|c|c|c|c|c|c|c|c|c|c|c|c|}
\hline $\begin{array}{l}\text { Unidade } \\
\text { Amostra }\end{array}$ & $\begin{array}{l}\text { BtHblP } \\
\text { MAl102 }\end{array}$ & & & & & & & $\begin{array}{l}\text { arpk-QzS } \\
\text { MAI108II }\end{array}$ & & & & & & & & & & & & & & & & & \\
\hline Cristal & 48 & 48 & 1 & 2 & 3 & 4 & 5 & 49 & 49 & 50 & 51 & 51 & 52 & 53 & 54 & 54 & 55 & 55 & 56 & 56 & 57 & 57 & 1 & 2 & 6 \\
\hline Textura ${ }^{2}$ & $n$ & b & TÜ & TÜ & TÜ & TÜ & Tül & $n$ & $n$ & $n$ & $n$ & $b$ & $n$ & $n$ & $n$ & $b$ & $<$ fen $\mathrm{kfl} n$ & <fen kfl b & $<$ fen kfl & $<$ fen kfl & $n$ & $b$ & TÜ & TÜ & TÜ \\
\hline$\overline{\mathrm{SiO}_{2}}$ & 51,80 & 50,12 & 51,59 & 51,62 & 50,89 & 52,23 & 51,03 & 53,14 & 53,66 & 53,14 & 53,52 & 53,57 & 53,73 & 53,94 & 53,87 & 54,26 & 53,99 & 54,07 & 52,63 & 52,15 & 52,85 & 53,62 & 52,40 & 52,86 & 52,96 \\
\hline $\mathrm{TiO}_{2}$ & 1,23 & 1,04 & 0,70 & 0,98 & 0,98 & 0,66 & 0,86 & 0,04 & 0,04 & 0,08 & 0,01 & 0,15 & 0,07 & 0,21 & 0,02 & 0,04 & 0,12 & & 0,05 & 0,15 & 0,05 & 0,04 & 0,08 & 0,08 & 0,09 \\
\hline $\mathrm{Al}_{2} \mathrm{O}_{3}$ & 2,78 & 3,28 & 1,70 & 2,03 & 2,46 & 1,61 & 2,30 & 0,33 & 0,30 & 0,83 & 0,29 & 0,30 & 0,27 & 0,30 & 0,25 & 0,19 & 0,77 & 0,57 & 0,43 & 0,50 & 0,36 & 0,34 & 0,21 & 0,31 & 0,27 \\
\hline $\mathrm{Cr}_{2} \mathrm{O}_{3}$ & & 0,01 & & & & & & & & & 0,00 & & & 0,02 & & 0,04 & & & & & 0,03 & & & & \\
\hline $\mathrm{ZrO}_{2}$ & 0,02 & 0,10 & 0,05 & 0,06 & 0,06 & 0,08 & 0,04 & 0,01 & & & & & & & 0,01 & & 0,00 & 0,01 & & & & & 0,00 & 0,00 & 0,00 \\
\hline $\mathrm{FeO}_{T}$ & 6,32 & 10,76 & 7,35 & 7,86 & 7,88 & 7,63 & 7,75 & 11,96 & 10,60 & 9,34 & 11,92 & 8,69 & 10,03 & 9,09 & 9,22 & 8,54 & 8,03 & 9,20 & 13,12 & 15,17 & 12,97 & 11,13 & 7,77 & 9,20 & 8,41 \\
\hline Mno & 0,69 & 0,99 & 1,07 & 1,15 & 1,02 & 1,19 & 1,05 & 2,09 & 1,96 & 2,54 & 1,99 & 1,98 & 1,96 & 1,91 & 2,13 & 2,14 & 1,23 & 1,27 & 2,13 & 1,83 & 2,19 & 2,12 & 2,98 & 2,02 & 2,08 \\
\hline $\mathrm{MgO}$ & 14,60 & 10,78 & 13,90 & 13,33 & 14,06 & 13,78 & 13,47 & 11,19 & 12,12 & 12,48 & 11,55 & 13,18 & 12,26 & 13,15 & 12,68 & 13,25 & 13,42 & 12,52 & 9,61 & 8,77 & 10,28 & 11,74 & 14,54 & 12,83 & 13,59 \\
\hline CaO & 22,03 & 21,38 & 22,17 & 22,12 & 21,92 & 22,25 & 22,06 & 20,91 & 21,11 & 21,07 & 20,45 & 21,50 & 21,72 & 21,02 & 21,44 & 21,64 & 22,90 & 22,44 & 22,14 & 21,59 & 20,83 & 21,12 & 20,42 & 21,05 & 21,49 \\
\hline $\mathrm{Na}_{2} \mathrm{O}$ & 1,03 & 1,44 & 0,89 & 1,15 & 0,89 & 0,96 & 0,98 & 1,14 & 0,93 & 0,71 & 1,23 & 0,84 & 0,97 & 0,88 & 1,07 & 0,89 & 0,53 & 0,95 & 0,64 & 0,88 & 1,07 & 0,98 & 0,64 & 1,30 & 0,78 \\
\hline $\mathrm{K}_{2} \mathrm{O}$ & & 0,04 & 0,00 & 0,01 & 0,00 & 0,00 & 0,01 & & 0,05 & 0,15 & 0,04 & 0,04 & 0,03 & & 0,02 & 0,10 & 0,02 & 0,05 & 0,01 & 0,01 & 0,01 & 0,03 & 0,02 & 0,00 & 0,01 \\
\hline Soma & 100,49 & 99,94 & 99,42 & 100,31 & 100,16 & 100,39 & 99,55 & 100,81 & 100,77 & 100,35 & 101,01 & 100,25 & 101,04 & 100,51 & 100,72 & 101,10 & 101,02 & 101,07 & 100,76 & 101,05 & 100,64 & 101,12 & 99,06 & 99,64 & 99,68 \\
\hline $\mathrm{Fe}_{2} \mathrm{O}_{3}$ & 3,28 & 4,68 & 3,79 & 4,30 & 4,93 & 3,61 & 4,27 & 2,78 & 1,62 & 1,44 & 2,80 & 1,72 & 2,20 & 0,90 & 2,23 & 1,78 & 0,43 & 1,60 & 0,89 & 2,14 & 2,18 & 1,95 & 3,53 & 4,27 & 2,79 \\
\hline $\mathrm{FeO}$ & 3,37 & 6,55 & 3,94 & 3,99 & 3,45 & 4,38 & 3,91 & 9,46 & 9,14 & 8,04 & 9,40 & 7,15 & 8,05 & 8,28 & 7,21 & 6,94 & 7,64 & 7,76 & 12,32 & 13,24 & 11,01 & 9,38 & 4,59 & 5,36 & 5,90 \\
\hline Total & 100,80 & 100,30 & 99,80 & 100,74 & 100,65 & 100,76 & 99,97 & 101,08 & 100,93 & 100,49 & 101,29 & 100,42 & 101,26 & 100,59 & 100,93 & 101,24 & 101,06 & 101,22 & 100,85 & 101,26 & 100,82 & 101,32 & 99,41 & 100,07 & 99,95 \\
\hline \multicolumn{26}{|c|}{ Número de cátions calculado na base de 6 oxigênios. } \\
\hline $\mathrm{Si}$ & 1,897 & 1,883 & 1,921 & 1,910 & 1,882 & 1,931 & 1,900 & 1,993 & 2,004 & 1,988 & 1,999 & 1,996 & 1,997 & 2,007 & 2,001 & 2,004 & 1,993 & 2,000 & 2,000 & 1,986 & 1,999 & 2,000 & 1,967 & 1,978 & 1,981 \\
\hline Al & 0,103 & 0,117 & 0,075 & 0,089 & 0,107 & 0,069 & 0,100 & 0,007 & 0,000 & 0,012 & 0,001 & 0,004 & 0,003 & 0,000 & 0,000 & 0,000 & 0,007 & 0,000 & 0,000 & 0,014 & 0,001 & 0,000 & 0,009 & 0,013 & 0,012 \\
\hline $\mathrm{Fe}^{3+}$ & 0,000 & 0,000 & 0,004 & 0,002 & 0,011 & 0,000 & 0,000 & 0,000 & 0,000 & 0,000 & 0,000 & 0,000 & 0,000 & 0,000 & 0,000 & 0,000 & 0,000 & 0,000 & 0,000 & 0,000 & 0,000 & 0,000 & 0,024 & 0,008 & 0,007 \\
\hline Soma $T$ & 2,000 & 2,000 & 2,000 & 2,000 & 2,000 & 2,000 & 2,000 & 2,000 & 2,004 & 2,000 & 2,000 & 2,000 & 2,000 & 2,007 & 2,001 & 2,004 & 2,000 & 2,000 & 2,000 & 2,000 & 2,000 & 2,000 & 2,000 & 2,000 & 2,000 \\
\hline Al & 0,017 & 0,028 & 0,000 & 0,000 & 0,000 & 0,002 & 0,001 & 0,008 & 0,013 & 0,025 & 0,012 & 0,009 & 0,009 & 0,013 & 0,011 & 0,008 & 0,027 & 0,025 & 0,019 & 0,009 & 0,015 & 0,015 & 0,000 & 0,000 & 0,000 \\
\hline $\mathrm{Ti}$ & 0,034 & 0,029 & 0,020 & 0,027 & 0,027 & 0,018 & 0,024 & 0,001 & 0,001 & 0,002 & 0,000 & 0,004 & 0,002 & 0,006 & 0,001 & 0,001 & 0,003 & 0,000 & 0,001 & 0,004 & 0,001 & 0,001 & 0,002 & 0,002 & 0,002 \\
\hline $\mathrm{Fe}^{3+}$ & 0,090 & 0,132 & 0,101 & 0,116 & 0,124 & 0,095 & 0,119 & 0,079 & 0,046 & 0,041 & 0,079 & 0,048 & 0,062 & 0,025 & 0,062 & 0,049 & 0,012 & 0,045 & 0,026 & 0,061 & 0,062 & 0,055 & 0,075 & 0,111 & 0,071 \\
\hline $\mathrm{Zr}$ & 0,000 & 0,002 & 0,001 & 0,001 & 0,001 & 0,001 & 0,001 & 0,000 & 0,000 & 0,000 & 0,000 & 0,000 & 0,000 & 0,000 & 0,000 & 0,000 & 0,000 & 0,000 & 0,000 & 0,000 & 0,000 & 0,000 & 0,000 & 0,000 & 0,000 \\
\hline $\mathrm{Mg}$ & 0,797 & 0,604 & 0,772 & 0,735 & 0,775 & 0,755 & 0,748 & 0,626 & 0,675 & 0,696 & 0,643 & 0,732 & 0,679 & 0,729 & 0,702 & 0,730 & 0,739 & 0,690 & 0,544 & 0,498 & 0,580 & 0,653 & 0,814 & 0,716 & 0,758 \\
\hline $\mathrm{Fe}^{2+}$ & 0,061 & 0,205 & 0,107 & 0,120 & 0,072 & 0,128 & 0,107 & 0,287 & 0,265 & 0,236 & 0,266 & 0,206 & 0,248 & 0,227 & 0,223 & 0,212 & 0,219 & 0,240 & 0,391 & 0,422 & 0,342 & 0,276 & 0,109 & 0,169 & 0,169 \\
\hline $\mathrm{Mn}$ & 0,000 & 0,000 & 0,000 & 0,000 & 0,000 & 0,000 & 0,000 & 0,000 & 0,000 & 0,000 & 0,000 & 0,000 & 0,000 & 0,000 & 0,000 & 0,000 & 0,000 & 0,000 & 0,018 & 0,006 & 0,000 & 0,000 & 0,000 & 0,002 & 0,000 \\
\hline Soma M1 & 1,000 & 1,000 & 1,000 & 1,000 & 1,000 & 1,000 & 1,000 & 1,000 & 1,000 & 1,000 & 1,000 & 1,000 & 1,000 & 1,000 & 1,000 & 1,000 & 1,000 & 1,000 & 1,000 & 1,000 & 1,000 & 1,000 & 1,000 & 1,000 & 1,000 \\
\hline Mg & & & 0,000 & 0,000 & 0,000 & 0,000 & 0,000 & & & & & & & & & & & & & & & & 0,000 & 0,000 & 0,000 \\
\hline $\mathrm{Fe}^{2+}$ & 0,042 & 0,001 & 0,017 & 0,004 & 0,036 & & 0,015 & 0,010 & 0,020 & 0,016 & 0,028 & 0,017 & 0,002 & 0,031 & 0,001 & 0,003 & 0,017 & 0,000 & 0,000 & 0,000 & 0,006 & 0,016 & 0,036 & 0,000 & 0,016 \\
\hline$M n$ & 0,021 & 0,031 & 0,034 & 0,036 & 0,032 & 0,0 & 0,033 & 0,066 & 0,062 & 0,081 & 0,063 & 0,062 & 0,062 & 0,060 & 0,067 & 0,067 & 0,038 & 0,040 & 0,051 & 0,053 & 0,070 & 0,067 & 095 & 0,062 & 066 \\
\hline $\mathrm{Ca}$ & 0,864 & 0,861 & 0,885 & 0,877 & 0,868 & 0,881 & 0,880 & 0,840 & 0,845 & 0,845 & 0,818 & 0,858 & 0,865 & 0,838 & 0,853 & 0,857 & 0,906 & 0,889 & 0,901 & 0,881 & 0,844 & 0,844 & 0,821 & 0,844 & 0,861 \\
\hline $\mathrm{Na}$ & 0,073 & 0,105 & 0,065 & 0,083 & 0,064 & 0,069 & 0,071 & 0,083 & 0,067 & 0,051 & 0,089 & 0,060 & 0,070 & 0,064 & 0,077 & 0,064 & 0,038 & 0,068 & 0,047 & 0,065 & 0,079 & 0,071 & 0,047 & 0,094 & 056 \\
\hline к & 0,000 & 0,002 & 0,000 & 0,000 & 0,000 & 0,000 & 0,000 & 0,000 & 0,002 & 0,008 & 0,002 & 0,002 & 0,001 & 0,000 & 0,001 & 0,005 & 0,001 & 0,002 & 0,001 & 0,000 & 0,001 & 0,001 & 0,001 & 0,000 & 0,001 \\
\hline Soma M2 & 1,000 & 1,000 & 1,000 & 1,000 & 1,000 & 1,000 & 1,000 & 1,000 & 0,996 & 1,000 & 1,000 & 1,000 & 1,000 & 0,993 & 0,999 & 0,996 & 1,000 & 1,000 & 1,000 & 1,000 & 1,000 & 1,000 & 1,000 & 1,000 & 1,000 \\
\hline Total & 4,000 & 4,000 & 4,000 & 4,000 & 4,000 & 4,000 & 4,000 & 4,000 & 4,000 & 4,000 & 4,000 & 4,000 & 4,000 & 4,000 & 4,000 & 4,000 & 4,000 & 4,000 & 4,000 & 4,000 & 4,000 & 4,000 & 4,000 & 4,000 & 4,000 \\
\hline \multicolumn{26}{|c|}{ Jadeite activity } \\
\hline $800^{\circ} \mathrm{C}$ & & & 0,045 & 0,060 & 0,054 & 0,04 & 0,059 & & & & & & & & & & & & & & & & 0,005 & 0,013 & 0,008 \\
\hline $900^{\circ} \mathrm{C}$ & & & 0,037 & 0,050 & 0,045 & ,038 & 0,049 & & & & & & & & & & & & & & & & 0,004 & 0,011 & 0,007 \\
\hline \multicolumn{26}{|c|}{ Hednbergite activity } \\
\hline $800^{\circ} \mathrm{C}$ & & & 0,107 & 0,121 & 0,078 & 123 & 0,108 & & & & & & & & & & & & & & & & 0,092 & 0,159 & 0,157 \\
\hline $900^{\circ} \mathrm{C}$ & & & 0,113 & 0,126 & 0,086 & 0,128 & 0,114 & & & & & & & & & & & & & & & & 0,102 & 0,164 & 0,163 \\
\hline
\end{tabular}

${ }^{\top}$ - n, núcleo; b, borda; <- sendo substituído por; - > substituindo; < incluso em; /, em contato com; aci, acicular; cav, em cavidade; idio, idiomórfico; ints, intersticial; poiq, poiquilítico 
ANEXO E - Tabela E.3 - Composição química de clinopiroxênios de rochas do Maciço Alcalino de Itatiaia. Continua..

\begin{tabular}{|c|c|c|c|c|c|c|c|c|c|c|c|c|c|c|c|c|c|c|c|c|c|c|c|c|c|}
\hline $\begin{array}{l}\text { Unidade } \\
\text { Amostra }\end{array}$ & $\begin{array}{l}\text { arpk-QzS } \\
\text { MAl108I }\end{array}$ & \begin{tabular}{|l|} 
BtHblP \\
MAI114
\end{tabular} & & & & & & & & & & & & & & & & & & & & & & & $\begin{array}{l}\text { HblP } \\
\text { MAl160 }\end{array}$ \\
\hline Cristal & & 58 & 58 & 58 & 59 & 60 & 60 & 61 & 61 & 62 & 63 & 63 & 64 & 65 & 66 & 66 & 67 & 67 & 67 & 1 & 2 & 3 & 4 & 5 & 68 \\
\hline Textura $^{1}$ & Tü| & $\rightarrow \operatorname{anf} n$ & $->\operatorname{anf} b$ & $\rightarrow$ anf $b$ & $<\mathrm{ttn}$ & $->a n f n$ & $\rightarrow$ anf $b$ & $\rightarrow \operatorname{anf} n$ & $->\operatorname{anf} b$ & $\rightarrow \operatorname{anf} n$ & $\rightarrow \operatorname{anf} n$ & $\rightarrow \operatorname{anf} n$ & $n$ & $n$ & $\rightarrow \operatorname{anf} n$ & $\rightarrow$ anf $b$ & $\rightarrow \operatorname{anf} n$ & $\rightarrow \operatorname{ann} n$ & $\rightarrow$ anf $b$ & TÜ & TÜ & TÜ & TÜ & Tü & $<-\operatorname{anf} n$ \\
\hline $\mathrm{SiO}_{2}$ & 51,84 & 52,02 & 50,56 & 51,53 & 51,01 & 50,85 & 49,77 & 51,76 & 51,13 & 50,74 & 51,51 & 51,73 & 51,38 & 51,70 & 51,99 & 50,65 & 52,59 & 51,50 & 51,37 & 49,47 & 51,56 & 50,38 & 50,90 & 50,73 & 52,35 \\
\hline $\mathrm{TiO}_{2}$ & 0,01 & 1,04 & 1,15 & 1,09 & 1,38 & 1,31 & 1,15 & 1,09 & 1,40 & 1,18 & 1,15 & 0,73 & 0,76 & 0,37 & 1,23 & 1,42 & 0,73 & 1,17 & 1,32 & 0,37 & 1,00 & 1,06 & 0,93 & 1,15 & 0,81 \\
\hline $\mathrm{Al}_{2} \mathrm{O}_{3}$ & 0,28 & 1,99 & 3,10 & 2,66 & 3,12 & 3,21 & 3,45 & 2,44 & 3,04 & 3,15 & 2,37 & 2,30 & 2,45 & 1,40 & 2,66 & 3,31 & 2,54 & 2,64 & 2,84 & 2,46 & 2,31 & 3,07 & 1,81 & 2,58 & 2,47 \\
\hline $\mathrm{Cr}_{2} \mathrm{O}_{3}$ & & & & & & 0,00 & 0,03 & 0,02 & 0,00 & 0,03 & & & 0,02 & & 0,02 & 0,01 & & 0,04 & 0,00 & & & & & & 0,03 \\
\hline $\mathrm{ZrO}_{2}$ & 0,00 & 0,04 & 0,09 & 0,02 & & 0,02 & 0,09 & 0,03 & & 0,04 & 0,03 & 0,13 & 0,23 & 0,42 & 0,03 & 0,01 & 0,05 & & 0,03 & 0,24 & 0,03 & 0,06 & 0,04 & 0,03 & 0,06 \\
\hline $\mathrm{FeO}_{\mathrm{T}}$ & 12,77 & 7,88 & 9,02 & 8,05 & 7,98 & 8,37 & 10,06 & 6,71 & 7,25 & 8,10 & 8,38 & 10,14 & 10,99 & 11,82 & 7,28 & 8,87 & 6,77 & 7,21 & 7,26 & 11,89 & 6,71 & 8,19 & 7,80 & 6,97 & 7,65 \\
\hline Mno & 2,21 & 1,25 & 0,99 & 0,95 & 0,88 & 0,91 & 1,04 & 0,94 & 0,87 & 0,89 & 1,24 & 1,42 & 1,53 & 1,87 & 0,94 & 1,00 & 0,90 & 0,95 & 0,91 & 1,43 & 0,89 & 0,97 & 1,20 & 0,86 & 0,78 \\
\hline MgO & 10,52 & 12,92 & 11,73 & 12,60 & 12,61 & 12,34 & 11,09 & 14,28 & 13,14 & 12,38 & 12,32 & 11,25 & 10,43 & 9,84 & 13,15 & 11,88 & 13,40 & 13,19 & 13,09 & 10,20 & 13,81 & 12,60 & 13,69 & 13,36 & 14,41 \\
\hline $\mathrm{CaO}$ & 20,55 & 21,29 & 22,52 & 21,92 & 22,13 & 22,05 & 22,07 & 21,35 & 21,58 & 22,53 & 22,06 & 21,84 & 21,28 & 21,04 & 22,30 & 22,40 & 22,56 & 21,65 & 22,21 & 21,88 & 22,52 & 22,80 & 21,82 & 22,49 & 21,36 \\
\hline $\mathrm{Na}_{2} \mathrm{O}$ & 1,24 & 1,23 & 1,08 & 1,19 & 1,07 & 1,18 & 1,26 & 0,93 & 1,29 & 1,09 & 1,26 & 1,35 & 1,34 & 1,48 & 1,24 & 1,18 & 1,03 & 1,10 & 1,11 & 1,55 & 1,20 & 1,09 & 1,10 & 1,20 & 0,83 \\
\hline $\mathrm{K}_{2} \mathrm{O}$ & 0,01 & 0,01 & 0,04 & & 0,01 & & & 0,01 & & 0,02 & 0,00 & 0,03 & 0,05 & 0,17 & 0,02 & 0,00 & & 0,03 & 0,02 & 0,02 & 0,01 & 0,00 & 0,00 & 0,03 & \\
\hline Soma & 99,43 & 99,68 & 100,28 & 100,02 & 100,18 & 100,24 & 100,01 & 99,55 & 99,70 & 100,16 & 100,33 & 100,91 & 100,46 & 100,11 & 100,87 & 100,72 & 100,57 & 99,48 & 100,16 & 99,52 & 100,04 & 100,22 & 99,30 & 99,41 & 100,74 \\
\hline $\mathrm{Fe}_{2} \mathrm{O}_{3}$ & 4,30 & 2,25 & 3,71 & 2,74 & 2,69 & 3,31 & 4,83 & 2,12 & 3,05 & 3,63 & 3,39 & 3,69 & 2,75 & 3,55 & 3,08 & 3,72 & 1,87 & 2,19 & 2,79 & 7,98 & 4,53 & 5,20 & 5,26 & 4,91 & 2,18 \\
\hline $\mathrm{FeO}$ & 8,90 & 5,85 & 5,68 & 5,59 & 5,56 & 5,39 & 5,71 & 4,80 & 4,50 & 4,83 & 5,33 & 6,82 & 8,52 & 8,63 & 4,51 & 5,53 & 5,09 & 5,24 & 4,75 & 4,71 & 2,63 & 3,51 & 3,07 & 2,55 & 5,69 \\
\hline Total & 99,86 & 99,87 & 100,56 & 100,27 & 100,45 & 100,55 & 100,37 & 99,72 & 100,00 & 100,44 & 100,63 & 101,15 & 100,48 & 100,05 & 101,13 & 101,08 & 100,71 & 99,66 & 100,41 & 100,32 & 100,49 & 100,74 & 99,82 & 99,90 & 100,88 \\
\hline \multicolumn{26}{|c|}{ Número de cátions calculado na base de 6 oxigênios. } \\
\hline Si & 1,978 & 1,939 & 1,885 & 1,915 & 1,894 & 1,889 & 1,867 & 1,920 & 1,898 & 1,886 & 1,913 & 1,924 & 1,931 & 1,958 & 1,910 & 1,878 & 1,935 & 1,919 & 1,902 & 1,874 & 903 & 1,869 & 899 & 1,886 & 1,922 \\
\hline Al & 0,013 & 0,061 & 0,115 & 0,085 & 0,106 & 0,111 & 0,133 & 0,080 & 0,102 & 0,114 & 0,087 & 0,076 & 0,069 & 0,042 & 0,090 & 0,122 & 0,065 & 0,081 & 0,098 & 0,110 & 0,097 & 0,131 & 0,080 & 0,113 & 0,078 \\
\hline $\mathrm{Fe}^{3+}$ & 0,010 & 0,000 & 0,000 & 0,000 & 0,000 & 0,000 & 0,000 & 0,000 & 0,000 & 0,000 & 0,000 & 0,000 & 0,000 & 0,000 & 0,000 & 0,000 & 0,000 & 0,000 & 0,000 & 0,016 & 0,000 & 0,000 & 0,021 & 0,001 & 0,000 \\
\hline Soma $T$ & 2,000 & 2,000 & 2,000 & 2,000 & 2,000 & 2,000 & 2,000 & 2,000 & 2,000 & 2,000 & 2,000 & 2,000 & 2,000 & 2,000 & 2,000 & 2,000 & 2,000 & 2,000 & 2,000 & 2,000 & 2,000 & 2,000 & 2,000 & 2,000 & 2,000 \\
\hline Al & 0,000 & 0,027 & 0,022 & 0,032 & 0,031 & 0,029 & 0,019 & 0,026 & 0,031 & 0,024 & 0,017 & 0,025 & 0,039 & 0,021 & 0,025 & 0,023 & 0,045 & 0,035 & 0,026 & 0,000 & 0,000 & 0,003 & 0,000 & 0,000 & 0,029 \\
\hline $\mathrm{Ti}$ & 0,000 & 0,029 & 0,032 & 0,030 & 0,038 & 0,036 & 0,032 & 0,030 & 0,039 & 0,033 & 0,032 & 0,020 & 0,021 & 0,010 & 0,034 & 0,040 & 0,020 & 0,033 & 0,037 & 0,010 & 028 & 0,030 & 026 & 0,032 & 0,023 \\
\hline $\mathrm{Fe}^{3+}$ & 0,113 & 0,063 & 0,104 & 0,077 & 0,075 & 0,093 & 0,136 & 0,059 & 0,085 & 0,102 & 0,095 & 0,103 & 0,078 & 0,101 & 0,085 & 0,104 & 0,052 & 0,061 & 0,078 & 0,207 & 0,125 & 0,144 & 0,125 & 0,135 & 0,060 \\
\hline $\mathrm{zr}$ & 0,000 & 0,001 & 0,002 & 0,000 & 0,000 & 0,000 & 0,002 & 0,001 & 0,000 & 0,001 & 0,001 & 0,002 & 0,004 & 0,008 & 0,001 & 0,000 & 0,001 & 0,000 & 0,001 & 0,005 & 0,001 & 0,001 & 0,001 & 0,001 & 0,001 \\
\hline $\mathrm{Mg}$ & 0,598 & 0,718 & 0,652 & 0,698 & 0,698 & 0,683 & 0,620 & 0,790 & 0,727 & 0,686 & 0,682 & 0,624 & 0,584 & 0,556 & 0,720 & 0,657 & 0,735 & 0,733 & 0,722 & 0,576 & 0,760 & 0,697 & 0,761 & 0,740 & 0,789 \\
\hline $\mathrm{Fe}^{2+}$ & 0,285 & 0,162 & 0,177 & 0,163 & 0,158 & 0,158 & 0,179 & 0,094 & 0,118 & 0,150 & 0,166 & 0,212 & 0,268 & 0,273 & 0,135 & 0,171 & 0,147 & 0,139 & 0,137 & 0,153 & 0,082 & 0,111 & 0,087 & 0,081 & 0,098 \\
\hline $\mathrm{Mn}$ & 0,004 & 0,000 & 0,011 & 0,000 & 0,000 & 0,000 & 0,012 & 0,000 & 0,000 & 0,005 & 0,008 & 0,013 & 0,006 & 0,031 & 0,000 & 0,006 & 0,000 & 0,000 & 0,000 & 0,046 & 0,004 & 0,015 & 0,000 & 0,011 & 0,000 \\
\hline Soma M1 & 1,000 & 1,000 & 1,000 & 1,000 & 1,000 & 1,000 & 1,000 & 1,000 & 1,000 & 1,000 & 1,000 & 1,000 & 1,000 & 1,000 & 1,000 & 1,000 & 1,000 & 1,000 & 1,000 & 0,997 & 1,000 & 1,000 & 1,000 & 1,000 & 1,000 \\
\hline Mg & 0,000 & & & & & & & & & & & & & & & & & & & 0,000 & 0,000 & 0,000 & 0,000 & 0,000 & \\
\hline $\mathrm{Fe}^{2+}$ & 0,000 & 0,020 & 0,000 & 0,011 & 0,015 & 0,009 & 0,000 & 0,055 & 0,022 & 0,000 & 0,000 & 0,000 & 0,000 & 0,000 & 0,0 & 0,000 & 0,009 & 0,025 & 0,010 & 0,000 & 0,000 & 0,000 & 0,010 & 0,000 & 0,077 \\
\hline $\mathrm{Mn}$ & 0,068 & 0,040 & 0,020 & 0,030 & 0,028 & 0,029 & 0,021 & 0,029 & 0,027 & 0,023 & 0,031 & 0,031 & 0,043 & 0,029 & 0,029 & 0,026 & 0,028 & 0,030 & 0,028 & 0,000 & 024 & 0,015 & 038 & 0,016 & 0,024 \\
\hline $\mathrm{Ca}$ & 0,840 & 0,850 & 0,900 & 0,873 & 0,880 & 0,877 & 0,887 & 0,848 & 0,858 & 0,897 & 0,878 & 0,870 & 0,857 & 0,854 & 0,878 & 0,890 & 0,889 & 0,864 & 0,881 & 0,888 & 891 & 0,906 & 872 & 0,896 & 0,840 \\
\hline $\mathrm{Na}$ & 0,092 & 0,089 & 0,078 & 0,086 & 0,077 & 0,085 & 0,092 & 0,067 & 0,093 & 0,079 & 0,091 & 0,097 & 0,097 & 0,109 & 0,089 & 0,085 & 0,074 & 0,079 & 0,079 & 0,114 & 0,086 & 0,079 & 0,079 & 0,087 & 0,059 \\
\hline к & 0,001 & 0,001 & 0,002 & 0,000 & 0,000 & 0,000 & 0,000 & 0,000 & 0,000 & 0,001 & 0,000 & 0,001 & 0,002 & 0,009 & 0,001 & 0,000 & 0,000 & 0,001 & 0,001 & 0,001 & 0,000 & 0,000 & 0,000 & 0,001 & 0,000 \\
\hline Soma M2 & 1,000 & 1,000 & 1,000 & 1,000 & 1,000 & 1,000 & 1,000 & 1,000 & 1,000 & 1,000 & 1,000 & 1,000 & 1,000 & 1,000 & 1,000 & 1,000 & 1,000 & 1,000 & 1,000 & 1,003 & 1,000 & 1,000 & 1,000 & 1,000 & 1,000 \\
\hline Total & 4,000 & 4,000 & 4,000 & 4,000 & 4,000 & 4,000 & 4,000 & 4,000 & 4,000 & 4,000 & 4,000 & 4,000 & 4,000 & 4,000 & 4,000 & 4,000 & 4,000 & 4,000 & 4,000 & 4,000 & 4,000 & 4,000 & 4,000 & 4,000 & 4,000 \\
\hline \multicolumn{26}{|c|}{ Jadeite activity } \\
\hline $800^{\circ} \mathrm{C}$ & 0,011 & & & & & & & & & & & & & & & & & & & 0,068 & 0,067 & 0,072 & 050 & 0,071 & \\
\hline $900^{\circ} \mathrm{C}$ & 0,009 & & & & & & & & & & & & & & & & & & & 0,058 & 0,056 & 0,060 & 0,042 & 0,060 & \\
\hline \multicolumn{26}{|c|}{ Hednbergite activity } \\
\hline $800^{\circ} \mathrm{C}$ & 0,278 & & & & & & & & & & & & & & & & & & & 0,158 & 0,08 & 0,108 & 076 & 0,084 & \\
\hline $900^{\circ} \mathrm{C}$ & 0,281 & & & & & & & & & & & & & & & & & & & 0,165 & 0,085 & 0,113 & 0,084 & 0,088 & \\
\hline
\end{tabular}

-n, núcleo; b, borda; <- sendo substituido por; -> substituindo; < incluso em; /, em contato com; aci, acicular; cav, em cavidade; idio, idiomórfico; ints, intersticial; poiq, poiquilitico 
ANEXO E - Tabela E.3 - Composição química de clinopiroxênios de rochas do Maciço Alcalino de Itatiaia. Continua..

\begin{tabular}{|c|c|c|c|c|c|c|c|c|c|c|c|c|c|c|c|c|c|c|c|c|c|c|c|c|c|}
\hline $\begin{array}{l}\text { Unidade } \\
\text { Amostra }\end{array}$ & $\begin{array}{l}\text { HblP } \\
\text { MAl160 }\end{array}$ & & & & & & & & & & & & & & & & \begin{tabular}{|l|} 
NeS-II \\
MAl166I \\
\end{tabular} & & & & & & & & \\
\hline Cristal & 68 & 69 & 69 & 69 & 70 & 70 & 71 & 71 & 71 & 72 & 72 & 72 & 72 & 1 & 3 & 4 & 73 & 73 & 73 & 74 & 74 & 75 & 75 & 76 & 77 \\
\hline Textura ${ }^{1}$ & $<-a n f b$ & $<-\operatorname{anf} n$ & $<-\operatorname{anf} b$ & $<-a n f b$ & $<-\operatorname{anf} n$ & $<-a n f b$ & $<-\operatorname{anf} n$ & $<-\operatorname{anf} b$ & $<$-anf b & l-anf & |-anf & /-anf b & $<-$ anf & TÜ & TÜ & Tü & $<-\operatorname{anf} n$ & $<-\operatorname{anf} b$ & $<-\operatorname{anf} b$ & $<$-anf n & $<-a n f b$ & $<-\operatorname{anf} n$ & $<-a n f b$ & $<-\operatorname{anfn}$ & $<-\operatorname{anf} \mathrm{n} 1$ \\
\hline $\mathrm{SiO}_{2}$ & 52,73 & 52,30 & 52,36 & 50,58 & 52,79 & 52,35 & 51,82 & 51,06 & 50,51 & 52,51 & 51,48 & 51,10 & 51,96 & 50,41 & 50,11 & 50,13 & 52,52 & 52,56 & 51,21 & 51,58 & 52,02 & 51,63 & 51,66 & 51,27 & 51,58 \\
\hline $\mathrm{TiO}_{2}$ & 0,84 & 0,80 & 0,84 & 0,90 & 0,60 & 1,02 & 0,84 & 1,24 & 0,85 & 0,79 & 0,61 & 0,96 & 0,84 & 0,89 & 0,83 & 0,92 & 0,79 & 0,84 & 0,77 & 0,78 & 0,66 & 0,70 & 0,68 & 0,40 & 0,92 \\
\hline $\mathrm{Al}_{2} \mathrm{O}_{3}$ & 2,38 & 2,22 & 2,22 & 2,93 & 2,30 & 2,36 & 2,47 & 3,57 & 3,05 & 2,14 & 2,63 & 2,88 & 2,40 & 2,59 & 2,28 & 2,37 & 2,19 & 2,24 & 2,51 & 1,87 & 2,02 & 2,11 & 2,16 & 1,91 & 2,68 \\
\hline $\mathrm{Cr}_{2} \mathrm{O}_{3}$ & 0,00 & & 0,01 & 0,05 & & & 0,02 & 0,03 & 0,04 & & & 0,01 & & & & & & 0,00 & & 0,01 & 0,01 & 0,02 & 0,01 & 0,02 & \\
\hline $\mathrm{ZrO}_{2}$ & 0,07 & 0,08 & 0,06 & 0,24 & 0,04 & 0,06 & 0,07 & 0,01 & 0,16 & 0,03 & 0,10 & 0,20 & 0,08 & 0,05 & 0,03 & 0,05 & & & 0,07 & 0,05 & & & 0,06 & 0,04 & \\
\hline $\mathrm{FeO}_{\mathrm{T}}^{2}$ & 7,78 & 7,75 & 8,43 & 12,06 & 7,73 & 8,51 & 8,49 & 8,66 & 12,02 & 7,40 & 11,10 & 10,29 & 8,44 & 7,85 & 6,43 & 7,00 & 7,55 & 7,57 & 10,85 & 9,22 & 9,50 & 10,29 & 10,64 & 12,56 & 9,42 \\
\hline $\mathrm{MnO}$ & 0,83 & 0,87 & 0,91 & 1,17 & 0,85 & 0,84 & 0,87 & 0,90 & 1,16 & 0,79 & 1,09 & 0,99 & 0,88 & 0,74 & 0,79 & 0,78 & 0,86 & 0,84 & 1,56 & 1,29 & 1,36 & 1,62 & 1,50 & 2,04 & 1,14 \\
\hline MgO & 13,30 & 13,74 & 13,28 & 9,97 & 13,37 & 13,21 & 13,14 & 11,78 & 9,54 & 13,82 & 10,56 & 11,23 & 13,08 & 12,67 & 14,41 & 13,70 & 13,95 & 14,02 & 10,79 & 12,33 & 12,00 & 11,04 & 11,13 & 9,55 & 12,33 \\
\hline $\mathrm{CaO}$ & 22,00 & 21,94 & 22,01 & 21,99 & 22,41 & 22,25 & 22,12 & 21,58 & 21,19 & 21,92 & 22,04 & 21,62 & 22,12 & 20,99 & 21,37 & 21,60 & 22,21 & 22,21 & 21,67 & 22,09 & 21,84 & 21,83 & 21,79 & 21,41 & 21,87 \\
\hline $\mathrm{Na}_{2} \mathrm{O}$ & 1,29 & 0,83 & 0,85 & 1,30 & 1,12 & 0,99 & 0,91 & 1,61 & 1,57 & 1,28 & 1,21 & 1,06 & 0,86 & 1,49 & 1,18 & 1,48 & 0,84 & 0,73 & 1,27 & 1,19 & 1,12 & 1,38 & 1,24 & 1,39 & 1,14 \\
\hline $\mathrm{K}_{2} \mathrm{O}$ & & & & 0,02 & & 0,02 & & 0,00 & & 0,09 & 0,01 & 0,03 & & 0,02 & 0,00 & 0,00 & 0,01 & 0,01 & 0,02 & 0,01 & & 0,00 & 0,02 & 0,01 & \\
\hline Soma & 101,23 & 100,53 & 100,97 & 101,21 & 101,21 & 101,61 & 100,76 & 100,44 & 100,09 & 100,77 & 100,83 & 100,36 & 100,66 & 97,70 & 97,43 & 98,04 & 100,91 & 101,02 & 100,72 & 100,40 & 100,53 & 100,62 & 100,89 & 100,61 & 101,08 \\
\hline $\mathrm{Fe}_{2} \mathrm{O}_{3}$ & 2,92 & 1,95 & 1,95 & 4,23 & 2,92 & 2,80 & 2,87 & 3,88 & 3,71 & 3,99 & 3,03 & 2,11 & 2,26 & 4,39 & 5,67 & 6,61 & 2,39 & 1,86 & 3,77 & 4,36 & 2,92 & 3,98 & 3,66 & 4,27 & 3,70 \\
\hline $\mathrm{FeO}$ & 5,15 & 5,99 & 6,68 & 8,25 & 5,10 & 5,99 & 5,90 & 5,17 & 8,68 & 3,81 & 8,38 & 8,39 & 6,41 & 3,90 & 1,33 & 1,05 & 5,40 & 5,90 & 7,46 & 5,30 & 6,87 & 6,71 & 7,35 & 8,71 & 6,09 \\
\hline Total & 101,44 & 100,65 & 101,10 & 101,34 & 101,46 & 101,83 & 100,95 & 100,79 & 100,25 & 101,15 & 101,03 & 100,36 & 100,81 & 98,14 & 98,00 & 98,70 & 101,15 & 101,20 & 101,03 & 100,79 & 100,81 & 101,00 & 101,19 & 100,97 & 101,45 \\
\hline \multicolumn{26}{|c|}{ Número de cátions calculado na base de 6 oxigênios. } \\
\hline Si & 1,929 & 1,930 & 1,931 & 1,893 & 1,933 & 1,917 & 1,914 & 1,891 & 1,909 & 1,924 & 1,924 & 1,915 & 1,922 & 1,909 & 1,888 & 1,881 & 1,928 & 1,929 & 1,915 & 1,918 & 1,936 & 1,927 & 1,926 & 1,935 & 1,905 \\
\hline Al & 0,071 & 0,070 & 0,069 & 0,107 & 0,067 & 0,083 & 0,086 & 0,109 & 0,091 & 0,076 & 0,076 & 0,085 & 0,078 & 0,091 & 0,101 & 0,105 & 0,072 & 0,071 & 0,085 & 0,082 & 0,064 & 0,073 & 0,074 & 0,065 & 0,095 \\
\hline $\mathrm{Fe}^{3+}$ & 0,000 & 0,000 & 0,000 & 0,000 & 0,000 & 0,000 & 0,000 & 0,000 & 0,000 & 0,000 & 0,000 & 0,000 & 0,000 & 0,000 & 0,011 & 0,014 & 0,000 & 0,000 & 0,000 & 0,000 & 0,000 & 0,000 & 0,000 & 0,000 & 0,000 \\
\hline Soma $T$ & 2,000 & 2,000 & 2,000 & 2,000 & 2,000 & 2,000 & 2,000 & 2,000 & 2,000 & 2,000 & 2,000 & 2,000 & 2,000 & 2,000 & 2,000 & 2,000 & 2,000 & 2,000 & 2,000 & 2,000 & 2,000 & 2,000 & 2,000 & 2,000 & 2,000 \\
\hline Al & 0,032 & 0,027 & 0,027 & 0,022 & 0,032 & 0,019 & 0,022 & 0,047 & 0,045 & 0,016 & 0,040 & 0,042 & 0,027 & 0,024 & 0,000 & 0,000 & 0,023 & 0,026 & 0,025 & 0,000 & 0,025 & 0,020 & 0,021 & 0,020 & 0,022 \\
\hline $\mathrm{Ti}$ & 0,024 & 0,022 & 0,024 & 0,025 & 0,017 & 0,028 & 0,024 & 0,034 & 0,024 & 0,022 & 0,017 & 0,027 & 0,024 & 0,025 & 0,023 & 0,026 & 0,022 & 0,023 & 0,021 & 0,022 & 0,018 & 0,019 & 0,019 & 0,011 & 0,026 \\
\hline $\mathrm{Fe}^{3+}$ & 0,080 & 0,054 & 0,054 & 0,119 & 0,080 & 0,077 & 0,080 & 0,108 & 0,106 & 0,110 & 0,085 & 0,059 & 0,063 & 0,124 & 0,148 & 0,170 & 0,066 & 0,051 & 0,106 & 0,122 & 0,082 & 0,112 & 0,103 & 0,121 & 0,103 \\
\hline $\mathrm{Zr}$ & 0,001 & 0,001 & 0,001 & 0,004 & 0,001 & 0,001 & 0,001 & 0,000 & 0,003 & 0,000 & 0,002 & 0,004 & 0,001 & 0,001 & 0,001 & 0,001 & 0,000 & 0,000 & 0,001 & 0,001 & 0,000 & 0,000 & 0,001 & 0,001 & 0,000 \\
\hline Mg & 0,726 & 0,756 & 0,730 & 0,556 & 0,730 & 0,721 & 0,724 & 0,650 & 0,538 & 0,755 & 0,588 & 0,627 & 0,721 & 0,715 & 0,809 & 0,766 & 0,763 & 0,767 & 0,601 & 0,684 & 0,666 & 0,614 & 0,619 & 0,537 & 0,679 \\
\hline $\mathrm{Fe}^{2+}$ & 0,137 & 0,139 & 0,164 & 0,258 & 0,141 & 0,154 & 0,150 & 0,160 & 0,274 & 0,097 & 0,262 & 0,241 & 0,164 & 0,111 & 0,019 & 0,036 & 0,126 & 0,133 & 0,233 & 0,165 & 0,209 & 0,210 & 0,229 & 0,275 & 0,171 \\
\hline$M n$ & 0,000 & 0,000 & 0,000 & 0,014 & 0,000 & 0,000 & 0,000 & 0,000 & 0,011 & 0,000 & 0,005 & 0,000 & 0,000 & 0,000 & 0,000 & 0,001 & 0,000 & 0,000 & 0,011 & 0,007 & 0,000 & 0,024 & 0,009 & 0,034 & 0,000 \\
\hline Soma M1 & 1,000 & 1,000 & 1,000 & 1,000 & 1,000 & 1,000 & 1,000 & 1,000 & 1,000 & 1,000 & 1,000 & 1,000 & 1,000 & 1,000 & 1,000 & 1,000 & 1,000 & 1,000 & 1,000 & 1,000 & 1,000 & 1,000 & 1,000 & 1,000 & 1,000 \\
\hline $\mathrm{Mg}$ & & & & & & & & & & & & & & 0,000 & 0,000 & 0,000 & & & & & & & & & \\
\hline $\mathrm{Fe}^{2+}$ & 0,021 & 0,046 & 0,042 & 0,000 & 0,015 & 0,030 & 0,032 & 0,000 & 0,000 & 0,020 & 0,000 & 0,022 & 0,034 & 0,014 & 0,025 & 0,000 & 0,040 & 0,048 & 0,000 & 0,000 & 0,005 & 0,000 & 0,000 & 0,000 & 0,017 \\
\hline $\mathrm{Mn}$ & 0,026 & 0,027 & 0,028 & 0,023 & 0,026 & 0,026 & 0,027 & 0,028 & 0,026 & 0,025 & 0,029 & 0,031 & 0,028 & 0,024 & 0,025 & 0,024 & 0,027 & 0,026 & 0,038 & 0,033 & 0,043 & 0,027 & 0,039 & 0,031 & 0,036 \\
\hline $\mathrm{Ca}$ & 0,863 & 0,868 & 0,869 & 0,882 & 0,879 & 0,873 & 0,875 & 0,856 & 0,858 & 0,860 & 0,883 & 0,868 & 0,877 & 0,852 & 0,863 & 0,868 & 0,874 & 0,873 & 0,868 & 0,880 & 0,871 & 0,873 & 0,870 & 0,866 & 0,865 \\
\hline $\mathrm{Na}$ & 0,092 & 0,059 & 0,061 & 0,094 & 0,079 & & 0,065 & 0,116 & 0,115 & 0,091 & & & 0,06 & 0,109 & & 0,108 & 0,060 & 0,052 & 0,092 & 0,086 & 0,081 & 0,100 & 0,090 & 0,102 & 0,082 \\
\hline $\mathrm{k}$ & 0,000 & 0,000 & 0,000 & 0,001 & 0,000 & 0,001 & 0,000 & 0,000 & 0,000 & 0,004 & 0,000 & 0,001 & 0,000 & 0,001 & 0,000 & 0,000 & 0,000 & 0,000 & 0,001 & 0,001 & 0,000 & 0,000 & 0,001 & 0,001 & 0,000 \\
\hline Soma M2 & 1,000 & 1,000 & 1,000 & 1,000 & 1,000 & 1,000 & 1,000 & 1,000 & 1,000 & 1,000 & 1,000 & 1,000 & 1,000 & 0,999 & 1,000 & 1,000 & 1,000 & 1,000 & 1,000 & 1,000 & 1,000 & 1,000 & 1,000 & 1,000 & 1,000 \\
\hline & 4,000 & 4,000 & 4,000 & 4,000 & 4,000 & 4,000 & 4,000 & 4,000 & 4,000 & 4,000 & 4,000 & 4,000 & 4,000 & 3,999 & 4,000 & 4,000 & 4,000 & 4,000 & 4,000 & 4,000 & 4,000 & 4,000 & 4,000 & 4,000 & 4,000 \\
\hline \multicolumn{26}{|c|}{ Jadeite activity } \\
\hline $800^{\circ} \mathrm{C}$ & & & & & & & & & & & & & & 0,090 & 0,0 & 0,071 & & & & & & & & & \\
\hline $900^{\circ} \mathrm{C}$ & & & & & & & & & & & & & & 0,076 & 0,053 & 0,060 & & & & & & & & & \\
\hline \multicolumn{26}{|l|}{ Hed } \\
\hline $800^{\circ} \mathrm{C}-(-1)$ & & & & & & & & & & & & & & 0,138 & 0,029 & 0,026 & & & & & & & & & \\
\hline $900^{\circ} \mathrm{C}$ & & & & & & & & & & & & & & 0,142 & 0,034 & 0,03 & & & & & & & & & \\
\hline
\end{tabular}

${ }^{\top}$ - n, núcleo; b, borda; <- sendo substituído por; - > substituindo; < incluso em; /, em contato com; aci, acicular; cav, em cavidade; idio, idiomórfico; ints, intersticial; poiq, poiquilítico 
ANEXO E - Tabela E.3 - Composição química de clinopiroxênios de rochas do Maciço Alcalino de Itatiaia. Continua...

\begin{tabular}{|c|c|c|c|c|c|c|c|c|c|c|c|c|c|c|c|c|c|c|c|c|c|c|c|c|c|}
\hline $\begin{array}{l}\text { Unidade } \\
\text { Amostra }\end{array}$ & $\begin{array}{l}\text { NeS-II } \\
\text { MAI166I }\end{array}$ & & & & & \begin{tabular}{|l} 
BtM \\
MAl182C
\end{tabular} & & & & & & & & & & & & & & & & & & & \\
\hline Cristal & 77 & 77 & 1 & $\overline{2}$ & $2 \mathrm{~b}$ & 78 & 78 & 79 & 79 & 80 & 81 & 81 & 82 & 83 & 83 & 84 & 84 & 85 & 85 & 86 & 86 & 87 & 87 & 88 & \\
\hline Textura ${ }^{2}$ & $<-\operatorname{anf} n 2$ & $<$-anf b & TÜ & TÜ & TÜ & poiq $n$ & poiq b & idion & idio b & $<b t n$ & $</ \mathrm{bt} \mathrm{n}$ & $</ b t b$ & $<b t n$ & poiq $n$ & poiq $b$ & poiq $n$ & poiq $b$ & poiq $n$ & poiq $b$ & $n$ & $b$ & $n$ & b & $<b t$ & TÜ \\
\hline$\overline{\mathrm{SiO}_{2}}$ & 51,90 & 50,60 & 51,37 & 47,54 & 48,77 & 52,86 & 52,10 & 51,87 & 52,91 & 52,31 & 52,97 & 52,90 & 53,22 & 52,88 & 52,65 & 53,00 & 52,86 & 52,11 & 52,76 & 51,92 & 52,57 & 53,19 & 52,73 & 52,89 & 51,61 \\
\hline $\mathrm{TiO}_{2}$ & 0,57 & 0,73 & 0,67 & 0,47 & 0,36 & 0,56 & 0,51 & 0,85 & 0,56 & 0,49 & 0,72 & 0,54 & 0,47 & 0,50 & 0,56 & 0,65 & 0,74 & 0,88 & 0,57 & 0,77 & 0,51 & 0,53 & 0,69 & 0,36 & 0,57 \\
\hline $\mathrm{Al}_{2} \mathrm{O}_{3}$ & 2,01 & 2,61 & 1,91 & 2,10 & 1,65 & 1,37 & 1,51 & 1,74 & 1,48 & 1,43 & 1,50 & 1,42 & 1,16 & 1,25 & 1,54 & 1,53 & 1,68 & 1,79 & 1,31 & 1,97 & 1,43 & 1,28 & 1,44 & 1,24 & 1,34 \\
\hline $\mathrm{Cr}_{2} \mathrm{O}_{3}$ & 0,01 & 0,02 & & & & 0,01 & & 0,03 & 0,00 & 0,02 & 0,05 & 0,02 & 0,02 & 0,02 & & 0,04 & & & & & & 0,02 & & & \\
\hline $\mathrm{ZrO}_{2}$ & 0,02 & 0,11 & 0,05 & 0,13 & 0,08 & 0,03 & 0,01 & 0,05 & 0,01 & 0,02 & 0,03 & 0,06 & 0,05 & 0,02 & & & & 0,09 & 0,01 & 0,07 & & 0,02 & 0,01 & 0,01 & 0,02 \\
\hline $\mathrm{FeO}_{T}$ & 9,72 & 11,82 & 8,35 & 11,88 & 11,60 & 10,00 & 9,75 & 10,90 & 10,07 & 10,63 & 10,10 & 9,94 & 9,39 & 10,25 & 9,67 & 9,85 & 10,23 & 9,88 & 10,18 & 10,86 & 10,62 & 10,16 & 11,37 & 10,03 & 8,83 \\
\hline $\mathrm{MnO}$ & 1,41 & 1,77 & 1,19 & 1,96 & 2,03 & 0,84 & 0,83 & 0,75 & 0,87 & 0,89 & 0,85 & 0,85 & 0,75 & 0,87 & 0,83 & 0,82 & 0,88 & 0,77 & 0,84 & 0,80 & 0,86 & 0,78 & 0,91 & 0,85 & 0,79 \\
\hline $\mathrm{MgO}$ & 11,87 & 10,03 & 12,78 & 9,61 & 9,95 & 14,77 & 13,83 & 13,86 & 13,73 & 13,86 & 14,59 & 13,87 & 14,33 & 14,30 & 13,95 & 14,66 & 14,05 & 14,37 & 14,03 & 13,53 & 14,51 & 15,24 & 14,87 & 14,67 & 14,00 \\
\hline CaO & 21,86 & 21,43 & 22,07 & 21,33 & 21,32 & 19,84 & 20,97 & 20,27 & 20,72 & 20,40 & 20,18 & 20,64 & 21,28 & 20,12 & 20,90 & 19,99 & 20,68 & 19,99 & 20,11 & 20,13 & 19,58 & 19,63 & 18,67 & 19,68 & 20,40 \\
\hline $\mathrm{Na}_{2} \mathrm{O}$ & 1,08 & 1,52 & 1,06 & 1,64 & 1,50 & 0,43 & 0,45 & 0,43 & 0,49 & 0,41 & 0,45 & 0,44 & 0,40 & 0,37 & 0,43 & 0,40 & 0,45 & 0,46 & 0,39 & 0,52 & 0,40 & 0,42 & 0,38 & 0,41 & 0,40 \\
\hline $\mathrm{K}_{2} \mathrm{O}$ & & 0,02 & 0,00 & 0,01 & 0,00 & 0,02 & 0,03 & 0,02 & 0,03 & 0,01 & 0,02 & 0,04 & & & 0,01 & 0,01 & & 0,01 & 0,01 & & & & 0,02 & & 0,01 \\
\hline Soma & 100,45 & 100,67 & 99,45 & 96,67 & 97,26 & 100,72 & 99,99 & 100,77 & 100,87 & 100,47 & 101,46 & 100,73 & 101,07 & 100,56 & 100,53 & 100,96 & 101,58 & 100,35 & 100,20 & 100,56 & 100,47 & 101,26 & 101,09 & 100,14 & 97,96 \\
\hline $\mathrm{Fe}_{2} \mathrm{O}_{3}$ & 3,03 & 5,30 & 3,84 & 9,56 & 7,75 & 1,00 & 1,67 & 1,74 & 0,63 & 1,44 & 1,06 & 0,40 & 0,80 & 0,45 & 0,79 & 0,39 & 1,00 & 1,00 & 0,04 & 1,27 & 1,07 & 1,26 & 0,98 & 0,65 & 0,42 \\
\hline $\mathrm{FeO}$ & 6,99 & 7,05 & 4,89 & 3,28 & 4,63 & 9,10 & 8,24 & 9,33 & 9,51 & 9,34 & 9,15 & 9,58 & 8,67 & 9,85 & 8,96 & 9,50 & 9,33 & 8,98 & 10,15 & 9,72 & 9,66 & 9,03 & 10,49 & 9,44 & 8,45 \\
\hline Total & 100,73 & 101,07 & 99,83 & 97,63 & 98,04 & 100,78 & 100,15 & 100,86 & 100,92 & 100,58 & 101,48 & 100,69 & 101,08 & 100,57 & 100,61 & 100,96 & 101,68 & 100,36 & 100,20 & 100,62 & 100,58 & 101,36 & 101,19 & 100,20 & 98,00 \\
\hline \multicolumn{26}{|c|}{ Número de cátions calculado na base de 6 oxigênios. } \\
\hline Si & 1,936 & 1,899 & 1,922 & 1,857 & 1,893 & 1,956 & 1,946 & 1,929 & 1,962 & 1,949 & 1,949 & 1,964 & 1,964 & 1,965 & 1,955 & 1,958 & 1,945 & 1,937 & 1,969 & 1,935 & 1,954 & 1,955 & 1,950 & 1,968 & 1,963 \\
\hline Al & 0,064 & 0,101 & 0,078 & 0,097 & 0,075 & 0,044 & 0,054 & 0,071 & 0,038 & 0,051 & 0,051 & 0,036 & 0,036 & 0,035 & 0,045 & 0,042 & 0,055 & 0,063 & 0,031 & 0,065 & 0,046 & 0,045 & 0,050 & 0,032 & 0,037 \\
\hline $\mathrm{Fe}^{3+}$ & 0,000 & 0,000 & 0,000 & 0,046 & 0,031 & 0,000 & 0,000 & 0,000 & 0,000 & 0,000 & 0,000 & 0,000 & 0,000 & 0,000 & 0,000 & 0,000 & 0,000 & 0,000 & 0,000 & 0,000 & 0,000 & 0,000 & 0,000 & 0,000 & 0,000 \\
\hline Soma $T$ & 2,000 & 2,000 & 2,000 & 2,000 & 2,000 & 2,000 & 2,000 & 2,000 & 2,000 & 2,000 & 2,000 & 2,000 & 2,000 & 2,000 & 2,000 & 2,000 & 2,000 & 2,000 & 2,000 & 2,000 & 2,000 & 2,000 & 2,000 & 2,000 & 2,000 \\
\hline Al & 0,024 & 0,015 & 0,007 & 0,000 & 0,000 & 0,016 & 0,012 & 0,005 & 0,026 & 0,012 & 0,014 & 0,026 & 0,014 & 0,020 & 0,023 & 0,024 & 0,018 & 0,016 & 0,027 & 0,021 & 0,016 & 0,010 & 0,013 & 0,023 & 0,023 \\
\hline $\mathrm{Ti}$ & 0,016 & 0,021 & 0,019 & 0,013 & 0,010 & 0,016 & 0,014 & 0,024 & 0,016 & 0,014 & 0,020 & 0,015 & 0,013 & 0,014 & 0,016 & 0,018 & 0,021 & 0,024 & 0,016 & 0,021 & 0,014 & 0,015 & 0,019 & 0,010 & 0,016 \\
\hline $\mathrm{Fe}^{3+}$ & 0,085 & 0,150 & 0,107 & 0,228 & 0,191 & 0,028 & 0,047 & 0,049 & 0,017 & 0,040 & 0,029 & 0,011 & 0,022 & 0,013 & 0,022 & 0,011 & 0,028 & 0,028 & 0,001 & 0,036 & 0,030 & 0,035 & 0,027 & 0,018 & 0,012 \\
\hline $\mathrm{Zr}$ & 0,000 & 0,002 & 0,001 & 0,002 & 0,002 & 0,000 & 0,000 & 0,001 & 0,000 & 0,000 & 0,001 & 0,001 & 0,001 & 0,000 & 0,000 & 0,000 & 0,000 & 0,002 & 0,000 & 0,001 & 0,000 & 0,000 & 0,000 & 0,000 & 0,000 \\
\hline $\mathrm{Mg}$ & 0,660 & 0,561 & 0,713 & 0,560 & 0,576 & 0,815 & 0,770 & 0,768 & 0,759 & 0,770 & 0,800 & 0,768 & 0,788 & 0,792 & 0,772 & 0,807 & 0,771 & 0,796 & 0,780 & 0,752 & 0,804 & 0,835 & 0,820 & 0,814 & 0,794 \\
\hline $\mathrm{Fe}^{2+}$ & 0,215 & 0,221 & 0,154 & 0,114 & 0,154 & 0,126 & 0,157 & 0,153 & 0,182 & 0,164 & 0,136 & 0,179 & 0,161 & 0,161 & 0,167 & 0,139 & 0,162 & 0,134 & 0,176 & 0,169 & 0,136 & 0,105 & 0,121 & 0,135 & 0,156 \\
\hline $\mathrm{Mn}$ & 0,000 & 0,030 & 0,000 & 0,065 & 0,067 & 0,000 & 0,000 & 0,000 & 0,000 & 0,000 & 0,000 & 0,000 & 0,000 & 0,000 & 0,000 & 0,000 & 0,000 & 0,000 & 0,000 & 0,000 & 0,000 & 0,000 & 0,000 & 0,000 & 0,000 \\
\hline Soma M1 & 1,000 & 1,000 & 1,000 & 0,982 & 1,000 & 1,000 & 1,000 & 1,000 & 1,000 & 1,000 & 1,000 & 1,000 & 1,000 & 1,000 & 1,000 & 1,000 & 1,000 & 1,000 & 1,000 & 1,000 & 1,000 & 1,000 & 1,000 & 1,000 & 1,000 \\
\hline $\mathrm{Mg}$ & & & 0,000 & 0,000 & 0,000 & & & & & & & & & & & & & & & & & & & & 0,000 \\
\hline $\mathrm{Fe}^{2+}$ & 0,004 & 0,000 & 0,001 & 0,000 & 0,000 & 0,156 & 0,101 & 0,137 & 0,113 & 0,127 & 0,145 & 0,119 & 0,107 & 0,145 & 0,111 & 0,154 & 0,125 & 0,146 & 0,141 & 0,134 & 0,165 & 0,173 & 0,203 & 0,159 & 0,113 \\
\hline$M n$ & 0,045 & 0,026 & 0,038 & 0,000 & 0,000 & 0,026 & 0,026 & 0,024 & 0,027 & 0,028 & 0,026 & 0,027 & 0,024 & 0,027 & 0,026 & 0,026 & 0,027 & 0,024 & 0,026 & 0,025 & 0,027 & 0,024 & 0,029 & 0,027 & 0,025 \\
\hline $\mathrm{Ca}$ & 0,874 & 0,862 & 0,885 & 0,893 & 0,887 & 0,787 & 0,839 & 0,808 & 0,823 & 0,814 & 0,795 & 0,821 & 0,841 & 0,801 & 0,832 & 0,791 & 0,815 & 0,796 & 0,804 & 0,804 & 0,780 & 0,773 & 0,740 & 0,785 & 0,831 \\
\hline $\mathrm{Na}$ & 0,078 & 0,111 & 0,077 & 0,124 & 0,113 & 0,031 & 0,032 & 0,031 & 0,035 & 0,029 & 0,032 & 0,031 & 0,029 & 0,026 & 0,031 & 0,029 & 0,032 & 0,033 & 0,028 & 0,037 & 0,029 & 0,030 & 0,027 & 0,030 & 0,030 \\
\hline $\mathrm{k}$ & 0,000 & 0,001 & 0,000 & 0,000 & 0,000 & 0,001 & 0,001 & 0,001 & 0,002 & 0,001 & 0,001 & 0,002 & 0,000 & 0,000 & 0,000 & 0,001 & 0,000 & 0,001 & 0,000 & 0,000 & 0,000 & 0,000 & 0,001 & 0,000 & 0,000 \\
\hline Soma M2 & 1,000 & 1,000 & 1,000 & 1,017 & 1,000 & 1,000 & 1,000 & 1,000 & 1,000 & 1,000 & 1,000 & 1,000 & 1,000 & 1,000 & 1,000 & 1,000 & 1,000 & 1,000 & 1,000 & 1,000 & 1,000 & 1,000 & 1,000 & 1,000 & 1,000 \\
\hline Total & 4,000 & 4,000 & 4,000 & 3,999 & 4,000 & 4,000 & 4,000 & 4,000 & 4,000 & 4,000 & 4,000 & 4,000 & 4,000 & 4,000 & 4,000 & 4,000 & 4,000 & 4,000 & 4,000 & 4,000 & 4,000 & 4,000 & 4,000 & 4,000 & 4,000 \\
\hline \multicolumn{26}{|c|}{ Jadeite activity } \\
\hline $800^{\circ} \mathrm{C}$ & & & 0,056 & 0,05 & 0,051 & & & & & & & & & & & & & & & & & & & & 0,025 \\
\hline $900^{\circ} \mathrm{C}$ & & & 0,047 & 0,050 & 0,043 & & & & & & & & & & & & & & & & & & & & 0,020 \\
\hline \multicolumn{26}{|c|}{ Hednbergite activity } \\
\hline $800^{\circ} \mathrm{C}$ & & & 0,15 & 0,108 & 0,16 & & & & & & & & & & & & & & & & & & & & 0,182 \\
\hline $900^{\circ} \mathrm{C}$ & & & 0,155 & 0,117 & 0,166 & & & & & & & & & & & & & & & & & & & & 0,191 \\
\hline
\end{tabular}

$\frac{1}{1}$-n, núcleo; b, borda; <- sendo substituído por; -> substituindo; < incluso em; /, em contato com; aci, acicular; cav, em cavidade; idio, idiomórfico; ints, intersticial; poiq, poiquilítico 
ANEXO E - Tabela E.3 - Composição química de clinopiroxênios de rochas do Maciço Alcalino de Itatiaia. Continua...

\begin{tabular}{|c|c|c|c|c|c|c|c|c|c|c|c|c|c|c|c|c|c|c|c|c|c|c|c|c|c|}
\hline $\begin{array}{l}\text { Unidade } \\
\text { Amostra }\end{array}$ & $\begin{array}{l}\text { BtM } \\
\text { MAl182C }\end{array}$ & & & & $\begin{array}{l}\text { tAgtNeS } \\
\text { MAl199 }\end{array}$ & & & & & & & & & & & & & & & & & & & & \\
\hline Cristal & & & & & 89 & 89 & 90 & 91 & 91 & 92 & 92 & 92 & 93 & 93 & 94 & 95 & 95 & 96 & 96 & 97 & 97 & 98 & 99 & 100 & 1 \\
\hline Textura ${ }^{1}$ & TÜ & TÜ & TÜ & TÜ & $\operatorname{lanf} n$ & /anf $b$ & $\operatorname{lanf} n$ & lanf & /anf poiq & $<$ anf & $\operatorname{lanf} \mathrm{n}$ & $\operatorname{lanf} b$ & $n$ & b & $n$ & $n$ & $\mathrm{~b}$ & lanf $n$ & $\operatorname{lanf} \mathrm{b}$ & $\operatorname{lanf} n$ & $\operatorname{lanf} \mathrm{b}$ & /anf poiq & idio & /anf-rin & TÜ \\
\hline $\mathrm{SiO}_{2}$ & 51,54 & 49,76 & 52,43 & 51,88 & 51,44 & 51,77 & 51,21 & 51,70 & 51,48 & 51,27 & 51,35 & 51,36 & 51,13 & 52,08 & 51,25 & 51,05 & 51,51 & 51,56 & 51,54 & 51,54 & 51,73 & 51,73 & 51,94 & 52,25 & 51,88 \\
\hline $\mathrm{TiO}_{2}$ & 0,51 & 0,69 & 0,65 & 0,53 & 0,96 & 0,91 & 0,97 & 0,46 & 0,82 & 1,23 & 1,02 & 0,83 & 1,11 & 0,89 & 1,21 & 1,08 & 0,96 & 0,90 & 0,81 & 1,30 & 1,16 & 0,63 & 0,80 & 0,92 & 1,08 \\
\hline $\mathrm{Al}_{2} \mathrm{O}_{3}$ & 1,16 & 1,83 & 1,53 & 1,40 & 1,10 & 1,55 & 1,05 & 1,09 & 0,98 & 1,03 & 1,06 & 1,04 & 1,03 & 1,06 & 1,01 & 0,99 & 0,90 & 0,92 & 1,07 & 1,02 & 1,14 & 1,05 & 1,08 & 1,12 & 1,00 \\
\hline $\mathrm{Cr}_{2} \mathrm{O}_{3}$ & & & & & & & 0,02 & & & 0,02 & & & & 0,03 & & & 0,02 & 0,05 & 0,02 & & 0,00 & & 0,03 & 0,06 & \\
\hline $\mathrm{ZrO}_{2}$ & 0,04 & 0,05 & 0,05 & 0,03 & 1,07 & 0,89 & 0,88 & 0,34 & 0,70 & 1,07 & 0,86 & 0,93 & 0,97 & 0,79 & 1,18 & 0,89 & 0,95 & 0,93 & 1,00 & 0,64 & 1,01 & 0,35 & 0,29 & 0,37 & 1,04 \\
\hline $\mathrm{FeO}_{\mathrm{T}}^{2}$ & 9,92 & 8,43 & 9,42 & 10,62 & 22,41 & 20,52 & 21,33 & 26,08 & 24,42 & 22,39 & 21,76 & 23,86 & 21,76 & 22,40 & 24,66 & 21,75 & 20,96 & 22,49 & 22,57 & 24,35 & 25,49 & 25,72 & 25,23 & 25,47 & 21,84 \\
\hline $\mathrm{MnO}$ & 0,86 & 0,70 & 0,85 & 0,92 & 1,66 & 1,73 & 1,68 & 0,64 & 1,09 & 1,72 & 1,76 & 1,35 & 1,78 & 1,48 & 1,15 & 1,73 & 1,72 & 1,59 & 1,39 & 1,24 & 1,14 & 0,98 & 0,96 & 0,87 & 1,86 \\
\hline MgO & 15,06 & 14,04 & 14,49 & 14,83 & 2,68 & 3,37 & 3,48 & 1,45 & 1,65 & 2,89 & 3,25 & 2,16 & 3,18 & 2,80 & 1,60 & 3,06 & 3,51 & 2,82 & 2,51 & 1,93 & 1,54 & 1,33 & 1,52 & 1,49 & 3,28 \\
\hline $\mathrm{CaO}$ & 18,77 & 18,94 & 20,40 & 19,85 & 7,80 & 8,70 & 9,17 & 3,56 & 5,47 & 8,25 & 8,78 & 6,37 & 8,75 & 7,25 & 4,49 & 8,53 & 8,87 & 7,56 & 6,43 & 6,07 & 4,77 & 4,62 & 4,99 & 4,36 & 9,07 \\
\hline $\mathrm{Na}_{2} \mathrm{O}$ & 0,39 & 0,48 & 0,43 & 0,38 & 8,82 & 8,49 & 7,99 & 11,30 & 10,01 & 8,75 & 8,19 & 9,53 & 8,07 & 9,11 & 10,52 & 8,42 & 8,05 & 8,96 & 9,21 & 9,87 & 10,48 & 10,50 & 10,46 & 10,82 & 8,86 \\
\hline $\mathrm{K}_{2} \mathrm{O}$ & 0,01 & 0,00 & 0,00 & 0,00 & & 0,00 & 0,01 & & 0,04 & 0,04 & & 0,02 & & 0,01 & 0,02 & 0,00 & 0,02 & 0,03 & 0,01 & 0,03 & 0,04 & 0,03 & 0,05 & 0,02 & 0,01 \\
\hline Soma & 98,26 & 94,92 & 100,25 & 100,45 & 97,94 & 97,93 & 97,79 & 96,62 & 96,65 & 98,66 & 98,04 & 97,44 & 97,78 & 97,89 & 97,10 & 97,50 & 97,46 & 97,81 & 96,57 & 98,00 & 98,48 & 96,94 & 97,35 & 97,75 & 99,92 \\
\hline $\mathrm{Fe}_{2} \mathrm{O}_{3}$ & 1,54 & 0,55 & 1,04 & 2,96 & 17,79 & 16,57 & 16,44 & 24,79 & 20,32 & 18,54 & 16,75 & 19,81 & 16,16 & 17,96 & 21,26 & 17,42 & 15,68 & 18,48 & 17,51 & 20,56 & 21,77 & 22,17 & 22,00 & 22,32 & 20,76 \\
\hline $\mathrm{FeO}$ & 8,54 & 7,93 & 8,49 & 7,96 & 6,40 & 5,61 & 6,54 & 3,77 & 6,13 & 5,71 & 6,69 & 6,04 & 7,22 & 6,24 & 5,54 & 6,08 & 6,85 & 5,86 & 6,81 & 5,85 & 5,90 & 5,77 & 5,43 & 5,39 & 3,16 \\
\hline Total & 98,42 & 94,98 & 100,35 & 100,75 & 98,65 & 98,70 & 98,54 & 98,77 & 97,98 & 99,43 & 98,86 & 98,50 & 98,43 & 98,88 & 98,05 & 98,36 & 98,07 & 98,68 & 97,30 & 99,42 & 99,66 & 98,81 & 99,24 & 99,55 & 102,00 \\
\hline \multicolumn{26}{|c|}{ Número de cátions calculado na base de 6 oxigênios. } \\
\hline $\mathrm{Si}$ & 1,951 & 1,947 & 1,948 & 1,926 & 1,987 & 1,988 & 1,981 & 1,993 & 2,005 & 1,967 & 1,982 & 1,989 & 1,983 & 2,003 & 1,987 & 1,980 & 1,998 & 1,990 & 2,012 & 1,982 & 1,980 & 2,003 & 2,001 & 2,002 & 1,957 \\
\hline Al & 0,049 & 0,053 & 0,052 & 0,061 & 0,013 & 0,012 & 0,019 & 0,007 & 0,000 & 0,033 & 0,018 & 0,011 & 0,017 & 0,000 & 0,013 & 0,020 & 0,002 & 0,010 & 0,000 & 0,018 & 0,020 & 0,000 & 0,000 & 0,000 & 0,043 \\
\hline $\mathrm{Fe}^{3+}$ & 0,000 & 0,000 & 0,000 & 0,012 & 0,000 & 0,000 & 0,000 & 0,000 & 0,000 & 0,000 & 0,000 & 0,000 & 0,000 & 0,000 & 0,000 & 0,000 & 0,000 & 0,000 & 0,000 & 0,000 & 0,000 & 0,000 & 0,000 & 0,000 & 0,000 \\
\hline Soma $T$ & 2,000 & 2,000 & 2,000 & 2,000 & 2,000 & 2,000 & 2,000 & 2,000 & 2,005 & 2,000 & 2,000 & 2,000 & 2,000 & 2,003 & 2,000 & 2,000 & 2,000 & 2,000 & 2,012 & 2,000 & 2,000 & 2,003 & 2,001 & 2,002 & 2,000 \\
\hline Al & 0,003 & 0,031 & 0,015 & 0,000 & 0,036 & 0,059 & 0,029 & 0,043 & 0,045 & 0,013 & 0,031 & 0,036 & 0,030 & 0,048 & 0,033 & 0,025 & 0,039 & 0,032 & 0,049 & 0,028 & 0,032 & 0,048 & 0,049 & 0,050 & 0,002 \\
\hline $\mathrm{Ti}$ & 0,014 & 0,019 & 0,018 & 0,015 & 0,027 & 0,025 & 0,027 & 0,013 & 0,023 & 0,034 & 0,029 & 0,023 & 0,031 & 0,025 & 0,034 & 0,030 & 0,027 & 0,025 & 0,023 & 0,036 & 0,032 & 0,018 & 0,022 & 0,026 & 0,030 \\
\hline $\mathrm{Fe}^{3+}$ & 0,044 & 0,016 & 0,029 & 0,070 & 0,517 & 0,479 & 0,479 & 0,719 & 0,596 & 0,535 & 0,487 & 0,577 & 0,472 & 0,520 & 0,620 & 0,508 & 0,458 & 0,537 & 0,514 & 0,595 & 0,627 & 0,646 & 0,638 & 0,644 & 0,561 \\
\hline $\mathrm{zr}$ & 0,001 & 0,001 & 0,001 & 0,001 & 0,020 & 0,017 & 0,017 & 0,006 & 0,013 & 0,020 & 0,016 & 0,018 & 0,018 & 0,015 & 0,022 & 0,017 & 0,018 & 0,018 & 0,019 & 0,012 & 0,019 & 0,007 & 0,005 & 0,007 & 0,019 \\
\hline $\mathrm{Mg}$ & 0,850 & 0,819 & 0,803 & 0,821 & 0,154 & 0,193 & 0,201 & 0,083 & 0,096 & 0,165 & 0,187 & 0,125 & 0,184 & 0,161 & 0,093 & 0,177 & 0,203 & 0,162 & 0,146 & 0,111 & 0,088 & 0,077 & 0,088 & 0,085 & 0,184 \\
\hline $\mathrm{Fe}^{2+}$ & 0,088 & 0,114 & 0,134 & 0,094 & 0,207 & 0,180 & 0,212 & 0,122 & 0,200 & 0,183 & 0,216 & 0,195 & 0,234 & 0,201 & 0,180 & 0,197 & 0,222 & 0,189 & 0,222 & 0,188 & 0,189 & 0,187 & 0,175 & 0,173 & 0,129 \\
\hline $\mathrm{Mn}$ & 0,000 & 0,000 & 0,000 & 0,000 & 0,039 & 0,047 & 0,036 & 0,013 & 0,028 & 0,049 & 0,035 & 0,026 & 0,031 & 0,031 & 0,018 & 0,046 & 0,033 & 0,038 & 0,026 & 0,030 & 0,014 & 0,018 & 0,023 & 0,015 & 0,059 \\
\hline Soma M1 & 1,000 & 1,000 & 1,000 & 1,000 & 1,000 & 1,000 & 1,000 & 1,000 & 1,000 & 1,000 & 1,000 & 1,000 & 1,000 & 1,000 & 1,000 & 1,000 & 1,000 & 1,000 & 1,000 & 1,000 & 1,000 & 1,000 & 1,000 & 1,000 & 0,984 \\
\hline Mg & 0,000 & 0,000 & 0,000 & 0,000 & & & & & & & & & & & & & & & & & & & & & 0,000 \\
\hline $\mathrm{Fe}^{2+}$ & 0,182 & 0,146 & 0,130 & 0,154 & 0,000 & 0,000 & 0,000 & 0,000 & 0,000 & 0,000 & 0,000 & 0,000 & 0,000 & 0,000 & 0,000 & 0,000 & 0,000 & 0,000 & 0,000 & 0,000 & 0,000 & 0,000 & 0,000 & 0,000 & 0,000 \\
\hline$M n$ & 0,028 & 0,023 & 0,027 & 0,029 & 0,016 & 0,009 & 0,019 & 0,008 & 0,008 & 0,007 & 0,023 & 0,018 & 0,028 & 0,017 & 0,020 & 0,011 & 0,024 & 0,014 & 0,020 & 0,011 & 0,023 & 0,014 & 0,008 & 0,013 & 0,000 \\
\hline $\mathrm{Ca}$ & 0,761 & 0,794 & 0,812 & 0,790 & 0,323 & 0,358 & 0,380 & 0,147 & 0,228 & 0,339 & 0,363 & 0,264 & 0,364 & 0,299 & 0,187 & 0,354 & 0,369 & 0,313 & 0,269 & 0,250 & 0,196 & 0,192 & 0,206 & 0,179 & 0,367 \\
\hline $\mathrm{Na}$ & 0,028 & 0,036 & 0,031 & 0,027 & 0,660 & 0,632 & 0,599 & 0,845 & 0,756 & 0,651 & 0,613 & 0,716 & 0,607 & 0,679 & 0,791 & 0,633 & 0,606 & 0,671 & 0,697 & 0,736 & 0,778 & 0,788 & 0,781 & 0,804 & 0,648 \\
\hline к & 0,000 & 0,000 & 0,000 & 0,000 & 0,000 & 0,000 & 0,000 & 0,000 & 0,002 & 0,002 & 0,000 & 0,001 & 0,000 & 0,001 & 0,001 & 0,000 & 0,001 & 0,001 & 0,001 & 0,002 & 0,002 & 0,001 & 0,003 & 0,001 & 0,000 \\
\hline Soma M2 & 1,000 & 0,999 & 1,000 & 1,000 & 0,999 & 0,999 & 0,999 & 0,999 & 0,994 & 0,999 & 0,999 & 0,999 & 0,999 & 0,996 & 0,998 & 0,999 & 0,999 & 0,999 & 0,987 & 0,999 & 0,999 & 0,996 & 0,998 & 0,997 & 1,015 \\
\hline & 4,000 & 3,999 & 4,000 & 4,000 & 3,999 & 3,999 & 3,999 & 3,999 & 3,999 & 3,999 & 3,999 & 3,999 & 3,999 & 3,999 & 3,998 & 3,999 & 3,999 & 3,999 & 3,999 & 3,999 & 3,999 & 3,999 & 3,999 & 3,999 & 3,999 \\
\hline \multicolumn{26}{|c|}{ Jadeite activity } \\
\hline $800^{\circ} \mathrm{C}$ & 0,020 & 0, & 0, & 0, & & & & & & & & & & & & & & & & & & & & & 0,043 \\
\hline $900^{\circ} \mathrm{C}$ & 0,016 & 0,031 & 0,022 & 0,016 & & & & & & & & & & & & & & & & & & & & & 0,042 \\
\hline \multicolumn{26}{|c|}{ Hednbergite activity } \\
\hline $800^{\circ} \mathrm{C}$ & 0,149 & 0,157 & 0,172 & 0,139 & & & & & & & & & & & & & & & & & & & & & 0,317 \\
\hline $900^{\circ} \mathrm{C}$ & 0,16 & 0,168 & 0,181 & 0,151 & & & & & & & & & & & & & & & & & & & & & 0,315 \\
\hline
\end{tabular}


ANEXO E - Tabela E.3 - Composição química de clinopiroxênios de rochas do Maciço Alcalino de Itatiaia.

Unidade BtAgtNeS

\begin{tabular}{|c|c|c|c|c|c|}
\hline Cristal & 2 & 3 & 4 & 5 & 6 \\
\hline Textura ${ }^{1}$ & TÜ & TÜ & TÜ & TÜ & TÜ \\
\hline $\mathrm{SiO}_{2}$ & 51,40 & 51,91 & 52,85 & 51,93 & 52,22 \\
\hline $\mathrm{TiO}_{2}$ & 0,71 & 1,48 & 0,73 & 1,31 & 1,09 \\
\hline $\mathrm{Al}_{2} \mathrm{O}_{3}$ & 0,78 & 0,96 & 1,02 & 0,96 & 1,08 \\
\hline \multicolumn{6}{|l|}{$\mathrm{Cr}_{2} \mathrm{O}_{3}$} \\
\hline $\mathrm{ZrO}_{2}$ & 0,77 & 1,18 & 0,66 & 1,16 & 0,83 \\
\hline $\mathrm{FeO}_{\mathrm{T}}$ & 21,74 & 25,14 & 26,22 & 25,01 & 24,08 \\
\hline $\mathrm{MnO}$ & 2,11 & 1,22 & 0,72 & 1,21 & 1,30 \\
\hline MgO & 3,48 & 1,35 & 1,39 & 1,83 & 2,14 \\
\hline $\mathrm{CaO}$ & 10,14 & 4,31 & 3,65 & 5,13 & 6,06 \\
\hline $\mathrm{Na}_{2} \mathrm{O}$ & 7,84 & 11,77 & 11,84 & 11,16 & 10,09 \\
\hline $\mathrm{K}_{2} \mathrm{O}$ & 0,01 & 0,01 & 0,01 & 0,01 & 0,06 \\
\hline Soma & 98,97 & 99,33 & 99,09 & 99,71 & 98,95 \\
\hline $\mathrm{Fe}_{2} \mathrm{O}_{3}$ & 18,79 & 27,59 & 27,55 & 26,55 & 22,25 \\
\hline $\mathrm{FeO}$ & 4,83 & 0,32 & 1,43 & 1,12 & 4,06 \\
\hline Total & 100,85 & 102,10 & 101,85 & 102,37 & 101,18 \\
\hline \multicolumn{6}{|c|}{ Número de cátions calculado na base de 6 oxigênios. } \\
\hline Si & 1,968 & 1,954 & 1,987 & 1,952 & 1,984 \\
\hline Al & 0,032 & 0,043 & 0,013 & 0,043 & 0,016 \\
\hline $\mathrm{Fe}^{3+}$ & 0,000 & 0,003 & 0,000 & 0,006 & 0,000 \\
\hline Soma $T$ & 2,000 & 2,000 & 2,000 & 2,000 & 2,000 \\
\hline Al & 0,003 & 0,000 & 0,032 & 0,000 & 0,032 \\
\hline $\mathrm{Ti}$ & 0,020 & 0,041 & 0,020 & 0,037 & 0,030 \\
\hline $\mathrm{Fe}^{3+}$ & 0,517 & 0,727 & 0,729 & 0,698 & 0,603 \\
\hline $\mathrm{zr}$ & 0,014 & 0,022 & 0,012 & 0,021 & 0,015 \\
\hline $\mathrm{Mg}$ & 0,199 & 0,076 & 0,078 & 0,103 & 0,121 \\
\hline $\mathrm{Fe}^{2+}$ & 0,179 & 0,061 & 0,096 & 0,082 & 0,162 \\
\hline Mn & 0,068 & 0,039 & 0,023 & 0,038 & 0,035 \\
\hline Soma M1 & 1,000 & 0,966 & 0,989 & 0,979 & 1,000 \\
\hline Mg & 0,000 & 0,000 & 0,000 & 0,000 & 0,000 \\
\hline $\mathrm{Fe}^{2+}$ & 0,000 & 0,000 & 0,000 & 0,000 & 0,000 \\
\hline $\mathrm{Mn}$ & 0,001 & 0,000 & 0,000 & 0,000 & 0,006 \\
\hline $\mathrm{Ca}$ & 0,416 & 0,174 & 0,147 & 0,207 & 0,247 \\
\hline $\mathrm{Na}$ & 0,582 & 0,859 & 0,863 & 0,813 & 0,743 \\
\hline K & 0,000 & 0,000 & 0,001 & 0,000 & 0,003 \\
\hline Soma M2 & 0,999 & 1,033 & 1,010 & 1,020 & 0,999 \\
\hline Total & 3,999 & 3,999 & 4,000 & 4,000 & 3,999 \\
\hline \multicolumn{6}{|c|}{ Jadeite activity } \\
\hline $800^{\circ} \mathrm{C}$ & 0,035 & 0,041 & 0,043 & 0,040 & 0,047 \\
\hline $900^{\circ} \mathrm{C}$ & 0,033 & 0,041 & 0,043 & 0,040 & 0,046 \\
\hline \multicolumn{6}{|c|}{ Hednbergite activity } \\
\hline $800^{\circ} \mathrm{C}$ & 0,42 & 0 & 0,743 & 0,133 & 0,437 \\
\hline $900^{\circ} \mathrm{C}$ & 0,419 & 0 & 0,717 & 0,134 & 0,437 \\
\hline
\end{tabular}

$\begin{array}{rrrrrr}800^{\circ} \mathrm{C} & 0,42 & 0 & 0,743 & 0,133 & 0,437 \\ \mathbf{9 0 0} \mathrm{C} & 0,419 & 0 & 0,717 & 0,134 & 0,437\end{array}$

-n, núcleo; b, borda; <- sendo substituído por; -> substituindo; < incluso em; /, em contato com; aci, acicular; cav, em cavidade; idio, idiomórfico; ints, intersticial; poiq, poiquilítico 
ANEXO E - Tabela E.4 - Composição química de anfibólios de rochas do Maciço Alcalino de Itatiaia. Continua...

\begin{tabular}{|c|c|c|c|c|c|c|c|c|c|c|c|c|c|c|c|c|c|c|c|c|c|c|c|}
\hline Unidade & BtHbNeS & & & & & & & & & & & & & & & & BtHblP & & & & & & \\
\hline Amostra & MAI036 & & & & & & & & & & & & & & & & MAI092I & & & & & & \\
\hline Cristal & 1 & 1 & 2 & 2 & 3 & 3 & 3 & 4 & 4 & $\begin{array}{r}5 \\
->\mathrm{cpx} \times \mathrm{c} /\end{array}$ & $\begin{array}{r}5 \\
\rightarrow>\mathrm{cp} \times \mathrm{c} /\end{array}$ & $\begin{array}{r}5 \\
->\mathrm{cp} \times \mathrm{c} /\end{array}$ & $\begin{array}{r}6 \\
->\mathrm{cpx} \times \mathrm{c} /\end{array}$ & $\begin{array}{r}6 \\
->\mathrm{cpx} c /\end{array}$ & $\begin{array}{r}7 \\
->\mathrm{cpxc} /\end{array}$ & $\begin{array}{r}7 \\
->c p x c / 1\end{array}$ & 8 & 8 & 9 & 10 & 11 & 11 & $\begin{array}{r}12 \\
->\mathrm{px} / \mathrm{bt}\end{array}$ \\
\hline & $\rightarrow c p x n$ & $\rightarrow c p \times b$ & $\rightarrow$ bt n & $\rightarrow$ - bt b & $n$ & $\mathrm{nb}$ & b & $c / \operatorname{lam} n$ & $c / \operatorname{lamb}$ & $\operatorname{lam} n$ & $\operatorname{lam} n$ & $\operatorname{lamb}$ & $\operatorname{lam} n$ & $\operatorname{lamb}$ & $\operatorname{lam} n$ & $\operatorname{lamb}$ & $\rightarrow>c p x n$ & $\rightarrow c p p x b$ & $\rightarrow c p x$ & idio & idion & idio b & \\
\hline $\mathrm{SiO}_{2}$ & 39,57 & 39,12 & 39,46 & 39,38 & 39,49 & 39,51 & 38,56 & 39,64 & 38,78 & 40,11 & 39,51 & 40,14 & 39,64 & 39,27 & 39,83 & 39,40 & 40,41 & 40,16 & 39,03 & 39,38 & 39,49 & 39,45 & 40,27 \\
\hline $\mathrm{TiO}_{2}$ & 4,60 & 3,56 & 4,07 & 3,72 & 3,48 & 4,38 & 2,59 & 4,47 & 2,26 & 3,79 & 4,06 & 2,89 & 2,65 & 3,74 & 1,80 & 2,30 & 2,39 & 1,38 & 2,30 & 1,41 & 1,37 & 1,28 & 2,63 \\
\hline $\mathrm{Al}_{2} \mathrm{O}_{3}$ & 12,26 & 12,77 & 12,21 & 12,52 & 12,15 & 12,39 & 12,78 & 12,96 & 13,39 & 12,26 & 12,37 & 13,94 & 12,02 & 12,50 & 12,57 & 12,72 & 11,75 & 11,52 & 11,56 & 11,61 & 11,47 & 11,72 & 11,59 \\
\hline MnO & 20 & 1,38 & 1,17 & 1,20 & 1,34 & 1,21 & 1,42 & 1,01 & 1,19 & 1,07 & 1,28 & 1,15 & 1,39 & 1,34 & 1,40 & 1,43 & 1,28 & 1,52 & 1,58 & 2,19 & 2,34 & 2,52 & 1,61 \\
\hline $\mathrm{FeO}_{\mathrm{T}}$ & 15,83 & 17,64 & 16,51 & 17,13 & 17,69 & 16,32 & 18,85 & 14,49 & 17,62 & 14,59 & 15,91 & 16,07 & 18,05 & 16,57 & 18,48 & 18,61 & 16,77 & 19,90 & 21,11 & 21,34 & 21,30 & 21,74 & 17,99 \\
\hline no & 03 & 0,06 & 0,09 & 0,06 & 0,04 & 0,08 & 0,05 & 0,03 & 0,04 & 0,05 & 0,06 & 0,06 & 0,04 & 0,02 & 0,05 & 0,07 & 0,04 & 0,07 & 0,08 & 0,12 & 0,07 & 0,13 & 0,03 \\
\hline hgo & 9,59 & 8,65 & 9,66 & 9,11 & 8,74 & 9,58 & 8,34 & 10,57 & 9,32 & 10,90 & 9,93 & 8,32 & 8,96 & 9,25 & 8,97 & 8,61 & 10,07 & 8,45 & 7,42 & 7,19 & 7,23 & 6,49 & 9,30 \\
\hline $\mathrm{CaO}$ & 10,55 & 10,99 & 10,74 & 11,00 & 10,89 & 10,68 & 10,88 & 10,75 & 10,77 & 10,91 & 10,67 & 10,05 & 10,88 & 10,84 & 11,12 & 10,94 & 10,96 & 10,16 & 10,39 & 10,24 & 10,38 & 10,22 & 10,59 \\
\hline $\mathrm{Na}_{2} \mathrm{O}$ & 2,92 & 2,72 & 2,87 & 2,83 & 2,76 & 2,90 & 2,64 & 2,92 & 2,65 & 2,99 & 2,88 & 2,60 & 2,78 & 2,74 & 2,76 & 2,67 & 3,00 & 3,23 & 3,04 & 3,19 & 3,11 & 3,04 & 3,00 \\
\hline $\mathrm{K}_{2} \mathrm{O}$ & 1,89 & 2,08 & 1,96 & 2,01 & 1,91 & 1,91 & 1,98 & 1,95 & 2,04 & 1,87 & 1,91 & 1,92 & 1,95 & 2,02 & 1,87 & 2,05 & 1,98 & 1,83 & 1,90 & 1,83 & 1,0 & 1,79 & 1,75 \\
\hline & 0,02 & 0,01 & 0,02 & & & 0,00 & & & & 0,01 & & & & & 0,01 & & 0,01 & & 0,00 & 0,01 & 0,00 & & 0,00 \\
\hline $\mathrm{Cl}$ & 0,03 & 0,06 & 0,05 & 0,04 & 0,05 & 0,05 & 0,03 & 0,05 & 0,03 & 0,05 & 0,02 & 0,04 & 0,05 & 0,06 & 0,05 & 0,05 & 0,01 & 0,02 & 0,04 & 0,01 & ,00 & 0,02 & 0,02 \\
\hline Soma & 98,47 & 99,03 & 98,80 & 99,00 & 98,54 & 99,01 & 98,12 & 98,84 & 98,09 & 98,58 & 98,60 & 97,19 & 98,41 & 98,35 & 98,91 & 98,84 & 98,67 & 98,24 & 98,46 & 98,52 & 98,56 & 98,40 & 98,79 \\
\hline $\mathrm{FeO}$ & 6,81 & 9,14 & 7,10 & 8,57 & 9,62 & 6,89 & 10,12 & 5,30 & 8,83 & 5,97 & 6,52 & 11,38 & 10,05 & 8,10 & 11,14 & 10,66 & 8,65 & 11,74 & 11,82 & 12,59 & 12,78 & 13,94 & 9,52 \\
\hline $\mathrm{Fe}_{2} \mathrm{O}_{3}$ & 10,03 & 9,45 & 10,46 & 9,52 & 8,97 & 10,48 & 9,70 & 10,21 & 9,77 & 9,58 & 10,43 & 5,22 & 8,89 & 9,41 & 8,15 & 8,83 & 9,02 & 9,07 & 10,32 & 9,72 & 9,47 & 8,67 & 9,42 \\
\hline Total & 99,48 & 99,98 & 99,85 & 99,96 & 99,44 & 100,06 & 99,09 & 99,86 & 99,07 & 99,54 & 99,65 & 97,71 & 99,30 & 99,29 & 99,73 & 99,73 & 99,57 & 99,15 & 99,49 & 99,50 & 99,51 & 99,27 & 99,73 \\
\hline \multicolumn{24}{|c|}{ ins calculado na base de 24 ânions. } \\
\hline Si & 5,989 & 5,933 & 5,959 & 5,957 & 6,015 & 5,953 & 5,904 & 5,930 & 5,881 & 6,009 & 5,957 & 6,137 & 6,033 & 5,968 & 6,021 & 5,977 & 6,081 & 6,121 & 6,004 & 6,048 & ,065 & ,091 & 6,085 \\
\hline & & 67 & 2 & 2,043 & & 2,047 & 96 & 2,070 & 2,119 & 1,991 & 43 & 1, & 1,967 & 2,032 & 1,979 & 2,023 & 1,919 & 1,879 & 1,996 & 2 & 5 & 909 & 1,915 \\
\hline & 00 & 0,000 & 0,000 & 0,000 & 0,000 & 0,000 & 0,000 & 0,000 & 0,000 & 0,000 & 0,000 & 0,000 & 0,000 & 0,000 & 0,000 & 0,000 & 0,000 & 0,000 & 0,000 & 0,000 & 0,000 & 0,000 & 0,000 \\
\hline Soma T & 8,000 & 8,000 & 8,000 & 8,000 & 8,000 & 8,000 & 8,000 & 8,000 & 8,000 & 8,000 & 8,000 & 8,000 & 8,000 & 8,000 & 8,000 & 8,000 & 8,000 & 8,000 & 8,000 & 8,000 & 8,000 & 8,000 & 8,000 \\
\hline ri & 0,524 & 0,406 & 0,462 & 0,423 & 0 , & 0,497 & 0,298 & 0,503 & 0,258 & 0,427 & 0,461 & 0,332 & 0,303 & 0,428 & 0,205 & 0,262 & 0,271 & 0,159 & 0,266 & 0,163 & 0,158 & 0,149 & 0,299 \\
\hline & & 0,216 & & & & & 0,210 & 0,215 & 0,274 & 0,174 & 0,155 & 0,649 & 0,189 & 0,207 & 0,261 & 0,251 & 0,165 & 0,191 & 0,100 & 0,150 & 0,141 & ,223 & 0,149 \\
\hline $\mathrm{e}^{3+}$ & & 78 & & & & 1 & & 1,150 & 1,114 & 1,080 & 1,184 & 0,599 & 1,01 & 1,077 & 0,928 & 1,008 & 1,021 & 1,039 & , 195 & 24 & 4 & 007 & 1,070 \\
\hline 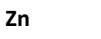 & & 0,006 & 0 & 0,0 & & 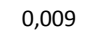 & 005 & 0,003 & 0,004 & 0,005 & 0 , & 0,007 & 0,005 & 0,002 & 0,00 & 0,007 & 0,004 & 0,008 & 9 & 0,014 & 88 & ,015 & 0,004 \\
\hline $\mathrm{Mn}$ & 29 & 0,177 & 35 & 0,1 & 0,162 & 0,132 & 169 & 0,108 & 0,123 & 0,131 & 0,140 & 0,060 & 0,172 & 0,162 & 0,170 & 0,171 & 0,163 & 0,186 & 0,206 & 0,285 & 0,302 & ,312 & 0,180 \\
\hline $\mathrm{Fe}^{2+}$ & & & & & & & 1,296 & 0,663 & 1,121 & 0748 & 0,822 & & 1,279 & 1,029 & 1,408 & 1,353 & 1,089 & 1,497 & 521 & ,617 & 1,641 & 800 & 1,203 \\
\hline . & 64 & 1,956 & 2,175 & 2,054 & 1,985 & 2,152 & 1,904 & 2,357 & 2,107 & 2,434 & 2,232 & 1,896 & 2,033 & 2,096 & 2,022 & 1,947 & 2,259 & 1,920 & ,702 & ,646 & ,655 & ,494 & 2,095 \\
\hline Soma & 5,000 & 4,998 & 4,999 & 4,993 & 5,000 & 5,001 & 4,999 & 4,999 & 5,001 & 4,999 & 5,001 & 4,998 & 4,999 & 5,001 & 5,000 & 4,999 & 4,972 & 5,000 & 4,999 & 4,999 & 4,999 & 5,000 & 5,000 \\
\hline in & 24 & 0,000 & 4 & 0,000 & $\perp$ & 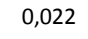 & 5 & 0,020 & 0,030 & 0,004 & 0,024 & 0,089 & 0,007 & 0,010 & 0,009 & 0,013 & 0,000 & 0,010 & 0,000 &, 000 & 0,003 & 0,018 & 0,026 \\
\hline 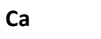 & & & & & & & & 1,723 & 1,750 & & 4 & & & & & 1,778 & 1,767 & 1,659 & & 5 & 8 & 91 & 1,715 \\
\hline $\mathrm{Na}$ & & & & & & & & & & & & & & & & 0,209 & & & & & & 2 & 0,260 \\
\hline Soma B & 2,000 & 2,000 & 2,000 & 2,000 & 2,000 & 2,000 & 2,000 & 2,000 & 2,001 & 1,999 & 2,000 & 2,000 & 2,000 & 2,000 & 2,000 & 2,000 & 2,000 & 2,000 & 2,000 & 2,000 & 2,000 & 2,001 & 2,001 \\
\hline $\mathrm{Na}$ & & & & & & & & 0,590 & 0.55 & 0,62 & 0,59 & & & 0,583 & 0,619 & 0,577 & 2 & 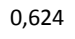 & 0,619 & & & 18 & 0,619 \\
\hline N & & 0,402 & & 0,388 & & t & & 0,372 & 0,395 & 0,357 & 0,367 & 0,374 & 0,379 & 0,392 & 0,361 & 0,397 & 0,380 & 0,356 & , ,373 & 0,359 & ,353 & ,353 & 0,337 \\
\hline Soma A & 0,957 & 0,988 & 0,970 & 1,001 & 0,974 & 0,960 & 0,970 & 0,962 & 0,954 & 0,981 & 0,957 & 0,880 & 0,980 & 0,975 & 0,980 & 0,974 & 1,022 & 0,980 & 0,992 & 0,994 & 0,990 & 0,971 & 0,956 \\
\hline 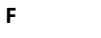 & 0,007 & 0, & 7 & 0,000 & 0,000 & 0 & bo & 0,000 & 0,000 & 0,003 & 0,000 & 0,000 & 0,000 & 0,000 & 0,004 & 0,000 & 0,003 & 0,000 & 0,002 & 0,007 & 0,002 & 0,000 & 0,001 \\
\hline $\mathrm{Cl}$ & & 0,014 & & 0,0 & & & & 0,012 & 0,009 & 0,012 & & & & & & 0,012 & 0,004 & 0,005 & 11 & & & & 0,006 \\
\hline Soma W & 0,013 & 0,018 & 0,019 & 0,011 & 0,012 & 0,013 & 0,007 & 0,012 & 0,009 & 0,015 & 0,006 & 0,011 & 0,012 & 0,015 & 0,016 & 0,012 & 0,007 & 0,005 & 0,013 & 0,009 & 0,003 & 0,004 & 0,007 \\
\hline
\end{tabular}

Total

n, núcleo; b, borda; <- sendo substituído por; -> substituindo; < incluso em; /, em contato com; idio, idiomórfico; c/ lam, comlamelas de titanita. 
ANEXO E - Tabela E.4 - Composição química de anfibólios de rochas do Maciço Alcalino de Itatiaia. Continua..

\begin{tabular}{|c|c|c|c|c|c|c|c|c|c|c|c|c|c|c|c|c|c|c|c|c|c|c|c|}
\hline \multirow{4}{*}{$\begin{array}{l}\text { Unidade } \\
\text { Amostra } \\
\text { Cristal } \\
\text { Textura }^{1}\end{array}$} & \multicolumn{9}{|l|}{ BtHblP } & & \multicolumn{7}{|l|}{ QzAFS-I } \\
\hline & MAI092I & & & & & & & & & & \multicolumn{6}{|c|}{$\begin{array}{l}\mathrm{N}-\mathrm{I} \\
\text { MAI097B }\end{array}$} & \multicolumn{7}{|l|}{ MAI110 } \\
\hline & & 13 & 13 & 14 & 14 & 15 & 15 & 16 & 17 & 18 & 18 & 19 & 19 & 20 & 20 & 21 & 22 & 22 & 23 & 24 & 24 & 25 & 25 \\
\hline & & $->c p \times n$ & $\rightarrow$ cpp b & idion & idio b & $\rightarrow b t n$ & $\rightarrow b t b$ & $\rightarrow>p p x$ & $\rightarrow>c p x b$ & $n$ & b & $n$ & b & $n$ & b & $n$ & $>c p \times n$ & $>c p \times b$ & $>c p \times b$ & $<-b t n$ & $<-b t b$ & $n 1$ & n2 \\
\hline $\mathrm{iO}_{2}$ & 39,14 & 40,38 & 39,74 & 39,49 & 38,81 & 38,91 & 39,26 & 39,53 & 40,00 & 51,71 & 52,69 & 52,93 & 52,36 & 52,29 & 50,69 & 49,01 & 52,86 & 49,95 & 49,77 & 51,18 & 49,45 & 49,24 & 49,73 \\
\hline $\mathrm{TiO}_{2}$ & 1,44 & 2,34 & 1,34 & 1,41 & 1,27 & 1,68 & 1,45 & 2,29 & 1,33 & 1,13 & 0,75 & 0,71 & 0,78 & 0,84 & 1,07 & 1,32 & 0,11 & 0,49 & 0,77 & 0,65 & 0,75 & 1,02 & 1,04 \\
\hline $\mathrm{Al}_{2} \mathrm{O}_{3}$ & 11,78 & 11,45 & 11,52 & 11,74 & 11,79 & 11,19 & 11,40 & 11,56 & 10,95 & 3,47 & 2,54 & 2,28 & 2,56 & 2,75 & 3,96 & 5,22 & 1,27 & 2,20 & 1,79 & 1,34 & 2,84 & 3,30 & 3,23 \\
\hline $\mathrm{MnO}$ & 1,99 & 2,03 & 2,51 & 2,57 & 2,57 & 2,62 & 2,55 & 1,86 & 2,51 & 1,89 & 2,00 & 2,14 & 2,28 & 1,97 & 1,92 & 2,11 & 2,46 & 2,85 & 3,32 & 2,88 & 2,85 & 2,37 & 2,65 \\
\hline $\mathrm{FeO}_{\mathrm{T}}$ & 21,35 & 16,79 & 20,34 & 20,93 & 22,05 & 22,45 & 21,05 & 20,93 & 20,59 & 10,38 & 10,35 & 10,73 & 11,20 & 10,36 & 9,86 & 12,01 & 19,79 & 23,19 & 24,19 & 21,11 & 21,25 & 18,65 & 19,38 \\
\hline $\mathrm{ZnO}$ & ,10 & 0,08 & 0,13 & 0,14 & 0,13 & 0,13 & 0,14 & 0,07 & 0,12 & 0,07 & 0,05 & 0,09 & 0,09 & 0,06 & 0,06 & 0,03 & 0,08 & 0,18 & 0,19 & 0,19 & 0,16 & 0,11 & 0,11 \\
\hline MgO & 7,41 & 9,93 & 7,60 & 7,16 & 6,40 & 6,79 & 7,10 & 7,33 & 7,60 & 16,42 & 16,57 & 16,26 & 15,68 & 16,67 & 16,25 & 15,31 & 10,35 & 7,75 & 6,70 & 9,49 & 8,90 & 10,63 & 10,11 \\
\hline $\mathrm{CaO}$ & 10,27 & 10,59 & 10,32 & 9,91 & 9,99 & 10,10 & 10,03 & 10,59 & 10,31 & 8,43 & 7,79 & 7,76 & 7,46 & 7,97 & 8,45 & 8,58 & 9,15 & 6,95 & 6,07 & 5,49 & 6,82 & 7,94 & 7,71 \\
\hline $\mathrm{Na}_{2} \mathrm{O}$ & 3,09 & 3,13 & 3,11 & 3,21 & 3,28 & 3,17 & 3,37 & 2,95 & 3,16 & 4,15 & 4,34 & 4,15 & 4,20 & 4,15 & 3,95 & 4,01 & 1,96 & 3,91 & 4,33 & 5,05 & 4,22 & 4,29 & 4,32 \\
\hline${ }_{2} \mathrm{O}$ & 1,92 & 1,67 & 1,79 & 1,85 & 1,92 & 1,89 & 1,78 & 1,85 & 1,82 & 1,07 & 0,94 & 0,97 & 0,96 & 0,93 & 1,08 & 1,14 & 0,48 & 1,04 & 1,00 & 0,87 & t & 90 & 0,90 \\
\hline-1 & & 0,02 & & & 0,01 & 0,00 & 0,00 & 0,02 & 0,00 & 0,00 & 0,02 & 0,01 & 0,01 & 0,02 & & 0,01 & 0,01 & 0,02 & 0,01 & 0,00 & 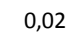 & 0,01 & 0,04 \\
\hline $\mathrm{Cl}$ & 0,00 & 0,01 & & 0,01 & 0,01 & 0,04 & 0,03 & 0,03 & 0,02 & 0,05 & 0,03 & 0,02 & & & 0,02 & 0,04 & 0,02 & 0,05 & 0,03 & 0,02 & 0,02 & 0,02 & 0,01 \\
\hline Soma & 98,49 & 98,41 & 98,40 & 98,41 & 98,23 & 98,98 & 98,16 & 99,01 & 98,41 & 98,76 & 98,06 & 98,05 & 97,59 & 98,02 & 97,31 & 98,78 & 98,55 & 98,58 & 98,17 & 98,27 & 98,42 & 98,48 & 99,24 \\
\hline eO & 12,13 & 8,24 & 12,12 & 12,06 & 12,90 & 11,94 & 11,98 & 12,47 & 12,44 & 8,10 & 8,03 & 8,38 & 8,64 & 7,79 & 7,57 & 6,83 & 15,83 & 20,57 & 21,26 & 17,88 & 18,38 & 16,39 & 17,02 \\
\hline $\mathrm{Fe}_{2} \mathrm{O}_{3}$ & 10,25 & 9,50 & 9,13 & 9,86 & 10,17 & 11,68 & 10,08 & 9,40 & 9,06 & 2,54 & 2,58 & 2,61 & 2,85 & 2,86 & 2,54 & 5,75 & 4,40 & 2,91 & 3,25 & 3,59 & 3,19 & 2,51 & 2,63 \\
\hline Total & 99,52 & 99,36 & 99,32 & 99,40 & 99,25 & 100,15 & 99,17 & 99,96 & 99,32 & 99,02 & 98,32 & 98,31 & 97,88 & 98,30 & 97,57 & 99,36 & 98,99 & 98,88 & 98,50 & 98,63 & 98,74 & 98,73 & 99,50 \\
\hline \multicolumn{24}{|c|}{ ions calculado na base de 24 ânions. } \\
\hline 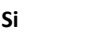 & 6,004 & 6,094 & 6,091 & 6,061 & 6,007 & 5,983 & 6,054 & 6,053 & 6,141 & 7,438 & 7,591 & 7,634 & 7,606 & 7,539 & 7,386 & 7,095 & 7,802 & 7,626 & 7,682 & 7,730 & 7,513 & 7,412 & 7,448 \\
\hline 1 & 1,996 & 1,906 & 1,909 & 1,939 & 1,993 & 2,017 & 1,946 & 1,947 & 1,859 & 0,562 & 0,409 & 0,366 & 0,394 & 0,461 & 0,614 & 0,891 & 0,198 & 0,374 & 0,318 & 0,239 & 0,487 & 0,585 & 0,552 \\
\hline & 0,000 & 0,000 & 0,000 & 0,000 & 0,000 & 0,000 & 0,000 & 0,000 & 0,000 & 0,000 & 0,000 & 0,000 & 0,000 & 0,000 & 0,000 & 0,015 & 0,000 & 0,000 & 0,000 & 0,031 & 0,000 & ,003 & 0,000 \\
\hline Soma T & 8,000 & 8,000 & 8,000 & 8,000 & 8,000 & 8,000 & 8,000 & 8,000 & 8,000 & 8,000 & 8,000 & 8,000 & 8,000 & 8,000 & 8,000 & 8,001 & 8,000 & 8,000 & 8,000 & 8,000 & 8,000 & 8,000 & 8,000 \\
\hline $\mathrm{Ti}$ & 0,166 & 0,266 & 0,154 & 0,162 & 0,148 & 0 , & 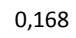 & 0,264 & 154 & 22 & 881 & 77 & 0,086 & 91 & 117 & 0,129 & 0,013 & 0,056 & 39 & 042 & 85 & 12 & ,117 \\
\hline Al & & & & & & & & 0,139 & 0,123 & 0,026 & 0,022 & 0 & 0,045 & 0,006 & 0,066 & 0,000 & 0,022 & 0,022 & 07 & 0,000 & 22 & 000 & 0,018 \\
\hline $\mathrm{Fe}^{3+}$ & 182 & 1,078 & 1,053 & 1,139 & 1,184 & 1,352 & 169 & 1,083 & 1,048 & 0,275 & 0,279 & 0,284 & 0,311 & 0,310 & 0,279 & 0,627 & 0,488 & 0,335 & 0,378 & 0,408 & 0,364 &, 284 & 0,297 \\
\hline 7 & 12 & 0,009 & 0,015 & & & & & 0,008 & 0,013 & 007 & 0,005 & 0,010 & 0,010 & 0,006 & 0,006 & 0,003 & 009 & 0,020 & 2 & 21 & 8 & 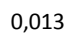 & 0,012 \\
\hline $\mathrm{Mn}$ & & & & & & & & & 0,326 & & & & & 0,065 & 0,080 & 0,110 & 0,236 & 0,177 & 8 & 34 & 58 & 4 & 0,168 \\
\hline $\mathrm{Fe}^{2+}$ & 557 & 1,041 & 1,554 & 1,548 & 1,670 & 1,535 & 1,545 & 1,598 & 1,596 & 0,974 & 0,968 & 1,011 & 1,049 & 0,939 & 0,922 & 0,827 & 1,954 & 2,626 & 2,744 & 2,258 & 2,336 & ,064 & 2,130 \\
\hline $\mathrm{Mr}$ & & & & 1,6 & & & & 1,673 & 1,739 & 521 & 3 & 3 & 3,396 & 3,583 & 3,530 & 3,304 & 2,277 & 1,764 & 42 & 37 & 16 & 385 & 2,257 \\
\hline Soma C & 5,000 & 5,001 & 4,999 & 5,000 & 4,988 & 4,999 & 4,989 & 5,000 & 4,999 & 5,000 & 5,000 & 5,000 & 5,000 & 5,000 & 5,000 & 5,000 & 4,999 & 5,000 & 5,000 & 5,000 & 4,999 & 5,000 & 4,999 \\
\hline $\mathrm{Mn}$ & & 0, & & & & & & & 000 & & & & & 0,176 & & 0,148 & 0,071 & 0,192 & 6 & 35 & 8 & 50 & 0,168 \\
\hline $\mathrm{Ca}$ & & & & & & & & & & & & & & & & 1,331 & 17 & & & & & & 237 \\
\hline No & 308 & 0,270 & 0,295 & 0,350 & 0,343 & 0,331 & 0,343 & 0,256 & 0,304 & 0,546 & 0,639 & 0,640 & 0,662 & 0,593 & 0,524 & 0,521 & 0,482 & 0,671 & ,780 & 0,877 & ,681 & , 559 & 0,595 \\
\hline Soma B & 2,000 & 2,000 & 2,001 & 2,000 & 2,000 & 2,000 & 2,000 & 2,001 & 2,000 & 2,000 & 2,000 & 2,000 & 2,000 & 2,000 & 2,000 & 2,000 & 2,000 & 2,000 & 2,000 & 2,000 & 1,999 & 2,000 & 2,000 \\
\hline $\mathrm{Va}$ & 0,611 & 0,646 & o & 0,605 & 0,641 & 0,614 & 5 & 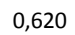 & 537 & 1 & 3 & 0,521 & 0 , & 0 & 0,592 & 0,605 & 0,079 & 0,486 & 16 & 02 &, 562 & 993 & 0,660 \\
\hline K & 0,376 & 0,322 & & & & & & 0,361 & 0,356 & 0,196 & 4 & 0,179 & 0,179 & 0,171 & 0,201 & 0,210 & 0,091 & 0,203 & 0,197 & 168 &, 221 & 173 & 0,173 \\
\hline Som & 0,987 & 0,968 & 0,980 & 0,967 & 1,020 & 0,985 & 1,015 & 0,981 & 0,993 & 0,807 & 0,747 & 0,700 & 0,700 & 0,738 & 0,793 & 0,815 & 0,170 & 0,689 & 0,713 & 0,770 & 0,783 & 0,866 & 0,833 \\
\hline & 00 & 0,00 & 0,00 & 0,0 & 0,0 & 0,0 & 2 & 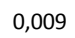 & 001 & 0,000 & 0 & 0, & 0,00 & 0,011 & 0,000 & 0,005 & 0,004 & 0,011 & 0,005 & 0,002 & ,009 & .004 & ,019 \\
\hline & & & & & & & & & & 12 & & & 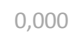 & 000 & 05 & 009 & 006 & 012 & 008 & 005 & 004 & 004 &, 003 \\
\hline oma W & 0,001 & 0, & 00 & 2 & 18 & 12 & 09 & 0,017 & 0,005 & 12 & 015 & 0,008 & 0,005 & 0,011 & 0,005 & 0,014 & 0,010 & 0,023 & 13 & 0,007 & ,013 & ,008 & 022 \\
\hline ta & 5,987 & ,969 & 980 & ,967 &, 008 &, 984 & 5,004 & 5,982 & 5,992 & 5,807 & 5,747 & 5,700 & 5,700 & 5,738 & 5,793 & 15,816 & 15,169 & 15,689 & 15,713 & 5,770 & 15,781 & 15,866 & 5,832 \\
\hline
\end{tabular}

n, núcleo; b, borda; <- sendo substituído por; -> substituindo; < incluso em; /, em contato com; idio, idiomórfico; c/ lam, comlamelas de titanita. 
ANEXO E - Tabela E.4 - Composição química de anfibólios de rochas do Maciço Alcalino de Itatiaia. Continua...

\begin{tabular}{|c|c|c|c|c|c|c|c|c|c|c|c|c|c|c|c|c|c|c|c|c|c|c|c|}
\hline \multirow{4}{*}{$\begin{array}{l}\text { Unidade } \\
\text { Amostra } \\
\text { Cristal } \\
\text { Textura }^{1}\end{array}$} & \multirow{3}{*}{$\begin{array}{r}\text { QzAFS-I } \\
\text { MAI110 } \\
25\end{array}$} & \multirow[b]{3}{*}{26} & \multirow[b]{3}{*}{26} & \multirow[b]{3}{*}{26} & \multirow[b]{3}{*}{27} & \multirow[b]{3}{*}{28} & \multirow[b]{3}{*}{28} & \multirow[b]{3}{*}{29} & \multirow[b]{3}{*}{30} & \multirow[b]{3}{*}{30} & \multirow[b]{3}{*}{30} & \multirow[b]{3}{*}{30} & \multirow[b]{3}{*}{30} & \multirow{2}{*}{\multicolumn{10}{|c|}{$\begin{array}{l}\text { BtHbIP } \\
\text { MAI114 }\end{array}$}} \\
\hline & & & & & & & & & & & & & & & & & & & & & & & \\
\hline & & & & & & & & & & & & & & 31 & 31 & 32 & 32 & 32 & 32 & 32 & 33 & 34 & 35 \\
\hline & $b$ & $n$ & $\mathrm{nb}$ & b & $\mathrm{n}$ & b & b & $n$ & $\mathrm{n} 1$ & n2 & n3 & n4 & ( & $<-c p x$ & $<-c p x$ & $\mathrm{n} 1$ & n2 & n3 & n4 & b & $<-c p x$ & $<-c p x$ & $<-c p x$ \\
\hline$\overline{\mathrm{SiO}_{2}}$ & 49,79 & 49,17 & 48,98 & 49,94 & 49,11 & 49,49 & 48,98 & 49,01 & 51,45 & 48,99 & 48,65 & 49,05 & 48,65 & 40,58 & 40,59 & 40,18 & 39,78 & 40,34 & 40,06 & 41,11 & 40,12 & 40,29 & 40,38 \\
\hline $\mathrm{TiO}_{2}$ & 0,94 & 0,91 & 0,91 & 69 & 95 &, 63 & 1,13 & 0,82 & 0,44 & 0,70 & 0,90 & 0,90 & 0,94 & 2,86 & 2,74 & 3,09 & 3,13 & 2,99 & 3,00 & 2,75 & 2,91 & 2,89 & 3,37 \\
\hline $\mathrm{Al}_{2} \mathrm{O}_{3}$ & 79 & 3,49 & 2,08 & 1,99 & 2,65 & 2,04 & 1,55 & 2,58 & 1,54 & 3,52 & 3,51 & 2,65 & 2,05 & 13,00 & 12,68 & 12,97 & 13,18 & 13,10 & 13,12 & 13,16 & 12,87 & 13,03 & 12,71 \\
\hline MnO & 3,31 & 2,59 & 3,10 & 3,11 & 2,91 & 3,17 & 3,43 & 3,01 & 2,73 & 2,59 & 2,62 & 2,84 & 3,28 & 1,12 & 1,04 & 1,20 & 1,25 & 1,19 & 1,19 & 1,27 & 1,18 & 1,12 & 1,27 \\
\hline $\mathrm{FeO}_{\mathrm{T}}$ & 24,59 & 18,35 & 27,03 & 24,24 & 22,39 & 24,21 & 28,09 & 23,97 & 19,30 & 19,85 & 20,31 & 22,73 & 25,42 & 16,47 & 16,04 & 16,60 & 16,92 & 17,06 & 16,98 & 16,68 & 16,62 & 15,91 & 16,10 \\
\hline $\mathrm{ZnO}$ & 0,20 & 0,08 &, 21 & 20 & 0,11 & 0,18 & 0,17 & 0,19 & 0,11 & 0,13 & 0,15 & 0,17 & 0,20 & 0,02 & 0,06 & 0,03 & 0,05 & 0,07 & 0,03 & 0,06 & 0,07 & 0,05 & 0,09 \\
\hline MgO & & 10,49 & & & & & & & 10,27 & & 9,13 & 49 & 79 & 10,12 & 10,50 & & 9, & 9,50 & 9,65 & 9,85 & 9,96 & 10,26 & 9,81 \\
\hline $\mathrm{CaO}$ & 56 & & 5,78 & 37 & 30 & 14 & 88 & 7,14 & 5,99 & 7,24 & 7,90 & 7,19 & 5,26 & 11,09 & 10,93 & 11,12 & 11,23 & 10,87 & 11,15 & 11,06 & 11,03 & 11,08 & 11,00 \\
\hline $\mathrm{Na}_{2} \mathrm{O}$ & 4 & 4, & 4,54 & 4,37 & 4,17 & 4,18 & 5,04 & 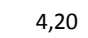 & 4,86 & 4,3 & 4,14 & 4,24 & 4,70 & 2,78 & 83 & 2,77 & 2,62 & 2,63 & 2,65 & 2,75 & 2,67 & 2,77 & 2,70 \\
\hline 0 & & & 1, & & ד & 1,04 & & & & 1,2 & 1,03 & 1,02 & 1,25 & 85 & & & & & 1,91 & 1,78 & 1,83 & & 1,75 \\
\hline$F$ & & & 0,00 & 0 , & 0,01 & 11 & 2 & & 0,02 & 0,01 & & 0,01 & 0,01 & & 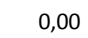 & 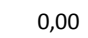 & & , & 0,00 & & 0,01 & 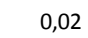 & 01 \\
\hline Cl & 0,01 & 0,03 & 04 & 03 & 03 & 04 & 0,02 & 0,02 & 0,04 & 0,01 & 0,02 & 0,03 & 0,04 & 0,04 & 0,04 & & 0,02 & 0,02 & 0,04 & 0,01 & 0,04 & ,01 & 0,03 \\
\hline Soma & 98,79 & 98,48 & 98,78 & 98,85 & 98,34 & 98,30 & 98,35 & 98,89 & 97,95 & 98,27 & 98,35 & 98,32 & 97,59 & 99,93 & 99,30 & 99,65 & 99,88 & 99,64 & 99,78 & 100,49 & 99,32 & 99,24 & 99,21 \\
\hline $\mathrm{FeO}$ & 21,30 & 16,46 & 24,03 & 21,50 & 19,28 & 21,35 & 23,71 & 21,55 & 16,93 & 17,49 & 18,24 & 20,55 & 22,09 & 8,83 & 8,23 & 8,75 & 8,43 & 9,50 & 9,10 & 9,77 & 8,64 & 8,32 & 8,73 \\
\hline $\mathrm{Fe}_{2} \mathrm{O}_{3}$ & 3,66 & 2,10 & 3,33 & 3,04 & 3,46 & 3,18 & 4,87 & 2,69 & 2,64 & 2,63 & 2,30 & 2,43 & 3,70 & 8,49 & 8,68 & 8,73 & 9,44 & 8,40 & 8,76 & 7,67 & 8,87 & 8,43 & 8,20 \\
\hline Total & 99,16 & 98,69 & 99,11 & 99,15 & 3,69 &, 62 & 84 & 9,16 & 98,21 & 98,53 & 98,58 & 98,56 & 97,97 & 00,78 & 00,17 & 00,52 & 100,83 & 100,48 & 100,65 & 101,25 & 100,21 & 100,08 & 100,03 \\
\hline Número d & tions calcu & lado na $b$ & ise de 24 & ânions. & & & & & & & & & & & & & & & & & & & \\
\hline $\mathrm{Si}$ & 7652 & 7,406 & 7,629 & 7,652 & 509 & ,630 & 7,674 & 7,535 & 7,750 & 7,427 & 7,405 & 7,544 & 620 & 019 & 041 & 992 & 28 & 6,021 & 5,975 & 6,067 & 5,996 & 5,007 & 6,047 \\
\hline A & & & & & & & & & & & 0,595 & $=$ & 378 & & & & & 1,979 & 2,025 & 1,933 & 2,004 & & 1,953 \\
\hline $\mathrm{Ti}$ & T & 0,000 & 0,000 & 00 & 13 & 0,000 & 0,040 & 0,00 & 0,000 & 0,000 & 0,000 & 0,000 & 001 & 000 & 0,000 & 0,00 & 0,000 & 0,000 & 0,000 & 0,000 & 0,000 & 0,000 & 0,000 \\
\hline Soma & 7,999 & 8,000 & 8,000 & 8,000 & 8,000 & 8,000 & 8,000 & 8,000 & 8,000 & 8,000 & 8,000 & 8,000 & 7,999 & 8,000 & 8,000 & 8,000 & 8,000 & 8,000 & 8,000 & 8,000 & 8,000 & 8,000 & 8,000 \\
\hline $\mathrm{Ti}$ & 0,085 & 0,104 & 0,107 & 0 , & 0,096 & 0 , & 0,093 & 0,0 & 0,0 & $0,08 c$ & 0,10 & 0,1 & 0,110 & 9 & 0,3 & 0,3 & 0,35 & 0,33 & 0,337 & 0,305 & 0,327 & 0,324 & 0,380 \\
\hline Al & & & & & & & & & & 0,056 & 0,035 & 0,024 & 0,000 & 2 & 0,2 & 0,2 & 0,242 & 0,325 & 0,281 & 0,356 & 0,263 & 97 & 0,290 \\
\hline $\mathrm{Fe}^{3+}$ & & & & & & & & & & & 0,264 & 0,280 & 7 & & 0,2 & & 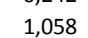 & 0,943 & 0,983 & 0,852 & 0,997 & & 0,923 \\
\hline $\mathrm{Z}$ & & & & & & & & & & & & & 23 & & & & & & 3 & & & 6 & 0,010 \\
\hline & & & 86 & & 50 & 0,204 & & & & 0,162 & 0,189 &, 212 & 184 & 7 & 0,0 & 0,1 & 0,128 & 0,089 & 0,116 & 0,106 & 0,105 &, 108 & 0,115 \\
\hline $\mathrm{Fe}^{2+}$ & & & & & & & & & & & 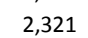 & 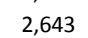 & & & & & & 1,187 & 1,135 & 1,207 & 1,080 & & 1,094 \\
\hline Mg & & & J2 & & & & & & 2,306 & 70 & 2,072 & 17 & 352 & 38 & 329 & 181 & 166 & 114 & 2,146 & 2,167 & 19 & ,281 & 2,190 \\
\hline Soma & 4,999 & 5,000 & 5,000 & 5,000 & 5,000 & 5,000 & 5,000 & 5,000 & 4,999 & 5,000 & 5,001 & 4,999 & 4,999 & 001 & 5,000 & 5,002 & 5,001 & 5,002 & 5,001 & 5,000 & 4,999 & 5,000 & 5,002 \\
\hline $\mathrm{Mn}$ & & & 0 & & & & & & & & ( & 58 & 1 & 4 & 6 & 4 & 30 & 0,061 & 0,034 & 0,053 & 0,045 & 34 & 0,047 \\
\hline C & & & & & & & & & & & & & & & & & & & & & & & 65 \\
\hline $\mathbf{N}$ & & & & & & & & & & & & & & & & & & & & & & & 88 \\
\hline Soma & , & 2,000 & 2,001 & 2,001 & 2,000 & 2,000 & 1,999 & 2,000 & 2,000 & 2,000 & 2,000 & 2,000 & 2,001 & 1,999 & 2,000 & 2,000 & 2,000 & 1,999 & 2,000 & 2,000 & 2,000 & ,000 & 2,000 \\
\hline$N$ & & & & & & & & & & & & & & & & & & & & 0.5 & & & 0,596 \\
\hline K & & & 0,226 & & & & & & & & & 0,201 & 250 & 50 & 349 & & 0,371 & 0,352 & 0,363 & 0,335 & 0,349 & ,342 & 0,334 \\
\hline Soma & 0,776 & 0,882 & 0,784 & 0,739 & 0,766 & 0,728 & 0,792 & 0,800 & 0,790 & 0,870 & 0,858 & 0,809 & 0,811 & 946 & 944 & 0,958 & 0,951 & 0,913 & 0,945 & 0,924 & 0,934 & 0,946 & 0,930 \\
\hline$F$ & & & 0,002 & & & & 0 & & 0, & 66 & 0,000 & 03 & 004 & 00 & 001 & 0,001 & 0,003 & 0,008 & 0,001 & 0,000 & 0,007 & 0,008 & 0,002 \\
\hline c| & & & & & & & & & & & & & & & & & & & & & 0,010 & & 0,007 \\
\hline & 0,007 & 0,010 & 0,014 & 0,012 & 0,012 & 0,014 & 0,014 & & 0,017 & 0,008 & 0,004 & 0,012 & 014 & 011 & , U11 & 001 & 0,008 & 0,014 & 0,011 & 0,004 & 0,017 & 0,012 & 0,009 \\
\hline rotal & 15,774 & 15,882 & 15,785 & 5,740 & 5,766 & 15,728 & 15,791 & 15,800 & 15,789 & 15,870 & 15,859 & 15,808 & 15,810 & 15,946 & 15,944 & 15,960 & 15,952 & 15,914 & 15,946 & 15,924 & 15,933 & 15,946 & 15,932 \\
\hline
\end{tabular}

n, núcleo; b, borda; <- sendo substituído por; -> substituindo; < incluso em; /, em contato com; idio, idiomórfico; c/ lam, comlamelas de titanita. 
ANEXO E - Tabela E.4 - Composição química de anfibólios de rochas do Maciço Alcalino de Itatiaia. Continua...

\begin{tabular}{|c|c|c|c|c|c|c|c|c|c|c|c|c|c|c|c|c|c|c|c|c|c|c|c|}
\hline \multirow{3}{*}{$\begin{array}{l}\text { Unidade } \\
\text { Amostra } \\
\text { Cristal }\end{array}$} & \multicolumn{10}{|l|}{ BtHblP } & \multirow{2}{*}{\multicolumn{13}{|c|}{$\begin{array}{l}\text { HblP } \\
\text { MAl160 }\end{array}$}} \\
\hline & MAl114 & & & & & & & & & & & & & & & & & & & & & & \\
\hline & 35 & 36 & 37 & 37 & 38 & 38 & 39 & 40 & 40 & 41 & 42 & 42 & 42 & 43 & 43 & 43 & 44 & 44 & 45 & 45 & 45 & 46 & 46 \\
\hline Textura $^{1}$ & $<-\mathrm{cpx}$ & $<-c p x$ & $n$ & b & $<-c p x b$ & $<-c p x n$ & $<-c p x n$ & $<-c p x n$ & $<-c p x b$ & <-cpx & $\rightarrow>c p x n$ & $\rightarrow c p x n b$ & $\rightarrow c p \times b$ & $\rightarrow c p x n$ & $\rightarrow>c p \times n 2$ & $\rightarrow c p \times b$ & $n$ & b & $\rightarrow c p x b$ & $\rightarrow$ cp $\mathrm{n} 2$ & $->\mathrm{cpx} \mathrm{n1}$ & $->c p \times n 1$ & $\rightarrow$ cpp $\mathrm{n} 2$ \\
\hline $\mathrm{iO}_{2}$ & 40,16 & 40,14 & 40,61 & 39,78 & 39,54 & 40,03 & 40,04 & 40,12 & 40,37 & 40,66 & 39,89 & 40,36 & 38,59 & 40,27 & 39,97 & 38,76 & 39,75 & 38,97 & 38,75 & 39,65 & 39,78 & 39,46 & 40,03 \\
\hline $\mathrm{TiO}_{2}$ & 2,86 & 2,99 & 2,90 & 16 & 2,70 & 3,01 & 3,05 & 3,02 & 3,10 & 2,86 & 3,28 & 3,73 & 3,22 & 3,09 & 2,78 & 2,68 & 3,63 & 3,06 & 3,12 & 3,87 & 3,66 & 3,80 & 1,81 \\
\hline $\mathrm{Al}_{2} \mathrm{O}_{3}$ & 13,20 & 13,07 & 12,91 & 13,65 & 13,46 & 13,07 & 12,72 & 12,80 & 12,76 & 12,97 & 12,33 & 12,73 & 13,39 & 12,90 & 13,53 & 13,32 & 12,89 & 13,28 & 13,30 & 13,06 & 12,72 & 13,10 & 13,89 \\
\hline UnO & 1,18 & 1,30 & ,27 & 1,25 & 1,21 & 1,21 & 1,46 & 1,26 & 1,31 & 1,24 & 1,34 & 1,13 & 1,46 & 1,14 & 1,27 & 1,46 & 1,22 & 1,47 & 1,36 & 1,21 & 1,31 & 1,18 & 1,15 \\
\hline eO & 16,45 & 16,12 & 16,32 & 16,37 & 16,53 & 16,40 & 16,82 & 16,23 & 16,45 & 15,94 & 19,57 & 18,80 & 21,95 & 17,72 & 19,26 & 22,11 & 19,81 & 22,07 & 21,87 & 18,83 & 19,13 & 18,62 & 19,32 \\
\hline no & 0,07 & 0,04 & 0,06 & 0,09 & 0,02 & 0,10 & 0,07 & 0,03 & 0,07 & 0,06 & 0,06 & 0,05 & 0,05 & 0,06 & 0,05 & 0,08 & 0,09 & 0,09 & 0,06 & 0,05 & 0,07 & 0,07 & 0,06 \\
\hline Igo & 10,12 & 9,93 & 5 & & 59 & 10,00 & 9,71 & 9,87 & 9,86 & 10,29 & 7,94 & 8,40 & 6,22 & 9,01 & 7,96 & 6,20 & 7,70 & 5,92 & 6,21 & 7,93 & 8,10 & 8,00 & 8,10 \\
\hline 0 & 11,04 & 11,13 & 11,15 & 10,85 & 10,91 & 10,97 & 11,05 & 11,13 & 11,07 & 11,12 & 10,75 & 11,11 & 10,64 & 10,99 & 10,34 & 10,60 & 10,65 & 10,83 & 10,73 & 10,95 & 10,75 & 11,12 & 10,40 \\
\hline $\mathrm{a}_{2} \mathrm{O}$ & 2,73 & 2,74 & 73 & 2,75 & 2,85 & 2,73 & 2,74 & 2,73 & 2,79 & 2,83 & 2,92 & 2,78 & 2,82 & 3,02 & 3,66 & 2,83 & 2,89 & 2,75 & 2,82 & 2,82 & 3,03 & 2,83 & 3,29 \\
\hline 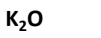 & 1,81 & 1,81 & 1,80 & 1,87 & 1,78 & 1,74 & 1,82 & 1,82 & 1,81 & 1,80 & 1,78 & 1,79 & 1,88 & 1,74 & 1,10 & 1,91 & 1,84 & 1,81 & 1,84 & 1,74 & 1,72 & ,90 & 1,43 \\
\hline & & & & 0,01 & & 0,02 & & & & 0,00 & 0,02 & 0,01 & 0, & 0,01 & 0,02 & 0,00 & & & 0,01 & & 0,01 & & 0,00 \\
\hline a & 0,03 & 0,04 & 0,05 & 0,02 & 0,00 & 0,04 & 0,07 & 0,02 & 0,02 & 0,04 & 0,04 & 0,01 & 0,04 & 0,04 & 0,04 & 0,04 & 0,04 & 0,03 & 0,05 & 0,07 & 0,02 & 0,05 & 0,03 \\
\hline ioma & 99,65 & 99,31 & 99,75 & 99,41 & 98,70 & 99,32 & 99,56 & 99,03 & 99,61 & 99,82 & 99,91 & 100,90 & 100,27 & 99,99 & 99,99 & 99,99 & 100,50 & 100,28 & 100,12 & 100,18 & 100,30 & 100,13 & 99,51 \\
\hline 0 & 8,29 & 8,58 & 9,14 & 8,28 & 8,53 & 8,25 & 8,56 & 8,78 & 8,72 & 8,46 & 11,31 & 10,98 & 12,86 & 10,14 & 11,09 & 13,55 & 11,13 & 14,26 & 13,38 & 10,85 & 10,37 & 10,63 & 12,17 \\
\hline $\mathrm{Fe}_{2} \mathrm{O}_{3}$ & 9,07 & 8,38 & 7,98 & 8,99 & 8,89 & 9,06 & 9,18 & 8,28 & 8,59 & 8,31 & 9,18 & 8,69 & 10,10 & 8,43 & 9,08 & 9,51 & 9,64 & 8,68 & 9,43 & 8,87 & 9,74 & 8,88 & 7,94 \\
\hline Total & 100,56 & 100,15 & 100,55 & 100,31 & 99,59 & 100,22 & $.00,48$ & 99,86 & 00,47 & 00,65 & 100,83 & 101,78 & 101,29 & 100,84 & 100,90 & 100,95 & 101,47 & 101,15 & 101,07 & 101,07 & 101,28 & 101,02 & 100,30 \\
\hline \multicolumn{24}{|c|}{ átions calculado na base de 24 ânions. } \\
\hline & 5,969 & 5,997 & 6,043 & 5,938 & 5,938 & 5,976 & 5,988 & 6,017 & 6,021 & 6,029 & 6,022 & 6,017 & 5,866 & 6,018 & 5,978 & 5,904 & 5,969 & 5,936 & 5,900 & 5,967 & 5,971 & 5,944 & 6,000 \\
\hline & 31 & 2,003 & 1 , & 2,062 & 2,062 & 2,024 & 2,012 & 1,983 & 1,979 & 1,971 & 1,978 & 1,983 & 2,134 & 1,982 & 2,022 & 2,096 & 2,031 & 2,064 & 2,100 & 2,033 & 9 & 2,056 & 2,000 \\
\hline & & 0,000 & & 0, & 0 & 0,000 & 0 & 0,000 & 0 & 0,000 & 0,000 & 0 & & 0,000 & 0,000 & 0,000 & 0,000 & 0,000 & 0,000 & 0,000 & 0,000 & 0,000 & 0,000 \\
\hline oma T & 8,000 & 8,000 & 8,000 & 8,000 & 8,000 & 8,000 & 8,000 & 8,000 & 8,000 & 8,000 & 8,000 & 8,000 & 8,000 & 8,000 & 8,000 & 8,000 & 8,000 & 8,000 & 8,000 & 8,000 & 8,000 & 8,000 & 8,000 \\
\hline ri & 20 & 0,336 & 0,325 & 0 & 0,305 & 0, & 0 , & 0,34 & 348 & 0,319 & 0,372 & 0,418 & 0 & 0 & 0,313 & 0,3 & 0,410 & 0,3 & 0,357 & 0,438 & 3 & 0,4 & 0,204 \\
\hline Al & 81 & 0,299 & & $0,34 c$ & 0,320 & 0,276 & 229 & 0,279 & 0,265 & 0,296 & 0,215 & 0,254 & 0,265 & 0,290 & 0,363 & 0,295 & 0,250 & 0,320 & 0,287 & 0,283 & 0,221 & 0,269 & 0,453 \\
\hline $\mathrm{Fe}^{3+}$ & 1,014 & 0,942 & 0,893 & 1,010 & 1,005 & 1,018 & 1,033 & 0,934 & 0,965 & 0,927 & 1,043 & 0,976 & 1,156 & 0,949 & 1,021 & 1,089 & 1,090 & 0,996 & 1,080 & 1,005 & 1,099 & 1,007 & 0,896 \\
\hline$n$ & & & & & & & & 0,003 & 8 & 0,007 & 006 & & & & & & 0,010 & 0,010 & & & & 0,008 & 0,006 \\
\hline $\mathrm{Mn}$ & 104 & 0,134 & 0,124 & 0 & 0,127 & 102 & 0,151 & 0,134 & 0,135 & 0,126 & 0,148 & 0,112 & 0,16 & 0,135 & 0,135 & 0,165 & 0,119 & 0,164 & 0,154 & 0,125 & 0,145 & 0,150 & 0,105 \\
\hline $\mathrm{Fe}^{2+}$ & 31 & 1,072 & 1,138 & 1, & 1, & 1,030 & 1,070 & 1,101 & 1,087 & 1,050 & 1,428 & 1,368 & 1, & 1, & 1,389 & 1,727 & 1,398 & 1,815 & 1,705 & 1,365 & 2 & 1,339 & 1,526 \\
\hline$M G$ & & & & & & & & 2 & 2,19 & 2,275 & 887 & & & & 1,775 & 1,4 & 1,724 & 1,344 & 1,410 & 1,779 & & 1,796 & 1,810 \\
\hline Soma & 4,999 & 5,000 & 5,000 & 5,000 & 4,999 & 5,001 & 4,999 & 4,999 & 5,000 & 5,000 & 4,999 & 5,001 & 5,001 & 5,000 & 5,002 & 4,999 & 5,001 & 5,000 & 5,000 & 5,000 & 4,999 & 5,000 & 5,000 \\
\hline Mn & 0,045 & 0,030 & 0,036 & 0,045 & 0,028 & 0,050 & 0,034 & 0,026 & 0,030 & 0,030 & 0,023 & 0,031 & 0,026 & 0,010 & 0,027 & 0, & $0, \mathrm{C}$ & 0,0 & 0,021 & 0,029 & م0 & 0.0 & 041 \\
\hline $\mathrm{Ca}$ & & & & & & & & 1 , & 1, & 1,767 & 739 & & & 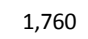 & 1 , & 1, & 1,713 & 1,767 & 51 & 66 & & 5 & 1,670 \\
\hline $\mathrm{Na}$ & 97 & 0,188 & & & 0,2 & 0,195 & 0,196 & 0,186 & 0,201 & 0,203 & 0,238 & 0 & 0,241 & 0,231 & 0,316 & 0,247 & 0,251 & 0,207 & 0,228 & 0,205 &, 250 & ,205 & 0,289 \\
\hline soma B & 2,000 & 2,000 & 2,000 & 2,000 & 2,001 & 2,000 & 2,000 & 2,000 & 2,000 & 2,000 & 2,000 & 2,001 & 2,000 & 2,001 & 2,000 & 2,000 & 2,000 & 1,999 & 2,000 & 2,000 & 2,000 & 2,000 & 2,000 \\
\hline $\mathrm{Na}$ & & 0,6 & & & & 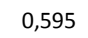 & & 0,6 & 0 & 511 & 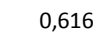 & 0 & & 0, & 0,745 & 0,589 & 0,5 & 0,605 & 0,604 & 17 & 2 & 21 & 0,667 \\
\hline & & & & & & & & & & 841 & & & & & 0,211 & 0,371 & 0,352 & 0, & 0,357 & 0,334 & & 365 & 0,273 \\
\hline Soma $\mathrm{A}$ & 0,933 & 0,951 & 0,944 & 0,932 & 0,954 & 0,926 & 0,946 & 0,956 & 0,950 & 0,952 & 0,959 & 0,949 & 0,955 & 0,976 & 0,956 & 0,960 & 0,943 & 0,957 & 0,961 & 0,951 & 0,961 & 0,986 & 0,940 \\
\hline & 00 & 0,000 & 0,0 & & 0,0 & 0,0 & & 0,000 & 0,00 & 0,001 & 008 & & & 0 , & 0,008 & 0,002 & 0,000 & 0,000 & 0,005 & 0,000 & 55 &, 000 &, 002 \\
\hline & & & & & & & & & & 09 & & & & & 0,011 & & 0,010 & 0,008 &, 014 & 19 & 66 & 0,013 & 0,007 \\
\hline Soma W & 0,008 & 0,010 & 0,013 & 0,011 & 0,001 & 0,020 & 0,018 & 0,005 & 0,005 & 0,010 & 0,018 & 0,010 & 0,018 & 0,016 & 0,019 & 0,014 & 0,010 & 0,008 & 0,019 & 0,019 & 0,011 & 0,013 & 0,009 \\
\hline (at) & 332 & 951 & 944 & 932 & 954 & 927 & ,945 &, 955 & ,950 & ,952 & ,958 & ,951 & ;,956 & ,977 & 15,958 & 5,959 & 15,944 & 15,956 & 15,961 & 15,951 & 15,960 & 15,986 & 5,940 \\
\hline
\end{tabular}

Total

n, núcleo; b, borda; <- sendo substituído por; -> substituindo; < incluso em; /, em contato com; idio, idiomórfico; c/ lam, comlamelas de titanita. 
ANEXO E - Tabela E.4 - Composição química de anfibólios de rochas do Maciço Alcalino de Itatiaia. Continua...

\begin{tabular}{|c|c|c|c|c|c|c|c|c|c|c|c|c|c|c|c|c|c|c|c|c|c|c|c|}
\hline \multirow{3}{*}{$\begin{array}{l}\text { Unidade } \\
\text { Amostra } \\
\text { Cristal }\end{array}$} & \multicolumn{4}{|l|}{$\mathrm{HbIP}$} & \multirow{2}{*}{\multicolumn{19}{|c|}{$\begin{array}{l}\text { NeS-II } \\
\text { MAI166I }\end{array}$}} \\
\hline & MAl160 & & & & & & & & & & & & & & & & & & & & & & \\
\hline & 46 & 47 & 47 & 47 & 48 & 48 & 49 & 49 & 50 & 50 & 51 & 51 & 52 & 53 & 53 & 54 & 54 & 55 & 55 & 56 & 56 & 57 & 57 \\
\hline Textura $^{1}$ & $\rightarrow c p x b$ & $->c p x$ & ints n & ints b & $>c p \times n$ & $>c p \times b$ & $n$ & b & $\rightarrow c p x n$ & $\rightarrow c p x b$ & $\rightarrow c p x n$ & $\rightarrow c p \times b$ & $\rightarrow>c p \times n$ & $->c p \times n$ & $\rightarrow c p \times b$ & $\rightarrow$ bt n & $\rightarrow$ btb & $\rightarrow>p p \times n$ & $\rightarrow c p \times b$ & $\rightarrow>c p \times n$ & $\rightarrow c p \times b$ & $n$ & \\
\hline$\overline{\mathrm{SiO}_{2}}$ & 38,36 & 39,00 & 38,69 & 38,63 & 39,99 & 41,42 & 41,16 & 41,05 & 41,58 & 41,35 & 40,59 & 41,07 & 40,86 & 40,80 & 40,80 & 41,03 & 41,38 & 41,10 & 40,89 & 42,96 & 40,96 & 41,40 & 41,11 \\
\hline $\mathrm{TiO}_{2}$ & 2,55 & 2,56 & 2,23 & 2,33 & 1,36 & 1,55 & 1,73 & 1,66 & 1,51 & 1,46 & 1,77 & 1,70 & 1,48 & 1,36 & 1,38 & 1,43 & 1,13 & 1,48 & 1,60 & 1,21 & 1,48 & 1,36 & 1,62 \\
\hline $\mathrm{Al}_{2} \mathrm{O}_{3}$ & 13,42 & 13,08 & 13,37 & 13,21 & 11,37 & 10,61 & 10,82 & 10,90 & 10,90 & 10,77 & 11,24 & 11,14 & 11,03 & 10,84 & 10,58 & 10,40 & 10,56 & 10,70 & 10,87 & 9,74 & 10,86 & 10,85 & 11,00 \\
\hline UnO & 1,49 & 1,45 & 1,50 & 1,68 & 2,59 & 2,63 & 2,61 & 2,59 & 2,40 & 2,70 & 2,54 & 2,66 & 2,61 & 2,77 & 2,66 & 2,44 & 2,65 & 2,72 & 2,53 & 2,29 & 2,67 & 2,57 & 2,55 \\
\hline $\mathrm{eO}_{\mathrm{T}}$ & 23,45 & 23,18 & 23,56 & 23,77 & 20,63 & 20,58 & 19,80 & 20,34 & 18,86 & 20,81 & 20,68 & 21,77 & 21,08 & 21,30 & 20,70 & 19,29 & 20,08 & 21,53 & 20,71 & 17,40 & 21,30 & 20,37 & 20,31 \\
\hline no & 0,06 & 0,03 & 0,09 & 0,09 & 0,14 & 0,11 & 0,18 & 0,12 & 0,10 & 0,14 & 0,16 & 0,16 & 0,13 & 0,18 & 0,10 & 0,15 & 0,14 & 0,12 & 0,11 & 0,06 & 0,15 & 0,10 & 0,14 \\
\hline Igo & 5,48 & 5,92 & 51 & 5,23 & 7,55 & 7,42 & 8,19 & 7,71 & 8,97 & 7,50 & 7,63 & 7,00 & 7,64 & 7,12 & 7,53 & 9,23 & 7,90 & 7,15 & 7,85 & 10,37 & 7,64 & , 17 & 7,64 \\
\hline ao & 10,56 & 10,39 & 10,46 & 10,22 & 9,95 & 9,85 & 9,85 & 10,17 & 10,16 & 10,07 & 10,20 & 9,78 & 9,92 & 9,62 & 9,63 & 10,11 & 9,75 & 9,90 & 10,33 & 10,55 & 10,18 & 10,06 & 10,32 \\
\hline $\mathrm{a}_{2} \mathrm{O}$ & 2,88 & 3,04 & 2,77 & 2,99 & 3,32 & 3,40 & 3,50 & 3,20 & 3,33 & 3,43 & 3,29 & 3,53 & 3,42 & 3,56 & 3,53 & 3,48 & 3,54 & 3,44 & 3,32 & 3,35 & 3,36 & 3,41 & 3,30 \\
\hline 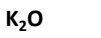 & 1,88 & 1,88 & 1,77 & 1,84 & 1,74 & 1,55 & 1,67 & 1,69 & 1,66 & 1,72 & 1,69 & 1,74 & 1,75 & 1,76 & 1,73 & 1,63 & 1,72 & 1,76 & 1,67 & 1,67 & ,64 & 1,75 & 1,71 \\
\hline & & 0,00 & 0,00 & 0,01 & & 0,01 & 0,01 & & & & & & 0,00 & 0,03 & 0,01 & 0,01 & & & 0,02 & 0,00 & & 0,01 & \\
\hline d & 0,05 & 0,03 & 0,05 & 0,06 & 0,00 & 0,02 & 0,01 & 0,00 & & & & & 0,00 & 0,03 & 0,02 & 0,00 & 0,01 & 0,03 & & 0,01 & 0,01 & 0,01 & 0,01 \\
\hline soma & 100,18 & 100,57 & 100,00 & 100,06 & 98,64 & 99,15 & 99,53 & 99,44 & 99,47 & 99,95 & 99,79 & 100,55 & 99,93 & 99,36 & 98,66 & 99,21 & 98,86 & 99,93 & 99,90 & 99,61 & 100,25 & 100,06 & 99,71 \\
\hline 0 & 14,49 & 14,09 & 15,17 & 14,93 & 11,88 & 13,48 & 11,25 & 12,73 & 11,13 & 13,15 & 12,12 & 13,08 & 12,23 & 12,84 & 12,40 & 9,92 & 12,63 & 13,35 & 12,36 & 10,84 & 12,57 & 12,14 & 12,98 \\
\hline $\mathrm{Fe}_{2} \mathrm{O}_{3}$ & 9,96 & 10,10 & 9,32 & 9,83 & 9,72 & 7,89 & 9,51 & 8,45 & 8,59 & 8,51 & 9,52 & 9,65 & 9,84 & 9,40 & 9,23 & 10,42 & 8,28 & 9,09 & 9,28 & 7,29 & 9,71 & 9,15 & 8,15 \\
\hline Total & 101,18 & 101,58 & 100,94 & 101,04 & 99,61 & 99,94 & 00,48 & 00,28 & 00,33 & 100,80 & 100,75 & 101,52 & 100,92 & 100,30 & 99,58 & 100,25 & 99,69 & 100,84 & 100,83 & 100,34 & 101,22 & 100,98 & 100,52 \\
\hline \multicolumn{24}{|c|}{ ́́tions calculado na base de 24 ânions. } \\
\hline & 5,862 & 5,917 & 5,914 & 5,914 & 6,109 & 6,303 & 6,210 & 6,225 & 6,242 & 6,248 & 6,138 & 6,183 & 6,166 & 6,210 & 6,235 & 6,178 & 6,291 & 6,229 & 6,176 & 6,399 & 6,171 & 6,219 & 6,223 \\
\hline & 38 & 2,083 & $2, \mathrm{C}$ & 2,086 & 1 & 1,697 & 1,790 & 1,775 & 1,758 & 1,752 & 1,862 & 1,817 & 1,834 & 1,790 & 1,765 & 1,822 & 1,709 & 1,771 & 1,824 & 1,601 & 1,829 & 1,781 & 1,777 \\
\hline & 00 & 0,000 & & 0,000 & 0 & 0,000 & ( & 0,000 & 0,000 & 0,000 & 0,000 & 0,000 & 0 , & 0,000 & 0,000 & 0,000 & 0,000 & 0,000 & 0,000 & 0,000 & 0,000 & 0,000 & 0,000 \\
\hline Soma $T$ & 8,000 & 8,000 & 8,000 & 8,000 & 8,000 & 8,000 & 8,000 & 8,000 & 8,000 & 8,000 & 8,000 & 8,000 & 8,000 & 8,000 & 8,000 & 8,000 & 8,000 & 8,000 & 8,000 & 8,000 & 8,000 & 8,000 & 8,000 \\
\hline $\mathrm{Ti}$ & 93 & 0,292 & 66 & 0,268 & 0,156 & 0,1 & 0,1 & 0,1 & 0,170 & 0,166 & 0 & 0 & 0 , & 0 , & 0,1 & 0,162 & 0,129 & 0,169 & 0,182 & 0,135 & 0,168 & 3 & 0,185 \\
\hline Al & 280 & 0,256 & $32 \angle$ & 0,297 & 0,157 & 0,206 & 104 & 0,173 & 0,170 & 0,166 & 0,141 & 0,160 & 0,127 & 0,155 & 0,140 & 0,023 & 0,183 & 0,140 & 0,111 & 0,109 & 0,099 & 0,140 & 0,186 \\
\hline $\mathrm{Fe}^{3+}$ & 1,145 & 1,154 & 1,073 & 1,131 & 1,117 & 0,902 & 1,079 & 0,966 & 0,970 & 0,967 & 1,083 & 1,093 & 1,117 & 1,077 & 1,060 & 1,180 & 0,947 & 1,036 & 1,054 & 0,817 & 1,101 & 1,034 & 0,928 \\
\hline $\mathrm{Zn}$ & & & & & & & & 0,014 & 0 & & & & & & & 0,017 & 0,015 & 0,013 & & & & & 0,016 \\
\hline$M n$ & 175 & 0,168 & 144 & 188 & 317 & 0,302 & 0,309 & 0,301 & 0,273 & 0,334 & 0,304 & 0,317 & 0,311 & 0,343 & 0,330 & 0,297 & 0,329 & 0,334 & 0,332 & 0,278 & 0,317 & 0,307 & 0,319 \\
\hline $\mathrm{Fe}^{2+}$ & 52 & 1,788 & 1, & 1,912 & 1, & 1,717 & 1,420 & 1,614 & 1,398 & 1,662 & 1,5 & 1,648 & 1,543 & 1,634 & 1,586 & 1,249 & 1,606 & 1,693 & 1,562 & 1,350 & 3 & 25 & 1,643 \\
\hline $\mathrm{Mo}$ & & & & & & & & 1,7 & 2,007 & & & & & & & 2,072 & 1,791 & 1,615 & 1,767 & 2,303 & 1,716 & 0 & 1,724 \\
\hline Soma C & 5,000 & 5,000 & 4,999 & 5,000 & 5,000 & 5,000 & 5,000 & 5,001 & 4,999 & 5,000 & 5,000 & 5,000 & 5,000 & 5,000 & 5,000 & 5,000 & 5,000 & 5,000 & 5,000 & 4,999 & 5,000 & 5,000 & 5,001 \\
\hline Mn & 0,018 & 0,019 & 0,050 & 0,030 & 0,019 & 0,037 & 0,024 & 0,032 & 0,032 & 0,011 & 0,021 & 0,022 & 0,023 & 0,014 & 0,015 & $0, c$ & 0 & $0, c$ & 0,012 & 0,0 & 0,023 & 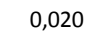 & 0,008 \\
\hline Ca & & 1 & & & & & & 1, & 4 & 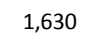 & & & & & 1, & 1,631 & 1,588 & 1,608 & 2 & 34 & 3 & 9 & 1,674 \\
\hline $\mathrm{Na}$ & 0,253 & 0,292 & 0,237 & 0,294 & 0,3 & 0,3 & 0,384 & 0,316 & 0,334 & 0,358 & 0,326 & 0,400 & 0,373 & 0,417 & 0,409 & 0,355 & 0,399 & 0,377 & 0,317 & 0,305 & ,333 & 361 & 0,318 \\
\hline Soma B & 2,000 & 2,000 & 2,000 & 2,000 & 2,001 & 2,000 & 2,000 & 2,000 & 2,000 & 1,999 & 2,000 & 2,000 & 2,000 & 2,000 & 2,001 & 2,001 & 2,000 & 2,000 & 2,001 & 2,000 & 1,999 & 2,000 & 2,000 \\
\hline $\mathrm{Na}$ & & 0 & & & & 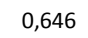 & 0,6 & 0, & P & 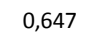 & 639 & & & 0, & 0,6 & 0,661 & 0,644 & 0,633 & 0,656 & 52 & 48 & 3 & 0,651 \\
\hline & & & & & & & & & & & & & & & & 0,313 & 34 & 0,340 & 22 & 17 & & & 0,330 \\
\hline Soma $\mathrm{A}$ & 0,967 & 0,966 & 0,929 & 0,952 & 0,970 & 0,947 & 0,961 & 0,952 & 0,953 & 0,979 & 0,965 & 0,964 & 0,964 & 0,976 & 0,974 & 0,974 & 0,978 & 0,973 & 0,978 & 0,979 & 0,963 & 0,968 & 0,981 \\
\hline & 0,000 & 0,0 & 0,0 & 0,0 & 0,0 & 0,0 & & 0,000 & 0,000 & 0,000 & 0,000 & 0,000 & 0 , & & 0,003 & 0,004 & 0,000 & 0,000 & 0,009 & 0,002 & 0,000 & 006 & 0,000 \\
\hline & & & & & & & & & & & & & & & & 0,001 & 0,004 & 0,008 & 0,000 & 0,002 & 0,002 & ,003 & 0,002 \\
\hline Soma W & 0,014 & 0,010 & 0,015 & 0,019 & 0,000 & 0,012 & 0,007 & 0,000 & 0,000 & 0,000 & 0,000 & 0,000 & 0,003 & 0,020 & 0,008 & 0,005 & 0,004 & 0,008 & 0,009 & 0,004 & 0,002 & 0,009 & 0,002 \\
\hline (at) & 967 & 966 & 928 & 952 & 971 & 947 & ,961 & 953 & ,952 & ,978 & ,965 & ,964 &, 964 &, 976 & 15,975 & 15,975 & 5,978 & 5,973 & 5,979 & 5,978 & 15,962 & 5,968 & ,982 \\
\hline
\end{tabular}

n, núcleo; b, borda; <- sendo substituído por; -> substituindo; < incluso em; /, em contato com; idio, idiomórfico; c/ lam, comlamelas de titanita. 
ANEXO E - Tabela E.4 - Composição química de anfibólios de rochas do Maciço Alcalino de Itatiaia. Continua...

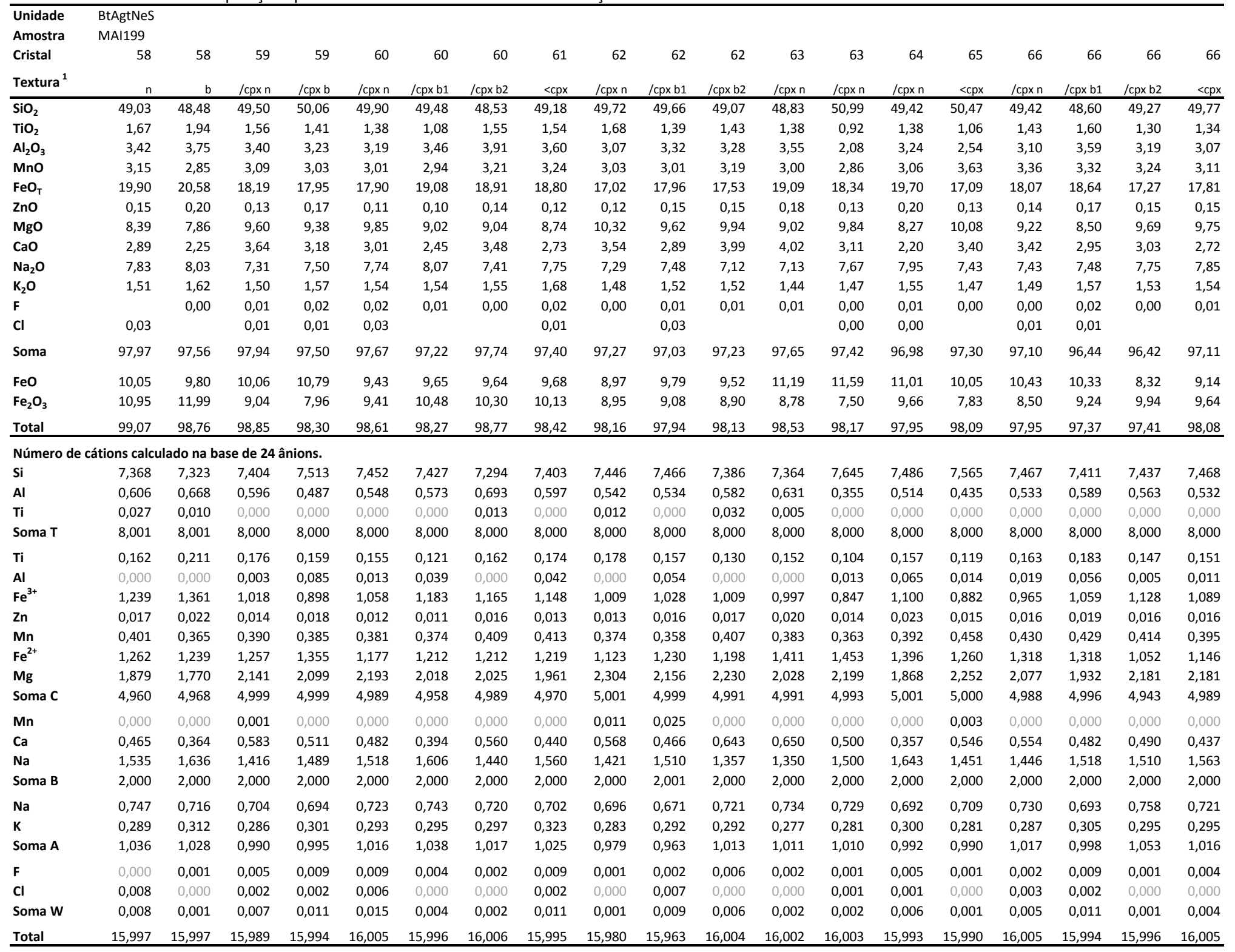

n, núcleo; b, borda; <- sendo substituído por; -> substituindo; < incluso em; /, em contato com; idio, idiomórfico; c/ lam, comlamelas de titanita. 
ANEXO E - Tabela E.5 - Composição química de titanitas de rochas do Maciço Alcalino de Itatiaia. Continua..

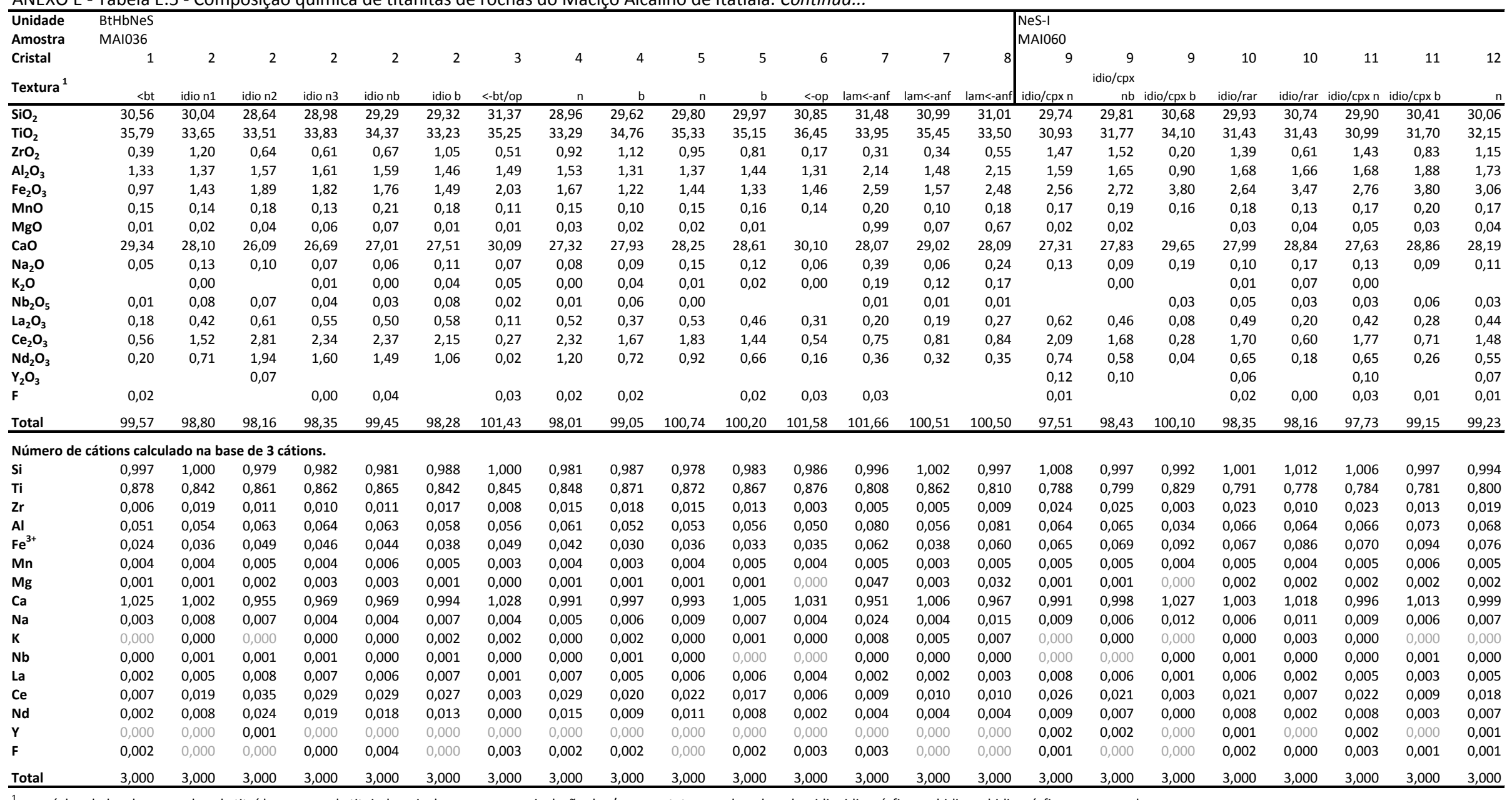

${ }^{1}$ - n, núcleo; b, borda; <- sendo substituído por; -> substituindo; < incluso em; >, com inclusão de; /, em contato com; lam, lamelar; idio, idiomórfico; subidio, subidiomórfico; zon, zonada. 
ANEXO E - Tabela E.5 - Composição química de titanitas de rochas do Maciço Alcalino de Itatiaia. Continua..

\begin{tabular}{|c|c|c|c|c|c|c|c|c|c|c|c|c|c|c|c|c|c|c|c|c|c|c|c|}
\hline \multirow{4}{*}{$\begin{array}{l}\text { Unidade } \\
\text { Amostra } \\
\text { Cristal } \\
\text { Textura }^{1}\end{array}$} & \multirow{3}{*}{$\begin{array}{l}\text { NeS-I } \\
\text { MAI060 }\end{array}$} & \multirow[b]{3}{*}{12} & \multirow[b]{3}{*}{13} & \multirow[b]{3}{*}{13} & \multirow[b]{3}{*}{13} & \multirow[b]{3}{*}{14} & \multirow[b]{3}{*}{14} & \multirow[b]{3}{*}{14} & \multirow{2}{*}{\multicolumn{15}{|c|}{\begin{tabular}{|l} 
BtHblP \\
MAl092I
\end{tabular}}} \\
\hline & & & & & & & & & & & & & & & & & & & & & & & \\
\hline & & & & & & & & & & 15 & 16 & 17 & 18 & 18 & 18 & 18 & 19 & 20 & 20 & 21 & 22 & 22 & 23 \\
\hline & & & $n$ & $\mathrm{~b} 1$ & b2 & $n$ & $\mathrm{nb}$ & & idio $n$ & idio b & $->$ anf/op & $\begin{array}{l}->a n f / \\
\text { op/bt }\end{array}$ & zon n1 & zon $\mathrm{n} 2$ & zon nb & zon b & lam<bt & idio $n$ & idio b & lam<bt & idion $n$ & idio b & \\
\hline$\overline{\mathrm{SiO}_{2}}$ & 29,74 & 30,59 & 30,49 & 29,58 & 30,27 & 29,69 & 30,68 & 30,63 & 30,60 & 30,46 & 30,55 & 31,07 & 30,20 & 28,98 & 29,36 & 30,49 & 30,96 & 29,93 & 30,66 & 30,91 & 28,99 & 29,82 & 30,62 \\
\hline $\mathrm{TiO}_{2}$ & 31,37 & 34,20 & 32,38 & 30,99 & 30,83 & 31,16 & 33,53 & 30,72 & 32,47 & 34,53 & 30,77 & 35,16 & 31,86 & 34,55 & 33,89 & 34,59 & 34,81 & 34,90 & 30,44 & 35,00 & 33,96 & 35,04 & 36,82 \\
\hline $\mathrm{ZrO}_{2}$ & 1,37 & 0,24 & 0,37 & 1,32 & 0,76 & 1,14 & 0,15 & 0,71 & 0,58 & 1,46 & 0,83 & 0,18 & 0,57 & 0,47 & 0,53 & 0,81 & 0,01 & 0,66 & 0,69 & 0,33 & 0,62 & 0,45 & 0,20 \\
\hline $\mathrm{Al}_{2} \mathrm{O}_{3}$ & 1,58 & 0,82 & 1,36 & 1,60 & 1,80 & 1,63 & 0,94 & 1,66 & 2,34 & 1,49 & 2,47 & 1,39 & 1,62 & 1,36 & 1,37 & 1,27 & 1,96 & 1,27 & 2,79 & 1,74 & 1,35 & 1,28 & 0,52 \\
\hline $\mathrm{Fe}_{2} \mathrm{O}_{3}$ & 2,72 & 2,73 & 3,41 & 2,69 & 3,39 & 2,91 & 3,30 & 3,33 & 2,77 & 1,86 & 3,57 & 2,28 & 3,61 & 1,91 & 1,90 & 1,56 & 2,18 & 1,54 & 3,00 & 1,83 & 1,93 & 1,53 & 2,39 \\
\hline Mno & 0,16 & 0,08 & 0,19 & 0,19 & 0,17 & 0,17 & 0,11 & 0,16 & 0,09 & 0,09 & 0,17 & 0,10 & 0,06 & 0,17 & 0,18 & 0,15 & 0,20 & 0,17 & 0,24 & 0,12 & 0,21 & 0,14 & 0,13 \\
\hline $\mathrm{MgO}$ & 0,04 & & 0,04 & 0,05 & 0,02 & 0,03 & 0,01 & 0,01 & 0,05 & 0,01 & 0,07 & 0,04 & 0,07 & 0,05 & 0,04 & 0,01 & 0,04 & 0,02 & 0,08 & 0,01 & 0,05 & 0,01 & 0,02 \\
\hline $\mathrm{CaO}$ & 27,51 & 29,47 & 28,84 & 27,37 & 29,10 & 28,29 & 29,77 & 29,39 & 29,09 & 29,80 & 28,69 & 29,58 & 29,09 & 26,66 & 27,61 & 29,45 & 30,06 & 28,71 & 29,00 & 30,33 & 27,15 & 28,30 & 29,69 \\
\hline $\mathrm{Na}_{2} \mathrm{O}$ & 0,16 & 0,26 & 0,23 & 0,11 & 0,16 & 0,12 & 0,26 & 0,18 & 0,14 & 0,07 & 0,21 & 0,15 & 0,10 & 0,11 & 0,05 & 0,05 & 0,14 & 0,14 & 0,15 & 0,20 & 0,15 & 0,16 & 0,22 \\
\hline $\mathrm{K}_{2} \mathrm{O}$ & 0,00 & 0,00 & 0,02 & & & 0,01 & 0,01 & & 0,03 & 0,01 & 0,04 & 0,02 & 0,00 & 0,00 & 0,00 & 0,01 & 0,11 & 0,02 & 0,09 & 0,03 & 0,01 & & 0,02 \\
\hline $\mathrm{Nb}_{2} \mathrm{O}_{5}$ & & 0,00 & 0,01 & 0,04 & 0,01 & 0,02 & 0,04 & & 0,02 & 0,09 & 0,07 & 0,04 & 0,04 & 0,02 & 0,01 & 0,00 & 0,05 & 0,03 & 0,02 & & 0,03 & 0,07 & 0,06 \\
\hline $\mathrm{La}_{2} \mathrm{O}_{3}$ & 0,43 & 0,12 & 0,16 & 0,53 & 0,15 & 0,38 & 0,06 & 0,21 & 0,22 & 0,20 & 0,32 & 0,08 & 0,11 & 0,51 & 0,33 & 0,23 & & 0,25 & 0,35 & 0,08 & 0,39 & 0,34 & 0,07 \\
\hline $\mathrm{Ce}_{2} \mathrm{O}_{3}$ & 1,87 & 0,57 & 0,69 & 1,92 & 0,64 & 1,49 & 0,35 & 0,66 & 0,59 & 0,53 & 0,76 & 0,30 & 0,87 & 2,07 & 1,60 & 0,61 & 0,05 & 1,19 & 0,76 & 0,15 & 2,18 & 1,29 & 0,23 \\
\hline $\mathrm{Nd}_{2} \mathrm{O}_{3}$ & 0,63 & 0,23 & 0,23 & 0,69 & 0,15 & 0,46 & 0,16 & 0,19 & 0,15 & 0,18 & 0,17 & 0,15 & 0,80 & 1,59 & 1,14 & 0,22 & 0,05 & 0,59 & 0,22 & 0,05 & 1,57 & 0,86 & 0,19 \\
\hline $\mathrm{Y}_{2} \mathrm{O}_{3}$ & 0,09 & & & 0,05 & & 0,08 & & & & & & & & 0,08 & 0,02 & & & & & & 0,10 & & \\
\hline $\mathbf{F}$ & & & & 0,01 & 0,02 & & & 0,03 & 0,03 & & 0,02 & & 0,03 & & 0,02 & & 0,03 & 0,02 & & & 0,03 & & 0,03 \\
\hline Total & 97,67 & 99,32 & 98,42 & 97,14 & 97,47 & 97,59 & 99,36 & 97,89 & 99,18 & 100,77 & 98,71 & 100,52 & 99,04 & 98,53 & 98,04 & 99,46 & 100,64 & 99,44 & 98,50 & 100,78 & 98,71 & 99,30 & 101,20 \\
\hline \multicolumn{24}{|c|}{ Número de cátions calculado na base de 3 cátions. } \\
\hline Si & 1,002 & 0,998 & 1,003 & 1,004 & 1,003 & 0,996 & 0,997 & 1,011 & 0,996 & 0,984 & 1,000 & 0,999 & 0,993 & 0,979 & 0,988 & 0,997 & 0,988 & 0,985 & 1,003 & 0,987 & 0,976 & 0,986 & 0,983 \\
\hline $\mathrm{Ti}$ & 0,795 & 0,839 & 0,801 & 0,791 & 0,768 & 0,786 & 0,820 & 0,762 & 0,795 & 0,839 & 0,758 & 0,850 & 0,788 & 0,878 & 0,857 & 0,850 & 0,836 & 0,864 & 0,749 & 0,840 & 0,860 & 0,871 & 0,889 \\
\hline $\mathrm{Zr}$ & 0,023 & 0,004 & 0,006 & 0,022 & 0,012 & 0,019 & 0,002 & 0,011 & 0,009 & 0,023 & 0,013 & 0,003 & 0,009 & 0,008 & 0,009 & 0,013 & 0,000 & 0,011 & 0,011 & 0,005 & 0,010 & 0,007 & 0,003 \\
\hline Al & 0,063 & 0,032 & 0,053 & 0,064 & 0,070 & 0,064 & 0,036 & 0,065 & 0,090 & 0,057 & 0,095 & 0,053 & 0,063 & 0,054 & 0,054 & 0,049 & 0,074 & 0,049 & 0,108 & 0,066 & 0,053 & 0,050 & 0,020 \\
\hline $\mathrm{Fe}^{3+}$ & 0,069 & 0,067 & 0,084 & 0,069 & 0,085 & 0,073 & 0,081 & 0,083 & 0,068 & 0,045 & 0,088 & 0,055 & 0,089 & 0,049 & 0,048 & 0,038 & 0,052 & 0,038 & 0,074 & 0,044 & 0,049 & 0,038 & 0,058 \\
\hline $\mathrm{Mn}$ & 0,005 & 0,002 & 0,005 & 0,005 & 0,005 & 0,005 & 0,003 & 0,004 & 0,002 & 0,002 & 0,005 & 0,003 & 0,002 & 0,005 & 0,005 & 0,004 & 0,005 & 0,005 & 0,007 & 0,003 & 0,006 & 0,004 & 0,004 \\
\hline $\mathrm{Mg}$ & 0,002 & 0,000 & 0,002 & 0,002 & 0,001 & 0,002 & 0,000 & 0,001 & 0,003 & 0,000 & 0,003 & 0,002 & 0,003 & 0,003 & 0,002 & 0,001 & 0,002 & 0,001 & 0,004 & 0,000 & 0,003 & 0,001 & 0,001 \\
\hline $\mathrm{Ca}$ & 0,993 & 1,030 & 1,017 & 0,995 & 1,033 & 1,017 & 1,037 & 1,039 & 1,015 & 1,032 & 1,007 & 1,019 & 1,025 & 0,965 & 0,995 & 1,031 & 1,028 & 1,013 & 1,016 & 1,038 & 0,980 & 1,002 & 1,022 \\
\hline $\mathrm{Na}$ & 0,011 & 0,017 & 0,015 & 0,007 & 0,010 & 0,007 & 0,016 & 0,011 & 0,009 & 0,004 & 0,013 & 0,009 & 0,007 & 0,007 & 0,003 & 0,003 & 0,008 & 0,009 & 0,009 & 0,012 & 0,010 & 0,011 & 0,013 \\
\hline K & 0,000 & 0,000 & 0,001 & 0,000 & 0,000 & 0,001 & 0,000 & 0,000 & 0,001 & 0,000 & 0,001 & 0,001 & 0,000 & 0,000 & 0,000 & 0,000 & 0,005 & 0,001 & 0,004 & 0,001 & 0,000 & 0,000 & 0,001 \\
\hline $\mathrm{Nb}$ & 0,000 & 0,000 & 0,000 & 0,001 & 0,000 & 0,000 & 0,001 & 0,000 & 0,000 & 0,001 & 0,001 & 0,001 & 0,001 & 0,000 & 0,000 & 0,000 & 0,001 & 0,000 & 0,000 & 0,000 & 0,001 & 0,001 & 0,001 \\
\hline La & 0,005 & 0,001 & 0,002 & 0,007 & 0,002 & 0,005 & 0,001 & 0,003 & 0,003 & 0,002 & 0,004 & 0,001 & 0,001 & 0,006 & 0,004 & 0,003 & 0,000 & 0,003 & 0,004 & 0,001 & 0,005 & 0,004 & 0,001 \\
\hline $\mathrm{Ce}$ & 0,023 & 0,007 & 0,008 & 0,024 & 0,008 & 0,018 & 0,004 & 0,008 & 0,007 & 0,006 & 0,009 & 0,004 & 0,011 & 0,026 & 0,020 & 0,007 & 0,001 & 0,014 & 0,009 & 0,002 & 0,027 & 0,016 & 0,003 \\
\hline $\mathrm{Nd}$ & 0,008 & 0,003 & 0,003 & 0,008 & 0,002 & 0,005 & 0,002 & 0,002 & 0,002 & 0,002 & 0,002 & 0,002 & 0,009 & 0,019 & 0,014 & 0,003 & 0,001 & 0,007 & 0,003 & 0,001 & 0,019 & 0,010 & 0,002 \\
\hline $\mathrm{Y}$ & 0,002 & 0,000 & 0,000 & 0,001 & 0,000 & 0,001 & 0,000 & 0,000 & 0,000 & 0,000 & 0,000 & 0,000 & 0,000 & 0,001 & 0,000 & 0,000 & 0,000 & 0,000 & 0,000 & 0,000 & 0,002 & 0,000 & 0,000 \\
\hline$F$ & 0,000 & 0,000 & 0,000 & 0,001 & 0,002 & 0,000 & 0,000 & 0,004 & 0,004 & 0,000 & 0,002 & 0,000 & 0,004 & 0,000 & 0,002 & 0,000 & 0,003 & 0,002 & 0,000 & 0,000 & 0,003 & 0,000 & 0,003 \\
\hline Total & 3,000 & 3,000 & 3,000 & 3,000 & 3,000 & 3,000 & 3,000 & 3,000 & 3,000 & 3,000 & 3,000 & 3,000 & 3,000 & 3,000 & 3,000 & 3,000 & 3,000 & 3,000 & 3,000 & 3,000 & 3,000 & 3,000 & 3,000 \\
\hline
\end{tabular}




\begin{tabular}{|c|c|c|c|c|c|c|c|c|c|c|c|c|c|c|c|c|c|c|c|c|c|c|c|}
\hline Unidade & \begin{tabular}{|l|l|} 
BtHblP & \\
\end{tabular} & N-I & & & & & & & & & & & & & & & & BtHbIP & & & & & \\
\hline $\begin{array}{l}\text { Amostra } \\
\text { Cristal }\end{array}$ & $\begin{array}{r}\text { MAIO0921 } \\
23\end{array}$ & MAI097B & 24 & 24 & 25 & 25 & & & & & & & & 28 & & & & MAI102 & & & & 33 & 33 \\
\hline \multirow{2}{*}{\multicolumn{2}{|c|}{ Textura $^{1}$}} & 24 & 24 & 24 & 25 & 25 & 25 & 26 & 26 & 26 & 27 & 27 & 27 & 28 & 29 & 29 & 29 & 30 & 31 & 31 & 32 & 33 & 33 \\
\hline & & subido $n$ & ubido nb & subido b & n & $n b$ & b & n & b & $/ \mathrm{mt} \mathrm{b}$ & $/ \mathrm{mt} \mathrm{n}$ & $/ \mathrm{mt} \mathrm{n} 2$ & $/ \mathrm{mt} \mathrm{b}$ & /anf-mt & $/ \mathrm{mt} \mathrm{n}$ & $/ \mathrm{mt} \mathrm{nb}$ & $\mid \mathrm{mt} \mathrm{nb}$ & $<-o p$ & $\mathrm{nb}$ & $b c l$ & /op-cpx & n & \\
\hline$\overline{\mathrm{SiO}_{2}}$ & 29,97 & 29,52 & 29,53 & 29,53 & 30,86 & 29,46 & 29,68 & 29,46 & 28,99 & 30,46 & 30,81 & 30,48 & 29,52 & 29,25 & 30,32 & 30,34 & 29,84 & 30,80 & 30,58 & 29,81 & 30,96 & 29,99 & 30,32 \\
\hline $\mathrm{TiO}_{2}$ & 34,76 & 33,71 & 33,04 & 33,85 & 36,91 & 32,31 & 34,79 & 32,69 & 32,75 & 35,14 & 34,07 & 33,52 & 31,70 & 31,74 & 32,90 & 34,72 & 32,01 & 37,54 & 34,43 & 34,07 & 35,25 & 33,09 & 32,53 \\
\hline $\mathrm{ZrO}_{2}$ & 0,62 & 0,48 & 0,56 & 0,44 & & 0,12 & 0,29 & 0,57 & 0,49 & 0,01 & 0,05 & 0,04 & 0,49 & 0,13 & 0,14 & 0,10 & 0,07 & 0,22 & 0,73 & 2,34 & 0,51 & 1,37 & 1,00 \\
\hline $\mathrm{Al}_{2} \mathrm{O}_{3}$ & 1,22 & 1,21 & 1,20 & 1,12 & 0,43 & 0,81 & 0,49 & 1,16 & 1,13 & 0,43 & 1,02 & 1,04 & 0,89 & 0,69 & 0,81 & 0,93 & 0,70 & 1,05 & 1,46 & 1,14 & 1,76 & 1,86 & 1,81 \\
\hline $\mathrm{Fe}_{2} \mathrm{O}_{3}$ & 1,41 & 2,66 & 2,49 & 2,41 & 2,21 & 3,58 & 3,43 & 2,60 & 2,63 & 3,62 & 3,50 & 3,87 & 4,13 & 4,10 & 3,10 & 3,03 & 4,20 & 1,64 & 1,58 & 1,54 & 2,41 & 1,98 & 2,56 \\
\hline $\mathrm{MnO}$ & 0,16 & 0,36 & 0,34 & 0,33 & 0,25 & 0,47 & 0,55 & 0,33 & 0,39 & 0,45 & 0,51 & 0,43 & 0,35 & 0,56 & 0,45 & 0,25 & 0,31 & 0,12 & 0,10 & 0,14 & 0,16 & 0,08 & 0,09 \\
\hline MgO & 0,01 & & & & & 0,14 & 0,05 & & & & & & 0,11 & 0,10 & & & & 0,01 & & 0,02 & 0,04 & 0,02 & 0,03 \\
\hline $\mathrm{CaO}$ & 28,80 & 27,33 & 27,59 & 27,29 & 30,01 & 26,86 & 27,47 & 27,25 & 26,90 & 29,06 & 29,47 & 29,01 & 27,37 & 26,71 & 28,56 & 29,25 & 28,70 & 29,75 & 29,43 & 28,38 & 30,38 & 27,94 & 28,64 \\
\hline $\mathrm{Na}_{2} \mathrm{O}$ & 0,08 & 0,07 & 0,08 & 0,14 & 0,07 & 0,28 & 0,26 & 0,06 & 0,10 & 0,11 & 0,05 & 0,01 & 0,19 & 0,25 & 0,09 & 0,04 & 0,08 & 0,08 & 0,09 & 0,14 & 0,04 & 0,10 & 0,09 \\
\hline $\mathrm{K}_{2} \mathrm{O}$ & 0,02 & 0,02 & & 0,03 & & 0,01 & 0,02 & 0,01 & 0,08 & 0,03 & 0,00 & & & 0,01 & & & 0,01 & 0,01 & 0,00 & 0,11 & 0,08 & 0,00 & 0,02 \\
\hline $\mathrm{Nb}_{2} \mathrm{O}_{5}$ & & & & & 0,00 & & 0,06 & 0,04 & 0,01 & 0,05 & & & & 0,01 & & & 0,01 & 0,00 & & 0,02 & 0,05 & 0,06 & 0,01 \\
\hline $\mathrm{La}_{2} \mathrm{O}_{3}$ & 0,28 & 0,45 & 0,52 & 0,51 & 0,01 & 0,43 & 0,31 & 0,54 & 0,47 & 0,15 & 0,02 & 0,23 & 0,43 & 0,47 & 0,25 & 0,06 & 0,14 & 0,17 & 0,31 & 0,37 & 0,09 & 0,50 & 0,32 \\
\hline $\mathrm{Ce}_{2} \mathrm{O}_{3}$ & 1,25 & 1,93 & 1,97 & 2,21 & 0,21 & 1,93 & 1,17 & 1,99 & 2,01 & 0,56 & 0,15 & 0,78 & 1,28 & 1,78 & 0,95 & 0,62 & 0,86 & 0,32 & 0,77 & 1,22 & 0,27 & 1,52 & 1,33 \\
\hline $\mathrm{Nd}_{2} \mathrm{O}_{3}$ & 0,61 & 0,86 & 0,86 & 0,92 & 0,09 & 0,89 & 0,44 & 1,08 & 0,96 & 0,18 & 0,02 & 0,13 & 0,43 & 0,74 & 0,25 & 0,36 & 0,61 & 0,16 & 0,29 & 0,54 & 0,09 & 0,50 & 0,46 \\
\hline $\mathrm{Y}_{2} \mathrm{O}_{3}$ & 0,05 & 0,24 & 0,21 & 0,22 & & 0,24 & 0,04 & 0,23 & 0,18 & & & & 0,10 & 0,19 & & 0,01 & 0,14 & & & & & & 0,01 \\
\hline $\mathbf{F}$ & 0,02 & 0,01 & 0,02 & 0,01 & & 0,01 & 0,01 & & 0,02 & 0,02 & & 0,02 & & 0,00 & & & & 0,03 & & & & 0,03 & \\
\hline Total & 99,27 & & & & & & & 97,99 & 97,11 & 100,27 & 99,67 & 99,56 & 96,99 & 96,75 & 97,82 & 99,73 & 97,68 & 101,91 & 99,76 & 99,83 & 102,09 & 99,05 & 99,22 \\
\hline \multicolumn{24}{|c|}{ Número de cátions calculado na base de 3 cátions. } \\
\hline Si & 0,989 & 0,988 & 0,992 & 0,989 & 0,991 & 0,996 & 0,985 & 0,997 & 0,989 & 0,991 & 1,000 & 0,997 & 0,998 & 0,997 & 1,009 & 0,990 & 0,997 & 0,983 & 0,997 & 0,985 & 0,981 & 0,995 & 0,998 \\
\hline $\mathrm{Ti}$ & 0,863 & 0,849 & 0,835 & 0,852 & 0,892 & 0,822 & 0,868 & 0,832 & 0,840 & 0,860 & 0,831 & 0,824 & 0,806 & 0,814 & 0,824 & 0,852 & 0,804 & 0,901 & 0,844 & 0,846 & 0,840 & 0,826 & 0,805 \\
\hline $\mathrm{Zr}$ & 0,010 & 0,008 & 0,009 & 0,007 & 0,000 & 0,002 & 0,005 & 0,009 & 0,008 & 0,000 & 0,001 & 0,001 & 0,008 & 0,002 & 0,002 & 0,002 & 0,001 & 0,003 & 0,012 & 0,038 & 0,008 & 0,022 & 0,016 \\
\hline Al & 0,048 & 0,048 & 0,048 & 0,044 & 0,016 & 0,032 & 0,019 & 0,046 & 0,046 & 0,016 & 0,039 & 0,040 & 0,035 & 0,028 & 0,032 & 0,036 & 0,028 & 0,039 & 0,056 & 0,045 & 0,066 & 0,073 & 0,070 \\
\hline $\mathrm{Fe}^{3+}$ & 0,035 & 0,067 & 0,063 & 0,061 & 0,053 & 0,091 & 0,086 & 0,066 & 0,068 & 0,089 & 0,085 & 0,095 & 0,105 & 0,105 & 0,078 & 0,075 & 0,106 & 0,039 & 0,039 & 0,038 & 0,057 & 0,049 & 0,063 \\
\hline$M n$ & 54 & 0,010 & 0,010 & 0,009 & 0,007 & 0,0 & 0 , & 0,009 & 0,011 & 0,013 & 0,014 & 0,012 & 0,010 & 0,016 & 0,013 & 0,007 & 0,009 & 0,003 & 0,003 & 0,004 & 0,004 & 0,002 & 0,003 \\
\hline Mg & & 0,000 & & 0,000 & 0,000 & $0, \mathrm{C}$ & & 0,000 & 0,000 & 0,000 & 0,000 & 0,000 & 0,006 & 0,005 & 0,000 & 0,000 & 0,000 & 0,000 & 0,000 & 0,001 & 0,002 & 0,001 & 0,001 \\
\hline $\mathrm{Ca}$ & 1,018 & 0,980 & 0,993 & 0,979 & 1,033 & 0,973 & 0,977 & 0,988 & 0,983 & 1,013 & 1,024 & 1,016 & 0,991 & 0,975 & 1,019 & 1,023 & 1,028 & 1,017 & 1,028 & 1,004 & 1,031 & 0,993 & 1,010 \\
\hline $\mathrm{Na}$ & & 05 & & & 0,004 & $0, \mathrm{C}$ & & & 0,006 & 0,007 & 0,003 & 0,001 & 0, & 0,017 & 0,006 & 0,003 & 0,005 & 0,005 & 0,006 & 0,009 & 0,003 & 0,007 & 0,006 \\
\hline K & 0,001 & 0,001 & 0,000 & 0,001 & 0,000 & 0,000 & 0 , & 0 , & 0,003 & 0,001 & 0,000 & 0,000 & 0,000 & 0,000 & 0,000 & 0,000 & 0,001 & 0,001 & 0,000 & 0,004 & 0,003 & 0,000 & 0,001 \\
\hline $\mathrm{Nk}$ & & & & & & & & & & & & & & & & & 0,000 & & 0,000 & 0,000 & 0,001 & 0,001 & 0,000 \\
\hline La & 0,003 & 0,006 & 0,006 & 0,006 & 0,000 & 0,005 & 0,004 & 0,007 & 0,006 & 0,002 & 0,000 & 0,003 & 0,005 & 0,006 & 0,003 & 0,001 & 0,002 & 0,002 & 0,004 & 0,004 & 0,001 & 0,006 & 0,004 \\
\hline $\mathrm{Ce}$ & 0,015 & 0,024 & 0,024 & 0,027 & & 0,024 & & 0,025 & 0,025 & 0,007 & 0,002 & 0,009 & 0,016 & 0,022 & 0,012 & 0,007 & 0,011 & 0,004 & 0,009 & 0,015 & 0,003 & 0,018 & 0,016 \\
\hline $\mathrm{Nd}$ & 67 & 0,010 & 0,010 & 0,011 & 0,001 & 0,011 & 0,005 & 0,013 & 0,012 & 0,002 & 0,000 & 0,001 & 0,005 & 0,009 & 0,003 & 0,004 & 0,007 & 0,002 & 0,003 & 0,006 & 0,001 & 0,006 & 0,005 \\
\hline$Y$ & 0,001 & 0,004 & 0,004 & 0,004 & 0,000 & 0,004 & 0,0 & 0,004 & 0,003 & 0,000 & 0,000 & 0,000 & 0,002 & 0,004 & 0,000 & 0,000 & 0,003 & 0,000 & 0,000 & 0,000 & 0,000 & 0,000 & 0,000 \\
\hline $\mathbf{F}$ & 0,002 & 0,001 & 0,002 & 0,001 & 0,000 & 0,001 & 0,001 & 0,000 & 0,002 & 0,002 & 0,000 & 0,002 & 0,000 & 0,000 & 0,000 & 0,000 & 0,000 & 0,003 & 0,000 & 0,000 & 0,000 & 0,003 & 0,000 \\
\hline Total & 3,000 & 3,000 & 3,000 & 3,000 & 3,000 & 3,000 & 3,000 & 3,000 & 3,000 & 3,000 & 3,000 & 3,000 & 3,000 & 3,000 & 3,000 & 3,000 & 3,000 & 3,000 & 3,000 & 3,000 & 3,000 & 3,000 & 3,000 \\
\hline
\end{tabular}


ANEXO E - Tabela E.5 - Composição química de titanitas de rochas do Maciço Alcalino de Itatiaia. Continua..

\begin{tabular}{|c|c|c|c|c|c|c|c|c|c|c|c|c|c|c|c|c|c|c|c|c|c|c|c|}
\hline \multirow{3}{*}{$\begin{array}{l}\text { Unidade } \\
\text { Amostra } \\
\text { Cristal }\end{array}$} & \multicolumn{8}{|l|}{ BtHblP } & \multicolumn{15}{|l|}{ arpk-QzS } \\
\hline & MAI102 & & & & & & & & MAI108II & & & & & & & & & & & & & & \\
\hline & 33 & 34 & 34 & 35 & 36 & 36 & 37 & 38 & 39 & 39 & 39 & 40 & 40 & 41 & 41 & 42 & 42 & 42 & 42 & 42 & 43 & 43 & 43 \\
\hline Textura $^{1}$ & b & idio/op & idio/op & /op & $/ b t$ & $<-o p<b t$ & $<-o p<c p x$ & |ор $<\mathrm{ppx} \mid$ & $n$ & nb & b & & & $<-i \operatorname{lm} n$ & $<-\lim$ b & $n$ & $\mathrm{n}$ & nb & b & b & $n$ & $n$ & b \\
\hline$\overline{\mathrm{SiO}_{2}}$ & 30,30 & 30,72 & 30,92 & 30,75 & 31,30 & 30,95 & 30,68 & 31,09 & 30,07 & 30,60 & 30,71 & 30,27 & 30,95 & 30,94 & 30,75 & 29,89 & 29,75 & 30,50 & 31,20 & 30,79 & 30,66 & 30,07 & 30,50 \\
\hline $\mathrm{TiO}_{2}$ & 32,47 & 36,36 & 37,23 & 35,11 & 35,42 & 37,59 & 35,22 & 36,30 & 28,96 & 31,36 & 30,57 & 33,56 & 34,45 & 34,74 & 35,73 & 26,88 & 26,49 & 29,16 & 32,36 & 35,80 & 27,54 & 28,34 & 30,88 \\
\hline $\mathrm{ZrO}_{2}$ & 1,59 & 0,27 & 0,25 & 1,00 & 0,15 & 0,05 & 0,35 & 0,29 & 0,26 & 0,09 & 0,09 & 0,08 & 0,05 & 0,05 & 0,05 & 0,20 & 0,28 & 0,10 & 0,05 & 0,04 & 0,14 & 0,80 & 0,20 \\
\hline $\mathrm{Al}_{2} \mathrm{O}_{3}$ & 2,08 & 1,69 & 1,38 & 1,90 & 2,44 & 1,20 & 0,92 & 1,30 & 2,09 & 2,22 & 3,60 & 0,78 & 0,75 & 0,97 & 1,01 & 3,27 & 2,90 & 3,00 & 2,48 & 0,94 & 3,96 & 2,50 & 2,77 \\
\hline $\mathrm{Fe}_{2} \mathrm{O}_{3}$ & 2,27 & 1,76 & 1,84 & 1,80 & 1,27 & 1,40 & 2,62 & 2,38 & 4,04 & 3,61 & 2,14 & 2,97 & 3,23 & 4,12 & 2,84 & 4,94 & 4,74 & 4,12 & 2,91 & 2,64 & 4,64 & 4,87 & 3,77 \\
\hline MnO & 0,09 & 0,14 & 0,12 & 0,09 & 0,07 & 0,15 & 0,16 & 0,14 & 0,38 & 0,38 & 0,19 & 0,33 & 0,30 & 0,54 & 0,56 & 0,36 & 0,38 & 0,42 & 0,35 & 0,44 & 0,45 & 0,42 & 0,36 \\
\hline MgO & 0,00 & 0,01 & & & 0,03 & 0,02 & 0,15 & 0,05 & 0,20 & 0,15 & 0,05 & 0,07 & 0,05 & 0,04 & 0,05 & 0,41 & 0,37 & 0,24 & 0,29 & 0,03 & 0,38 & 0,40 & 0,23 \\
\hline $\mathrm{CaO}$ & 29,02 & 29,90 & 30,31 & 30,38 & 30,10 & 30,49 & 28,61 & 29,40 & 27,57 & 28,25 & 29,66 & 28,72 & 28,65 & 29,68 & 29,60 & 27,50 & 27,28 & 28,54 & 29,77 & 29,87 & 28,38 & 27,64 & 28,10 \\
\hline $\mathrm{Na}_{2} \mathrm{O}$ & 0,08 & 0,09 & 0,06 & 0,04 & 0,08 & 0,08 & 0,07 & 0,06 & 0,09 & 0,09 & 0,05 & 0,12 & 0,07 & 0,07 & 0,08 & 0,04 & 0,10 & 0,07 & 0,06 & 0,06 & 0,07 & 0,09 & 0,10 \\
\hline $\mathrm{K}_{2} \mathrm{O}$ & 0,04 & 0,07 & 0,07 & 0,00 & 0,00 & 0,09 & 0,20 & 0,07 & 0,00 & & 0,01 & & 0,14 & 0,01 & 0,01 & 0,00 & 0,00 & & 0,04 & 0,01 & & 0,03 & 0,08 \\
\hline $\mathrm{Nb}_{2} \mathrm{O}_{5}$ & 0,08 & 0,00 & 0,05 & 0,02 & & 0,04 & 0,04 & 0,01 & & 0,02 & 0,01 & 0,06 & & & 0,03 & & & 0,03 & 0,01 & 0,02 & 0,07 & 0,07 & 0,05 \\
\hline $\mathrm{La}_{2} \mathrm{O}_{3}$ & 0,27 & 0,06 & 0,04 & 0,04 & 0,06 & 0,05 & 0,29 & 0,10 & 0,35 & 0,22 & 0,00 & 0,23 & 0,30 & 0,01 & 0,06 & 0,22 & 0,22 & 0,20 & & 0,09 & 0,36 & 0,50 & 0,36 \\
\hline $\mathrm{Ce}_{2} \mathrm{O}_{3}$ & 0,74 & 0,14 & 0,15 & 0,14 & 0,06 & 0,10 & 1,00 & 0,52 & 1,35 & 1,03 & 0,09 & 0,96 & 0,97 & 0,15 & 0,17 & 1,15 & 1,00 & 0,89 & & 0,28 & 1,21 & 1,92 & 1,53 \\
\hline $\mathrm{Nd}_{2} \mathrm{O}_{3}$ & 0,29 & 0,05 & 0,00 & 0,03 & 0,04 & 0,04 & 0,55 & 0,24 & 0,64 & 0,55 & 0,08 & 0,45 & 0,25 & 0,05 & 0,06 & 0,56 & 0,68 & 0,49 & 0,01 & 0,12 & 0,60 & 0,71 & 0,61 \\
\hline $\mathrm{Y}_{2} \mathrm{O}_{3}$ & 0,03 & & & & & & 0,07 & & 0,19 & 0,20 & 0,02 & 0,18 & 0,00 & & & 0,82 & 1,06 & 0,27 & 0,13 & & 0,15 & 0,09 & 0,03 \\
\hline $\mathrm{F}$ & & & & & 0,03 & & 0,00 & & & 0,02 & 0,03 & & 0,00 & & 0,01 & & 0,02 & 0,03 & & & & 0,04 & 0,03 \\
\hline Total & 99,35 & 101,25 & 102,45 & 101,31 & 101,03 & 102,27 & 100,92 & 101,94 & 96,19 & 98,79 & 97,31 & 98,76 & 100,17 & 101,38 & 101,00 & 96,24 & 95,28 & 98,08 & 99,67 & 101,13 & 98,62 & 98,49 & 99,60 \\
\hline \multicolumn{24}{|c|}{ Número de cátions calcula } \\
\hline נונ & 0,993 & 0,980 & 0,977 & 0,981 & 0,995 & 0,978 & 0,995 & 0,992 & 1,016 & 1,005 & 1,004 & 1,000 & 1,008 & 0,989 & 0,986 & 1,003 & 1,010 & 1,002 & 1,001 & 0,987 & 1,000 & 0,998 & 0,995 \\
\hline $\mathrm{Ti}$ & 0,800 & 0,872 & 0,885 & 0,842 & 0,847 & 0,894 & 0,859 & 0,871 & 0,736 & 0,775 & 0,751 & 0,834 & 0,844 & 0,835 & 0,862 & 0,679 & 0,676 & 0,721 & 0,780 & 0,863 & 0,675 & 0,707 & 0,758 \\
\hline $\mathrm{zr}$ & 0,025 & 0,004 & 0,004 & 0,016 & 0,002 & 0,001 & 0,006 & 0,005 & 0,004 & 0,001 & 0,001 & 0,001 & 0,001 & 0,001 & 0,001 & 0,003 & 0,005 & 0,002 & 0,001 & 0,001 & 0,002 & 0,013 & 0,003 \\
\hline Al & 0,080 & 0,063 & 0,052 & 0,071 & 0,091 & 0,045 & 0,035 & 0,049 & 0,083 & 0,086 & 0,139 & 0,030 & 0,029 & 0,037 & 0,038 & 0,129 & 0,116 & 0,116 & 0,094 & 0,036 & 0,152 & 0,098 & 0,107 \\
\hline $\mathrm{Fe}^{3+}$ & 0,056 & 0,042 & 0,044 & 0,043 & 0,030 & 0,033 & 0,064 & 0,057 & 0,103 & 0,089 & 0,053 & 0,074 & 0,079 & 0,099 & 0,069 & 0,125 & 0,121 & 0,102 & 0,070 & 0,064 & 0,114 & 0,122 & 0,093 \\
\hline $\mathrm{Mn}$ & 0,002 & 0,004 & 0,003 & 0,002 & 0,002 & 0,004 & 0,004 & 0,004 & 0,011 & 0,011 & 0,005 & 0,009 & 0,008 & 0,015 & 0,015 & 0,010 & 0,011 & 0,012 & 0,010 & 0,012 & 0,012 & 0,012 & 0,010 \\
\hline $\mathrm{Mg}$ & 0,000 & 0,001 & 0,000 & 0,000 & 0,001 & 0,001 & 0,007 & 0,002 & 0,010 & 0,007 & 0,002 & 0,003 & 0,003 & 0,002 & 0,002 & 0,020 & 0,019 & 0,012 & 0,014 & 0,001 & 0,018 & 0,020 & 0,011 \\
\hline $\mathrm{Ca}$ & 1,019 & 1,022 & 1,026 & 1,038 & 1,025 & 1,033 & 0,994 & 1,005 & 0,998 & 0,994 & 1,038 & 1,017 & 1,000 & 1,016 & 1,017 & 0,989 & 0,992 & 1,005 & 1,023 & 1,026 & 0,992 & 0,983 & 0,983 \\
\hline $\mathrm{Na}$ & 0,005 & 0,005 & 0,004 & 0,003 & 0,005 & 0,005 & 0,005 & 0,004 & 0,006 & 0,005 & 0,003 & 0,008 & 0,004 & 0,004 & 0,005 & 0,002 & 0,007 & 0,005 & 0,003 & 0,004 & 0,004 & 0,006 & 0,006 \\
\hline $\mathrm{K}$ & 0,002 & 0,003 & 0,003 & 0,000 & 0,000 & 0,004 & 0,008 & 0,003 & 0,000 & 0,000 & 0,001 & 0,000 & 0,006 & 0,001 & 0,000 & 0,000 & 0,000 & 0,000 & 0,002 & 0,000 & 0,000 & 0,001 & 0,003 \\
\hline $\mathrm{Nb}$ & 0,001 & 0,000 & 0,001 & 0,000 & 0,000 & 0,001 & 0,001 & 0,000 & 0,000 & 0,000 & 0,000 & 0,001 & 0,000 & 0,000 & 0,000 & 0,000 & 0,000 & 0,001 & 0,000 & 0,000 & 0,001 & 0,001 & 0,001 \\
\hline La & 0,003 & 0,001 & 0,001 & 0,000 & 0,001 & 0,001 & 0,003 & 0,001 & 0,004 & 0,003 & 0,000 & 0,003 & 0,004 & 0,000 & 0,001 & 0,003 & 0,003 & 0,002 & 0,000 & 0,001 & 0,004 & 0,006 & 0,004 \\
\hline $\mathrm{Ce}$ & 0,009 & 0,002 & 0,002 & 0,002 & 0,001 & 0,001 & 0,012 & 0,006 & 0,017 & 0,012 & 0,001 & 0,012 & 0,012 & 0,002 & 0,002 & 0,014 & 0,012 & 0,011 & 0,000 & 0,003 & 0,014 & 0,023 & 0,018 \\
\hline Nd & 0,003 & 0,001 & 0,000 & 0,000 & 0,000 & 0,000 & 0,006 & 0,003 & 0,008 & 0,006 & 0,001 & 0,005 & 0,003 & 0,001 & 0,001 & 0,007 & 0,008 & 0,006 & 0,000 & 0,001 & 0,007 & 0,008 & 0,007 \\
\hline 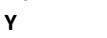 & 0,001 & 0,000 & 0,000 & 0,000 & 0,000 & 0,000 & 0,001 & 0,000 & 0,003 & 0,003 & 0,000 & 0,003 & 0,000 & 0,000 & 0,000 & 0,015 & 0,019 & 0,005 & 0,002 & 0,000 & 0,003 & 0,002 & 0,000 \\
\hline F & 0,000 & 0,000 & 0,000 & 0,000 & 0,003 & 0,000 & 0,000 & 0,000 & 0,000 & 0,002 & 0,003 & 0,000 & 0,000 & 0,000 & 0,001 & 0,000 & 0,002 & 0,003 & 0,000 & 0,000 & 0,000 & 0,004 & 0,004 \\
\hline Total & 3,000 & 3,000 & 3,000 & 3,000 & 3,000 & 3,000 & 3,000 & 3,000 & 3,000 & 3,000 & 3,000 & 3,000 & 3,000 & 3,000 & 3,000 & 3,000 & 3,000 & 3,000 & 3,000 & 3,000 & 3,000 & 3,000 & 3,000 \\
\hline
\end{tabular}




\begin{tabular}{|c|c|c|c|c|c|c|c|c|c|c|c|c|c|c|c|c|c|c|c|c|c|c|c|}
\hline \multirow{3}{*}{$\begin{array}{l}\text { Unidade } \\
\text { Amostra } \\
\text { Cristal }\end{array}$} & \multirow{3}{*}{$\begin{array}{r}\text { arpkQzS } \\
\text { MAI108II } \\
44\end{array}$} & \multicolumn{16}{|l|}{ QzAFS-I } & \\
\hline & & MAI110 & & & & & & & & & & & & & & & & MAl114 & & & & & \\
\hline & & & 45 & 45 & 46 & 46 & 47 & 47 & 47 & 47 & 48 & 48 & 49 & 49 & 49 & 49 & 49 & 50 & 50 & 50 & 51 & 51 & 52 \\
\hline Textura $^{1}$ & & $/ \mathrm{mt} \mathrm{n} 1$ & $/ \mathrm{mt} \mathrm{n} 2$ & $/ \mathrm{mt} \mathrm{b}$ & $/ \mathrm{mt} \mathrm{n}$ & $/ \mathrm{mt} \mathrm{b}$ & $/ \mathrm{mt} \mathrm{n} 1$ & $/ \mathrm{mt} \mathrm{n} 2$ & $/ \mathrm{mt} \mathrm{b} 1$ & $/ \mathrm{mt} \mathrm{b} 2$ & $\mathrm{n}$ & b & $\mathrm{n} 1$ & $\mathrm{n} 2$ & n3 & $\mathrm{n} 4$ & & $\mathrm{n}$ & nb & b & $\mathrm{n}$ & b & \\
\hline$\overline{\mathrm{SiO}_{2}}$ & 30,33 & 30,06 & 29,85 & 30,37 & 29,48 & 29,46 & 29,80 & 30,02 & 29,97 & 29,63 & 29,93 & 30,37 & 29,90 & 29,89 & 29,84 & 29,75 & 30,11 & 29,91 & 30,03 & 30,43 & 29,48 & 30,15 & 30,26 \\
\hline $\mathrm{TiO}_{2}$ & 30,51 & 31,90 & 31,61 & 32,11 & 31,09 & 30,89 & 32,01 & 32,26 & 33,45 & 31,36 & 31,85 & 32,20 & 32,19 & 33,09 & 31,53 & 32,18 & 32,33 & 35,57 & 35,23 & 34,49 & 34,75 & 34,39 & 33,37 \\
\hline $\mathrm{ZrO}_{2}$ & 0,29 & 0,15 & 0,11 & 0,04 & 0,10 & 0,24 & 0,23 & 0,22 & 0,08 & 0,07 & 0,10 & 0,04 & 0,24 & 0,08 & 0,17 & 0,09 & 0,04 & 0,66 & 0,57 & 1,08 & 0,59 & 0,98 & 2,04 \\
\hline $\mathrm{Al}_{2} \mathrm{O}_{3}$ & 2,46 & 0,46 & 0,55 & 0,54 & 0,33 & 0,36 & 0,49 & 0,52 & 0,53 & 0,59 & 0,58 & 0,55 & 0,36 & 0,34 & 0,36 & 0,42 & 0,52 & 1,20 & 1,32 & 1,52 & 1,18 & 1,39 & 1,55 \\
\hline $\mathrm{Fe}_{2} \mathrm{O}_{3}$ & 3,63 & 4,46 & 4,49 & 4,91 & 5,41 & 4,82 & 4,42 & 4,27 & 4,00 & 4,49 & 4,03 & 4,01 & 4,57 & 4,13 & 4,54 & 4,91 & 4,81 & 1,57 & 1,63 & 1,90 & 1,57 & 1,49 & 1,87 \\
\hline $\mathrm{MnO}$ & 0,40 & 0,35 & 0,44 & 0,39 & 0,44 & 0,42 & 0,37 & 0,44 & 0,51 & 0,39 & 0,38 & 0,38 & 0,39 & 0,41 & 0,49 & 0,43 & 0,41 & 0,17 & 0,17 & 0,11 & 0,20 & 0,16 & 0,13 \\
\hline MgO & 0,19 & & & & & & & & & 0,01 & & & & & & & & 0,04 & 0,03 & 0,01 & 0,04 & 0,02 & 0,03 \\
\hline $\mathrm{CaO}$ & 28,13 & 27,54 & 27,05 & 27,97 & 26,36 & 25,92 & 27,83 & 27,53 & 28,31 & 27,00 & 27,18 & 27,71 & 26,95 & 27,35 & 26,45 & 27,86 & 27,96 & 28,43 & 28,95 & 29,15 & 27,76 & 28,79 & 29,14 \\
\hline $\mathrm{Na}_{2} \mathrm{O}$ & 0,10 & 0,42 & 0,45 & 0,23 & 0,59 & 0,78 & 0,46 & 0,41 & 0,36 & 0,50 & 0,43 & 0,42 & 0,59 & 0,49 & 0,70 & 0,34 & 0,30 & 0,07 & 0,03 & 0,06 & 0,09 & 0,11 & 0,05 \\
\hline $\mathrm{K}_{2} \mathrm{O}$ & 0,06 & & & 0,08 & & 0,05 & & & & 0,01 & 0,01 & 0,01 & & & & 0,01 & 0,00 & & & 0,04 & & 0,07 & \\
\hline $\mathrm{Nb}_{2} \mathrm{O}_{5}$ & 0,02 & & 0,02 & 0,02 & 0,01 & 0,04 & 0,01 & & & 0,01 & & & & & & 0,02 & 0,03 & 0,05 & 0,06 & 0,03 & 0,02 & 0,05 & 0,05 \\
\hline $\mathrm{La}_{2} \mathrm{O}_{3}$ & 0,25 & 0,19 & 0,24 & 0,16 & 0,19 & 0,19 & 0,18 & 0,12 & 0,09 & 0,24 & 0,25 & 0,18 & 0,24 & 0,20 & 0,20 & 0,22 & 0,17 & 0,40 & 0,29 & 0,28 & 0,39 & 0,24 & 0,29 \\
\hline $\mathrm{Ce}_{2} \mathrm{O}_{3}$ & 1,00 & 1,00 & 1,17 & 0,78 & 0,81 & 0,87 & 0,99 & 0,72 & 0,64 & 1,12 & 1,26 & 0,97 & 0,90 & 0,82 & 0,90 & 0,93 & 0,79 & 1,32 & 1,20 & 0,69 & 1,61 & 0,84 & 0,51 \\
\hline $\mathrm{Nd}_{2} \mathrm{O}_{3}$ & 0,53 & 0,44 & 0,62 & 0,56 & 0,50 & 0,62 & 0,48 & 0,46 & 0,38 & 0,75 & 0,66 & 0,55 & 0,54 & 0,42 & 0,55 & 0,51 & 0,49 & 0,63 & 0,56 & 0,27 & 0,87 & 0,33 & 0,13 \\
\hline $\mathrm{Y}_{2} \mathrm{O}_{3}$ & 0,15 & 0,16 & 0,25 & 0,14 & 1,46 & 1,29 & 0,15 & 0,14 & 0,07 & 0,33 & 0,22 & 0,15 & 0,35 & 0,41 & 0,60 & 0,30 & 0,20 & 0,05 & 0,04 & & 0,10 & & \\
\hline $\mathrm{F}$ & & & 0,02 & & & & & & 0,02 & & & 0,02 & & 0,03 & 0,00 & 0,00 & 0,01 & 0,01 & & 0,00 & & & 0,04 \\
\hline Total & 98,05 & 97,13 & 96,85 & 98,30 & 96,78 & 95,96 & 97,43 & 97,10 & 98,39 & 96,50 & 96,89 & 97,55 & 97,21 & 97,67 & 96,33 & 97,98 & 98,17 & 100,07 & 100,11 & 100,07 & 98,64 & 99,01 & 99,45 \\
\hline \multicolumn{24}{|c|}{ ions calculado na b } \\
\hline $\mathrm{Si}$ & 1,002 & 1,010 & 1,008 & 1,009 & 1,000 & 1,006 & 0,998 & 1,007 & 0,991 & 1,004 & 1,011 & 1,015 & 1,005 & 1,000 & 1,011 & 0,993 & 1,001 & 0,983 & 0,983 & 0,991 & 0,986 & 0,993 & 0,993 \\
\hline $\mathrm{Ti}$ & 0,758 & 0,806 & 0,803 & 0,802 & 0,793 & 0,793 & 0,806 & 0,814 & 0,832 & 0,799 & 0,809 & 0,809 & 0,814 & 0,832 & 0,804 & 0,808 & 0,809 & 0,879 & 0,867 & 0,845 & 74 & 52 & 0,824 \\
\hline $\mathrm{Zr}$ & 005 & 0,002 & 0,002 & 0,001 & 0,002 & 0,004 & 0,004 & 0,004 & 0,001 & 0,001 & 0,002 & 0,001 & 0,004 & 0,001 & 0,003 & 0,001 & 0,001 & 0,011 & 0,009 & 0,017 & 0,010 & 0,016 & 0,033 \\
\hline Al & 0,096 & 0,018 & 0,022 & 0,021 & 0,013 & 0,015 & 0,019 & 0,021 & 0,020 & 0,023 & 0,023 & 0,022 & 0,014 & 0,014 & 0,014 & 0,016 & 0,020 & 0,046 & 0,051 & 0,058 & 0,046 & 0,054 & 0,060 \\
\hline $\mathrm{Fe}^{3+}$ & 0,090 & 0,113 & 0,114 & 0,123 & 0 & 0,124 & 0,111 & 0,108 & 0,100 & 0,114 & 0,102 & 0,101 & 0,116 & 0,104 & 0,116 & 0,123 & 0,120 & 0,039 & 0,040 & 0,047 & 0,039 & 0,037 & 0,046 \\
\hline $\mathrm{Mn}$ & 11 & 0,010 & 0,013 & 0,011 & 0,0 & 0,012 & 0,010 & 0,013 & 0,014 & 0,011 & 0,011 & 0,011 & 0,011 & 0,012 & 0,014 & 0,012 & 0,011 & 0,005 & 0,005 & 0,003 & 0,006 & 54 & 0,004 \\
\hline $\mathrm{Mg}$ & 0,009 & 0,000 & 0,000 & 0,000 & 0,000 & 0,000 & 0,000 & 0,000 & 0,000 & 0,001 & 0,000 & 0,000 & 0,000 & 0,000 & 0,000 & 0,000 & 0,000 & 0,002 & 0,002 & 0,001 & 0,002 & ,001 & 0,002 \\
\hline $\mathrm{Ca}$ & 96 & 0,991 & 0,979 & 0,995 & 0,958 & 0,948 & 0,998 & 0,990 & 1,003 & 0,980 & 0,983 & 0,992 & 0,971 & 0,980 & 0,961 & 0,997 & 0,996 & 1,001 & 1,015 & 1,017 & 0,995 & 1,016 & 1,025 \\
\hline $\mathrm{Na}$ & 0,006 & 0,028 & 0,030 & 0,015 & 0,039 & 0,051 & 0,030 & 0,027 & 0,023 & 0,033 & 0,028 & 0,027 & 0,038 & 0,032 & 0,046 & 0,022 & 0,019 & 0,005 & 0,002 & 0,004 & 0,006 &, 007 & 0,003 \\
\hline K & & 0,000 & 0,000 & 0,004 & 0,000 & & 0,000 & 0,000 & 0,000 & 0,0 & 0,001 & 0,000 & 0,000 & 0,000 & 0,000 & 0,000 & 0,000 & 0,000 & 0,000 & 0,002 & 0,000 & 0,003 & 0,000 \\
\hline $\mathrm{Nb}$ & 0,000 & 0,000 & 0,000 & 0,000 & 0,000 & 0,001 & 0,000 & 0,000 & 0,000 & 0,000 & 0,000 & 0,000 & 0,000 & 0,000 & 0,000 & 0,000 & 0,000 & 0,001 & 0,001 & 0,000 & 0,000 & 001 & ,001 \\
\hline La & 0,003 & 0,002 & 0,003 & 0,002 & 0,002 & 0,002 & 0,002 & 0,001 & 0,001 & 0,003 & 0,003 & 0,002 & 0,003 & 0,002 & 0,002 & 0,003 & 0,002 & 0,005 & 0,004 & 0,003 & 0,005 & 0,003 & 0,003 \\
\hline $\mathrm{Ce}$ & 0,012 & 0,012 & 0,014 & 0,010 & 0,010 & 0,011 & 0,012 & 0,009 & 0,008 & 0,014 & 0,016 & 0,012 & 0,011 & 0,010 & 0,011 & 0,011 & 0,010 & 0,016 & 0,014 & 0,008 & 0,020 & 0,010 & 0,006 \\
\hline $\mathrm{No}$ & 0,006 & 0,005 & 0,007 & 0,007 & 0,006 & 0,008 & 0,006 & 0,005 & 0,005 & 0,009 & 0,008 & 0,007 & 0,006 & 0,005 & 0,007 & 0,006 & 0,006 & 0,007 & 0,007 & 0,003 & 0,010 & 0,004 & 0,002 \\
\hline$x$ & 0,003 & 0,003 & 0,004 & 0,002 & 0,026 & 0,023 & 0,003 & 0,003 & 0,001 & 0,006 & 0,004 & 0,003 & 0,006 & 0,007 & 0,011 & 0,005 & 0,003 & 0,001 & 0,001 & 0,000 & 0,002 & 0,000 & 0,000 \\
\hline $\mathbf{F}$ & 0,000 & 0,000 & 0,002 & 0,000 & 0,000 & 0,000 & 0,000 & 0,000 & 0,002 & 0,000 & 0,000 & 0,002 & 0,000 & 0,003 & 0,001 & 0,000 & 0,002 & 0,001 & 0,000 & 0,000 & 0,000 & 0,000 & 0,004 \\
\hline Total & 3,000 & 3,000 & 3,000 & 3,000 & 3,000 & 3,000 & 3,000 & 3,000 & 3,000 & 3,000 & 3,000 & 3,000 & 3,000 & 3,000 & 3,000 & 3,000 & 3,000 & 3,000 & 3,000 & 3,000 & 3,000 & 3,000 & 3,000 \\
\hline
\end{tabular}


ANEXO E - Tabela E.5 - Composição química de titanitas de rochas do Maciço Alcalino de Itatiaia. Continua..

\begin{tabular}{|c|c|c|c|c|c|c|c|c|c|c|c|c|c|c|c|c|c|c|c|c|c|c|c|}
\hline $\begin{array}{l}\text { Unidade } \\
\text { Amostra }\end{array}$ & $\begin{array}{l}\text { BtHblP } \\
\text { MAl114 }\end{array}$ & & & & & \begin{tabular}{|l|} 
N-II \\
MAI136
\end{tabular} & & & \begin{tabular}{|l|} 
HbIP \\
MAl160
\end{tabular} & & & & & & & & & & & & & & \\
\hline Cristal & 52 & 53 & 53 & 54 & 54 & 55 & 56 & 57 & 58 & 58 & 58 & 59 & 59 & 59 & 60 & 60 & 61 & 61 & 61 & 62 & 62 & 62 & 63 \\
\hline Textura $^{1}$ & & $=\lim n$ & $>\operatorname{ilmb}$ & $n$ & b & & & & b & $\mathrm{nb}$ & $n$ & $n$ & $n$ & $b$ & $n$ & $b$ & zon1 & zon2 & zon3 & zon1 & zon2 & zon3 & \\
\hline$\overline{\mathrm{SiO}_{2}}$ & 30,28 & 30,02 & 29,65 & 30,27 & 30,35 & 29,38 & 29,56 & 29,65 & 30,37 & 30,17 & 30,84 & 30,43 & 30,75 & 30,33 & 30,25 & 30,88 & 31,17 & 30,20 & 30,58 & 30,29 & 29,88 & 30,07 & 30,99 \\
\hline $\mathrm{TiO}_{2}$ & 33,26 & 33,84 & 34,94 & 35,17 & 34,43 & 32,53 & 32,48 & 33,06 & 32,49 & 33,65 & 35,20 & 33,21 & 32,53 & 32,54 & 32,86 & 33,17 & 32,52 & 31,77 & 32,48 & 33,30 & 32,84 & 33,15 & 33,74 \\
\hline $\mathrm{ZrO}_{2}$ & 1,49 & 1,19 & 0,45 & 0,56 & 1,24 & 1,08 & 0,95 & 1,16 & 1,43 & 1,24 & 0,63 & 1,29 & 0,39 & 1,19 & 2,18 & 1,44 & 0,31 & 2,48 & 1,70 & 1,14 & 2,46 & 1,77 & 0,23 \\
\hline $\mathrm{Al}_{2} \mathrm{O}_{3}$ & 1,68 & 1,65 & 1,40 & 1,34 & 1,23 & 0,96 & 0,84 & 0,88 & 1,76 & 1,72 & 1,44 & 1,57 & 3,50 & 1,67 & 1,74 & 1,55 & 2,93 & 1,57 & 1,64 & 1,59 & 1,54 & 1,70 & 2,19 \\
\hline $\mathrm{Fe}_{2} \mathrm{O}_{3}$ & 1,96 & 2,08 & 1,72 & 1,69 & 1,58 & 2,83 & 3,32 & 2,73 & 1,99 & 1,96 & 1,26 & 1,71 & 1,26 & 1,92 & 1,98 & 1,79 & 1,93 & 1,83 & 1,94 & 1,89 & 1,77 & 1,83 & 2,10 \\
\hline $\mathrm{MnO}$ & 0,15 & 0,19 & 0,17 & 0,15 & 0,19 & 0,35 & 0,38 & 0,35 & 0,09 & 0,07 & 0,09 & 0,09 & 0,00 & 0,11 & 0,12 & 0,11 & 0,02 & 0,11 & 0,09 & 0,10 & 0,12 & 0,10 & 0,05 \\
\hline $\mathrm{MgO}$ & 0,02 & 0,02 & 0,03 & 0,02 & 0,02 & 0,05 & 0,07 & 0,05 & 0,01 & 0,01 & & 0,00 & & & 0,01 & & & & 0,00 & 0,02 & 0,01 & 0,01 & \\
\hline $\mathrm{CaO}$ & 29,15 & 28,29 & 27,91 & 28,65 & 28,88 & 26,72 & 27,23 & 27,06 & 28,77 & 29,44 & 30,37 & 29,01 & 30,03 & 28,56 & 29,17 & 28,80 & 30,27 & 28,61 & 29,22 & 29,54 & 28,60 & 29,05 & 29,93 \\
\hline $\mathrm{Na}_{2} \mathrm{O}$ & 0,04 & 0,09 & 0,12 & 0,09 & 0,13 & 0,15 & 0,17 & 0,19 & 0,12 & 0,08 & 0,09 & 0,12 & 0,06 & 0,08 & 0,06 & 0,11 & 0,09 & 0,15 & 0,08 & 0,12 & 0,13 & 0,09 & 0,12 \\
\hline $\mathrm{K}_{2} \mathrm{O}$ & 0,08 & & 0,00 & & 0,01 & 0,01 & & & 0,10 & 0,02 & 0,02 & 0,00 & 0,00 & 0,08 & 0,01 & 0,02 & 0,02 & 0,02 & 0,02 & & & 0,00 & 0,00 \\
\hline $\mathrm{Nb}_{2} \mathrm{O}_{5}$ & 0,02 & & 0,01 & 0,03 & 0,01 & 0,04 & 0,01 & 0,02 & 0,04 & 0,06 & 0,04 & 0,00 & 0,02 & 0,03 & 0,11 & 0,04 & 0,00 & 0,01 & 0,05 & 0,02 & 0,04 & 0,03 & 0,02 \\
\hline $\mathrm{La}_{2} \mathrm{O}_{3}$ & 0,25 & 0,32 & 0,35 & 0,29 & 0,39 & 0,32 & 0,39 & 0,37 & 0,33 & 0,37 & 0,14 & 0,29 & 0,03 & 0,30 & 0,38 & 0,31 & 0,04 & 0,42 & 0,29 & 0,30 & 0,31 & 0,34 & 0,11 \\
\hline $\mathrm{Ce}_{2} \mathrm{O}_{3}$ & 0,50 & 1,00 & 1,62 & 1,19 & 0,98 & 1,62 & 1,37 & 1,78 & 0,92 & 0,77 & 0,42 & 0,96 & 0,21 & 0,91 & 0,79 & 0,85 & 0,20 & 1,23 & 0,89 & 0,89 & 1,21 & 1,20 & 0,44 \\
\hline $\mathrm{Nd}_{2} \mathrm{O}_{3}$ & 0,09 & 0,71 & 1,08 & 0,58 & 0,37 & 0,97 & 0,67 & 0,96 & 0,36 & 0,30 & 0,07 & 0,29 & 0,16 & 0,30 & 0,32 & 0,29 & 0,15 & 0,35 & 0,34 & 0,26 & 0,42 & 0,56 & 0,18 \\
\hline $\mathrm{Y}_{2} \mathrm{O}_{3}$ & & 0,05 & 0,14 & 0,03 & & 0,31 & 0,23 & 0,26 & 0,05 & 0,02 & & 0,03 & & 0,04 & & 0,02 & & 0,03 & 0,01 & & 0,06 & 0,07 & \\
\hline $\mathrm{F}$ & 0,00 & 0,03 & 0,02 & & 0,02 & & 0,01 & 0,02 & & 0,00 & 0,02 & 0,02 & 0,04 & 0,01 & & & 0,01 & 0,00 & & & & 0,01 & \\
\hline Total & 98,98 & 99,48 & 99,62 & 100,07 & 99,82 & 97,32 & 97,66 & 98,53 & 98,82 & 99,88 & 100,62 & 99,03 & 98,98 & 98,07 & 99,97 & 99,37 & 99,67 & 98,79 & 99,31 & 99,45 & 99,39 & 99,97 & 100,11 \\
\hline \multicolumn{24}{|c|}{ Número de cátions calculado na base de 3 cátions. } \\
\hline $\mathrm{Si}$ & 0,994 & 0,990 & 0,982 & 0,991 & 0,995 & 1,000 & 0,998 & 0,998 & 1,002 & 0,984 & 0,991 & 1,002 & 0,993 & 1,007 & 0,990 & 1,013 & 1,000 & 1,003 & 1,004 & 0,991 & 0,988 & 0,986 & 0,997 \\
\hline $\mathrm{Ti}$ & 0,821 & 0,839 & 0,870 & 0,866 & 0,849 & 0,832 & 0,825 & 0,837 & 0,806 & 0,826 & 0,851 & 0,822 & 0,790 & 0,813 & 0,809 & 0,818 & 0,785 & 0,793 & 0,802 & 0,819 & 0,817 & 0,818 & 0,816 \\
\hline $\mathrm{zr}$ & 0,024 & 0,019 & 0,007 & 0,009 & 0,020 & 0,018 & 0,016 & 0,019 & 0,023 & 0,020 & 0,010 & 0,021 & 0,006 & 0,019 & 0,035 & 0,023 & 0,005 & 0,040 & 0,027 & 0,018 & 0,040 & 0,028 & 0,004 \\
\hline Al & 0,065 & 0,064 & 0,055 & 0,052 & 0,048 & 0,038 & 0,033 & 0,035 & 0,068 & 0,066 & 0,055 & 0,061 & 0,133 & 0,065 & 0,067 & 0,060 & 0,111 & 0,061 & 0,063 & 0,061 & 0,060 & 0,066 & 0,083 \\
\hline $\mathrm{Fe}^{3+}$ & 0,048 & 0,052 & 0,043 & 0,042 & 0,039 & 0,073 & 0,084 & 0,069 & 0,049 & 0,048 & 0,030 & 0,042 & 0,031 & 0,048 & 0,049 & 0,044 & 0,047 & 0,046 & 0,048 & 0,046 & 0,044 & 0,045 & 0,051 \\
\hline $\mathrm{Mn}$ & 0,004 & 0,005 & 0,005 & 0,004 & 0,005 & 0,010 & 0,011 & 0,010 & 0,002 & 0,002 & 0,003 & 0,002 & 0,000 & 0,003 & 0,003 & 0,003 & 0,000 & 0,003 & 0,003 & 0,003 & 0,003 & 0,003 & 0,001 \\
\hline $\mathrm{Mg}$ & 0,001 & 0,001 & 0,001 & 0,001 & 0,001 & 0,002 & 0,003 & 0,002 & 0,000 & 0,000 & 0,000 & 0,000 & 0,000 & 0,000 & 0,000 & 0,000 & 0,000 & 0,000 & 0,000 & 0,001 & 0,001 & 0,000 & 0,000 \\
\hline $\mathrm{Ca}$ & 1,025 & 0,999 & 0,990 & 1,005 & 1,014 & 0,974 & 0,985 & 0,976 & 1,017 & 1,029 & 1,046 & 1,023 & 1,039 & 1,016 & 1,023 & 1,012 & 1,041 & 1,018 & 1,028 & 1,035 & 1,014 & 1,021 & 1,032 \\
\hline $\mathrm{Na}$ & 0,003 & 0,006 & 0,008 & 0,006 & 0,008 & 0,010 & 0,011 & 0,012 & 0,008 & 0,005 & 0,006 & 0,008 & 0,004 & 0,005 & 0,004 & 0,007 & 0,006 & 0,010 & 0,005 & 0,008 & 0,008 & 0,006 & 0,007 \\
\hline K & 0,003 & 0,000 & 0,000 & 0,000 & 0,000 & 0,000 & 0,000 & 0,000 & 0,004 & 0,001 & 0,001 & 0,000 & 0,000 & 0,003 & 0,000 & 0,001 & 0,001 & 0,001 & 0,001 & 0,000 & 0,000 & 0,000 & 0,000 \\
\hline $\mathbf{N b}$ & 0,000 & 0,000 & 0,000 & 0,000 & 0,000 & 0,001 & 0,000 & 0,000 & 0,001 & 0,001 & 0,001 & 0,000 & 0,000 & 0,000 & 0,002 & 0,001 & 0,000 & 0,000 & 0,001 & 0,000 & 0,001 & 0,000 & 0,000 \\
\hline La & 0,003 & 0,004 & 0,004 & 0,004 & 0,005 & 0,004 & 0,005 & 0,005 & 0,004 & 0,004 & 0,002 & 0,003 & 0,000 & 0,004 & 0,005 & 0,004 & 0,000 & 0,005 & 0,003 & 0,004 & 0,004 & 0,004 & 0,001 \\
\hline $\mathrm{Ce}$ & 0,006 & 0,012 & 0,020 & 0,014 & 0,012 & 0,020 & 0,017 & 0,022 & 0,011 & 0,009 & 0,005 & 0,012 & 0,002 & 0,011 & 0,009 & 0,010 & 0,002 & 0,015 & 0,011 & 0,011 & 0,015 & 0,014 & 0,005 \\
\hline $\mathrm{Nd}$ & 0,001 & 0,008 & 0,013 & 0,007 & 0,004 & 0,012 & 0,008 & 0,012 & 0,004 & 0,003 & 0,001 & 0,003 & 0,002 & 0,004 & 0,004 & 0,003 & 0,002 & 0,004 & 0,004 & 0,003 & 0,005 & 0,007 & 0,002 \\
\hline$Y$ & 0,000 & 0,001 & 0,003 & 0,000 & 0,000 & 0,006 & 0,004 & 0,005 & 0,001 & 0,000 & 0,000 & 0,001 & 0,000 & 0,001 & 0,000 & 0,000 & 0,000 & 0,001 & 0,000 & 0,000 & 0,001 & 0,001 & 0,000 \\
\hline$F$ & 0,000 & 0,003 & 0,002 & 0,000 & 0,002 & 0,000 & 0,001 & 0,002 & 0,000 & 0,000 & 0,002 & 0,002 & 0,004 & 0,001 & 0,000 & 0,000 & 0,001 & 0,000 & 0,000 & 0,000 & 0,000 & 0,001 & 0,000 \\
\hline Total & 3,000 & 3,000 & 3,000 & 3,000 & 3,000 & 3,000 & 3,000 & 3,000 & 3,000 & 3,000 & 3,000 & 3,000 & 3,000 & 3,000 & 3,000 & 3,000 & 3,000 & 3,000 & 3,000 & 3,000 & 3,000 & 3,000 & 3,000 \\
\hline
\end{tabular}


ANEXO E - Tabela E.5 - Composição química de titanitas de rochas do Maciço Alcalino de Itatiaia. Continua..

\begin{tabular}{|c|c|c|c|c|c|c|c|c|c|c|c|c|c|c|c|c|c|c|c|c|c|c|c|}
\hline \multirow{3}{*}{$\begin{array}{l}\text { Unidade } \\
\text { Amostra } \\
\text { Cristal }\end{array}$} & \multirow{2}{*}{\multicolumn{5}{|c|}{$\begin{array}{l}\mathrm{HblP} \\
\text { MAl160 }\end{array}$}} & \multirow{2}{*}{\multicolumn{10}{|c|}{\begin{tabular}{|l|} 
NeS-II \\
MAI166I
\end{tabular}}} & \multirow{2}{*}{\multicolumn{8}{|c|}{\begin{tabular}{|l} 
BtAgtNeS \\
MAl199
\end{tabular}}} \\
\hline & & & & & & & & & & & & & & & & & & & & & & & \\
\hline & 63 & 63 & 63 & 64 & 64 & 65 & 65 & 66 & 66 & 67 & 67 & 67 & 68 & 68 & 68 & 69 & 69 & 69 & 70 & 70 & 70 & 70 & 71 \\
\hline Textura $^{1}$ & & & & $/ \mathrm{mt}$ & $/ \mathrm{mt}$ & $n$ & b & $n$ & b & zon1 & zon2 & zon3 & zon1 & zon2 & & $n$ & $\mathrm{n}$ & b & $n$ & $n$ & $n b$ & b & $<m t n$ \\
\hline $\mathrm{SiO}_{2}$ & 29,84 & 30,31 & 30,53 & 30,54 & 30,84 & 30,56 & 30,12 & 30,10 & 30,66 & 29,79 & 30,39 & 30,15 & 29,80 & 30,00 & 30,17 & 30,29 & 29,87 & 29,72 & 30,10 & 30,56 & 30,03 & 29,82 & 29,92 \\
\hline $\mathrm{TiO}_{2}$ & 32,18 & 32,45 & 33,70 & 33,73 & 34,10 & 31,93 & 30,65 & 33,13 & 30,39 & 32,95 & 32,06 & 30,65 & 33,49 & 32,82 & 31,68 & 35,85 & 33,91 & 33,71 & 34,57 & 36,44 & 33,90 & 33,38 & 34,93 \\
\hline $\mathrm{ZrO}_{2}$ & 2,46 & 2,48 & 1,19 & 1,02 & 0,44 & 1,33 & 1,58 & 0,97 & 1,99 & 0,91 & 0,96 & 1,34 & 0,90 & 0,79 & 1,26 & 0,23 & 0,59 & 0,91 & 0,42 & 0,18 & 0,56 & 0,96 & 0,70 \\
\hline $\mathrm{Al}_{2} \mathrm{O}_{3}$ & 1,57 & 1,63 & 1,71 & 2,06 & 2,04 & 2,08 & 1,82 & 1,39 & 2,09 & 1,43 & 1,99 & 1,87 & 1,25 & 1,44 & 2,01 & 0,29 & 0,39 & 0,39 & 0,37 & 0,23 & 0,38 & 0,41 & 0,37 \\
\hline $\mathrm{Fe}_{2} \mathrm{O}_{3}$ & 1,83 & 1,83 & 2,02 & 2,11 & 2,60 & 3,03 & 3,30 & 2,38 & 3,46 & 2,53 & 3,19 & 3,26 & 2,27 & 2,49 & 2,86 & 1,58 & 2,48 & 2,36 & 2,21 & 1,31 & 2,43 & 2,60 & 2,47 \\
\hline $\mathrm{MnO}$ & 0,11 & 0,11 & 0,11 & 0,09 & 0,09 & 0,18 & 0,20 & 0,16 & 0,12 & 0,20 & 0,16 & 0,18 & 0,17 & 0,19 & 0,18 & 0,17 & 0,24 & 0,27 & 0,24 & 0,20 & 0,27 & 0,30 & 0,29 \\
\hline $\mathrm{MgO}$ & & & 0,00 & 0,02 & 0,00 & 0,10 & 0,09 & 0,02 & 0,08 & 0,04 & 0,07 & 0,07 & 0,02 & 0,03 & 0,09 & & 0,01 & 0,04 & 0,01 & 0,00 & 0,03 & 0,04 & 0,03 \\
\hline $\mathrm{CaO}$ & 28,62 & 29,10 & 28,81 & 29,41 & 30,19 & 28,79 & 28,68 & 27,80 & 28,62 & 28,04 & 29,34 & 28,81 & 27,81 & 28,27 & 28,52 & 26,41 & 26,25 & 25,62 & 26,18 & 26,45 & 26,33 & 25,98 & 26,22 \\
\hline $\mathrm{Na}_{2} \mathrm{O}$ & 0,18 & 0,10 & 0,10 & 0,11 & 0,06 & 0,19 & 0,23 & 0,15 & 0,19 & 0,14 & 0,20 & 0,24 & 0,13 & 0,12 & 0,23 & 1,31 & 1,06 & 1,05 & 1,06 & 1,43 & 1,08 & 1,03 & 1,20 \\
\hline $\mathrm{K}_{2} \mathrm{O}$ & 0,01 & & 0,08 & 0,00 & & 0,00 & 0,03 & & & 0,00 & & 0,13 & & 0,00 & 0,06 & 0,01 & & 0,02 & & 0,01 & & & 0,02 \\
\hline $\mathrm{Nb}_{2} \mathrm{O}_{5}$ & 0,04 & 0,09 & 0,00 & 0,03 & 0,03 & 0,07 & 0,06 & 0,02 & 0,06 & 0,03 & 0,07 & 0,01 & 0,02 & 0,03 & 0,04 & & 0,03 & 0,03 & 0,02 & & 0,03 & 0,04 & \\
\hline $\mathrm{La}_{2} \mathrm{O}_{3}$ & 0,44 & 0,32 & 0,41 & 0,18 & 0,09 & 0,31 & 0,25 & 0,56 & 0,28 & 0,54 & 0,25 & 0,27 & 0,43 & 0,40 & 0,33 & 0,34 & 0,36 & 0,38 & 0,28 & 0,22 & 0,31 & 0,38 & 0,41 \\
\hline $\mathrm{Ce}_{2} \mathrm{O}_{3}$ & 1,08 & 0,85 & 1,06 & 0,27 & 0,26 & 0,80 & 0,86 & 1,79 & 0,78 & 1,78 & 0,63 & 0,80 & 1,93 & 1,58 & 1,09 & 0,85 & 1,31 & 1,41 & 1,24 & 1,02 & 1,15 & 1,47 & 1,43 \\
\hline $\mathrm{Nd}_{2} \mathrm{O}_{3}$ & 0,33 & 0,25 & 0,39 & 0,05 & 0,06 & 0,25 & 0,33 & 0,56 & 0,17 & 0,59 & 0,20 & 0,25 & 0,80 & 0,57 & 0,30 & 0,38 & 0,63 & 0,85 & 0,48 & 0,44 & 0,56 & 0,70 & 0,64 \\
\hline $\mathrm{Y}_{2} \mathrm{O}_{3}$ & 0,01 & 0,01 & 0,04 & & & 0,00 & 0,04 & 0,11 & 0,00 & 0,12 & & 0,04 & 0,14 & 0,08 & 0,03 & & & 0,03 & & & & 0,00 & \\
\hline $\mathrm{F}$ & 0,00 & & & & 0,01 & & 0,02 & & 0,04 & 0,02 & 0,03 & 0,02 & 0,00 & 0,01 & 0,01 & 0,01 & & & 0,01 & & 0,02 & 0,00 & 0,01 \\
\hline Total & 98,70 & 99,52 & 100,16 & 99,62 & 100,79 & 99,62 & 98,28 & 99,14 & 98,94 & 99,12 & 99,53 & 98,09 & 99,15 & 98,82 & 98,87 & 97,71 & 97,13 & 96,80 & 97,19 & 98,49 & 97,08 & 97,11 & 98,63 \\
\hline \multicolumn{24}{|c|}{ Número de cátions calculado na base de 3 cátions. } \\
\hline 0. & 0,992 & 0,997 & 0,996 & 0,991 & 0,987 & 0,997 & 0,997 & 1,000 & 1,008 & 0,990 & 0,989 & 0,996 & 0,993 & 0,996 & 0,993 & 1,005 & 1,004 & 1,007 & 1,009 & 1,005 & 1,008 & 1,006 & 0,992 \\
\hline $\mathrm{Ti}$ & 04 & 0,802 & 0,827 & 0,823 & 0,821 & 0,783 & 0,763 & 0,828 & 0,751 & 0,823 & 0,784 & 0,762 & 0,839 & 0,820 & 0,784 & 0,894 & 0,857 & 0,859 & 0,872 & 0,901 & 0,855 & 0,847 & 0,871 \\
\hline $7 x$ & 0,040 & 0,040 & 0,019 & 0,016 & 0,007 & 0,021 & 0,025 & 0,016 & 0,032 & 0,015 & 0,015 & 0,022 & 0,015 & 0,013 & 0,020 & 0,004 & 0,010 & 0,015 & 0,007 & 0,003 & 0,009 & 0,016 & 0,011 \\
\hline 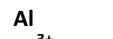 & 61 & 0,063 & 0,066 & 0,079 & 0,077 & 0,080 & 0,071 & 0,055 & 0,081 & 0,056 & 0,076 & 0,073 & 0,049 & 0,056 & 0,078 & 0,011 & 0,015 & 0,016 & 0,015 & 0,009 & 0,015 & 0,016 & 0,014 \\
\hline $\mathrm{Fe}^{3+}$ & 0,046 & 0,045 & 0,050 & 0,052 & 0,063 & 0,074 & 0,082 & 0,059 & 0,085 & 0,063 & 0,078 & 0,081 & 0,057 & 0,062 & 0,071 & 0,039 & 0,063 & 0,060 & 0,056 & 0,032 & 0,061 & 0,066 & 0,062 \\
\hline $\mathrm{Mn}$ & & 0,003 & & 0, & 0,002 & 05 & & & & & 0, & 0, & 0,005 & 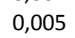 & 5 & 5 & 0,007 & 8 & 77 & 55 & 0,008 & 0,009 & 0,008 \\
\hline $\mathrm{Mg}$ & 0,000 & 0, & 0, & 0, & 0,000 & 0,005 & 0 & & 0 , & & 0,004 & 0,004 & 0,001 & 0,001 & 0,005 & 0,000 & 0,000 & 2 & 00 & 0,000 & 0,002 & 0,002 & 0,001 \\
\hline $\mathrm{Ca}$ & 1,019 & 1,025 & 1,007 & 1,023 & 1,035 & 1,006 & 1 & 0 , & 1, & 0 & 1,023 & 1,020 & 0,993 & 1,006 & 1,005 & 38 & 0,946 & 0 & 941 & 932 & 0,947 & 0,939 & 0,932 \\
\hline $\mathrm{Na}$ & & 0,006 & & 0 , & 0,003 & 12 & 0 & 0 , & 0, & 0, & 0,012 & 0,015 & 0,008 & 0, & 0,015 & 0,084 & 0, & 9 & 0 & 91 & 0,070 & 0,067 & 0,077 \\
\hline 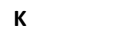 & 0 & 0,000 & 0 & 0 , & 0,000 & 0,000 & 0 , & 0,000 & 0,000 & & 0,000 & 0,005 & 0,000 & 0,000 & 0,003 & 0,000 & 0,000 & 1 & 0,000 & 0,000 & 0,000 & 0,000 & 0,001 \\
\hline $\mathrm{Nb}$ & & & & & & & & & & & & & 0,000 & & 0,001 & 0,000 & 0,000 & 0 & 0,000 & 0,000 & 0,000 & 0,001 & 0,000 \\
\hline La & 0,005 & 0,004 & 0,005 & 0,002 & 0,001 & 0,004 & 0,003 & 0,007 & 0,003 & 0,007 & 0,003 & 0,003 & 0,005 & 0,005 & 0,004 & 0,004 & 0,004 & 005 & 003 & 0,003 & 0,004 & 0,005 & 0,005 \\
\hline & & & & & 0,003 & & & & & & & & 0,024 & & & 0 & 0,016 & & 0,015 & 012 & 0,014 & 0,018 & 0,017 \\
\hline $\mathbf{N d}$ & 0,004 & 0,003 & 0,005 & 0,001 & 0,001 & 0,003 & 0,004 & 0,007 & 0,002 & 0,007 & 0,002 & 0,003 & 0,009 & 0,007 & 0,004 & 0,004 & 0,008 & 0,010 & 0,006 & 0,005 & 0,007 & 0,008 & 0,008 \\
\hline$r$ & 0 & 0,000 & 0,001 & 0,000 & 0,000 & 0,000 & 0,001 & 0,002 & 0,000 & & 0,000 & & 0,002 & & 0,001 & 0,000 & 0,000 & 0,000 & 0,000 & 0,000 & 0,000 & 0,000 & 0,000 \\
\hline I & 0,000 & 0,000 & 0,000 & 0,000 & 0,001 & 0,000 & 0,003 & 0,000 & 0,004 & 0,002 & 0,003 & 0,002 & 0,000 & 0,001 & 0,001 & 0,001 & 0,000 & 0,000 & 0,001 & 0,000 & 0,002 & 0,001 & 0,001 \\
\hline Total & 3,000 & 3,000 & 3,000 & 3,000 & 3,000 & 3,000 & 3,000 & 3,000 & 3,000 & 3,000 & 3,000 & 3,000 & 3,000 & 3,000 & 3,000 & 3,000 & 3,000 & 3,000 & 3,000 & 3,000 & 3,000 & 3,000 & 3,000 \\
\hline
\end{tabular}

${ }^{1}$ - n, núcleo; b, borda; <- sendo substituído por; -> substituindo; < incluso em; >, com inclusão de; /, em contato com; lam, lamelar; idio, idiomórfico; subidio, subidiomórfico; zon, zonada. 
$\frac{\text { ANEXO E - Tabela E.5 - Composição química de titanitas de rochas do Maciço Alcalino de Itatiaia. }}{\text { Unidade BtAgtNeS }}$

\begin{tabular}{ll}
\hline Unidade & BtAgtNeS \\
Amostra & MAl199
\end{tabular}

Cristal

$\begin{array}{lllllll}71 & 71 & 72 & 72 & 73 & 73 & 74\end{array}$

\begin{tabular}{|c|c|c|c|c|c|c|c|c|c|}
\hline Textura $^{1}$ & $<\mathrm{mt} \mathrm{b}$ & & zon1 & zon2 & $n$ & $\mathrm{~b}$ & $n$ & $\mathrm{nb}$ & b \\
\hline$\overline{\mathrm{SiO}_{2}}$ & 29,84 & 30,01 & 29,91 & 30,10 & 29,65 & 29,53 & 29,99 & 30,12 & 29,89 \\
\hline $\mathrm{TiO}_{2}$ & 34,09 & 34,90 & 34,47 & 35,71 & 35,71 & 33,76 & 34,31 & 35,36 & 34,47 \\
\hline $\mathrm{ZrO}_{2}$ & 0,91 & 0,54 & 0,65 & 0,25 & 0,41 & 0,95 & 0,28 & 0,30 & 0,48 \\
\hline $\mathrm{Al}_{2} \mathrm{O}_{3}$ & 0,41 & 0,37 & 0,37 & 0,32 & 0,39 & 0,39 & 0,44 & 0,39 & 0,43 \\
\hline $\mathrm{Fe}_{2} \mathrm{O}_{3}$ & 2,70 & 2,14 & 2,11 & 1,52 & 2,17 & 2,60 & 2,30 & 2,01 & 2,43 \\
\hline $\mathrm{MnO}$ & 0,29 & 0,25 & 0,29 & 0,22 & 0,26 & 0,26 & 0,18 & 0,25 & 0,22 \\
\hline MgO & 0,04 & 0,03 & 0,02 & & 0,03 & 0,04 & 0,02 & 0,02 & 0,01 \\
\hline $\mathrm{CaO}$ & 26,00 & 26,28 & 26,13 & 26,37 & 26,48 & 25,60 & 27,03 & 26,19 & 26,59 \\
\hline $\mathrm{Na}_{2} \mathrm{O}$ & 1,11 & 1,17 & 1,15 & 1,34 & 1,09 & 1,08 & 0,74 & 1,24 & 0,91 \\
\hline $\mathrm{K}_{2} \mathrm{O}$ & 0,01 & 0,00 & & 0,02 & 0,00 & 0,01 & & & 0,02 \\
\hline $\mathrm{Nb}_{2} \mathrm{O}_{5}$ & 0,06 & & 0,04 & & 0,05 & 0,03 & 0,00 & 0,02 & 0,01 \\
\hline $\mathrm{La}_{2} \mathrm{O}_{3}$ & 0,42 & 0,38 & 0,37 & 0,31 & 0,30 & 0,38 & 0,42 & 0,30 & 0,52 \\
\hline $\mathrm{Ce}_{2} \mathrm{O}_{3}$ & 1,51 & 1,10 & 1,41 & 0,99 & 1,09 & 1,48 & 1,56 & 1,20 & 1,66 \\
\hline $\mathrm{Nd}_{2} \mathrm{O}_{3}$ & 0,72 & 0,51 & 0,75 & 0,51 & 0,41 & 0,75 & 0,61 & 0,60 & 0,68 \\
\hline $\mathrm{Y}_{2} \mathrm{O}_{3}$ & 0,00 & & & & & 0,02 & 0,10 & 0,01 & 0,06 \\
\hline$F$ & & 0,00 & 0,02 & 0,03 & & 0,01 & & & \\
\hline Total & 98,10 & 97,69 & 97,68 & 97,69 & 98,04 & 96,90 & 98,01 & 98,00 & 98,38 \\
\hline
\end{tabular}

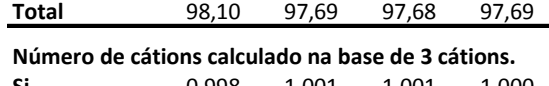

$\begin{array}{llllllllll}\mathbf{S i} & 0,998 & 1,001 & 1,001 & 1,000 & 0,986 & 1,000 & 1,002 & 1,001 & 0,997\end{array}$

$\begin{array}{llllllllll}\text { Ti } & 0,857 & 0,875 & 0,868 & 0,892 & 0,893 & 0,860 & 0,862 & 0,883 & 0,865\end{array}$

$\begin{array}{llllllllll}\mathrm{Zr} & 0,015 & 0,009 & 0,011 & 0,004 & 0,007 & 0,016 & 0,005 & 0,005 & 0,008 \\ \mathrm{Al} & 0,016 & 0,015 & 0,014 & 0,013 & 0,015 & 0,016 & 0,017 & 0,015 & 0,017\end{array}$

$\begin{array}{llllllllll}\mathrm{Al}^{3+} & 0,068 & 0,054 & 0,053 & 0,038 & 0,054 & 0,066 & 0,058 & 0,050 & 0,061\end{array}$

$\begin{array}{llllllllll}\text { Mn } & 0,008 & 0,007 & 0,008 & 0,006 & 0,007 & 0,007 & 0,005 & 0,007 & 0,006\end{array}$

$\begin{array}{llllllllll}\mathrm{Mg} & 0,002 & 0,001 & 0,001 & 0,000 & 0,002 & 0,002 & 0,001 & 0,001 & 0,001 \\ \mathrm{Ca} & 0,931 & 0,939 & 0,937 & 0,938 & 0,943 & 0,929 & 0,968 & 0,932 & 0,950\end{array}$

$\begin{array}{llllllllll}\mathrm{Na} & 0,931 & 0,939 & 0,937 & 0,938 & 0,943 & 0,929 & 0,968 & 0,932 & 0,950 \\ \mathrm{Na} & 0,072 & 0,075 & 0,074 & 0,086 & 0,070 & 0,071 & 0,048 & 0,080 & 0,059\end{array}$

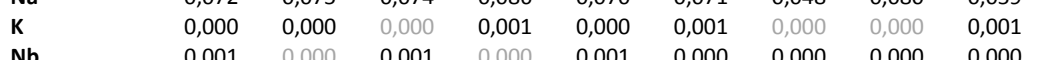

$\begin{array}{llllllllll}\text { La } & 0,001 & 0,000 & 0,001 & 0,000 & 0,001 & 0,000 & 0,000 & 0,000 & 0,000 \\ & 0,005 & 0,005 & 0,005 & 0,004 & 0,004 & 0,005 & 0,005 & 0,004 & 0,006\end{array}$

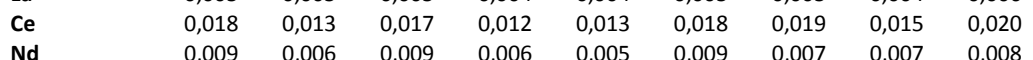

$\begin{array}{llllllllll}\mathbf{Y} & 0,009 & 0,006 & 0,009 & 0,006 & 0,005 & 0,009 & 0,007 & 0,007 & 0,008 \\ \mathbf{F} & 0,000 & 0,000 & 0,000 & 0,000 & 0,000 & 0,000 & 0,002 & 0,000 & 0,001\end{array}$

\begin{tabular}{llllllllll} 
Total & 3,000 & 3,000 & 3,000 & 3,000 & 3,000 & 3,000 & 3,000 & 3,000 & 3,000 \\
\hline
\end{tabular}

${ }^{1}$ - n, núcleo; b, borda; <- sendo substituído por; -> substituindo; < incluso em; >, com inclusão de; /, em contato com; lam, lamelar; idio, idiomórfico; subidio, subidiomórfico; zon, zonada. 
ANEXO E - Tabela E.6 - Composição química de biotitas de rochas do Maciço Alcalino de Itatiaia. Continua...

\begin{tabular}{|c|c|c|c|c|c|c|c|c|c|c|c|c|c|c|c|c|c|c|c|c|c|c|c|}
\hline Unidade & $\mathrm{BtHbNeS}$ & & & & & & & & & & & & & & $\mathrm{mA}$ & & & & & & BtHblP & & \\
\hline Amostra & MAI036 & & & & & & & & & & & & & & MAI070B & & & & & & MAI092I & & \\
\hline Cristal & 1 & 1 & 2 & 2 & 3 & 3 & 4 & 5 & 5 & 6 & 6 & 6 & 7 & 7 & 8 & 9 & 10 & 11 & 12 & 12 & 13 & 13 & 14 \\
\hline Textura $^{1}$ & $n$ & $b$ & $n$ & b & $n$ & b & $>m t-a p$ & $<-$ anf $n$ & $<-a n f b$ & $\mathrm{n}$ & $/ \mathrm{ttn}$ & b & $n$ & b & ints & & ints & ints & ints n & ints b & $<-\operatorname{anf} n$ & $<-a n f b$ & \\
\hline $\mathrm{SiO}_{2}$ & 35,68 & 35,49 & 35,91 & 35,79 & 35,92 & 35,71 & 35,34 & 36,69 & 36,33 & 36,13 & 36,00 & 36,17 & 36,00 & 35,91 & 39,48 & 42,14 & 37,45 & 40,16 & 40,08 & 40,69 & 35,62 & 35,87 & 36,16 \\
\hline $\mathrm{Al}_{2} \mathrm{O}_{3}$ & 14,63 & 14,74 & 14,75 & 15,14 & 14,82 & 15,11 & 15,38 & 14,94 & 15,15 & 15,16 & 15,06 & 15,54 & 14,87 & 15,48 & 8,77 & 7,93 & 9,51 & 8,38 & 8,20 & 8,66 & 14,11 & 13,88 & 14,02 \\
\hline $\mathrm{TiO}_{2}$ & 4,05 & 4,25 & 3,34 & 3,31 & 4,39 & 4,23 & 3,86 & 3,03 & 2,63 & 3,92 & 3,83 & 3,97 & 3,64 & 2,92 & 3,12 & 2,06 & 2,36 & 3,11 & 3,11 & 3,05 & 2,74 & 2,78 & 2,41 \\
\hline $\mathrm{FeO}_{\mathrm{T}}$ & 19,79 & 20,87 & 19,23 & 19,00 & 19,89 & 20,20 & 20,45 & 16,53 & 16,75 & 20,08 & 19,46 & 19,95 & 18,93 & 19,22 & 26,50 & 25,20 & 31,17 & 27,96 & 26,96 & 25,87 & 22,71 & 23,12 & 21,67 \\
\hline MnO & 1,20 & 1,27 & 1,15 & 1,15 & 1,19 & 1,14 & 1,29 & 0,95 & 0,97 & 1,15 & 1,16 & 1,21 & 1,18 & 1,14 & 2,28 & 2,53 & 3,14 & 2,66 & 2,28 & 2,30 & 1,36 & 1,39 & 1,34 \\
\hline MgO & 11,44 & 10,88 & 12,11 & 12,21 & 11,60 & 11,48 & 10,93 & 14,21 & 14,01 & 11,23 & 11,78 & 10,98 & 12,11 & 12,34 & 6,59 & 6,84 & 3,55 & 5,04 & 6,63 & 6,50 & 10,43 & 10,29 & 11,50 \\
\hline $\mathrm{ZnO}$ & 0,09 & 0,10 & 0,08 & 0,09 & 0,08 & 0,09 & 0,12 & 0,09 & 0,05 & 0,09 & 0,10 & 0,06 & 0,08 & 0,09 & 0,14 & 0,13 & 0,10 & 0,11 & 0,15 & 0,08 & 0,09 & 0,12 & 0,05 \\
\hline $\mathrm{CaO}$ & & & 0,05 & 0,01 & & & 0,02 & 0,05 & 0,02 & 0,01 & 0,06 & 0,01 & & 0,02 & 0,03 & 0,06 & 0,03 & & 0,00 & & 0,02 & & 0,01 \\
\hline BaO & 0,02 & & & & & & & & & & & 0,01 & 0,04 & 0,05 & 0,05 & 0,04 & & & & & 0,64 & 0,02 & 0,03 \\
\hline $\mathrm{Na}_{2} \mathrm{O}$ & 0,25 & 0,27 & 0,25 & 0,23 & 0,28 & 0,25 & 0,25 & 0,36 & 0,34 & 0,28 & 0,25 & 0,24 & 0,31 & 0,28 & 0,23 & 0,09 & 0,12 & 0,20 & 0,29 & 0,15 & 0,41 & 0,41 & 0,35 \\
\hline $\mathrm{K}_{2} \mathrm{O}$ & 10,21 & 10,23 & 10,03 & 10,20 & 10,10 & 10,44 & 10,45 & 10,11 & 10,31 & 10,08 & 10,32 & 10,22 & 10,01 & 10,07 & 9,38 & 9,30 & 9,18 & 9,11 & 9,27 & 9,34 & 9,49 & 9,96 & 9,98 \\
\hline $\mathrm{cl}$ & 0,01 & 0,04 & 0,05 & 0,00 & 0,02 & 0,01 & 0,00 & & & & & 0,01 & & 0,03 & 0,21 & 0,31 & 0,11 & 0,17 & 0,20 & 0,24 & 0,01 & 0,00 & \\
\hline $\mathrm{F}$ & 0,01 & & 0,01 & 0,01 & & 0,01 & & 0,00 & & 0,01 & & 0,01 & 0,00 & & 0,01 & & 0,00 & 0,02 & 0,00 & & 0,01 & 0,01 & 0,01 \\
\hline Total & 97,38 & 98,14 & 96,96 & 97,14 & 98,28 & 98,67 & 98,10 & 96,97 & 96,56 & 98,13 & 98,02 & 98,37 & 97,16 & 97,54 & 96,79 & 96,64 & 96,72 & 96,92 & 97,17 & 96,88 & 97,65 & 97,85 & 97,54 \\
\hline \multicolumn{24}{|c|}{ Número de cátions calculado na base de 11 oxigênios. } \\
\hline Si & 2,711 & 2,692 & 2,728 & 2,711 & 2,700 & 2,682 & 2,677 & 2,744 & 2,736 & 2,718 & 2,709 & 2,713 & 2,723 & 2,709 & 3,115 & 3,287 & 3,044 & 3,177 & 3,149 & 3,181 & 2,744 & 2,756 & 2,764 \\
\hline Al & 1,289 & 1,308 & 1,272 & 1,289 & 1,300 & 1,318 & 1,323 & 1,256 & 1,264 & 1,282 & 1,291 & 1,287 & 1,277 & 1,291 & 0,815 & 0,713 & 0,911 & 0,781 & 0,759 & 0,798 & 1,256 & 1,244 & 1,236 \\
\hline $\mathrm{Fe}^{3+}$ & 0,000 & 0,000 & 0,000 & 0,000 & 0,000 & 0,000 & 0,000 & 0,000 & 0,000 & 0,000 & 0,000 & 0,000 & 0,000 & 0,000 & 0,070 & 0,000 & 0,046 & 0,042 & 0,092 & 0,021 & 0,000 & 0,000 & 0,000 \\
\hline Soma Z & 4,000 & 4,000 & 4,000 & 4,000 & 4,000 & 4,000 & 4,000 & 4,000 & 4,000 & 4,000 & 4,000 & 4,000 & 4,000 & 4,000 & 4,000 & 4,000 & 4,000 & 4,000 & 4,000 & 4,000 & 4,000 & 4,000 & 4,000 \\
\hline Al & 0,021 & 0,009 & 0,049 & 0,063 & 0,013 & 0,020 & 0,051 & 0,061 & 0,080 & 0,062 & 0,045 & 0,086 & 0,049 & 0,085 & 0,000 & 0,016 & 0,000 & 0,000 & 0,000 & 0,000 & 0,025 & 0,013 & 0,027 \\
\hline $\mathrm{Fe}^{2+}$ & 1,258 & 1,324 & 1,222 & 1,204 & 1,250 & 1,269 & 1,296 & 1,034 & 1,055 & 1,263 & 1,225 & 1,251 & 1,198 & 1,213 & 1,678 & 1,644 & 2,073 & 1,808 & 1,680 & 1,670 & 1,463 & 1,486 & 1,385 \\
\hline $\mathrm{Ti}$ & & 0,242 & 0,191 & 0,189 & 0,248 & 0,239 & 0,220 & 0,170 & 0,149 & 0,222 & 0,217 & 0,224 & 0,207 & 0,166 & 185 & 0,121 & 0,144 & 0,185 & 0,184 & 0,179 & 0,159 & 0,161 & 0,139 \\
\hline $\mathrm{Mn}$ & 0,077 & 0,082 & 0,074 & 0,074 & 0,075 & 0,073 & 0,083 & 0,060 & 0,062 & 0,073 & 0,074 & 0,077 & 0,075 & 0,073 & 0,152 & 0,167 & 0,216 & 0,178 & 0,152 & 0,152 & 0,089 & 0,090 & 0,087 \\
\hline Mg & 1,296 & 1,230 & 1,372 & 1,379 & 1,300 & 1,286 & 1,235 & 1,584 & 1,573 & 1,259 & 1,322 & 1,228 & 1,366 & 1,388 & 0,775 & 0,795 & 0,430 & 0,594 & 0,777 & 0,757 & 1,198 & 1,179 & 1,310 \\
\hline $\mathrm{Zn}$ & 55 & 0,005 & 0,004 & 0,005 & 0,005 & 0,005 & 0,007 & 0,005 & 0,003 & 0,005 & 0,005 & 0,003 & 0,004 & 0,005 & 0,008 & 0,007 & 0,006 & 0,006 & 0,008 & 0,005 & 0,005 & 0,007 & 0,003 \\
\hline Soma Y & 2,884 & 2,887 & 2,907 & 2,908 & 2,886 & 2,886 & 2,884 & 2,910 & 2,919 & 2,879 & 2,882 & 2,866 & 2,895 & 2,924 & 2,791 & 2,744 & 2,864 & 2,766 & 2,792 & 2,759 & 2,933 & 2,928 & 2,948 \\
\hline $\mathrm{Ca}$ & 0,000 & 0,000 & 0,004 & 0,001 & 0,000 & 0,000 & 0,002 & 0,004 & 0,002 & 0,001 & 0,005 & 0,001 & 0,000 & 0,001 & 0,002 & 0,005 & 0,002 & 0,000 & 0,000 & 0,000 & 0,002 & 0,000 & 0,001 \\
\hline Ba & 0,001 & 0,000 & 0,000 & 0,000 & 0,000 & 0,000 & 0,000 & 0,000 & 0,000 & 0,000 & 0,000 & 0,000 & 0,001 & 0,001 & 0,001 & 0,001 & 0,000 & 0,000 & 0,000 & 0,000 & 0,019 & 0,001 & 0,001 \\
\hline $\mathrm{Na}$ & & 0,039 & 0,037 & 0,034 & 0,040 & 0,036 & 0,037 & 0,053 & 0,050 & 0,040 & 0,037 & 0,034 & 0,046 & 0,042 & 0,035 & 0,014 & 0,018 & 0,031 & 0,044 & 0,022 & 0,061 & 0,062 & 0,053 \\
\hline к & 0,990 & 0,990 & 0,972 & 0,986 & 0,968 & 1,000 & 1,010 & 0,965 & 0,990 & 0,967 & 0,991 & 0,978 & 0,966 & 0,969 & 0,944 & 0,926 & 0,952 & 0,919 & 0,929 & 0,931 & 0,933 & 0,976 & 0,973 \\
\hline Soma X & 1,027 & 1,029 & 1,013 & 1,021 & 1,009 & 1,036 & 1,048 & 1,021 & 1,042 & 1,008 & 1,033 & 1,013 & 1,013 & 1,013 & 0,983 & 0,946 & 0,972 & 0,950 & 0,974 & 0,954 & 1,015 & 1,039 & 1,027 \\
\hline $\mathrm{Cl}$ & 0,001 & 0,006 & 0,006 & 0,001 & 0,002 & 0,002 & 0,000 & 0,000 & 0,000 & 0,000 & 0,000 & 0,001 & 0,000 & 0,004 & 0,028 & 0,041 & 0,015 & 0,023 & 0,026 & 0,032 & 0,002 & 0,001 & 0,000 \\
\hline r & 0,002 & 0,000 & 0,002 & 0,002 & 0,000 & 0,001 & 0,000 & 0,000 & 0,000 & 0,001 & 0,000 & 0,001 & 0,000 & 0,000 & 0,004 & 0,000 & 0,001 & 0,006 & 0,000 & 0,000 & 0,002 & 0,001 & 0,003 \\
\hline Total & 7,911 & 7,916 & 7,921 & 7,929 & 7,895 & 7,923 & 7,932 & 7,931 & 7,960 & 7,887 & 7,915 & 7,879 & 7,908 & 7,938 & 7,774 & 7,690 & 7,836 & 7,716 & 7,766 & 7,713 & 7,948 & 7,967 & 7,976 \\
\hline
\end{tabular}


ANEXO E - Tabela E.6 - Composição química de biotitas de rochas do Maciço Alcalino de Itatiaia. Continua...

\begin{tabular}{|c|c|c|c|c|c|c|c|c|c|c|c|c|c|c|c|c|c|c|c|c|c|c|c|}
\hline \multirow{3}{*}{$\begin{array}{l}\text { Unidade } \\
\text { Amostra } \\
\text { Cristal }\end{array}$} & \multirow{2}{*}{\multicolumn{8}{|c|}{$\begin{array}{l}\text { BtHblP } \\
\text { MAI092I }\end{array}$}} & \multirow{2}{*}{\multicolumn{6}{|c|}{$\mathrm{N}-\mathrm{I}$}} & \multirow{2}{*}{\multicolumn{9}{|c|}{\begin{tabular}{|l|} 
BtHblP \\
MAl102
\end{tabular}}} \\
\hline & & & & & & & & & & & & & & & & & & & & & & & \\
\hline & 14 & 15 & 16 & 16 & 17 & 17 & 18 & 18 & 19 & 20 & 21 & 22 & 22 & 23 & 24 & 24 & 25 & 25 & 26 & 26 & 27 & 27 & 28 \\
\hline Textura $^{1}$ & b & /anf & $<-\operatorname{anf} n$ & $<-a n f b$ & $n$ & b & $n$ & & $n$ & $\mathrm{n}$ & $n$ & $\mathrm{n}$ & b & & n & b & $n$ & $b$ & $n$ & b & $n$ & b & \\
\hline $\mathrm{SiO}_{2}$ & 35,57 & 36,55 & 36,96 & 36,24 & 36,37 & 36,43 & 36,12 & 36,19 & 37,35 & 38,79 & 38,87 & 37,96 & 39,31 & 37,73 & 37,14 & 38,01 & 37,10 & 37,67 & 36,66 & 36,73 & 36,61 & 36,74 & 36,79 \\
\hline $\mathrm{Al}_{2} \mathrm{O}_{3}$ & 14,17 & 14,30 & 13,74 & 13,90 & 13,83 & 13,80 & 13,80 & 14,08 & 13,94 & 12,96 & 13,24 & 13,46 & 12,60 & 14,12 & 14,40 & 14,71 & 14,32 & 14,01 & 14,28 & 14,75 & 14,17 & 14,11 & 14,68 \\
\hline $\mathrm{TiO}_{2}$ & 2,94 & 2,20 & 2,10 & 2,58 & 2,65 & 2,83 & 2,16 & 2,32 & 3,99 & 3,26 & 3,42 & 3,83 & 2,41 & 4,10 & 5,59 & 5,40 & 5,71 & 5,39 & 5,36 & 5,54 & 5,66 & 5,56 & 5,62 \\
\hline $\mathrm{FeO}_{\mathrm{T}}$ & 23,09 & 21,59 & 21,02 & 22,11 & 22,18 & 21,17 & 22,13 & 21,63 & 13,51 & 12,87 & 12,33 & 12,69 & 11,90 & 13,53 & 14,24 & 13,96 & 14,48 & 14,19 & 14,57 & 14,13 & 14,42 & 13,83 & 14,40 \\
\hline MnO & 1,42 & 2,15 & 2,08 & 2,19 & 1,22 & 1,16 & 2,28 & 2,21 & 1,39 & 1,18 & 1,29 & 1,06 & 1,01 & 1,29 & 0,80 & 0,78 & 0,72 & 0,64 & 0,76 & 0,75 & 0,69 & 0,70 & 0,81 \\
\hline MgO & 10,07 & 10,50 & 11,21 & 10,34 & 11,03 & 11,10 & 10,56 & 10,63 & 15,64 & 16,34 & 16,52 & 16,39 & 17,16 & 15,34 & 14,90 & 14,68 & 14,94 & 15,16 & 15,27 & 14,96 & 15,12 & 14,85 & 14,85 \\
\hline $\mathrm{ZnO}$ & 0,10 & 0,21 & 0,18 & 0,20 & 0,09 & 0,08 & 0,19 & 0,15 & 0,12 & 0,11 & 0,14 & 0,07 & 0,08 & 0,08 & 0,07 & 0,06 & 0,03 & 0,03 & 0,05 & 0,05 & 0,03 & 0,02 & 0,04 \\
\hline $\mathrm{CaO}$ & & 0,00 & 0,02 & 0,00 & 0,04 & 0,00 & & 0,01 & 0,03 & 0,02 & 0,00 & 0,03 & & & 0,01 & 0,02 & 0,00 & 0,08 & 0,02 & 0,00 & 0,01 & 0,06 & 0,02 \\
\hline $\mathrm{BaO}$ & 0,06 & 0,03 & 0,05 & 0,01 & 0,06 & 0,00 & & 0,03 & & 0,02 & & 0,07 & 0,06 & & 0,01 & & 0,00 & & 0,07 & 0,08 & & 0,00 & \\
\hline $\mathrm{Na}_{2} \mathrm{O}$ & 0,26 & 0,28 & 0,25 & 0,26 & 0,33 & 0,28 & 0,31 & 0,30 & 0,55 & 0,53 & 0,54 & 0,52 & 0,40 & 0,53 & 0,61 & 0,57 & 0,60 & 0,58 & 0,56 & 0,60 & 0,61 & 0,40 & 0,56 \\
\hline $\mathrm{K}_{2} \mathrm{O}$ & 9,97 & 9,88 & 10,23 & 10,04 & 9,89 & 10,01 & 9,91 & 9,85 & 9,79 & 9,85 & 9,79 & 9,77 & 10,20 & 9,87 & 9,77 & 9,63 & 9,78 & 9,82 & 9,76 & 9,81 & 9,74 & 9,98 & 9,92 \\
\hline $\mathrm{Cl}$ & 0,01 & 0,03 & & 0,02 & 0,01 & 0,00 & 0,01 & 0,02 & 0,04 & 0,03 & 0,06 & 0,04 & 0,03 & 0,03 & 0,04 & 0,02 & 0,01 & 0,00 & 0,03 & 0,02 & 0,00 & 0,02 & \\
\hline$F$ & 0,02 & 0,00 & 0,03 & & & & 0,01 & 0,02 & 0,02 & & & 0,01 & 0,02 & 0,02 & 0,01 & & 0,01 & 0,02 & 0,01 & 0,01 & & 0,01 & \\
\hline Total & 97,67 & 97,73 & 97,87 & 97,89 & 97,70 & 96,87 & 97,47 & 97,44 & 96,37 & 95,96 & 96,19 & 95,90 & 95,19 & 96,64 & 97,60 & 97,84 & 97,70 & 97,59 & 97,40 & 97,42 & 97,07 & 96,28 & 97,69 \\
\hline \multicolumn{24}{|c|}{ Número de cátions calculado na base de 11 oxigênios. } \\
\hline $\mathrm{Si}$ & 2,739 & 2,793 & 2,816 & 2,778 & 2,779 & 2,793 & 2,782 & 2,778 & 2,775 & 2,875 & 2,866 & 2,816 & 2,924 & 2,790 & 2,726 & 2,767 & 2,722 & 2,760 & 2,705 & 2,702 & 2,706 & 2,732 & 2,702 \\
\hline Al & 1,261 & 1,207 & 1,184 & 1,222 & 1,221 & 1,207 & 1,218 & 1,222 & 1,221 & 1,125 & 1,134 & 1,177 & 1,076 & 1,210 & 1,246 & 1,233 & 1,238 & 1,210 & 1,242 & 1,279 & 1,234 & 1,237 & 1,271 \\
\hline $\mathrm{Fe}^{3+}$ & 0,000 & 0,000 & 0,000 & 0,000 & 0,000 & 0,000 & 0,000 & 0,000 & 0,004 & 0,000 & 0,000 & 0,007 & 0,000 & 0,000 & 0,028 & 0,000 & 0,040 & 0,031 & 0,053 & 0,019 & 0,059 & 0,031 & 0,027 \\
\hline Soma Z & 4,000 & 4,000 & 4,000 & 4,000 & 4,000 & 4,000 & 4,000 & 4,000 & 4,000 & 4,000 & 4,000 & 4,000 & 4,000 & 4,000 & 4,000 & 4,000 & 4,000 & 4,000 & 4,000 & 4,000 & 4,000 & 4,000 & 4,000 \\
\hline Al & 0,025 & 0,080 & 0,050 & 0,034 & 0,024 & 0,040 & 0,034 & 0,052 & 0,000 & 0,007 & 0,016 & 0,000 & 0,028 & 0,021 & 0,000 & 0,028 & 0,000 & 0,000 & 0,000 & 0,000 & 0,000 & 0,000 & 0,000 \\
\hline $\mathrm{Fe}^{2+}$ & 1,487 & 1,380 & 1,339 & 1,417 & 1,417 & 1,357 & 1,425 & 1,389 & 0,836 & 0,798 & 0,760 & 0,780 & 0,740 & 0,837 & 0,846 & 0,850 & 0,848 & 0,839 & 0,846 & 0,850 & 0,832 & 0,829 & 0,857 \\
\hline $\mathrm{Ti}$ & 0,170 & 0,126 & 0,120 & 0,149 & 0,152 & 0,163 & 0,125 & 0,134 & 0,223 & 0,182 & 0,190 & 0,214 & 0,135 & 0,228 & 0,309 & 0,296 & 0,315 & 0,297 & 0,298 & 0,307 & 0,315 & 0,311 & 0,311 \\
\hline $\mathrm{Mn}$ & 0,093 & 0,139 & 0,134 & 0,142 & 0,079 & 0,075 & 0,149 & 0,144 & 0,087 & 0,074 & 0,080 & 0,066 & 0,064 & 0,081 & 0,050 & 0,048 & 0,045 & 0,040 & 0,047 & 0,047 & 0,043 & 0,044 & 0,050 \\
\hline Mg & 1,156 & 1,196 & 1,273 & 1,182 & 1,256 & 1,269 & 1,212 & 1,217 & 1,732 & 1,805 & 1,816 & 1,813 & 1,903 & 1,691 & 1,631 & 1,593 & 1,634 & 1,656 & 1,680 & 1,641 & 1,666 & 1,646 & 1,626 \\
\hline $\mathrm{Zn}$ & 0,006 & 0,012 & 0,010 & 0,011 & 0,005 & 0,004 & 0,011 & 0,008 & 0,007 & 0,006 & 0,007 & 0,004 & 0,004 & 0,005 & 0,004 & 0,003 & 0,002 & 0,001 & 0,003 & 0,003 & 0,002 & 0,001 & 0,002 \\
\hline Soma $Y$ & 2,931 & 2,922 & 2,917 & 2,924 & 2,929 & 2,905 & 2,946 & 2,935 & 2,879 & 2,866 & 2,863 & 2,873 & 2,870 & 2,858 & 2,836 & 2,815 & 2,842 & 2,831 & 2,871 & 2,844 & 2,856 & 2,830 & 2,844 \\
\hline $\mathrm{Ca}$ & 0,000 & 0,000 & 0,001 & 0,000 & 0,004 & 0,000 & 0,000 & 0,001 & 0,003 & 0,002 & 0,000 & 0,002 & 0,000 & 0,000 & 0,001 & 0,002 & 0,000 & 0,006 & 0,002 & 0,000 & 0,001 & 0,005 & 0,002 \\
\hline Ba & & 0,001 & 0,002 & 0,000 & 0,002 & 0,000 & 0,000 & & 0,000 & 0,001 & 0,000 & 0,002 & 0,002 & 0,000 & 000 & 0,000 & 0,000 & 0,000 & 0,002 & 0,002 & 0,000 & 0,000 & 0,000 \\
\hline $\mathrm{Na}$ & 0,038 & 0,041 & 0,038 & 0,038 & 0,049 & 0,041 & 0,046 & 0,045 & 0,079 & 0,076 & 0,077 & 0,075 & 0,057 & 0,076 & 0,087 & 0,080 & 0,085 & 0,082 & 0,081 & 0,085 & 0,088 & 0,057 & 0,080 \\
\hline K & 0,979 & 0,963 & 0,994 & 0,982 & 0,964 & 0,979 & 0,974 & 0,965 & 0,928 & 0,931 & 0,921 & 0,925 & 0,968 & 0,931 & 0,915 & 0,894 & 0,915 & 0,918 & 0,919 & 0,921 & 0,918 & 0,947 & 0,929 \\
\hline Soma X & 1,019 & 1,006 & 1,035 & 1,020 & 1,018 & 1,021 & 1,020 & 1,012 & 1,010 & 1,010 & 0,998 & 1,005 & 1,027 & 1,007 & 1,003 & 0,976 & 1,001 & 1,006 & 1,003 & 1,008 & 1,007 & 1,009 & 1,011 \\
\hline $\mathrm{Cl}$ & 0,001 & 0,004 & 0,000 & 0,003 & 0,001 & 0,001 & 0,001 & 0,002 & 0,006 & 0,003 & 0,007 & 0,005 & 0,004 & 0,004 & 0,004 & 0,003 & 0,002 & 0,001 & 0,003 & 0,003 & 0,000 & 0,002 & 0,000 \\
\hline F & 0,004 & 0,001 & 0,007 & 0,000 & 0,000 & 0,000 & 0,002 & 0,004 & 0,004 & 0,000 & 0,000 & 0,002 & 0,006 & 0,005 & 0,003 & 0,000 & 0,001 & 0,005 & 0,002 & 0,002 & 0,000 & 0,002 & 0,000 \\
\hline Total & 7,951 & 7,927 & 7,952 & 7,944 & 7,948 & 7,926 & 7,966 & 7,947 & 7,888 & 7,875 & 7,861 & 7,878 & 7,897 & 7,865 & 7,839 & 7,791 & 7,843 & 7,837 & 7,873 & 7,852 & 7,863 & 7,839 & 7,855 \\
\hline
\end{tabular}


ANEXO E - Tabela E.6 - Composição química de biotitas de rochas do Maciço Alcalino de Itatiaia. Continua...

\begin{tabular}{|c|c|c|c|c|c|c|c|c|c|c|c|c|c|c|c|c|c|c|c|c|c|c|c|}
\hline Unidade & BtHblP & arpk-QzS & & & & & & & & & & & QZAFS-I & & & & & BthblP & & & & & \\
\hline Amostra & MAl102 & MAI108II & & & & & & & & & & & MAl110 & & & & & MAI114 & & & & & \\
\hline Cristal & & 29 & 29 & 30 & 30 & 31 & 31 & 31 & 32 & 32 & 33 & 33 & 34 & 35 & 36 & 37 & 38 & 39 & 39 & 40 & 40 & 41 & 41 \\
\hline Textura $^{1}$ & & $n$ & b & $\mathrm{n}$ & b & $n$ & b & b & $n$ & b & $n$ & b] & $\mathrm{n}$ & idio & & & & $\mathrm{n}$ & b & b & b & $\mathrm{n}$ & \\
\hline $\mathrm{SiO}_{2}$ & 36,44 & 37,71 & 40,40 & 38,36 & 39,63 & 37,53 & 37,06 & 39,03 & 37,36 & 37,52 & 38,11 & 38,48 & 36,75 & 38,39 & 36,43 & 36,80 & 37,39 & 36,50 & 36,65 & 36,62 & 37,01 & 36,51 & 36,60 \\
\hline $\mathrm{Al}_{2} \mathrm{O}_{3}$ & 14,43 & 13,77 & 12,45 & 13,59 & 13,10 & 14,37 & 14,59 & 13,47 & 14,31 & 14,17 & 13,94 & 13,62 & 11,92 & 11,20 & 11,72 & 12,06 & 11,66 & 14,38 & 14,29 & 14,24 & 14,44 & 14,41 & 14,48 \\
\hline $\mathrm{TiO}_{2}$ & 5,59 & 3,82 & 3,18 & 3,85 & 2,96 & 3,94 & 4,15 & 3,22 & 3,57 & 3,75 & 3,73 & 3,44 & 5,02 & 3,32 & 4,53 & 4,71 & 3,54 & 5,36 & 5,28 & 5,41 & 5,36 & 5,32 & 5,36 \\
\hline $\mathrm{FeO}_{\mathrm{T}}$ & 14,01 & 13,92 & 11,69 & 13,34 & 11,76 & 13,50 & 13,81 & 12,04 & 13,31 & 13,28 & 13,90 & 13,32 & 24,57 & 22,62 & 25,67 & 24,15 & 22,41 & 16,85 & 16,93 & 17,07 & 16,66 & 17,08 & 17,04 \\
\hline MnO & 0,80 & 0,48 & 0,45 & 0,57 & 0,48 & 0,48 & 0,48 & 0,42 & 0,53 & 0,52 & 0,59 & 0,57 & 1,60 & 1,28 & 1,55 & 1,48 & 1,32 & 0,92 & 0,89 & 0,94 & 0,93 & 1,00 & 1,00 \\
\hline MgO & 15,08 & 16,25 & 18,53 & 16,63 & 18,13 & 16,70 & 15,86 & 18,16 & 16,50 & 16,50 & 16,23 & 16,92 & 8,24 & 9,84 & 7,67 & 8,77 & 10,37 & 12,97 & 12,96 & 13,03 & 12,86 & 12,78 & 12,76 \\
\hline $\mathrm{ZnO}$ & 0,05 & 0,09 & 0,04 & 0,05 & 0,07 & 0,08 & 0,08 & 0,05 & 0,06 & 0,05 & 0,09 & 0,09 & 0,19 & 0,12 & 0,18 & 0,13 & 0,13 & 0,09 & 0,09 & 0,08 & 0,06 & 0,06 & 0,06 \\
\hline $\mathrm{CaO}$ & 0,04 & 0,01 & 0,02 & 0,05 & 0,01 & & 0,00 & 0,03 & 0,04 & & 0,04 & 0,02 & & & 0,03 & & 0,02 & 0,02 & 0,01 & & 0,05 & 0,01 & \\
\hline $\mathrm{BaO}$ & 0,04 & 1,26 & 0,00 & 0,15 & 0,00 & 0,79 & 1,53 & 0,08 & 0,83 & 0,93 & 0,79 & 0,23 & 0,04 & 0,03 & & & & 0,05 & & & 0,03 & & 0,11 \\
\hline $\mathrm{Na}_{2} \mathrm{O}$ & 0,57 & 0,25 & 0,23 & 0,27 & 0,22 & 0,34 & 0,29 & 0,24 & 0,24 & 0,27 & 0,22 & 0,23 & 0,50 & 0,32 & 0,38 & 0,52 & 0,34 & 0,46 & 0,43 & 0,50 & 0,48 & 0,44 & 0,47 \\
\hline $\mathrm{K}_{2} \mathrm{O}$ & 9,72 & 9,82 & 10,46 & 10,15 & 10,29 & 9,74 & 9,48 & 10,37 & 9,97 & 9,85 & 9,87 & 10,12 & 9,20 & 9,68 & 9,50 & 9,53 & 9,57 & 9,58 & 9,61 & 9,78 & 9,86 & 9,85 & 9,86 \\
\hline $\mathrm{cl}$ & 0,03 & 0,17 & 0,12 & 0,14 & 0,14 & 0,11 & 0,13 & 0,13 & 0,16 & 0,09 & 0,18 & 0,10 & 0,06 & 0,05 & 0,04 & 0,06 & 0,04 & 0,03 & 0,01 & 0,01 & & & \\
\hline F & 0,02 & 0,01 & 0,00 & 0,01 & & 0,01 & 0,01 & 0,01 & 0,03 & 0,02 & 0,03 & 0,00 & & & 0,01 & & 0,02 & 0,01 & 0,01 & & & 0,01 & \\
\hline Total & 96,81 & 97,56 & 97,57 & 97,15 & 96,80 & 97,59 & 97,48 & 97,24 & 96,90 & 96,95 & 97,71 & 97,13 & 98,09 & 96,85 & 97,71 & 98,22 & 96,82 & 97,21 & 97,17 & 97,67 & 97,75 & 97,47 & 97,74 \\
\hline \multicolumn{24}{|c|}{ Número de cátions calculado na base de 11 oxigênios. } \\
\hline $\mathrm{Si}$ & 2,699 & 2,787 & 2,917 & 2,816 & 2,887 & 2,754 & 2,741 & 2,840 & 2,766 & 2,773 & 2,800 & 2,824 & 2,830 & 2,957 & 2,838 & 2,827 & 2,884 & 2,725 & 2,736 & 2,725 & 2,744 & 2,724 & 2,724 \\
\hline Al & 1,260 & 1,199 & 1,060 & 1,176 & 1,113 & 1,243 & 1,259 & 1,155 & 1,234 & 1,227 & 1,200 & 1,176 & 1,082 & 1,017 & 1,076 & 1,092 & 1,060 & 1,265 & 1,257 & 1,249 & 1,256 & 1,267 & 1,270 \\
\hline $\mathrm{Fe}^{3+}$ & 0,041 & 0,014 & 0,023 & 0,008 & 0,000 & 0,003 & 0,000 & 0,004 & 0,000 & 0,000 & 0,000 & 0,000 & 0,088 & 0,027 & 0,086 & 0,082 & 0,056 & 0,010 & 0,007 & 0,026 & 0,000 & 0,009 & 0,006 \\
\hline Soma Z & 4,000 & 4,000 & 4,000 & 4,000 & 4,000 & 4,000 & 4,000 & 4,000 & 4,000 & 4,000 & 4,000 & 4,000 & 4,000 & 4,000 & 4,000 & 4,000 & 4,000 & 4,000 & 4,000 & 4,000 & 4,000 & 4,000 & 4,000 \\
\hline Al & 0,000 & 0,000 & 0,000 & 0,000 & 0,012 & 0,000 & 0,012 & 0,000 & 0,015 & 0,007 & 0,007 & 0,001 & 0,000 & 0,000 & 0,000 & 0,000 & 0,000 & 0,000 & 0,000 & 0,000 & 0,005 & 0,000 & 0,000 \\
\hline $\mathrm{Fe}^{2+}$ & 0,826 & 0,846 & 0,683 & 0,811 & 0,717 & 0,825 & 0,854 & 0,728 & 0,824 & 0,821 & 0,854 & 0,817 & 1,495 & 1,430 & 1,586 & 1,469 & 1,390 & 1,042 & 1,050 & 1,036 & 1,033 & 1,056 & 1,054 \\
\hline $\mathrm{Ti}$ & 0,311 & 0,212 & 0,173 & 0,213 & 0,162 & 0,218 & 0,231 & 0,176 & 0,199 & 0,209 & 0,206 & 0,190 & 0,291 & 0,192 & 0,265 & 0,272 & 0,205 & 0,301 & 0,296 & 0,303 & 0,299 & 0,299 & 0,300 \\
\hline$M n$ & 0,050 & 0,030 & 0,028 & 0,035 & 0,030 & 0,030 & 0,030 & 0,026 & 0,033 & 0,033 & 0,037 & 0,036 & 0,104 & 0,083 & 0,102 & 0,096 & 0,086 & 0,058 & 0,057 & 0,059 & 0,059 & 0,063 & 0,063 \\
\hline Mg & 1,665 & 1,790 & 1,995 & 1,820 & 1,969 & 1,827 & 1,749 & 1,970 & 1,821 & 1,818 & 1,778 & 1,851 & 0,946 & 1,130 & 0,891 & 1,004 & 1,193 & 1,443 & 1,442 & 1,445 & 1,421 & 1,421 & 1,416 \\
\hline $\mathrm{Zn}$ & 0,003 & 0,005 & 0,002 & 0,003 & 0,004 & 0,004 & 0,004 & 0,003 & 0,003 & 0,003 & 0,005 & 0,005 & 0,011 & 0,007 & 0,010 & 0,007 & 0,008 & 0,005 & 0,005 & 0,004 & 0,003 & 0,004 & 0,003 \\
\hline Soma $Y$ & 2,853 & 2,878 & 2,878 & 2,879 & 2,890 & 2,900 & 2,876 & 2,901 & 2,892 & 2,888 & 2,882 & 2,895 & 2,836 & 2,836 & 2,845 & 2,842 & 2,875 & 2,844 & 2,845 & 2,843 & 2,817 & 2,839 & 2,833 \\
\hline $\mathrm{Ca}$ & 0,003 & 0,001 & 0,002 & 0,004 & 0,001 & 0,000 & 0,000 & 0,002 & 0,003 & 0,000 & 0,003 & 0,001 & 0,000 & 0,000 & 0,003 & 0,000 & 0,001 & 0,001 & 0,001 & 0,000 & 0,004 & 0,001 & 0,000 \\
\hline $\mathrm{Ba}$ & & 0,036 & 0,000 & 0,004 & 0,000 & 0,023 & & 0,002 & 0,024 & 0,027 & 0,023 & 0,007 & 0,001 & 0,001 & 0,000 & 0,000 & 0,000 & 0,001 & 0,000 & 0,000 & 0,001 & 0,000 & 0,003 \\
\hline $\mathrm{Na}$ & 0,082 & 0,037 & 0,032 & 0,038 & 0,031 & 0,049 & 0,042 & 0,034 & 0,034 & 0,039 & 0,032 & 0,033 & 0,075 & 0,048 & 0,058 & 0,078 & 0,052 & 0,066 & 0,063 & 0,072 & 0,070 & 0,064 & 0,068 \\
\hline$\kappa$ & 0,918 & 0,926 & 0,964 & 0,951 & 0,956 & 0,912 & 0,894 & 0,963 & 0,942 & 0,929 & 0,925 & 0,947 & 0,904 & 0,951 & 0,944 & 0,934 & 0,942 & 0,912 & 0,915 & 0,928 & 0,933 & 0,937 & 0,936 \\
\hline Soma X & 1,004 & 0,999 & 0,997 & 0,996 & 0,988 & 0,984 & 0,981 & 1,001 & 1,003 & 0,995 & 0,982 & 0,988 & 0,980 & 1,000 & 1,005 & 1,012 & 0,995 & 0,981 & 0,979 & 1,000 & 1,007 & 1,002 & 1,008 \\
\hline $\mathrm{Cl}$ & 0,004 & 0,022 & 0,014 & ,017 & 0,017 & 0,014 & 0,017 & 0,016 & 0,019 & 0,011 & 0,022 & 0,012 & 0,008 & 0,006 & 0,005 & 0,008 & 0,005 & 0,004 & 0,001 & 0,002 & 0,000 & 0,000 & 0,000 \\
\hline $\mathrm{F}$ & 0,004 & 0,003 & 0,001 & 0,002 & 0,000 & 0,002 & 0,003 & 0,003 & 0,008 & 0,004 & 0,007 & 0,001 & 0,000 & 0,000 & 0,002 & 0,000 & 0,005 & 0,002 & 0,002 & 0,000 & 0,000 & 0,001 & 0,000 \\
\hline Total & 7,857 & 7,878 & 7,876 & 7,875 & 7,878 & 7,883 & 7,856 & 7,901 & 7,896 & 7,883 & 7,864 & 7,883 & 7,816 & 7,835 & 7,849 & 7,854 & 7,869 & 7,826 & 7,823 & 7,844 & 7,824 & 7,842 & 7,840 \\
\hline
\end{tabular}


ANEXO E - Tabela E.6 - Composição química de biotitas de rochas do Maciço Alcalino de Itatiaia. Continua...

\begin{tabular}{|c|c|c|c|c|c|c|c|c|c|c|c|c|c|c|c|c|c|c|c|c|c|c|c|}
\hline Unidade & BtHblP & & $\mathrm{N}-\mathrm{II}$ & & & & & & & & & & HblP & & & & & & & NeS-II & & & \\
\hline Amostra & MAI114 & & MAl136 & & & & & & & & & & MAl160 & & & & & & & MAl166| & & & \\
\hline Cristal & 42 & 42 & 43 & 44 & 45 & 45 & 46 & 46 & 47 & 47 & 48 & 48 & 49 & 49 & 50 & 50 & 51 & 52 & 53 & 54 & 54 & 55 & 56 \\
\hline Textura $^{1}$ & & & idio & idio & $n$ & b & $n$ & $\mathrm{~b}$ & $n$ & $\mathrm{~b}$ & $n$ & & $n$ & b & $n$ & b & & & & $<$ <anf & $<$-anf & $<$ <anf & inf \\
\hline$\overline{\mathrm{SiO}_{2}}$ & 36,75 & 36,22 & 37,76 & 36,60 & 36,63 & 37,17 & 36,98 & 37,68 & 36,23 & 37,02 & 39,46 & 37,64 & 35,81 & 35,48 & 35,85 & 34,77 & 35,64 & 35,21 & 35,55 & 38,60 & 37,48 & 38,37 & 38,20 \\
\hline $\mathrm{Al}_{2} \mathrm{O}_{3}$ & 14,37 & 14,43 & 13,36 & 12,61 & 13,05 & 12,53 & 12,54 & 12,67 & 13,27 & 13,15 & 9,82 & 11,46 & 14,03 & 14,78 & 13,76 & 14,54 & 13,81 & 14,36 & 14,38 & 12,56 & 13,44 & 12,79 & 12,81 \\
\hline $\mathrm{TiO}_{2}$ & 5,04 & 5,33 & 6,06 & 4,67 & 5,26 & 5,29 & 5,19 & 5,02 & 6,16 & 5,62 & 3,04 & 3,80 & 3,64 & 3,68 & 4,08 & 4,13 & 4,42 & 4,22 & 3,21 & 2,52 & 2,34 & 2,99 & 2,27 \\
\hline $\mathrm{FeO}_{\mathrm{T}}$ & 16,95 & 16,73 & 15,11 & 18,72 & 19,76 & 18,79 & 18,93 & 15,91 & 16,86 & 15,86 & 16,79 & 17,87 & 25,10 & 24,89 & 25,44 & 26,17 & 25,55 & 25,61 & 24,83 & 19,12 & 20,84 & 18,37 & 18,66 \\
\hline MnO & 1,01 & 1,00 & 0,88 & 1,52 & 1,52 & 1,54 & 1,45 & 1,14 & 1,11 & 1,02 & 1,41 & 1,46 & 1,24 & 1,31 & 1,20 & 1,27 & 1,22 & 1,27 & 1,16 & 1,87 & 2,17 & 1,78 & 2,21 \\
\hline MgO & 12,88 & 12,93 & 13,63 & 12,15 & 10,80 & 11,29 & 11,87 & 13,91 & 12,64 & 13,00 & 15,11 & 13,54 & 8,09 & 8,07 & 8,05 & 7,28 & 7,78 & 7,66 & 8,38 & 12,51 & 11,09 & 12,44 & 12,85 \\
\hline $\mathrm{ZnO}$ & 0,07 & 0,10 & 0,06 & 0,09 & 0,13 & 0,12 & 0,09 & 0,11 & 0,10 & 0,09 & 0,15 & 0,13 & 0,10 & 0,14 & 0,09 & 0,12 & 0,14 & 0,15 & 0,12 & 0,21 & 0,19 & 0,15 & 0,23 \\
\hline $\mathrm{CaO}$ & & & 0,00 & 0,00 & 0,02 & 0,01 & 0,00 & & 0,01 & 0,03 & 0,01 & & 0,02 & 0,02 & 0,02 & 0,06 & & 0,00 & 0,02 & 0,05 & 0,00 & & 0,03 \\
\hline $\mathrm{BaO}$ & & & & & & 0,00 & 0,01 & & 0,44 & 0,10 & 0,01 & & 0,11 & & 0,11 & 0,04 & 0,04 & 0,03 & 0,30 & & 0,06 & & 0,00 \\
\hline $\mathrm{Na}_{2} \mathrm{O}$ & 0,41 & 0,47 & 0,47 & 0,47 & 0,53 & 0,59 & 0,53 & 0,64 & 0,53 & 0,52 & 0,52 & 0,59 & 0,39 & 0,39 & 0,35 & 0,36 & 0,46 & 0,36 & 0,30 & 0,40 & 0,41 & 0,44 & 0,44 \\
\hline $\mathrm{K}_{2} \mathrm{O}$ & 9,93 & 9,73 & 9,49 & 9,44 & 9,41 & 9,43 & 9,30 & 9,44 & 9,41 & 9,48 & 9,66 & 9,52 & 9,59 & 9,59 & 9,49 & 9,69 & 9,60 & 9,60 & 9,71 & 9,79 & 9,63 & 9,84 & 9,74 \\
\hline Cl & & 0,01 & 0,02 & 0,02 & 0,02 & 0,03 & 0,03 & 0,06 & & 0,03 & 0,04 & 0,04 & 0,03 & 0,00 & 0,03 & 0,02 & 0,05 & & 0,02 & 0,01 & & & 0,01 \\
\hline $\mathrm{F}$ & & & 0,03 & 0,00 & 0,01 & 0,02 & 0,00 & 0,02 & 0,00 & 0,01 & & 0,01 & & & & 0,01 & 0,02 & 0,01 & 0,00 & & 0,02 & & 0,01 \\
\hline Total & 97,42 & 96,95 & 96,87 & 96,31 & 97,15 & 96,80 & 96,93 & 96,61 & 96,76 & 95,93 & 96,02 & 96,06 & 98,15 & 98,35 & 98,48 & 98,46 & 98,73 & 98,49 & 97,98 & 97,64 & 97,66 & 97,17 & 97,47 \\
\hline \multicolumn{24}{|c|}{ Número de cátions calculado na base de 11 oxigênios. } \\
\hline $\mathrm{Si}$ & 2,741 & 2,714 & 2,797 & 2,793 & 2,783 & 2,820 & 2,801 & 2,819 & 2,733 & 2,790 & 2,985 & 2,868 & 2,762 & 2,725 & 2,758 & 2,694 & 2,741 & 2,715 & 2,748 & 2,903 & 2,848 & 2,889 & 2,879 \\
\hline Al & 1,259 & 1,274 & 1,166 & 1,134 & 1,168 & 1,120 & 1,120 & 1,117 & 1,180 & 1,168 & 0,876 & 1,029 & 1,238 & 1,275 & 1,242 & 1,306 & 1,252 & 1,285 & 1,252 & 1,097 & 1,152 & 1,111 & 1,121 \\
\hline $\mathrm{Fe}^{3+}$ & 0,000 & 0,012 & 0,037 & 0,072 & 0,049 & 0,059 & 0,079 & 0,064 & 0,088 & 0,041 & 0,139 & 0,103 & 0,000 & 0,000 & 0,000 & 0,000 & 0,008 & 0,000 & 0,000 & 0,000 & 0,000 & 0,000 & 0,000 \\
\hline Soma Z & 4,000 & 4,000 & 4,000 & 4,000 & 4,000 & 4,000 & 4,000 & 4,000 & 4,000 & 4,000 & 4,000 & 4,000 & 4,000 & 4,000 & 4,000 & 4,000 & 4,000 & 4,000 & 4,000 & 4,000 & 4,000 & 4,000 & 4,000 \\
\hline Al & 0,003 & 0,000 & 0,000 & 0,000 & 0,000 & 0,000 & 0,000 & 0,000 & 0,000 & 0,000 & 0,000 & 0,000 & 0,037 & 0,064 & 0,005 & 0,022 & 0,000 & 0,019 & 0,058 & 0,016 & 0,052 & 0,024 & 0,017 \\
\hline $\mathrm{Fe}^{2+}$ & 1,057 & 1,036 & 0,899 & 1,122 & 1,207 & 1,133 & 1,120 & 0,931 & 0,976 & 0,958 & 0,923 & 1,036 & 1,619 & 1,599 & 1,637 & 1,696 & 1,636 & 1,651 & 1,605 & 1,203 & 1,325 & 1,157 & 1,176 \\
\hline $\mathrm{Ti}$ & 0,283 & 0,300 & 0,338 & 0,268 & 0,301 & 0,302 & 0,296 & 0,283 & 0,350 & 0,319 & 0,173 & 0,218 & 0,211 & 0,213 & 0,236 & 0,241 & 0,256 & 0,245 & 0,187 & 0,143 & 0,134 & 0,169 & 0,129 \\
\hline $\mathrm{Mn}$ & 0,064 & 0,064 & 0,056 & 0,098 & 0,098 & 0,099 & 0,093 & 0,072 & 0,071 & 0,065 & 0,090 & 0,094 & 0,081 & 0,085 & 0,078 & 0,083 & 0,079 & 0,083 & 0,076 & 0,119 & 0,140 & 0,114 & 0,141 \\
\hline Mg & 1,432 & 1,444 & 1,505 & 1,382 & 1,223 & 1,277 & 1,340 & 1,551 & 1,421 & 1,461 & 1,704 & 1,538 & 0,930 & 0,924 & 0,923 & 0,841 & 0,892 & 0,880 & 0,966 & 1,403 & 1,256 & 1,396 & 1,444 \\
\hline $\mathrm{Zn}$ & 0,004 & 0,005 & 0,003 & 0,005 & 0,007 & 0,007 & 0,005 & 0,006 & 0,006 & 0,005 & 0,008 & 0,007 & 0,006 & 0,008 & 0,005 & 0,007 & 0,008 & 0,009 & 0,007 & 0,011 & 0,010 & 0,008 & 0,013 \\
\hline Soma $Y$ & 2,839 & 2,844 & 2,797 & 2,871 & 2,828 & 2,811 & 2,849 & 2,837 & 2,817 & 2,803 & 2,890 & 2,886 & 2,878 & 2,885 & 2,880 & 2,882 & 2,863 & 2,879 & 2,891 & 2,883 & 2,907 & 2,861 & 2,907 \\
\hline $\mathrm{Ca}$ & 0,000 & 0,000 & 0,000 & 0,000 & 0,002 & 0,000 & 0,000 & 0,000 & 0,001 & 0,003 & 0,001 & 0,000 & 0,001 & 0,002 & 0,002 & 0,005 & 0,000 & 0,000 & 0,001 & 0,004 & 0,000 & 0,000 & 0,003 \\
\hline Ba & 0,000 & 0,000 & 0,000 & 0,000 & 0,000 & 0,000 & 0,000 & 0,000 & 0,013 & 0,003 & 0,000 & 0,000 & 0,003 & 0,000 & 0,003 & 0,001 & 0,001 & 0,001 & 0,009 & 0,000 & 0,002 & 0,000 & 0,000 \\
\hline $\mathrm{Na}$ & 0,060 & 0,068 & 0,068 & 0,070 & 0,079 & 0,087 & 0,078 & 0,094 & 0,078 & 0,075 & 0,077 & 0,087 & 0,058 & 0,057 & 0,053 & 0,053 & 0,069 & 0,054 & 0,046 & 0,059 & 0,061 & 0,065 & 0,065 \\
\hline K & 0,945 & 0,930 & 0,897 & 0,919 & 0,912 & 0,913 & 0,899 & 0,901 & 0,905 & 0,912 & 0,932 & 0,925 & 0,944 & 0,940 & 0,931 & 0,958 & 0,942 & 0,944 & 0,958 & 0,939 & 0,934 & 0,945 & 0,937 \\
\hline Soma $X$ & 1,004 & 0,998 & 0,965 & 0,989 & 0,992 & 1,000 & 0,977 & 0,994 & 0,997 & 0,993 & 1,010 & 1,012 & 1,006 & 0,999 & 0,989 & 1,018 & 1,012 & 1,000 & 1,014 & 1,002 & 0,996 & 1,010 & 1,004 \\
\hline Cl & 0,000 & 0,001 & 0,002 & 0,003 & 0,003 & 0,004 & 0,004 & 0,007 & 0,000 & 0,004 & 0,005 & 0,005 & 0,004 & 0,000 & 0,004 & 0,003 & 0,006 & 0,000 & 0,002 & 0,002 & 0,000 & 0,000 & 0,002 \\
\hline$F$ & 0,000 & 0,000 & 0,006 & 0,001 & 0,002 & 0,004 & 0,001 & 0,004 & 0,001 & 0,002 & 0,000 & 0,004 & 0,000 & 0,000 & 0,000 & 0,003 & 0,004 & 0,003 & 0,001 & 0,000 & 0,004 & 0,000 & 0,002 \\
\hline Total & 7,844 & 7,843 & 7,762 & 7,861 & 7,820 & 7,811 & 7,826 & 7,831 & 7,814 & 7,795 & 7,900 & 7,898 & 7,885 & 7,884 & 7,869 & 7,900 & 7,875 & 7,879 & 7,905 & 7,885 & 7,903 & 7,870 & 7,911 \\
\hline
\end{tabular}


ANEXO E - Tabela E.6 - Composição química de biotitas de rochas do Maciço Alcalino de Itatiaia.

\begin{tabular}{|c|c|c|c|c|c|c|c|c|c|c|c|c|c|}
\hline Unidade & $\mathrm{BtM}$ & & & & & & & & & & & & BtAgtNeS \\
\hline Amostra & MAl182C & & & & & & & & & & & & MAl199 \\
\hline Cristal & 57 & 58 & 59 & 60 & 61 & 62 & 62 & 63 & 63 & 64 & 65 & 65 & 66 \\
\hline Textura $^{1}$ & poiq & $<\mathrm{kfl}$ & $<\mathrm{kfl}$ & $<\mathrm{kfl}$ & poiq & poiq $n$ & poiq b & poiq $n$ & poiq b & & poiq $n$ & poiq b & <-anf/cpx \\
\hline$\overline{\mathrm{SiO}_{2}}$ & 37,48 & 37,44 & 37,96 & 37,56 & 38,12 & 38,30 & 37,76 & 37,73 & 37,53 & 38,16 & 37,67 & 37,69 & 39,35 \\
\hline $\mathrm{Al}_{2} \mathrm{O}_{3}$ & 13,12 & 13,35 & 13,29 & 13,16 & 13,05 & 13,55 & 13,21 & 13,05 & 13,18 & 13,12 & 13,17 & 13,18 & 10,29 \\
\hline $\mathrm{TiO}_{2}$ & 3,78 & 6,20 & 5,26 & 5,28 & 6,72 & 5,43 & 6,75 & 6,82 & 5,58 & 6,33 & 6,46 & 4,82 & 2,17 \\
\hline $\mathrm{FeO}_{\mathrm{T}}$ & 19,77 & 14,93 & 18,10 & 19,99 & 17,26 & 14,49 & 18,10 & 14,92 & 15,86 & 16,06 & 18,09 & 17,55 & 18,99 \\
\hline MnO & 0,25 & 0,22 & 0,24 & 0,25 & 0,24 & 0,18 & 0,29 & 0,22 & 0,23 & 0,23 & 0,25 & 0,26 & 2,49 \\
\hline MgO & 12,47 & 14,38 & 12,60 & 11,72 & 13,08 & 15,39 & 11,93 & 13,75 & 13,72 & 14,01 & 12,38 & 13,20 & 11,88 \\
\hline $\mathrm{ZnO}$ & 0,05 & 0,03 & 0,05 & 0,01 & 0,01 & 0,02 & 0,07 & 0,02 & 0,08 & 0,03 & 0,04 & & \\
\hline $\mathrm{CaO}$ & & 0,03 & & 0,00 & & 0,03 & 0,00 & & & & 0,03 & & 0,08 \\
\hline BaO & 0,53 & 0,48 & 0,58 & 0,49 & 0,47 & 0,50 & 0,48 & 0,45 & 0,51 & 0,55 & 0,50 & 0,43 & \\
\hline $\mathrm{Na}_{2} \mathrm{O}$ & 0,12 & 0,21 & 0,15 & 0,17 & 0,33 & 0,23 & 0,24 & 0,39 & 0,22 & 0,28 & 0,30 & 0,10 & 0,43 \\
\hline $\mathrm{K}_{2} \mathrm{O}$ & 9,69 & 10,05 & 9,85 & 9,73 & 9,65 & 10,03 & 9,82 & 9,46 & 9,70 & 9,55 & 9,66 & 9,92 & 9,58 \\
\hline $\mathrm{Cl}$ & 0,16 & 0,17 & 0,15 & 0,13 & 0,13 & 0,11 & 0,14 & 0,11 & 0,12 & 0,12 & 0,15 & 0,11 & \\
\hline 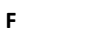 & & & & 0,01 & & 0,02 & & 0,02 & & 0,01 & 0,02 & 0,00 & 0,01 \\
\hline Total & 97,42 & 97,49 & 98,24 & 98,49 & 99,06 & 98,28 & 98,79 & 96,95 & 96,73 & 98,46 & 98,72 & 97,26 & 95,27 \\
\hline \multicolumn{14}{|c|}{ Número de cátions calculado na base de 11 oxigênios. } \\
\hline Si & 2,829 & 2,768 & 2,819 & 2,805 & 2,791 & 2,794 & 2,789 & 2,794 & 2,802 & 2,796 & 2,784 & 2,818 & 3,038 \\
\hline Al & 1,167 & 1,163 & 1,163 & 1,158 & 1,126 & 1,165 & 1,150 & 1,139 & 1,160 & 1,133 & 1,147 & 1,162 & 0,936 \\
\hline $\mathrm{Fe}^{3+}$ & 0,003 & 0,069 & 0,018 & 0,037 & 0,083 & 0,041 & 0,061 & 0,068 & 0,038 & 0,072 & 0,069 & 0,020 & 0,025 \\
\hline Soma $\mathrm{Z}$ & 4,000 & 4,000 & 4,000 & 4,000 & 4,000 & 4,000 & 4,000 & 4,000 & 4,000 & 4,000 & 4,000 & 4,000 & 4,000 \\
\hline Al & 0,000 & 0,000 & 0,000 & 0,000 & 0,000 & 0,000 & 0,000 & 0,000 & 0,000 & 0,000 & 0,000 & 0,000 & 0,000 \\
\hline $\mathrm{Fe}^{2+}$ & 1,245 & 0,855 & 1,106 & 1,212 & 0,974 & 0,843 & 1,057 & 0,856 & 0,952 & 0,912 & 1,049 & 1,077 & 1,201 \\
\hline $\mathrm{Ti}$ & 0,215 & 0,345 & 0,294 & 0,297 & 0,370 & 0,298 & 0,375 & 0,380 & 0,313 & 0,349 & 0,359 & 0,271 & 0,126 \\
\hline$M n$ & 0,016 & 0,014 & 0,015 & 0,016 & 0,015 & 0,011 & 0,018 & 0,014 & 0,014 & 0,014 & 0,016 & 0,017 & 0,163 \\
\hline $\mathrm{Mg}$ & 1,403 & 1,585 & 1,395 & 1,305 & 1,428 & 1,674 & 1,314 & 1,518 & 1,527 & 1,530 & 1,364 & 1,471 & 1,367 \\
\hline $\mathrm{Zn}$ & 0,003 & 0,002 & 0,003 & 0,001 & 0,001 & 0,001 & 0,004 & 0,001 & 0,004 & 0,002 & 0,002 & 0,000 & 0,000 \\
\hline Soma $Y$ & 2,879 & 2,798 & 2,809 & 2,829 & 2,787 & 2,825 & 2,763 & 2,768 & 2,807 & 2,805 & 2,788 & 2,837 & 2,857 \\
\hline $\mathrm{Ca}$ & 0,000 & 0,002 & 0,000 & 0,000 & 0,000 & 0,002 & 0,000 & 0,000 & 0,000 & 0,000 & 0,002 & 0,000 & 0,006 \\
\hline Ва & 0,016 & 0,014 & 0,017 & 0,014 & 0,014 & 0,014 & 0,014 & 0,013 & 0,015 & 0,016 & 0,014 & 0,013 & 0,000 \\
\hline $\mathrm{Na}$ & 0,017 & 0,030 & 0,021 & 0,024 & 0,046 & 0,032 & 0,034 & 0,056 & 0,032 & 0,040 & 0,043 & 0,015 & 0,064 \\
\hline 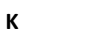 & 0,933 & 0,948 & 0,933 & 0,927 & 0,901 & 0,933 & 0,925 & 0,894 & 0,924 & 0,893 & 0,911 & 0,946 & 0,944 \\
\hline Soma X & 0,966 & 0,994 & 0,971 & 0,965 & 0,961 & 0,982 & 0,974 & 0,963 & 0,971 & 0,948 & 0,971 & 0,974 & 1,014 \\
\hline $\mathrm{Cl}$ & 0,021 & 0,021 & 0,019 & 0,017 & 0,016 & 0,014 & 0,017 & 0,014 & 0,015 & 0,015 & 0,019 & 0,014 & 0,000 \\
\hline $\mathrm{F}$ & 0,000 & 0,000 & 0,000 & 0,001 & 0,000 & 0,005 & 0,000 & 0,004 & 0,000 & 0,002 & 0,005 & 0,001 & 0,003 \\
\hline Total & 7,845 & 7,793 & 7,780 & 7,794 & 7,749 & 7,807 & 7,737 & 7,731 & 7,778 & 7,754 & 7,758 & 7,810 & 7,871 \\
\hline
\end{tabular}




\begin{tabular}{|c|c|c|c|c|c|c|c|c|c|c|c|c|}
\hline \multirow{2}{*}{\multicolumn{2}{|c|}{$\begin{array}{l}\text { Unidade } \mathrm{N}-\mathrm{I} \\
\text { Amostra MAI097B }\end{array}$}} & \multirow[b]{3}{*}{3} & \multirow[b]{3}{*}{4} & \multirow{3}{*}{$\begin{array}{r}\text { QzAFS-I } \\
\text { MAI110 } \\
1\end{array}$} & \multirow[b]{3}{*}{3} & \multirow[b]{3}{*}{4} & \multirow[b]{3}{*}{5} & \multirow{2}{*}{\multicolumn{3}{|c|}{$\begin{array}{l}\text { arpk-QzS } \\
\text { MAI108II }\end{array}$}} & \multirow{2}{*}{\multicolumn{2}{|c|}{$\begin{array}{l}\text { BtHblP } \\
\text { MAI114 }\end{array}$}} \\
\hline & & & & & & & & & & & & \\
\hline Crystal & 2 & & & & & & & 1 & 2 & 7 & $3 a$ & $3 b$ \\
\hline $\mathrm{SiO}_{2}$ & 0,03 & 0,00 & 0,00 & 0,03 & 0,00 & 0,01 & 0,00 & 0,01 & 0,03 & 0,05 & 0,00 & 0,00 \\
\hline $\mathrm{TiO}_{2}$ & 47,46 & 46,59 & 47,35 & 48,94 & 49,08 & 49,11 & 48,21 & 44,64 & 44,55 & 47,05 & 50,46 & 50,68 \\
\hline $\mathrm{Al}_{2} \mathrm{O}_{3}$ & 0,02 & 0,01 & 0,02 & 0,00 & 0,00 & 0,02 & 0,00 & 0,01 & 0,01 & 0,02 & 0,04 & 0,05 \\
\hline $\mathrm{FeO}_{(\mathrm{T})}$ & 29,24 & 34,82 & 36,58 & 36,21 & 36,49 & 35,70 & 35,51 & 44,84 & 45,05 & 35,37 & 37,28 & 37,10 \\
\hline Mno & 19,98 & 15,15 & 12,58 & 13,89 & 13,73 & 14,26 & 14,69 & 7,47 & 6,48 & 14,42 & 10,95 & 10,76 \\
\hline MgO & 0,04 & 0,00 & 0,00 & 0,04 & 0,07 & 0,06 & 0,07 & 0,08 & 0,06 & 0,04 & 1,71 & 1,99 \\
\hline $\mathrm{CaO}$ & 0,04 & 0,03 & 0,04 & 0,09 & 0,01 & 0,03 & 0,03 & 0,02 & 0,30 & 0,12 & 0,00 & 0,00 \\
\hline Zno & 0,93 & 1,20 & 0,97 & 0,06 & 0,06 & 0,05 & 0,08 & 0,07 & 0,17 & 0,11 & 0,02 & 0,05 \\
\hline $\mathrm{Nb}_{2} \mathrm{O}_{3}$ & 0,37 & 1,02 & 1,01 & 0,95 & 0,64 & 0,69 & 1,27 & 0,73 & 0,63 & 0,75 & 0,14 & 0,11 \\
\hline Sum & 98,10 & 98,83 & 98,54 & 100,21 & 100,07 & 99,93 & 99,85 & 97,87 & 97,28 & 97,93 & 100,60 & 100,74 \\
\hline $\mathrm{Fe}_{2} \mathrm{O}_{3}$ & 8,55 & 10,40 & 8,48 & 7,18 & 7,14 & 6,82 & 8,06 & 13,86 & 13,50 & 8,80 & 6,72 & 6,67 \\
\hline $\mathrm{FeO}$ & 21,55 & 25,46 & 28,95 & 29,75 & 30,07 & 29,56 & 28,26 & 32,37 & 32,90 & 27,45 & 31,23 & 31,10 \\
\hline Total & 98,96 & 99,87 & 99,39 & 100,93 & 100,79 & 100,61 & 100,66 & 99,26 & 98,64 & 98,81 & 101,27 & 101,41 \\
\hline \multicolumn{13}{|c|}{ Formulae based on 3 oxygens } \\
\hline Si & 0,001 & 0,000 & 0,000 & 0,001 & 0,000 & 0,000 & 0,000 & 0,000 & 0,001 & 0,001 & 0,000 & 0,000 \\
\hline $\mathrm{Ti}$ & 0,914 & 0,893 & 0,911 & 0,925 & 0,928 & 0,930 & 0,915 & 0,861 & 0,864 & 0,909 & 0,936 & 0,937 \\
\hline Al & 0,000 & 0,000 & 0,001 & 0,000 & 0,000 & 0,000 & 0,000 & 0,000 & 0,000 & 0,001 & 0,001 & 0,001 \\
\hline $\mathrm{Fe}^{-}$ & 0,165 & 0,199 & 0,163 & 0,136 & 0,135 & 0,129 & 0,153 & 0,267 & 0,262 & 0,170 & 0,125 & 0,123 \\
\hline $\mathrm{Fe}^{-}$ & 0,461 & 0,543 & 0,620 & 0,625 & 0,632 & 0,623 & 0,596 & 0,694 & 0,709 & 0,589 & 0,644 & 0,639 \\
\hline Mn & 0,433 & 0,327 & 0,273 & 0,296 & 0,292 & 0,304 & 0,314 & 0,162 & 0,141 & 0,314 & 0,229 & 0,224 \\
\hline Mg & 0,002 & 0,000 & 0,000 & 0,002 & 0,002 & 0,002 & 0,003 & 0,003 & 0,002 & 0,002 & 0,063 & 0,073 \\
\hline $\mathrm{Ca}$ & 0,001 & 0,001 & 0,001 & 0,002 & 0,000 & 0,001 & 0,001 & 0,001 & 0,008 & 0,003 & 0,000 & 0,000 \\
\hline Zn & 0,018 & 0,023 & 0,018 & 0,001 & 0,001 & 0,001 & 0,001 & 0,001 & 0,003 & 0,002 & 0,000 & 0,001 \\
\hline $\mathrm{Nb}$ & 0,005 & 0,013 & 0,013 & 0,012 & 0,008 & 0,009 & 0,016 & 0,010 & 0,008 & 0,010 & 0,002 & 0,001 \\
\hline Total & 2,000 & 2,000 & 2,000 & 2,000 & 2,000 & 2,000 & 2,000 & 2,000 & 2,000 & 2,000 & 2,000 & 2,000 \\
\hline \multicolumn{13}{|c|}{ IImenite activity } \\
\hline $800^{\circ} \mathrm{C}$ & 0,510 & 0,580 & 0,647 & 0,637 & 0,639 & 0,633 & 0,608 & 0,673 & 0,697 & 0,601 & 0,642 & 0,637 \\
\hline $900^{\circ} \mathrm{C}$ & 0,502 & 0,574 & 0,644 & 0,633 & 0,635 & 0,629 & 0,604 & 0,671 & 0,696 & 0,596 & 0,639 & 0,634 \\
\hline
\end{tabular}

\begin{tabular}{|c|c|c|c|c|c|c|c|c|c|c|c|}
\hline \multirow{2}{*}{\multicolumn{2}{|c|}{$\begin{array}{l}\text { Unidade BtHblP } \\
\text { Amostra MAl114 }\end{array}$}} & & \multirow{2}{*}{$\begin{array}{l}\text { HblP } \\
\text { MAI160 }\end{array}$} & \multirow{2}{*}{\multicolumn{3}{|c|}{$\begin{array}{l}\text { BtM } \\
\text { MAI182C }\end{array}$}} & \multirow{2}{*}{\multicolumn{5}{|c|}{$\begin{array}{l}\text { BtAgtNeS } \\
\text { MAI199 }\end{array}$}} \\
\hline & & & & & & & & & & & \\
\hline Crystal & 4 & 6 & 5 & 1 & 5 & 6 & $3 b$ & 4 & 6 & 9 & $9 b$ \\
\hline $\mathrm{SiO}_{2}$ & 0,00 & $\overline{0,00}$ & 0,00 & $\overline{0,00}$ & $\overline{0,00}$ & 0,00 & 0,00 & 0,00 & $\overline{0,01}$ & 0,00 & 0,05 \\
\hline $\mathrm{TiO}_{2}$ & 50,68 & 50,64 & 49,90 & 47,60 & 49,08 & 49,60 & 51,81 & 51,52 & 52,17 & 51,73 & 51,54 \\
\hline $\mathrm{Al}_{2} \mathrm{O}_{3}$ & 0,06 & 0,04 & 0,01 & 0,02 & 0,01 & 0,03 & 0,01 & 0,02 & 0,00 & 0,00 & 0,02 \\
\hline $\mathrm{FeO}_{(\mathrm{T})}$ & 39,63 & 36,88 & 32,45 & 46,23 & 45,84 & 46,19 & 26,27 & 32,59 & 23,81 & 29,68 & 33,78 \\
\hline MnO & 8,01 & 11,07 & 15,55 & 3,27 & 3,47 & 3,34 & 22,26 & 16,20 & 24,96 & 19,24 & 14,65 \\
\hline MgO & 2,11 & 1,89 & 0,49 & 0,09 & 0,08 & 0,08 & 0,00 & 0,07 & 0,11 & 0,03 & 0,04 \\
\hline $\mathrm{CaO}$ & 0,06 & 0,02 & 0,16 & 0,01 & 0,01 & 0,00 & 0,01 & 0,04 & 0,00 & 0,00 & 0,00 \\
\hline $\mathrm{ZnO}$ & 0,02 & 0,03 & 0,02 & 0,07 & 0,02 & 0,02 & 0,57 & 0,00 & 0,46 & 0,09 & 0,05 \\
\hline $\mathrm{Nb}_{2} \mathrm{O}_{3}$ & 0,15 & 0,05 & 0,16 & 0,45 & 0,19 & 0,21 & 0,21 & 0,30 & 0,09 & 0,45 & 0,59 \\
\hline Sum & 100,71 & 100,63 & 98,74 & 97,73 & 98,70 & 99,47 & 101,14 & 100,73 & 101,60 & 101,22 & 100,72 \\
\hline $\mathrm{Fe}_{2} \mathrm{O}_{3}$ & 6,67 & 6,62 & 4,90 & 7,72 & 5,97 & 5,68 & 3,03 & 3,14 & 3,04 & 3,07 & 2,57 \\
\hline $\mathrm{FeO}$ & 33,63 & 30,92 & 28,04 & 39,28 & 40,47 & 41,08 & 23,55 & 29,77 & 21,07 & 26,91 & 31,47 \\
\hline Total & 101,38 & 101,29 & 99,23 & 98,51 & 99,30 & 100,04 & 101,44 & 101,05 & 101,91 & 101,52 & 100,98 \\
\hline \multicolumn{12}{|c|}{ Formulae based on 3 oxygens } \\
\hline Si & 0,000 & 0,000 & 0,000 & 0,000 & 0,000 & 0,000 & 0,000 & 0,000 & 0,000 & 0,000 & 0,001 \\
\hline $\mathrm{Ti}$ & 0,937 & 0,938 & 0,952 & 0,922 & 0,941 & 0,944 & 0,970 & 0,968 & 0,971 & 0,968 & 0,971 \\
\hline Al & 0,002 & 0,001 & 0,000 & 0,001 & 0,000 & 0,001 & 0,000 & 0,000 & 0,000 & 0,000 & 0,000 \\
\hline $\mathrm{Fe}^{--}$ & 0,123 & 0,123 & 0,093 & 0,150 & 0,115 & 0,108 & 0,057 & 0,059 & 0,057 & 0,058 & 0,048 \\
\hline $\mathrm{Fe}^{-}$ & 0,691 & 0,636 & 0,595 & 0,846 & 0,863 & 0,869 & 0,490 & 0,622 & 0,436 & 0,560 & 0,659 \\
\hline Mn & 0,167 & 0,231 & 0,334 & 0,071 & 0,075 & 0,072 & 0,469 & 0,343 & 0,523 & 0,406 & 0,311 \\
\hline $\mathbf{M g}$ & 0,077 & 0,069 & 0,018 & 0,003 & 0,003 & 0,003 & 0,000 & 0,002 & 0,004 & 0,001 & 0,001 \\
\hline $\mathrm{Ca}$ & 0,002 & 0,001 & 0,004 & 0,000 & 0,000 & 0,000 & 0,000 & 0,001 & 0,000 & 0,000 & 0,000 \\
\hline $\mathrm{Zn}$ & 0,000 & 0,001 & 0,000 & 0,001 & 0,000 & 0,000 & 0,010 & 0,000 & 0,008 & 0,002 & 0,001 \\
\hline $\mathrm{Nb}$ & 0,002 & 0,001 & 0,002 & 0,006 & 0,003 & 0,003 & 0,003 & 0,004 & 0,001 & 0,006 & 0,008 \\
\hline Total & 2,000 & 2,000 & 2,000 & 2,000 & 2,000 & 2,000 & 2,000 & 2,000 & 2,000 & 2,000 & 2,000 \\
\hline \multicolumn{12}{|c|}{ Ilmenite activity } \\
\hline $800^{\circ} \mathrm{C}$ & 0,686 & 0,636 & 0,619 & 0,814 & 0,834 & 0,841 & 0,555 & 0,650 & 0,503 & 0,619 & 0,683 \\
\hline $900^{\circ} \mathrm{C}$ & 0,681 & 0,632 & 0,614 & 0,815 & 0,834 & 0,841 & 0,549 & 0,646 & 0,496 & 0,614 & 0,680 \\
\hline
\end{tabular}


ANEXO E - Tabela E.7a - Composição química de magnetitas de rochas do Maciço Alcalino de Itatiaia. Continua...

\begin{tabular}{|c|c|c|c|c|c|c|c|c|c|c|c|c|c|c|c|c|}
\hline $\begin{array}{l}\text { Unidade } \\
\text { Amostra }\end{array}$ & $\begin{array}{l}\text { BtHblNeS } \\
\text { MAI036 }\end{array}$ & & & & $\begin{array}{l}\text { VeS-I } \\
\text { MAI060 }\end{array}$ & & & & & & $\begin{array}{l}\mathrm{HblP} \\
\text { Al092I }\end{array}$ & & & & & $\begin{array}{l}\mathrm{A}-\mathrm{I} \\
\mathrm{AAI097B} \\
\end{array}$ \\
\hline Cristal & $1 \mathrm{R}$ & $2 R$ & $3 R$ & $5 R$ & 1 & $2 a$ & $2 b$ & 3 & 4 & 5 & 1 & 4 & 5 & 6 & 7 & 1 \\
\hline Been $\emptyset^{1}$ & 1 & 1 & 1 & 1 & 20 & 20 & 20 & 20 & 20 & 20 & 1 & 1 & 1 & 1 & 1 & 20 \\
\hline \# Analyses ${ }^{2}$ & $3 / 2$ & $3 / 2$ & $3 / 3$ & $3 / 3$ & 1 & 1 & 1 & 1 & 1 & 1 & 3 & 2 & 2 & 2 & 3 & 1 \\
\hline $\mathrm{SiO}_{2}$ & & & & & 0,05 & 0,00 & 0,02 & 0,00 & 0,00 & 0,00 & 0,01 & 0,00 & 0,00 & 0,03 & 0,00 & 0,02 \\
\hline $\mathrm{TiO}_{2}$ & 12,51 & 6,64 & 9,46 & 18,53 & 4,96 & 4,46 & 4,05 & 5,42 & 5,34 & 4,14 & 3,57 & 1,96 & 2,53 & 2,11 & 3,07 & 1,50 \\
\hline $\mathrm{Al}_{2} \mathrm{O}_{3}$ & 0,24 & 0,29 & 0,29 & 0,25 & 0,67 & 0,27 & 0,31 & 0,45 & 0,37 & 0,17 & 0,67 & 0,56 & 0,40 & 0,55 & 0,70 & 0,18 \\
\hline $\mathrm{FeO}_{(\mathrm{T})}$ & 74,06 & 81,51 & 77,89 & 68,38 & 82,56 & 83,24 & 84,43 & 81,98 & 82,93 & 83,36 & 85,97 & 87,41 & 86,48 & 89,31 & 85,78 & 90,48 \\
\hline MnO & 6,19 & 4,02 & 4,89 & 6,58 & 5,63 & 5,57 & 5,12 & 5,89 & 5,55 & 4,94 & 3,15 & 3,24 & 2,03 & 1,67 & 3,63 & 1,41 \\
\hline MgO & 0,13 & 0,06 & 0,08 & 0,21 & 0,03 & 0,02 & 0,01 & 0,06 & 0,02 & 0,02 & 0,00 & 0,04 & 0,07 & 0,03 & 0,03 & 0,02 \\
\hline $\mathrm{CaO}$ & & & & & 0,00 & 0,00 & 0,02 & 0,00 & 0,00 & 0,00 & 0,02 & 0,04 & 0,01 & 0,05 & 0,01 & 0,02 \\
\hline Zno & 0,02 & 0,02 & 0,01 & 0,01 & 0,53 & 0,44 & 0,42 & 0,58 & 0,37 & 0,22 & 0,35 & 0,40 & 0,21 & 0,18 & 0,41 & 0,22 \\
\hline $\mathrm{Nb}_{2} \mathrm{O}_{3}$ & 0,02 & 0,02 & 0,01 & 0,02 & 0,06 & 0,01 & 0,00 & 0,01 & 0,00 & 0,01 & 0,00 & 0,00 & 0,02 & 0,03 & 0,00 & 0,05 \\
\hline Sum & 93,16 & 92,57 & 92,62 & 93,98 & 94,48 & 94,02 & 94,38 & 94,39 & 94,58 & 92,86 & 93,73 & 93,65 & 91,74 & 93,94 & 93,63 & 93,90 \\
\hline $\mathrm{Fe}_{2} \mathrm{O}_{3}$ & 42,90 & 54,49 & 48,72 & 31,06 & 58,73 & 60,09 & 61,10 & 58,16 & 58,56 & 60,03 & 61,18 & 64,65 & 62,27 & 64,47 & 62,13 & 66,17 \\
\hline $\mathrm{FeO}$ & 35,46 & 32,48 & 34,05 & 40,43 & 29,72 & 29,17 & 29,45 & 29,65 & 30,24 & 29,35 & 30,91 & 29,24 & 30,45 & 31,29 & 29,87 & 30,94 \\
\hline Total & 97,46 & 98,03 & 97,50 & 97,10 & 100,36 & 100,04 & 100,50 & 100,21 & 100,44 & 98,88 & 99,86 & 100,13 & 97,98 & 100,40 & 99,85 & 100,53 \\
\hline \multicolumn{17}{|c|}{ Formulae based on 4 oxygens } \\
\hline Si & 0,000 & 0,000 & 0,000 & 0,000 & 0,002 & 0,000 & 0,001 & 0,000 & 0,000 & 0,000 & 0,000 & 0,000 & 0,000 & 0,001 & 0,000 & 0,001 \\
\hline $\mathrm{Ti}$ & 0,366 & 0,195 & 0,278 & 0,541 & 0,142 & 0,128 & 0,116 & 0,155 & 0,153 & 0,121 & 0,103 & 0,056 & 0,074 & 0,061 & 0,088 & 0,043 \\
\hline Al & 0,011 & 0,014 & 0,014 & 0,011 & 0,030 & 0,012 & 0,014 & 0,020 & 0,017 & 0,008 & 0,030 & 0,025 & 0,018 & 0,025 & 0,032 & 0,008 \\
\hline $\mathrm{Fe}^{+3}$ & 1,256 & 1,597 & 1,431 & 0,907 & 1,681 & 1,731 & 1,752 & 1,669 & 1,677 & 1,751 & 1,763 & 1,862 & 1,833 & 1,852 & 1,791 & 1,904 \\
\hline $\mathrm{Fe}^{+2}$ & 1,154 & 1,058 & 1,111 & 1,312 & 0,946 & 0,934 & 0,939 & 0,945 & 0,963 & 0,951 & 0,990 & 0,936 & 0,996 & 0,999 & 0,957 & 0,989 \\
\hline $\mathrm{Mn}$ & 0,204 & 0,133 & 0,162 & 0,216 & 0,181 & 0,181 & 0,165 & 0,190 & 0,179 & 0,162 & 0,102 & 0,105 & 0,067 & 0,054 & 0,118 & 0,046 \\
\hline Mg & 0,007 & 0,003 & 0,004 & 0,012 & 0,002 & 0,001 & 0,001 & 0,003 & 0,001 & 0,001 & 0,000 & 0,002 & 0,004 & 0,002 & 0,001 & 0,001 \\
\hline $\mathrm{Ca}$ & 0,000 & 0,000 & 0,000 & 0,000 & 0,000 & 0,000 & 0,001 & 0,000 & 0,000 & 0,000 & 0,001 & 0,002 & 0,000 & 0,002 & 0,000 & 0,001 \\
\hline $\mathrm{Zn}$ & 0,001 & 0,000 & 0,000 & 0,000 & 0,015 & 0,012 & 0,012 & 0,016 & 0,010 & 0,006 & 0,010 & 0,011 & 0,006 & 0,005 & 0,012 & 0,006 \\
\hline $\mathrm{Nb}$ & 0,000 & 0,000 & 0,000 & 0,000 & 0,001 & 0,000 & 0,000 & 0,000 & 0,000 & 0,000 & 0,000 & 0,000 & 0,000 & 0,000 & 0,000 & 0,001 \\
\hline Total & 3,000 & 3,000 & 3,000 & 3,000 & 3,000 & 3,000 & 3,000 & 3,000 & 3,000 & 3,000 & 3,000 & 3,000 & 3,000 & 3,000 & 3,000 & 3,000 \\
\hline \multicolumn{17}{|c|}{ Magnetite activity } \\
\hline $800^{\circ} \mathrm{C}$ & 0,573 & 0,695 & 0,635 & 0,426 & 0,718 & 0,727 & 0,742 & 0,711 & 0,712 & 0,74 & 0,783 & 0,826 & 0,831 & 0,856 & 0,787 & 0,886 \\
\hline $900^{\circ} \mathrm{C}$ & 0,523 & 0,673 & 0,599 & 0,364 & 0,702 & 0,713 & 0,731 & 0,694 & 0,695 & 0,728 & 0,774 & 0,823 & 0,827 & 0,853 & 0,78 & 0,884 \\
\hline
\end{tabular}

ANEXO E - Tabela E.7a - Composição química de magnetitas de rochas do Maciço Alcalino de Itatiaia. Continua...

\begin{tabular}{|c|c|c|c|c|c|c|c|c|c|c|c|c|c|c|c|c|}
\hline $\begin{array}{l}\text { Unidade } \\
\text { Amostra }\end{array}$ & $\begin{array}{l}\mathrm{N}-\mathrm{I} \\
\text { MAI097B }\end{array}$ & & & & $\begin{array}{l}\text { HblP } \\
\text { MAl107 }\end{array}$ & & & & & $\begin{array}{l}\text { ok-QzS } \\
\text { Al108II }\end{array}$ & & & & $\begin{array}{l}\text { ZAFS-I } \\
\text { AII110 }\end{array}$ & & \\
\hline Cristal & 2 & 3 & 4 & 5 & $1 R$ & $2 R$ & $4 R$ & $5 R$ & $6 \mathrm{R}$ & 1 & 2 & 4 & 7 & 1 & 2 & 3 \\
\hline Been $\emptyset^{1}$ & 20 & 20 & 20 & 20 & 1 & 1 & 1 & 1 & 1 & 1 & 1 & 1 & 1 & 20 & 20 & 20 \\
\hline \# Analyses ${ }^{2}$ & 1 & 1 & 1 & 1 & $3 / 1$ & $3 / 3$ & $3 / 2$ & $3 / 1$ & $3 / 3$ & 1 & 1 & 1 & 1 & 1 & 1 & 1 \\
\hline $\mathrm{SiO}_{2}$ & 0,01 & 0,03 & 0,01 & 0,01 & & & & & & 0,00 & 0,05 & 0,00 & 0,02 & 0,08 & 0,06 & 0,08 \\
\hline $\mathrm{TiO}_{2}$ & 6,90 & 5,37 & 6,38 & 4,81 & 9,99 & 9,72 & 8,25 & 11,46 & 12,34 & 0,91 & 0,46 & 0,56 & 0,71 & 5,94 & 5,58 & 5,68 \\
\hline $\mathrm{Al}_{2} \mathrm{O}_{3}$ & 0,16 & 0,02 & 0,01 & 0,04 & 0,68 & 0,58 & 0,48 & 0,36 & 0,66 & 0,34 & 0,76 & 0,42 & 0,25 & 0,09 & 0,09 & 0,10 \\
\hline $\mathrm{FeO}_{(\mathrm{T})}$ & 83,81 & 84,86 & 84,76 & 85,36 & 79,43 & 80,85 & 82,14 & 79,31 & 77,58 & 90,35 & 90,31 & 91,51 & 91,07 & 85,76 & 86,11 & 85,80 \\
\hline Mno & 3,34 & 3,13 & 2,99 & 3,37 & 4,70 & 3,74 & 3,61 & 4,08 & 4,79 & 0,63 & 0,42 & 0,24 & 0,30 & 2,05 & 2,17 & 2,21 \\
\hline MgO & 0,03 & 0,02 & 0,05 & 0,06 & 0,04 & 0,05 & 0,03 & 0,02 & 0,03 & 0,00 & 0,02 & 0,01 & 0,00 & 0,03 & 0,03 & 0,03 \\
\hline $\mathrm{CaO}$ & 0,03 & 0,05 & 0,01 & 0,03 & & & & & & 0,10 & 0,09 & 0,04 & 0,08 & 0,13 & 0,06 & 0,00 \\
\hline Zno & 0,17 & 0,01 & 0,02 & 0,18 & 0,20 & 0,20 & 0,09 & 0,08 & 0,18 & 0,23 & 0,45 & 0,30 & 0,18 & 0,06 & 0,06 & 0,05 \\
\hline $\mathrm{Nb}_{2} \mathrm{O}_{3}$ & 0,06 & 0,06 & 0,03 & 0,00 & 0,02 & 0,01 & 0,02 & 0,05 & 0,03 & 0,00 & 0,02 & 0,00 & 0,00 & 0,01 & 0,00 & 0,03 \\
\hline Sum & 94,51 & 93,55 & 94,26 & 93,86 & 95,05 & 95,16 & 94,62 & 95,35 & 95,60 & 92,57 & 92,58 & 93,09 & 92,61 & 94,13 & 94,15 & 93,98 \\
\hline $\mathrm{Fe}_{2} \mathrm{O}_{3}$ & 55,47 & 58,08 & 56,60 & 59,55 & 48,88 & 49,65 & 52,41 & 46,44 & 44,44 & 66,26 & 66,55 & 67,26 & 66,78 & 57,17 & 57,96 & 57,53 \\
\hline $\mathrm{FeO}$ & 33,90 & 32,60 & 33,83 & 31,78 & 35,44 & 36,17 & 34,98 & 37,53 & 37,60 & 30,73 & 30,43 & 30,99 & 30,98 & 34,32 & 33,96 & 34,04 \\
\hline Total & 100,07 & 99,37 & 99,93 & 99,82 & 99,95 & 100,13 & 99,87 & 100,00 & 100,06 & 99,20 & 99,24 & 99,83 & 99,30 & 99,86 & 99,96 & 99,74 \\
\hline \multicolumn{17}{|c|}{ Formulae based on 4 oxygens } \\
\hline $\mathrm{Si}$ & 0,001 & 0,001 & 0,000 & 0,000 & 0,000 & 0,000 & 0,000 & 0,000 & 0,000 & 0,000 & 0,002 & 0,000 & 0,001 & 0,003 & 0,002 & 0,003 \\
\hline $\mathrm{Ti}$ & 0,198 & 0,156 & 0,184 & 0,139 & 0,286 & 0,278 & 0,237 & 0,328 & 0,352 & 0,027 & 0,013 & 0,016 & 0,021 & 0,171 & 0,161 & 0,164 \\
\hline Al & 0,007 & 0,001 & 0,000 & 0,002 & 0,030 & 0,026 & 0,022 & 0,016 & 0,030 & 0,016 & 0,035 & 0,019 & 0,011 & 0,004 & 0,004 & 0,005 \\
\hline $\mathrm{Fe}^{+3}$ & 1,594 & 1,685 & 1,631 & 1,720 & 1,398 & 1,419 & 1,504 & 1,328 & 1,267 & 1,931 & 1,935 & 1,948 & 1,946 & 1,648 & 1,670 & 1,661 \\
\hline $\mathrm{Fe}^{+2}$ & 1,083 & 1,051 & 1,083 & 1,020 & 1,126 & 1,149 & 1,116 & 1,193 & 1,191 & 0,995 & 0,983 & 0,998 & 1,003 & 1,099 & 1,087 & 1,092 \\
\hline $\mathrm{Mn}$ & 0,108 & 0,102 & 0,097 & 0,110 & 0,151 & 0,120 & 0,117 & 0,131 & 0,154 & 0,021 & 0,014 & 0,008 & 0,010 & 0,067 & 0,070 & 0,072 \\
\hline Mg & 0,001 & 0,001 & 0,003 & 0,003 & 0,002 & 0,003 & 0,002 & 0,001 & 0,002 & 0,000 & 0,001 & 0,001 & 0,000 & 0,002 & 0,001 & 0,002 \\
\hline $\mathrm{Ca}$ & 0,001 & 0,002 & 0,000 & 0,001 & 0,000 & 0,000 & 0,000 & 0,000 & 0,000 & 0,004 & 0,004 & 0,002 & 0,003 & 0,005 & 0,002 & 0,000 \\
\hline $\mathrm{Zn}$ & 0,005 & 0,000 & 0,000 & 0,005 & 0,006 & 0,006 & 0,003 & 0,002 & 0,005 & 0,007 & 0,013 & 0,009 & 0,005 & 0,002 & 0,002 & 0,001 \\
\hline $\mathrm{Nb}$ & 0,001 & 0,001 & 0,001 & 0,000 & 0,000 & 0,000 & 0,000 & 0,001 & 0,001 & 0,000 & 0,000 & 0,000 & 0,000 & 0,000 & 0,000 & 0,001 \\
\hline Total & 3,000 & 3,000 & 3,000 & 3,000 & 3,000 & 3,000 & 3,000 & 3,000 & 3,000 & 3,000 & 3,000 & 3,000 & 3,000 & 3,000 & 3,000 & 3,000 \\
\hline \multicolumn{17}{|c|}{ Magnetite activity } \\
\hline $800^{\circ} \mathrm{C}$ & 0,698 & 0,735 & 0,712 & 0,745 & 0,631 & 0,638 & 0,668 & 0,603 & 0,586 & 0,932 & 0,96 & 0,961 & 0,952 & 0,73 & 0,739 & 0,736 \\
\hline $900^{\circ} \mathrm{C}$ & 0,678 & 0,72 & 0,693 & 0,732 & 0,594 & 0,604 & 0,641 & 0,561 & 0,54 & 0,932 & 0,96 & 0,961 & 0,951 & 0,714 & 0,724 & 0,72 \\
\hline
\end{tabular}

2 - number of analyses reintegrated: magnetite / ilmenite 
ANEXO E - Tabela E.7a - Composição química de magnetitas de rochas do Maciço Alcalino de Itatiaia. Continua...

\begin{tabular}{|c|c|c|c|c|c|c|c|c|c|c|c|c|c|c|c|c|}
\hline $\begin{array}{l}\text { Unidade } \\
\text { Amostra }\end{array}$ & $\begin{array}{l}\text { QzAFS-I } \\
\text { MAI110 }\end{array}$ & & $\begin{array}{l}\text { BtHblP } \\
\text { MAI114 }\end{array}$ & & & & & & Al160 & & & & & $\begin{array}{l}-11 \\
|1166| \\
\end{array}$ & & \\
\hline Cristal & 4 & 5 & 3 & 4 & $4 b$ & 6 & 7 & 8 & 1 & 2 & 3 & 4 & 5 & 1 & 2 & 3 \\
\hline Been $\emptyset^{1}$ & 20 & 20 & 20 & 20 & 20 & 20 & 20 & 20 & 20 & 20 & 20 & 20 & 20 & 20 & 20 & 20 \\
\hline \# Analyses ${ }^{2}$ & 1 & 1 & 1 & 1 & 2 & 2 & 1 & 1 & 3 & 3 & 1 & 1 & 1 & 1 & 1 & 1 \\
\hline $\mathrm{SiO}_{2}$ & 0,03 & 0,07 & 0,00 & 0,01 & 0,07 & 0,11 & 0,00 & 0,00 & 0,02 & 0,10 & 0,00 & 0,03 & 0,36 & 0,00 & 0,00 & 0,00 \\
\hline $\mathrm{TiO}_{2}$ & 5,80 & 5,38 & 8,77 & 8,30 & 8,10 & 8,72 & 9,21 & 8,35 & 3,08 & 6,01 & 1,46 & 1,62 & 3,54 & 3,92 & 4,68 & 3,99 \\
\hline $\mathrm{Al}_{2} \mathrm{O}_{3}$ & 0,10 & 0,09 & 1,78 & 1,89 & 1,52 & 1,74 & 1,60 & 1,41 & 0,66 & 0,88 & 0,63 & 0,67 & 0,59 & 0,50 & 0,61 & 0,52 \\
\hline $\mathrm{FeO}_{(\mathrm{T})}$ & 85,64 & 85,95 & 79,35 & 81,24 & 81,39 & 79,83 & 79,52 & 81,52 & 85,69 & 77,39 & 88,19 & 88,36 & 85,33 & 84,22 & 82,53 & 83,19 \\
\hline Mno & 2,31 & 2,05 & 4,38 & 2,66 & 3,24 & 3,63 & 3,98 & 3,33 & 2,14 & 1,61 & 1,56 & 1,80 & 1,40 & 3,74 & 4,19 & 4,20 \\
\hline MgO & 0,00 & 0,01 & 0,85 & 0,75 & 0,59 & 0,77 & 0,69 & 0,29 & 0,12 & 0,10 & 0,03 & 0,12 & 0,09 & 0,07 & 0,04 & 0,02 \\
\hline $\mathrm{CaO}$ & 0,02 & 0,01 & 0,01 & 0,04 & 0,03 & 0,03 & 0,01 & 0,01 & 0,02 & 0,15 & 0,03 & 0,05 & 0,46 & 0,01 & 0,00 & 0,00 \\
\hline Zno & 0,04 & 0,01 & 0,42 & 0,37 & 0,29 & 0,42 & 0,34 & 0,30 & 0,23 & 0,28 & 0,21 & 0,24 & 0,19 & 0,32 & 0,41 & 0,43 \\
\hline $\mathrm{Nb}_{2} \mathrm{O}_{3}$ & 0,01 & 0,00 & 0,00 & 0,00 & 0,00 & 0,00 & 0,00 & 0,02 & 0,00 & 0,03 & 0,01 & 0,04 & 0,02 & 0,00 & 0,04 & 0,00 \\
\hline Sum & 93,94 & 93,57 & 95,55 & 95,25 & 95,22 & 95,25 & 95,35 & 95,23 & 91,97 & 86,55 & 92,12 & 92,93 & 91,98 & 92,77 & 92,51 & 92,35 \\
\hline $\mathrm{Fe}_{2} \mathrm{O}_{3}$ & 57,39 & 57,90 & 50,86 & 51,38 & 52,00 & 50,48 & 49,93 & 51,62 & 60,94 & 50,36 & 64,44 & 64,63 & 59,29 & 60,03 & 58,05 & 59,50 \\
\hline $\mathrm{FeO}$ & 34,00 & 33,85 & 33,59 & 35,01 & 34,60 & 34,41 & 34,59 & 35,08 & 30,86 & 32,07 & 30,20 & 30,21 & 31,98 & 30,21 & 30,30 & 29,65 \\
\hline Total & 99,69 & 99,37 & 100,65 & 100,40 & 100,43 & 100,31 & 100,35 & 100,40 & 98,08 & 91,59 & 98,58 & 99,40 & 97,92 & 98,79 & 98,32 & 98,31 \\
\hline \multicolumn{17}{|c|}{ Formulae based on 4 oxygens } \\
\hline Si & 0,001 & 0,003 & 0,000 & 0,000 & 0,003 & 0,004 & 0,000 & 0,000 & 0,001 & 0,004 & 0,000 & 0,001 & 0,014 & 0,000 & 0,000 & 0,000 \\
\hline $\mathrm{Ti}$ & 0,168 & 0,156 & 0,246 & 0,234 & 0,229 & 0,246 & 0,260 & 0,237 & 0,090 & 0,188 & 0,043 & 0,047 & 0,104 & 0,114 & 0,137 & 0,117 \\
\hline Al & 0,004 & 0,004 & 0,078 & 0,083 & 0,067 & 0,077 & 0,071 & 0,063 & 0,030 & 0,043 & 0,029 & 0,030 & 0,027 & 0,023 & 0,028 & 0,024 \\
\hline $\mathrm{Fe}^{+3}$ & 1,658 & 1,679 & 1,429 & 1,448 & 1,470 & 1,424 & 1,409 & 1,464 & 1,787 & 1,573 & 1,886 & 1,873 & 1,737 & 1,749 & 1,698 & 1,743 \\
\hline $\mathrm{Fe}^{+2}$ & 1,092 & 1,091 & 1,049 & 1,097 & 1,087 & 1,078 & 1,085 & 1,105 & 1,006 & 1,113 & 0,982 & 0,973 & 1,041 & 0,978 & 0,985 & 0,965 \\
\hline $\mathrm{Mn}$ & 0,075 & 0,067 & 0,139 & 0,084 & 0,103 & 0,115 & 0,126 & 0,106 & 0,071 & 0,057 & 0,051 & 0,059 & 0,046 & 0,123 & 0,138 & 0,138 \\
\hline Mg & 0,000 & 0,001 & 0,047 & 0,042 & 0,033 & 0,043 & 0,039 & 0,016 & 0,007 & 0,006 & 0,002 & 0,007 & 0,005 & 0,004 & 0,002 & 0,001 \\
\hline $\mathrm{Ca}$ & 0,001 & 0,000 & 0,000 & 0,001 & 0,001 & 0,001 & 0,000 & 0,000 & 0,001 & 0,007 & 0,001 & 0,002 & 0,019 & 0,000 & 0,000 & 0,000 \\
\hline $\mathrm{Zn}$ & 0,001 & 0,000 & 0,011 & 0,010 & 0,008 & 0,012 & 0,009 & 0,008 & 0,007 & 0,008 & 0,006 & 0,007 & 0,006 & 0,009 & 0,012 & 0,012 \\
\hline $\mathrm{Nb}$ & 0,000 & 0,000 & 0,000 & 0,000 & 0,000 & 0,000 & 0,000 & 0,000 & 0,000 & 0,001 & 0,000 & 0,001 & 0,000 & 0,000 & 0,001 & 0,000 \\
\hline Total & 3,000 & 3,000 & 3,000 & 3,000 & 3,000 & 3,000 & 3,000 & 3,000 & 3,000 & 3,000 & 3,000 & 3,000 & 3,000 & 3,000 & 3,000 & 3,000 \\
\hline \multicolumn{17}{|c|}{ Magnetite activity } \\
\hline $800^{\circ} \mathrm{C}$ & 0,733 & 0,745 & 0,634 & 0,655 & 0,659 & 0,64 & 0,632 & 0,662 & 0,807 & 0,714 & 0,882 & 0,797 & 0,803 & 0,76 & 0,737 & 0,753 \\
\hline $900^{\circ} \mathrm{C}$ & 0,717 & 0,731 & 0,604 & 0,628 & 0,633 & 0,611 & 0,6 & 0,635 & 0,8 & 0,696 & 0,88 & 0,789 & 0,796 & 0,75 & 0,723 & 0,742 \\
\hline
\end{tabular}

ANEXO E - Tabela E.7a - Composição química de magnetitas de rochas do Maciço Alcalino de Itatiaia.

\begin{tabular}{|c|c|c|c|c|c|c|c|c|c|c|c|}
\hline $\begin{array}{l}\text { Unidade } \\
\text { Amostra }\end{array}$ & $\begin{array}{l}\text { NeS-II } \\
\text { MAI166I }\end{array}$ & $\begin{array}{l}\text { BtM } \\
\text { MAI182C }\end{array}$ & & & & \begin{tabular}{|l} 
BrAgtNeS \\
MAl199
\end{tabular} & & & & & \\
\hline Cristal & 4 & $1 R$ & $3 R$ & $5 R$ & $7 R$ & $2 R$ & 4 & $5 R$ & 6 & 9 & $3 b$ \\
\hline Been $\emptyset^{1}$ & 20 & 1 & 1 & 1 & 1 & 1 & 1 & 1 & 1 & 20 & 20 \\
\hline \# Analyses ${ }^{2}$ & 1 & $3 / 2$ & $3 / 2$ & $3 / 2$ & $3 / 3$ & $3 / 2$ & 1 & $3 / 2$ & 2 & 2 & 2 \\
\hline $\mathrm{SiO}_{2}$ & 0,02 & & & & & & 0,02 & & 0,23 & 0,01 & 0,02 \\
\hline $\mathrm{TiO}_{2}$ & 3,57 & 12,53 & 21,90 & 13,30 & 13,92 & 20,90 & 3,29 & 22,78 & 6,48 & 6,41 & 6,95 \\
\hline $\mathrm{Al}_{2} \mathrm{O}_{3}$ & 0,43 & 0,40 & 0,19 & 0,46 & 0,58 & 0,10 & 0,05 & 0,07 & 0,13 & 0,10 & 0,12 \\
\hline $\mathrm{FeO}_{(\mathrm{T})}$ & 83,15 & 76,18 & 70,93 & 78,82 & 79,38 & 64,37 & 90,35 & 63,53 & 83,73 & 84,72 & 83,05 \\
\hline $\mathrm{MnO}$ & 3,83 & 0,94 & 1,57 & 1,04 & 1,06 & 10,51 & 0,78 & 9,61 & 3,79 & 3,01 & 3,51 \\
\hline MgO & 0,02 & 0,04 & 0,04 & 0,04 & 0,05 & 0,07 & 0,00 & 0,02 & 0,06 & 0,03 & 0,02 \\
\hline $\mathrm{CaO}$ & 0,03 & & & & & & 0,34 & & 0,03 & 0,00 & 0,01 \\
\hline Zno & 0,36 & 0,07 & 0,10 & 0,15 & 0,15 & 0,84 & 0,05 & 0,67 & 0,31 & 0,11 & 0,61 \\
\hline $\mathrm{Nb}_{2} \mathrm{O}_{3}$ & 0,05 & 0,01 & 0,04 & 0,01 & 0,00 & 0,05 & 0,00 & 0,04 & 0,00 & 0,01 & 0,00 \\
\hline Sum & 91,45 & 90,17 & 94,77 & 93,81 & 95,16 & 96,83 & 94,88 & 96,73 & 94,75 & 94,37 & 94,28 \\
\hline $\mathrm{Fe}_{2} \mathrm{O}_{3}$ & 59,73 & 40,35 & 24,55 & 41,35 & 40,92 & 28,30 & 63,44 & 24,35 & 56,08 & 56,53 & 55,25 \\
\hline $\mathrm{FeO}$ & 29,40 & 39,88 & 48,84 & 41,61 & 42,57 & 38,91 & 33,27 & 41,62 & 33,27 & 33,85 & 33,33 \\
\hline Total & 97,44 & 94,21 & 97,23 & 97,95 & 99,26 & 99,66 & 101,23 & 99,17 & 100,37 & 100,04 & 99,82 \\
\hline \multicolumn{12}{|c|}{ Formulae based on 4 oxygens } \\
\hline Si & 0,001 & 0,000 & 0,000 & 0,000 & 0,000 & 0,000 & 0,001 & 0,000 & 0,009 & 0,000 & 0,001 \\
\hline $\mathrm{Ti}$ & 0,106 & 0,379 & 0,638 & 0,387 & 0,400 & 0,595 & 0,094 & 0,650 & 0,185 & 0,184 & 0,200 \\
\hline Al & 0,020 & 0,019 & 0,009 & 0,021 & 0,026 & 0,004 & 0,002 & 0,003 & 0,006 & 0,004 & 0,005 \\
\hline $\mathrm{Fe}^{+3}$ & 1,766 & 1,222 & 0,715 & 1,204 & 1,175 & 0,805 & 1,809 & 0,695 & 1,606 & 1,626 & 1,593 \\
\hline $\mathrm{Fe}^{+2}$ & 0,966 & 1,342 & 1,581 & 1,347 & 1,358 & 1,231 & 1,054 & 1,321 & 1,059 & 1,082 & 1,068 \\
\hline Mn & 0,127 & 0,032 & 0,051 & 0,034 & 0,034 & 0,337 & 0,025 & 0,309 & 0,122 & 0,097 & 0,114 \\
\hline Mg & 0,001 & 0,002 & 0,002 & 0,002 & 0,003 & 0,004 & 0,000 & 0,001 & 0,003 & 0,002 & 0,001 \\
\hline $\mathrm{Ca}$ & 0,001 & 0,000 & 0,000 & 0,000 & 0,000 & 0,000 & 0,014 & 0,000 & 0,001 & 0,000 & 0,001 \\
\hline $\mathrm{Zn}$ & 0,010 & 0,002 & 0,003 & 0,004 & 0,004 & 0,023 & 0,001 & 0,019 & 0,009 & 0,003 & 0,017 \\
\hline $\mathrm{Nb}$ & 0,001 & 0,000 & 0,001 & 0,000 & 0,000 & 0,001 & 0,000 & 0,001 & 0,000 & 0,000 & 0,000 \\
\hline Total & 3,000 & 3,000 & 3,000 & 3,000 & 3,000 & 3,000 & 3,000 & 3,000 & 3,000 & 3,000 & 3,000 \\
\hline \multicolumn{12}{|c|}{ Magnetite activity } \\
\hline $800^{\circ} \mathrm{C}$ & 0,767 & 0,558 & 0,324 & 0,552 & 0,542 & 0,365 & 0,83 & 0,301 & 0,704 & 0,712 & 0,695 \\
\hline $900^{\circ} \mathrm{C}$ & 0,758 & 0,517 & 0,275 & 0,509 & 0,498 & 0,302 & 0,824 & 0,247 & 0,683 & 0,693 & 0,673 \\
\hline
\end{tabular}

${ }^{2}$ - number of analyses reintegrated: magnetite / ilmenite 
ANEXO E - Tabela E.7c - Composição química de hercynita de rochas do Maciço Alcalino de Itatiaia.

\begin{tabular}{|c|c|c|c|c|c|c|c|c|c|c|c|c|c|}
\hline Unidade & $\mathrm{NeS}-\mathrm{I}$ & & & & & & & & & & & & \\
\hline Amostra & MAI030 & & & & & & & & & & & & \\
\hline Cristal & 1 & 2 & 3 & 4 & 5 & 6 & 7 & 8 & 9 & 10 & 11 & 12 & 13 \\
\hline $\mathrm{SiO}_{2}$ & 0,13 & 0,11 & 0,13 & 0,11 & 0,12 & 0,09 & 0,09 & 0,09 & 0,07 & 0,15 & 0,06 & 0,71 & 0,12 \\
\hline $\mathrm{TiO}_{2}$ & & & 0,10 & 0,07 & 0,04 & & 0,16 & 0,19 & 0,01 & 0,06 & 0,02 & 0,06 & 0,09 \\
\hline $\mathrm{Al}_{2} \mathrm{O}_{3}$ & 51,66 & 34,43 & 52,21 & 52,32 & 52,13 & 48,72 & 52,54 & 53,66 & 52,93 & 53,24 & 53,63 & 3,13 & 52,33 \\
\hline $\mathrm{Fe}_{2} \mathrm{O}_{3 \mathrm{t}}$ & 46,75 & 65,59 & 46,70 & 46,34 & 45,94 & 49,87 & 46,22 & 45,34 & 44,53 & 44,49 & 45,43 & 96,17 & 44,18 \\
\hline MnO & 3,89 & 2,54 & 3,21 & 3,74 & 3,41 & 3,27 & 2,99 & 2,94 & 3,17 & 3,24 & 3,99 & 0,28 & 3,27 \\
\hline MgO & 1,10 & 0,78 & 1,16 & 1,24 & 1,09 & 1,00 & 1,16 & 0,84 & 1,49 & 1,47 & 0,82 & 0,02 & 1,50 \\
\hline $\mathrm{CaO}$ & 0,05 & 0,06 & 0,04 & & 0,05 & 0,06 & 0,05 & 0,06 & 0,05 & 0,07 & & 0,02 & 0,06 \\
\hline $\mathrm{Cr}_{2} \mathrm{O}_{3}$ & & 0,03 & & & 0,02 & & & & & & 0,02 & 0,02 & 0,01 \\
\hline Zno & 0,51 & 0,40 & 0,49 & 0,39 & 0,50 & 0,59 & 0,49 & 0,56 & 0,29 & 0,28 & 0,49 & & 0,34 \\
\hline $\mathrm{Nb}_{2} \mathrm{O}_{3}$ & 0,36 & 0,59 & 0,41 & 0,47 & 0,01 & 0,03 & 0,02 & & & 0,08 & 0,04 & 0,05 & 0,01 \\
\hline $\mathrm{Fe}_{2} \mathrm{O}_{3}$ & 8,72 & 28,81 & 7,81 & 8,00 & 7,51 & 11,86 & 7,16 & 5,52 & 6,49 & 6,15 & 6,53 & 61,38 & 6,52 \\
\hline $\mathrm{FeO}$ & 34,22 & 33,10 & 35,00 & 34,50 & 34,58 & 34,20 & 35,15 & 35,83 & 34,23 & 34,50 & 35,00 & 31,30 & 33,88 \\
\hline Total & 100,68 & 100,87 & 100,57 & 100,91 & 99,48 & 99,87 & 99,82 & 99,74 & 98,78 & 99,23 & 100,67 & 97,10 & 98,15 \\
\hline \multicolumn{14}{|c|}{ Formulae based on 4 oxygens } \\
\hline $\mathrm{Si}$ & 0,004 & 0,004 & 0,004 & 0,003 & 0,004 & 0,003 & 0,003 & 0,003 & 0,002 & 0,004 & 0,002 & 0,028 & 0,004 \\
\hline $\mathrm{Ti}$ & 0,000 & 0,000 & 0,002 & 0,002 & 0,001 & 0,000 & 0,004 & 0,004 & 0,000 & 0,001 & 0,001 & 0,002 & 0,002 \\
\hline Al & 1,794 & 1,294 & 1,810 & 1,808 & 1,823 & 1,725 & 1,828 & 1,863 & 1,850 & 1,851 & 1,850 & 0,143 & 1,842 \\
\hline $\mathrm{Fe} 3$ & 0,193 & 0,691 & 0,173 & 0,176 & 0,168 & 0,268 & 0,159 & 0,122 & 0,145 & 0,137 & 0,144 & 1,795 & 0,147 \\
\hline $\mathrm{Fe} 2$ & 0,843 & 0,882 & 0,861 & 0,846 & 0,858 & 0,859 & 0,868 & 0,883 & 0,849 & 0,851 & 0,857 & 1,017 & 0,846 \\
\hline$M n$ & 0,097 & 0,069 & 0,080 & 0,093 & 0,086 & 0,083 & 0,075 & 0,073 & 0,080 & 0,081 & 0,099 & 0,009 & 0,083 \\
\hline Mg & 0,048 & 0,037 & 0,051 & 0,054 & 0,048 & 0,045 & 0,051 & 0,037 & 0,066 & 0,065 & 0,036 & 0,001 & 0,067 \\
\hline $\mathrm{Ca}$ & 0,002 & 0,002 & 0,001 & 0,000 & 0,002 & 0,002 & 0,002 & 0,002 & 0,001 & 0,002 & 0,000 & 0,001 & 0,002 \\
\hline $\mathrm{Cr}$ & 0,000 & 0,001 & 0,000 & 0,000 & 0,000 & 0,000 & 0,000 & 0,000 & 0,000 & 0,000 & 0,000 & 0,001 & 0,000 \\
\hline $\mathrm{Zn}$ & 0,011 & 0,009 & 0,011 & 0,008 & 0,011 & 0,013 & 0,011 & 0,012 & 0,006 & 0,006 & 0,011 & 0,000 & 0,008 \\
\hline Nb & 0,005 & 0,010 & 0,006 & 0,007 & 0,000 & 0,000 & 0,000 & 0,000 & 0,000 & 0,001 & 0,001 & 0,001 & 0,000 \\
\hline Totalcat & 3,000 & 2,999 & 3,000 & 3,001 & 3,000 & 3,002 & 3,000 & 3,002 & 3,002 & 3,000 & 3,001 & 3,004 & 3,000 \\
\hline
\end{tabular}

ANEXO E - Tabela E.7c - Composição química de coríndon de rochas do Maciço Alcalino de Itatiaia.

\begin{tabular}{|c|c|c|c|c|c|}
\hline Unidade & $\mathrm{NeS}-\mathrm{I}$ & & & & \\
\hline Amostra & MAI030 & & & & \\
\hline Cristal & 14 & 15 & 16 & 17 & 18 \\
\hline$\overline{\mathrm{SiO}_{2}}$ & 0,09 & 0,06 & 0,08 & 0,07 & 0,10 \\
\hline $\mathrm{TiO}_{2}$ & 0,11 & 0,20 & 0,02 & 0,03 & 0,01 \\
\hline $\mathrm{Al}_{2} \mathrm{O}_{3}$ & 102,35 & 101,28 & 100,79 & 101,12 & 99,36 \\
\hline $\mathrm{Fe}_{2} \mathrm{O}_{3 \mathrm{t}}$ & 0,93 & 1,19 & 0,84 & 0,96 & 2,03 \\
\hline Mno & & & 0,01 & 0,01 & \\
\hline MgO & 0,01 & 0,01 & 0,01 & & \\
\hline $\mathrm{CaO}$ & & 0,00 & 0,01 & & \\
\hline $\mathrm{Cr}_{2} \mathrm{O}_{3}$ & & 0,00 & 0,00 & 0,04 & 0,01 \\
\hline Zno & & & & 0,00 & 0,01 \\
\hline $\mathrm{Nb}_{2} \mathrm{O}_{3}$ & 0,04 & 0,04 & 0,03 & & \\
\hline total & 98,12 & 97,42 & 96,47 & 96,92 & 96,26 \\
\hline \multicolumn{6}{|c|}{ Formulae based on 4 oxygens } \\
\hline $\mathbf{S i}$ & 0,002 & 0,001 & 0,002 & 0,002 & 0,003 \\
\hline $\mathrm{Ti}$ & 0,002 & 0,004 & 0,000 & 0,001 & 0,000 \\
\hline Al & 2,978 & 2,971 & 2,981 & 2,978 & 2,958 \\
\hline \multicolumn{6}{|l|}{ Fe3 } \\
\hline$M n$ & 0,000 & 0,000 & 0,000 & 0,000 & 0,000 \\
\hline $\mathrm{Mg}$ & 0,000 & 0,001 & 0,000 & 0,000 & 0,000 \\
\hline $\mathrm{Ca}$ & 0,000 & 0,000 & 0,000 & 0,000 & 0,000 \\
\hline $\mathrm{Cr}$ & 0,000 & 0,000 & 0,000 & 0,001 & 0,000 \\
\hline $\mathrm{Zn}$ & 0,000 & 0,000 & 0,000 & 0,000 & 0,000 \\
\hline Nb & 0,000 & 0,001 & 0,000 & 0,000 & 0,000 \\
\hline Totalcat & 3,000 & 3,000 & 3,000 & 3,001 & 3,001 \\
\hline
\end{tabular}


ANEXO E - Tabela E.8 - Composição química de minerais acessórios de rochas do Maciço Alcalino de Itatiaia. Continua...

\begin{tabular}{|c|c|c|c|c|c|c|c|c|c|c|c|c|c|c|c|c|c|}
\hline \multirow{2}{*}{$\begin{array}{l}\text { Mineral } \\
\text { Unidade }\end{array}$} & \multicolumn{2}{|l|}{ Andradite } & \multicolumn{2}{|l|}{ Ankerita } & \multicolumn{3}{|c|}{ Britholit Calkinsite-(Ce) } & \multicolumn{10}{|c|}{\begin{tabular}{|l|l|} 
Catapleii Chevkinite \\
\end{tabular}} \\
\hline & $\mathrm{NeS}-\mathrm{II}$ & & AegN & & NeS-II & AegN & & NeS-I & arpk-QzS & & QZAFS-I & & & & $\mathrm{N}-\mathrm{II}$ & & \\
\hline Amostra & MAI166I & & MAI090 & & MAI166I & MAI090 & & MAI058I & MAI108II & & MAI110 & & & & MAI136 & & \\
\hline Método & WDS & WDS & WDS & WDS & WDS & WDS & WDS & WDS & WDS & WDS & WDS & WDS & WDS & WDS & WDS & WDS & WDS \\
\hline Análise & 5 & 4 & 19 & 18 & 11 & 3 & 2 & 5 & 17 & 18 & 17 & 18 & 19 & 20 & 10 & 2 & 3 \\
\hline $\mathrm{SiO}_{2}$ & 35,46 & 35,68 & 0,06 & 0,11 & 21,43 & 2,56 & & 43,29 & 20,90 & 20,98 & 19,98 & 20,12 & 18,18 & 21,15 & 20,31 & 20,41 & 20,41 \\
\hline $\mathrm{TiO}_{2}$ & 2,22 & 2,68 & 0,07 & & 0,02 & 1,21 & 0,15 & 0,02 & 18,64 & 18,72 & 17,48 & 17,13 & 17,36 & 19,52 & 17,61 & 18,40 & 17,81 \\
\hline $\mathrm{ZrO}_{2}$ & 0,18 & 0,14 & 0,03 & 0,02 & & & 0,03 & 34,15 & 1,22 & 1,26 & 1,12 & 0,67 & 0,37 & 2,06 & 1,88 & 1,71 & 1,33 \\
\hline $\mathrm{Al}_{2} \mathrm{O}_{3}$ & 3,00 & 3,29 & 0,13 & 0,05 & 0,80 & 0,17 & 0,04 & 0,05 & 2,82 & 2,71 & 0,33 & 0,28 & 1,34 & 1,68 & 0,09 & 0,13 & 0,04 \\
\hline $\mathrm{Fe}_{2} \mathrm{O}_{3}$ & 23,40 & 22,87 & 39,26 & 36,15 & & 1,71 & & 0,04 & 7,49 & 7,75 & 10,17 & 10,38 & 13,35 & 7,60 & 10,25 & 10,17 & 10,40 \\
\hline MnO & 2,17 & 2,17 & 9,64 & 7,21 & 0,14 & & & 0,02 & 0,25 & 0,21 & 0,67 & 0,76 & 0,75 & 0,44 & 0,75 & 0,78 & 0,86 \\
\hline MgO & 0,10 & 0,10 & 2,78 & 8,05 & & 0,01 & & & 1,15 & 1,09 & 0,35 & 0,36 & 0,10 & 0,76 & 0,23 & 0,20 & 0,23 \\
\hline $\mathrm{CaO}$ & 31,12 & 31,62 & 5,55 & 6,89 & 15,99 & 6,79 & 1,20 & 0,53 & 6,27 & 6,25 & 4,12 & 3,83 & 2,46 & 6,30 & 5,31 & 4,98 & 4,12 \\
\hline $\mathrm{Na}_{2} \mathrm{O}$ & 0,21 & 0,17 & 0,05 & 0,03 & 0,46 & & & 6,20 & & & & & 0,35 & 0,02 & 0,13 & 0,05 & 0,02 \\
\hline $\mathrm{K}_{2} \mathrm{O}$ & 0,02 & 0,03 & 0,01 & 0,01 & 0,09 & 0,03 & & 0,01 & 0,00 & 0,02 & 0,00 & 0,03 & 0,14 & 0,02 & 0,01 & 0,02 & \\
\hline $\mathrm{Nb}_{2} \mathrm{O}_{5}$ & & & & & 0,07 & 0,02 & & 0,85 & 0,15 & 0,09 & 0,12 & 0,12 & 0,14 & 0,14 & 0,09 & 0,13 & 0,16 \\
\hline $\mathrm{La}_{2} \mathrm{O}_{3}$ & & & & & 12,42 & 15,80 & 18,88 & 0,00 & 8,24 & 8,76 & 9,20 & 8,86 & 6,48 & 8,72 & 11,85 & 10,93 & 11,46 \\
\hline $\mathrm{Ce}_{2} \mathrm{O}_{3}$ & & & & & 28,45 & 28,72 & 33,37 & 0,06 & 20,27 & 20,85 & 22,05 & 22,51 & 18,49 & 20,88 & 19,50 & 21,02 & 21,36 \\
\hline $\mathrm{Nd}_{2} \mathrm{O}_{3}$ & & & & & 6,89 & 4,78 & 4,62 & & 6,36 & 5,91 & 6,49 & 6,68 & 6,17 & 5,76 & 2,71 & 4,17 & 4,36 \\
\hline $\mathrm{Y}_{2} \mathrm{O}_{3}$ & & & & & & & & & & & & & & & & & \\
\hline$F$ & & & & & 0,22 & 0,03 & 0,06 & & 0,04 & 0,01 & 0,02 & 0,03 & 0,09 & 0,02 & 0,01 & 0,02 & 0,01 \\
\hline $\mathrm{BaO}$ & & & & & 0,03 & 0,02 & & 0,03 & & & & & & & & & \\
\hline $\mathrm{P}_{2} \mathrm{O}_{5}$ & & & & & & & & & & & & & & & & & \\
\hline $\mathrm{Dy} \mathrm{y}_{2} \mathrm{O}_{3}$ & & & & & & & & & & & & & & & & & \\
\hline $\mathrm{Er}_{2} \mathrm{O}_{3}$ & & & & & & & & & & & & & & & & & \\
\hline $\mathrm{Yb}_{2} \mathrm{O}_{3}$ & & & & & & & & & & & & & & & & & \\
\hline $\mathrm{U}_{3} \mathrm{O}_{8}$ & & & & & & & & & & & & & & & & & \\
\hline $\mathrm{Th}+\mathrm{O}_{2}$ & & & & & & & & & & & & & & & & & \\
\hline $\mathrm{PbO}$ & & & & & & & & & & & & & & & & & \\
\hline Soma & 97,89 & 98,75 & 57,57 & 58,51 & 87,01 & 61,86 & 58,35 & 85,27 & 93,79 & 94,61 & 92,11 & 91,76 & 85,77 & 95,07 & 90,72 & 93,11 & 92,56 \\
\hline
\end{tabular}

ANEXO E - Tabela E.8 - Composição química de minerais acessórios de rochas do Maciço Alcalino de Itatiaia. Continua...

\begin{tabular}{|c|c|c|c|c|c|c|c|c|c|c|c|c|c|c|c|c|c|}
\hline Mineral & Chevkini & Hiortdahlit & & & & & & & & upletskite & & & & & & & \\
\hline Unidade & $\mathrm{N}-\mathrm{II}$ & $\mathrm{NeS}-\mathrm{I}$ & \multirow{2}{*}{\multicolumn{15}{|c|}{ |MAI058I }} \\
\hline Amostra & MAI136 & MAI060 & & & & & & & & & & & & & & & \\
\hline Método & WDS & WDS & WDS & WDS & WDS & WDS & WDS & WDS & WDS & WDS & WDS & WDS & WDS & WDS & WDS & WDS & WDS \\
\hline Análise & 9 & 23 & 20 & 18 & 17 & 21 & 22 & 24 & 19 & 1 & 7 & 3 & 6 & 9 & 10 & 8 & 4 \\
\hline $\mathrm{SiO}_{2}$ & 22,30 & 31,16 & 31,36 & 31,38 & 31,44 & 31,56 & 31,59 & 31,64 & 32,01 & 34,25 & 34,82 & 34,91 & 35,10 & 35,80 & 35,80 & 35,94 & 36,09 \\
\hline $\mathrm{TiO}_{2}$ & 17,35 & 1,34 & 1,16 & 1,01 & 1,31 & 1,94 & 0,72 & 1,09 & 3,09 & 9,84 & 10,55 & 7,44 & 11,02 & 9,94 & 9,66 & 10,64 & 10,45 \\
\hline $\mathrm{ZrO}_{2}$ & 1,95 & 15,23 & 13,99 & 13,41 & 12,99 & 10,52 & 13,34 & 12,72 & 9,77 & 0,20 & 0,09 & 3,68 & 0,79 & 0,95 & 0,99 & 1,03 & 0,56 \\
\hline $\mathrm{Al}_{2} \mathrm{O}_{3}$ & 0,55 & 0,04 & 0,02 & 0,01 & 0,03 & 0,06 & 0,02 & 0,03 & 0,03 & 1,23 & 1,14 & 0,84 & 1,17 & 0,66 & 2,30 & 0,78 & 0,28 \\
\hline $\mathrm{Fe}_{2} \mathrm{O}_{3}$ & 8,76 & 0,20 & 1,20 & 1,21 & 1,25 & 1,35 & 1,30 & 1,32 & 1,48 & 11,65 & 12,16 & 11,50 & 11,66 & 10,67 & 10,64 & 11,10 & 11,06 \\
\hline MnO & 0,86 & 2,22 & 2,67 & 2,48 & 2,35 & 2,71 & 2,44 & 2,54 & 2,91 & 24,69 & 23,32 & 23,53 & 21,65 & 22,91 & 20,90 & 23,43 & 23,39 \\
\hline MgO & 0,29 & 0,02 & 0,34 & 0,08 & 0,28 & 0,04 & 0,07 & 0,09 & 0,06 & 0,36 & 0,80 & 0,96 & 1,88 & 1,79 & 1,96 & 1,40 & 0,91 \\
\hline $\mathrm{CaO}$ & 4,73 & 27,94 & 33,74 & 39,80 & 35,56 & 39,21 & 40,28 & 40,36 & 40,38 & 1,63 & 1,58 & 1,00 & 1,56 & 1,13 & 1,36 & 1,46 & 1,14 \\
\hline $\mathrm{Na}_{2} \mathrm{O}$ & 0,22 & 7,91 & 6,45 & 5,27 & 6,16 & 5,87 & 5,25 & 5,22 & 5,32 & 2,29 & 2,41 & 2,65 & 2,52 & 2,91 & 3,30 & 2,72 & 3,05 \\
\hline $\mathrm{K}_{2} \mathrm{O}$ & 0,10 & 0,02 & & 0,02 & & & 0,01 & 0,01 & 0,02 & 6,27 & 6,25 & 6,16 & 6,31 & 6,15 & 5,81 & 5,94 & 6,03 \\
\hline $\mathrm{Nb}_{2} \mathrm{O}_{5}$ & 0,07 & 0,13 & 0,26 & 0,31 & 0,21 & 0,24 & 0,43 & 0,31 & 0,22 & 0,12 & 0,06 & 0,16 & 0,13 & 0,13 & 0,15 & 0,13 & 0,11 \\
\hline $\mathrm{La}_{2} \mathrm{O}_{3}$ & 10,81 & 0,04 & & & 0,03 & 0,07 & 0,04 & 0,04 & & 0,07 & 0,11 & & 0,08 & 0,01 & 0,05 & 0,00 & 0,00 \\
\hline $\mathrm{Ce}_{2} \mathrm{O}_{3}$ & 18,04 & 0,11 & 0,02 & 0,18 & 0,05 & 0,22 & 0,11 & 0,11 & 0,13 & 0,08 & 0,15 & & 0,27 & 0,09 & 0,19 & 0,10 & 0,01 \\
\hline $\mathrm{Nd}_{2} \mathrm{O}_{3}$ & 2,46 & 0,04 & 0,01 & 0,07 & 0,03 & 0,07 & 0,01 & 0,02 & 0,09 & & 0,05 & 0,02 & 0,01 & 0,01 & 0,04 & & \\
\hline \multicolumn{18}{|l|}{$\mathrm{Y}_{2} \mathrm{O}_{3}$} \\
\hline $\mathbf{F}$ & 0,02 & & & & & & & 0,05 & 0,01 & 0,01 & 0,04 & & 0,03 & 0,01 & 0,03 & 0,03 & \\
\hline $\mathrm{BaO}$ & & & 0,05 & 0,06 & & & 0,01 & & & & & & & & 0,01 & & \\
\hline \multicolumn{18}{|l|}{$\mathrm{P}_{2} \mathrm{O}_{5}$} \\
\hline \multicolumn{18}{|l|}{$\mathrm{Dy}_{2} \mathrm{O}_{3}$} \\
\hline \multicolumn{18}{|l|}{$\mathrm{Er}_{2} \mathrm{O}_{3}$} \\
\hline \multicolumn{18}{|l|}{$\mathrm{Yb}_{2} \mathrm{O}_{3}$} \\
\hline \multicolumn{18}{|l|}{$\mathrm{U}_{3} \mathrm{O}_{8}$} \\
\hline \multicolumn{18}{|l|}{$\mathrm{Th}+\mathrm{O}_{2}$} \\
\hline \multicolumn{18}{|l|}{ PbO } \\
\hline Soma & 88,51 & 86,40 & 91,26 & 95,29 & 91,67 & 93,85 & 95,63 & 95,55 & 95,50 & 92,69 & 93,53 & 92,85 & 94,17 & 93,15 & 93,19 & 94,70 & 93,07 \\
\hline
\end{tabular}


ANEXO E - Tabela E.8 - Composição química de minerais acessórios de rochas do Maciço Alcalino de Itatiaia. Continua...

\begin{tabular}{|c|c|c|c|c|c|c|c|c|c|c|c|c|c|c|c|c|c|}
\hline \multirow[t]{2}{*}{ Mineral } & \multirow[b]{2}{*}{ NeS-I } & \multicolumn{5}{|l|}{ Lavenite } & \multicolumn{3}{|c|}{ Rinkite } & \multicolumn{4}{|c|}{ Synchysite-(Ce) } & \multicolumn{4}{|c|}{ Zirconolite } \\
\hline & & $\begin{array}{l}\text { BtAgtNeS } \\
\text { MAl199 }\end{array}$ & & & & & & & & $\begin{array}{l}\text { N-II } \\
\text { MAI136 }\end{array}$ & & & & $\begin{array}{l}\text { BtHblP } \\
\text { MAl102 }\end{array}$ & & MAl114 & \\
\hline Método & WDS & WDS & WDS & WDS & WDS & WDS & WDS & WDS & WDS & WDS & WDS & WDS & WDS & WDS & WDS & WDS & $\overline{\text { WDS }}$ \\
\hline Análise & 2 & 12 & 13 & 23 & 24 & 25 & 26 & 11 & 18 & 4 & 5 & 6 & 8 & 5 & 10 & 13 & 14 \\
\hline $\mathrm{SiO}_{2}$ & 36,30 & 30,46 & 30,85 & 30,30 & 30,17 & 30,58 & 30,63 & 29,13 & 29,46 & & 0,07 & 0,35 & 0,06 & 0,25 & 0,38 & 0,08 & 0,09 \\
\hline $\mathrm{TiO}_{2}$ & 9,81 & 5,45 & 8,28 & 6,16 & 6,00 & 5,75 & 6,49 & 7,40 & 7,68 & 0,46 & 0,20 & 0,50 & 0,81 & 30,52 & 30,97 & 21,51 & 22,38 \\
\hline $\mathrm{ZrO}_{2}$ & 0,67 & 20,34 & 16,31 & 19,88 & 21,10 & 20,81 & 19,54 & 1,37 & 1,48 & & & & & 33,06 & 31,76 & 30,19 & 28,79 \\
\hline $\mathrm{Al}_{2} \mathrm{O}_{3}$ & 0,28 & 0,04 & 0,07 & 0,07 & 0,04 & 0,01 & 0,01 & 0,01 & 0,04 & & & 0,08 & 0,00 & 0,33 & 0,39 & 0,30 & 0,33 \\
\hline $\mathrm{Fe}_{2} \mathrm{O}_{3}$ & 11,22 & 4,97 & 5,60 & 5,39 & 4,87 & 4,86 & 5,20 & 0,17 & 0,11 & 0,00 & & 0,43 & 0,32 & 6,65 & 6,64 & 8,24 & 8,00 \\
\hline MnO & 23,80 & 6,24 & 7,13 & 6,36 & 6,04 & 5,96 & 6,24 & 0,12 & 0,35 & & & & & 0,40 & 0,31 & 0,99 & 0,91 \\
\hline MgO & 0,37 & 0,36 & 0,38 & 0,42 & 0,36 & 0,44 & 0,48 & & 0,00 & & & 0,05 & & 0,09 & 0,03 & 0,10 & 0,08 \\
\hline $\mathrm{CaO}$ & 1,13 & 13,11 & 14,34 & 14,04 & 13,20 & 13,65 & 14,43 & 26,69 & 26,96 & 16,33 & 18,40 & 10,59 & 21,86 & 10,98 & 10,44 & 9,70 & 10,38 \\
\hline $\mathrm{Na}_{2} \mathrm{O}$ & 3,11 & 10,55 & 9,88 & 10,09 & 10,48 & 10,35 & 10,00 & 8,75 & 8,28 & & & & & & & 0,02 & \\
\hline $\mathrm{K}_{2} \mathrm{O}$ & 5,84 & 0,00 & & 0,01 & & 0,00 & 0,02 & 0,01 & 0,02 & & 0,01 & 0,01 & 0,01 & 0,03 & 0,18 & 0,07 & 0,12 \\
\hline $\mathrm{Nb}_{2} \mathrm{O}_{5}$ & 0,13 & 0,35 & 0,41 & 0,43 & 0,51 & 0,54 & 0,51 & 0,04 & 0,03 & 0,07 & & 0,02 & 0,02 & 0,84 & 0,83 & 0,58 & 0,61 \\
\hline $\mathrm{La}_{2} \mathrm{O}_{3}$ & 0,03 & & 0,01 & & 0,00 & 0,01 & & 3,39 & 2,83 & 14,55 & 5,94 & 13,51 & 5,38 & 0,65 & 1,54 & 1,72 & 0,83 \\
\hline $\mathrm{Ce}_{2} \mathrm{O}_{3}$ & & 0,01 & 0,01 & 0,05 & 0,02 & 0,06 & 0,12 & 9,71 & 8,76 & 26,22 & 21,77 & 28,35 & 20,17 & 3,61 & 7,17 & 5,10 & 3,88 \\
\hline $\mathrm{Nd}_{2} \mathrm{O}_{3}$ & 0,03 & 0,01 & 0,01 & 0,03 & 0,02 & 0,06 & & 3,49 & 3,67 & 5,24 & 12,69 & 8,25 & 9,60 & 2,16 & 2,21 & 1,12 & 1,68 \\
\hline $\mathrm{Y}_{2} \mathrm{O}_{3}$ & & & & & & & & & & & & & & & & & \\
\hline $\mathbf{F}$ & 0,02 & & & & & & & 0,01 & & 0,01 & 0,09 & 0,06 & 0,00 & & & & \\
\hline $\mathrm{BaO}$ & & & & & & & & & & & 0,02 & 0,01 & 0,01 & & & & \\
\hline $\mathrm{P}_{2} \mathrm{O}_{5}$ & & & & & & & & & & & & & & & & & \\
\hline $\mathrm{Dy}_{2} \mathrm{O}_{3}$ & & & & & & & & & & & & & & & & & \\
\hline $\mathrm{Er}_{2} \mathrm{O}_{3}$ & & & & & & & & & & & & & & & & & \\
\hline $\mathrm{Yb}_{2} \mathrm{O}_{3}$ & & & & & & & & & & & & & & & & & \\
\hline $\mathrm{U}_{3} \mathrm{O}_{8}$ & & & & & & & & & & & & & & & & & \\
\hline $\mathrm{Th}+\mathrm{O}_{2}$ & & & & & & & & & & & & & & & & & \\
\hline $\mathrm{PbO}$ & & & & & & & & & & & & & & & & & \\
\hline Soma & 92,73 & 91,90 & 93,28 & 93,24 & 92,82 & 93,08 & 93,67 & 90,29 & 89,66 & 62,87 & 59,18 & 62,20 & 58,24 & 89,57 & 92,86 & 79,72 & 78,08 \\
\hline
\end{tabular}

ANEXO E - Tabela E.8 - Composição química de minerais acessórios de rochas do Maciço Alcalino de Itatiaia. Continua...

\begin{tabular}{|c|c|c|c|c|c|c|c|c|c|c|c|c|c|c|c|c|c|}
\hline \multirow[t]{2}{*}{ Mineral } & \multicolumn{2}{|l|}{ Zirconolite } & \multicolumn{2}{|c|}{$? \quad$ Allanite } & \multicolumn{5}{|l|}{ Britholite } & \multicolumn{4}{|c|}{ Chevkinite } & \multicolumn{3}{|l|}{ Lavenite } & \multirow{2}{*}{\begin{tabular}{|l} 
Pyrochlol \\
$\mathrm{mA}$
\end{tabular}} \\
\hline & BtHblP & & BtAgtNe & $\mathrm{NeS}-\mathrm{II}$ & BtAgtNeS & & & & NeS-II & $\mathrm{mA}$ & apkv-Qzd & $\mathrm{N}-\mathrm{II}$ & BtAgtNeS & \multirow{2}{*}{\multicolumn{2}{|c|}{ MAI208 }} & & \\
\hline Amostra & MAI114 & & MAl199 & MAI166I & MAI199 & \multicolumn{2}{|c|}{ MAl208 } & & MAI 166 & MAI070B & MAI108I & MAI136 & MAI199 & & & & MAI070B \\
\hline Método & WDS & WDS & WDS & EDS & EDS & EDS & EDS & EDS & EDS & EDS & EDS & EDS & EDS & EDS & EDS & EDS & EDS \\
\hline Análise & 15 & 12 & \multicolumn{2}{|c|}{22 eds $5-5 ?$} & eds 12 & eds $20-2$ & 14 & 10 & eds 2 - 1 & eds 7 - 1 & eds $1-5$ & eds $5-1$ & eds $13-2$ & eds 4-1 & 3 & 5 & eds $3-1$ \\
\hline $\mathrm{SiO}_{2}$ & 0,25 & 5,96 & 10,15 & 34,73 & 25,75 & 21,99 & 20,24 & 20,81 & 24,24 & 27,41 & 25,17 & 23,83 & 22,94 & 28,43 & 30,47 & 30,49 & \\
\hline $\mathrm{TiO}_{2}$ & 20,21 & 19,00 & 10,47 & & & & 0,06 & 0,22 & & 24,62 & 21,12 & 21,73 & 18,89 & 5,22 & 1,91 & 1,48 & 5,77 \\
\hline $\mathrm{ZrO}_{2}$ & 28,71 & 27,39 & 0,58 & & & & & & 1,64 & & 2,24 & 2,43 & & 23,27 & 14,37 & 14,66 & \\
\hline $\mathrm{Al}_{2} \mathrm{O}_{3}$ & 0,31 & 2,57 & 1,25 & 12,62 & & & 0,03 & 0,00 & & 0,75 & 2,76 & & & & 0,03 & 0,11 & \\
\hline $\mathrm{Fe}_{2} \mathrm{O}_{3}$ & 8,52 & 7,77 & 1,51 & 18,75 & & & 0,27 & 0,34 & & 9,57 & 8,63 & 11,15 & 10,11 & 3,65 & 1,29 & 0,61 & \\
\hline MnO & 1,04 & 0,96 & 0,69 & 3,18 & & & 0,48 & 0,45 & & & & & 3,61 & 5,64 & 3,80 & 3,29 & \\
\hline MgO & 0,11 & 0,10 & 0,17 & & & & & & & & 0,90 & & & & 0,38 & 0,22 & \\
\hline $\mathrm{CaO}$ & 10,06 & 9,42 & 4,70 & 12,35 & 10,98 & 10,90 & 15,99 & 13,71 & 15,94 & 3,91 & 7,85 & 5,57 & 2,00 & 11,17 & 24,98 & 24,28 & 15,17 \\
\hline $\mathrm{Na}_{2} \mathrm{O}$ & & 0,06 & 0,52 & & & & 0,03 & & & & & & & 10,56 & 7,42 & 7,46 & 5,70 \\
\hline $\mathrm{K}_{2} \mathrm{O}$ & 0,07 & 1,37 & 0,12 & & & & 0,00 & 0,02 & & & & & & & 0,01 & & \\
\hline $\mathrm{Nb}_{2} \mathrm{O}_{5}$ & 0,55 & 0,55 & & & & & 0,03 & 0,05 & & 10,78 & 0,83 & 1,97 & 1,45 & 3,32 & 0,19 & 0,10 & 57,32 \\
\hline $\mathrm{La}_{2} \mathrm{O}_{3}$ & 0,86 & 1,17 & 4,01 & 8,49 & 17,45 & 24,43 & 10,82 & 14,08 & 23,07 & & 9,68 & 13,57 & 22,40 & & 0,08 & 0,04 & \\
\hline $\mathrm{Ce}_{2} \mathrm{O}_{3}$ & 4,04 & 3,54 & 6,40 & 9,87 & 35,52 & 31,95 & 19,87 & 29,28 & 30,75 & 17,49 & 19,33 & 19,75 & 17,17 & & 0,24 & 0,11 & \\
\hline $\mathrm{Nd}_{2} \mathrm{O}_{3}$ & 1,58 & 1,03 & 3,00 & & 7,89 & 3,33 & 8,14 & 9,42 & 2,12 & 1,55 & & & & & 0,08 & 0,12 & \\
\hline $\mathrm{Y}_{2} \mathrm{O}_{3}$ & & & & & & & 5,92 & 1,48 & & & & & & & 0,81 & 0,68 & \\
\hline $\mathbf{F}$ & & & & & & & 0,21 & 0,13 & & & & & & 8,74 & & & 8,27 \\
\hline $\mathrm{BaO}$ & & & & & & & 0,08 & 0,07 & & & & & & & 0,01 & 0,04 & \\
\hline $\mathrm{P}_{2} \mathrm{O}_{5}$ & & & & & & 1,62 & & & 2,24 & & & & & & & & \\
\hline \multicolumn{18}{|l|}{$\mathrm{Dy}_{2} \mathrm{O}_{3}$} \\
\hline \multicolumn{18}{|l|}{$\mathrm{Er}_{2} \mathrm{O}_{3}$} \\
\hline \multicolumn{18}{|l|}{$\mathrm{Yb}_{2} \mathrm{O}_{3}$} \\
\hline $\mathrm{U}_{3} \mathrm{O}_{8}$ & & & & & & 0,50 & & & & & & & & & & & \\
\hline $\mathrm{Th}+\mathrm{O}_{2}$ & & & & & 2,40 & 5,29 & & & & 3,93 & 1,50 & & 1,42 & & & & 1,30 \\
\hline \multicolumn{18}{|l|}{$\mathrm{PbO}$} \\
\hline Soma & 76,30 & 80,87 & 43,58 & & & & 82,19 & 90,06 & 100,00 & 100,01 & 100,01 & 100,00 & & & 86,09 & 83,70 & 93,53 \\
\hline
\end{tabular}


ANEXO E - Tabela E.8 - Composição química de minerais acessórios de rochas do Maciço Alcalino de Itatiaia. Continua...

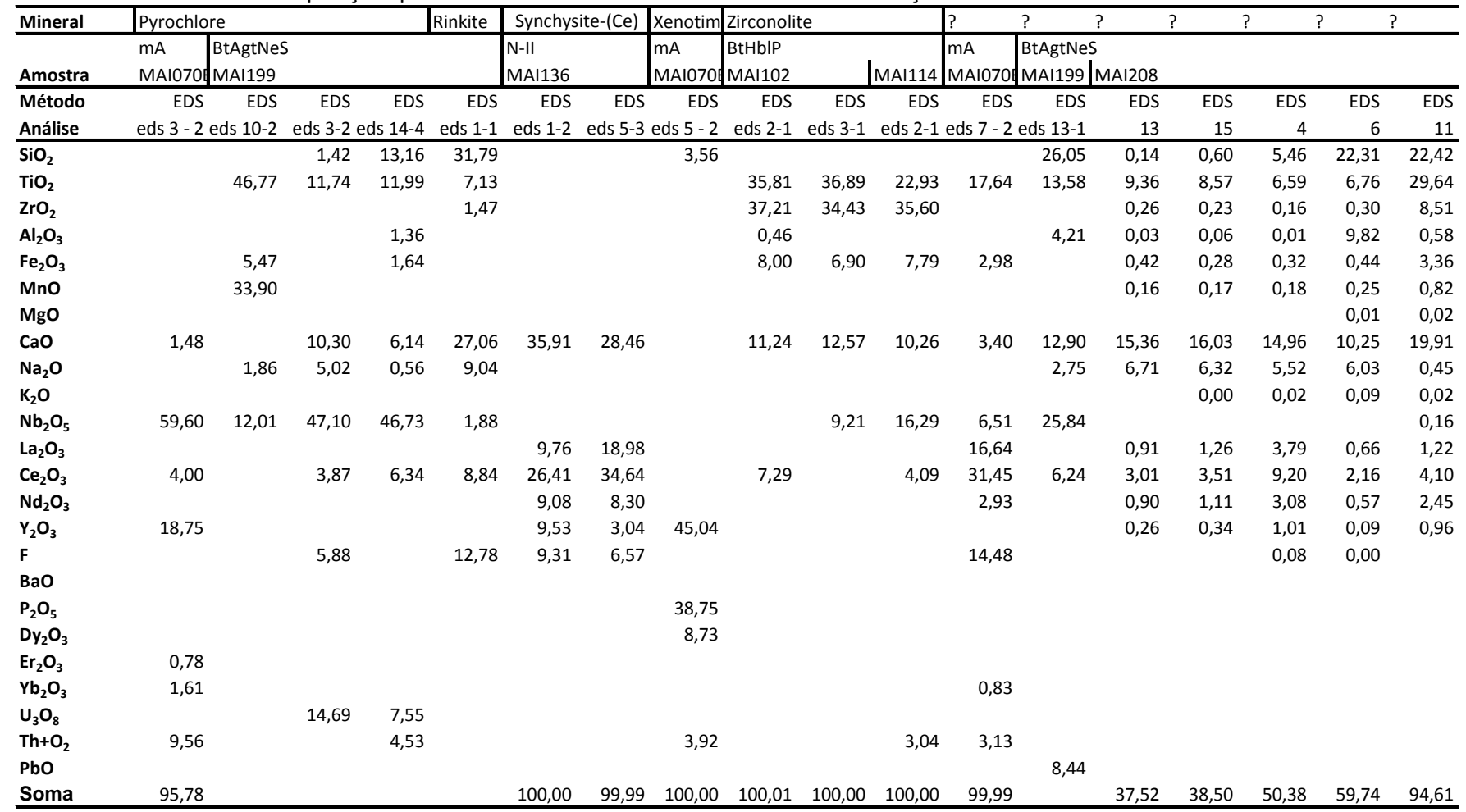


Tabela de análises de geoquímica elemental

ANEXO F 
ANEXO F - Tabela de composição química das rochas do Maciço Alcalino de Itatiaia. Continua...

\begin{tabular}{|c|c|c|c|c|c|c|c|c|c|c|c|}
\hline Amostra & MAI043 & MAI030 & MAI012 & MAI050 & MAI068 & MAI060 & MAI058B & MAI053I & MAI053II & MAI046F & MAI046E \\
\hline Unidade & NeS-I & NeS-I & NeS-I & NeS-I & NeS-I & NeS-I & NeS-I & NeS-I & Diq-Foid & Diq-Foid & Diq-Maf \\
\hline Lab. & A & $\mathrm{B}$ & A & A & A & A & A & B & B & A & B \\
\hline$\overline{\mathrm{SiO}_{2}}$ & 55,50 & 56,63 & 55,95 & 55,92 & 53,32 & 53,57 & 55,35 & 54,43 & 55,27 & 55,05 & 45,49 \\
\hline $\mathrm{TiO}_{2}$ & 0,34 & 0,49 & 0,43 & 0,49 & 0,60 & 0,37 & 0,27 & 0,57 & 0,13 & 0,53 & 2,98 \\
\hline $\mathrm{Al}_{2} \mathrm{O}_{3}$ & 23,77 & 22,60 & 22,53 & 23,21 & 22,02 & 22,52 & 20,95 & 21,86 & 21,14 & 22,41 & 16,46 \\
\hline $\mathrm{Fe}_{2} \mathrm{O}_{3}$ & 2,05 & 2,64 & 2,63 & 2,40 & 2,60 & 2,03 & 2,38 & 2,62 & 3,49 & 2,51 & 9,31 \\
\hline $\mathrm{MnO}$ & 0,25 & 0,19 & 0,17 & 0,18 & 0,19 & 0,16 & 0,32 & 0,20 & 0,26 & 0,16 & 0,16 \\
\hline MgO & 0,14 & 0,20 & 0,20 & 0,23 & 0,29 & 0,18 & 0,11 & 0,26 & 0,11 & 0,25 & 2,43 \\
\hline $\mathrm{CaO}$ & 1,74 & 1,46 & 2,10 & 1,35 & 1,54 & 1,23 & 0,83 & 1,48 & 0,97 & 1,34 & 6,82 \\
\hline $\mathrm{Na}_{2} \mathrm{O}$ & 1,49 & 3,48 & 4,74 & 5,85 & 8,44 & 8,18 & 8,27 & 7,28 & 9,10 & 5,71 & 5,22 \\
\hline $\mathrm{K}_{2} \mathrm{O}$ & 12,24 & 9,75 & 8,61 & 9,47 & 8,04 & 8,62 & 8,61 & 8,12 & 6,64 & 8,67 & 6,39 \\
\hline $\mathrm{P}_{2} \mathrm{O}_{5}$ & 0,02 & 0,05 & 0,06 & 0,05 & 0,07 & 0,03 & 0,01 & 0,07 & & 0,06 & 0,82 \\
\hline $\mathrm{SO}_{3}$ & 0,08 & 0,01 & 0,07 & 0,03 & 0,14 & 0,16 & 0,08 & 0,15 & 0,08 & 0,09 & 0,28 \\
\hline LOI & 1,30 & 1,25 & 1,32 & 1,68 & 1,49 & 1,69 & 1,30 & 1,78 & 1,73 & 2,11 & 2,59 \\
\hline Total & 99,23 & 99,13 & 99,26 & 101,18 & 99,14 & 98,93 & 98,91 & 99,25 & 99,26 & 99,21 & 99,41 \\
\hline$\overline{\mathbf{L i}}$ & 18,40 & 28,15 & 26,60 & 30,20 & 21,20 & 11,90 & 29,30 & 12,86 & 29,41 & 18,40 & 19,33 \\
\hline Cs & & 1,03 & & & & & & 1,10 & 1,87 & & 2,37 \\
\hline $\mathbf{R b}$ & 229,90 & 198,08 & 248,50 & 182,20 & 101,70 & 132,60 & 176,40 & 78,83 & 169,87 & 131,50 & 231,12 \\
\hline Ba & 22,00 & 294,43 & 316,00 & 123,00 & 286,00 & 9,00 & 32,00 & 378,62 & 7,52 & 246,00 & 1508,13 \\
\hline $\mathrm{Be}$ & $<5$ & 5,09 & $<5$ & $<5$ & $<5$ & $<5$ & $<5$ & 3,74 & 10,94 & $<5$ & 2,42 \\
\hline $\mathrm{Sr}$ & 1026,00 & 1619,70 & 1891,00 & 900,00 & 1206,00 & 302,00 & 192,00 & 661,89 & 126,88 & 1274,00 & 1420,12 \\
\hline $\mathrm{Pb}$ & 24,20 & 13,85 & 32,80 & 18,40 & 15,90 & 10,20 & 44,40 & 10,89 & 33,49 & 23,90 & 10,23 \\
\hline Th & 30,10 & 20,45 & 33,90 & 21,00 & 16,20 & 26,50 & 46,00 & 12,17 & 27,08 & 12,00 & 11,11 \\
\hline U & 3,00 & 2,86 & 8,10 & 3,60 & 1,50 & 2,80 & 10,40 & 5,18 & 6,40 & 1,60 & 3,00 \\
\hline $\mathrm{Zr}$ & & 541,15 & & & & & & 805,67 & 1289,22 & & 478,41 \\
\hline $\mathrm{Hf}$ & & 11,52 & & & & & & 15,51 & 24,95 & & 11,41 \\
\hline Ta & 7,40 & 8,36 & 13,70 & 11,10 & 12,90 & 11,70 & 10,20 & 12,32 & 3,42 & 7,80 & 5,91 \\
\hline $\mathbf{Y}$ & 26,50 & 27,45 & 36,80 & 17,60 & 18,50 & 32,30 & 42,70 & 17,30 & 17,79 & 9,70 & 30,77 \\
\hline $\mathbf{N b}$ & 201,70 & 175,63 & 298,20 & 238,50 & 234,70 & 173,00 & 436,20 & 245,65 & 182,66 & 200,50 & 97,42 \\
\hline Sc & $<1$ & 0,11 & $<1$ & $<1$ & $<1$ & $<1$ & 1,00 & 0,03 & 0,11 & $<1$ & 7,15 \\
\hline $\mathrm{Cr}$ & 2,00 & 2,82 & 2,00 & 2,00 & 1,00 & 2,00 & 2,00 & 2,05 & $<1$ & 2,00 & 8,34 \\
\hline $\mathrm{Ni}$ & 1,00 & $<0,5$ & 0,60 & 1,10 & $<0,5$ & $<0,5$ & 0,60 & $<0,5$ & $<0,5$ & 1,50 & 3,55 \\
\hline Sn & 1,70 & 1,87 & 2,00 & 1,70 & 2,30 & 2,10 & 1,90 & 1,93 & 3,42 & 1,40 & 2,53 \\
\hline Co & $<1$ & 0,32 & $<1$ & $<1$ & $<1$ & $<1$ & $<1$ & 0,48 & 0,14 & $<1$ & 19,26 \\
\hline v & 14,00 & 36,45 & 19,00 & 26,00 & 33,00 & 16,00 & 13,00 & 33,16 & 35,77 & 32,00 & 132,46 \\
\hline w & 1,60 & 1,69 & 3,60 & 1,30 & 2,10 & 4,70 & 2,40 & 1,09 & 0,67 & 2,40 & 5,99 \\
\hline Ga & & 27,80 & & & & & & 27,66 & 43,99 & & 27,18 \\
\hline $\mathrm{Zn}$ & 141,00 & 101,62 & 127,00 & 129,00 & 122,00 & 99,00 & 265,00 & 98,81 & 155,40 & 117,00 & 118,25 \\
\hline $\mathrm{Cu}$ & $<0,5$ & 4,67 & 1,40 & 1,40 & 0,60 & 0,70 & 0,70 & 2,43 & 0,65 & 3,90 & 23,98 \\
\hline Mo & 2,40 & 2,66 & 3,50 & 0,50 & 3,80 & 13,70 & 4,30 & 2,02 & 1,07 & 2,40 & 1,35 \\
\hline $\mathrm{Bi}$ & $<0,5$ & 0,106 & $<0,5$ & $<0,5$ & $<0,5$ & $<0,5$ & $<0,5$ & 0,061 & 0,153 & $<0,5$ & 0,046 \\
\hline Cd & $<0,5$ & 0,184 & $<0,5$ & $<0,5$ & $<0,5$ & $<0,5$ & $<0,5$ & 0,256 & 0,319 & $<0,5$ & 0,068 \\
\hline Sb & $<0,5$ & 0,431 & $<0,5$ & $<0,5$ & $<0,5$ & $<0,5$ & $<0,5$ & 0,172 & 0,391 & $<0,5$ & 0,260 \\
\hline La & & 211,82 & & & & & & 89,68 & 94,64 & & 89,37 \\
\hline $\mathrm{Ce}$ & & 334,47 & & & & & & 140,23 & 169,43 & & 175,07 \\
\hline $\mathrm{Pr}$ & & 26,48 & & & & & & 12,47 & 7,35 & & 17,88 \\
\hline Nd & & 69,54 & & & & & & 35,47 & 16,18 & & 69,66 \\
\hline Sm & & 7,306 & & & & & & 4,290 & 1,660 & & 12,490 \\
\hline Eu & & 2,223 & & & & & & 1,274 & 0,479 & & 3,879 \\
\hline Gd & & 7,027 & & & & & & 3,891 & 2,307 & & 9,860 \\
\hline Tb & & 0,791 & & & & & & 0,478 & 0,275 & & 1,251 \\
\hline Dy & & 4,512 & & & & & & 2,813 & 1,928 & & 6,658 \\
\hline Ho & & 0,965 & & & & & & 0,581 & 0,468 & & 1,144 \\
\hline $\mathrm{Er}$ & & 2,937 & & & & & & 1,742 & 1,606 & & 2,799 \\
\hline $\mathrm{Tm}$ & & 0,450 & & & & & & 0,265 & 0,297 & & 0,353 \\
\hline Yb & & 2,846 & & & & & & 1,811 & 2,237 & & 2,053 \\
\hline Lu & & 0,416 & & & & & & 0,279 & 0,381 & & 0,293 \\
\hline mg\# & 11,92 & 13,05 & 13,09 & 15,96 & 18,10 & 14,94 & 8,39 & 16,43 & 5,88 & 16,48 & 34,09 \\
\hline R1 & 247,12 & 178,98 & $-45,53$ & $-638,12$ & $-1404,31$ & $-1410,80$ & $-1328,19$ & $-937,11$ & $-1192,34$ & $-463,25$ & $-624,87$ \\
\hline R2 & 659,46 & 609,53 & 676,63 & 611,21 & 611,17 & 582,36 & 505,29 & 600,12 & 523,99 & 595,44 & 1173,17 \\
\hline IA & 0,66 & 0,72 & 0,76 & 0,86 & 1,03 & 1,01 & 1,09 & 0,95 & 1,05 & 0,84 & 0,94 \\
\hline A/NK & 1,51 & 1,39 & 1,32 & 1,17 & 0,97 & 0,99 & 0,91 & 1,05 & 0,95 & 1,19 & 1,06 \\
\hline A/CNK & 1,26 & 1,19 & 1,08 & 1,04 & 0,87 & 0,90 & 0,86 & 0,93 & 0,88 & 1,06 & 0,59 \\
\hline $\mathrm{K}_{2} \mathrm{O} / \mathrm{Na}_{2} \mathrm{O}$ & 8,21 & 2,80 & 1,82 & 1,62 & 0,95 & 1,05 & 1,04 & 1,12 & 0,73 & 1,52 & 1,22 \\
\hline $\mathrm{Nb} / \mathrm{Ta}$ & 27,26 & 21,01 & 21,77 & 21,49 & 18,19 & 14,79 & 42,76 & 19,93 & 53,38 & 25,71 & 16,49 \\
\hline $\mathrm{Zr} / \mathrm{Hf}$ & & 46,98 & & & & & & 51,94 & 51,68 & & 41,95 \\
\hline $\mathrm{Eu} / \mathrm{Eu}^{*}$ & & 0,95 & & & & & & 0,95 & 0,75 & & 1,07 \\
\hline$(\mathrm{La} / \mathrm{Lu}) \mathrm{N}$ & & 52,85 & & & & & & 33,36 & 25,78 & & 31,66 \\
\hline $\mathbf{Q}$ & - & - & - & - & - & - & - & - & - & - & - \\
\hline C & 5,06 & 3,79 & 1,82 & 1,04 & - & - & - & - & - & 1,46 & - \\
\hline or & 72,33 & 57,61 & 50,88 & 55,96 & 47,51 & 50,94 & 50,88 & 47,98 & 39,24 & 51,23 & 32,46 \\
\hline$a b$ & 3,78 & 19,68 & 19,62 & 11,10 & 6,48 & 5,73 & 10,28 & 13,67 & 19,74 & 16,76 & - \\
\hline an & 8,50 & 6,92 & 10,03 & 6,37 & - & - & - & 3,49 & - & 6,26 & 3,59 \\
\hline ne & 4,49 & 5,27 & 10,86 & 20,70 & 33,60 & 33,65 & 26,84 & 25,45 & 28,19 & 16,77 & 22,93 \\
\hline Ic & - & - & - & - & - & - & - & - & - & - & 4,15 \\
\hline ac & - & - & - & - & 1,76 & 0,30 & 2,14 & - & 3,13 & - & - \\
\hline di & - & - & - & - & 5,63 & 3,91 & 3,56 & 2,90 & 4,25 & - & 20,42 \\
\hline hy & - & - & - & - & - & - & - & - & - & - & - \\
\hline ol & 1,57 & 1,80 & 1,84 & 1,67 & - & - & 0,97 & 0,68 & 1,75 & 1,70 & 0,50 \\
\hline mt & 0,92 & 1,19 & 1,18 & 1,08 & 0,29 & 0,76 & - & 1,18 & - & 1,13 & 3,57 \\
\hline il & 0,65 & 0,93 & 0,82 & 0,93 & 1,14 & 0,70 & 0,51 & 1,08 & 0,25 & 1,01 & 5,66 \\
\hline $\mathrm{hm}$ & - & - & - & - & - & - & - & - & - & - & - \\
\hline ap & 0,05 & 0,12 & 0,14 & 0,12 & 0,17 & 0,07 & 0,02 & 0,17 & - & 0,14 & 1,94 \\
\hline $\mathrm{aq}$ & 1,30 & 1,25 & 1,32 & 1,68 & 1,49 & 1,69 & 1,30 & 1,78 & 1,73 & 2,11 & 2,59 \\
\hline
\end{tabular}

Lab.: Laboratório utilizado nas análises dos elementos traço e ETRs: A- AcmeLabs, via ICP-AES/ICP-MS; B- UNICAMP, via ICP-MS; C- Geoanalítica-USP, via ICP-MS. Óxidos analisados via FRX pela Acmelabs, exceto nas amostras analisadas pela Geoanalítica-USP. 
ANEXO F - Tabela de composição química das rochas do Maciço Alcalino de Itatiaia. Continua..

\begin{tabular}{|c|c|c|c|c|c|c|c|c|c|c|c|}
\hline Amostra & MAl067 & MAI022BI & MAI036 & MAI061 & MAI192 & MAI063 & MAI208 & MAI199 & MAI197 & MAI206I & $\begin{array}{l}\text { MAI089B } \\
\text { BtAgtNeS }\end{array}$ \\
\hline Unidade & BtHblNeS & BtHblNeS & BtHblNeS & SdINeS & SdINeS & SdINeS & BtAgtNeS & BtAgtNeS & BtAgtNeS & BtAgtNeS & BtAgtNeS \\
\hline Lab. & A & B & B & A & A & A & A & B & A & A & A \\
\hline $\mathrm{SiO}_{2}$ & 58,47 & 55,86 & 56,01 & 58,29 & 58,51 & 60,92 & 58,33 & 58,56 & 58,57 & 58,12 & 59,75 \\
\hline $\mathrm{TiO}_{2}$ & 0,89 & 1,12 & 1,64 & 0,85 & 0,87 & 0,77 & 0,49 & 0,88 & 0,53 & 1,06 & 0,84 \\
\hline $\mathrm{Al}_{2} \mathrm{O}_{3}$ & 18,87 & 19,30 & 18,26 & 19,49 & 19,03 & 18,71 & 20,23 & 18,83 & 19,97 & 18,53 & 18,55 \\
\hline $\mathrm{Fe}_{2} \mathrm{O}_{3}$ & 3,28 & 3,67 & 5,04 & 3,03 & 3,08 & 2,92 & 2,74 & 3,15 & 2,22 & 3,37 & 2,94 \\
\hline $\mathrm{MnO}$ & 0,14 & 0,20 & 0,23 & 0,20 & 0,24 & 0,22 & 0,36 & 0,33 & 0,18 & 0,26 & 0,21 \\
\hline MgO & 0,87 & 1,00 & 1,41 & 0,39 & 0,56 & 0,36 & 0,24 & 0,48 & 0,28 & 0,54 & 0,56 \\
\hline $\mathrm{CaO}$ & 2,06 & 2,84 & 2,65 & 1,57 & 1,24 & 1,19 & 0,74 & 0,91 & 0,88 & 1,29 & 0,96 \\
\hline $\mathrm{Na}_{2} \mathrm{O}$ & 4,31 & 6,40 & 4,32 & 6,00 & 7,41 & 6,65 & 9,17 & 8,33 & 8,13 & 7,09 & 6,53 \\
\hline $\mathrm{K}_{2} \mathrm{O}$ & 8,86 & 6,83 & 8,39 & 8,22 & 6,68 & 6,61 & 5,53 & 6,16 & 6,23 & 6,74 & 6,73 \\
\hline $\mathrm{P}_{2} \mathrm{O}_{5}$ & 0,24 & 0,39 & 0,42 & 0,08 & 0,12 & 0,08 & 0,03 & 0,09 & 0,05 & 0,10 & 0,11 \\
\hline $\mathrm{SO}_{3}$ & 0,04 & 0,45 & 0,01 & 0,08 & 0,23 & 0,08 & 0,27 & 0,09 & 0,06 & 0,26 & 0,09 \\
\hline LOI & 1,19 & 0,97 & 0,97 & 0,66 & 1,06 & 0,76 & 0,91 & 1,10 & 1,56 & 1,29 & 1,62 \\
\hline Total & 99,37 & 99,41 & 99,50 & 99,37 & 99,14 & 99,38 & 99,31 & 99,14 & 98,76 & 98,80 & 99,00 \\
\hline$\overline{\mathrm{Li}}$ & 10,70 & 19,77 & 9,75 & 10,10 & 15,90 & 7,70 & 28,50 & 27,25 & 23,80 & 14,40 & 9,80 \\
\hline Cs & & 0,63 & 0,98 & & & & & 3,19 & & & \\
\hline $\mathbf{R b}$ & 96,50 & 109,04 & 81,44 & 148,00 & 143,30 & 109,80 & 185,00 & 193,45 & 145,60 & 146,80 & 127,40 \\
\hline $\mathrm{Ba}$ & 33,00 & 486,92 & 18,78 & 8,00 & 7,00 & $<5$ & $<5$ & 0,62 & $<5$ & 5,00 & 9,00 \\
\hline $\mathrm{Be}$ & $<5$ & 3,10 & 1,23 & $<5$ & $<5$ & $<5$ & $<5$ & 4,75 & $<5$ & $<5$ & $<5$ \\
\hline $\mathrm{Sr}$ & 589,00 & 1453,32 & 462,18 & 99,00 & 30,00 & 13,00 & $<5$ & 1,82 & 6,00 & 21,00 & 62,00 \\
\hline $\mathrm{Pb}$ & 10,70 & 12,21 & 7,11 & 15,10 & 14,60 & 11,80 & 28,10 & 19,19 & 10,60 & 10,80 & 12,50 \\
\hline Th & 6,30 & 11,34 & 8,44 & 24,50 & 13,60 & 10,50 & 28,20 & 31,98 & 10,20 & 12,20 & 8,40 \\
\hline U & 1,40 & 2,34 & 1,30 & 3,40 & 2,30 & 2,10 & 8,10 & 3,42 & 1,80 & 1,40 & 1,50 \\
\hline $\mathrm{Zr}$ & & 418,48 & 281,95 & & & & & 916,62 & & & \\
\hline $\mathrm{Hf}$ & & 11,24 & 7,19 & & & & & 20,98 & & & \\
\hline Ta & 3,90 & 6,90 & 5,74 & 18,00 & 8,60 & 11,80 & 18,60 & 15,49 & 7,50 & 18,70 & 8,80 \\
\hline $\mathbf{Y}$ & 20,60 & 33,31 & 36,39 & 42,20 & 32,80 & 38,00 & 46,50 & 64,79 & 22,00 & 50,90 & 32,90 \\
\hline $\mathrm{Nb}$ & 63,90 & 105,06 & 84,74 & 266,30 & 166,00 & 122,40 & 331,20 & 231,84 & 123,80 & 218,90 & 124,60 \\
\hline Sc & 2,00 & 1,86 & 3,03 & 1,00 & 1,00 & 4,00 & 2,00 & 1,96 & 2,00 & 2,00 & 1,00 \\
\hline $\mathrm{Cr}$ & 2,00 & $<1$ & 4,13 & 1,00 & 2,00 & 2,00 & 1,00 & 0,75 & 2,00 & 2,00 & 2,00 \\
\hline $\mathrm{Ni}$ & 1,30 & $<0,5$ & $<0,5$ & $<0,5$ & 0,70 & $<0,5$ & $<0,5$ & $<0,5$ & 0,70 & $<0,5$ & 0,90 \\
\hline Sn & 1,40 & 2,56 & 2,33 & 4,30 & 3,50 & 3,70 & 6,20 & 5,13 & 2,90 & 4,50 & 2,80 \\
\hline Co & $<1$ & 1,27 & 0,22 & $<1$ & $<1$ & $<1$ & $<1$ & $<1$ & $<1$ & $<1$ & $<1$ \\
\hline v & $<10$ & 28,54 & 21,86 & 21,00 & 18,00 & 10,00 & 10,00 & 21,09 & 13,00 & 26,00 & 21,00 \\
\hline w & 2,30 & 4,30 & 1,59 & 1,60 & 2,50 & 2,20 & $<0,5$ & 1,99 & 0,80 & 3,30 & 3,70 \\
\hline Ga & & 21,29 & 20,35 & & & & & 27,71 & & & \\
\hline $\mathrm{Zn}$ & 102,00 & 95,74 & 123,78 & 123,00 & 133,00 & 99,00 & 177,00 & 152,27 & 81,00 & 132,00 & 115,00 \\
\hline $\mathrm{Cu}$ & 0,70 & 9,32 & 7,19 & 0,80 & 2,20 & $<0,5$ & 1,30 & 3,19 & 1,30 & 2,10 & 0,90 \\
\hline Mo & 5,60 & 15,99 & 2,35 & 3,50 & 7,50 & 5,90 & 0,60 & 3,85 & 2,10 & 6,60 & 8,90 \\
\hline $\mathrm{Bi}$ & $<0,5$ & 0,042 & 0,025 & $<0,5$ & $<0,5$ & $<0,5$ & $<0,5$ & 0,139 & $<0,5$ & $<0,5$ & $<0,5$ \\
\hline Cd & $<0,5$ & 0,446 & 0,107 & $<0,5$ & $<0,5$ & $<0,5$ & $<0,5$ & 0,282 & $<0,5$ & $<0,5$ & $<0,5$ \\
\hline Sb & $<0,5$ & 0,068 & 0,066 & $<0,5$ & $<0,5$ & $<0,5$ & $<0,5$ & 0,168 & $<0,5$ & $<0,5$ & $<0,5$ \\
\hline La & & 165,72 & 253,93 & & & & & 271,39 & & & \\
\hline $\mathrm{Ce}$ & & 331,23 & 508,12 & & & & & 540,11 & & & \\
\hline $\mathrm{Pr}$ & & 35,53 & 54,91 & & & & & 55,51 & & & \\
\hline Nd & & 133,34 & 210,52 & & & & & 198,48 & & & \\
\hline Sm & & 18,169 & 27,464 & & & & & 27,974 & & & \\
\hline Eu & & 6,480 & 8,980 & & & & & 2,786 & & & \\
\hline Gd & & 13,074 & 19,167 & & & & & 20,641 & & & \\
\hline Tb & & 1,473 & 1,991 & & & & & 2,522 & & & \\
\hline Dy & & 7,153 & 8,883 & & & & & 13,065 & & & \\
\hline Ho & & 1,228 & 1,416 & & & & & 2,339 & & & \\
\hline $\mathrm{Er}$ & & 3,145 & 3,488 & & & & & 6,175 & & & \\
\hline $\mathrm{Tm}$ & & 0,400 & 0,395 & & & & & 0,827 & & & \\
\hline Yb & & 2,442 & 2,273 & & & & & 5,059 & & & \\
\hline Lu & & 0,363 & 0,335 & & & & & 0,748 & & & \\
\hline$\overline{\mathrm{mg \#}}$ & 34,45 & 35,06 & 35,66 & 20,32 & 26,48 & 19,63 & 14,79 & 23,19 & 19,99 & 24,10 & 27,40 \\
\hline R1 & 188,67 & $-268,35$ & 68,27 & $-266,45$ & $-394,39$ & 58,66 & $-744,48$ & $-598,17$ & $-510,81$ & $-332,79$ & $-6,90$ \\
\hline R2 & 633,78 & 732,12 & 711,73 & 569,71 & 533,81 & 512,26 & 487,98 & 490,61 & 499,84 & 528,36 & 494,43 \\
\hline IA & 0,88 & 0,93 & 0,89 & 0,96 & 1,02 & 0,97 & 1,04 & 1,08 & 1,01 & 1,02 & 0,97 \\
\hline A/NK & 1,13 & 1,08 & 1,13 & 1,04 & 0,98 & 1,03 & 0,96 & 0,92 & 0,99 & 0,98 & 1,03 \\
\hline A/CNK & 0,92 & 0,84 & 0,87 & 0,90 & 0,88 & 0,92 & 0,90 & 0,85 & 0,92 & 0,87 & 0,94 \\
\hline $\mathrm{K}_{2} \mathrm{O} / \mathrm{Na}_{2} \mathrm{O}$ & 2,06 & 1,07 & 1,94 & 1,37 & 0,90 & 0,99 & 0,60 & 0,74 & 0,77 & 0,95 & 1,03 \\
\hline $\mathrm{Nb} / \mathrm{Ta}$ & 16,38 & 15,22 & 14,77 & 14,79 & 19,30 & 10,37 & 17,81 & 14,97 & 16,51 & 11,71 & 14,16 \\
\hline $\mathrm{Zr} / \mathrm{Hf}$ & & 37,22 & 39,21 & & & & & 43,68 & & & \\
\hline Eu/Eu* & & 1,28 & 1,19 & & & & & 0,35 & & & \\
\hline (La/Lu)N & & 47,39 & 78,68 & & & & & 37,69 & & & \\
\hline$\overline{\mathbf{Q}}$ & - & - & - & - & - & - & - & - & - & - & - \\
\hline C & - & - & - & - & - & - & - & - & - & - & - \\
\hline or & 52,35 & 40,36 & 49,58 & 48,57 & 39,47 & 39,06 & 32,68 & 36,40 & 36,81 & 39,83 & 39,77 \\
\hline$a b$ & 25,69 & 27,35 & 21,86 & 26,32 & 35,39 & 44,16 & 37,65 & 35,90 & 37,37 & 35,33 & 41,89 \\
\hline an & 6,11 & 5,33 & 5,70 & 2,25 & - & 1,96 & - & - & - & - & 1,75 \\
\hline ne & 5,71 & 12,92 & 7,92 & 12,96 & 13,70 & 6,28 & 19,29 & 14,44 & 16,61 & 12,17 & 6,91 \\
\hline Ic & - & - & - & - & - & - & - & - & - & - & - \\
\hline ac & - & - & - & - & 0,46 & - & 2,23 & 2,83 & 0,30 & 0,42 & - \\
\hline di & 2,09 & 5,08 & 3,84 & 4,23 & 4,49 & 2,90 & 3,02 & 3,34 & 3,43 & 4,80 & 1,90 \\
\hline hy & - & - & - & - & - & - & - & - & - & - & - \\
\hline ol & 2,07 & 1,29 & 2,78 & 0,36 & 0,75 & 0,86 & 1,48 & 1,69 & 0,35 & 0,57 & 1,51 \\
\hline mt & 1,48 & 1,65 & 2,27 & 1,36 & 1,15 & 1,31 & 0,12 & - & 0,85 & 1,31 & 1,32 \\
\hline il & 1,69 & 2,13 & 3,11 & 1,61 & 1,65 & 1,46 & 0,93 & 1,67 & 1,01 & 2,01 & 1,60 \\
\hline $\mathrm{hm}$ & - & - & - & - & - & - & - & - & - & - & - \\
\hline ap & 0,57 & 0,92 & 0,99 & 0,19 & 0,28 & 0,19 & 0,07 & 0,21 & 0,12 & 0,24 & 0,26 \\
\hline aq & 1,19 & 0,97 & 0,97 & 0,66 & 1,06 & 0,76 & 0,91 & 1,10 & 1,56 & 1,29 & 1,62 \\
\hline
\end{tabular}

Lab.: Laboratório utilizado nas análises dos elementos traço e ETRs: A- AcmeLabs, via ICP-AES/ICP-MS; B- UNICAMP, via ICP-MS; C- Geoanalítica-USP, via ICP-MS. Óxidos analisados via FRX pela Acmelabs, exceto nas amostras analisadas pela Geoanalítica-USP. 
ANEXO F - Tabela de composição química das rochas do Maciço Alcalino de Itatiaia. Continua..

\begin{tabular}{|c|c|c|c|c|c|c|c|c|c|c|c|}
\hline Amostra & MAI204 & MAl196 & MAI206II & MAI198IV & MAI066A & MAI202 & MAI144B & MAI114 & MAI102 & MAl098 & MAI092I \\
\hline Unidade & BtAgtNes & BtAgtNeS & Diq-Trq & Diq-Trq & BtHblP & BtHblP & BtHblP & BtHblP & BtHblP & BtHblP & BtHblP \\
\hline Lab. & B & $\mathrm{A}$ & A & A & A & A & $\mathrm{A}$ & $\mathrm{B}$ & A & A & $B$ \\
\hline$\overline{\mathrm{SiO}_{2}}$ & 60,18 & 60,21 & 60,78 & 60,69 & 59,24 & 59,40 & 58,35 & 58,35 & 58,16 & 58,07 & 58,40 \\
\hline $\mathrm{TiO}_{2}$ & 1,21 & 0,89 & 0,52 & 0,84 & 1,06 & 0,88 & 1,09 & 1,09 & 1,17 & 1,17 & 1,10 \\
\hline $\mathrm{Al}_{2} \mathrm{O}_{3}$ & 17,74 & 18,20 & 18,58 & 18,87 & 18,06 & 18,28 & 18,40 & 18,44 & 18,35 & 18,49 & 18,56 \\
\hline $\mathrm{Fe}_{2} \mathrm{O}_{3}$ & 3,47 & 2,70 & 2,61 & 3,16 & 3,86 & 3,83 & 3,36 & 3,33 & 3,86 & 3,94 & 3,51 \\
\hline $\mathrm{MnO}$ & 0,22 & 0,16 & 0,21 & 0,40 & 0,14 & 0,16 & 0,15 & 0,15 & 0,15 & 0,15 & 0,17 \\
\hline MgO & 0,84 & 0,69 & 0,39 & 0,31 & 1,16 & 1,07 & 0,98 & 0,93 & 1,13 & 1,15 & 0,96 \\
\hline $\mathrm{CaO}$ & 1,38 & 1,36 & 0,82 & 0,19 & 2,20 & 2,09 & 2,09 & 2,14 & 2,38 & 2,40 & 2,14 \\
\hline $\mathrm{Na}_{2} \mathrm{O}$ & 6,04 & 5,77 & 6,55 & 5,89 & 4,70 & 5,18 & 4,62 & 4,90 & 5,09 & 4,61 & 5,65 \\
\hline $\mathrm{K}_{2} \mathrm{O}$ & 6,74 & 7,16 & 7,14 & 6,70 & 7,50 & 6,90 & 7,75 & 7,75 & 7,43 & 7,54 & 7,56 \\
\hline $\mathrm{P}_{2} \mathrm{O}_{5}$ & 0,22 & 0,21 & 0,06 & 0,09 & 0,37 & 0,39 & 0,28 & 0,28 & 0,39 & 0,39 & 0,30 \\
\hline $\mathrm{SO}_{3}$ & 0,03 & 0,02 & 0,04 & & 0,01 & 0,01 & 0,01 & 0,02 & 0,07 & 0,01 & 0,14 \\
\hline LOI & 0,96 & 1,30 & 0,71 & 1,66 & 0,64 & 0,84 & 1,55 & 1,17 & 0,64 & 1,00 & 0,94 \\
\hline Total & 99,17 & 98,74 & 98,70 & 98,98 & 99,20 & 99,38 & 98,86 & 98,82 & 99,06 & 99,15 & 99,69 \\
\hline$\overline{\mathbf{L i}}$ & 6,25 & 11,00 & 11,40 & 74,30 & 18,10 & 24,10 & 24,90 & 8,69 & 9,40 & 17,20 & 19,14 \\
\hline Cs & 0,69 & & & & & & & 1,09 & & & 1,16 \\
\hline $\mathbf{R b}$ & 56,88 & 70,10 & 147,70 & 189,00 & 90,10 & 92,00 & 103,50 & 109,67 & 96,20 & 88,70 & 141,47 \\
\hline Ba & 36,92 & 7,00 & 94,00 & $<5$ & 540,00 & 1115,00 & 333,00 & 420,53 & 491,00 & 435,00 & 427,20 \\
\hline $\mathrm{Be}$ & 0,95 & $<5$ & $<5$ & $<5$ & $<5$ & $<5$ & $<5$ & 1,40 & $<5$ & $<5$ & 1,52 \\
\hline $\mathrm{Sr}$ & 27,84 & 30,00 & 391,00 & 50,00 & 1129,00 & 1254,00 & 1070,00 & 1201,52 & 1160,00 & 1133,00 & 1221,52 \\
\hline $\mathrm{Pb}$ & 3,92 & 9,20 & 11,00 & 20,40 & 12,40 & 12,10 & 10,00 & 9,29 & 10,00 & 9,90 & 11,30 \\
\hline Th & 5,91 & 4,10 & 27,00 & 12,10 & 6,90 & 7,70 & 6,50 & 8,05 & 6,40 & 6,90 & 9,55 \\
\hline U & 0,75 & 0,80 & 7,70 & 3,50 & 1,70 & 1,70 & 1,40 & 1,57 & 1,40 & 1,50 & 2,05 \\
\hline $\mathrm{Zr}$ & 227,43 & & & & & & & 200,23 & & & 262,92 \\
\hline $\mathrm{Hf}$ & 6,68 & & & & & & & 5,48 & & & 6,54 \\
\hline Ta & 13,84 & 3,60 & 19,60 & 10,90 & 3,60 & 4,90 & 4,60 & 5,00 & 3,90 & 3,80 & 4,92 \\
\hline $\mathbf{Y}$ & 51,86 & 16,10 & 50,10 & 32,20 & 21,20 & 23,70 & 24,90 & 29,22 & 22,50 & 19,40 & 30,39 \\
\hline $\mathbf{N b}$ & 111,84 & 62,10 & 261,40 & 194,40 & 63,80 & 81,60 & 76,40 & 69,11 & 64,40 & 60,60 & 77,48 \\
\hline Sc & 1,71 & 3,00 & 1,00 & 2,00 & 4,00 & 5,00 & 3,00 & 2,56 & 3,00 & 4,00 & 2,38 \\
\hline $\mathrm{Cr}$ & 1,92 & 3,00 & 3,00 & 2,00 & 2,00 & 3,00 & 4,00 & 2,16 & 1,00 & $<1$ & 2,59 \\
\hline $\mathrm{Ni}$ & $<0,5$ & $<0,5$ & $<0,5$ & $<0,5$ & 0,60 & 0,80 & 1,20 & $<0,5$ & 0,50 & $<0,5$ & $<0,5$ \\
\hline Sn & 3,42 & 1,50 & 3,40 & 4,50 & 1,60 & 2,10 & 1,70 & 1,79 & 1,90 & 1,40 & 1,95 \\
\hline Co & 0,03 & $<1$ & $<1$ & $<1$ & 2,00 & $<1$ & 1,00 & 0,53 & 2,00 & 1,00 & 0,55 \\
\hline v & 24,23 & 14,00 & $<10$ & 17,00 & 25,00 & 11,00 & 23,00 & 26,43 & 19,00 & 24,00 & 27,16 \\
\hline w & 0,81 & 0,90 & 1,50 & 1,60 & 1,30 & 1,50 & $<0,5$ & 1,50 & 1,00 & $<0,5$ & 5,75 \\
\hline Ga & 19,47 & & & & & & & 17,71 & & & 18,95 \\
\hline $\mathrm{Zn}$ & 71,03 & 75,00 & 126,00 & 165,00 & 93,00 & 94,00 & 81,00 & 80,83 & 91,00 & 82,00 & 93,99 \\
\hline $\mathrm{Cu}$ & 4,39 & 1,20 & 1,20 & 1,60 & 4,20 & 1,40 & 3,60 & 4,67 & 4,90 & $<0,5$ & 5,17 \\
\hline Mo & 2,06 & 2,30 & 1,20 & 1,50 & 2,70 & 3,60 & 1,10 & 2,64 & 2,70 & $<0,5$ & 4,65 \\
\hline $\mathrm{Bi}$ & 0,019 & $<0,5$ & $<0,5$ & $<0,5$ & $<0,5$ & $<0,5$ & $<0,5$ & 0,018 & $<0,5$ & $<0,5$ & 0,032 \\
\hline Cd & 0,075 & $<0,5$ & $<0,5$ & $<0,5$ & $<0,5$ & $<0,5$ & $<0,5$ & 0,073 & $<0,5$ & $<0,5$ & 0,091 \\
\hline Sb & 0,062 & $<0,5$ & $<0,5$ & $<0,5$ & $<0,5$ & $<0,5$ & $<0,5$ & 0,057 & $<0,5$ & $<0,5$ & 0,079 \\
\hline La & 194,81 & & & & & & & 114,97 & & & 123,61 \\
\hline $\mathrm{Ce}$ & 435,08 & & & & & & & 246,53 & & & 252,22 \\
\hline $\mathrm{Pr}$ & 55,83 & & & & & & & 27,86 & & & 27,78 \\
\hline Nd & 228,88 & & & & & & & 114,34 & & & 111,13 \\
\hline Sm & 37,270 & & & & & & & 17,199 & & & 16,701 \\
\hline Eu & 3,263 & & & & & & & 5,760 & & & 5,769 \\
\hline Gd & 24,376 & & & & & & & 11,897 & & & 11,596 \\
\hline Tb & 2,974 & & & & & & & 1,391 & & & 1,368 \\
\hline Dy & 13,871 & & & & & & & 6,799 & & & 6,720 \\
\hline Ho & 2,126 & & & & & & & 1,128 & & & 1,134 \\
\hline $\mathrm{Er}$ & 4,789 & & & & & & & 2,788 & & & 2,839 \\
\hline $\mathrm{Tm}$ & 0,514 & & & & & & & 0,334 & & & 0,370 \\
\hline Yb & 2,795 & & & & & & & 1,916 & & & 2,222 \\
\hline Lu & 0,356 & & & & & & & 0,278 & & & 0,329 \\
\hline mg\# & 32,42 & 33,61 & 22,84 & 16,27 & 37,32 & 35,63 & 36,62 & 35,62 & 36,71 & 36,64 & 35,14 \\
\hline R1 & 170,78 & 197,82 & $-24,92$ & 284,34 & 400,33 & 385,99 & 322,87 & 224,23 & 203,60 & 340,29 & 0,96 \\
\hline R2 & 537,37 & 536,81 & 471,61 & 405,93 & 647,26 & 635,34 & 633,23 & 636,88 & 670,72 & 676,60 & 640,73 \\
\hline IA & 0,97 & 0,95 & 1,00 & 0,90 & 0,88 & 0,87 & 0,87 & 0,89 & 0,89 & 0,85 & 0,94 \\
\hline A/NK & 1,03 & 1,06 & 1,00 & 1,11 & 1,14 & 1,14 & 1,15 & 1,12 & 1,12 & 1,17 & 1,06 \\
\hline A/CNK & 0,90 & 0,92 & 0,93 & 1,09 & 0,91 & 0,92 & 0,93 & 0,91 & 0,88 & 0,92 & 0,87 \\
\hline $\mathrm{K}_{2} \mathrm{O} / \mathrm{Na}_{2} \mathrm{O}$ & 1,12 & 1,24 & 1,09 & 1,14 & 1,60 & 1,33 & 1,68 & 1,58 & 1,46 & 1,64 & 1,34 \\
\hline $\mathrm{Nb} / \mathrm{Ta}$ & 8,08 & 17,25 & 13,34 & 17,83 & 17,72 & 16,65 & 16,61 & 13,82 & 16,51 & 15,95 & 15,75 \\
\hline $\mathrm{Zr} / \mathrm{Hf}$ & 34,03 & & & & & & & 36,57 & & & 40,21 \\
\hline $\mathrm{Eu} / \mathrm{Eu}^{*}$ & 0,33 & & & & & & & 1,23 & & & 1,26 \\
\hline (La/Lu)N & 56,80 & & & & & & & 42,93 & & & 39,00 \\
\hline $\mathbf{Q}$ & - & - & - & - & - & - & - & - & - & - & - \\
\hline C & - & - & - & 1,80 & - & - & - & - & - & - & - \\
\hline or & 39,83 & 42,31 & 42,19 & 39,59 & 44,32 & 40,77 & 45,80 & 45,80 & 43,90 & 44,55 & 44,67 \\
\hline$a b$ & 43,30 & 41,09 & 41,19 & 49,66 & 36,51 & 40,25 & 33,19 & 32,22 & 33,00 & 33,10 & 31,57 \\
\hline an & 1,47 & 2,67 & 0,33 & 0,36 & 6,07 & 6,27 & 6,61 & 5,51 & 5,50 & 7,51 & 3,43 \\
\hline ne & 4,14 & 4,13 & 7,58 & 0,09 & 1,73 & 1,92 & 3,17 & 4,93 & 5,23 & 3,18 & 8,31 \\
\hline Ic & - & - & - & - & - & - & - & - & - & - & - \\
\hline ac & - & - & - & - & - & - & - & - & - & - & - \\
\hline di & 3,22 & 2,21 & 2,82 & - & 1,99 & 1,28 & 1,57 & 2,67 & 3,06 & 1,51 & 4,27 \\
\hline hy & - & - & - & - & - & - & - & - & - & - & - \\
\hline ol & 1,46 & 1,35 & 1,03 & 2,20 & 2,80 & 3,13 & 2,27 & 1,77 & 2,24 & 2,88 & 1,39 \\
\hline mt & 1,56 & 1,21 & 1,17 & 1,42 & 1,74 & 1,72 & 1,51 & 1,50 & 1,74 & 1,77 & 1,58 \\
\hline il & 2,30 & 1,69 & 0,99 & 1,60 & 2,01 & 1,67 & 2,07 & 2,07 & 2,22 & 2,22 & 2,09 \\
\hline $\mathrm{hm}$ & - & - & - & - & - & - & - & - & - & - & - \\
\hline ap & 0,52 & 0,50 & 0,14 & 0,21 & 0,88 & 0,92 & 0,66 & 0,66 & 0,92 & 0,92 & 0,71 \\
\hline aq & 0,96 & 1,30 & 0,71 & 1,66 & 0,64 & 0,84 & 1,55 & 1,17 & 0,64 & 1,00 & 0,94 \\
\hline
\end{tabular}

Lab.: Laboratório utilizado nas análises dos elementos traço e ETRs: A- AcmeLabs, via ICP-AES/ICP-MS; B- UNICAMP, via ICP-MS; C- Geoanalítica-USP, via ICP-MS. Óxidos analisados via FRX pela Acmelabs, exceto nas amostras analisadas pela Geoanalítica-USP. 
ANEXO F - Tabela de composição química das rochas do Maciço Alcalino de Itatiaia. Continua..

\begin{tabular}{|c|c|c|c|c|c|c|c|c|c|c|c|}
\hline $\begin{array}{l}\text { Unidade } \\
\text { Lab. }\end{array}$ & BtHblP & BtHblP & Diq-Foid & Diq-Trq & AgtN & $N-1$ & $\sqrt{2-1}$ & QzAFS-I & QzAFS-I & QZAFS-I & QzAFS-I \\
\hline Lab. & A & B & B & A & B & A & B & B & A & A & A \\
\hline$\overline{\mathrm{SiO}_{2}}$ & 60,02 & 59,08 & 57,40 & 61,16 & 64,30 & 62,28 & 62,69 & 64,05 & 64,63 & 64,36 & 63,34 \\
\hline $\mathrm{TiO}_{2}$ & 1,06 & 1,06 & 0,16 & 0,83 & 0,40 & 0,81 & 0,70 & 0,64 & 0,80 & 0,72 & 0,81 \\
\hline $\mathrm{Al}_{2} \mathrm{O}_{3}$ & 18,15 & 18,48 & 22,68 & 19,22 & 17,12 & 17,56 & 17,92 & 17,15 & 16,76 & 16,81 & 17,54 \\
\hline $\mathrm{Fe}_{2} \mathrm{O}_{3}$ & 2,35 & 3,16 & 1,75 & 2,84 & 2,20 & 2,83 & 2,75 & 2,85 & 2,80 & 2,70 & 2,59 \\
\hline $\mathrm{MnO}$ & 0,08 & 0,20 & 0,09 & 0,21 & 0,28 & 0,13 & 0,10 & 0,22 & 0,18 & 0,21 & 0,16 \\
\hline MgO & 0,88 & 0,89 & 0,02 & 0,49 & 0,13 & 0,50 & 0,38 & 0,41 & 0,43 & 0,43 & 0,37 \\
\hline $\mathrm{CaO}$ & 0,68 & 1,88 & 0,61 & 1,33 & 0,36 & 1,02 & 0,82 & 0,60 & 0,73 & 0,70 & 0,78 \\
\hline $\mathrm{Na}_{2} \mathrm{O}$ & 4,54 & 4,51 & 9,41 & 5,93 & 6,70 & 5,62 & 5,71 & 5,74 & 5,58 & 6,06 & 6,12 \\
\hline $\mathrm{K}_{2} \mathrm{O}$ & 8,43 & 7,59 & 6,22 & 6,85 & 5,95 & 6,67 & 7,12 & 6,36 & 6,47 & 6,24 & 6,54 \\
\hline $\mathrm{P}_{2} \mathrm{O}_{5}$ & 0,24 & 0,28 & & 0,10 & 0,02 & 0,16 & 0,12 & 0,08 & 0,09 & 0,08 & 0,09 \\
\hline $\mathrm{SO}_{3}$ & 0,04 & 0,02 & 0,05 & 0,01 & 0,01 & 0,01 & 0,01 & & 0,00 & & 0,01 \\
\hline LOI & 2,37 & 1,84 & 0,81 & 1,23 & 1,38 & 1,12 & 1,07 & 1,21 & 0,66 & 0,61 & 0,60 \\
\hline Total & 99,06 & 99,27 & 99,38 & 100,38 & 99,01 & 98,94 & 99,54 & 99,52 & 99,32 & 99,13 & 99,14 \\
\hline$\overline{L i}$ & 34,20 & 21,58 & 4,93 & 27,60 & 4,82 & 12,10 & 12,70 & 7,63 & 17,00 & 16,20 & 8,10 \\
\hline Cs & & 1,75 & 0,82 & & 2,09 & & 1,48 & 0,53 & & & \\
\hline $\mathbf{R b}$ & 162,00 & 142,09 & 124,57 & 155,30 & 187,20 & 192,80 & 92,53 & 108,60 & 176,40 & 146,60 & 140,90 \\
\hline Ba & 430,00 & 455,84 & 7,31 & 90,00 & 1,07 & 162,00 & 25,99 & 8,64 & 27,00 & 10,00 & $<5$ \\
\hline $\mathrm{Be}$ & $<5$ & 2,51 & 1,28 & $<5$ & 6,21 & $<5$ & 2,69 & 3,15 & $<5$ & $<5$ & $<5$ \\
\hline $\mathrm{Sr}$ & 904,00 & 1139,38 & 63,30 & 337,00 & 6,28 & 305,00 & 45,28 & 9,16 & 18,00 & 10,00 & 5,00 \\
\hline $\mathrm{Pb}$ & 33,30 & 22,57 & 11,88 & 16,20 & $14,89 \mid$ & 17,90 & 9,79 & 5,06 & 21,10 & 10,30 & 16,10 \\
\hline Th & 9,60 & 7,27 & 7,02 & 14,70 & 20,72 & 23,50 & 6,41 & 13,00 & 16,70 & 18,80 & 10,90 \\
\hline U & 1,00 & 1,46 & 7,42 & 2,90 & 8,22 & 3,80 & 2,74 & 2,08 & 2,90 & 2,50 & 1,30 \\
\hline $\mathrm{Zr}$ & & 208,47 & 356,98 & & 358,07 & & 371,49 & 805,30 & & & \\
\hline $\mathrm{Hf}$ & & 5,59 & 6,39 & & 11,47 & & 10,01 & 18,45 & & & \\
\hline Ta & 2,40 & 5,22 & 0,89 & 9,50 & 2,83 & 13,90 & 8,70 & 9,72 & 9,20 & 7,90 & 8,00 \\
\hline $\mathbf{Y}$ & 19,00 & 30,22 & 2,78 & 30,40 & 17,83 & 57,90 & 25,59 & 20,42 & 32,60 & 33,90 & 35,20 \\
\hline $\mathrm{Nb}$ & 43,00 & 74,77 & 39,65 & 167,00 & $166,66 \mid$ & 191,40 & 121,31 & 161,90 & 158,40 & 146,60 & 110,20 \\
\hline Sc & 2,00 & 2,33 & $<1$ & 1,00 & 1,49 & 3,00 & 1,84 & 2,29 & 7,00 & 7,00 & 8,00 \\
\hline $\mathrm{Cr}$ & 2,00 & 0,51 & 0,37 & $<1$ & 2,94 & 2,00 & 3,30 & 2,43 & 1,00 & $<1$ & 1,00 \\
\hline $\mathrm{Ni}$ & $<0,5$ & $<0,5$ & $<0,5$ & $<0,5$ & $<0,5$ & 0,60 & 0,26 & 0,29 & 0,60 & $<0,5$ & 1,00 \\
\hline Sn & 4,60 & 6,46 & 0,52 & 3,50 & 4,58 & 7,00 & 3,40 & 3,50 & 5,00 & 3,90 & 3,10 \\
\hline Co & 1,00 & 0,25 & $<1$ & $<1$ & 0,02 & $<1$ & 0,30 & 0,23 & $<1$ & $<1$ & $<1$ \\
\hline v & 14,00 & 23,99 & 5,91 & 18,00 & 5,19 & $<10$ & 12,17 & 6,31 & $<10$ & $<10$ & 11,00 \\
\hline W & 9,90 & 3,43 & 1,45 & 1,10 & 2,11 & 1,50 & 2,72 & 0,78 & 1,50 & 0,70 & 2,30 \\
\hline Ga & & 17,56 & 36,85 & & 24,92 & & 19,88 & 22,01 & & & \\
\hline $\mathrm{Zn}$ & 66,00 & 103,10 & 63,02 & 113,00 & 110,38 & 93,00 & 94,01 & 77,26 & 108,00 & 96,00 & 92,00 \\
\hline $\mathrm{Cu}$ & 6,40 & 3,60 & 0,49 & 3,40 & 4,78 & 3,30 & 2,70 & 3,18 & 1,20 & $<0,5$ & 1,10 \\
\hline Mo & 48,60 & 3,07 & 3,24 & 1,00 & 8,53 & 2,70 & 11,78 & 0,73 & 1,30 & 0,60 & 2,40 \\
\hline Bi & $<0,5$ & 0,170 & 0,025 & $<0,5$ & 0,146 & $<0,5$ & 0,044 & 0,023 & $<0,5$ & $<0,5$ & $<0,5$ \\
\hline Cd & $<0,5$ & 0,613 & 0,101 & $<0,5$ & 0,105 & $<0,5$ & 0,109 & 0,052 & $<0,5$ & $<0,5$ & $<0,5$ \\
\hline Sb & $<0,5$ & 0,035 & 0,026 & $<0,5$ & 0,251 & $<0,5$ & 0,045 & 0,025 & $<0,5$ & $<0,5$ & $<0,5$ \\
\hline La & & 122,53 & 28,55 & & 89,33 & & 52,27 & 113,57 & & & \\
\hline $\mathrm{Ce}$ & & 256,84 & 24,39 & & 137,03 & & 116,79 & 128,11 & & & \\
\hline $\mathrm{Pr}$ & & 28,61 & 1,61 & & 13,77 & & 13,38 & 21,91 & & & \\
\hline Nd & & 113,24 & 3,56 & & 42,28 & & 52,35 & 74,36 & & & \\
\hline Sm & & 16,777 & 0,333 & & 5,289 & & 8,255 & 9,644 & & & \\
\hline Eu & & 5,659 & 0,166 & & 0,418 & & 1,619 & 0,622 & & & \\
\hline Gd & & 11,839 & 0,407 & & 4,247 & & 6,172 & 6,726 & & & \\
\hline Tb & & 1,386 & 0,040 & & 0,514 & & 0,848 & 0,821 & & & \\
\hline Dy & & 6,655 & 0,284 & & 3,035 & & 4,947 & 4,379 & & & \\
\hline Ho & & 1,125 & 0,072 & & 0,583 & & 0,930 & 0,807 & & & \\
\hline $\mathrm{Er}$ & & 2,806 & 0,297 & & 1,859 & & 2,530 & 2,247 & & & \\
\hline $\mathrm{Tm}$ & & 0,339 & 0,065 & & 0,299 & & 0,373 & 0,343 & & & \\
\hline$Y b$ & & 2,026 & 0,592 & & 2,100 & & 2,368 & 2,394 & & & \\
\hline Lu & & 0,283 & 0,120 & & 0,330 & & 0,349 & 0,385 & & & \\
\hline mg\# & 42,59 & 35,82 & 2,21 & 25,48 & 10,48 & 25,93 & 21,49 & 22,18 & 23,33 & 23,99 & 22,06 \\
\hline R1 & 329,67 & 453,64 & $-1019,67$ & 274,66 & 447,35 & 502,04 & 397,04 & 653,42 & 720,38 & 590,25 & 431,49 \\
\hline R2 & 472,51 & 607,87 & 511,22 & 543,69 & 380,85 & 478,45 & 458,17 & 421,01 & 428,26 & 426,03 & 445,93 \\
\hline IA & 0,91 & 0,85 & 0,98 & 0,89 & 1,02 & 0,94 & 0,95 & 0,95 & 0,97 & 0,99 & 0,98 \\
\hline A/NK & 1,09 & 1,18 & 1,02 & 1,12 & 0,98 & 1,07 & 1,05 & 1,05 & 1,04 & 1,01 & 1,02 \\
\hline A/CNK & 1,02 & 0,97 & 0,97 & 0,98 & 0,94 & 0,96 & 0,96 & 0,98 & 0,96 & 0,93 & 0,94 \\
\hline $\mathrm{K}_{2} \mathrm{O} / \mathrm{Na}_{2} \mathrm{O}$ & 1,86 & 1,68 & 0,66 & 1,16 & 0,89 & 1,19 & 1,25 & 1,11 & 1,16 & 1,03 & 1,07 \\
\hline $\mathrm{Nb} / \mathrm{Ta}$ & 17,92 & 14,31 & 44,75 & 17,58 & 58,99 & 13,77 & 13,95 & 16,66 & 17,22 & 18,56 & 13,78 \\
\hline $\mathrm{Zr} / \mathrm{Hf}$ & & 37,27 & 55,86 & & 31,23 & & 37,10 & 43,64 & & & \\
\hline $\mathrm{Eu} / \mathrm{Eu}^{*}$ & & 1,22 & 1,37 & & 0,27 & & 0,69 & 0,24 & & & \\
\hline (La/Lu)N & & 44,94 & 24,69 & & 28,10 & & 15,55 & 30,62 & & & \\
\hline $\mathbf{Q}$ & - & - & - & - & 1,43 & 1,20 & 0,00 & 3,85 & 5,11 & 3,18 & 0,68 \\
\hline C & 0,95 & 0,12 & - & - & - & - & - & - & - & - & - \\
\hline or & 49,81 & 44,85 & 36,75 & 40,48 & 35,16 & 39,41 & 42,07 & 37,58 & 38,23 & 36,87 & 38,65 \\
\hline$a b$ & 38,13 & 37,31 & 30,44 & 44,12 & 54,93 & 47,51 & 48,27 & 48,57 & 47,19 & 51,27 & 51,74 \\
\hline an & 1,81 & 7,50 & 1,45 & 5,64 & - & 3,01 & 2,26 & 2,25 & 1,59 & 0,24 & 1,09 \\
\hline ne & 0,01 & 0,39 & 26,47 & 3,23 & - & - & - & - & - & - & - \\
\hline Ic & - & - & - & - & - & - & - & - & - & - & - \\
\hline ac & - & - & - & - & 1,50 & - & - & - & - & - & - \\
\hline di & - & - & 1,40 & 0,26 & 1,45 & 0,83 & 0,86 & 0,18 & 1,21 & 2,27 & 1,83 \\
\hline hy & - & - & - & - & 1,80 & 2,23 & 1,33 & 2,80 & 1,95 & 1,52 & 1,25 \\
\hline ol & 1,90 & 2,64 & 0,58 & 1,94 & - & - & 0,48 & - & - & - & - \\
\hline mt & 1,06 & 1,42 & 0,79 & 1,28 & 0,24 & 1,27 & 1,24 & 1,28 & 1,26 & 1,21 & 1,17 \\
\hline il & 2,01 & 2,01 & 0,30 & 1,58 & 0,76 & 1,54 & 1,33 & 1,22 & 1,52 & 1,37 & 1,54 \\
\hline $\mathrm{hm}$ & - & - & - & - & - & - & - & - & - & - & - \\
\hline ap & 0,57 & 0,66 & - & 0,24 & 0,05 & 0,38 & 0,28 & 0,19 & 0,21 & 0,19 & 0,21 \\
\hline aq & 2,37 & 1,84 & 0,81 & 1,23 & 1,38 & 1,12 & 1,07 & 1,21 & 0,66 & 0,61 & 0,60 \\
\hline
\end{tabular}

Lab.: Laboratório utilizado nas análises dos elementos traço e ETRs: A- AcmeLabs, via ICP-AES/ICP-MS; B- UNICAMP, via ICP-MS; C- Geoanalítica-USP, via ICP-MS. Óxidos analisados via FRX pela Acmelabs, exceto nas amostras analisadas pela Geoanalítica-USP. 
ANEXO F - Tabela de composição química das rochas do Maciço Alcalino de Itatiaia. Continua..

\begin{tabular}{|c|c|c|c|c|c|c|c|c|c|c|c|}
\hline Amostra & MAI073 & MAI130 & MAI129 & MAI133 & MAI093 & MAI081 & MAI074 & MAI070B & MAI138II & MAI136 & MAI146C \\
\hline Unidade & QzAFS-I & Diq-Rto & Diq-Rto & QZAFS-II & QZAFS-II & QZAFS-II & Diq-Rto & $\mathrm{mA}$ & $\mathrm{N}-\mathrm{II}$ & $\mathrm{N}-\mathrm{II}$ & $\mathrm{N}-\mathrm{II}$ \\
\hline Lab. & A & B & A & B & A & A & A & B & A & B & A \\
\hline $\mathrm{SiO}_{2}$ & 64,60 & 73,14 & 67,99 & 66,64 & 65,50 & 64,48 & 72,49 & 70,47 & 62,59 & 61,80 & 63,61 \\
\hline $\mathrm{TiO}_{2}$ & 0,72 & 0,18 & 0,36 & 0,46 & 0,59 & 0,55 & 0,17 & 0,22 & 0,79 & 0,75 & 0,69 \\
\hline $\mathrm{Al}_{2} \mathrm{O}_{3}$ & 17,50 & 13,06 & 15,90 & 16,11 & 16,19 & 16,15 & 13,36 & 13,54 & 17,46 & 17,54 & 17,05 \\
\hline $\mathrm{Fe}_{2} \mathrm{O}_{3}$ & 2,25 & 1,81 & 2,13 & 2,83 & 2,91 & 2,79 & 2,25 & 2,17 & 3,05 & 2,75 & 2,91 \\
\hline MnO & 0,11 & & & 0,15 & 0,22 & 0,28 & 0,10 & 0,19 & 0,23 & 0,19 & 0,23 \\
\hline MgO & 0,22 & 0,06 & 0,08 & 0,15 & 0,34 & 0,20 & 0,06 & 0,19 & 0,51 & 0,53 & 0,44 \\
\hline $\mathrm{CaO}$ & 0,38 & 0,05 & & 0,17 & 0,38 & 0,50 & 0,15 & 0,46 & 0,47 & 1,04 & 0,78 \\
\hline $\mathrm{Na}_{2} \mathrm{O}$ & 5,90 & 3,57 & 5,49 & 5,83 & 5,75 & 5,63 & 4,95 & 4,27 & 5,85 & 5,63 & 6,01 \\
\hline $\mathrm{K}_{2} \mathrm{O}$ & 6,79 & 5,67 & 5,38 & 5,80 & 5,97 & 5,98 & 4,87 & 5,47 & 6,50 & 6,82 & 6,31 \\
\hline $\mathrm{P}_{2} \mathrm{O}_{5}$ & 0,07 & 0,02 & 0,03 & 0,06 & 0,08 & 0,07 & & 0,01 & 0,17 & 0,14 & 0,13 \\
\hline $\mathrm{SO}_{3}$ & 0,00 & & & 0,01 & & 0,02 & 0,00 & 0,01 & 0,00 & 0,01 & \\
\hline LOI & 0,68 & 1,16 & 1,14 & 1,00 & 0,74 & 2,00 & 0,56 & 1,70 & 1,02 & 2,20 & 0,88 \\
\hline Total & 99,54 & 98,80 & 98,69 & 99,43 & 98,89 & 98,85 & 99,15 & 98,82 & 98,78 & 99,52 & 99,22 \\
\hline$\overline{\mathrm{Li}}$ & 7,00 & 4,04 & 7,60 & 9,44 & 12,00 & 10,70 & 14,30 & 22,00 & 26,50 & 8,56 & 15,10 \\
\hline Cs & & 1,02 & & 0,98 & & & & 2,79 & & 0,83 & \\
\hline $\mathbf{R b}$ & 142,80 & 263,00 & 212,20 & 143,97 & 161,60 & 207,60 & 255,50 & 334,75 & 152,40 & 106,87 & 161,00 \\
\hline Ba & $<5$ & 0,10 & $<5$ & 2,59 & 12,00 & 14,00 & $<5$ & 18,80 & 134,00 & 59,04 & 100,00 \\
\hline $\mathrm{Be}$ & $<5$ & 4,18 & $<5$ & 2,99 & $<5$ & $<5$ & $<5$ & 6,55 & $<5$ & 2,24 & $<5$ \\
\hline Sr & $<5$ & 0,27 & 6,00 & 3,74 & 9,00 & 21,00 & 6,00 & 21,14 & 182,00 & 114,96 & 136,00 \\
\hline $\mathrm{Pb}$ & 12,20 & 5,04 & 18,00 & 9,35 & 16,80 & 12,10 & 37,10 & 23,33 & 13,40 & 11,21 & 18,90 \\
\hline Th & 13,80 & 0,85 & 27,70 & 11,45 & 17,50 & 25,80 & 37,40 & 32,94 & 13,60 & 10,37 & 15,20 \\
\hline U & 2,00 & 6,17 & 4,00 & 3,41 & 2,00 & 5,30 & 10,60 & 11,57 & 2,20 & 2,70 & 2,80 \\
\hline $\mathrm{Zr}$ & & 467,78 & & 759,87 & & & & 429,46 & & 429,02 & \\
\hline $\mathrm{Hf}$ & & 16,80 & & 18,30 & & & & 15,58 & & 10,46 & \\
\hline Ta & 5,60 & 17,20 & 15,10 & 3,86 & 8,60 & 13,70 & 16,00 & 12,43 & 5,50 & 6,89 & 7,10 \\
\hline Y & 30,80 & 1,75 & 32,70 & 19,24 & 22,00 & 35,90 & 69,10 & 42,46 & 50,40 & 29,19 & 29,50 \\
\hline $\mathrm{Nb}$ & 107,80 & 248,39 & 274,20 & 141,63 & 143,30 & 217,10 & 241,50 & 244,26 & 117,90 & 102,79 & 146,30 \\
\hline Sc & 5,00 & 0,41 & 3,00 & 2,79 & 8,00 & 5,00 & 2,00 & 1,45 & 4,00 & 2,81 & 4,00 \\
\hline $\mathrm{Cr}$ & $<1$ & 2,42 & 2,00 & $<1$ & 2,00 & 2,00 & 1,00 & 0,53 & 2,00 & 0,73 & 3,00 \\
\hline $\mathbf{N i}$ & $<0,5$ & $<0,5$ & 0,90 & $<0,5$ & $<0,5$ & 0,70 & $<0,5$ & $<0,5$ & $<0,5$ & $<0,5$ & 0,70 \\
\hline Sn & 2,70 & 7,99 & 7,70 & 3,82 & 3,90 & 4,40 & 10,10 & 7,00 & 3,00 & 2,80 & 3,90 \\
\hline Co & $<1$ & $<1$ & $<1$ & 0,08 & $<1$ & $<1$ & $<1$ & 0,13 & $<1$ & $<1$ & $<1$ \\
\hline V & $<10$ & 2,64 & $<10$ & 3,42 & $<10$ & $<10$ & $<10$ & 2,76 & $<10$ & 5,24 & $<10$ \\
\hline W & 9,70 & 3,14 & 1,60 & 1,45 & 0,60 & 1,40 & 2,10 & 11,35 & 0,70 & 1,82 & 0,60 \\
\hline Ga & & 20,64 & & 21,89 & & & & 23,67 & & 18,77 & \\
\hline $\mathrm{Zn}$ & 68,00 & 34,40 & 27,00 & 89,39 & 116,00 & 152,00 & 218,00 & 130,65 & 114,00 & 91,28 & 112,00 \\
\hline $\mathrm{Cu}$ & 0,60 & 0,92 & 3,40 & 1,81 & 0,90 & $<0,5$ & 1,20 & 2,51 & 2,70 & 2,61 & 2,90 \\
\hline Mo & 0,90 & 0,85 & $<0,5$ & 0,89 & $<0,5$ & 2,10 & 1,40 & 3,60 & 0,70 & 0,53 & 0,60 \\
\hline Bi & $<0,5$ & 0,329 & $<0,5$ & 0,097 & $<0,5$ & $<0,5$ & $<0,5$ & 0,241 & $<0,5$ & 0,056 & $<0,5$ \\
\hline Cd & $<0,5$ & $<0,5$ & $<0,5$ & 0,117 & $<0,5$ & $<0,5$ & $<0,5$ & 0,377 & $<0,5$ & 0,110 & $<0,5$ \\
\hline Sb & $<0,5$ & 0,300 & $<0,5$ & 0,063 & $<0,5$ & $<0,5$ & $<0,5$ & 0,301 & $<0,5$ & 0,096 & $<0,5$ \\
\hline La & & 1,15 & & 76,60 & & & & 78,36 & & 102,82 & \\
\hline $\mathrm{Ce}$ & & 6,55 & & 79,80 & & & & 156,21 & & 192,56 & \\
\hline $\mathrm{Pr}$ & & 0,21 & & 14,45 & & & & 16,86 & & 22,22 & \\
\hline Nd & & 0,80 & & 51,22 & & & & 57,22 & & 80,46 & \\
\hline Sm & & 0,157 & & 7,189 & & & & 10,078 & & 11,658 & \\
\hline Eu & & 0,008 & & 0,231 & & & & 0,256 & & 2,508 & \\
\hline Gd & & 0,153 & & 5,266 & & & & 7,621 & & 8,543 & \\
\hline Tb & & 0,026 & & 0,681 & & & & 1,205 & & 1,064 & \\
\hline Dy & & 0,201 & & 3,682 & & & & 7,565 & & 5,894 & \\
\hline Ho & & 0,046 & & 0,691 & & & & 1,495 & & 1,090 & \\
\hline Er & & 0,177 & & 1,907 & & & & 4,422 & & 2,975 & \\
\hline $\mathrm{Tm}$ & & 0,044 & & 0,279 & & & & 0,715 & & 0,420 & \\
\hline Yb & & 0,340 & & 1,931 & & & & 4,895 & & 2,714 & \\
\hline Lu & & 0,064 & & 0,315 & & & & 0,740 & & 0,404 & \\
\hline mg\# & 16,23 & 6,16 & 6,93 & 9,50 & 18,80 & 12,44 & 5,02 & 14,78 & 24,89 & 27,63 & 23,05 \\
\hline R1 & 545,84 & 2227,47 & 1258,35 & 929,67 & 837,22 & 813,59 & 1870,43 & 1837,96 & 475,73 & 435,01 & 537,22 \\
\hline R2 & 394,91 & 264,56 & 315,92 & 341,70 & 375,16 & 380,27 & 281,14 & 324,29 & 418,14 & 481,69 & 439,79 \\
\hline IA & 0,97 & 0,92 & 0,93 & 0,99 & 0,98 & 0,97 & 1,00 & 0,96 & 0,95 & 0,95 & 0,98 \\
\hline A/NK & 1,03 & 1,09 & 1,07 & 1,02 & 1,02 & 1,03 & 1,00 & 1,05 & 1,05 & 1,05 & 1,02 \\
\hline A/CNK & 0,99 & 1,08 & 1,07 & 1,00 & 0,97 & 0,97 & 0,98 & 0,98 & 1,00 & 0,95 & 0,94 \\
\hline $\mathrm{K}{ }_{2} \mathrm{O} / \mathrm{Na}_{2} \mathrm{O}$ & 1,15 & 1,59 & 0,98 & 0,99 & 1,04 & 1,06 & 0,98 & 1,28 & 1,11 & 1,21 & 1,05 \\
\hline $\mathrm{Nb} / \mathrm{Ta}$ & 19,25 & 14,44 & 18,16 & 36,74 & 16,66 & 15,85 & 15,09 & 19,65 & 21,44 & 14,92 & 20,61 \\
\hline $\mathrm{Zr} / \mathrm{Hf}$ & & 27,85 & & 41,52 & & & & 27,56 & & 41,03 & \\
\hline Eu/Eu* & & 0,16 & & 0,11 & & & & 0,09 & & 0,77 & \\
\hline (La/Lu)N & & 1,87 & & 25,24 & & & & 10,99 & & 26,42 & \\
\hline $\mathbf{Q}$ & 2,95 & 29,95 & 14,85 & 9,22 & 7,34 & 6,98 & 24,00 & 22,74 & 1,59 & 0,04 & 2,16 \\
\hline C & - & 1,01 & 1,12 & 0,08 & - & - & - & - & 0,36 & - & - \\
\hline or & 40,12 & 33,50 & 31,79 & 34,27 & 35,28 & 35,34 & 28,78 & 32,32 & 38,41 & 40,30 & 37,29 \\
\hline ab & 49,91 & 30,21 & 46,45 & 49,30 & 48,65 & 47,54 & 41,60 & 36,10 & 49,47 & 47,60 & 50,85 \\
\hline an & 1,22 & 0,12 & - & 0,45 & 0,73 & 1,19 & - & 1,64 & 1,22 & 2,47 & 0,91 \\
\hline ne & - & - & - & - & - & - & - & - & - & - & - \\
\hline Ic & - & - & - & - & - & - & - & - & - & - & - \\
\hline ac & - & - & - & - & - & - & 0,23 & - & - & - & - \\
\hline di & 0,18 & - & - & - & 0,54 & 0,72 & 0,66 & 0,50 & - & 1,48 & 1,78 \\
\hline hy & 1,46 & 1,45 & 1,49 & 2,39 & 2,58 & 2,20 & 1,76 & 2,12 & 3,09 & 2,13 & 2,06 \\
\hline ol & - & - & - & - & - & - & - & - & - & - & - \\
\hline mt & 1,01 & 0,81 & 0,96 & 1,27 & 1,31 & 1,26 & 0,90 & 0,98 & 1,37 & 1,24 & 1,31 \\
\hline il & 1,37 & 0,34 & 0,68 & 0,87 & 1,12 & 1,04 & 0,32 & 0,42 & 1,50 & 1,42 & 1,31 \\
\hline hm & - & - & - & - & - & - & - & - & - & - & - \\
\hline ap & 0,17 & 0,05 & 0,07 & 0,14 & 0,19 & 0,17 & - & 0,02 & 0,40 & 0,33 & 0,31 \\
\hline$a q$ & 0,68 & 1,16 & 1,14 & 1,00 & 0,74 & 2,00 & 0,56 & 1,70 & 1,02 & 2,20 & 0,88 \\
\hline
\end{tabular}

Lab.: Laboratório utilizado nas análises dos elementos traço e ETRs: A- AcmeLabs, via ICP-AES/ICP-MS; B- UNICAMP, via ICP-MS; C- Geoanalítica-USP, via ICP-MS. Óxidos analisados via FRX pela Acmelabs, exceto nas amostras analisadas pela Geoanalítica-USP. 
ANEXO F - Tabela de composição química das rochas do Maciço Alcalino de Itatiaia. Continua..

\begin{tabular}{|c|c|c|c|c|c|c|c|c|c|c|c|}
\hline Amostra & MAl189 & MAI154 & MAI137 & MAI108II & MAI118B & MAI122 & MAl120 & MAI087 & MAl112B & MAI113II & MAl144 \\
\hline Unidade & arpk-QzS & arpk-QzS & arpk-QzS & arpk-QzS & $\mathrm{T}-\mathrm{I}$ & $T-1$ & $T-1$ & $\mathrm{~T}-\mathrm{I}$ & $\mathrm{T}-\mathrm{I}$ & $\mathrm{T}-\mathrm{I}$ & $T-1$ \\
\hline Lab. & A & A & A & B & A & B & A & A & B & A & A \\
\hline $\mathrm{SiO}_{2}$ & 58,30 & 62,49 & 62,86 & 63,53 & 60,26 & 60,99 & 62,67 & 62,58 & 64,93 & 63,45 & 59,59 \\
\hline $\mathrm{TiO}_{2}$ & 1,08 & 0,79 & 0,85 & 0,67 & 0,94 & 0,77 & 0,71 & 0,82 & 0,61 & 0,80 & 1,14 \\
\hline $\mathrm{Al}_{2} \mathrm{O}_{3}$ & 17,99 & 16,83 & 17,12 & 16,76 & 17,85 & 17,50 & 17,69 & 18,31 & 16,79 & 18,04 & 18,85 \\
\hline $\mathrm{Fe}_{2} \mathrm{O}_{3}$ & 5,02 & 3,76 & 3,60 & 3,18 & 4,19 & 3,39 & 3,16 & 3,62 & 2,85 & 2,78 & 2,96 \\
\hline MnO & 0,18 & 0,19 & 0,14 & 0,13 & 0,18 & 0,16 & 0,15 & 0,21 & 0,13 & 0,22 & 0,10 \\
\hline MgO & 1,40 & 0,81 & 0,85 & 0,71 & 0,88 & 0,81 & 0,71 & 0,66 & 0,42 & 0,45 & 0,75 \\
\hline $\mathrm{CaO}$ & 2,89 & 1,52 & 2,11 & 1,71 & 2,29 & 1,90 & 1,34 & 0,96 & 0,92 & 0,89 & 1,47 \\
\hline $\mathrm{Na}_{2} \mathrm{O}$ & 4,99 & 5,06 & 5,00 & 5,06 & 5,06 & 4,94 & 4,51 & 4,25 & 5,24 & 4,73 & 4,39 \\
\hline $\mathrm{K}_{2} \mathrm{O}$ & 5,71 & 6,33 & 6,28 & 6,10 & 5,99 & 6,55 & 6,94 & 6,28 & 6,62 & 6,64 & 8,12 \\
\hline $\mathrm{P}_{2} \mathrm{O}_{5}$ & 0,51 & 0,25 & 0,33 & 0,22 & 0,41 & 0,24 & 0,18 & 0,17 & 0,12 & 0,11 & 0,37 \\
\hline $\mathrm{SO}_{3}$ & 0,01 & 0,01 & & 0,00 & 0,01 & 0,01 & & 0,01 & & 0,00 & 0,01 \\
\hline LOI & 0,72 & 0,61 & 1,50 & 0,85 & 0,89 & 1,73 & 0,51 & 1,43 & 0,66 & 0,89 & 1,10 \\
\hline Total & 99,41 & 98,90 & 100,98 & 99,28 & 99,43 & 99,30 & 98,91 & 99,58 & 99,49 & 99,19 & 99,03 \\
\hline$\overline{\mathrm{Li}}$ & 11,50 & 20,60 & 13,60 & 26,19 & 21,20 & 14,10 & 31,10 & 15,10 & 14,97 & 19,70 & 4,10 \\
\hline Cs & & & & 2,01 & & 2,07 & & & 2,91 & & \\
\hline $\mathbf{R b}$ & 135,20 & 172,70 & 139,60 & 137,43 & 146,60 & 90,68 & 211,00 & 160,60 & 144,37 & 226,10 & 92,80 \\
\hline Ba & 2068,00 & 654,00 & 1026,00 & 1153,78 & 1589,00 & 630,69 & 641,00 & 485,00 & 244,73 & 153,00 & 282,00 \\
\hline $\mathrm{Be}$ & $<5$ & $<5$ & $<5$ & 3,66 & $<5$ & 4,12 & $<5$ & $<5$ & 3,04 & $<5$ & $<5$ \\
\hline Sr & 2303,00 & 510,00 & 1309,00 & 694,04 & 1852,00 & 422,27 & 864,00 & 474,00 & 143,88 & 223,00 & 707,00 \\
\hline $\mathrm{Pb}$ & 20,40 & 23,40 & 15,10 & 12,87 & 15,60 & 11,30 & 36,50 & 17,60 & 15,28 & 125,40 & 11,60 \\
\hline Th & 10,80 & 18,00 & 9,30 & 21,94 & 14,30 & 13,16 & 22,10 & 17,10 & 24,35 & 20,60 & 6,00 \\
\hline U & 2,20 & 3,80 & 2,00 & 5,26 & 2,90 & 4,51 & 2,90 & 2,20 & 5,00 & 3,40 & 1,30 \\
\hline $\mathrm{Zr}$ & & & & 389,67 & & 527,91 & & & 554,58 & & \\
\hline $\mathrm{Hf}$ & & & & 10,78 & & 13,43 & & & 14,18 & & \\
\hline Ta & 4,90 & 6,50 & 3,20 & 6,97 & 5,70 & 8,22 & 9,70 & 8,60 & 7,58 & 10,40 & 3,40 \\
\hline Y & 23,90 & 36,90 & 25,20 & 30,15 & 36,60 & 31,30 & 28,40 & 27,30 & 28,25 & 38,90 & 19,40 \\
\hline $\mathrm{Nb}$ & 95,60 & 115,90 & 59,50 & 102,24 & 96,70 & 126,77 & 158,00 & 130,80 & 127,29 & 175,10 & 62,20 \\
\hline Sc & 5,00 & 5,00 & 4,00 & 3,47 & 5,00 & 1,39 & 4,00 & 4,00 & 3,36 & 3,00 & 4,00 \\
\hline $\mathrm{Cr}$ & $<1$ & 2,00 & 3,00 & 1,44 & 2,00 & 1,69 & 3,00 & 1,00 & 0,92 & 3,00 & 3,00 \\
\hline $\mathbf{N i}$ & 0,50 & $<0,5$ & 0,70 & $<0,5$ & $<0,5$ & $<0,5$ & $<0,5$ & 1,00 & $<0,5$ & $<0,5$ & 1,50 \\
\hline Sn & 3,70 & 3,10 & 2,20 & 3,87 & 2,00 & 3,33 & 4,80 & 4,00 & 3,17 & 3,10 & 1,40 \\
\hline Co & $<1$ & 2,00 & 1,00 & 1,92 & 2,00 & 0,66 & 1,00 & 1,00 & 0,68 & $<1$ & 2,00 \\
\hline V & 34,00 & 14,00 & 12,00 & 24,85 & 21,00 & 15,60 & 14,00 & 19,00 & 8,84 & 13,00 & 18,00 \\
\hline W & 2,60 & 1,90 & 0,70 & 1,38 & 1,30 & 2,64 & 2,60 & 1,80 & 1,69 & 1,50 & $<0,5$ \\
\hline Ga & & & & 19,82 & & 21,44 & & & 22,51 & & \\
\hline $\mathrm{Zn}$ & 64,00 & 132,00 & 88,00 & 78,92 & 146,00 & 83,37 & 97,00 & 133,00 & 68,61 & 167,00 & 80,00 \\
\hline $\mathrm{Cu}$ & 2,30 & 4,20 & 3,70 & 3,89 & 3,50 & 3,02 & 8,10 & 1,30 & 2,56 & 3,40 & 4,70 \\
\hline Mo & 4,50 & 2,20 & 3,00 & 1,24 & 1,30 & 2,34 & 1,90 & 2,30 & 3,89 & 2,80 & 1,10 \\
\hline $\mathrm{Bi}$ & $<0,5$ & $<0,5$ & $<0,5$ & 0,250 & $<0,5$ & 0,018 & $<0,5$ & $<0,5$ & 0,044 & $<0,5$ & $<0,5$ \\
\hline Cd & $<0,5$ & $<0,5$ & $<0,5$ & 0,070 & $<0,5$ & 0,195 & $<0,5$ & $<0,5$ & 0,040 & $<0,5$ & $<0,5$ \\
\hline Sb & $<0,5$ & $<0,5$ & $<0,5$ & 0,068 & $<0,5$ & 0,131 & $<0,5$ & $<0,5$ & 0,023 & $<0,5$ & $<0,5$ \\
\hline La & & & & 97,60 & & 103,28 & & & 135,61 & & \\
\hline $\mathrm{Ce}$ & & & & 188,85 & & 191,77 & & & 236,33 & & \\
\hline $\mathrm{Pr}$ & & & & 19,77 & & 21,57 & & & 26,82 & & \\
\hline Nd & & & & 70,31 & & 79,67 & & & 90,19 & & \\
\hline Sm & & & & 10,694 & & 11,699 & & & 12,390 & & \\
\hline Eu & & & & 2,544 & & 3,267 & & & 1,471 & & \\
\hline Gd & & & & 7,883 & & 8,575 & & & 8,993 & & \\
\hline Tb & & & & 1,038 & & 1,078 & & & 1,080 & & \\
\hline Dy & & & & 5,782 & & 5,902 & & & 5,675 & & \\
\hline Ho & & & & 1,087 & & 1,078 & & & 1,041 & & \\
\hline Er & & & & 3,003 & & 2,989 & & & 2,920 & & \\
\hline Tm & & & & 0,437 & & 0,427 & & & 0,443 & & \\
\hline Yb & & & & 2,847 & & 2,815 & & & 2,924 & & \\
\hline Lu & & & & 0,445 & & 0,429 & & & 0,470 & & \\
\hline mg\# & 35,59 & 29,91 & 31,87 & 30,67 & 29,38 & 32,13 & 30,80 & 26,54 & 22,60 & 24,28 & 33,42 \\
\hline R1 & 623,31 & 771,40 & 831,51 & 911,88 & 687,84 & 672,53 & 853,18 & 1079,34 & 829,50 & 904,34 & 409,41 \\
\hline R2 & 731,62 & 533,01 & 603,81 & 547,00 & 638,87 & 586,81 & 525,66 & 494,69 & 448,68 & 471,48 & 564,31 \\
\hline IA & 0,80 & 0,90 & 0,88 & 0,89 & 0,83 & 0,87 & 0,84 & 0,75 & 0,94 & 0,83 & 0,85 \\
\hline A/NK & 1,25 & 1,11 & 1,14 & 1,12 & 1,21 & 1,15 & 1,18 & 1,33 & 1,06 & 1,21 & 1,18 \\
\hline A/CNK & 0,92 & 0,94 & 0,91 & 0,93 & 0,94 & 0,94 & 1,02 & 1,18 & 0,96 & 1,09 & 1,01 \\
\hline $\mathrm{K}{ }_{2} \mathrm{O} / \mathrm{Na}_{2} \mathrm{O}$ & 1,14 & 1,25 & 1,26 & 1,21 & 1,18 & 1,33 & 1,54 & 1,48 & 1,26 & 1,40 & 1,85 \\
\hline $\mathrm{Nb} / \mathrm{Ta}$ & 19,51 & 17,83 & 18,59 & 14,66 & 16,96 & 15,41 & 16,29 & 15,21 & 16,79 & 16,84 & 18,29 \\
\hline $\mathrm{Zr} / \mathrm{Hf}$ & & & & 36,16 & & 39,30 & & & 39,10 & & \\
\hline Eu/Eu* & & & & 0,84 & & 0,99 & & & 0,42 & & \\
\hline (La/Lu)N & & & & 22,77 & & 24,99 & & & 29,95 & & \\
\hline $\mathbf{Q}$ & 0,00 & 4,32 & 4,52 & 6,23 & 1,82 & 2,05 & 5,60 & 10,27 & 6,29 & 7,58 & 0,00 \\
\hline C & - & - & - & - & - & - & 0,75 & 3,19 & - & 1,72 & 1,06 \\
\hline or & 33,74 & 37,40 & 37,11 & 36,05 & 35,40 & 38,70 & 41,01 & 37,11 & 39,12 & 39,24 & 47,98 \\
\hline ab & 42,18 & 42,78 & 42,31 & 42,79 & 42,78 & 41,75 & 38,16 & 35,93 & 44,34 & 39,99 & 37,11 \\
\hline an & 9,85 & 4,53 & 5,72 & 5,02 & 8,32 & 6,26 & 5,47 & 3,65 & 2,74 & 3,70 & 4,88 \\
\hline ne & - & - & - & - & - & - & - & - & - & - & - \\
\hline Ic & - & - & - & - & - & - & - & - & - & - & - \\
\hline ac & - & - & - & - & - & - & - & - & - & - & - \\
\hline di & 0,95 & 1,15 & 2,14 & 1,69 & 0,30 & 1,33 & - & - & 0,88 & - & - \\
\hline hy & 4,15 & 3,82 & 3,09 & 2,88 & 4,52 & 3,38 & 3,67 & 3,88 & 2,36 & 2,66 & 0,48 \\
\hline ol & 1,36 & - & - & - & - & - & - & - & - & - & 1,67 \\
\hline mt & 2,26 & 1,69 & 1,62 & 1,43 & 1,89 & 1,53 & 1,42 & 1,63 & 1,28 & 1,25 & 1,33 \\
\hline il & 2,05 & 1,50 & 1,61 & 1,27 & 1,79 & 1,46 & 1,35 & 1,56 & 1,16 & 1,52 & 2,17 \\
\hline hm & - & - & - & - & - & - & - & - & - & - & - \\
\hline ap & 1,21 & 0,59 & 0,78 & 0,52 & 0,97 & 0,57 & 0,43 & 0,40 & 0,28 & 0,26 & 0,88 \\
\hline$a q$ & 0,72 & 0,61 & 1,50 & 0,85 & 0,89 & 1,73 & 0,51 & 1,43 & 0,66 & 0,89 & 1,10 \\
\hline
\end{tabular}

Lab.: Laboratório utilizado nas análises dos elementos traço e ETRs: A- AcmeLabs, via ICP-AES/ICP-MS; B- UNICAMP, via ICP-MS; C- Geoanalítica-USP, via ICP-MS. Óxidos analisados via FRX pela Acmelabs, exceto nas amostras analisadas pela Geoanalítica-USP. 
ANEXO F - Tabela de composição química das rochas do Maciço Alcalino de Itatiaia. Continua..

\begin{tabular}{|c|c|c|c|c|c|c|c|c|c|c|c|}
\hline Amostra & MAl150B & MAl115II & MAI182C & MAI155 & MAI163 & MAI190 & MAl107 & MAI160 & MAI178 & MAI180 & MAI174B \\
\hline Unidade & $T-I$ & $\mathrm{~T}-\mathrm{I}$ & BtM & $\mathrm{N}-\mathrm{III}$ & $\mathrm{N}-\mathrm{III}$ & HblP & HblP & $\mathrm{HblP}$ & MG-mts & NeS-II & $\mathrm{NeS}-\mathrm{II}$ \\
\hline Lab. & A & A & B & A & B & A & B & B & B & A & A \\
\hline$\overline{\mathrm{SiO}_{2}}$ & 61,48 & 62,68 & 54,55 & 61,76 & 61,48 & 60,44 & 59,52 & 58,73 & 46,87 & 60,69 & 61,78 \\
\hline $\mathrm{TiO}_{2}$ & 1,00 & 0,93 & 1,65 & 0,75 & 0,66 & 0,58 & 0,80 & 0,62 & 2,94 & 0,72 & 0,67 \\
\hline $\mathrm{Al}_{2} \mathrm{O}_{3}$ & 19,10 & 18,36 & 17,29 & 18,28 & 18,16 & 18,45 & 18,23 & 19,47 & 12,34 & 18,44 & 17,88 \\
\hline $\mathrm{Fe}_{2} \mathrm{O}_{3}$ & 2,44 & 1,05 & 6,74 & 2,70 & 2,96 & 3,00 & 3,70 & 2,97 & 16,18 & 2,43 & 2,77 \\
\hline $\mathrm{MnO}$ & 0,17 & 0,17 & 0,16 & 0,21 & 0,21 & 0,14 & 0,16 & 0,14 & 0,24 & 0,18 & 0,23 \\
\hline MgO & 0,57 & 0,26 & 2,18 & 0,40 & 0,45 & 0,74 & 0,95 & 0,66 & 4,59 & 0,38 & 0,43 \\
\hline $\mathrm{CaO}$ & 0,67 & 0,48 & 4,23 & 0,56 & 0,50 & 1,47 & 1,71 & 2,07 & 8,23 & 1,25 & 0,98 \\
\hline $\mathrm{Na}_{2} \mathrm{O}$ & 4,16 & 5,12 & 4,60 & 5,15 & 5,40 & 5,74 & 5,43 & 6,42 & 3,95 & 6,05 & 7,18 \\
\hline $\mathrm{K}_{2} \mathrm{O}$ & 9,37 & 8,27 & 5,22 & 7,13 & 6,66 & 7,19 & 7,25 & 6,21 & 2,24 & 6,78 & 5,67 \\
\hline $\mathrm{P}_{2} \mathrm{O}_{5}$ & 0,16 & 0,14 & 0,96 & 0,08 & 0,08 & 0,20 & 0,25 & 0,23 & 0,42 & 0,08 & 0,08 \\
\hline $\mathrm{SO}_{3}$ & 0,01 & 0,02 & 0,00 & 0,00 & 0,00 & 0,02 & 0,02 & 0,01 & 0,04 & 0,05 & 0,10 \\
\hline LOI & 1,00 & 1,11 & 0,52 & 2,03 & 2,30 & 1,05 & 0,82 & 1,08 & 1,04 & 1,49 & 0,79 \\
\hline Total & 100,29 & 98,71 & 98,82 & 99,12 & 99,04 & 99,15 & 98,95 & 99,14 & 99,32 & 98,81 & 98,69 \\
\hline$\overline{L i}$ & 27,20 & 6,60 & 15,97 & 6,60 & 13,22 & 14,00 & 8,88 & 49,07 & 117,69 & 43,30 & 26,60 \\
\hline Cs & & & 1,15 & & 0,98 & & 1,11 & 3,66 & 10,14 & & \\
\hline $\mathbf{R b}$ & 223,40 & 170,60 & 93,16 & 126,90 & 112,34 & 110,00 & 68,95 & 116,64 & 118,91 & 177,20 & 141,90 \\
\hline Ba & 78,00 & 22,00 & 2736,06 & 47,00 & 6,74 & 257,00 & 64,18 & 1390,66 & 378,14 & 225,00 & 13,00 \\
\hline $\mathrm{Be}$ & $<5$ & $<5$ & 1,12 & $<5$ & 3,56 & $<5$ & 1,30 & 4,18 & 7,04 & $<5$ & $<5$ \\
\hline $\mathrm{Sr}$ & 223,00 & 53,00 & 2355,82 & 44,00 & 3,89 & 381,00 & 144,87 & 1822,13 & 156,41 & 357,00 & 32,00 \\
\hline $\mathrm{Pb}$ & 20,40 & 22,70 & 12,44 & 11,50 & 4,21 & 14,00 & 6,20 & 17,44 & 20,24 & 26,20 & 16,40 \\
\hline Th & 13,40 & 11,50 & 3,86 & 6,50 & 6,60 & 5,30 & 4,20 & 19,04 & 5,64 & 25,70 & 13,50 \\
\hline U & 2,20 & 2,40 & 0,92 & 1,70 & 2,27 & 1,30 & 1,22 & 5,07 & 1,93 & 6,00 & 4,40 \\
\hline $\mathrm{Zr}$ & & & 192,21 & & 551,24 & & 196,96 & 435,12 & 231,75 & & \\
\hline $\mathrm{Hf}$ & & & 5,04 & & 14,31 & & 4,87 & 10,78 & 6,48 & & \\
\hline Ta & 7,80 & 4,70 & 4,01 & 3,90 & 12,03 & 3,40 & 4,44 & 8,13 & 1,24 & 9,50 & 9,20 \\
\hline $\mathbf{Y}$ & 35,10 & 21,60 & 33,41 & 13,20 & 6,80 & 13,30 & 15,36 & 18,77 & 138,46 & 44,60 & 34,20 \\
\hline $\mathbf{N b}$ & 132,80 & 82,60 & 64,32 & 70,60 & 153,28 & 62,50 & 64,31 & 134,84 & 17,90 & 191,90 & 153,60 \\
\hline Sc & 2,00 & 3,00 & 6,96 & 4,00 & 0,45 & 2,00 & 1,18 & 1,77 & 36,89 & $<1$ & 2,00 \\
\hline $\mathrm{Cr}$ & 3,00 & 3,00 & 1,29 & 1,00 & 2,24 & 3,00 & $<1$ & 2,52 & 49,04 & $<1$ & $<1$ \\
\hline $\mathrm{Ni}$ & $<0,5$ & $<0,5$ & $<0,5$ & $<0,5$ & 0,67 & 0,50 & $<0,5$ & $<0,5$ & 60,46 & $<0,5$ & $<0,5$ \\
\hline Sn & 2,50 & 2,20 & 1,53 & 1,90 & 4,20 & 1,60 & 1,74 & 2,56 & 3,46 & 3,90 & 3,90 \\
\hline Co & $<1$ & $<1$ & 8,43 & $<1$ & 0,54 & $<1$ & 0,86 & 1,32 & 43,92 & $<1$ & $<1$ \\
\hline v & 13,00 & $<10$ & 82,89 & $<10$ & 13,55 & 11,00 & 18,21 & 19,78 & 388,11 & $<10$ & $<10$ \\
\hline w & 1,10 & 4,00 & 0,39 & 0,60 & 2,11 & $<0,5$ & 0,53 & 3,12 & 3,74 & 1,70 & 2,20 \\
\hline Ga & & & 20,96 & & 22,65 & & 16,88 & 19,72 & 20,90 & & \\
\hline $\mathrm{Zn}$ & 135,00 & 37,00 & 116,39 & 82,00 & 64,43 & 74,00 & 58,96 & 73,51 & 198,16 & 115,00 & 125,00 \\
\hline $\mathrm{Cu}$ & 2,30 & 3,20 & 6,91 & 3,40 & 2,54 & 1,80 & 3,16 & 4,82 & 341,59 & 2,50 & 2,10 \\
\hline Mo & 2,60 & 8,40 & 1,90 & 0,60 & 0,48 & 1,40 & 1,67 & 6,31 & 4,82 & 2,60 & 3,00 \\
\hline $\mathbf{B i}$ & $<0,5$ & $<0,5$ & 0,015 & $<0,5$ & 0,069 & $<0,5$ & 0,043 & 0,112 & 0,392 & $<0,5$ & $<0,5$ \\
\hline Cd & $<0,5$ & $<0,5$ & 0,109 & $<0,5$ & 0,088 & $<0,5$ & 0,112 & 0,099 & 1,844 & $<0,5$ & $<0,5$ \\
\hline Sb & $<0,5$ & $<0,5$ & 0,032 & $<0,5$ & 0,058 & $<0,5$ & 0,067 & 0,226 & 0,090 & $<0,5$ & $<0,5$ \\
\hline La & & & 105,11 & & 30,76 & & 59,23 & 77,71 & 88,46 & & \\
\hline $\mathrm{Ce}$ & & & 216,54 & & 66,26 & & 112,00 & 137,40 & 82,92 & & \\
\hline $\mathrm{Pr}$ & & & 23,17 & & 5,52 & & 12,14 & 14,00 & 21,38 & & \\
\hline Nd & & & 90,50 & & 18,67 & & 46,39 & 48,13 & 92,37 & & \\
\hline Sm & & & 14,331 & & 2,330 & & 7,030 & 6,838 & 20,749 & & \\
\hline Eu & & & 4,949 & & 0,191 & & 2,321 & 3,068 & 5,043 & & \\
\hline Gd & & & 10,535 & & 1,881 & & 5,041 & 5,375 & 22,484 & & \\
\hline Tb & & & 1,315 & & 0,224 & & 0,620 & 0,671 & 3,613 & & \\
\hline Dy & & & 6,885 & & 1,235 & & 3,172 & 3,688 & 22,930 & & \\
\hline Ho & & & 1,232 & & 0,241 & & 0,558 & 0,677 & 4,510 & & \\
\hline $\mathrm{Er}$ & & & 3,167 & & 0,726 & & 1,464 & 1,931 & 11,406 & & \\
\hline $\mathrm{Tm}$ & & & 0,421 & & 0,107 & & 0,191 & 0,289 & 1,511 & & \\
\hline Yb & & & 2,586 & & 0,742 & & 1,201 & 1,888 & 9,016 & & \\
\hline Lu & & & 0,377 & & 0,124 & & 0,178 & 0,289 & 1,340 & & \\
\hline mg\# & 31,64 & 32,91 & 39,06 & 22,69 & 23,15 & 32,83 & 33,72 & 30,57 & 35,98 & 23,65 & 23,52 \\
\hline R1 & 341,45 & 374,05 & 569,21 & 531,58 & 529,71 & 217,01 & 228,76 & 90,44 & 715,93 & 230,15 & 153,58 \\
\hline R2 & 474,69 & 424,47 & 899,95 & 438,40 & 432,11 & 555,97 & 587,75 & 636,20 & 1350,37 & 514,37 & 476,98 \\
\hline IA & 0,89 & 0,95 & 0,76 & 0,89 & 0,89 & 0,93 & 0,92 & 0,89 & 0,72 & 0,94 & 1,00 \\
\hline A/NK & 1,12 & 1,06 & 1,31 & 1,13 & 1,13 & 1,07 & 1,09 & 1,13 & 1,38 & 1,07 & 1,00 \\
\hline A/CNK & 1,05 & 1,01 & 0,83 & 1,06 & 1,07 & 0,93 & 0,92 & 0,93 & 0,52 & 0,94 & 0,91 \\
\hline $\mathrm{K}_{2} \mathrm{O} / \mathrm{Na}_{2} \mathrm{O}$ & 2,25 & 1,62 & 1,13 & 1,38 & 1,23 & 1,25 & 1,34 & 0,97 & 0,57 & 1,12 & 0,79 \\
\hline $\mathrm{Nb} / \mathrm{Ta}$ & 17,03 & 17,57 & 16,04 & 18,10 & 12,75 & 18,38 & 14,47 & 16,58 & 14,46 & 20,20 & 16,70 \\
\hline $\mathrm{Zr} / \mathrm{Hf}$ & & & 38,11 & & 38,52 & & 40,47 & 40,35 & 35,77 & & \\
\hline $\mathrm{Eu} / \mathrm{Eu}^{*}$ & & & 1,23 & & 0,28 & & 1,19 & 1,54 & 0,71 & & \\
\hline (La/Lu)N & & & 28,94 & & 25,75 & & 34,54 & 27,91 & 6,85 & & \\
\hline $\mathbf{Q}$ & - & 0,33 & - & 2,27 & 2,22 & - & - & - & - & - & - \\
\hline C & 1,29 & 0,48 & - & 1,27 & 1,36 & - & - & - & - & - & - \\
\hline or & 55,37 & 48,87 & 30,85 & 42,13 & 39,35 & 42,49 & 42,84 & 36,70 & 13,24 & 40,06 & 33,50 \\
\hline$a b$ & 34,86 & 43,18 & 37,30 & 43,56 & 45,66 & 40,43 & 37,98 & 39,57 & 23,51 & 44,32 & 52,72 \\
\hline an & 2,28 & 1,47 & 11,13 & 2,26 & 1,96 & 3,42 & 4,02 & 6,01 & 9,45 & 3,29 & 0,14 \\
\hline ne & 0,15 & - & 0,87 & - & - & 4,33 & 4,25 & 7,95 & 5,24 & 3,56 & 4,01 \\
\hline Ic & - & - & - & - & - & - & - & - & - & - & - \\
\hline ac & - & - & - & - & - & - & - & - & - & - & - \\
\hline di & - & - & 2,95 & - & - & 2,13 & 2,34 & 2,29 & 23,84 & 2,00 & 3,53 \\
\hline hy & - & 0,65 & - & 2,53 & 3,04 & - & - & - & - & - & - \\
\hline ol & 1,63 & - & 6,06 & - & - & 2,02 & 2,54 & 1,75 & 9,88 & 0,92 & 0,79 \\
\hline mt & 1,10 & - & 2,59 & 1,21 & 1,33 & 1,35 & 1,66 & 1,34 & 4,99 & 1,09 & 1,25 \\
\hline il & 1,90 & 1,74 & 3,13 & 1,42 & 1,25 & 1,10 & 1,52 & 1,18 & 5,58 & 1,37 & 1,27 \\
\hline $\mathrm{hm}$ & - & 0,33 & - & - & - & - & - & - & - & - & - \\
\hline ap & 0,38 & 0,33 & 2,27 & 0,19 & 0,19 & 0,47 & 0,59 & 0,54 & 0,99 & 0,19 & 0,19 \\
\hline aq & 1,00 & 1,11 & 0,52 & 2,03 & 2,30 & 1,05 & 0,82 & 1,08 & 1,04 & 1,49 & 0,79 \\
\hline
\end{tabular}

Lab.: Laboratório utilizado nas análises dos elementos traço e ETRs: A- AcmeLabs, via ICP-AES/ICP-MS; B- UNICAMP, via ICP-MS; C- Geoanalítica-USP, via ICP-MS. Óxidos analisados via FRX pela Acmelabs, exceto nas amostras analisadas pela Geoanalítica-USP. 
Tabela de análises de geoquímica isotópica

ANEXO G 
ANEXO G - Tabela de composição isotópica das rochas do Maciço Alcalino de Itatiaia

\begin{tabular}{|c|c|c|c|c|c|c|c|c|c|c|}
\hline Amostra & Unidade & ${ }^{143} \mathrm{Nd} /{ }^{144} \mathrm{Nd}(\mathrm{m})$ & $147 \mathrm{Sm} / 144 \mathrm{Nd}$ & ${ }^{143} \mathrm{Nd} /{ }^{144} \mathrm{Nd}_{(\mathrm{i})}$ & $\varepsilon \mathrm{Nd}_{(\mathrm{i})}$ & TDM & ${ }^{87} \mathrm{Sr} /{ }^{86} \mathrm{Sr}_{(\mathrm{m})}$ & ${ }^{87} \mathrm{Rb} /{ }^{86} \mathrm{Sr}$ & ${ }^{87} \mathrm{Sr} /{ }^{86} \mathrm{Sr}_{(\mathrm{i})}$ & Idade \\
\hline$\overline{\text { MAI030 }}$ & NeS-I & 0,512426 & 0,063530 & 0,512396 & $-2,93$ & 637 & 0,705297 & 0,353855 & 0,704939 & 71,3 \\
\hline MAI053 & NeS-I & 0,512443 & 0,073145 & 0,512409 & $-2,68$ & 661 & 0,705039 & 0,344587 & 0,704690 & 71,3 \\
\hline MAI046E & Diq-Maf & 0,512507 & 0,108427 & 0,512457 & $-1,75$ & 785 & 0,705317 & 0,470906 & 0,704841 & 71,3 \\
\hline MAI166I & NeS-II & 0,512352 & 0,089509 & 0,512313 & $-4,66$ & 855 & 0,707477 & 1,802029 & 0,705749 & 67,5 \\
\hline MAI036 & $\mathrm{BtHblNeS}$ & 0,512399 & 0,078887 & 0,512362 & $-3,60$ & 738 & 0,705542 & 0,509880 & 0,705026 & 71,3 \\
\hline MAI114 & BtHblP & 0,512370 & 0,090959 & 0,512329 & $-4,28$ & 843 & 0,705709 & 0,264121 & 0,705448 & 69,9 \\
\hline MAI092I & BtHblP & 0,512366 & 0,090880 & 0,512324 & $-4,37$ & 848 & 0,705741 & 0,335129 & 0,705409 & 69,7 \\
\hline MAI160 & HblP & 0,512345 & 0,085912 & 0,512307 & $-4,76$ & 840 & 0,705716 & 0,185222 & 0,705538 & 67,5 \\
\hline MAI090 & AgtN & 0,512314 & 0,075650 & 0,512280 & $-5,24$ & 812 & 0,754477 & 86,697055 & 0,668800 & 69,6 \\
\hline MAI110 & QzAFS-I & 0,512291 & 0,078430 & 0,512256 & $-5,74$ & 854 & 0,730521 & 34,396084 & 0,696974 & 68,7 \\
\hline MAI130 & Diq-Rto & 0,512284 & 0,119269 & 0,512230 & $-6,22$ & 1225 & 0,793208 & 2896,541120 & $-2,062271$ & 69,4 \\
\hline MAI070B & $\mathrm{mA}$ & 0,512277 & 0,106497 & 0,512229 & $-6,24$ & 1092 & 0,743709 & 46,000579 & 0,698361 & 69,4 \\
\hline MAI108II & arpk-QzS & 0,512265 & 0,091977 & 0,512223 & $-6,37$ & 979 & 0,706988 & 0,573040 & 0,706429 & 68,7 \\
\hline MAI122 & $T-1$ & 0,512315 & 0,088802 & 0,512275 & $-5,36$ & 895 & 0,706539 & 0,621447 & 0,705933 & 68,7 \\
\hline MAI226 & MG-mts & 0,512440 & 0,109415 & 0,512391 & $-3,12$ & 889 & 0,705395 & 0,063766 & 0,705333 & 67,5 \\
\hline MAI027 & Emb & 0,512141 & 0,122509 & 0,511679 & $-4,25$ & 1505 & 0,739809 & 2,681350 & 0,717826 & 580,0 \\
\hline MAI194C & Emb & 0,511712 & 0,111612 & 0,511273 & $-11,55$ & 1988 & 0,740940 & 4,103474 & 0,705829 & 600,0 \\
\hline MAI168 & $\mathrm{Emb}$ & 0,511440 & 0,118276 & 0,510959 & $-17,17$ & 2578 & 0,754741 & 2,338648 & 0,734061 & 620,0 \\
\hline Amostra & & ${ }^{206} \mathrm{~Pb} /{ }^{204} \mathrm{~Pb}_{(\mathrm{m})}$ & ${ }^{207} \mathrm{~Pb} /{ }^{204} \mathrm{~Pb}_{(\mathrm{m})}$ & ${ }^{208} \mathrm{~Pb} /{ }^{204} \mathrm{~Pb}_{(\mathrm{m})}$ & ${ }^{232} \mathrm{Th} /{ }^{238} \mathrm{U}$ & ${ }^{38} \mathrm{U} /{ }^{204} \mathrm{~Pb}$ & ${ }^{206} \mathrm{~Pb} /{ }^{204} \mathrm{~Pb}_{(\mathrm{i})}$ & ${ }^{207} \mathrm{~Pb} /{ }^{204} \mathrm{~Pb}_{(\mathrm{i})}$ & ${ }^{208} \mathrm{~Pb} /{ }^{204} \mathrm{~Pb}_{(\mathrm{i})}$ & Idade \\
\hline$\overline{\text { MAI030 }}$ & NeS-I & 18,406 & 15,505 & 38,853 & 7,390 & 13,158 & 18,259 & 15,498 & 38,510 & 71,3 \\
\hline MAI053I & NeS-I & 18,543 & 15,529 & 38,942 & 2,429 & 30,416 & 18,205 & 15,513 & 38,681 & 71,3 \\
\hline MAI046E & Diq-Maf & 18,602 & 15,556 & 38,976 & 3,834 & 18,762 & 18,393 & 15,546 & 38,722 & 71,3 \\
\hline MAI166I & $\mathrm{NeS}-\mathrm{II}$ & 18,633 & 15,560 & 38,648 & 4,223 & 13,211 & 18,494 & 15,553 & 38,462 & 67,5 \\
\hline MAI036 & $\mathrm{BtHblNeS}$ & 18,256 & 15,495 & 38,561 & 6,701 & 11,597 & 18,127 & 15,489 & 38,286 & 71,3 \\
\hline MAI114 & BtHblP & 18,485 & 15,553 & 38,708 & 5,304 & 10,767 & 18,368 & 15,547 & 38,510 & 69,9 \\
\hline MAI092I & BtHblP & 18,498 & 15,557 & 38,701 & 4,803 & 11,586 & 18,372 & 15,551 & 38,509 & 69,7 \\
\hline MAI160 & $\mathrm{HblP}$ & 18,687 & 15,558 & 38,703 & 3,883 & 18,562 & 18,491 & 15,549 & 38,461 & 67,5 \\
\hline MAI090 & AgtN & 18,740 & 15,577 & 38,795 & 2,606 & 35,334 & 18,356 & 15,559 & 38,478 & 69,6 \\
\hline MAI110 & QzAFS-I & 18,323 & 15,562 & 38,721 & 6,467 & 26,110 & 18,043 & 15,549 & 38,146 & 68,7 \\
\hline MAI130 & Diq-Rto & 18,582 & 15,593 & 38,712 & 0,143 & 78,143 & 17,736 & 15,552 & 38,673 & 69,4 \\
\hline MAI070B & $\mathrm{mA}$ & 18,638 & 15,590 & 38,623 & 2,943 & 31,648 & 18,296 & 15,574 & 38,302 & 69,4 \\
\hline MAI108II & arpk-QzS & 18,843 & 15,595 & 38,776 & 4,309 & 26,216 & 18,563 & 15,582 & 38,392 & 68,7 \\
\hline MAI122 & $T-1$ & 18,701 & 15,590 & 38,777 & 3,017 & 25,539 & 18,427 & 15,577 & 38,515 & 68,7 \\
\hline MAI226 & MG-mts & 18,467 & 15,547 & 38,741 & 5,513 & 14,133 & 18,319 & 15,540 & 38,480 & 67,5 \\
\hline MAI027 & Emb & 17,836 & 15,589 & 38,745 & 7,074 & 3,210 & 17,801 & 15,587 & 38,664 & 580,0 \\
\hline MAI194C & Emb & 19,080 & 15,724 & 38,959 & 3,216 & 13,538 & 18,933 & 15,717 & 38,808 & 600,0 \\
\hline MAI168 & Emb & 19,747 & 15,699 & 38,576 & 3,316 & 12,513 & 19,616 & 15,693 & 38,437 & 620,0 \\
\hline
\end{tabular}


Tabela de análises de U-Pb

ANEXO H 
ANEXO H - Resultados SHRIMP U-Pb em zircões de rochas do Maciço Alcalino de Itatiaia

\begin{tabular}{|c|c|c|c|c|c|c|c|c|c|c|c|c|c|c|c|c|c|}
\hline \multirow[t]{2}{*}{$\overline{\text { Amostra }}$} & \multirow[t]{2}{*}{ Cristal } & \multirow{2}{*}{$\underset{(\mathrm{ppm})}{\mathbf{U}}$} & \multirow{2}{*}{$\begin{array}{c}\text { Th } \\
(\mathrm{ppm})\end{array}$} & \multirow[t]{2}{*}{$T h / U$} & \multirow{2}{*}{$\begin{array}{c}{ }^{206} \mathrm{~Pb}_{\text {rad }} \\
(\mathrm{ppm})\end{array}$} & \multicolumn{2}{|c|}{${ }^{207} \mathrm{~Pb} /{ }^{206} \mathrm{~Pb}$} & \multicolumn{2}{|c|}{${ }^{206} \mathrm{~Pb} /{ }^{238} \mathrm{U}$} & \multicolumn{2}{|c|}{${ }^{208} \mathrm{~Pb} /{ }^{232} \mathrm{Th}$} & \multicolumn{2}{|c|}{${ }^{206} \mathrm{~Pb} /{ }^{238} \mathrm{U}$} & \multicolumn{2}{|c|}{${ }^{207} \mathrm{~Pb} /{ }^{206} \mathrm{~Pb}$} & \multicolumn{2}{|c|}{${ }^{208} \mathrm{~Pb} /{ }^{232} \mathrm{Th}$} \\
\hline & & & & & & razão & \% erro & razão & $\%$ erro & razão & $\%$ erro & Idade & $1 \sigma$ & Idade & $1 \sigma$ & & $1 \sigma$ \\
\hline MAI036 & 1 & 539 & 140 & 0,26 & 5,07 & 0,0805 & 4,37 & 0,0110 & 1,19 & 0,00695 & 5,50 & 67,38 & 0,94 & 100,31 & 400,53 & 70,17 & 13,93 \\
\hline MAI036 & 2 & 181 & 130 & 0,72 & 1,74 & 0,0690 & 4,93 & 0,0112 & 1,41 & 0,00447 & 4,72 & 69,98 & 1,23 & 44,66 & 482,67 & 72,62 & 7,44 \\
\hline MAI036 & 3 & 300 & 525 & 1,75 & 2,82 & 0,0515 & 2,45 & 0,0110 & 1,28 & 0,00354 & 2,34 & 70,19 & 0,91 & 203,27 & 114,51 & 70,95 & 1,79 \\
\hline MAI036 & 4 & 308 & 243 & 0,79 & 2,92 & 0,0514 & 2,23 & 0,0111 & 1,27 & 0,00369 & 3,07 & 70,54 & 0,93 & 49,51 & 155,10 & 71,35 & 2,94 \\
\hline MAI036 & 5 & 158 & 242 & 1,53 & 1,55 & 0,0711 & 2,66 & 0,0114 & 1,44 & 0,00409 & 3,05 & 70,64 & 1,37 & 73,07 & 548,82 & 73,57 & 4,47 \\
\hline MAI036 & 6 & 117 & 106 & 0,90 & 1,17 & 0,0835 & 7,12 & 0,0116 & 1,73 & 0,00450 & 4,26 & 70,74 & 1,92 & $-2,99$ & 967,43 & 66,23 & 10,91 \\
\hline MAI036 & 7 & 802 & 15 & 0,02 & 7,65 & 0,0502 & 1,27 & 0,0111 & 1,13 & 0,00608 & 7,48 & 70,96 & 0,80 & 108,27 & 61,82 & 63,23 & 32,21 \\
\hline MAI036 & 8 & 513 & 155 & 0,30 & 4,94 & 0,0548 & 1,63 & 0,0112 & 1,18 & 0,00396 & 3,35 & 71,15 & 0,86 & 26,00 & 140,40 & 64,30 & 5,06 \\
\hline MAI036 & 9 & 320 & 206 & 0,64 & 3,10 & 0,0517 & 2,63 & 0,0113 & 1,26 & 0,00360 & 3,24 & 71,58 & 0,93 & $-43,83$ & 181,26 & 66,78 & 3,43 \\
\hline MAI036 & 10 & 684 & 1630 & 2,38 & 6,57 & 0,0490 & 1,55 & 0,0112 & 1,16 & 0,00350 & 1,65 & 71,69 & 0,84 & 140,33 & 93,86 & 70,58 & 1,23 \\
\hline MAI036 & 11 & 282 & 382 & 1,35 & 2,72 & 0,0505 & 2,40 & 0,0112 & 1,65 & 0,00359 & 2,93 & 71,79 & 1,19 & 134,40 & 109,80 & 71,77 & 2,25 \\
\hline MAI036 & 12 & 902 & 1879 & 2,08 & 8,82 & 0,0496 & 1,34 & 0,0114 & 1,21 & 0,00360 & 1,62 & 72,59 & 0,88 & 12,47 & 76,30 & 71,74 & 1,20 \\
\hline MAI036 & 13 & 166 & 117 & 0,70 & 1,62 & 0,0503 & 4,96 & 0,0114 & 1,41 & 0,00388 & 4,09 & 72,72 & 1,22 & 146,08 & 374,78 & 77,24 & 6,89 \\
\hline MAI036 & & 170 & 2 & 0,01 & 1,48 & 0,0642 & 2,68 & 0,0101 & 1,37 & 0,02830 & 10,51 & 63,49 & 1,11 & 2,25 & 476,53 & & \\
\hline MAI0921 & 1 & 431 & 1068 & 2,48 & 3,87 & 0,0514 & 1,84 & 0,0105 & 1,29 & 0,00325 & 1,92 & 66,79 & 0,87 & 121,40 & 95,18 & 64,93 & 1,28 \\
\hline MAI092I & 2 & 166 & 469 & 2,82 & 1,52 & 0,0551 & 4,68 & 0,0106 & 1,45 & 0,00330 & 3,48 & 67,72 & 1,02 & 144,15 & 216,38 & 65,40 & 2,32 \\
\hline MAI0921 & 3 & 390 & 615 & 1,58 & 3,63 & 0,0576 & 4,25 & 0,0108 & 1,28 & 0,00363 & 2,27 & 68,54 & 0,96 & 37,13 & 279,69 & 69,52 & 2,28 \\
\hline MAI0921 & 4 & 266 & 743 & 2,80 & 2,46 & 0,0538 & 2,97 & 0,0108 & 1,35 & 0,00343 & 2,17 & 68,63 & 0,97 & 121,83 & 186,35 & 68,20 & 1,62 \\
\hline MAIO92I & 5 & 445 & 527 & 1,18 & 4,15 & 0,0499 & 2,07 & 0,0109 & 1,28 & 0,00348 & 2,41 & 69,32 & 0,90 & 40,95 & 123,02 & 68,72 & 1,91 \\
\hline MAI092I & 6 & 358 & 629 & 1,76 & 3,35 & 0,0514 & 2,08 & 0,0109 & 1,29 & 0,00344 & 2,21 & 69,34 & 0,95 & 37,34 & 201,70 & 67,95 & 1,91 \\
\hline MAI092I & 7 & 635 & 1949 & 3,07 & 5,95 & 0,0513 & 1,57 & 0,0109 & 1,23 & 0,00340 & 1,69 & 69,50 & 0,90 & 30,52 & 177,95 & 67,71 & 1,26 \\
\hline MAI092I & 8 & 519 & 942 & 1,81 & 4,86 & 0,0513 & 1,74 & 0,0109 & 1,36 & 0,00338 & 2,05 & 69,60 & 0,96 & 88,83 & 101,90 & 67,09 & 1,46 \\
\hline MAI092I & 9 & 729 & 2020 & 2,77 & 6,84 & 0,0491 & 1,51 & 0,0109 & 1,31 & 0,00345 & 1,68 & 69,89 & 0,91 & 95,22 & 74,94 & 69,42 & 1,19 \\
\hline MAI092I & 10 & 423 & 903 & 2,14 & 4,01 & 0,0500 & 2,00 & 0,0110 & 1,85 & 0,00342 & 2,43 & 70,58 & 1,31 & 50,64 & 116,34 & 68,20 & 1,74 \\
\hline MAI092I & 11 & 466 & 1215 & 2,60 & 4,45 & 0,0491 & 1,77 & 0,0111 & 1,25 & 0,00342 & 1,89 & 70,99 & 0,90 & 57,20 & 120,77 & 68,54 & 1,31 \\
\hline MAI092I & 12 & 287 & 682 & 2,38 & 2,85 & 0,0786 & 1,94 & 0,0116 & 1,93 & 0,00464 & 2,52 & 71,42 & 1,54 & 152,12 & 415,07 & 86,27 & 2,88 \\
\hline MAI0921 & 13 & 340 & 1543 & 4,55 & 3,26 & 0,0497 & 2,1 & 0,0112 & 1,33 & 0,00355 & 3,34 & 71,45 & 0,97 & 47,03 & 132,74 & 71,25 & 1,99 \\
\hline MAIO90 & 1 & 306 & 474 & 1,55 & 2,86 & 0,0663 & 4,89 & 0,0109 & 1,46 & 0,00364 & 2,45 & 68,14 & 1,22 & 113,35 & 451,96 & 66,88 & 3,38 \\
\hline MAIO90 & 2 & 306 & 427 & 1,40 & 2,82 & 0,0520 & 5,11 & 0,0107 & 1,31 & 0,00342 & 2,46 & 68,44 & 0,93 & 34,44 & 220,12 & 66,97 & 2,08 \\
\hline MAIO90 & 3 & 470 & 874 & 1,86 & 4,36 & 0,0522 & 1,71 & 0,0108 & 1,24 & 0,00341 & 1,92 & 68,79 & 0,87 & 52,46 & 129,70 & 67,36 & 1,46 \\
\hline MAIO90 & 4 & 517 & 344 & 0,66 & 4,79 & 0,0521 & 1,66 & 0,0108 & 1,24 & 0,00373 & 2,49 & 68,80 & 0,86 & 130,04 & 99,67 & 72,31 & 2,35 \\
\hline MAIO90 & 5 & 682 & 1505 & 2,21 & 6,35 & 0,0504 & 1,47 & 0,0108 & 1,38 & 0,00339 & 1,79 & 69,18 & 0,97 & 32,23 & 136,05 & 67,41 & 1,36 \\
\hline MAI090 & 6 & 450 & 797 & 1,77 & 4,21 & 0,0520 & 2,07 & 0,0109 & 1,25 & 0,00344 & 1,99 & 69,55 & 0,96 & 75,43 & 236,69 & 67,91 & 1,97 \\
\hline MAIO9O & 7 & 649 & 1219 & 1,88 & 6,11 & 0,0535 & 1,96 & 0,0110 & 1,22 & 0,00351 & 1,74 & 69,77 & 0,87 & 70,07 & 138,00 & 68,91 & 1,40 \\
\hline MAIO90 & 8 & 393 & 701 & 1,79 & 3,69 & 0,0480 & 2,13 & 0,0109 & 1,27 & 0,00335 & 2,11 & 69,77 & 0,95 & $-31,84$ & 228,89 & 66,80 & 1,90 \\
\hline MAIO90 & 9 & 718 & 1463 & 2,04 & 6,74 & 0,0490 & 1,44 & 0,0109 & 1,21 & 0,00344 & 1,67 & 69,85 & 0,85 & 45,60 & 96,78 & 68,80 & 1,24 \\
\hline MAIO9O & 10 & 279 & 451 & 1,62 & 2,64 & 0,0543 & 2,33 & 0,0110 & 1,34 & 0,00363 & 2,49 & 70,23 & 0,94 & 154,06 & 79,92 & 71,43 & 1,81 \\
\hline MAIO90 & 11 & 253 & 381 & 1,50 & 2,41 & 0,0534 & 4,63 & 0,0111 & 1,36 & 0,00371 & 2,65 & 70,54 & 1,11 & 58,53 & 344,77 & 72,49 & 3,04 \\
\hline MAIO90 & 12 & 1037 & 2498 & 2,41 & 9,87 & 0,0480 & 1,21 & 0,0111 & 1,18 & 0,00348 & 1,51 & 71,05 & 0,84 & 103,63 & 28,69 & 70,34 & 1,04 \\
\hline MAI110 & 1 & 310 & 310 & 1,00 & 2,84 & 0,0556 & 2,55 & 0,0107 & 1,32 & 0,00345 & 2,80 & 67,67 & 0,95 & 69,74 & 215,63 & 65,16 & 2,81 \\
\hline MAI110 & 2 & 90 & 136 & 1,51 & 0,84 & 0,0671 & 5,46 & 0,0108 & 1,72 & 0,00346 & 4,29 & 67,74 & 1,44 & 40,81 & 560,32 & 62,46 & 4,50 \\
\hline MAI110 & 3 & 198 & 242 & 1,2 & 1, & 0,0538 & 2, & 0,0108 & 1,41 & 0,00362 & 3,06 & 68,29 & 0,99 & $-71,04$ & 190,43 & 68,93 & 2,50 \\
\hline MAI110 & 4 & 189 & 158 & 0,83 & 1,74 & 0,0525 & 3,04 & 0,0107 & 1,42 & 0,00333 & 3,76 & 68,33 & 1,05 & 86,57 & 246,57 & 64,15 & 3,90 \\
\hline MAI110 & 5 & 367 & 415 & 1,13 & 3,40 & 0,0565 & 2,56 & 0,0108 & 1,51 & 0,00349 & 2,87 & 68,36 & 1,07 & 64,84 & 201,51 & 66,05 & 2,58 \\
\hline MAI110 & 6 & 311 & 230 & 0,74 & 2,88 & 0,0512 & 2,70 & 0,0108 & 1,32 & 0,00363 & 3,10 & 68,51 & 0,91 & $-124,52$ & 126,08 & 67,64 & 2,39 \\
\hline MAI110 & 7 & 493 & 410 & 0,83 & 4,56 & 0,0505 & 1,76 & 0,0108 & 1,25 & 0,00348 & 2,44 & 68,73 & 0,87 & 81,44 & 117,30 & 68,38 & 2,19 \\
\hline MAI110 & 7 & 212 & 214 & 1,0 & 1,9 & 0,0549 & 4,8 & 0,0104 & 1,44 & 0,00333 & 3,27 & 66,09 & 0,97 & $-27,34$ & 214,91 & 62,30 & 2,53 \\
\hline MAI110 & 8 & 237 & 285 & 1,21 & 2,20 & 0,0524 & 2,67 & 0,0108 & 1,41 & 0,00344 & 2,90 & 68,83 & 1,00 & $-83,57$ & 182,90 & 65,85 & 2,31 \\
\hline MAI110 & 9 & 261 & 205 & 0,78 & 2,43 & 0,0539 & 2,28 & 0,0108 & 1,34 & 0,00349 & 3,20 & 68,87 & 0,93 & 19,48 & 109,49 & 65,16 & 2,35 \\
\hline
\end{tabular}


ANEXO H - Resultados SHRIMP U-Pb em zircões de rochas do Maciço Alcalino de Itatiaia

\begin{tabular}{|c|c|c|c|c|c|c|c|c|c|c|c|c|c|c|c|c|c|}
\hline \multirow[t]{2}{*}{ Amostra } & \multirow[t]{2}{*}{ Cristal } & \multirow{2}{*}{$\underset{(\mathrm{ppm})}{\mathrm{U}}$} & \multirow{2}{*}{$\begin{array}{c}\text { Th } \\
(\mathrm{ppm})\end{array}$} & \multirow[t]{2}{*}{ Th/U } & \multirow{2}{*}{$\begin{array}{c}{ }^{206} \mathrm{~Pb}_{\text {rad }} \\
(\mathrm{ppm})\end{array}$} & \multicolumn{2}{|c|}{${ }^{207} \mathrm{~Pb} /{ }^{206} \mathrm{~Pb}$} & \multicolumn{2}{|c|}{${ }^{206} \mathrm{~Pb} /{ }^{238} \mathrm{U}$} & \multicolumn{2}{|c|}{${ }^{208} \mathrm{~Pb} /{ }^{232} \mathrm{Th}$} & \multicolumn{2}{|c|}{${ }^{206} \mathrm{~Pb} / /^{238} \mathrm{U}$} & \multicolumn{2}{|c|}{${ }^{207} \mathrm{~Pb} /{ }^{206} \mathrm{~Pb}$} & \multicolumn{2}{|c|}{${ }^{208} \mathrm{~Pb} /{ }^{232} \mathrm{Th}$} \\
\hline & & & & & & razão & $\%$ erro & razão & $\%$ erro & razão & $\%$ erro & Idade & $1 \sigma$ & Idade & $1 \sigma$ & Idade & 10 \\
\hline MAl110 & 10 & 468 & 395 & 0,85 & 4,37 & 0,0520 & 1,81 & 0,0109 & 1,25 & 0,00344 & 2,51 & 69,24 & 0,90 & 47,76 & 164,85 & 66,13 & 2,59 \\
\hline MAI110 & 11 & 397 & 301 & 0,76 & 3,73 & 0,0520 & 1,97 & 0,0109 & 1,28 & 0,00333 & 2,85 & 69,52 & 0,92 & 51,97 & 166,27 & 63,53 & 2,89 \\
\hline MAI110 & 12 & 457 & 401 & 0,88 & 4,31 & 0,0563 & 2,88 & 0,0110 & 1,39 & 0,00364 & 2,82 & 69,54 & 0,98 & 79,41 & 138,19 & 67,92 & 2,17 \\
\hline MAI110 & 13 & 424 & 405 & 0,96 & 4,02 & 0,0503 & 1,97 & 0,0110 & 1,28 & 0,00350 & 2,57 & 70,55 & 0,92 & 80,76 & 134,49 & 69,02 & 2,30 \\
\hline MAI070B & 1 & 1172 & 1018 & 0,87 & 10,58 & 0,0533 & 1,40 & 0,0105 & 1,28 & 0,00345 & 1,88 & 66,92 & 0,86 & 97,93 & 97,15 & 66,35 & 1,64 \\
\hline MAIO70B & 2 & 565 & 383 & 0,68 & 5,15 & 0,0521 & 1,64 & 0,0106 & 1,24 & 0,00350 & 2,52 & 67,60 & 0,85 & 87,09 & 120,02 & 67,19 & 2,43 \\
\hline MAIO70B & 3 & 422 & 447 & 1,06 & 3,88 & 0,0530 & 2,91 & 0,0107 & 1,27 & 0,00354 & 2,41 & 68,13 & 0,87 & 3,13 & 107,66 & 67,95 & 1,74 \\
\hline MAI070B & 4 & 1156 & 1047 & 0,91 & 10,74 & 0,0515 & 1,82 & 0,0108 & 1,24 & 0,00353 & 1,84 & 68,96 & 0,87 & 65,53 & 103,80 & 68,60 & 1,66 \\
\hline MAIO70B & 5 & 836 & 711 & 0,85 & 7,82 & 0,0554 & 2,01 & 0,0109 & 1,20 & 0,00362 & 1,94 & 69,10 & 0,86 & 63,60 & 166,07 & 67,75 & 2,34 \\
\hline MAI070B & 6 & 1256 & 1169 & 0,93 & 11,73 & 0,0503 & 1,14 & 0,0109 & 1,18 & 0,00347 & 2,50 & 69,43 & 0,83 & 69,92 & 86,07 & 68,33 & 1,95 \\
\hline MAI070B & 7 & 1122 & 791 & 0,71 & 10,49 & 0,0485 & 1,22 & 0,0109 & 1,19 & 0,00347 & 1,95 & 69,60 & 0,83 & 3,01 & 75,11 & 68,16 & 1,67 \\
\hline MAIOTOB & 8 & 912 & 741 & 0,81 & 8,59 & 0,0497 & 1,34 & 0,0110 & 1,24 & 0,00341 & 2,68 & 70,00 & 0,86 & 20,57 & 46,99 & 66,53 & 1,82 \\
\hline MAIOTOB & 9 & 1033 & 777 & 0,75 & 9,72 & 0,0494 & 1,25 & 0,0110 & 1,19 & 0,00355 & 1,97 & 70,10 & 0,83 & 84,98 & 46,06 & 70,43 & 1,47 \\
\hline MAIO70B & 10 & 1544 & 1806 & 1,17 & 14,57 & 0,0481 & 1,04 & 0,0110 & 1,17 & 0,00344 & 1,58 & 70,40 & 0,82 & 95,56 & 51,69 & 69,37 & 1,18 \\
\hline MAIO70B & 11 & 1164 & 1065 & 0,91 & 10,99 & 0,0482 & 1,21 & 0,0110 & 1,18 & 0,00345 & 1,81 & 70,43 & 0,83 & 105,27 & 52,31 & 69,55 & 1,37 \\
\hline MAI070B & 12 & 1914 & 2105 & 1,10 & 18,62 & 0,0482 & 0,90 & 0,0113 & 1,16 & 0,00357 & 1,49 & 72,46 & 0,84 & 21,66 & 48,79 & 71,04 & 1,14 \\
\hline MAIOTOB & 13 & 2145 & 4307 & 2,01 & 21,53 & 0,0484 & 0,86 & 0,0117 & 1,23 & 0,00366 & 1,44 & 74,80 & 0,91 & 81,28 & 43,82 & 73,55 & 1,07 \\
\hline MAI108II & 1 & 374 & 316 & 0,85 & 3,36 & 0,0502 & 2,12 & 0,0105 & 1,24 & 0,00339 & 2,82 & 66,78 & 0,83 & 49,46 & 93,19 & 66,29 & 2,05 \\
\hline MAI108II & 2 & 231 & 255 & 1,10 & 2,12 & 0,0604 & 2,44 & 0,0107 & 1,55 & 0,00362 & 3,16 & 67,38 & 1,07 & 130,21 & 167,46 & 67,12 & 2,53 \\
\hline MAI108II & 3 & 288 & 233 & 0,81 & 2,64 & 0,0523 & 2,41 & 0,0107 & 1,29 & 0,00355 & 3,17 & 67,99 & 0,93 & 33,10 & 203,13 & 67,74 & 3,28 \\
\hline MAI108II & 4 & 331 & 300 & 0,91 & 3,04 & 0,0495 & 2,26 & 0,0107 & 1,26 & 0,00359 & 2,8 & 68,30 & 0,89 & 26,54 & 164,02 & 70,66 & 2,66 \\
\hline MAI108II & 5 & 229 & 174 & 0,76 & 2,10 & 0,0503 & 4,23 & 0,0107 & 1,75 & 0,00329 & 3,85 & 68,33 & 1,20 & 57,57 & 153,07 & 64,20 & 2,90 \\
\hline MAI108II & 6 & 200 & 154 & 0,77 & 1,85 & 0,0525 & 3,61 & 0,0108 & 1,38 & 0,00357 & 3,76 & 68,58 & 1,07 & 38,17 & 325,06 & 67,88 & 4,99 \\
\hline MAI108II & 7 & 398 & 636 & 1,60 & 3,66 & 0,0478 & 2,08 & 0,0107 & 1,46 & 0,00336 & 2,33 & 68,69 & 1,00 & 92,39 & 49,16 & 67,75 & 1,57 \\
\hline MAI108II & 8 & 474 & 406 & 0,86 & 4,37 & 0,0487 & 1,98 & 0,0107 & 1,20 & 0,00354 & 2,72 & 68,77 & 0,86 & 112,01 & 143,03 & 71,09 & 2,61 \\
\hline MAI108II & 9 & 181 & 183 & 1,01 & 1,67 & 0,0512 & 3,08 & 0,0108 & 1,41 & 0,00371 & 3,51 & 68,88 & 1,02 & 167,29 & 199,55 & 73,95 & 3,35 \\
\hline MAI108II & 10 & 104 & 123 & 1,18 & 1,00 & 0,0761 & 7,30 & 0,0112 & 1,60 & 0,00392 & 4,20 & 69,10 & 1,93 & 101,49 & 955,94 & 65,44 & 9,03 \\
\hline MAI108II & 11 & 177 & 214 & 1,21 & 1,77 & 0,1041 & 5,44 & 0,0116 & 1,39 & 0,00513 & 3,71 & 69,20 & 1,56 & 73,27 & 863,52 & 75,61 & 7,40 \\
\hline MAI108II & 12 & 558 & 210 & 0,38 & 5,24 & 0,0567 & 3,75 & 0,0109 & 1,18 & 0,00389 & 4,31 & 69,40 & 0,85 & 166,08 & 175,06 & 67,57 & 5,20 \\
\hline MAI108II & 13 & 409 & 408 & 1,00 & 3,82 & 0,0503 & 3,0 & 0,0109 & 1,22 & 0,00355 & 2,5 & 69,46 & 0,87 & 21,58 & 145,58 & 69,44 & 2,16 \\
\hline MAI108II & 14 & 276 & 281 & 1,02 & 2,59 & 0,0499 & 2,46 & 0,0109 & 1,29 & 0,00349 & 2,96 & 69,82 & 0,92 & 118,85 & 126,04 & 69,59 & 2,39 \\
\hline MAI108II & 15 & 181 & 248 & 1,37 & 1,71 & 0,0528 & 5,00 & 0,0110 & 1,45 & 0,00350 & 3,85 & 69,91 & 1,06 & 11,14 & 239,72 & 67,86 & 3,00 \\
\hline MAI108II & 16 & 174 & 140 & 0,80 & 2,06 & 0,1301 & 3,09 & 0,0138 & 1,35 & 0,00713 & 3,15 & 79,54 & 1,81 & 210,92 & 871,75 & 73,50 & 13,03 \\
\hline MAI166I & 1 & 596 & 463 & 0,7 & 5,30 & 0,0517 & 1,65 & 0,0103 & 1,47 & 0,00342 & 2,5 & 66,00 & 0,98 & 69,35 & 133,94 & 66,11 & 2,36 \\
\hline MAI166I & 2 & 678 & 1121 & 1,6 & 6,07 & 0,0465 & 1,68 & 0,0104 & 1,17 & 0,00328 & 1,86 & 66,76 & 0,80 & 15,98 & 110,85 & 66,13 & 1,39 \\
\hline MAI166I & 3 & 618 & 526 & 0,85 & 5,59 & 0,0494 & 1,70 & 0,0105 & 1,18 & 0,00341 & 2,3 & 67,43 & 0,79 & 81,80 & 63,20 & 67,76 & 1,67 \\
\hline MAI166I & 4 & 879 & 1087 & 1,24 & 8,01 & 0,0484 & 1,41 & 0,0106 & 1,22 & 0,00338 & 2,28 & 68,04 & 0,83 & 100,56 & 39,81 & 68,01 & 1,56 \\
\hline MAl166l & 5 & 307 & 158 & 0,5 & 2,93 & 0,0530 & 3,24 & 0,0111 & 1,27 & 0,00358 & 3,6 & 70,62 & 0,92 & 53,84 & 171,37 & 65,88 & 3,92 \\
\hline MAI166I & 6 & 750 & 732 & 0, & 6, & 0,0483 & 1, & & 1,15 & 0,00329 & 2, & 67,13 & 0,78 & 62,78 & 76,74 & 65,84 & 1,52 \\
\hline MAI166I & 7 & 341 & 138 & 0,40 & 3,12 & 0,0494 & 2,24 & 0,0107 & 1,25 & 0,00338 & 3,89 & 68,25 & 0,87 & 113,06 & 109,88 & 66,77 & 3,70 \\
\hline MAl16 & 8 & 1241 & 1654 & 1 & 11,42 & 0,0488 & 1,16 & 0,0107 & 1,15 & 0,00341 & 1, & 68,60 & 0,78 & 72,23 & 44,48 & 68,34 & 1,12 \\
\hline MAI166I & 9 & 806 & 618 & 0,77 & 7,25 & 0,0502 & 1,50 & 0,0105 & 1,15 & 0,00330 & 2,39 & 66,84 & 0,78 & 31,15 & 94,23 & 64,17 & 1,90 \\
\hline MAl166I & 10 & 400 & 267 & 0,6 & 31,82 & 0,0597 & 0,6 & 0,0925 & 1,11 & 0,02823 & 1,60 & 570,05 & 6,05 & 571,05 & 19,29 & 558,16 & 8,42 \\
\hline MAI166I & 11 & 378 & 320 & 0,85 & 3,50 & 0,0549 & 2,88 & 0,0108 & 1,24 & 0,00358 & 2,77 & 68,50 & 0,94 & 85,95 & 253,32 & 67,63 & 3,59 \\
\hline MAI166I & 12 & 310 & 112 & 0,36 & 2,97 & 0,0969 & 3,14 & 0,0111 & 1,46 & 0,00683 & 4,75 & 67,05 & 1,29 & 115,31 & 604,37 & 60,95 & 16,35 \\
\hline MAI166I & 13 & 247 & 102 & 0,41 & 2,23 & 0,0541 & 2,51 & 0,0105 & 1,37 & 0,00371 & 4,34 & 66,97 & 0,96 & 90,29 & 193,98 & 66,63 & 5,48 \\
\hline
\end{tabular}

